
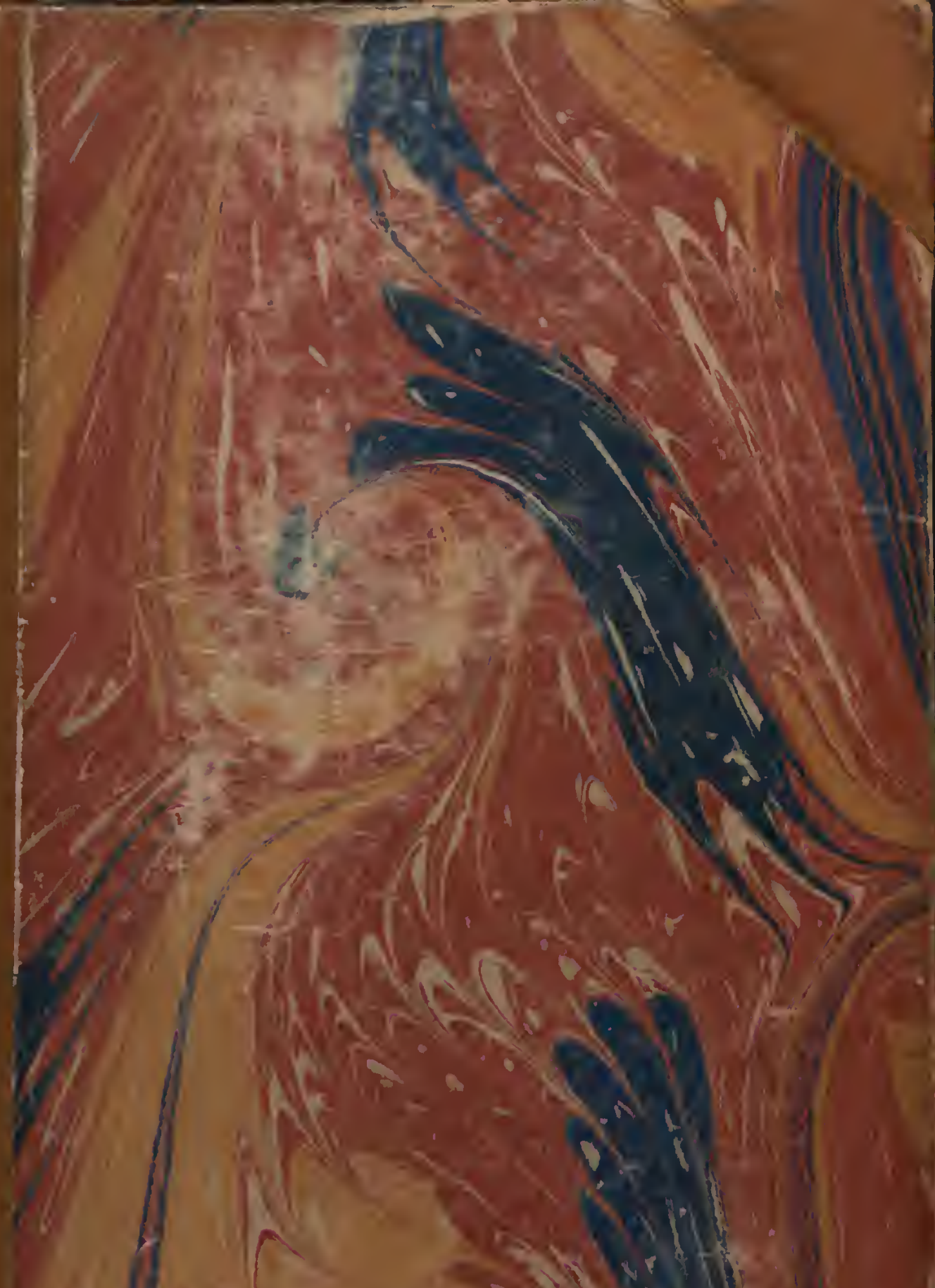

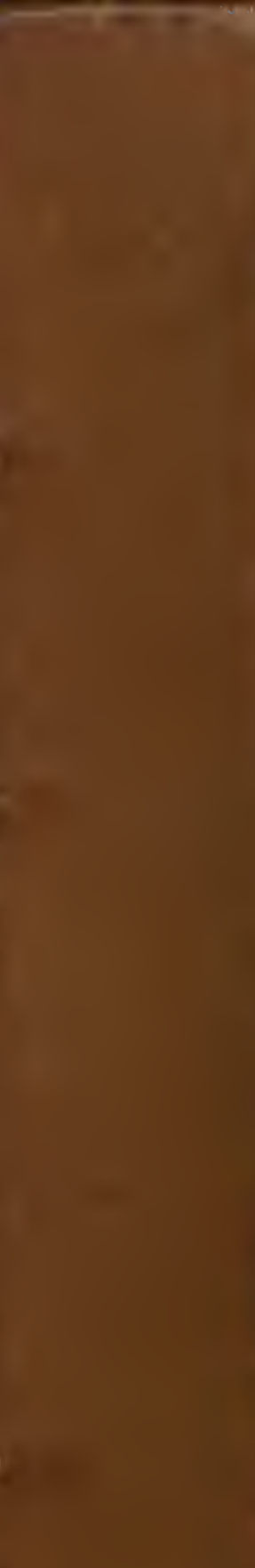




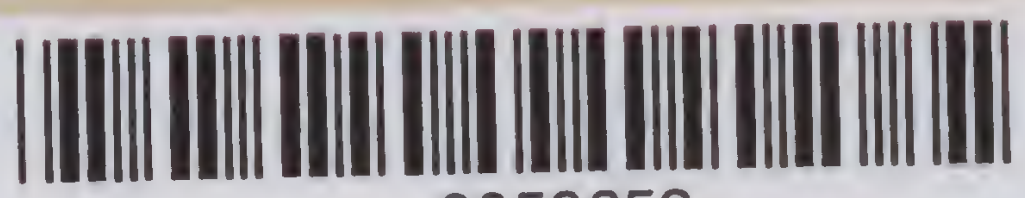 0059653}

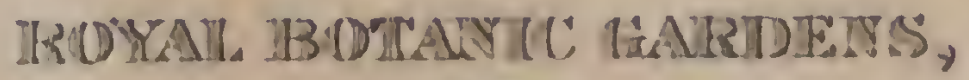
KKE'W。

a

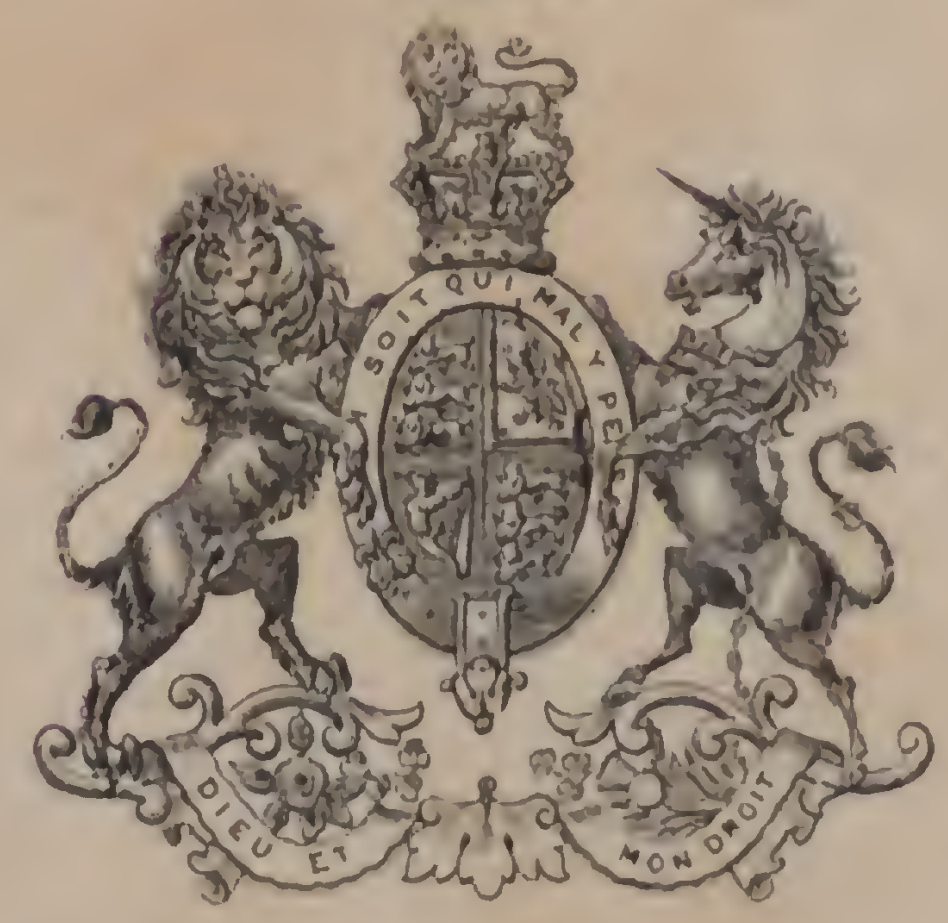

$12 G$ 


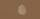





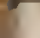

(1)

.

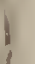

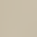





\section{H O OKER'S}

\section{ICONES PLANTARUM;}

or,

FIGURES, WITII DESCRIPTIYE CHARACTERS AND REMIARKS,

OF NEW AND RARE PIANTS,

SELECTED FROM THE

KEW IIERBARIUM.

FIFTH SERIES.

EDITED FOR THE BENTHAM TRUSTEES BY

SIR ARTHUR W. HILL, K.C.M.G., Sc.D., F.R.S.

hoNorary fellow, KING'S COLLEGE, CAMBRIDGE;

DIRECTOR, ROYAL BOTANIC GARDENS, KEW.

VOL. II.

OR VOL. XXXII. OF THE ENTIRE WOIR.

PART 1. 3101-3125, August 1927.

PART II. 3126-3150, October 1930.

PART III. 3151-31\%5, June 1932.

PART IV. 3176-3200, May 1933.

DULAU \& CO., LTD.

32 OLD BOND STREET, LONDON, W.I.

1933. 


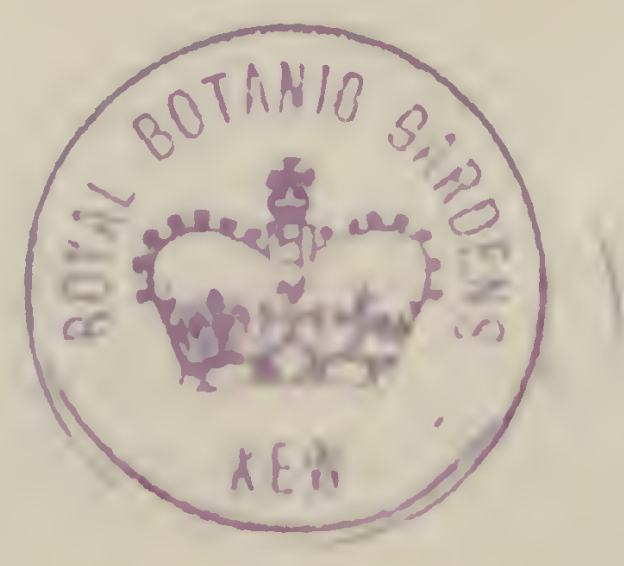




\section{INDEX T() THF PLATES AND NAUES}

The names given in clarendon type are those of plants described or renamed in tho work; an ${ }^{*}$ is prefixed to the nanes of those not figured. Synonyms aro printerl in ifalics; nanes in roman charaeters are those of plants discussed in the toxt.

\begin{tabular}{|c|c|c|c|}
\hline er sycopseold & $\begin{array}{l}\text { Plate } \\
3160\end{array}$ & Canthium Gueinzii, Sond. & $\begin{array}{l}\text { Plate } \\
3170\end{array}$ \\
\hline llium an isopodium, Ledeb. & 3182 & - hispidum, Benth. & 3170 \\
\hline $\begin{array}{l}\text { - bidentatum, Fisch. } \\
\text { - dentigeruin, Prokhanov }\end{array}$ & 3181 & Cerinthe minor var. bispida, & \\
\hline - dentigeruin, Prokhanov & $\begin{array}{l}3181 \\
3181\end{array}$ & Chamaeraphis bordeacea, $R . \dot{B r}$. & 3140 \\
\hline - polyrrhizum y Polanini, & & Clematis gruta, Wall. & 3129 \\
\hline — Regel & 3181 & — rubifolia, C.II. IIright & $\begin{array}{l}3129 \\
3100\end{array}$ \\
\hline — subangulatum, Regel : : & $\begin{array}{l}3181 \\
3181\end{array}$ & $\begin{array}{l}\text { Tightiana, Wall. } \\
\text { Commiphora abyssinica, Engl. }\end{array}$ & $\begin{array}{l}3129 \\
3111\end{array}$ \\
\hline - tenuissimum y purpureum, & & - allophylla, sprague & 3110 \\
\hline $\begin{array}{l}\text { Regel } \\
-\quad \text { Zimme }\end{array}$ & 3182 & — candidula, Sprague & 3106 \\
\hline m, Gilg. & 3182 & — crassispina, Nprogue & 3107 \\
\hline$n$ sect. Lasiorrhachis, & & - Drake-Brockmanii, Sprugue & 3112 \\
\hline $\begin{array}{l}\text { Hack. } \\
\text { IIildebrandt }\end{array}$ & 3124 & erythraen, Engl. . . . & 3112 \\
\hline IIildebrand & & — Ha viflora, Engl. & 3106 \\
\hline Gamblei, $C . E . C$. & & $\begin{array}{l}\text { _oliacea, Sprague } \\
\text { _owlello, sprague }\end{array}$ & 3109 \\
\hline Fischer. & 3183 & — hodai, sprague & 3111 \\
\hline stragalus ajubcnsis, Bunge & 3115 & — Myrrha var. molinol, Engl, & 3110 \\
\hline Domin : & $\begin{array}{l}3115 \\
3142\end{array}$ & $\begin{array}{l}\text { - Opolalsamum, Engl. . } \\
\text { - Seineri, Engl. . . }\end{array}$ & $\begin{array}{l}3105 \\
3109\end{array}$ \\
\hline pectinata var. triticoides, & & — socotrana, Engl. . . & 3107 \\
\hline F. M. Bailey & 3142 & — somalensis, Engl. . & 110 \\
\hline squarrosa, $C$ & $\begin{array}{l}31+2 \\
31+2\end{array}$ & $\begin{array}{l}\text { - truncnta, Engl. } \\
\text { tubuk, Sprague }\end{array}$ & 3108 \\
\hline triticoides var. lappacea, & & Consolida macedonica, Soó . & 3152 \\
\hline Tenth & $31+2$ & $\begin{array}{l}\text { - olopetala var. pa phlagonic } \\
\text { Hayek }\end{array}$ & 3152 \\
\hline ada, Gleason & 3172 & Cotoneaster affinis, Lindl. & 3146 \\
\hline & 3114 & - Cooperi, Marquand & $31+6$ \\
\hline fragilis, Robinso & 3114 & _- foreolata, Rehd. et Wils, & $31+5$ \\
\hline *tenera, Turrill & $\begin{array}{l}3114 \\
3198\end{array}$ & $\begin{array}{l}\text { nitidifolia, Marquand } \\
\text { Cotyledon lassithiensis, Hayek }\end{array}$ & 3145 \\
\hline $\begin{array}{l}\text { lepharis Buclineri, Landau } \\
\text { - glunacea, } S \text {. Moore }\end{array}$ & 3198 & Dendulinus, Batt. & $\begin{array}{l}3100 \\
3155\end{array}$ \\
\hline $\begin{array}{l}\text { menocotyle, Milne-Redhead } \\
\text { ia muricata, C. H. Wright . }\end{array}$ & $\begin{array}{l}3198 \\
3101\end{array}$ & $\begin{array}{c}\text { Crassula a phylla, Schonl. ot } \mathrm{F}, \mathrm{G} \\
\text { Baker }\end{array}$ & 3171 \\
\hline $\begin{array}{l}\text { - Sehinziana, Aschers, et } \\
\text { Gürke. . }\end{array}$ & 310 & $\begin{array}{c}\text { yptosepalum arboreum, } E \text {. } \\
\text { Baker }\end{array}$ & \\
\hline Buddleja gynandra, MIarquand. & 3164 & — pseudotaxus, E. G. Baker. & 3196 \\
\hline
\end{tabular}


Dalbergiella Gossweileri, $E . G$. Baker nyasae, $E$. G. Baker Welwitschii, E. G. Baker.

Danthonia lappacea, Lindl.

Delphinium acutilobum, Turrill armeniacum, Stapf ex Huth holopetalum, Griseb. macedonicum, Halácsy et Charrel paphlagonicum, Huth.

Thirkeanum, Boiss.

Dianthus arborescens, Hoffmgg. .

- arboreus, $L$. . . . . Bisignani, Ten. . . . 3176 involucratus, Poir. . . 3176 rupicola, Biv. . . . . 3176 suffruticosus, Willd. . . 3176

Diclidanthera, Mart. . . . 3172

Dombeya brachystemma, MilneRedhead. parvifolia, $K$. Schum. . rosea, E. G. Baker

Dorisia, Gillespie (gen. nov.) rarissima, Gillespie

Ectrosia mutica, Hack. ex Probst

Epimedium alpinum, $L$. . . . alpinum var. pubigerum, I)C.

pubigerum, Morren et Decaisne . . .

Euphorbia epicyparissias, $E$. Mey. . . . . . . 3193 Euryops, Bullock . . . 3193 Schimperiana, Scheele . 3193

Fagus orientalis, Lipsly . . . 3137 sylvatica, $L$. . . . 3137

Ficus Bellingeri, Moore et Betcho 3187

- cylindrica, Warb. . glandifera, Summerhayes. laevis, $B l$.

3188

3188

3189

3187 $\begin{array}{ll}\text { nasuta, Summerhayes - } & 3189 \\ \text { obtusa, Hassh. } & 3189\end{array}$

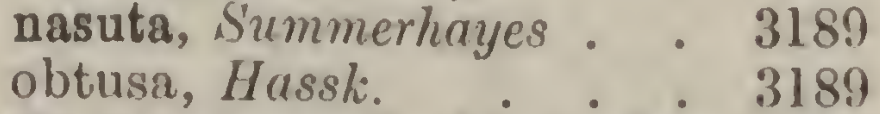
Watkinsiana, $F . M$. Bailey 3187

Fingerhuthia, Nees ex Lehm. $\quad 3122$

Genista anxantica, Griseb. . . 3154 elata, Wender. . . . 3154 clatior, Koch . . . . 3154 frutescens, Schloss. et Vuk. 3154 gracilis, Poir.

3154 sibirica, Reichb. . . . 3154

tincloria var. elata, Aschers. et Graebn.
Genista tinctoria var elatior Reichb. . . . . 3154

3154

3154

Genistoides elata, Moench • 3154

Gentiana heptaphylla, Balf. $f$. et Forrest . . . 3162

- setulifolia, Marquand . . 3162

Hemarthria compressa, R. Br. . 3139

Herpetacanthus, Nees . . . 3113

Hypericum afromontanum, Bullock . . . . . . 3192

— intermedium, steud. . . 3192

Ichnanthus, P. Beauv. . . . 3123

Isotheca alba, Turrill . . . 3113

Isotoma anethifolia, Summerhayes 3186 axillaris, Lindl. . . . $31 S 6$

Jasione bulgarica, Stoy. et Stef. . 3132 orbiculata, Griseb. . . . 3132 orbiculata var orbelica, Vel. 3132

Keetia transvaalensis, Phillips . 3170

Kingdon-Wardia codonopsidoides, Marquand . . . . . 3163

Lasiorrhachis, Stapf (gen. nov.) 3124 Hildebrandtii, Stapf . . 3124

Lecomtella madagascariensis, $A$. Camus . . . . . 3123

Leptocoryphium, Nees . . . 3125

Leptosaccharum filiforme, $A$. Camus . . . . 3125

Leycesteria subgen. Euleycesteria, Airy-Shaw . . . . subgen. Paralestera, AiryShaw . . . . 3165 sect. Fistularia, Airy-Shaw 3165 sect. Pentapyxis, Fritsch . 3165 series Crocothyrsae, AiryShaw . . . . . 3165 series Formosae, Airy-Shaw 3165 series Glaucophyllae, AiryShaw . . . . . 3165 series Stipulatae, Airy-Shaw 3165 crocothyrsos, Airy-Sthaw . 3165 formosa, Wall. . . . . 3165 glaucophylla, Hook.f. 3165, 3166 gracilis, Airy-Shaw . . 3166 stipulata, Fritsch . . . 3165

Lonicera glaucophylla, Lindl. . 3166 — gracilis, Kurz . . . . $3160^{\circ}$ Lychnis Otites, Scop. . . . 3131

Magallana porifolia, Cav. . $\quad 3150$

Mastixia, Bl. . . . . . . 3190 Mastixiodendron, Melch. $\quad$ • $\quad 3190$ 
Megaskepasma erythrochlamys, Lindau .

Miscrnthidium slupf . 3128

- 3124

Neocheiropteris palmatopedata, C. Chriat.

Waltoni, Ching

Olyra, $L$.

Onopordon clatum, Sibtli, et Sin. eriocephalum, Rouy

tauricum, Willd.

virens, J)C.

Oreacanthus Mannii, Benth.

montifuga, Milne-Redhead

Othonna euphorbioides, Iutchinson

Paraphyadanthe coriacea, Mildbr.

— flagellillora, Mildbr. . . lophoearpa, Gilg . 3168 sufiruticosa, Milne-licdhead 3168

Pavetta uniflora, Bremekamp - 3194

Pelargonium frutetorum, $K$. $A$.

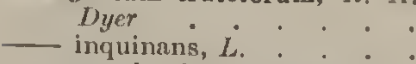

Pennisetum Basedowii, Summer. hayes et C. E. Hubbard

villosum, $R$. Br.

3123

3150

3156

3156

3156

3197

3197

3138

3168

3168

3168

3200

$3 \div 00$

3200

3185

3185

$31: 23$

Plectromia Gueinzii, Sin . . . 3170

Pleiadelphia, Slayf (gen. nov.) . $31: 1$ Gossweileri, Slapf . . . 31:1

Polypodium clathralum var. lobatum, Takeda . . . 3158 hastalum, Honsl. . . . 3158

Porpliyroeoma, Schweidw. . . 3128

Primula Duclouxii, I'etilmengin $31: 27$

Pseudoraphis paradoxa, Pilger . 3140

Pscudoscolopia Fraseri, Phillips 311!) polyantha, Gilg . . . 311!

Pterostyrax Cacaleriei, Guillaumin 3161

- eorynbosus, Sied. el Zucc. 3161 hispidus, Sieb. el Zuce. . 3161

- hispidus, WV. IV. Smith . 3161

— Leveillci, Chun . . . . 3161

Randia sootoponsis, Craib . . 3143 uranthera, C. E.C. Fischer 3143 Rhacodiscus, Lindau . . . 31:s

Rhamnus infectorius var. pubes. cens, Griseb.

3178

rumeliaceus, liriv. . . rupestris var. rumeliacus, llayek
Rhamnus saxalilis var. rhodopeus, Stoy, ct Stcf. . . . . 3177 tinetorius, $H$. el $k$. . . 3177 linclorius var. pubescens, Degen et Dörfler . . . 3177

Rhopalota aphylla, N. E. Brown 3171

Rottboellia compressa, Vanderyst 3139 exaltata, Linn. $f$. . . . 3139 purpurascens, Robyns. . 3139

Saccharum subgen. Ieptosaecharum, Hack. .

filiforme, Hack. Mine-Redhead. . . .

- melanostictum, Pax et $K$. Hoffm. . 3199

- suffirutieosum, $P a x$. . 3199

Scilla albanica, Turrill . . . 3180

- messeniaen, Boiss.. . . 3180

Scleria Barteri, Boech. . . . 3191

_- ovuligera, Rendle . . . 3191

- reflexa, Benth. . . . . 3191

Setaria Haareri. Stapf et II ubbard 3/41

- longiseta, $P$. Beauv. . . 3141

Selosa erectu, Ewart et Cookson 3140

- hordeacea, Ewart . . 3140

Sideritis euboen, Heldr. . . . 3157

- florida, Boiss. et Heldr. $\quad 3157$

scardica, Griseh. . . . 3157

Silene Otites var. pseudotites, $\mathrm{V} i \mathrm{~s}^{\circ} \quad 3131$

- pseudotites, Besscr . . . 3131

Sloanea Chingii, Hu . $\quad \cdot \quad \cdot 3159$

- dasycarpa, Hemsl. . . . - 3150

- elegans, Chun . . . . 3159

Smilax megalantha, $C^{\circ}$. II. Wright 3130

Stenopetala, A. Gray . . 3130

Sorghum, Pers. . . . . . 3124

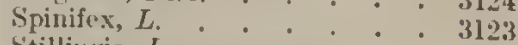

Stillingia, L. . . . . . . . $\quad$ - 3199

Struthiola epacridioides, $C,{ }^{\circ}{ }^{\circ}$ Hright..... . 3102

- erecta, $L$. . . . . . 3103

— floribunda, $\dot{C} . \dot{H}$. U'right . 3104

- longiflora, Lam. . . 3104

- longifolia, C. II. Hright - 3103

- ovata. Thunb. . . . . 3102

Strychnos diaboli, Sandwith . $\quad$. 3173

_ Melinoniana, Buill. • • 317.4

rhexioides, Klotzsch • • 3175

- Solcrederi, Gilg . . . 3174

— tomentoss, Benth. - 3173,3175 toxifera, Rob. Schomb. ex Benth.

- triplinervia, Mart • . 3175

Styrax Caraleriei, siarl.. 3173

Staverillé . . 31til

Leveillei, Fedde ex Léveillé 3161

Symplocos Maingayi, Benth. . 3144

3178 Sukoci, C. E. C. Fischer: 3144 


\section{INDEX TO THE PLATES AND NAMES}

Tamarix Hampeana var. aegaea, Turrill . . . . 3153

Taraktogenos calophylla, Ridley 3167

- Kurzii, King . . . . 3167

Teucrium brevifolium, Schreb. . 3179

charamaniense, Cav. . 3179

creticum, $L . \quad .3179$

hyssopifolium, Schreb. $\quad$. 3179

rosmarinifolium, Lam. . 3179

Thellungia advena, Stapf . $\quad 3184$

Tropacolum pentaphyllum, Lam. 3150

Umbilicus lassithiensis, Gand. . 3155

Verbascum luteo-viride, Turrill 3134 pinnatifidum, Vahl . 3134

Veronica Chamaedrys, Linn. $\quad 3118$ euxina, Turrill . . . . 3135 orchidea, Crantz . $\quad 3136$
Veronica rigida, Turrill . . $\quad 3118$

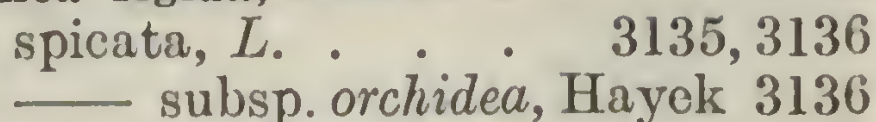

Viguierella madagascariensis, $A$. Camus et Stapf . . . 3122

Viola cazorlensis, Gand. . . . 3117

- coronifera, W. Becker . . 3147 delphinantha, Boiss. . . 3117 escondidaënsis, $W$. Becker 3148 Hillii, W. Becker . . . 3149 Košaninii, Degen . . . 3117

— sacculus, Skottsb. . . . 3148

Widdringtonia stipitata, Stapf 3126 Whytoi, Rendle . . 3126

Zygotritonia bongensis, Mildbr. . 3120 crocea, Stapf • . . . 3120 *praecox, Stapf . . . 3120 



\section{Tabula 3101.}

\section{BOOTIA MURICATA, C. H. Wright.}

\section{HYDROCHARITACEAE.}

B. muricata, C. II. Wright in Thisellon-Dyer, Fl. Trop. Afr. vol. vii. p. 569 ; speeies $B$. Sehinziance, $\Lambda$ sehers. et Gürke, affinis, spatha eylindrica breviore murieata differt.

Planta aquatiea, floribus exceptis submersa. Folia lanceolata, acuta, integra, cireiter 7 -nervia, $22 \mathrm{em}$. longa, $4 \mathrm{em}$. lata; petiolus clongatus, inermis; vagina $15 \mathrm{~cm}$. longa, muricata. Flores maseuli solitarii ; pedunculus metralis vel ultra, murientus ; spatha eylindrica, bilobata, muricata, $6 \cdot 5 \mathrm{em}$. longa. Calyeis tubus, $8 \mathrm{~cm}$. longus, $2 \mathrm{~mm}$. diametro, eylindricus; lobi lineares, obtusi, $2 \mathrm{em}$. longi, $3 \mathrm{~mm}$. lati, virides. Petala obovata, alla, $3 \mathrm{~cm}$. longa, $2 \cdot 5 \mathrm{~cm}$. lata. Antherae oblongac, luteac. Flos femineus ignotus.

Soutu Tropical, Africa. Ngamiland: Botletle River, $F$. D. and E. J. Lugard, 13; Okarango River, E. J. Lugard, 279 ; River Chobe, Atherstone, 35, MeCabe, 33. Rhodesia: Kafue River, C. E. H'. Allen, 329.

This speeies was first diseovered by Dr. Atherstone in 1856 , but the material he collected was insufficient for speeific deseription, and it was not until 1896 that adequate material for that purposc was eolleeted by Major F. D. and Licut. E. J. Lugard. Since then speeimens with leaves have been found, bit the female flower is still unknown. The plant ineluding the leaves is submerged to within 2 or 3 inehes of the flowers, whieh alone protrude into the air, and grows in water 10 to 12 feet deep. The ncarest ally of this species is B. Sehinziana, Asehers. ct Gürke, which has smaller thicker leaves and shorter ovoid spathes.C. H. Wright.

Fia. 1, leaf, nalural size; 2, male flower, natural size; 3, stamen, much enlarged. 



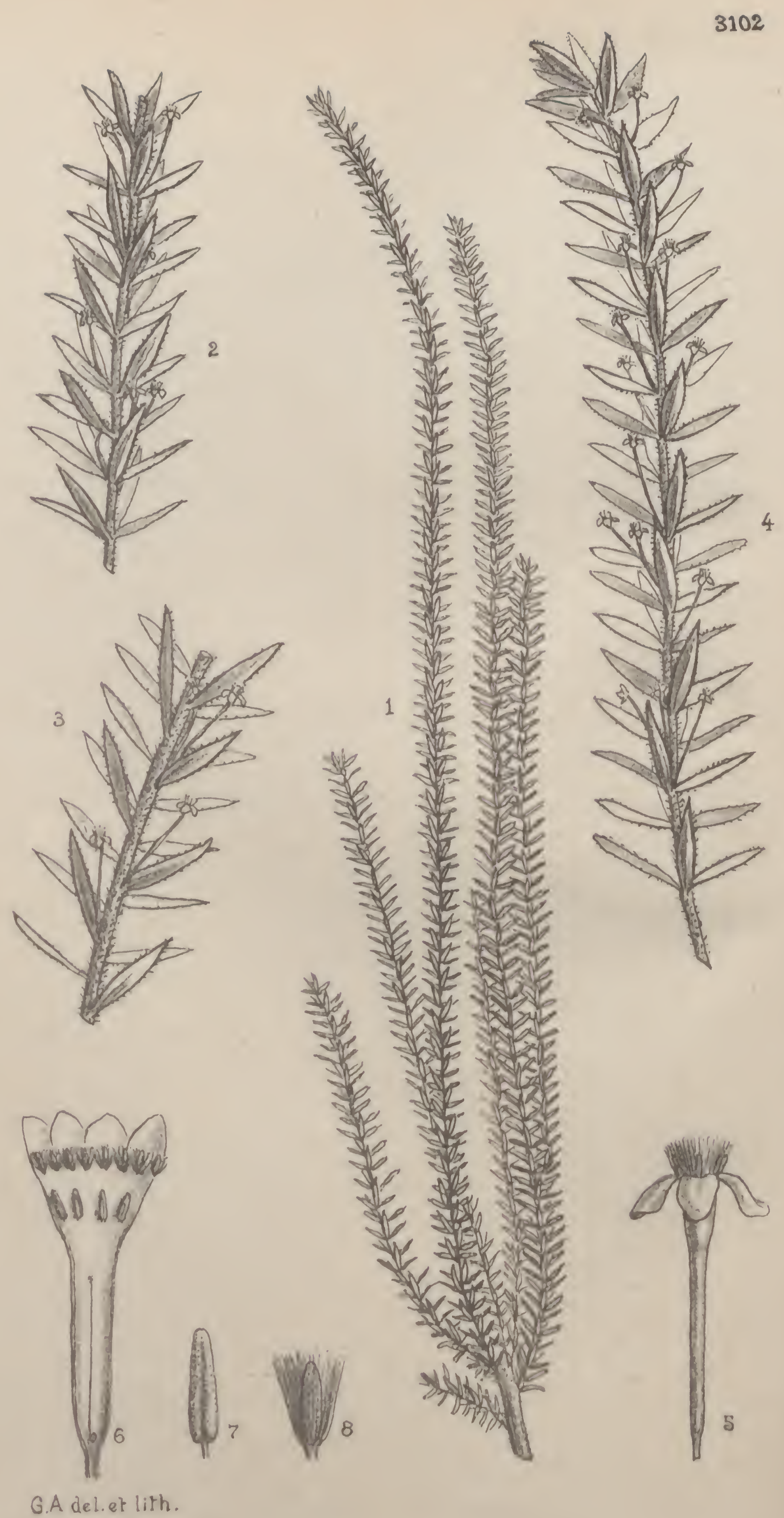


\section{TABULA 3102.}

\section{STRUTHIOLA EPACRIDIOIDES, C. H. Wright.}

\section{Thymelaeaceae. Tribus Euthymelaeeae.}

S. epacridioides, C. II. Wright in Kcw Bulletin, 1915, p. 387, and in Thisellon-Dyer, Fl. Cap. vol. v. sect. 2, 1. 29 ; species $S$. ovalae, Thunb., affinis, foliis patentibus floribusque in axillis fere foliorum omniun dispositis differt.

Rami longi, primum pilosi, denum glabri. Folia patentia, lanccolata, plana, acuminata, $1 \cdot 2 \mathrm{~cm}$. longa, $3 \mathrm{~mm}$. lata, marginibus ciliatis. Flores axillares; bractcolac fere $4 \mathrm{~mm}$. longae, subulatac, leviter recurvac, eiliatae. Calycis tubus subreetus, glaber, $1.4 \mathrm{~cm}$. longus, $0.7 \mathrm{~mm}$. diametro ; lobi ovati, obtusi, $2 \mathrm{~mm}$. longi, $1.5 \mathrm{~mm}$. lati. Pelala $8,1.5 \mathrm{~mm}$. longa, pilis aequilongis circumdatis instrueta. Antherae breviter oblongae, paullo super ealycis faueen affixae. Otarium oblongum, glabrum; stylus filiformis, calycis tubo brevior; stigma penicillatum.

Soutu AFrics, without precise locality, Mund, 19.

This is a very distinct species with the general apjearance of an Epacris. It difiers from its ncarest ally, $S$. orula, Thumb., in bcaring flowers in the axils of most of the leaves, instead of their being congested into an infloreseenec at the apex of the stem, and thus nust be a very attractive plant when in flower. The fleshy petals are entirely surrounded by hairs. It is unfortunate that Mund, who collceted between 1827 and 1829 , las not recorded the locality where he collected this plant.-C. II. Wrignt.

lik. 1, portion of the plant to show branching, reduced; 2,3 and 4 , portions of flowering branches, natural size; 5, entire flower, enlarged three times; 6 , flower cut open, enlarged ; 7, anther, enlarged; 8, petal, enlarged four times. 




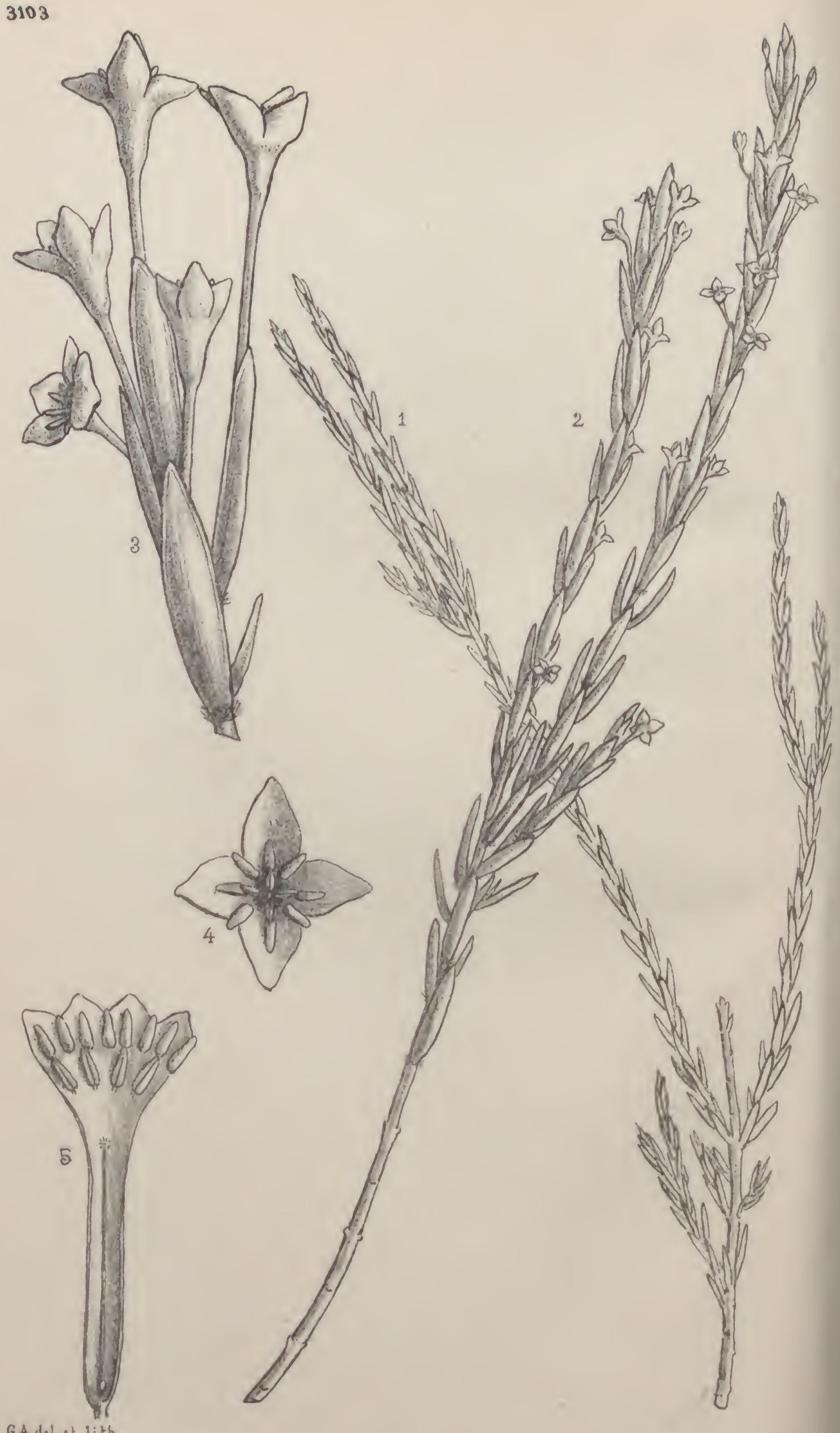




\section{Tabula 3103.}

\section{STRUTHIOLA LONGIFOLIA, C. II. Wright.}

\section{Thimmeaneaceae. Tribus Eutirymeianeae.}

S. longifolia, C. H. Wright in Kew Bulletin, 1915, 1. 389, and in Thiselton-Dyer, $F$. Cap. vol. v. seet. 2, p. 33 ; affinis S. erectae, L., foliis oblongis duplo longioribus differt.

Planta lignea, ramosa. Rami erecti, virgati, quadrangulares, glabri, ciea trieibus prominentibus foliorum delapsorum vestiti. Folia oblonga, acuta, glabra, 1.2-1.4 cm. longa, 1-2 $\mathrm{mm}$. lata. Flores in axillis foliorum plurium dispositi; bractcolae oblongae, obtusae, earinatac, glabrar, 5 mm. longae, narginibus membranaeeis. Calyx glaber; tubus parte inferiore eylindrieus, parte superiore inflatus, $1.2 \mathrm{~cm}$. longus; lobi ovati, aeuti, apice inerassati, $3 \mathrm{~mm}$. longi, $2 \mathrm{~mm}$. lati. I'etule 8 , carnosa, glabra vel basi pilis paueis brevibus vestita. Antherae connectivo aento coronatac. Oiarium oblougum; stylus filiformis, $1 \mathrm{em}$. longus; stigna penicillatum.

Sou'u Aruca. Caledon Division: Zoetemelks Valley, Burchell, 7578 .

This spreies is allied to $S$. erecta, Is., but has the leaves at least twice as long in proportion to their widtl, and its flowers are borne in the axils of the leaves for a long distanee down the stem, while those of $S$. erecta are gencrally confined to the regiou near the apex, thus giving a different facies to eaeh species. Further, the petals of $S$. ercela are surrounded by lairs as long as themselves, while those of $S$. longifolia are either glabrous or seautily hairy. Meisner has written on the sheet of Burchell's 7578 "Strwhioln erecta var. vulgaris, Meisn.," but it is a totally difierent plant from 13ureliell's 208 from the Cape Wlats, on which he has written the same name.-C. H. WrignT.

Fia. 1, portion of plant to show branching, reduced; 2 , upper part of plant, nalural size; 3 , npex of floweling brunch; 4, flower seen from above; 5 , flower laid open; tho last threo much enlarged. 

-

.

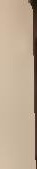

.

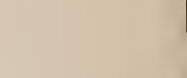

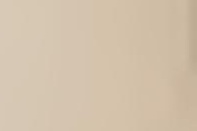

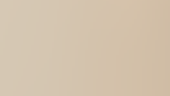

(n)

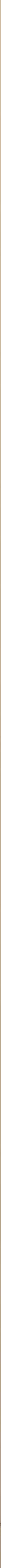


3104

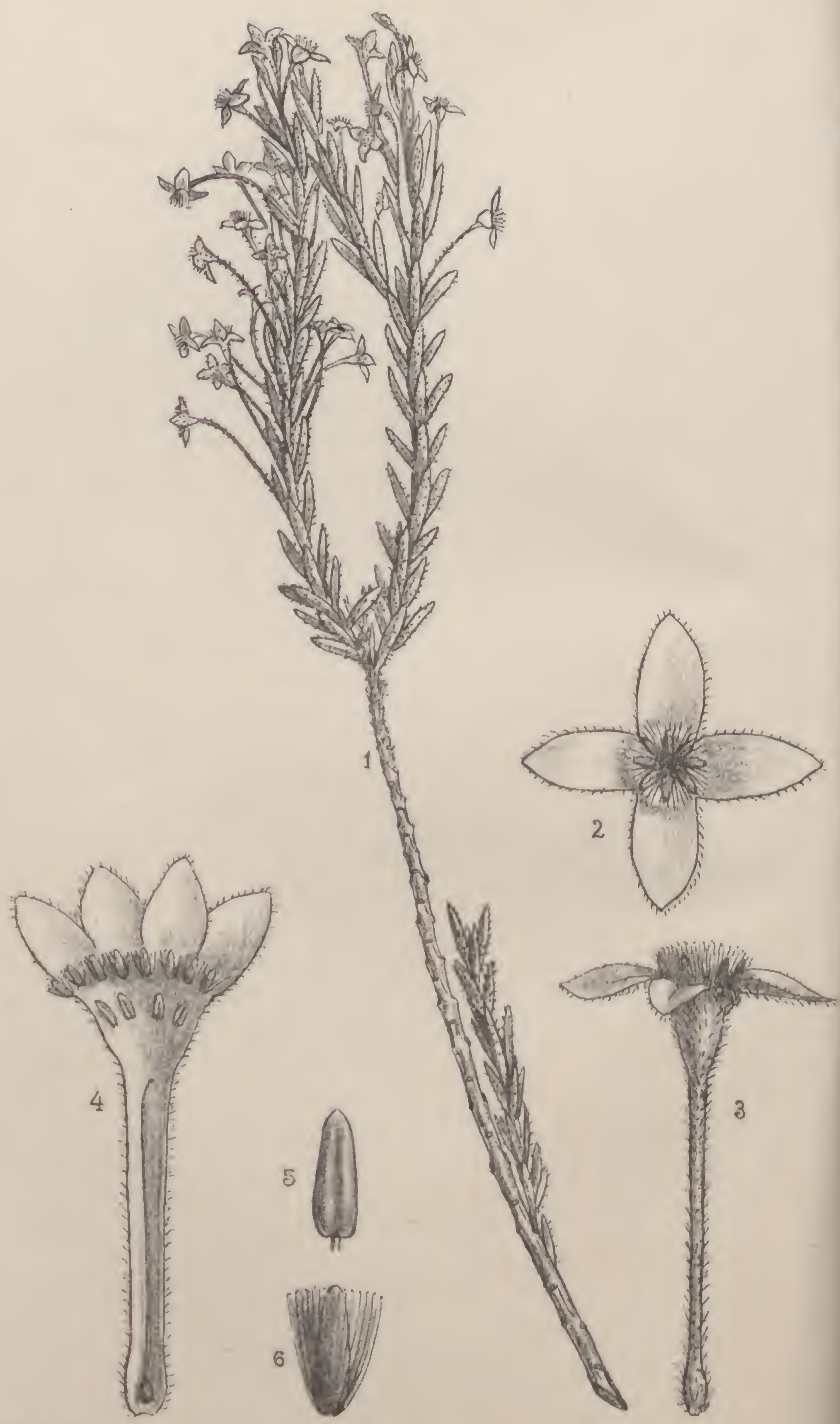

GA. del.et lith 


\section{TABULA 3104.}

\section{STRUTHIOLA FLORIBUNDA, C. H. Wright.}

Thymblafenae. Tribus Futhymelaeeae.

S. floribunda, C. II. Wright in Kew Bulletin, 1916, p. 43, and in Thiselton-Dyer, Fl. Cap. vol. v. seet. 2, p. 35; species S. longiflorae, Lam., affinis, foliis oblongis, obtusis, pilosis differt.

Caulis ramosus, ligneus; rami primum pubesentes. Folia opposita, approximata, oblonga, obtusa, $7 \mathrm{~mm}$. longa, $1.5 \mathrm{~mm}$. lata, primum pilosa, demum dorso verrucosa. Flores axillares, sceundum ranos dispositi ; bracteolac $6 \mathrm{~mm}$. longae, $0.6 \mathrm{~mm}$. latae, oblongae, obtusae, longe eiliatae. Calyx pubeseens; tubus tenuis, $1.7 \mathrm{em}$. longus; lobi oblongi, obtusi, $5 \mathrm{~mm}$. longi, $2 \mathrm{~mm}$. lati. Pelala 8 , oblonga, $1.5 \mathrm{~mm}$. longa, pilis nequilongis circumdata. Antherae obtusae. Ovarim oblongum, glabrun! ; stylus filiformis, $9 \mathrm{~mm}$. longus ; stigna penieillatum.

Soutu AFica. ('lanwilliam Division: Zekoe Vley, Schlecher, 8506. Without loeality, MacOwan, 2470.

This speeies is allied to the widely spread $S$. longiflora, Lam., whieh differs in having ovate- or linear-laneeolate aeuminate leaves, which are eiliate in the early stage. The hairs at length break away from $S$. floribunda, leaving asperities on the back of the leaves. The numerous flowers elustered at the ends of the branehes must make this a beautiful objeet, and it is a matter for regret that so few of the showy-flowered members of this family have found their way into cultivation.-C. H. WRIGITT.

Fic. 1, portion of plant, nalural size; 2 , flower soon from above; 3 , flower seen from sido; 4, flower cut open; 5, anther; 6 , petal with surrounding hairs, 2-6 much enlurged. 




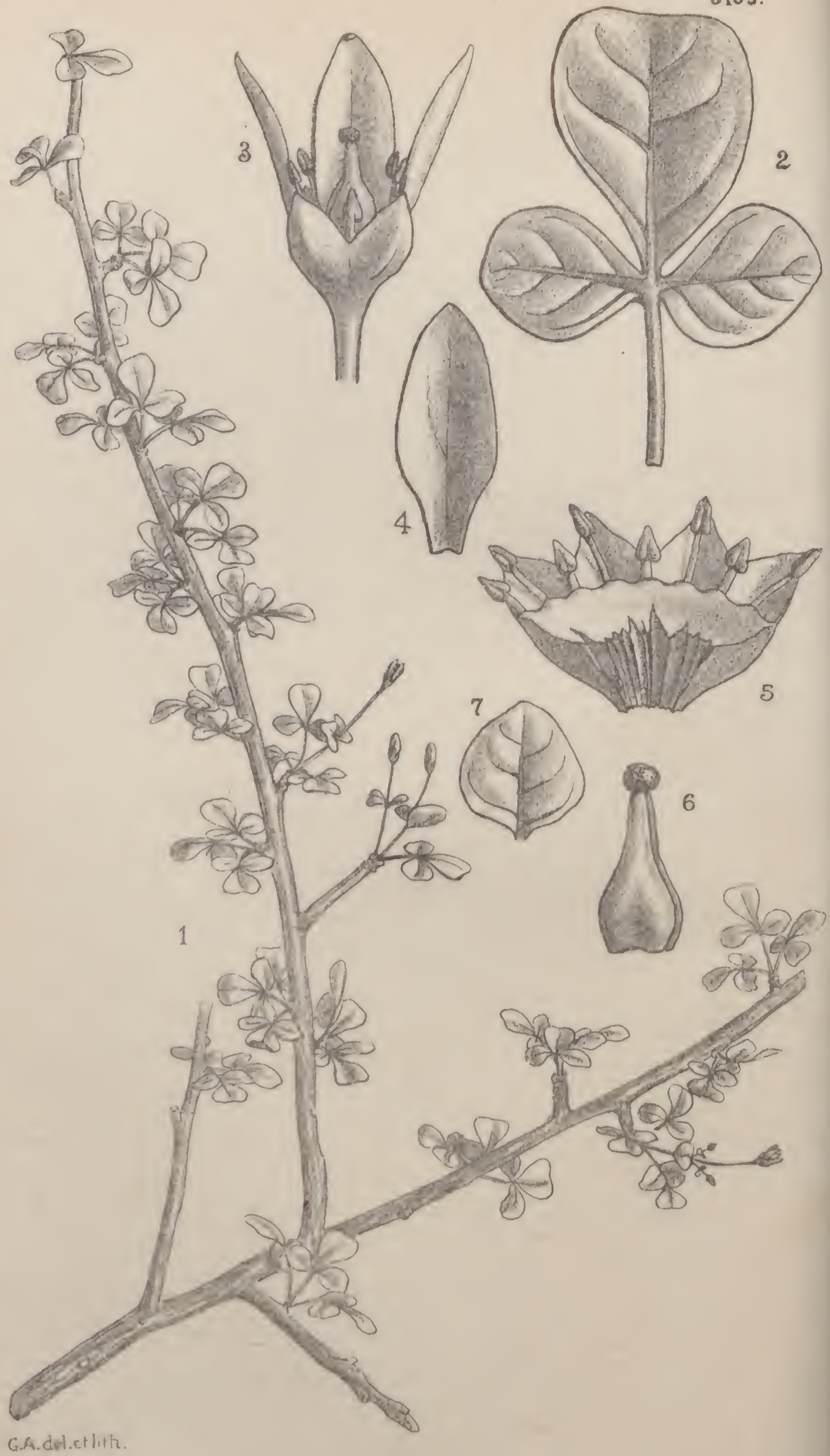




\section{Tabula 3105.}

\section{COMMIPHORA FOLIACEA, Sprague.}

\section{Burseraceaf.}

C. foliacea, Sprague; specics nova, affinis C. Opobalsamo, (T..) Engl., a qua pedunculis longis gracilibus, bracteolis inagnis foliaccis, pediccllis longis gracilibus recedit.

Ramuli incrmes, leviter flexuosi, longitudinaliter rugoso-costatuli, fusci, glahri, satis gracilcs, eirciter $3 \mathrm{~mm}$. diametro $15 \mathrm{~cm}$. infra apices. Ramuli abbreriati usque ad $1.5 \mathrm{~cm}$. longi, plerunque multo breviores, cicatricibus foliorum asperati, apice minutc pilosi, folia plura et interdum infloresentias 1-2 gcrentes. Folia trifoliolata, $0 \cdot 5-1.5 \mathrm{~cm}$. longa, glabra; petiolus graeilis, 2-9 mm. longus; foliolia sessilia, terminali quam lateralibus najore; foliolum terminale olsovatum vel cuncato-obovatum, apice obtusum usque ad subtruneatum, in basin cuncato-angustatum, in foliis majoribus 5-10 $1 \mathrm{~nm}$. longum, 4.5-7 mm. latum; foliola latcralin late obovata vel suborbicularia, apicc obtusa vel rotundata, intcrdum apiculata, basi plus minusve inacquilatcralia, in foliis majoribus 3-6 $\mathrm{mm}$. longa, $2 \cdot 5-5 \mathrm{~mm}$. lata ; nervi lateralcs utrinsecus 3-4; areuato-patuli, procul a marginc indistincte anastomosantes. Pedunculi plerumque 1-flori, rarius 3-flori, 0.5-1 cm. longi, graciles, apice bractcolas 2 gerentes. Bracteolac foliaceac, suborbicularcs, apiec obtusac rotundatae vel rctusac, interdum apiculatac, basi rotundatac vel levitcr cordatac, $2 \cdot 5-5 \cdot 5 \mathrm{~mm}$. diametro, glabrac. Pedicelli floris solitarii vel terminalis graciles, circitcr $1 \mathrm{~cm}$. longi, superne in basin floris sensim ampliati ; pedicclli florum latcralium inultotics breviores. Flores 0 : Calycis tubus cupularis, $0.8 \mathrm{~mm}$. longus; lobi $0.6 \mathrm{~mm}$. longi. Petala lanccolato-oblonga, apice uncinatoinflexn, $3.2 \mathrm{~mm}$. longa partc inflcxa $0.3 \mathrm{~mm}$. longa cxclusa. Stamina antcpctala $1.8 \mathrm{~mm}$. longa; anthcrac ovato-oblongac, obtuse apiculatac, $0.75 \mathrm{~mm}$. longac; stamina autcsepala longiora. Discus intrastaminalis crenulatus, calycis tubum vesticns. P'istillodium minimum, inn basi calycis tubi situm. Flores o : Calyx cxtra minuto sparse pilosulus; tubus patelliformis ; lobi deltoidci, $0 \cdot 7-0 \cdot 8 \mathrm{~mm}$. longi, obtuse carinati. Staminodic antesepalia $1.5 \mathrm{~mm}$. longa, antherodiis oblongis, antcpetala $1 \mathrm{~mm}$. longa, anthcrodiis ovato-acuminatis. Iniscus intrasteminodialis crenulatus, ercnis cun staminodiis altcrnantibus. Pistillun vix ultra 
$2 \mathrm{~mm}$. longum; ovarium ellipsoideum, $1 \mathrm{~mm}$. longum, vix $1 \mathrm{~mm}$. diametro, bisulcatum; stylus $1 \mathrm{~mm}$. longus; stigma capitatum, indistincte bilobum, circiter $0.5 \mathrm{~mm}$. diametro.

Arabia. At the foot of the Dhofar Mountains, S.E. Arabia, Bent, 137 (type).

C. foliacea is remarkable for its foliaceous bracteoles, which with the slender peduncles and pedicels serve to distinguish the species from C. Opobalsamum, (L.) Engl., with which it has hitherto been identified.-T. A. Sprague.

Fig. 1, branch with short-shoots bearing leaves and inflorescences; 2, leaf; 3 , female flower with one of the petals remover; 4 , petal; 5 , interior of female flower, with the petals and pistil removed ; 6 , pistil; 7, a bracteole. All enlarged except $\mathrm{l}$, which is of natural size. 


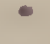




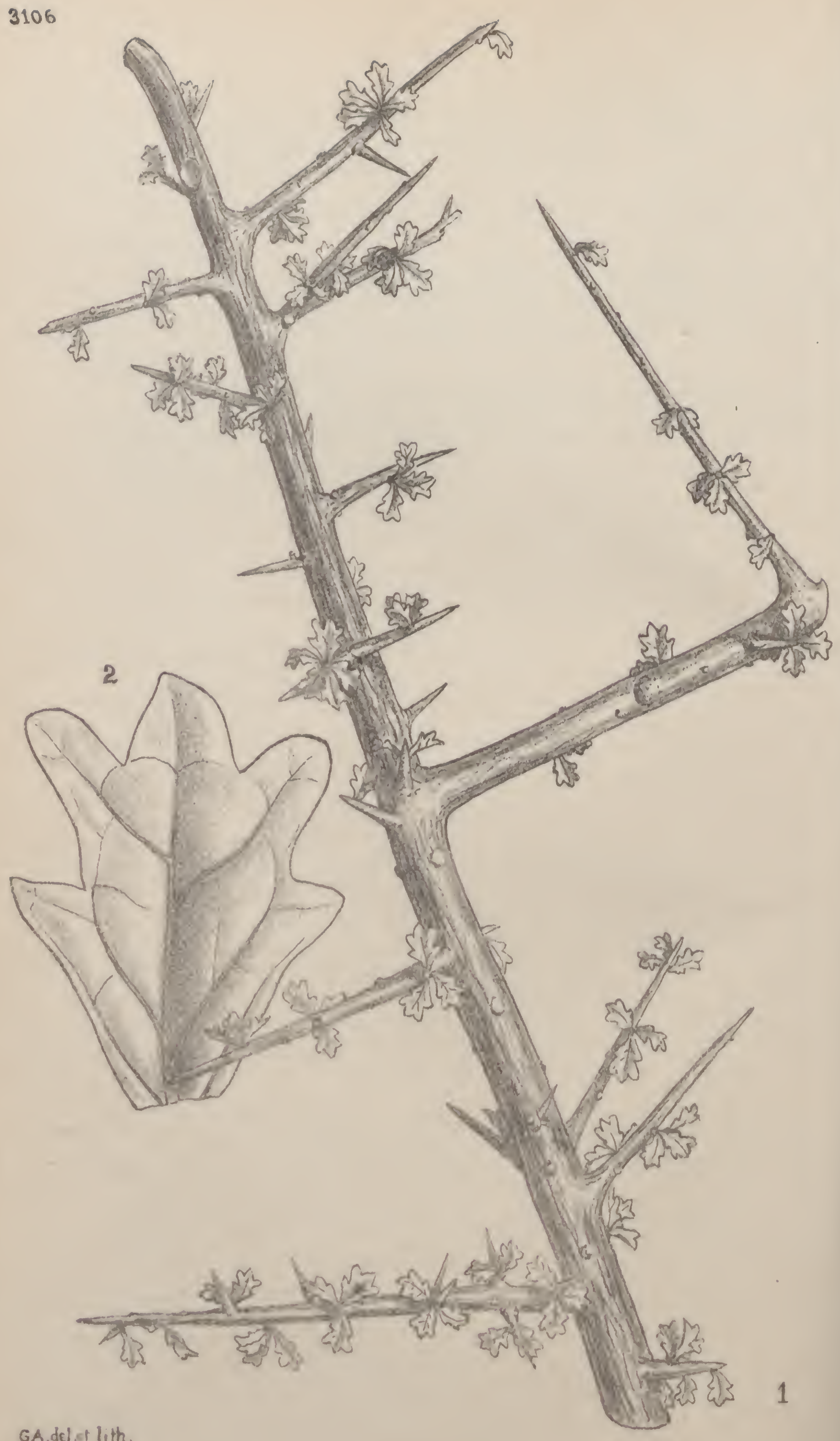

GA.delst lith 


\section{TABULA 3106.}

COMMIPHORA CANDIDULA, Sprague.

\section{BURSERACFAE.}

C. candidula, Sprague; species nova affinis C. flatiflorac, Engl., a qua eortice ramulorum candidulo, foliis multo minoribus et pro rata inagis incisis reecdit; a $C$. crenulala, Chiov., forma et magnitudine foliorum differt.

Arbuscula valde spinosa, $1 \cdot 8-2 \cdot 1 \mathrm{~m}$. alta. Rami subreeti, erassi, circiter $8 \mathrm{~mm}$. diametro $20-25 \mathrm{~cm}$. inf ra apices, longitudinaliter rugosi, eeterum lacves, glabri, fuseo-cinerei, juniores candiduli : internodia plerunque $0 \cdot 5-1 \mathrm{~cm}$. longa ; ramuli patentes spina valida terminati, $1-8.5 \mathrm{em}$. longi, ina basi $2-3.5 \mathrm{~mm}$. diametro, a basi usque ad apieem sensim angustati, plus minusve longitndinaliter rugosi, candiduli, glabri; ramulorum internorlia plerumique $3-5 \mathrm{~mm}$. longa. Ramuli abbreviati initio perbreves, applanati, breviter rufo-pilosi, demum lente acereseentes ad $2 \mathrm{~mm}$. longi, interdum tanden in ramulum spiniformem flus minusve elongatum ereseentes. Folia ad ramulos abbreviatos plura, faseieulata, sessilia, enneiformi-obovata, $4-7 \mathrm{~mm}$. longa, 3-5 mm. lata, superne grosse ineiso-dentata, inferne integra, in basin angustata, ehartaeea, glabra, supra nervo medio et nervis lateralibus leviter elevatis, subtus pallicliora, nervis reteque venularum fuscis itacjue manifestis; dentes flerumque ovati, $0 \cdot 75-1.5 \mathrm{~mm}$. longi. Flores et fruclus ignoti.

Britisn Somatlland. Ilaud Distriet, Drake-Brocliman, 799 (type).

C. caudidula belongs to $\S$ Subsessilifoliue, kngl. in Engl. Jalırb. vol. xlviii. p. 460 (1912), and is easily distinguishable from the other species of this Series by its sniall cunea te-obovate deeply ineised leaves.

It is a thorny tree, growing to a leight of 6 or 7 feet, and ealled Rahanreb by the Somalis. It yields a very dark yellowish-red bdellium known as Habbak Rahanreb (vide Drake-Brockman, British Somaliland, p. $317:$ 1912).-T. A. Srragur.

Fia. 1, lenfy branch and branchlets, natural size; 2, a leaf, enlarged. 

S.

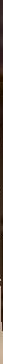




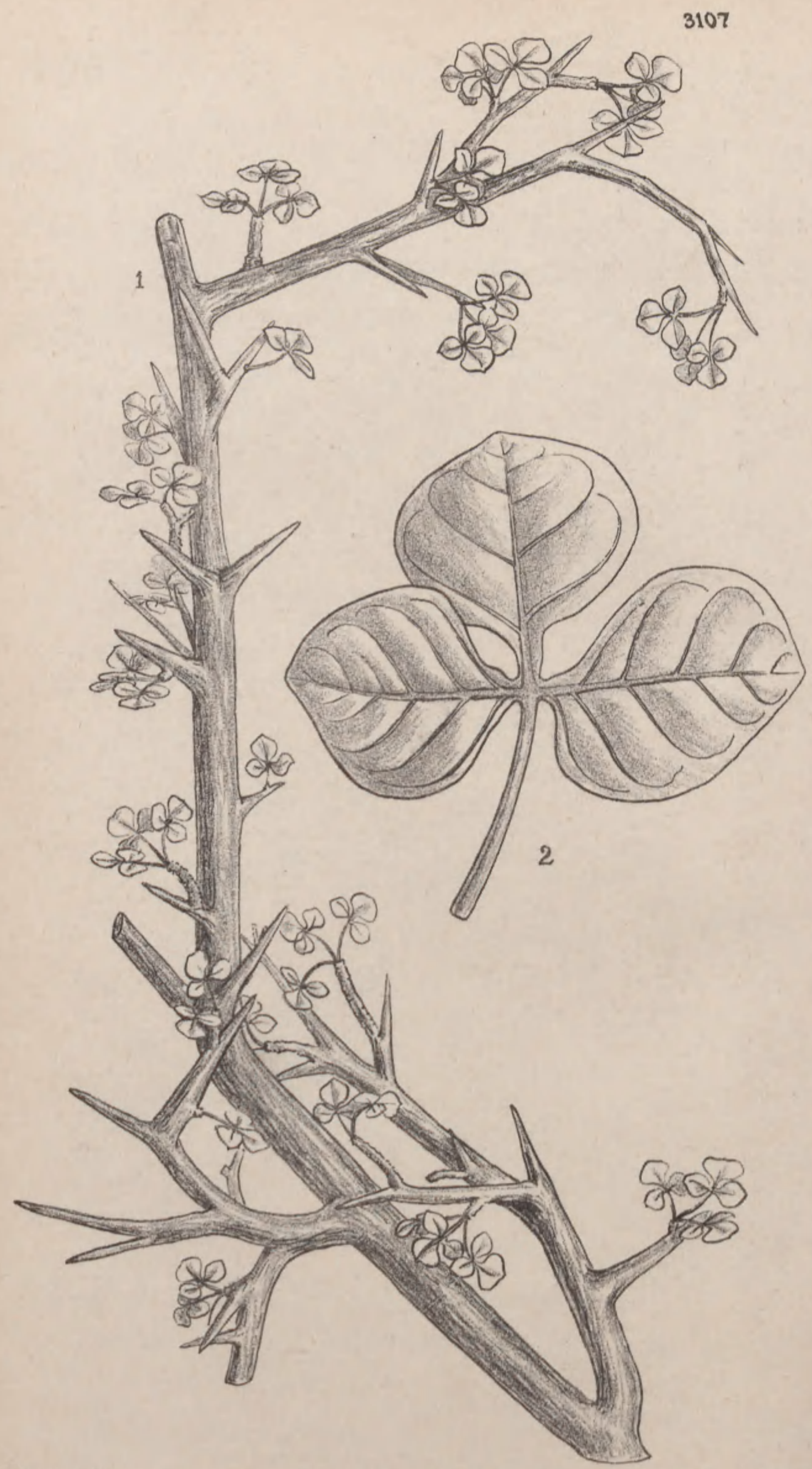

G.A.del.et lith. 


\section{Tabula 3107.}

COMMIPHORA CRASSISPINA, Sprague.

\section{BuRSERACEAE.}

C. crassispina, Sprague; speeies nova, forsan e Serie Orbicularium, spinis nigris brevibus in basin valde inerassatis, foliis eutrifoliolatis glabris, foliolis subintegris, lateralibus oblique ovatis obtusis distineta.

Dumus parvus, nigrescens, intricate ramosus, spinosus, glaber. Rami seniores exstantes $5-7$ mm. diametro, leviter flexuosi, longitudinaliter rugosi, fuseo-nigrescentes; ramuli spiniformes $1-10 \mathrm{em}$. longi, basi $2 \cdot 5-7 \mathrm{~mm}$. dianetro, satis reeti, spinn valisla pungente terminati, spinas ordinis inferioris et ramulos abbreviatos foliatos gerentes. Ramuli abbreviati initio brevissini, pulviniformes, tandem usque ad $1.5 \mathrm{~cm}$. longi, basi $2-2.5 \mathrm{~mm}$. diametro, irregulariter rugosi, eieatrieibus foliorum subasperati. Folia trifoliolata, foliolis sessilibus; petiolus gracilis, 7-8 mm. longus; foliolum terminale transverse elliptienu, apiee obtusissimum, in basin abrupte breviter euneatum, usque ad 8-9 mm. longum, et 9-10 mm. latum, integrum vel brevissime erenulatum ; nervi laterales utrinseeus cireiter 4 , e basi patula areuatoaseendentes, satis procul a llargine anastomosantes, rete venularum utrinque manifesto erebro venulis translueentibus; foliola lateralia late ovata, apiee obtusissima, basi inaequilateralia, dimidio versus basin petioli speetante basi rotundato, dimidio altero basi oblique aseendente, usque ad $9 \mathrm{~mm}$. longn, et 7-8 $\mathrm{ulm}$. lata; petioli et foliola supra juventute minute papillato-pilosi, demun glabreseentes. Fructus (immaturi tantum visi) breviter peduneulati et pedieellati ; peduneulus $1 \mathrm{~mm}$. longus; pedieellus $3 \mathrm{~mm}$. longus, vix $1 \mathrm{~mm}$. supra basin bibracteolatus.

\section{Britisi Somalitand. Nogal Valley, Drake-Brockman, 770 (type).}

C. crassispina is a well-marked speeies whieh may provisionally be referrerl to § Orbiculares, lingl. in lingl. Jahrb. vol. xlviii. p. 454 (1912). This and \$ Socotranac, Engl., l.e., are, however, elosely allied, and may have to be united when they are better known. C. crassispina has the outrifoliolate leaves of the Orbiculares, but the leaflets are sometimes shortly erenilate, and the short-shoots reseinble those of $C$. socotrana, (I. B. Balf.) Engl, whieh is probably its nearest ally. 
It is a small black thick-set thorny bush, with very black and stout thorns. The Somali name is Aliboy, and it yields a gum known as Habbak Aliboy, which is at first quite clear and colourless, but when old becomes semi-opaque (vide Drake-Brockman, British Somaliland, p. 318 : 1912).-'T. A. Sprague.

FIG. 1, leafy branch, natural size; 2, leaf, enlarged. 



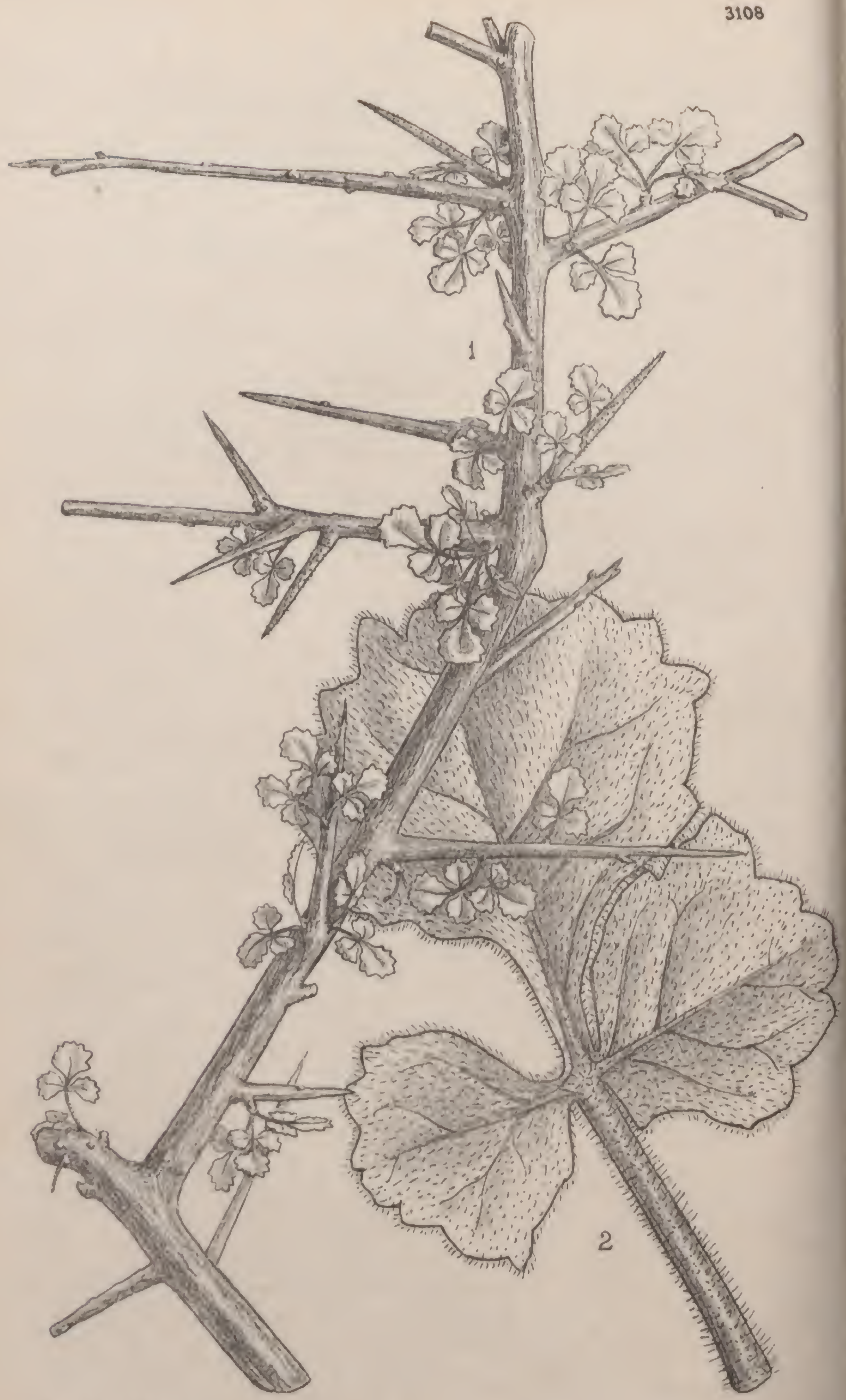

G.A.del.et lith. 


\section{Tabula 3108.}

\section{COMMIPHORA TUBUK, Sprague.}

\section{Burseraceae.}

C. tubuk, Sprague; species nova affinis $C$. truncatae, Engl., sel spinosa, ramulis foliisque patenter pilosis, foliis minoribus, foliolo terminali orbieulari-obovato rotundato.

Arbusculu usquo ad $1.8 \mathrm{~m}$. alta vel ultra, valde spinosa, cortice trunci et ramorum majormun flavo exfoliante. Rami seniores exstantes fusci, rugosuli, glabrati, ciroiter 7-8 $\mathrm{mm}$. diametro $15 \mathrm{~cm}$. infra apices, ramulos plus minusve elongatos spiniformes et ramulos abbreviatos inermes gerentes ; ramuli spiniformes $1 \cdot 5-13 \mathrm{em}$. longi a basi ad apieem angustati, primum fulvi, costati, dense patule pilosi. domum fusoobrunnei, glabrati. Lameli abbrevinti initio pulviniformes tandem usque ad $0.5 \mathrm{~cm}$. longi, basibus foliorum persistentibus asperati, nigreseentes, apice jilosi, interdum serius in ramulos spiniformes crescentes. Folia trifoliolata, 1-2 cm. longa; petiolus $4-7.5 \mathrm{~nm}$. longus, flense patule pilosus ; foliola grosse irregulariter erenato-serrata, densiuseulo pilosa, pilis suberectis; foliolum terminale obovatoorbieulare, suporne late rotundatum, in basin abrupte anguste cuneatum; foliola lateralia oblique elliptieu, dimidio versus basin petioli spectante majore basi truncato vel rotundato, dimidio altero - basi oblique aseendente. Fruelus unicus exstans sessilis, oblique ovoideus, aliquantum jlano-convexus, $7 \mathrm{~mm}$. longus, glaber.

Britisi Somaliland. Haud District, Drake-Brockman, 780.

C. tubuk bolongs to § Pilosac, Engl. in Engl. Jahrb. vol, xlviii. p. 464 (1912), and is olosely related to C. truncata, Engl., from which it differs in the presence of spines. the shape of the terminal leaflet, and the spreading indumentum of the branclilets and loaves.

"The tree grows to a height of six feet or more. The bark of the trunk and larger branches is of a yellow colour and usually seen to be peeling off. It is found in the Haud, Western Nogal Valley, and Ogadyn,

The Somali name of the tree is Tuluk, and it yiolds a rare gum known as Habbak Tubuk (vide Drake-Brockman, British Somaliland,
p. 320 : 1912).-T. A. Spracue.

Fia. 1, leafy branch, nalural size; 2, leaf, enlarged. 



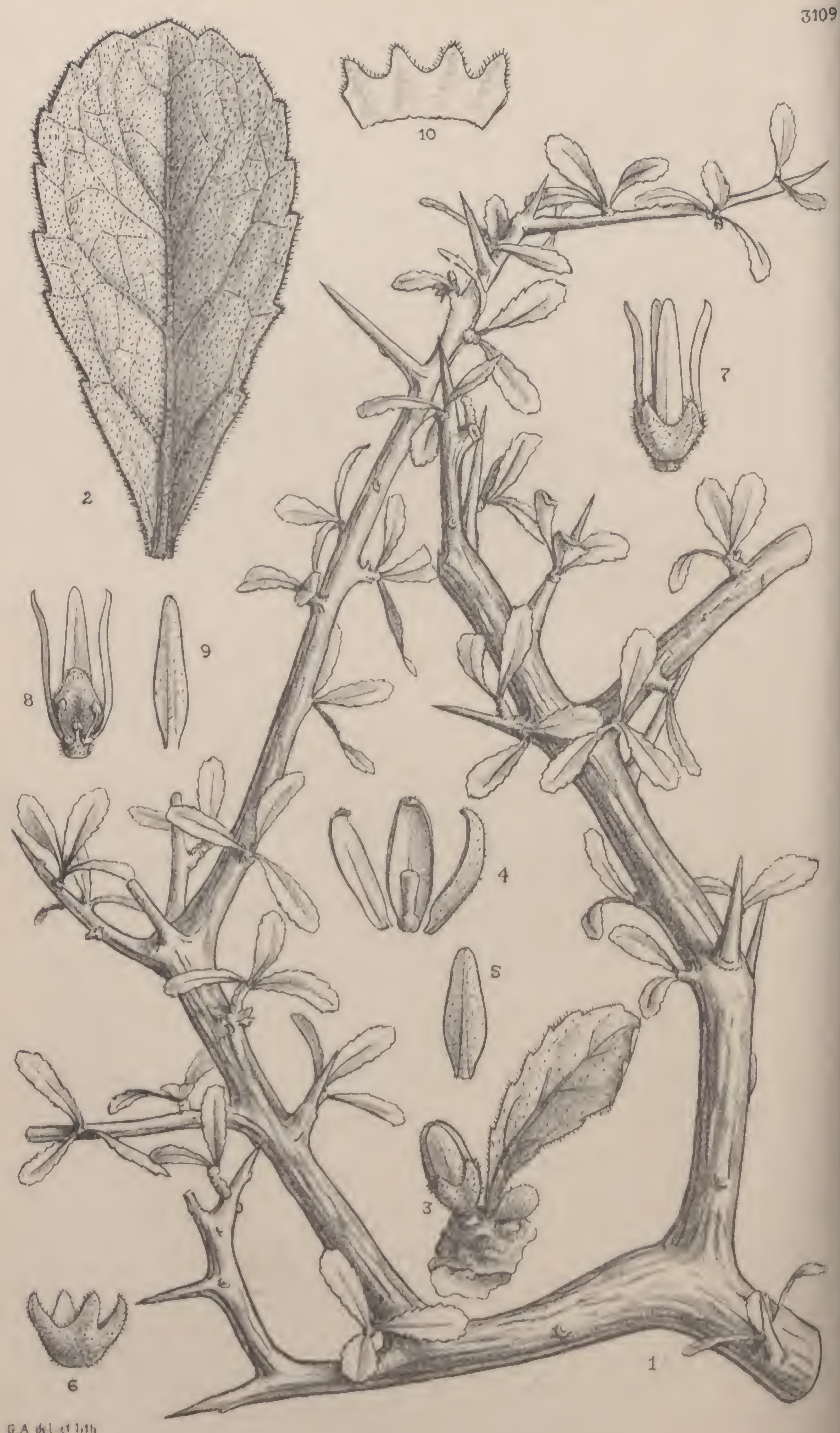




\section{Tabula 3109.}

\section{COMMIPHORA GOWLELLO, Sprague.}

\section{Burseraceat.}

C. gowlello, Sprague; species egregia, foliis sessilibus simplieibus breviter dense pilosis erenato-serratis, floribus sessilibus facile dignoseendia.

Arbuscula 1-1.51n, alta, spinosa. Remi erassi, fusei, longitudinaliter rugosi, glabrati, seniores exstintes basi fere 1 cul. diametro; ramuli patuli, plerumque subrecti, citius seriusve spina valida pungente terminati, 1-23 em. longi, ramulns spiniformes vel spino terminatos et ramulos abbreviatos gerentes, juniores costati, einerei, dense mimute pilosi. Ramuli ahbreviati usque arl 1 en. longi, basi $1 \cdot 5-2 \cdot 5 \mathrm{~mm}$. diametro, rugosi et cicatricibus foliorum asperati, apice breviter pilosi. Folia sessilia, simplicia, anguste obovata, plerumquo oireiter $1 \mathrm{em}$. longa et 5-6 mu. lata, apice rotundata, in basin euncatim angustata, conspieue erenato-serrata, utrinque breviter dense pilosa; nervi laterales utrinsecus cireiter 4 , obliqui, procul a margine anastonosantes, subtus manifestiores; rote veriulirum in sicco oceultum. Flores versus apices ramulormm abbreviatorun sessiles. Flores o : Calyx cupularis, extra dense pilosus; lobi anguste triangulares, cireiter $0.8 \mathrm{~mm}$. longi. I'etala extra pilosa, enrinata, vix ultra $2.5 \mathrm{~mm}$. longa, 0.75 inn. lata. Stamina in flore dissecto cxesa. Pistillorlinm stylodio mingno quan parte basali latiore. Flores o: Calycis lobi eirciter $0.6 \mathrm{~mm}$. longi. Pelala eireiter $3 \mathrm{~mm}$. longa. Staminodia antesepala cireiter $0.75 \mathrm{~mm}$. Jonga, antepetala duplo breviora. Orarium late ovoideum stigmate sessili. Fructus ignoti.

Britisil Somalilan1). Haud Distriet, Drake-Brockman, 800 (type).

C. goulello eannot be placed satisfactorily in any of the Series of Commiphora as defined by Engler in Engl. Jahrl). vol. xlviii. 1. 451 (1912), but may be attached provisionally to $\$$ Subsessilifoliae, near C. Seineri, the only species of that Series having pilose leaves.

The specifie name of $C$. gowlello is the Somali name of the tree, which yields a pale opaque bitter gum known as Habbak Cowlello, used by the Sommalis in the preparation of ink (vide Drake-Proekman, British Somaliland, p. 317 : 1912).-T. A. Sprarul.

Fia. 1, branch; 2, leaf; 3, short-shoot, bearing a leaf and flower-buds; 4 , petals and pistillode of male flower; 5 , petal from back; 6 , calyx; 7 , fomale flowor ; 8 , female fluwer, with calyx and one petal removed; 9 , petal from back; 10 , calyx laid open. All enlarged, excepl 1 , which is of nalural size. 


.




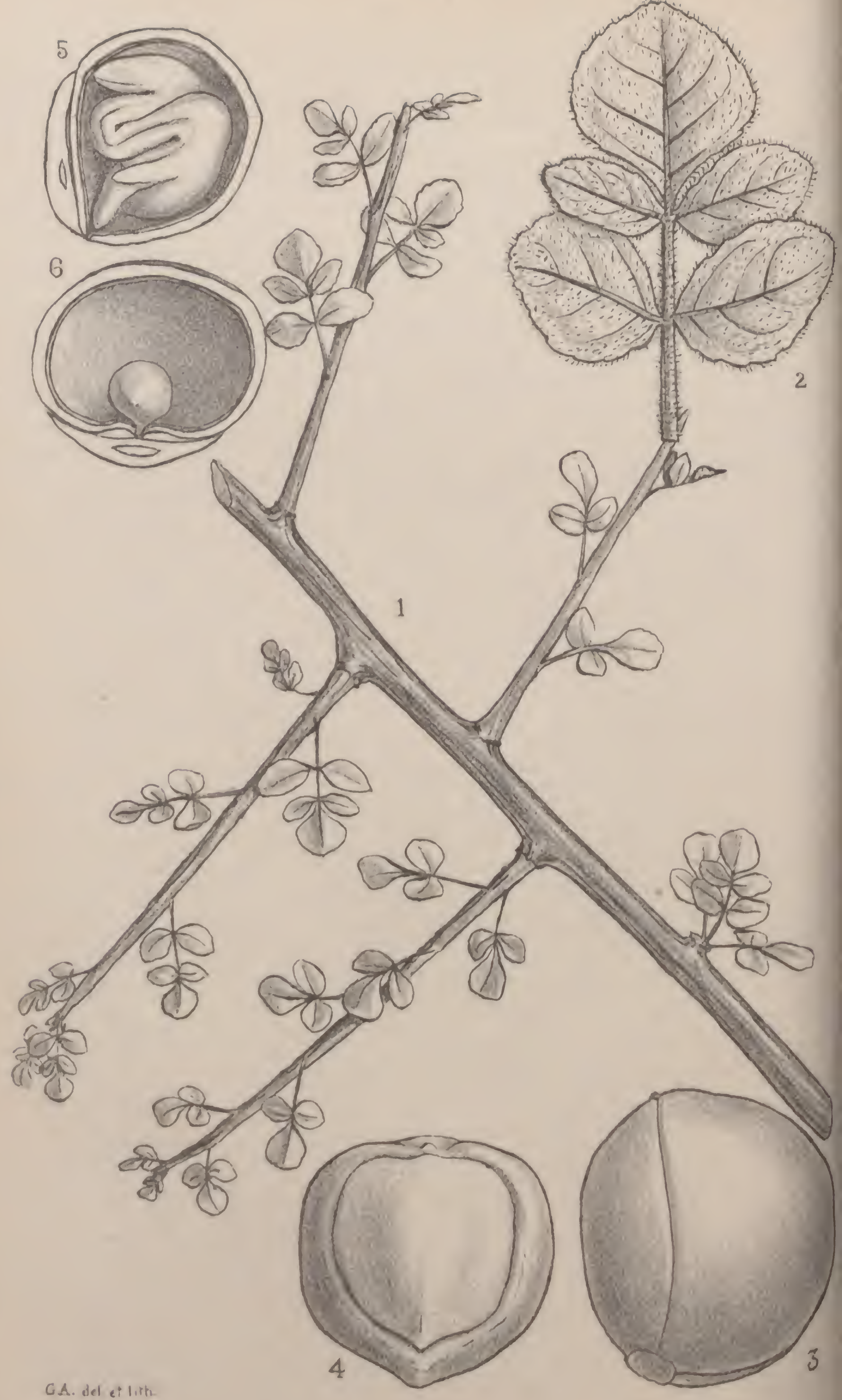




\section{Tabula 3110.}

\section{COMMIPHORA ALLOPHYLLA, Sprague.}

\section{BURSERACEAE.}

C. allophylla, Sprague; species nova affinis $C$. somalensi, Engl., a qua foliis minoribus saepe bijugis, foliolis lateralibus sessilibus basi inaequaliter rotundatis, nervis lateralibus minus obliquis indumento densiore differt.

Arbor usque ad 3-3.6 m. alta. Rami seniores leviter sinnosi, crassiusculi, cireiter $6 \mathrm{~mm}$. diametro $25-30 \mathrm{~cm}$. infra apiecs, striatorugosuli, fusco-brunnei, pubcruli, tanden glabrati; internodia $1 \cdot 5$ $2.5 \mathrm{~cm}$. longa; rami juniores satis graeiles, circiter $3 \mathrm{~mm}$. dianctro $15 \mathrm{~cm}$. infra apiees, leviter costati, brunnci, minute pubescentes vel puberuli ; ramuli jatentes vel patuli, $5-8(-16) \mathrm{cm}$. longi, dense inoanopubeseentes; ramulorum internodia irregularia, sacpius $0.5-2 \mathrm{~cm}$. longa. Ramuli ablreviati $3-5 \mathrm{~nm}$. longi, dense pubescentes. Folia plerumque 1-3 cm. longa, heteromorpha, plerumque trifoliolata, snepe quinquefoliolata; petiolus $0 \cdot 2-\mathrm{I} \cdot 4 \mathrm{~cm}$. lougus, dense pubescens; foliola supra dense pubescentia, subtus subvelutima; foliolum terminale sessile vel petiolulatum petiolulo usque ad $3 \mathrm{~mm}$. longo, euncatoobovatum, apiec plerumque rotundatum vel subtruncatum, usque ad $1.5 \mathrm{~cm}$. longum et $1.2 \mathrm{~cm}$. latum, superne inconspicue crenulatum, inferne integrum, nervis lateralibus utrinsecus circiter 4, ascendentes, satis procul a margine nastowosantes, rete venularum utrinque incouspicuo; foliola lateralia oblique elliptiea vel elliptieo-ovata, usque ad $1 \mathrm{~cm}$. longa et $0.7 \mathrm{~cm}$. lata, basi valde inaequilateralia, margine inferiore rotundato vel subtruncato, siperiore oblique ascendente. Fructus trinsverse ellipsoidei, eireiter $5 \mathrm{~mm}$. longi et $6 \mathrm{~mm}$. lati, glabri, apice stylo persistente eirciter $0.2 \mathrm{~mm}$. longo cuspidutuli, uniloculares, carpcllo altero valde applanato loculo minimo vacuo; cndoearpiuu carpelli sterilis aspidiforme, longitudinaliter costatum. Embryo cotyledonibus pluries conduplicatis.

Britisir Somalitand. Maritime lills south of Berbera, DrakeBrockman, 754, 756 (type), 757, 760, 761 ; near Bulhar, Drake-Brock-
man, 670 .

C. allophylln is a tree which grows to a height of 10 or 12 fect in suitable localities, and is fairly common on the maritime hills to the 
south of Berbera, as far as the Golis range. Its Somali name is Hagar Madow, and it yields a bdellium called Habbak Hagar which is sometimes found mixed with Guban myrrh (C. Mymha var. molmol, Engl.). For further details see Drake-Brockman, British Somaliland, p. 308 (1912).-T. A. SPrague.

FIG. 1, leafy branch ; 2, a quinquefoliolate leaf ; 3, fruit, side view ; 4, endocarp, showing the shield-shaped sterile segment; 5 , longitudinal section of endocarp showing the conduplicate embryo; 6 , transverse section of endocarp, with an immature embryo. All enlarged except 1 , which is of natural size. 



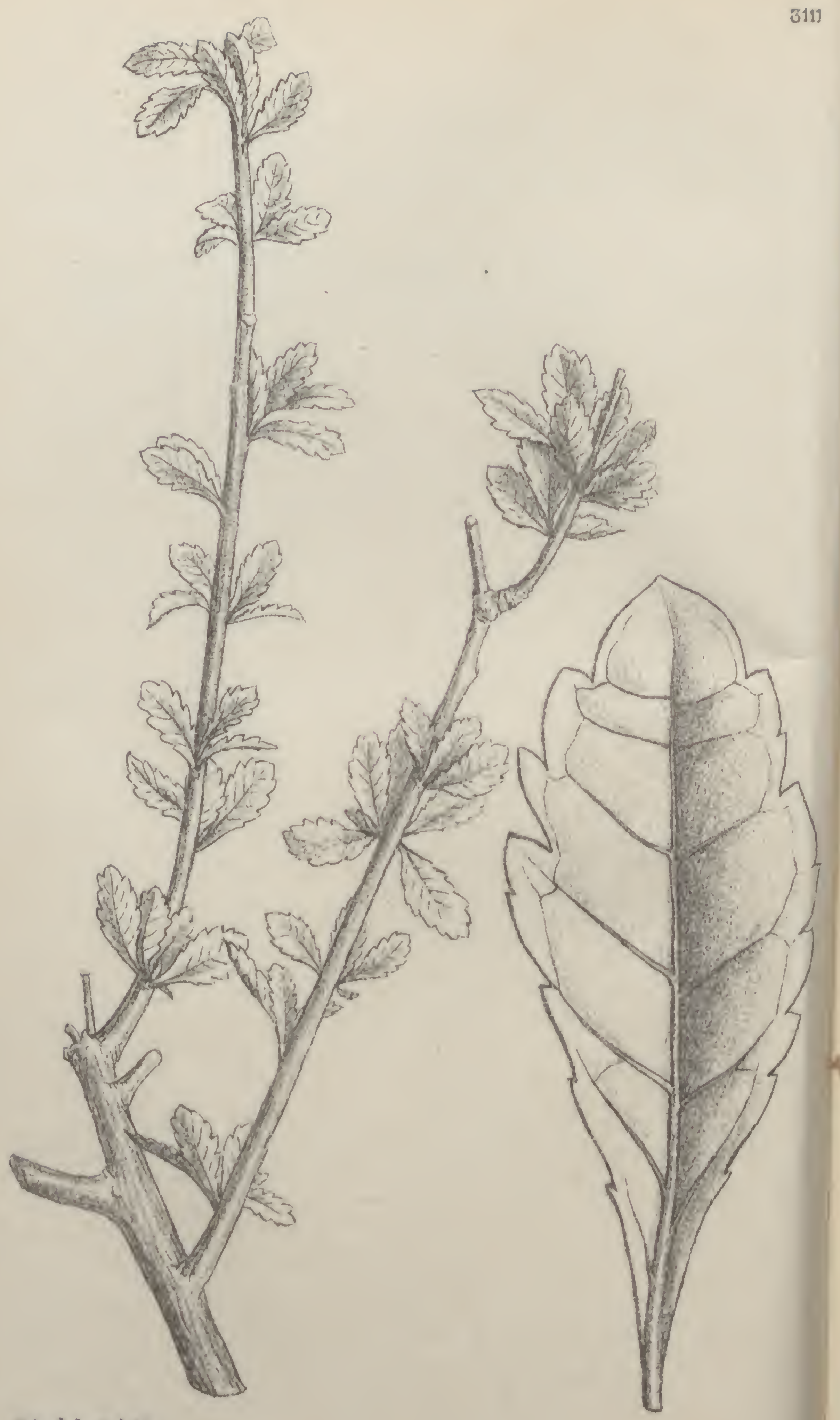

GA del et lith. 


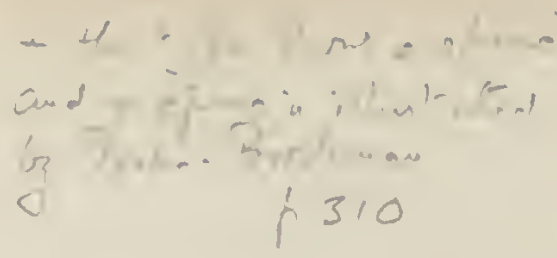

\section{Tabula 3111.}

\section{COMMIPHORA HODAI, Sprague.}

\section{Burseraceae.}

C. hodai, Sprague; species nova affinis $C$. abyssinicae, (Berg) Engl., a qua habitu inerni, ramulis annotinis brunneis nitidulis, foliis minoribus profundius erenato-serratis recedit.

Arbor 2-2.4 m. alta, incrmis, trunco ad $20 \mathrm{~cm}$. diametro vel ultra. Rami seniores rugosi, fusco-cinerei, unicus exstans 5-6 mm. diametro ; ranuli annotini basi fere patentes demum aseendentes, satis graeiles, 14-25 cm. longi, costati, lacte brunnei, nitiduli, glabri, a basi 3-1 mm. diametro ad apicem sensim angustati, ramulos abbreviatos foliatos primum pulviniformes serius lente ereseentes gerentes. Folin papyracea plerunque 1-2 cm. longa, simplicia, nomunlla trifoliolata, foliolis lateralibus pro rata nuininis vel parvis; petiolus gracilis, $1 \cdot 5-3 \cdot 5$ inm. longus, supra canalieulatus, sparse ferrugineo-pilosus ; foliolun terminale (vel unieum) plerunque obovatum usque ad oblanecolatum, rarissime ovatum, 1-1.5 cm. longum, 5-9 mm. latum, apico obtusum vel rotundatum, in basin euneatim angustatum, grossc irregulariter crenato-serratum, glabrum, nervo medio utrinque manifesto, supra nervis lateralibus inconspicuis rete venularum suboeculto. subtus nervis lateralibus et rete sub leute consjicuo; nervi laterales utrinsecus 4-6, satis procul a margine anastomosantes. Flores et fructus ignoti.

Britisil Somalimand. Maritime lills south of Berbera, DraticBrockman, 688; Nogal valley, Drake-Brockman, 781 (type), 785.

C. hodai is evidently elosely related to $C$. abyssinica, (Berg) Engl., from which it may easily be distinguished hy the coarser serration and otler chirseters mentioned above.

It is deseriberl as a tree 7 or 8 feet in leight, and is said to be fairly eommon on tho nuritine mountains to the south and southwest of Berbera, where it is known under the Somali name Hodai.

It yields an opaque bdellium ealled Habbak Hodai and used by the Somali wonen for washing their lrair, and also as a liniment for rubbing over an inflamed area. Some Somalis also give it in emulsion to their lorses as a purgative (vide Drake-Brockman, British Somaliland, Pp. 250-252, 310: 1912).-T. A. Sirague.

Leafy branch, nalural size; a singlo 'eaf, enlarged. 


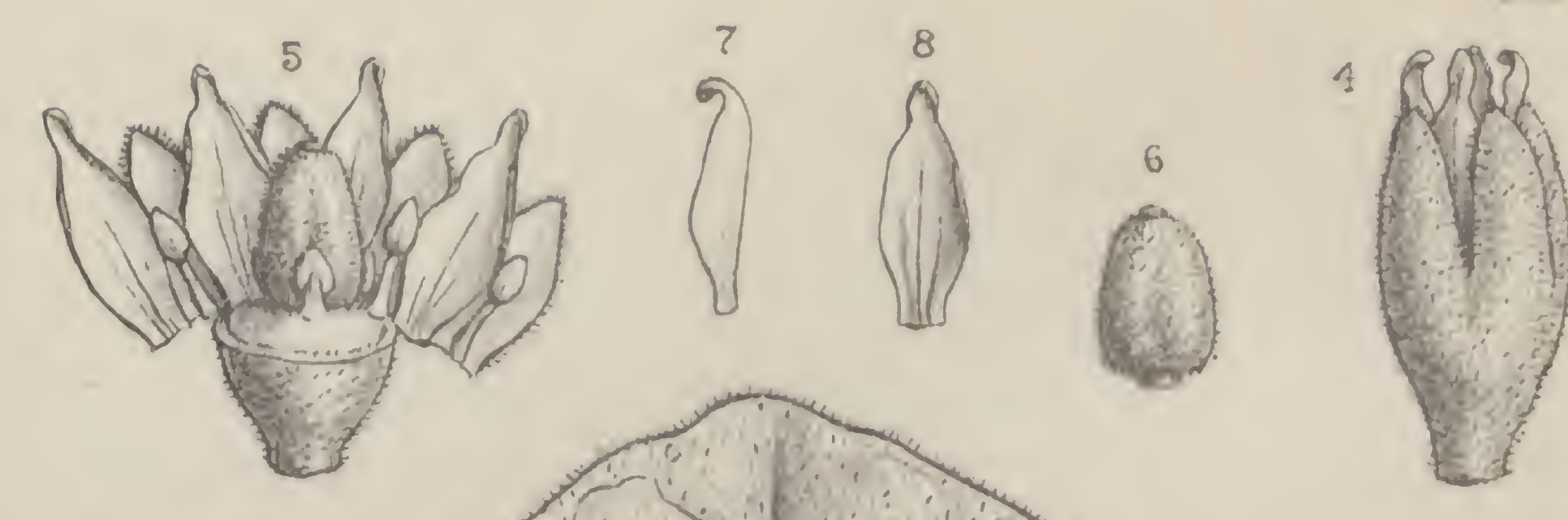

$8 \quad$
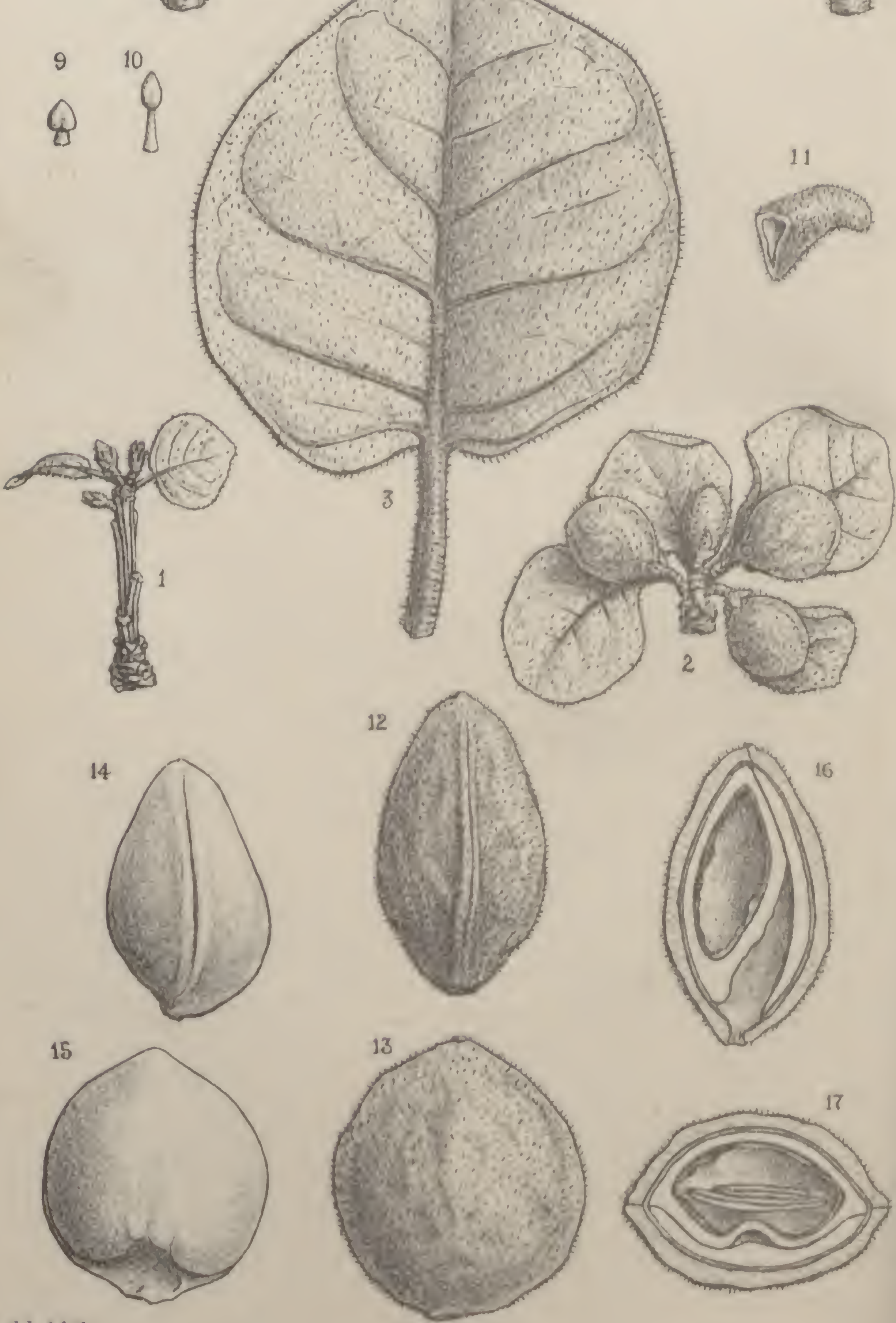


\section{TABUla 3112.}

COMMIPHORA DRAKE-BROCKMANII, Sprague.

\section{BurstraceaE.}

C. Drake-Brockmanii, Sprayue; speeies nova affinis C. erythraene, (Elirenb.) kingl, a qua foliis simplicibus integris rete venularum ineonspieuo necnon floribus subsessilibus differt.

Arluscula cireiter 1 111. alta. Ramuli exstantes 0)5-2 ein. longi, breviter dense retrorse pulbeseentes, alius abbreviatus, $0.5 \mathrm{~cm}$. longus, eicatrieibus foliorum notatus, apice folia braetens inflorescentiasque axillares gereus, alius eireiter $2 \mathrm{em}$. longus, inferne eieatrieibus crebris notatus, apice folia infloreseentiasque gerentes, internodiis intermediis satis elongatis; folia intermedia lujus ramuli delapsa, de caule per internodia duo decurrentin, eieatriec trilobato, parte deenrrente valde prominente tricostato costa media quam lateralibus majore. Folia simplieia, longiuscule petiolata, suborbieularia vel subreniformia, apice obtusissima, rotundata vel leviter retusa, basi subtruneata vel subeordata, $1-1.8 \mathrm{~cm}$. dianetro, corineen, utrinque pilis valde eurvatis dense pubeseentia ; nervi laterales utrinsecus circiter 4 , satis irregulares, proeul a margino anastomosantes, utrinque praecipue subtus prominentes, reto venularum in siceo ineonspieuo; petioli $4-6$ mur. longi, satis graeiles, pubeseentes vel tomentelli, basi in formam triangularem valde inerassati. Inflorescentiae plerumque triflorac, in axillis foliorum vel bractearum solitarine; bracteae suffulcientes cieatrice eordiformi basali lateraliter compressae, $2-2 \cdot 5 \mathrm{~mm}$. longac, tomentellac, a latere visae interlum semilunares; pedunculus $2-1 \mathrm{~mm}$. longus, tomentellus; pedicelli $0 \cdot 5-1 \mathrm{~nm}$. longi. Flores o tantum visi. Calyx in toto $3 \mathrm{~mm}$. longus, extra rotrorse tomentellus, iutus sparse appresse pilosus; tubus (ab exteriore visus) $1.7 \mathrm{~mm}$. longus; lobi ovato-deltoidei, $1.3 \mathrm{~mm}$. longi. l'etala lanceolato-oblonga, $2.5 \mathrm{~mm}$. longa, parte suprema $1 \mathrm{~mm}$. longa marginibus inflexis, dorso incrassata, medio $1 \mathrm{~mm}$. lata, apiee inflexa. Staminodia antesepala longiora $1 \cdot 1-1 \cdot 2 \mathrm{~mm}$. longa antheroliis ovatis, antepetala breviora $0.6 \mathrm{~mm}$. longa ant licrodiis lote ovatis basi cordatis. Orarimm oblongun, ovoideum, $2 \mathrm{~mm}$. longum (emin stignate subsessili $2 \cdot 3 \mathrm{~mm}$. longum) basi $1.5 \mathrm{~mm}$. diametro, pilis brevibus plerumque retrorsis tomentellum, biloeulare 0.2 altero biovulato altero vacuo; stylus subnullus (usque ad $0.2 \mathrm{mın}$. longus); stigına capitatum, cireiter $0.5 \mathrm{~mm}$. diametro. 
Ovula ascendentia, $\frac{1}{3}$ supra basin suam affixa. Drupa compressoellipsoidea, 9-11 mm. longa, $9 \mathrm{~mm}$. lata, 6-7 mm. crassa, epicarpio velutino-pubescente, mesocarpio tenui carnoso valde reticulato, endocarpio lenticulari 5 5-7 mm. longo, 6.5-7 mm. lato, 4-5 $\mathrm{mm}$. crasso. Semen solitarium. Cotyledones foliaceae, basi cordatac.

British Somaliland, Maritime hills S.E. of Berbera, DrakeBrockman, 755 (type), 758 .

C. Drake-Brockmanii, though very different in appearance from C. erythraea, (Ehrenb.) Engl., seems to be closely related to that species. The indumentum is of the same character, and the drupes are almost alike. The step from trifoliolate to unifoliolate (simple) leaves is a small one in Commiphora, leaves of both types frequently being present on the same species. The entire margin and indistinct reticulation of the leaves, and the much reduced inflorescences with subsessile flowers, form the best diagnostic characters of C. Drake-Brockmanii. It is known by the Somalis under the name Dunkal, and is described by the collector as a tree, seldom more than 3 or 4 feet in height, with a sturdy gnarled appearance, and only scantily covered with leaves. It yields a kind of bdellium known as Habbak Dunkal (vide Drake-Brockman, British Somaliland, p. 311 : 1912).--T. A. Spracive.

Fra. 1, branchlet with female flowers; 2 , branchlet with fruits; 3 , leaf : 4, female flower; 5, do., laid open; 6, pistil; 7, 8, petals; 9, antepetalous staminode ; 10, antesepalous staminode; 11, bract; 12, 13, fruit, side and faco views; 14, 15, endocarp, side and face vicws; 16, 17, endocarp, longitudinal and transverse sections. All enlarged, except 1 and 2, which are of natural size. 



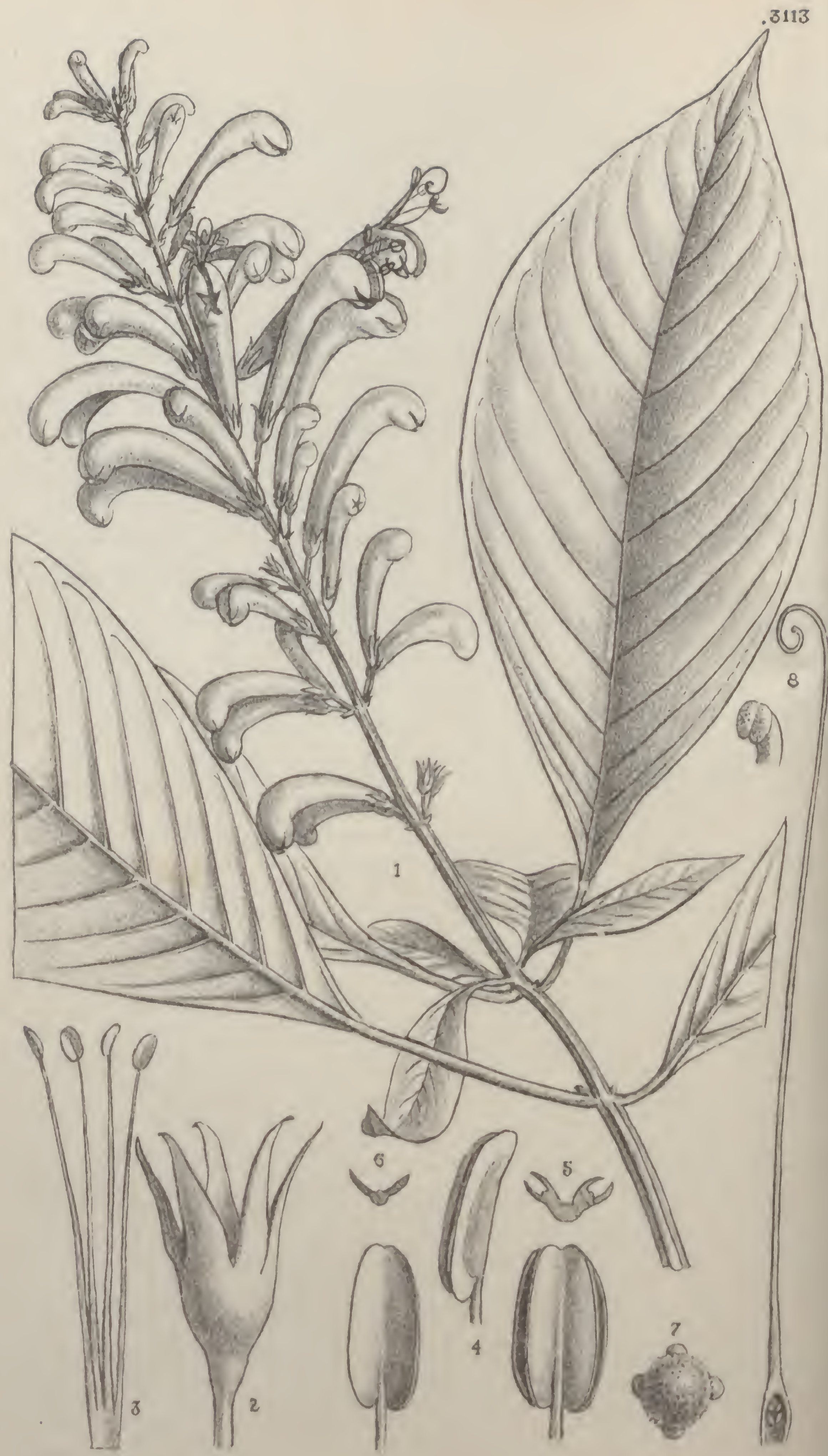

G.A.del et lith. 


\section{TABUla 3113.}

ISOTHECA ALBA, Turrill.

Acanthaceae. Tribus Justicieate.

Isotheca, Turrill in Kew Bulletin, 1922, p. 187; ab Herpetacantho, Nees, floribus in thyrsum terminalem clispositis, staminum abaxialium thceis aequalibus parallchis, pollinis granulis ad typum "Stachclpollen" pertinentibus differt.

Calyx 5-partitus, segmentis angustis acutis subaequalibus. Corollae tubus elongatus, superne parum ampliatus; limbus 2-labiatus, labio adaxiali e scgmentis 2 lateralibus composito, abaxiali breviter trilobo. Stamina 4, didynama, filamentis basi per paria laterulia connatis; antherae staminum adaxialium monotheeae, abaxialium dithecae, thecis oblongis aequalibus parallelis mutieis. Pollinis granula sphateroidea, e typo "Staclelpollen." Discus annularis, brevis. Stylus filiformis, apiee minute 2-dentatus; ovula in quoque boculo 2. Capsula (fere matura) oblongo-elavata, basi iu stipitem lougum solidum contracta. Herba vel suffrutex, ereeta. Folia iutegerrima. Flores pedicellati, flavi, faseiculati vel solitarii, in axillis braetearum parvarum in thyrsum terminalem dispositi.

\section{I. alba, Turrill, species unica.}

Canles erecti, glabri. Folia elliptiea, apice acute angustata vel acuminata, basi in petiolum cuneato-angustata, usque ad $2.2 \mathrm{dm}$. longa (petiolo exelušo), costa nervisque in pagina superiore subimpressis, in pagiua inferiore eonspieuris, lateralibus utriusceus circiter 12 marginem versus anastomosantibus, glaberrima; petiolus usque ad 5 em. longus, glaber. Inflorescentia thyrsoidea, terminalis, eum peduneulo $3 \mathrm{~cm}$. longo $2 \mathrm{dm}$. longa, glabra. Calyeis segmenta 5 , lauecolato-acieularia, subaequalia, apiee aeuminata, 7 um. longa. Corolla alba (ex Williams), tubo $4 \mathrm{~cm}$. longo fauee $8 \mathrm{~mm}$. diametro glabro; labii adiaxislis segmenta 2, lateralia, $7 \mathrm{~mm}$. longa, $2.5 \mathrm{~mm}$. lata, labio abaxiali trilobo. lobis subaequatibus $1.5 \mathrm{~mm}$. longis. Stamina leviter exsertn; antlierne theeis 4 mu. longis, filamentis cireiter $4 \cdot 5 \mathrm{~cm}$. longis; pollinis granula cireiter $65 \mathrm{k}$ diametro. Ovarium eylindrieum, $3 \mathrm{~mm}$. altum, $1.5 \mathrm{~mm}$. dinrnetro, glabrum, loculis biovulatis ; stylus $5.5 \mathrm{~mm}$. longus.

WEst Innw: Trinidad: lreights of Aripo, 13.1.1922, $R . O$. Williams, - W. B. Turrild.

FIo. 1, portion of plant; 2 , calyx ; 3 , androceium; 4 , anthors: 5 , transverso 8 . gynneceun with anther; 6 , transverse section of adaxial anther: 7 , pollen grain : enlarged excepl fig. 1. 



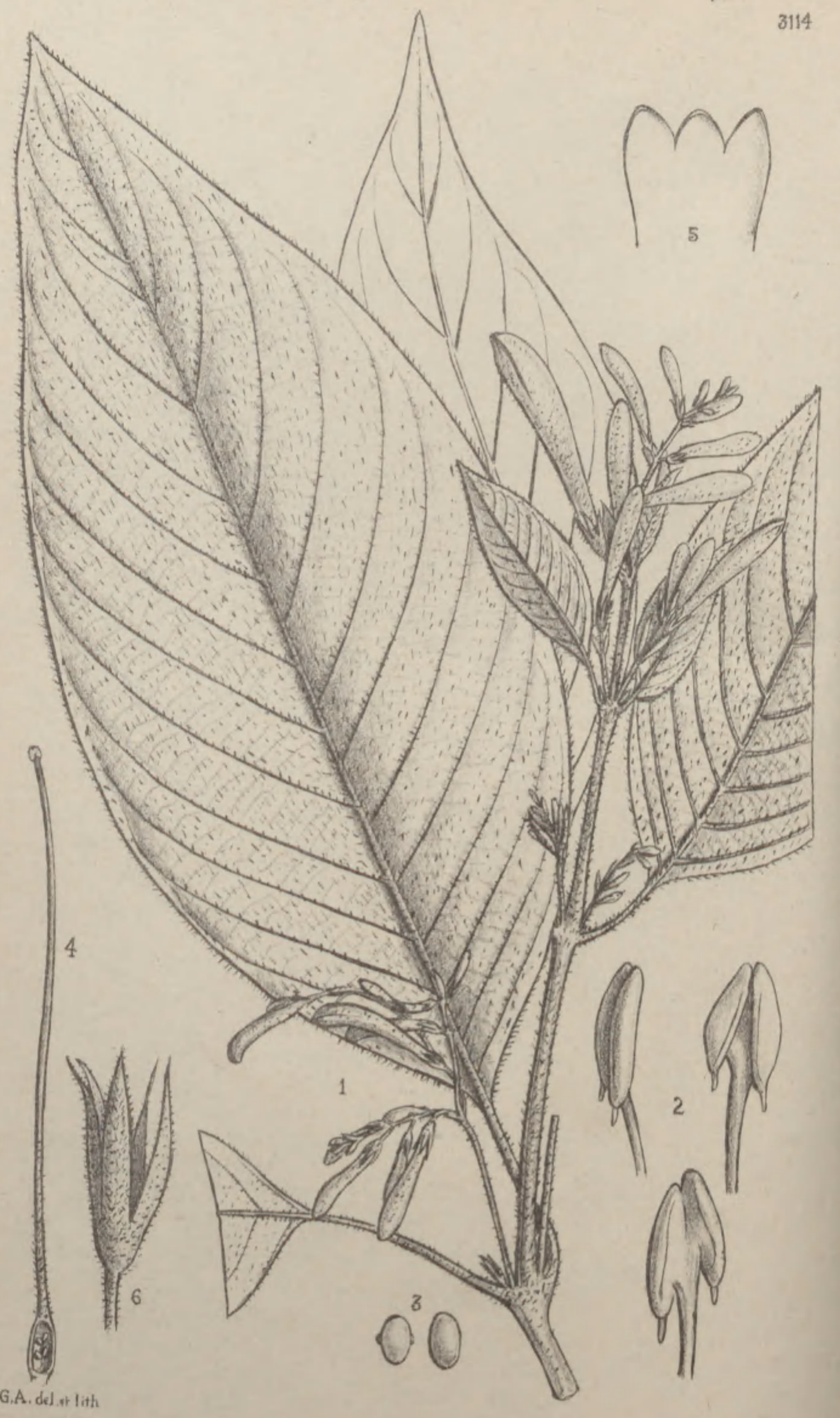




\section{TABUla 3114.}

\section{BELOPERONE FLAVIFLORA, Turrill.}

\section{ACantilaceae. Tribus Justicieae.}

B. flaviflora, Turrill in Keno Bulletin, 1922, p. 187; a B. tenera, Turrill, planta fulvo-hirsuta, foliis multo majoribus, floribus flavis facile distinguitur.

Herla (vel suffrutex) erceta, eaulibus subterctibus junioril,us dense fulvo-hirsutis deinde subglabris. Folia oblongo-elliptica vel elliptica, usque ad $2.75 \mathrm{dm}$. longa (petiolo excluso) et $1 \cdot 1 \mathrm{dm}$. lata, apico acute acuminata basi cuneata vel acuta, costa nervisque in pagina utraque conspicuis pilis fulvis in juventute praecipue instructis, nervis lateralibus utrinsecus circiter 12 ; petiolus usque ad $6 \mathrm{~cm}$. longus, fulvo-hirsutus. Inflorescentiae axillares vel terminales; bracteae lineari-lanceolatae, 3 mun. longar, extra dense glanduloso-puberulac, caducae; bracteolae lineares, $2 \cdot 5$ mur. longae, dense glanduloso-puberulae. Calyeis sermenta lanceolato-linearia, acuta, $5 \mathrm{~mm}$. longa, $1 \mathrm{~mm}$. lata, pubcrula. Corolla anguste cylindrica, superne leviter ampliata, $2 \cdot 8$ cm. longa, flava, extra glanduloso-puberula, labio adaxiali $1.2 \mathrm{em}$. longo apice cmarginato. abaxiali $1.2 \mathrm{~cm}$. longo leviter aequaliterque trilobato. Sumina 2, leviter exserta, flamentis $1.8 \mathrm{~cm}$. longis inferne pilis brevibus reflexis instructis, nutheris dithecis, thecis superpositis utrisque vix $2 \mathrm{~mm}$. longis calcaratis; pollinis granula ellijsoidco-oblonga, $\overline{5} \bar{j}-\bar{j} 8 \mu$

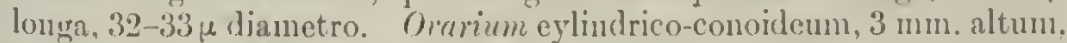
basi $1 \cdot 25$ mm. dianctru, pubcrulum; stylus $2 \cdot 2$ em. longus, inferne jubcrulus.

Wrst Ixples. Trinidad: heights of Aripo, 13.1.1922, R. O Williams.

This is a very distinct suecies of Beloperone. It is related to a plant. collected by C. C. Pringle at Ias (anoas, State of San Luis l'otosi, Mexico, 1891, no. 3933, and described by B. I. Robinson in I'roc. Amer. Acad. vol. xxvii. p. 183 (1892), as Beloperone fragilis, Rob. Unfortunately this uame camnot stancl, since the same combination harl bcen used previously by IIartius in Flor. Bras. vol. ix. p. 140 (1817), to resignato a plant, which, from the description, is a quite distinct species, from l'rov. Balria, Brazil. For the Mcxican plant it is jroposed that the mame Belourrome tenera, Turrill, should be substituted for Beloperone fragilis, Rohinson.-- W'. 13. Tum11L1.

Fra. 1, portion of flant: 2, stanens; 3, pollen graina; 4, gynareenn with ovary in longitudinal section; 5 , lower lip of corolla; 6 , calyx. All enlarged except fig. 1 . 



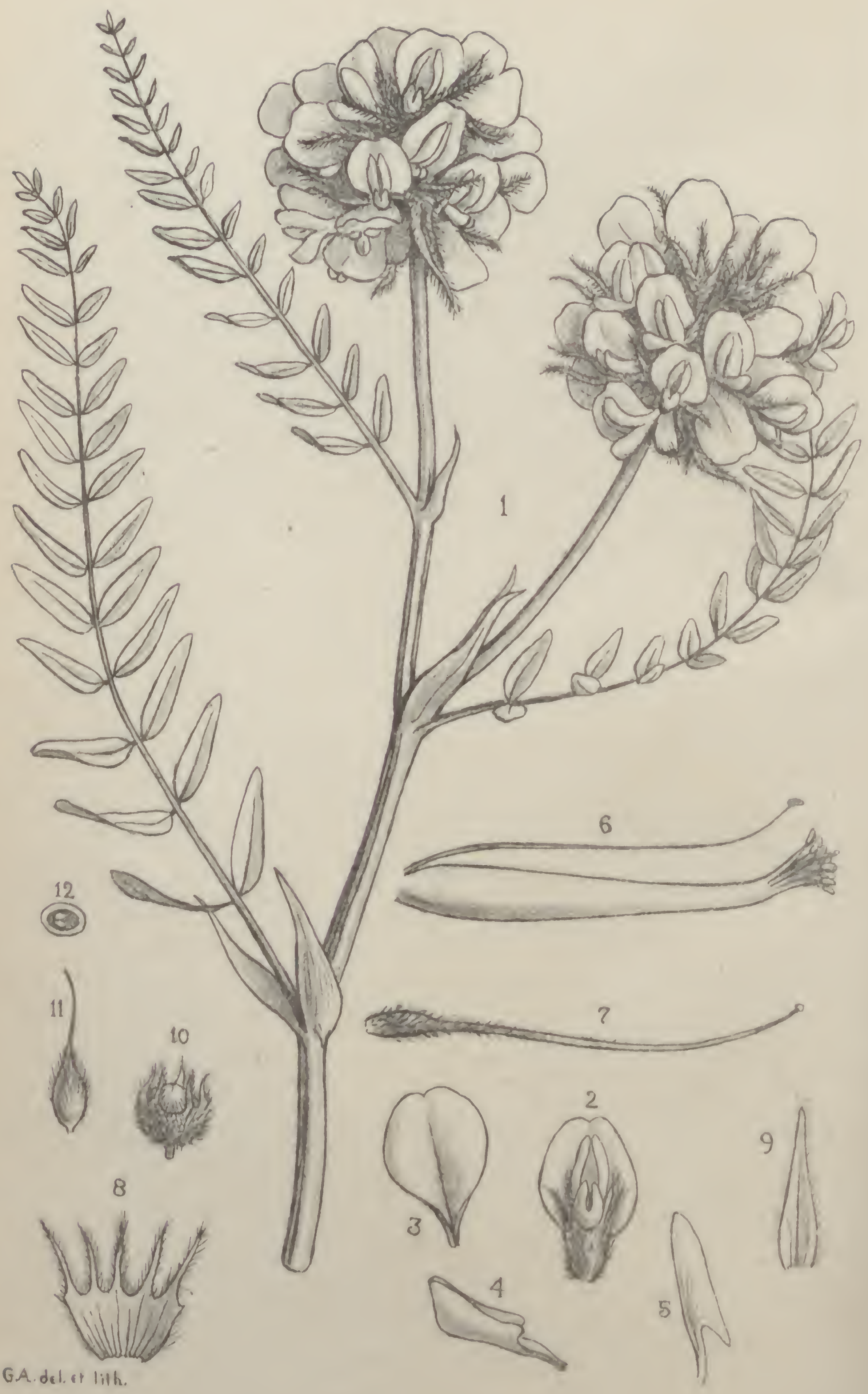




\section{TABULa 3115.}

\section{ASTRAGALUS DURHAMII, Turrill.}

\section{Jeguminosae. Tribus Galegeae.}

A. Durhamii, Turrill in Kew Bulletin, 1922, p. 294, ct 1.e. 1924, p. 320 ; ab A. ajubense, Bge, vexilli lamina elliptieo-ovata latiore differt.

Canles glabri, leviter longitudinaliter costati, teretes. Folia caulina usque ad $1.7 \mathrm{dm}$. longa, glabra vel fere glabra, foliolis eireiter 30 ellipticolanceolatis vel oblongo-lanecolatis apiec obt usis saepe breviter apiculat is basi rotundatis petiolulatis petiolulis $1 \mathrm{~mm}$. longis eosta in pagina utraque prominente nervis lateralibus in pagina superiore impressis in pagina inferiore prominentibus; stipulae lascelatae, apice ittenuatae, usque ad $2 \cdot 7 \mathrm{~cm}$. longae, interdum pilis albis longis paueis instruetae. Infloreseentice axillares, inultiflorae, globosae; peduneuli usque ad $5.5 \mathrm{em}$. longi, pilis albis paueis dispersis praediti, braeteae lineari-laneeolatae, apiee attenuatac, eireiter $1 \mathrm{~cm}$. longae; margine longe albo-eiliatac. Calyx longe albo-pilosus, tubo $9 \mathrm{~mm}$. longo, dentibus linerri-aeieularibus usque ad $9 \mathrm{inm}$. longis inter se subaequalibus. Corolla intense luten, vexillo $2 \cdot 2 \mathrm{em}$. longo, lamina a te elliptico-ovata a piee leviter emarginata $1.5 \mathrm{em}$. longa $1.2 \mathrm{em}$. lata, alis $2 \cdot 1 \mathrm{~cm}$. longis $4 \mathrm{~mm}$. latis, earina $2 \cdot 1 \mathrm{em}$. longa 6 inm. lata basi filanentorum tubo distinete adnata. Filamenta glabra. Ovarium longe denseque albo-pilosum; stylus inferne pilis albis dispersis instructus.

Wurore. Gallipoli Peninsula, Durham, 11.

Further specimens of this interesting plant were eolleeted by Capt. Ingoldby on the eliff at Maidos in 1923 and sliow that the leaves and leaflots are sonetines lirger than those of the original specimen. The 1.3 cin up to 3 clin. in lengtli, and the leaflets up to $4.5 \mathrm{em}$. long and $i_{11}$ a persistent. Fruit was also colleeted. Wach legume is enelosed and eorollent calyx, whieh becomes enlarged and membranaeeous, the uprolli, and lias long white silky hairs which are inueh denser in being per part; it is sliglitly keeled on both sutures, the adaxial keel latoral conder than the abaxial; it is nearly ellipsoid with a slight suture to suturson, and its lengtl is 8 to $10 \mathrm{~mm}$., its breadth from sure to suture nearly $6 \mathrm{~mm}$., and at right angles to the suture plane 
$5 \mathrm{~mm}$.; it is completely divided from suture to suture into two loculi by a yellow shining septum. Apparently only one ovule in each loculus normally matures to a seed. All the seeds examined had collapsed.

The section Alopecias, to which our plant belongs, consists of two series, A. Durhamii being placed in the Ebracteolati and in the subseries Megalotropi. In this subseries it is further delimited by its globose and long peduncled inflorescences. From species with similar characters, other than $A$. ajubensis, it is distinguished by its indumentum, the shape and teeth of the calyx, and the details of corolla structure. Of species occurring in Europe it most nearly resembles A. ponticus, Pall., from which it differs in its glabrous stems and nearly glabrous foliage, its long peduncle, linear-acicular calyx teeth which are subequal and approximately as long as the calyx-tube, the larger corolla and broader vexillum, and in the lamina of the carina being broader than that of the wings.-W. B. Turkils.

Fig. 1, plant ; 2, flower ; 3, standard ; 4, keel ; 5, wing ; 6, androecium ; 7 , gynaceum ; 8, calyx spread open ; 9 , bract ; 10 , fruit and calyx ; 11, fruit ; 12, transverse section of fruit. All enlarged except fig. 1. 


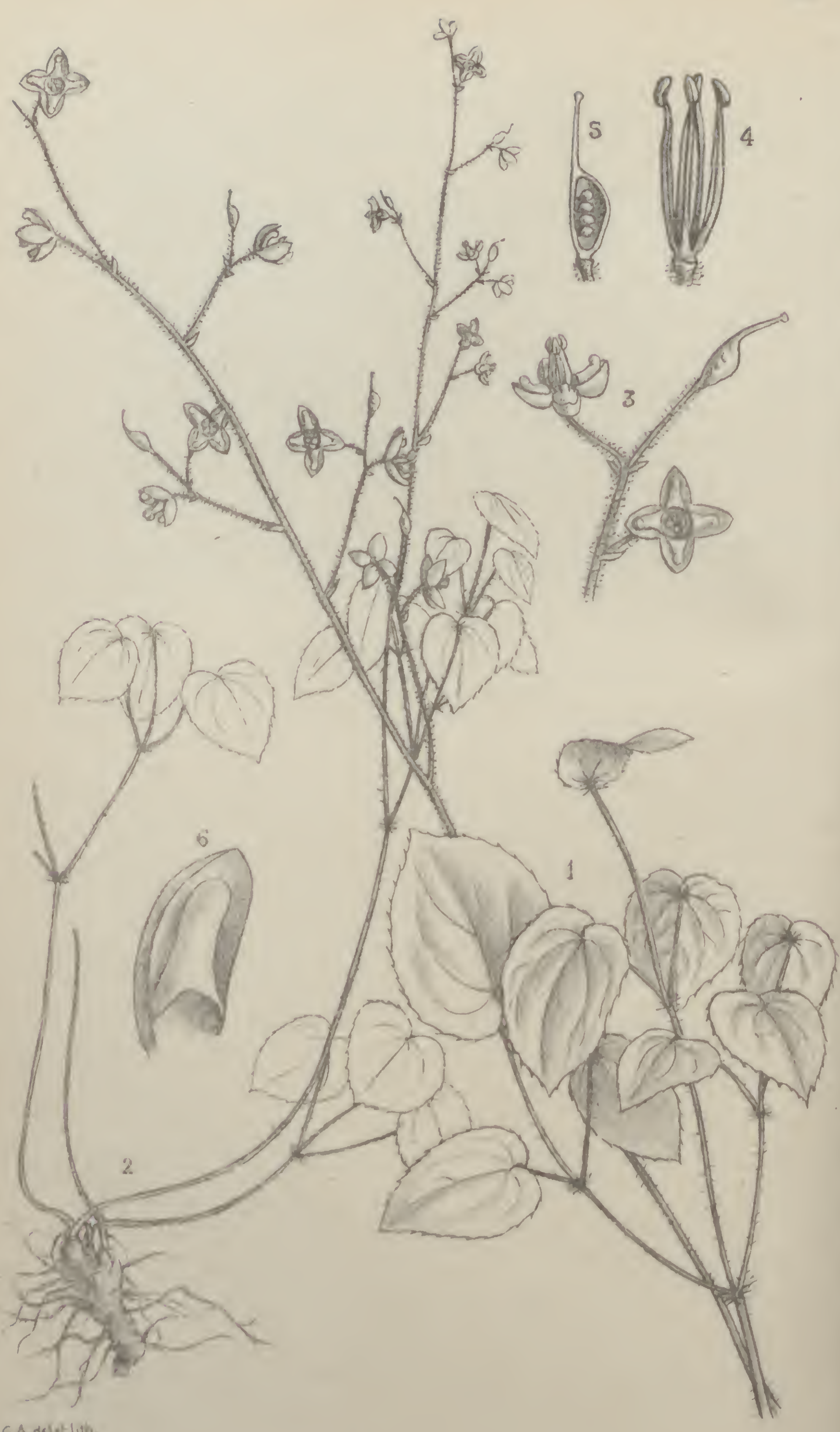


\section{Tabula 3116.}

\section{EPIMEDIUM PUBIGERUM, Morren et Decaisne.}

\section{Berberidaceae. Tribus Berbereae.}

E. pubigerum, Morren et Decaisne in Ann. Sci. Nat. $2^{m e}$ Sér. vol. ii. p. 35) (1834) ; Boiss. Flor. Or. vol. i. p. 101 (1867) ; Stoyanoff, N., et Stefanoff, 13., in Oestcrr. Bot. Zeitschr. vol. lxx. p. 296 (1921), et in Flore de la Bulgarie, p. 468, t. 565 (1924). E. alpinum var. puligerum, DC. Syst. vol. ii. p. 28 (1821), et Prodr. vol. i. p. 110 (1824); D'Urville in Mém. Soc. Jimm. Paris, vol. i. p. 274 (1822); lranchet in 13ull. Soc. Bot. Fr. vol. xxxiii. p. 107 (1886); ab E. alpino, Linn., rhizomate brcviorc crassiorc, foliis maturis latioribus valdc cordatıs subtus in axillis lanatis margincm versus linca rubra haud vel vix instructis, floribus pallidioribus luteis differt.

Rhizoma horizontiliter vel subhorizontaliter repens, crassum, radices numerosas emittens, squamarum vestigiis vestitum, nodosum, nodis squanis subrotundatis concavis venosis fuscis foliorum basin circumdantibus instructis. Folia radicalia $1-2$, usque ad $2 \cdot 7 \mathrm{dm}$. longa, saepissime tritcrnata, petiolo eommuni circitcr $7-10 \mathrm{em}$. longo ad petiolulorum insertioncs intumescenti piloso pilis mollibus coloratis fortassc glandulosis, pctiolulis lateralibus $3-5 \mathrm{~cm}$. longis ad foliolorum insertioncen piloso-lanatis; foliola subrotundato-ovata, apice acuta vel breviter acuminata, basi valde cordata, $4-4 \cdot 5 \mathrm{~cm}$. longa, $3-3 \cdot 5 \mathrm{~cm}$. lata, margine acutissime dentata, dentibus ad folioli apiceln curvatis, adulta chartacea, supra viriclia, subnitida, subtus glaucescentia, rcticulatovenosa, venis prominulis, juniora submembranacea, pilis mollibus albis inspersa ad petioluli insertionem dense lanata ; folium caulinum ${ }^{8 a}$ pissine solitarium, foliis radicalibus simile sed brevius. In foreseentia tcrminalis, laxiflora, crecta, pilis numerosis articulatis probabiliter glaudulosis instructa ; bracteac ovatae, $1-4$ mm. longae. flores pedicellis 4-9 mm. longis suffulti. Sepala 4, inaequalia, exteriora minora. Jelala 4, aequalia, ovato-oblonga, obtusa, sepalis duplo najora, 5-7 inm. longa, neetariis breviter cylindricis apice rotundatis. Stamina gynaeceo longiora. Otarium ellipsoideo. ovoideuin, stylo laterali.

Bulgaria. Strandja l'lanina, in wet forests of Fagus orientalis, Iay $1921, \mathcal{N}$. Sloyunoff and $B$. Stefanoff. 
The species figured in our plate is, so far as is known, limited, in the Balkan Peninsula, to the south-eastern part from the Belgrade Forest, north of Constantinople, to the north-western Strandja in S.E. Bulgaria. It is also recorded from Asia Minor and the Caucasus. It was collected in Thrace by D'Urville and by Sibthorp. An oversight in the Flora Graeca requires attention. In the Sibthorp Herbarium at Oxford there are two specimens of Epimedium, both without flowers and fruits. One is certainly E. pubigerum, little doubt from the Belgrade Forest, the other may or may not be this species. In the Flora Graeca, t. 150 (1913), the plant figured is E. alpinum, and this is the name correctly used there for the plate, though the locality is given as "in sylvis ad pagum Belgrad, in agro Constantinopolitano." It would thus appear that the plant figured and described was not that collected by Sibthorp in Thrace, but was possibly a cultivated specimen.-W. B. 'Turrit.

Fia. 1, portion of plant, natural size; 2, plant, reduced; 3 , flowers and young fruit; 4, androecium; 5, longitudinal section of gynaecum; 6, potal. All enlarged except figs. 1 and 2. 


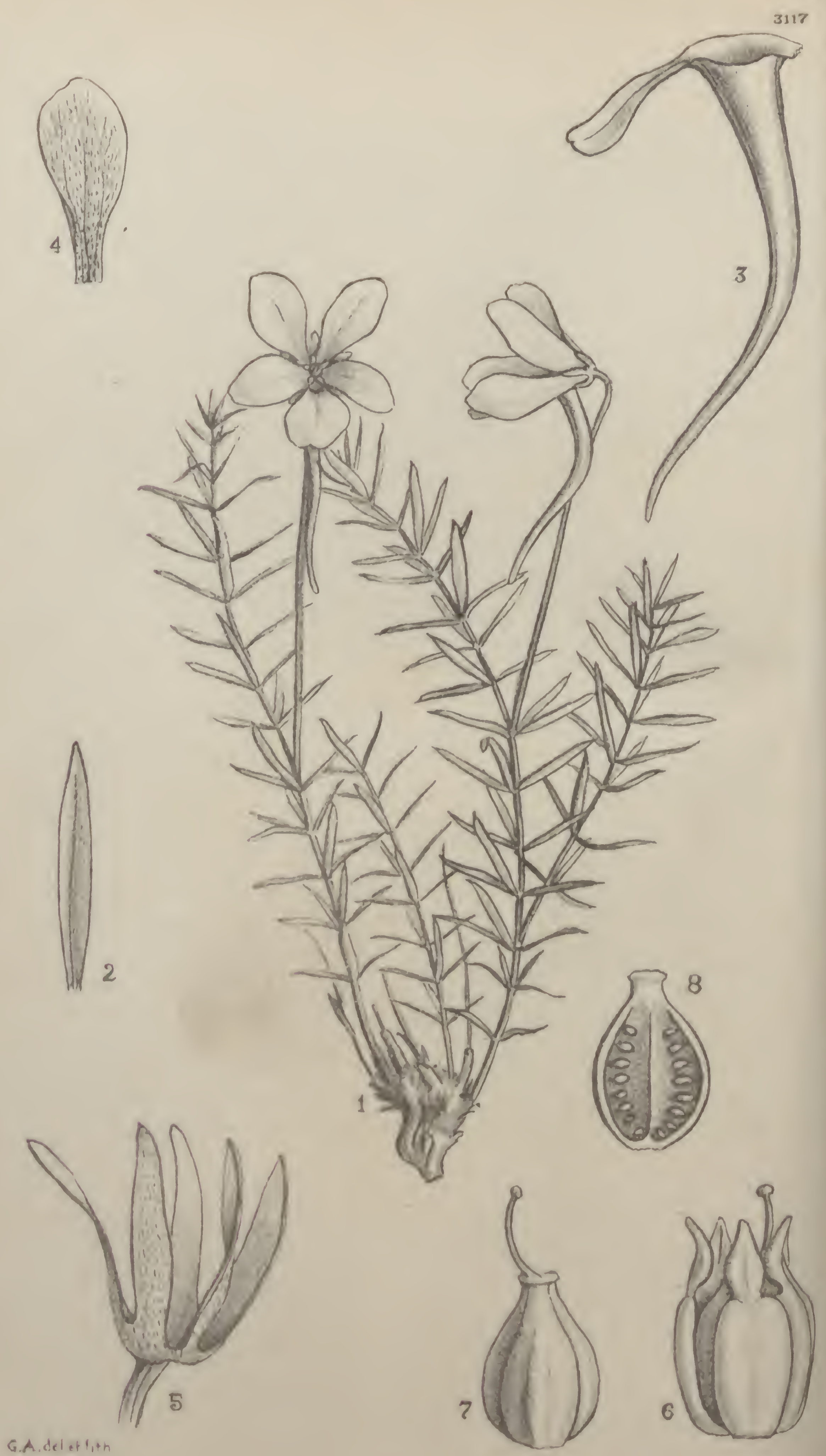




\section{Tabula 3117.}

\section{VIOLA DELPHINANTHA, Boiss.}

\section{Vrolaceae. Tribus Violeak.}

V. delphinantha, Boiss., Dingn. Ser. I. vol. i. p. 7 (1842), et Flor. Or. vol. i. p. 453 (1867); 1lal. Consp. Flor. Gr. vol. i. p. 137 (1900); Ifervier in Bull. Aead. Internat. de Géogr. Bot. vol. xv. p. 58 (1905); Breker Violae luropene 73 (1910), et in Fedde Repert. vol. xviii. p. 14? (1922); N. Stoyanoff in Oesterr. Bot. Zeitsehr. vol. Ixx. p. 110 (1921); ab V. cazorlensi, Gidgr, sepalis lineari-lanecolatis acutis, dorso ad medium gibbosis, lasi rotındatis appendicibus minutis semilunarihus instruetis, petalis obovatis, petalo infimo cacteris subaequali apice
leviter emarginato reedit.

Planta perennis, glabra, eaulibus numerosis erectis vel suberectis limplicibus e rlizomate suffrutieoso orientibus. Folic linearia vel line:ri-oblanceolata, usque ad $1.5 \mathrm{~cm}$. longa et $1.5 \mathrm{~mm}$. lata, acuta, sessilia, basin versus attenuata, minervia, nervo subprominente; bus pulac in foliis superioribus integrae, folio persimiles, in foliis inferioribus bi partitac partitionibus exterioribus folio minoribus. Flos singulus, medii ulo $2 \cdot 5-5 \mathrm{em}$. longo ereeto ebracteolato e folii inferioris vel 5-6 inmilla oriens. Sepala linearia vel lincari-lanecolata, acutiuseula, obovat louga, obtuse ot brevissime a ppendiculata. Pelala persistentia, adpress $1 \cdot 1 \mathrm{~cm}$. Ionga ; ealear $1 \cdot 5-2.5 \mathrm{~cm}$. longum. Stamina ovario $1 \mathrm{~mm}$. lon filanentis planis $1 \mathrm{~mm}$. longis $1 \mathrm{~mm}$. latis, antheris vix inferiore geniculatus, in ovoidcum, I. $25 \mathrm{~mm}$. altum; stylus in parte breviter geniculatus, in parto superiore capitato-erassatus antice Butcama

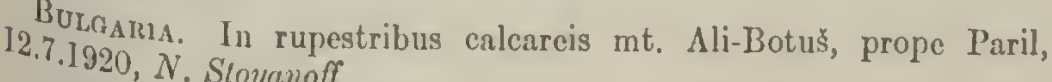
The No Sloyanoff.

Thessaly remarkable violet figured is limited to MIt. Olympus in Westraly, Mt. Athos in S. Macedonia, and Mt. Ali-Botuš, a southrecently that it lias be Rodope Mountains in S. Bulgaria!' It is only to whon we are indeen discovered on MIt. Ali-Botus by Dr. Stoyanoff, Not only are indebted for the specinens figured.

Ingically remarta is the species gcographically isolated, it is also morphowith only two rable since it has important characters which are shared only two other known species: V. cazorlensis, Gandoger in Bull.de 
l'Assoc. franç. de Bot. vol. v. p. 226 (1902) non vidi, et in Bull. Acad. Intern. Géogr. Bot. vol. xv. p. 57 (1905), and V. Košaninii, Degen in Mag. Bot. Lap. vol. x. pp. 109, 116 (1911). V. cazorlensis occurs in South Spain, Prov. Jaën : in fissuris calcarum mont. dict. Sierra de Castril et de Cazorla 15-1900 m.; Barrancon de Valentina, sources du Guadalquivir; Sierra del Poza ; Cerro Jilio, ad fontem del Tejo ; Sierra de Cabrilla. The subsection Delphinoideae of the section Nomimium was formed by Boissier in Flor. Or. vol. i. p. 451 (1867), for $V$. delphinantha, and V. cazorlensis has been placed by Becker, l.c., in the same subsection. A careful account by Hervier, l.c., makes clear the characters which separate the two species, and also clears up certain mistakes in Gandoger's original description of $V$. cazorlensis. V. Košaninii was described by Degen, l.c. p. 108, as V. delphinantha subsp. Košaninii, but the specific combination is made as cited above, and also by Hayek in Denkschr. Akad. Wiss. Wien, vol. xciv. p. 155 (1918). It was originally described from specimens collected on Mit. Solunska, the highest peak of the Jakupica, in the southern part of the Golešnica Planina, south of Ueskueb (Skoplje), by Dr. Košanin. Dörfler also collected it on the Albanian-Montenegrin boundary near Rapša. It differs from $V$. delphinantha in having the petals much narrower, the lower anticous one more deeply emarginate, nearly bilobed, and the spur only half as long or even shorter.-W. B. T'URRILL.

Fig. 1, plant; 2, leaf ; 3, abaxial petal and spur ; 4, an adaxial petal ; 5, calyx ; 6 , androecium and gynaecem ; 7, gynaeceum ; 8, longitudinal section of ovary. All enlarged except fig. 1. 


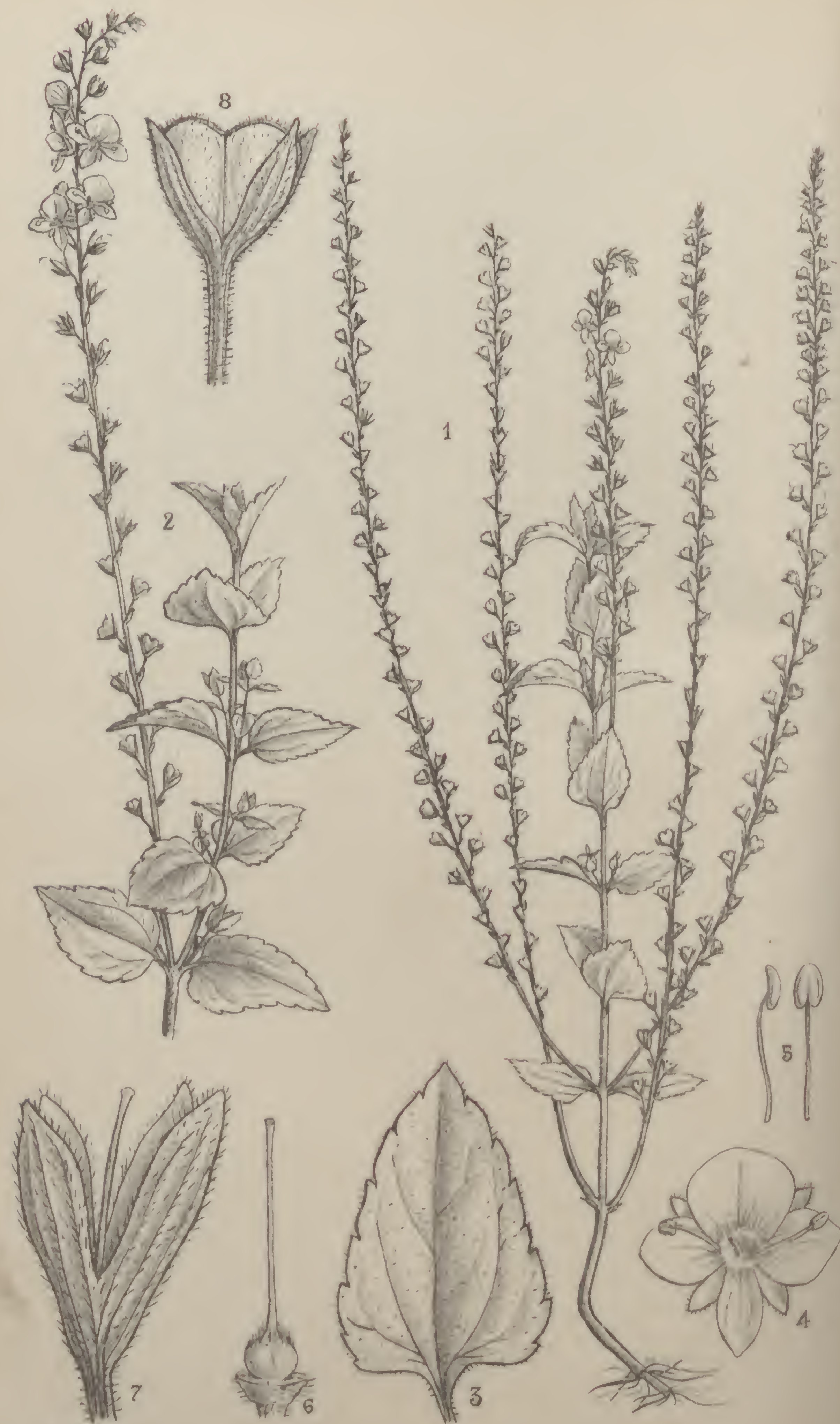

$G A$. del et lith 


\section{Tabula 3118.}

\section{VERONICA RIGIDA, Turrill.}

\section{Scropiulariaceate. Tribus Digitaleae.}

V. rigida, Turrill in Kew Bull. 1922, p. 186 ; ab V. Chamaedrys, I., caulibus rigidioribus ramosioribus, foliis petiolatis, infructescentiis sacpe longioribus, pediccllis brevioribus, corollis minoribus differt.

Planta perennis (vel interdum bicnuis), caulibus cylindricis adscendentibus ramosis rigidis inferne pilis in lineis duabus dispositis instructis superne undique hirsutis. Folia oblongo-ovata vel ovata, apicc subobtusa, basi subcordata dcinde in petiolum angustata, usque ad $3.8 \mathrm{~cm}$. longa et $2.7 \mathrm{~cm}$. lata (petiolo excluso), sacpissime minora et circiter $2 \mathrm{~cm}$. longa et $1.5 \mathrm{~cm}$. lata, marginc inciso-dcntata, in pagina superiore leviter hispida vel glabra nervis impressis, in pagina inferiore ncrvis prominentibus valdc hispidis ; petiolus $6-7 \mathrm{~mm}$. longus, hispidohirsutus. Infloreseentia 3-12 cm. longa, glanduloso-lirsuta; bractcae lineari-lnnccolatae, 4-5 nm. longae, $1 \mathrm{~mm}$. latae, glanduloso-hirsutae; pedicelli floriferi $2 \mathrm{~mm}$. longi. Infructescentia usque ad $3.4 \mathrm{dm}$. longa; pedicclli fructiferi $4 \mathrm{~mm}$. longi. Calyx $5 \mathrm{~mm}$. longus, sepalis costis extrn prominentibus instructis. Corolla $8-10 \mathrm{~mm}$. diametro, intense caerulca, lolis latcralibus adaxialique $3-5 \mathrm{~mm}$. latis, abaxiali circitcr 2 nm. lato. Stemina $3 \mathrm{~mm}$. longa, crerulca. Orarium biconvexun, a nbitu circulare, $0.75 \mathrm{~mm}$. altun, marginibus a piccque albo-hirsutum; stylus $3.5 \mathrm{~mm}$. longus, infernc albus, medio purpurcus, supernc intense eneruleus. Capsula obcordata, $3.5 \mathrm{~min}$. longa, $4 \mathrm{~mm}$. lata, margine albo-hirsuta, saepissime pubesccns ; scmina oblongo-orbicularia, pallide flava.

Greek MLacfionia. Southern slopes of Krusa Balkan; north of Karanudli, Turrill, (sced-number) 49, sceds collected 18.6.17, in flower and fruit at Kew from Nay to Septcmber.

This plant was originally described (in Kew Bull. 1920, p. 192) as a variety of Veronica Chamaedrys, I. After cultivating it for five successive years and finding that its inportant differential characters remain constant it was thought advisable to raisc it to specific rank. In cultivation it has bchnved both as a biennial and as a perennial flowering the second and succceding years after being sown.1i. B. T'UrRtL.

5, Fta. 1, plant, reducel; 2, portion of plant, nalural size; 3, leaf ; 4, flower; 5, stamens; 6 , gynaeceum; 7 , ealyx and gynaecum; 8 , fruit. All enlarged except figs. 1 and 2 . 




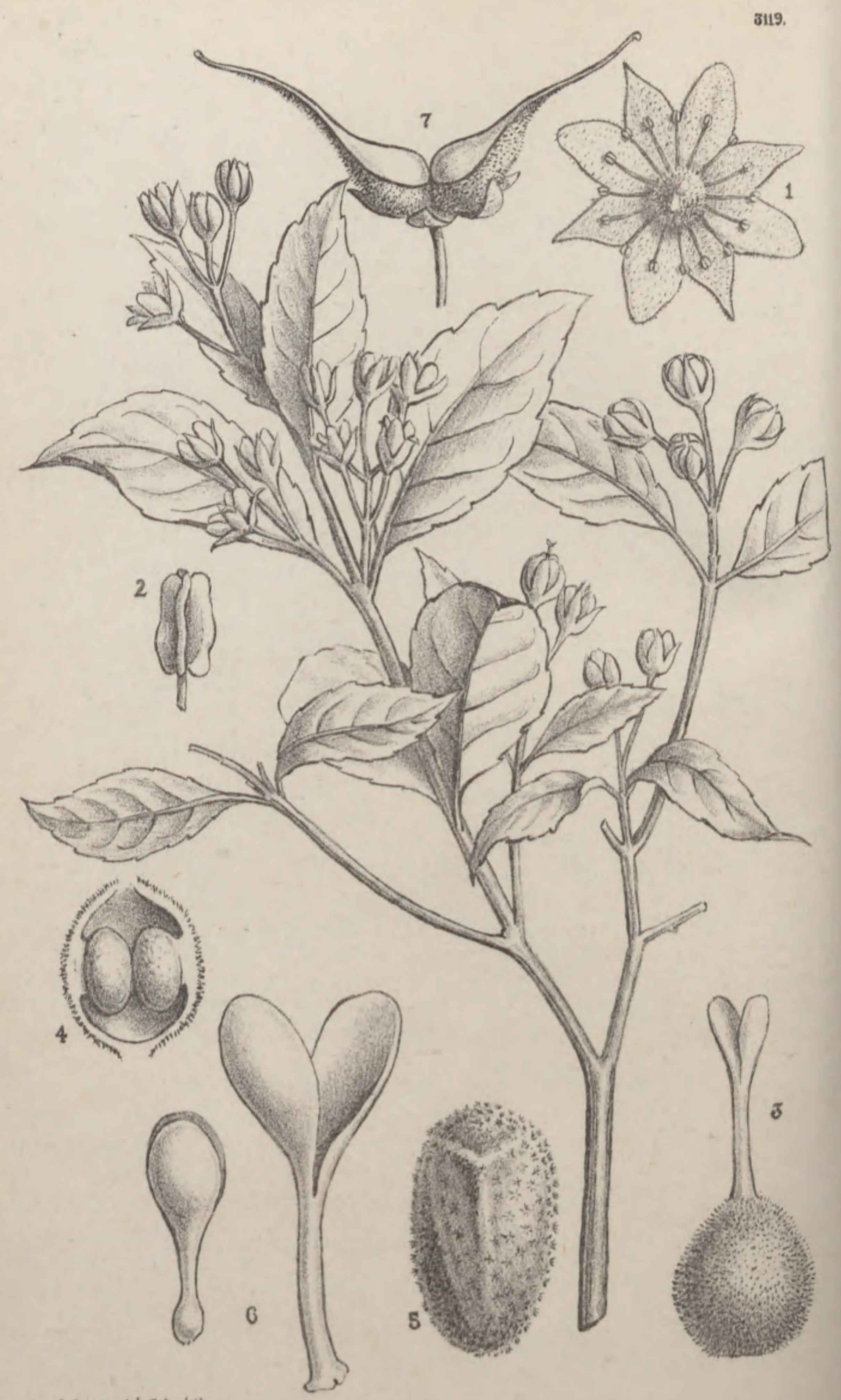

S.Gower del.G.A. lith. 


\title{
TabUla 3119.
}

\section{PSEUdOSCOLOPIA POLYANTHA, Gilg.}

\author{
Flacourtiacear. 'Tribus Scolopieae.
}

P. polyantha, Gilg in Engl. Bot. Jahrb. vol. liv. p. 343 (1917); spccies unica foliis oppositis placentis uniovulatis valde distineta.

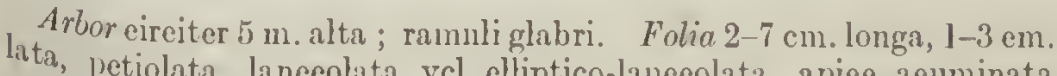
vel petiolata, lanceolata $\mathrm{vcl}$ elliptico-laneeolata, apice acuminata Cymal aeuminata, basi nngustata, subintegra vel serrata, glabra. glabri foliis breviores. I'edicelli $1 \cdot 2 \mathrm{em}$. longi, pubescentes vel sub2.5 loasi bricteolati. Sepala ferc ad basin libera, $7 \mathrm{~mm}$. longa, lelula. lata, lanccolata, apicc obtusa, pubescentia, eiliata, venosa. filifa sepalis subsimilia. Stamina $\infty$; filamenta $4 \cdot 5 \mathrm{~mm}$. longa, teres, ap, glabra. Ovarium 1-locularc, ovulis 2 ; stylıs $3 \mathrm{~mm}$. longns, apice apice bilobus. Capsula $9 \mathrm{~mm}$. longa, basi $6 \mathrm{~mm}$. lata, ovoidea, frace acuminata. Semina arillata, pilis stellatis tccta.-Pseudoscolopia ascri, Phillips, Gen. South Afr. Fl. Pl. 416 (1926).

S. Afr. Arrica. Pondoland: Ntsubane Forcst, Fraser in Herb. 1417. Forest Dept. 3058, 3105, 31.33; and in National Hcrbarium 500 in On the linkweni and in the Egosa Forest, along streams, up to

The specimen fron whiclı the accompanying platc was drawn was In eted by Forester G. Fraser in the Ntsubanc Forest, Polidoland. seen thisding specinens Forester Fraser writes: "So far I have only forest edge with 100 yards of the cdgc of the forcst or on the actual well within with the exception of a few small individuals which grow that its nathe forest among taller timber trees. It appears therefore specimen natural habitat is on the fringe of the forest. The largest abrut 15 feet line across measured $3 \mathrm{ft} .10 \mathrm{in}$. in cireumferenec and forest on feet high, and this was growing about 30 yards within the 'The bark steep slope. The trees usially do not grow to this licight. to ascertis rongh and flaky, and the wood, as far as I lave becn ablc 'The is not pist to any economic usc."-E. P. Pulluirs.

botanists, and Penloscolopia has becn deseribed independently by two , and it is a remarkablc coincidence that both of them should 
have selected the same name for the plant in reference to the affinity with the genus Scolopia. In the family Flacourtiaceae the genus is well marked on account of its opposite leaves and uniovulate placentas.-J. Hutchisson.

Fig. 1, flower seen from above ; 2 , anther ; 3 , pistil ; 4 , longitudinal section of ovary showing the uniovulate placentas; 5 , seed; 6 , stigmas and style; 7 , open capsule. All enlarged. 



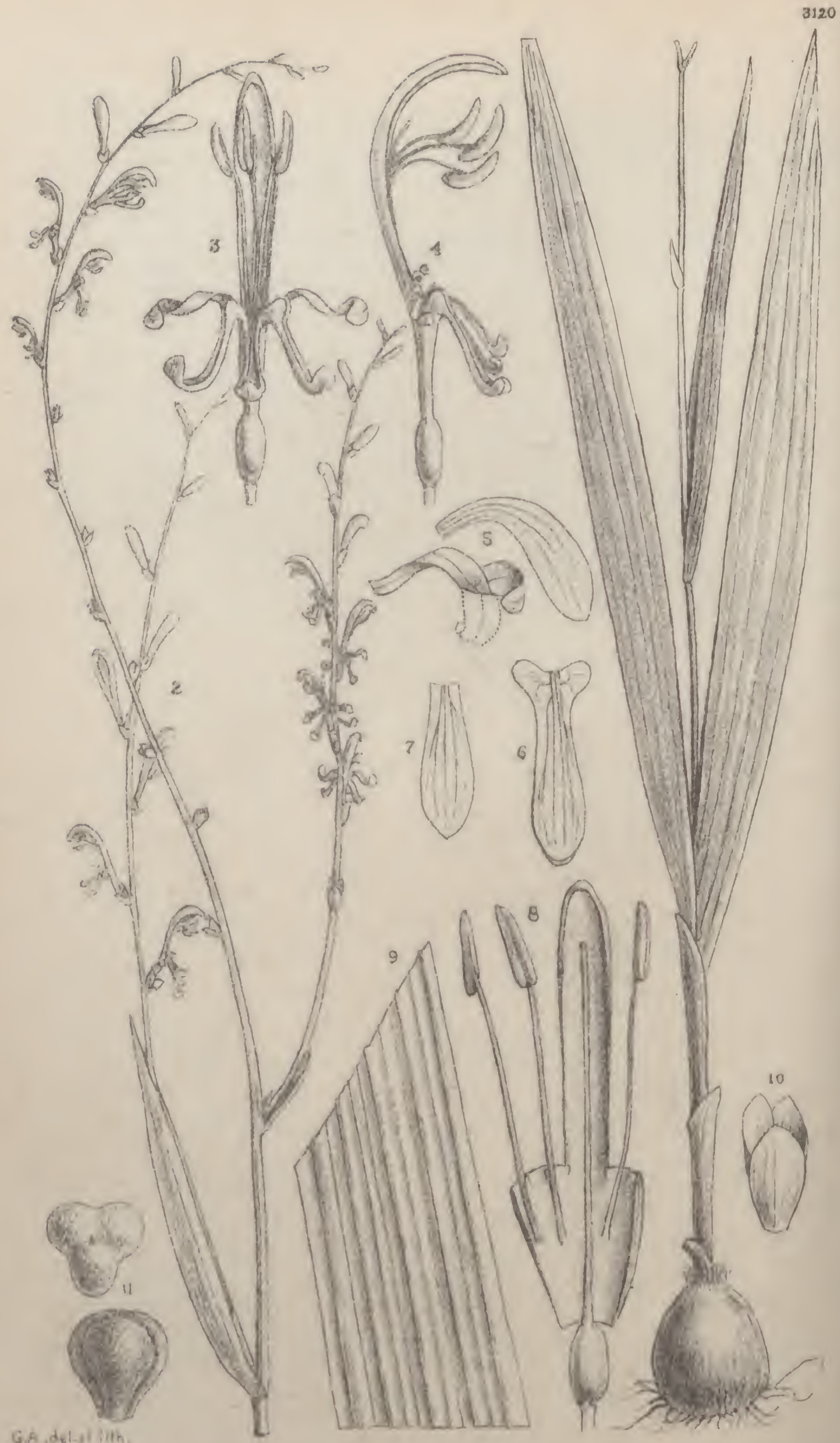




\section{Tabula 3120.}

\section{ZYGOTRITONIA CROCEA, Stapf.}

\section{IRIDACEAE. Tribus IxIEAE.}

Z. crocea, Stapf; species nova Z. bongensi, Mildbr., proxima, sed caule elongato, foliis latioribus, floribus croceis, perianthii segmento postico semper incurvato, nec demuin erecto distincta.

IIerba pcrennis, sub anthcsi 2-4 dn. alta. Cormus globoso-bulbosus cum tumicis arcte reticulato-fibrosis, ad $3 \mathrm{~cm}$. diametro. Cataphylla 2-3-na, vagiuantia, einereo-brunnea, arete nervoso-striata, ore valde obliquo, summum ad $8 \mathrm{~cm}$. longum, subacutum. Folia 2 -na e vagina summa exserta, aliud eaulinum internodio ad $15 \mathrm{~cm}$. longo rcmotum, illa equitantia, e basi longissime anguste attenunta lanceolato-linearia, longe acuta, 20-30 cm. longa, 12-25 mm. lata, breviter marginata, nervis crassioribus 3 , rarius 4 , hoe ad medium vel fere totum compresse eymbiforme, 5-15 cm. longum, 5-8 mm. latum. Inflorescentia pedunculo $5-8 \mathrm{~cm}$. longo suffulta, e spicis 3 (rarius $2 \mathrm{vel} 1$ ) distantibus virgatis laxis constituta; spieac bracteis spathoideis anguste acutis, quarum infima $3-5 \mathrm{~cm}$. longa (caeteris multo minoribus), suffultae, laterales $10-16 \mathrm{~cm}$. longae, terminalis paulo longior; spathae floralcs late ovatae, 3-5 mm. longae, apice seariosac, adaxialis brcvitcr 2 -loba. flores 5-8 mul. distnntes, crocei (fide Daliel). Perianthii tubus leviter vel vix eurvatus, $4-5 \mathrm{~mm}$. longus; segunentum posticum anguste galeatmu, eireiter $6 \mathrm{~mm}$. altum, demum magis apertum, sed minime rcetum, cuetera spatulato-oblonga, obtusa, 4-5 mm. longa, 1.5-1. $55 \mathrm{~mm}$. lata. Filamenta ad $6 \mathrm{~mm}$. longa; antherae $3 \mathrm{~mm}$. Inngac. Receptaculum $2 \mathrm{~mm}$. longum, spathis inclusum; stylus galea brevior. Capsula subglobosa, 3-loba, lobis in dorso obtusissimis, 5-f min. diametro. Semen 1 (raro 2) pro loculo.

Nortures Niarera. Zungeru, Dalziel, 558; Abinsi, Katsina Allah, on stony hills, Dalziel, 818 (19.6.12).

\section{Frexcu Gursea. "Bissikrima," Pobéguin, 1123, p.p.}

The Abinsi specimens have simple or ncarly simple spikes and, like flowers plan's plant, slightly less obtuse floral spatlics, whilst the few 2. bon preserved are more of the type of those of the Sudaneso bongensis, although smaller. Dr. Dalziel also collected near Abinsi, 
and about the same time, another species, which differs rather strikingly from $Z$. crccea as well as from Z. bongensis. This may be diagnosed here briefly as Z. praecox, Stapf (nov. spec.) :

Planta sub anthesi $15-35 \mathrm{~cm}$. alta, gracilis. Cormus $1 \cdot 5-3 \mathrm{~cm}$. diametro, tunicis laxe reticulato-fibrosis. Cataphylla 2 vel 3, tenuiter striata, parte supravaginali $5-10 \mathrm{~m}$. longa, acuta vel acutissima, apice summi 5-12 cm. supra cormum. Folium basale unicum, caulem floriferum praeiens, sub anthesi nullum, $15-20 \mathrm{~cm}$. longum, $2 \cdot 5-5 \mathrm{~mm}$. latum, longe acutum, nervis crassioribus 2 vel 3 ; folia caulina 1 vel 2 distantia, valde reducta. Spicae 3-1, terminalis $10-15 \mathrm{~cm}$. longa, laterales breviores, interdum pauciflorae. Spathae florales $2 \cdot 5-3 \mathrm{~mm}$. longae, obtusae. Flores intermedii $5-6 \mathrm{~mm}$. distantes, albi. Perianthii tubus $3 \mathrm{~mm}$. longus, anguste infundibuliformis; segmentum posticum leviter incurvum vel demum rectum, $6 \mathrm{~mm}$. longum, lateralia 3-4 m. longa. Capsula $4 \mathrm{~cm}$. diametro, lobis in dorso sub dehiscentia ipsa subcarinatis.

Northern Nigeria. Abinsi, on alluvial soil amongst grasses, Dalziel, 847 (1.6.1912).

The sheet of specimens collected by Pobéguin at "Bissikrima" in French Guinea (no. 1123) contains a combination similar to that of Dalziel's Abinsi collecting-namely, a flowering stem with a pair of basal leaves, like Dalziel 848, and a flowering stem without basal leaves, like Dalziel 847. The description on the label of the flowers as "jaune roux" refers evidently to the former, the flowers of the latter being very pale but not so uniformly white as in Dalziel 847.- O. STAPF.

Fia. 1, corm and leaves, natural size; 2, inflorescence, nalural size; 3, a flower in front view, $\times 6 ; 4$, the same in side view, $\times 6 ; 5$, one of the lateral inner perianth-segments, flattened out and (below) in its natural condition, $x .9 ; 6$, onc of tho lateral outer perianth-segments, flattened out, $x 9 ; 7$, the frontal perianthsegment, flattened out, $\times 9 ; 8$, part of the perianth tube with stamens and dorsal segment, straightened and flattened out; the pistil in front, $\times 9$; 9 , part of $a$ leaf, $\times 2 ; 10$, floral spathes, $\times 6 ; 11$, fruit in top and side view, $\times 4$. 


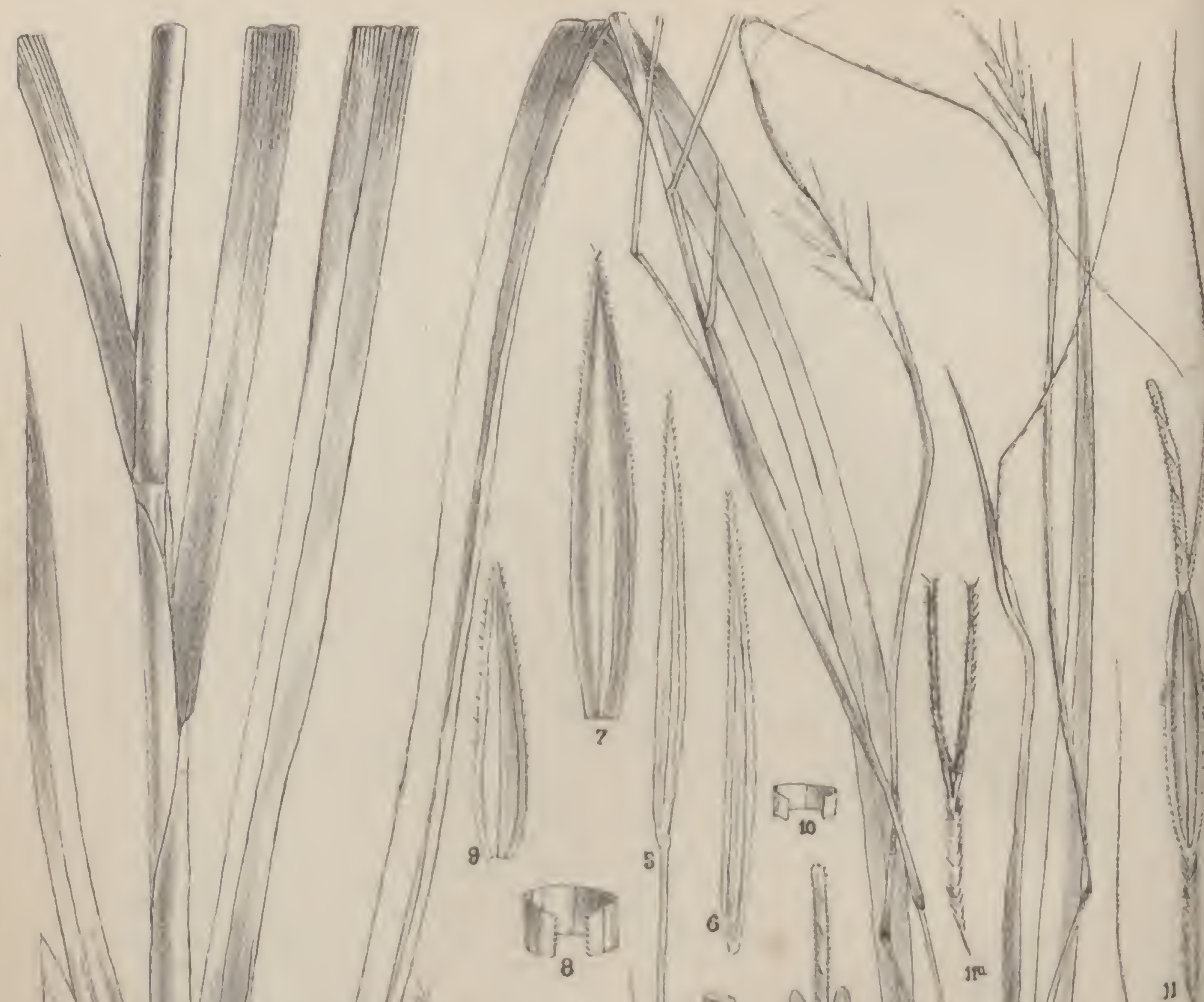

NiI)

MN

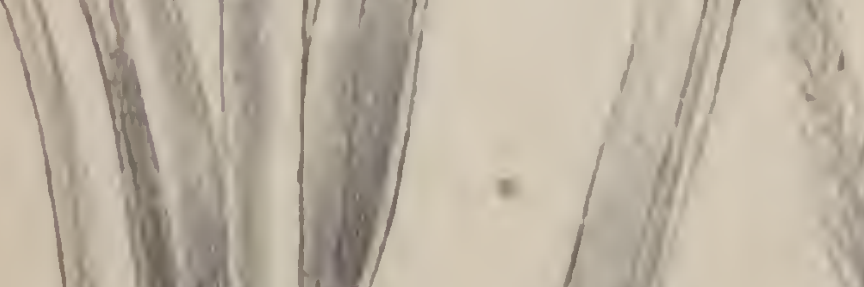

4
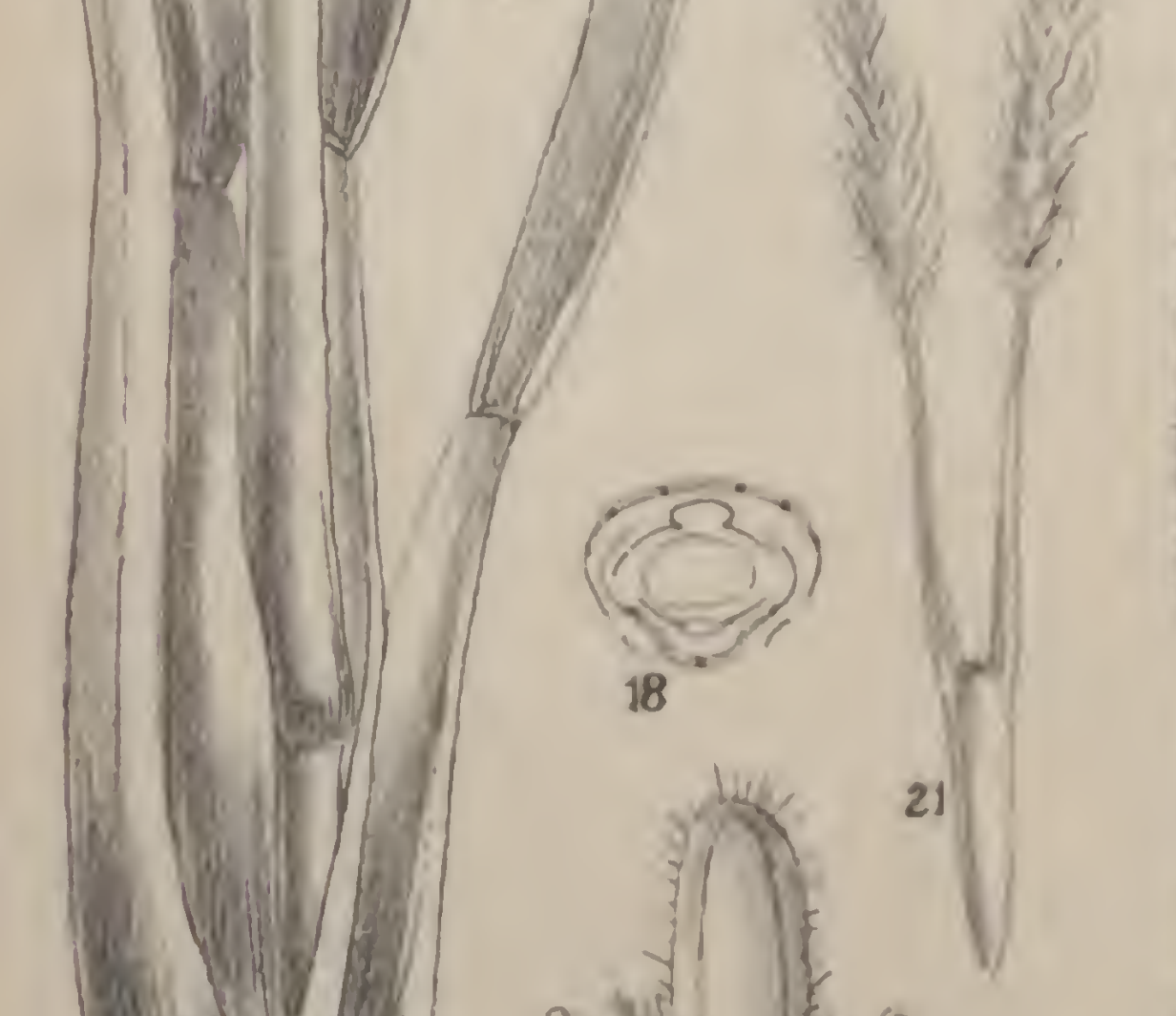

$x$ N
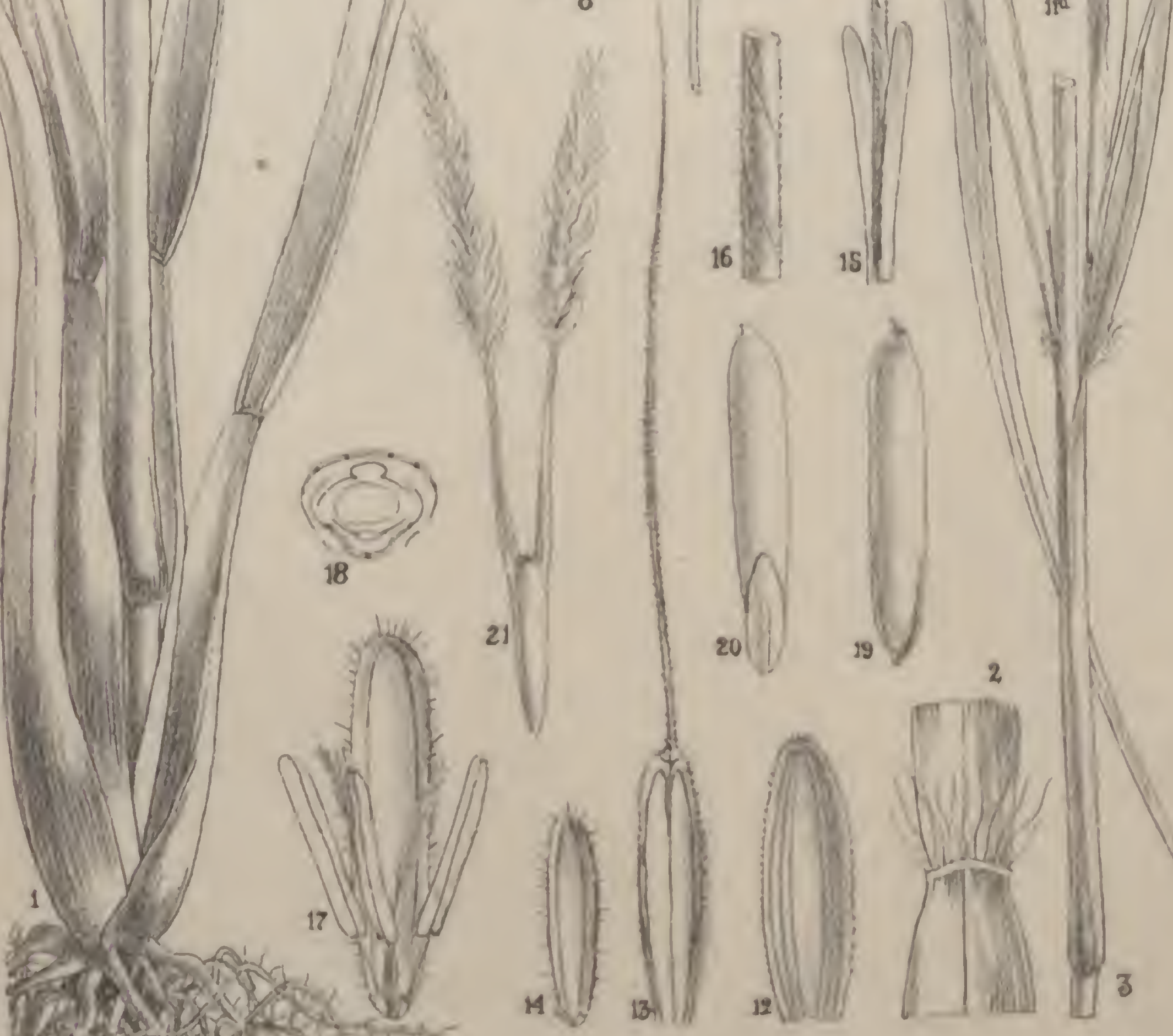

15
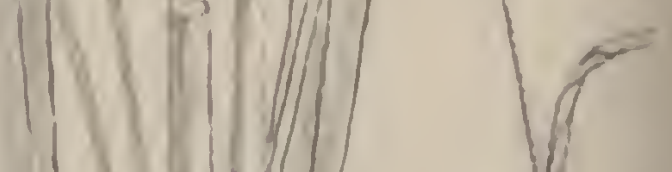


\section{TABULA 3121.}

\section{PLEIADELPHIA GOSSWEILERI, Slapf.}

Graminfan. Tribus $\Lambda$ moropogonean.

Pleiadelphia, Stayf; genus novum cun .1nadelphia, Hack., ct cum Elymandra, Stapf, comparandum; ab illa racemis aliter constitutis, e spicularum paribus $3 \mathrm{vel} 4$ inferis neutris homomorphis et spicula unicr fertili cum pedicellis 2 -nis vacuis adiectis trionem terminalem imperfectum formante compositis; ab bae racemis solitariis, spiculis parium homomorphorum ad glunas reductis distinctum.

Spiculae 2-natae; illae parimn inferiorun 3 vel 4 neutrae, homomorphae, ma sessilis, altera pedicellata, summa fertilis pedicellis trionis terminalis vacuis adiectis; paria sterilia secundun raceni rhachin laxe disposita, rhachi inter en tenace. Racemi solitarii, pedunculo gracili fere toto in spatheola ineluso suffulti, in paniculam pedieollin spatheatamque collecti, matnri infra spiculam fertilem cum filifornis adiectis decilnam disarticulati ; articuli pedicellique tenuiter reductum. Anthoccio 2 in spicula fertili, inferius al lemma vacuum sulutetum, superius of mullin in spiculis neutris. Spicula fertilis Gilumes, aristata, callo longo pungente dense sericeo-tomentoso. ecarinat subaequales; inferior sulbeoriacea, in dorso rotundata. tota e sinuta, apice obtusa, 6-nervis ; smperior tenuior, minnte entarginata. recipiendos, aristata, utrinque leviter sulcata ad perlicellos adiectos ciliatum. attenuatiun, superius 2-lobun, infra lobos hyalinos eciliatos valde ncdio atim, e sinu loborum aristatum, arista valida appresse pubescente Staminu columnam ot setam divisa. Lodiculac 2, minntac, glabrae. Caryopsis subcylinutu lateraliter oxserta; styli subterminales, liberi. sentellum dibcylinclrica, ol) styli basin persistentem minute apiculata; acutae, mutien caryopsis subaequans. Spiculac neutrae subulatae, acuta vel unitiene, callo nullo; glume inferior explanata lanceolata, lateralibus in vitimo bilenticulati, late involuta, ecarinata, nervis 9 , eolleetis, superior sim virides a nervo et a inargine aeque distantibus culmos, superior similis, minor, hyalina, 3-nervis.--Gramen annum, soluto, folionalirlo pro maxima parte in paniculan foliata en decompositaun Speeics forum laminis longis angustis cluris. 
P. Gossweileri, Stapf; species nova, unica.

Gramen annuum, plerumque pluricaule, ultra $1.5 \mathrm{~m}$. altum, subglabrum. Culmi erecti, multinodes, inferne validiusculi, simplices et teretes, superne (a nodo $3^{\circ}$ vel $6^{\circ}$ ) ramosi et in latere ad ramos spectante magis minusve sulcati; internodia infera $5-12 \mathrm{~cm}$, supera ad $15 \mathrm{~cm}$. longa; rami simplices vel iterum ramosi, saepe perlongi, erecti, uti ramuli $2-5$-ni cincinnatim fasciculati; ramuli omnes florentes. Foliorum vaginae $7-9 \mathrm{~cm}$. longae, dorso rotundatae, glabrae laevesque, firmae, infimae laxae, latae, intra rubro-castaneae, superiores arctae ; ligulae brevissimae, truncatae, scariosae, ciliolatac; laminae lineares, e basi vix $5 \mathrm{~mm}$. latiore longe attenuatae, acutae, ad $30 \mathrm{~cm}$. longae, facie virides, hicinde vel rubro suffusae vel maculatac, dorso subglaucae, ad ligulam plus minusve barbatae, pilis albis longis, costa albida facie basin versus latiuscula, dorso tenui, nervis lateralibus primariis utrinque 3-4, margine asperulo. Panicula saepe $1 \mathrm{~m}$. excedens, decomposita, foliata foliis sursum gradatim angustioribus et eorum laminis redactis, ultimis anguste spathuloideis; spatheolae angustissime involutae, laminam setaceam gerentes vel subelaminatae, circiter $8 \mathrm{~cm}$. longae; pedunculi tenuiter filiformes, glabri, breviter e spatheola exserti. Racemorum rhachis $6-10 \mathrm{~mm}$. longa, glabra; pedicelli tenuissimi, inferiores ad $3 \mathrm{~mm}$. longi, laeves vel sublaeves, ei trionis $2 \mathrm{~mm}$. Iongi et ciliati. Spricula fertilis cum callo $14-16 \mathrm{~mm}$. longa, callo fulvo-tomentoso $5-6 \mathrm{~mm}$. longo ; gluma inferior matura flavido-brumnea, $8-10 \mathrm{~mm}$. longa, dense appresse pubescens, superioris aristula ad $3 \mathrm{~cm}$. longa, scaberula; lemmatis fertilis arista 8-9 $\mathrm{cm}$. longa, medio geniculata, abhinc setosa; antherae ad $6 \mathrm{~mm}$. longae. Spiculae neutrae 6-7 mm. longae, ad nervos laete virides, caeterum pallidae. Caryopsis brunnea, circiter $6 \mathrm{~mm}$. longa, $1 \mathrm{~mm}$. diametro.

Tropical Arrica. Portuguese Congo; Sumba, Peco, near the Congo in sandy soil, 30 m. alt., Gossweiler 8739, coll. 1923.

The genus now proposed affords a further instance of the wealth of types of structure exhibited by the Andropogoneae of tropical Africa, where the factors governing the building up and grouping of the racemes and spikelets of the tribe induce much diversity without, however, obscuring the essential linkages in which the tribal characters find expression. This diversity cannot, except along fractional lines, be reduced to such a direct course of evolution as might be rendered graphically in a phylogenetic tree.

By its general appearance Pleiadelphice suggests an Elymandic (see t. 3092 of this series) in which one member of the raceme-pait is tracelessly suppressed and the male spikelets either become nenter or, in the terminal trio, are lost altogether. The spikelets too I $^{-}$ call those of Elymandra, except that, as in Anadelphia-another more distantly related type-the upper glume of the fertile spikelet is notched and awned and the reduction of the hyaline wings of the upper lemma is less marked, whilst the distribution of the nerves of 
the lower glume of the neuter spikelets points to derivation from a dorsally more flattened, two-keeled state. Otherwise Anadelphia differs typieally in the absence of homogamous spikelets, all the pairs being heterogamous.- 0 . STAPF.

Fra. 1, base of a plant, natural size; 2 , a portion of a leaf from the junetion of blado and slieatl, natural size; 3 , a portion of a paniele, natural size; 4 , a raceme, $\times 2$ (awn eut); 5 , a pedieelled spikelet, $\times 6 ; 6$, a sessile neuter spikelet, $\times 6$; 7 , the lower glume of a neuter spikelet, $\times 6$ (flattened out); 8 , a portion of the same in the fresl state, $\times 6 ; 9$, upper glume of a neuter spikelet, $\times 9$ (flattened out); 10 , a portion of the same in the fresh state, $\times 6 ; 11$, a fertile spikelet, $\times 2$ (nwn eut); 11 , the empty pedieels of a trio with the callus of tho fertilo spikelet, $\times 2$ (the eiliao of tho pedieels aro drawn too sliort); 12, lower glume of a fertile spikelet, $\times 3$ (flattened out and seen from within); 13, upper glume of the same, $\times 3$ (druwn in tho same eondition as 12); 14, lower lemma with tho loclicules of the upper floret attaclied, $\times 3 ; 15$, upper (fertile) lemma, $\times 4$ (nwn cut); 16, a portion of the eolumn of the awn, $\times 8$ (the minute hairs of the awn are nuch more munerous than slown liere, and they are elosely appressed); 17, a flower and lower lemma, $\times 4 ; 18$, diagram of a fertile spikelet; 19 and 20, earyopsis in back and front view, $\times 5$. 




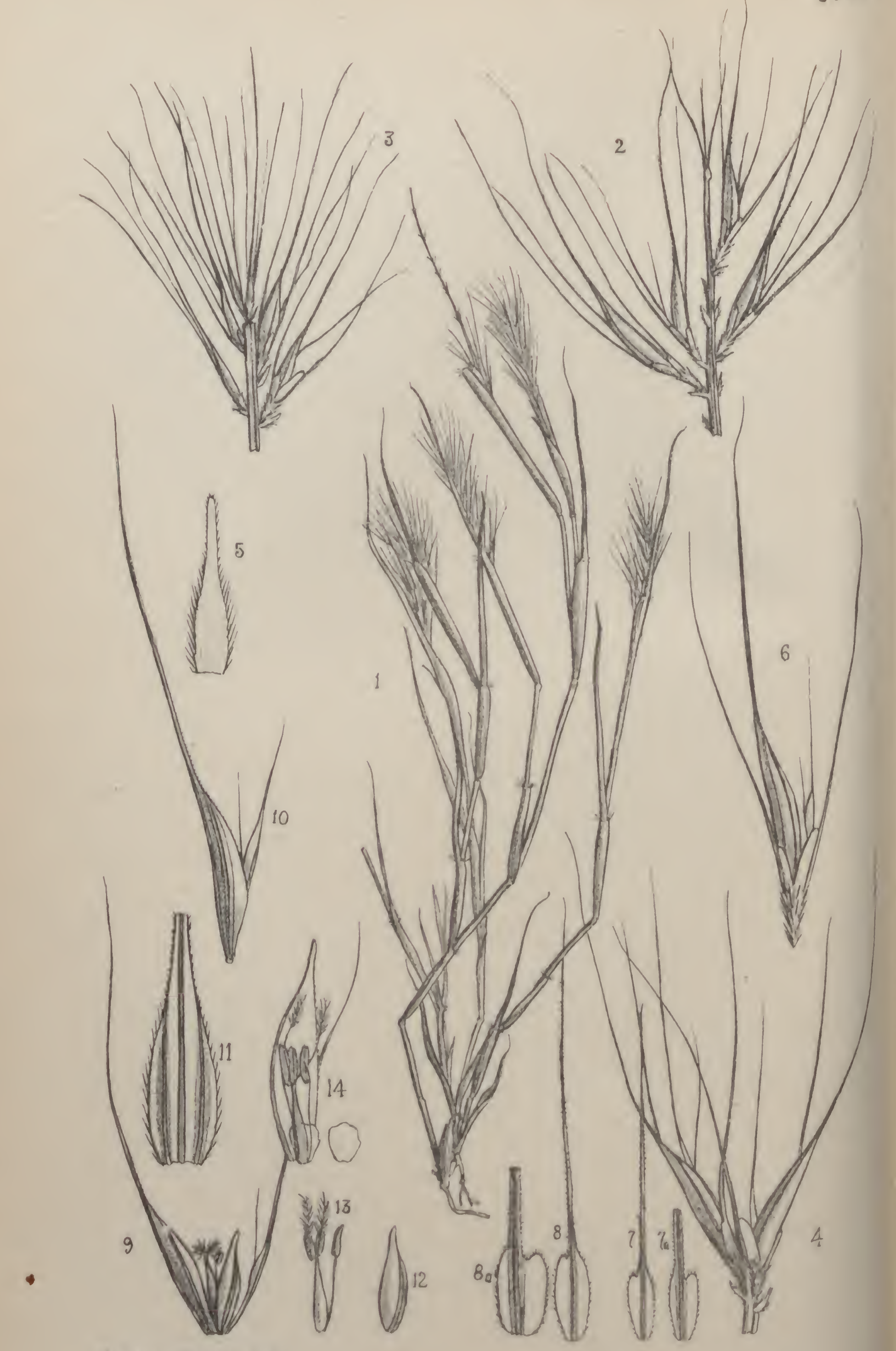

O.S ancl. G.A del.er lith 


\section{Tabula 3122.}

\section{VIGUIERELla MADAGASCARIENSIS, A. Camus el Stapf.}

\section{Cramineat. Tribus Festuckae.}

V. madagascariensis, A. Camus ct Stapf in Bull. Bimens. Sne. Limm. Lyon (1926), 11, et in Bull. Soc. Bot. France, vol. Ixxiii. p. 404 (1926); species unica.

fromen annum, 10-20 cm. altum. Culmi c basi ascendente genieulati, plurinodes, ramosi, grnciles, glabri. Folionum raginac summis tumidulis exceptis angustae et quam internodia breviores, glabrac. l.igulue arl serient pilorum redactae; laminue anguste lineares, exsiecando involutac, $2 \cdot 5-4 \mathrm{~cm}$. longae, explientae fere ad $2 \mathrm{~mm}$. latac, rigirlulas, facie et clorso pilosae pilis illie crebris hic sparsis paucisque flexuosis ultra $1 \mathrm{~mm}$. longis tenuissimis, sursum seaberulac. Inforescentia lasi vagina summa involuta, bracteata, spicata, densa vel laxa, crecta, $4 \cdot 5-5 \mathrm{~cm}$. longa, axi angulato supri bractearum insertionem canaliculato-excavato; lincteae explicatae oblongae, longiuseule rcuminatac, $2 \mathrm{~mm}$. longae, enerves, ciliolatae, spiculas suffuleientes vel vieuae, persistentes. Spiculae sessiles solitariae, totac lecirluae, irrogulariter dispositae, nune 2-3 mm. distantes, nunc magis nploximatae, nunc specic gemimatae vel ternatae, oblique impetae, eallo aristisque demptis $4-5 \mathrm{~mm}$. longae, nonnullae varie imperfectao minoresque, summa ad aristas redacta; perfectae cum pilosuluse ; eallus fere acicularis, $1 \mathrm{~mm}$. longus, dense appresse inaequalite Glumere subrequales, oblongae, saepe obliquae, apiec inferior $1.5-1.75$ biter bilobe, e sinu aristatac, 1-nerves, ciliolatae, gracilis, $1 \cdot 5-1.75 \mathrm{~mm}$. longa, superior paulo longior; arista recta, internoclio $10 \mathrm{~mm}$. longa, scaberula. Anthoccia 2, rhachillae filiformes superius $1.5 \mathrm{~mm}$. longo glabro separata: inferius perfectum, longann ndmolum redactmm; rlachilla ultra id in setulam ad $2.5 \mathrm{~mm}$. oljlique laneducta. Lemma ferlile a latere valde compressum, carinatum, sensin lanecolatum, explicatum ovato-oblongum, 3-t $\mathrm{mm}$. longum, glabrun aristam rectan gracilem $6-7$ mm. longam abiens, pallidum, cariua scaberue nervis prominulis viridi-marginatis, ciliolatum, in 2-carinatabrulum. I'alen navicularis, oblique lanceolata, rostrata, quadrutac. Sarinis upproximatis, 2-5 mm. Inoga. Lodieulae 2, sublineari-oblongtamina 3 ; filamenta capillaria, $2 \mathrm{~mm}$. longa ; antherae eari-oblongae, $0 \cdot 1 \mathrm{~mm}$. longat, vel breviter oblongac, minores. 
Ovarium lageniforme; styli ad $0.5 \mathrm{~mm}$. longi, stigmata aequantia. Lemma sterile $1 \mathrm{~mm}$. longum, arista ut in fertili, sine palea. Caryopsis ignota.

Madagascar. Sakoa-be, on dry alluvial hills, Perrier de la Bathie, 889 ; near Majunga on the north-west coast, on limestone cliffs, Perrier de la Bathie, 11044, 13018; near Amposimentera, on triassic sandstone, Perrier de la Bathie, 11246.

The affinity of this remarkable little grass is evidently with Fingerhuthia, a genus belonging to a group of Festuceae rich in peculiarly modified and specialised types. The structure of the spikelets is, apart from the very definite limitation of the nerves of the fertile lemma to three, similar to that of Fingerhuthin, with which the grass also shares the spicate inflorescence and the shedding of the spikelets as wholes, no disarticulation occurring within them. It possesses, however. this striking peculiarity, that each of the spikelets, whether perfect or not, is supported by a small persistent bract. Moreover this bract is also present whenever the spikelet has become entirely suppressed and its presence is merely suggested by a groove, conforming to the excavation of the rhachis which accompanies the insertion of the spikelets which have actually developed. In our original description these bracts were disguised in the term "(spiculis) lateralibus reductis," the assumption being that the spikelets occurred in triplets, the central one being perfect and deciduous and the lateral reduced to solitary persistent glumes. Some such arrangement is suggested where two bracts owing to the extreme reduction of the intervening internode become practically collateral and only one spikelet is present. the other being either suppressed or having been shed. In such a case the spikelet may appear to rise from between the two bracts, forming with them a "triplet." Renewed and more careful examination, however, indicates that in this we were mistaken. The spikelets are arranged in an irregular alternately expanded and contracted spiral. They are sessile on a rhachis which is grooved from the insertion of each spikelet upwards, the collateral grooves being separated by narrow ridges which give the rhachis its angular appearance. It is just below the theoretical insertion-point of the spikelets that those supposed "lateral reduced spikelets" occur, their insertion stretching right across the corresponding groove and between the accompanying ridges. Bracts, grooves and ridges are present in just the same relative position, whether the spikelets are perfect, more or less reduced or quite suppressed, but with this difference, that the grooves, and with them at least one of the corresponding ridges, become less marked and even faint whenever the co-ordinated spikelets are reduced, and still more so when they are suppressed and at the same time situated in a contracted section of the rhachis. They are in every respect placed as one would expect bracts to be placed. They are small, membranous, nerveless, more or less involute along their margins when dry, but when wetted they assume the shape shown in fig. 5 
of the aceompanying plate. Braets are kuown to occur occasionally in the inflorescenees of grasses aud particularly in the Festuceae. Godron (in Mém. Soe. Nat. Sei. Nat, ex Math. Cherbourg, vol. xxii. pp. 247, $248 ; 1880$ ) has given a list of genera (almost all Festuceae) in whieh bracts are known to oceur, but their oeeurrenee was eonsidered by him, no doubt rightly, as anomalous. In Viguicrclla we have thus the very exceptional ease of a grass with a normally bracteate inflorescence. $A$ priori one would be inelined to see in this a "primitive" feature, but it is difficult to reconcile such " primitiveness" with the otherwise highly specialised structure of the inflorescence and the spikelets. We therefore prefer to treat Viguierella as an isolated type of Festuceac approaching most nearly to Fingcrhuthic, a genus with a wide but remarkably disconnected area, the main area covering all South Africa, whilst a very small subarea occurs on the Punjab-Afghanistan frontier.

Fra. 1, whole plant, natural size; 2 , top of an infloresence, $\times 4 ; 3$, middle part of another inflorescenee, $\times 4 ; 4$, n pair of closely rpproximate spikelets, $\times 6$; 5 , a brict, expanded, $\times 20 ; 6$, a perfect spikelet, $\times 6$; 7 and 8 , lower glumes, expanderl, $\times 6 ; 7 n$ and $8 n$, upper glumes expanded, $\times 6 ; n, n$ spikelet without its glumes, opened out, $\times 6 ; 10$, a spikelet in its usual closed condition, without it glumes, $\times 6 ; 11$, lemma of the fertile floret with the awn cut off. flattened out, $\times 6$; 12, palen, $\times 6 ; 13$, stamens and pistil of a cleistogamous (?) flower, $\times 12$; 14, flower with the halved palea behind it and one of the lodicules detached to the right, $\times 12$. 




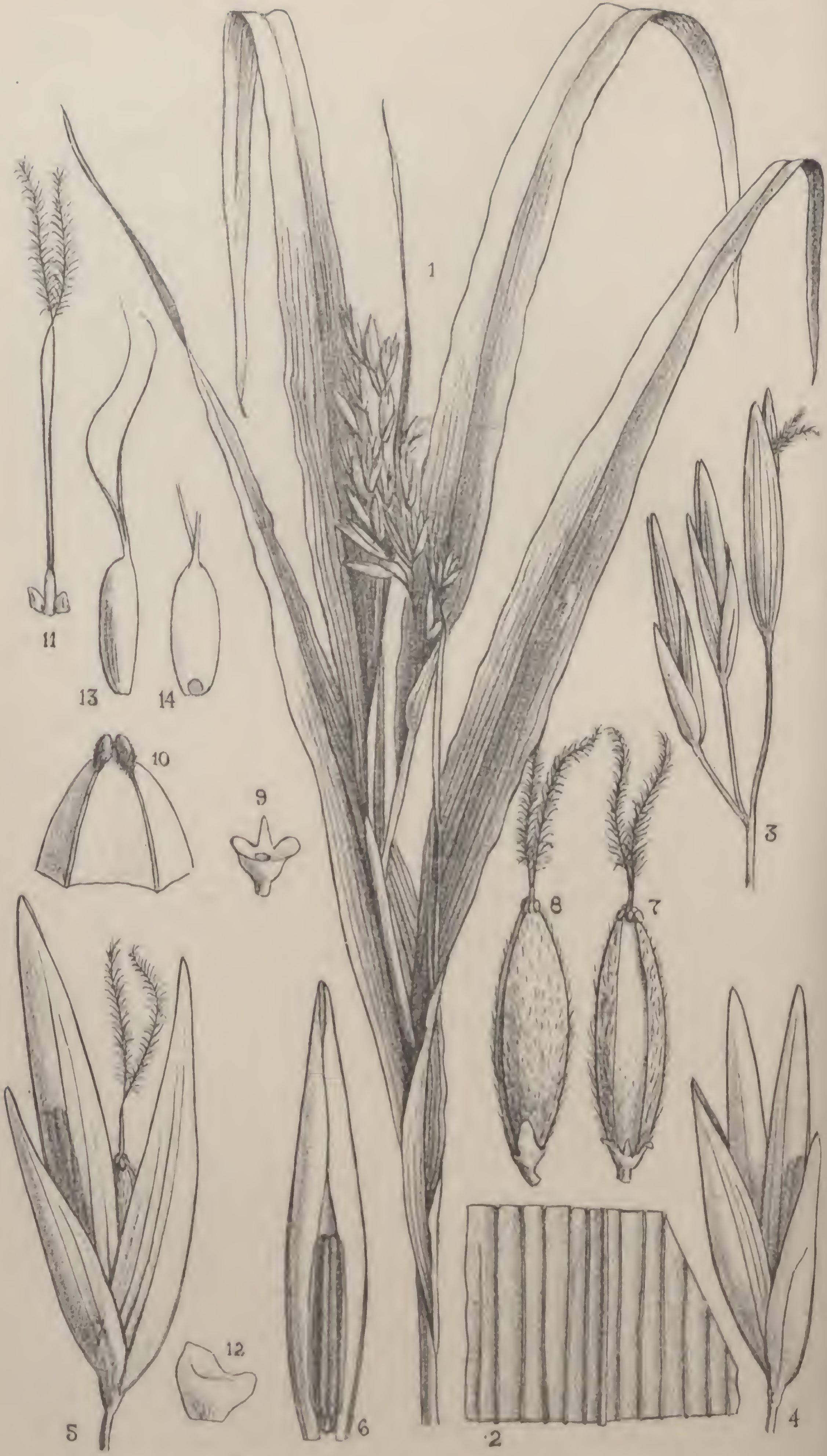

O.S anal.G del et lith 


\section{Tabula 3123.}

\section{LECOMTELLA MADAGASCARIENSIS, A. Camus.}

\section{Gramingae. Tribus Panicean.}

L. madagascariensis, A. Camus in Bull. Soc. Bot. France, vol. Ixxiii. P. 405 (1926); species uniea adhue nota.

Gramen perenne, 1-2 mm. altum, multiramosum, undique glabrum. Culmi fistulosi, terctes, internodiis superioribus vaginis inclusis. Foliorum vagince terctes, laeves, superiores $5-3 \mathrm{~cm}$. longae; ligulae ad rimam dense ciliatam redactae; laminac lineari-laneeolatac, longrssime aeutae, $12-22 \mathrm{~cm}$. longae, $1-1 \cdot 8 \mathrm{~mm}$. latae, clartaceae, ad margines eartilagineas seaberulae, nervis primaris utrinque 6 uti costa abida gracilibus, nervis secundariis 6-9-nis arete approximatis interjeetis, venis transversis mullis. P'anicula contracta, angusta, a fi cin. longa, ramulis sacpius paucifloris ; pedicelli tenues, filiformes, ajpice vix erassiores, trunenti, $3-5 \mathrm{~mm}$. longi. Spiculae lanecolatoformgac, jullicle virides, 2-florae, 9-10 mm. longae, omnes eadem nona, sed sexu diversae, nempe inferiores unisexualcs ô. summae olumallae bisexuales, eum flore superiore ㅇ. Spiculae unisexuales: acume tenuiter lierbaeeo-papyraeeae, a latere angustc lanceolatae, longa anga; lemma inferius utriusque anthoeeii glumarum indole nisi snf 2-cárimans; palen lineari-laneeolata, hyalina, lemma subaequans, late f mm. Sume. Stamina 3 ; filamenta 5 mm. longa; antherae 4.5Iongin. longae. Spiculae biscruales: ylumac ut in spiculis ơ, scd spientics, supcrior spienla jaulo brevior; anthoecium inferius ut in (stipite) of amlunecium supcrius o, breviter stipitatum, articulo I!n ad spiculae insertionem utrinque obtuse aurieulato, in mucronus)tusurutun continuato ; lemmu ambitu oblongum. dorso convexum, 2 inm. elartacem vel demum erustaccum, 4-5 mm. longum, fere mea latum, apice coromm tubcreulorm notatum, obscurc 5-nerve; 2-hervis astentia et longiturline lemmatis nisi ad margines tennior, Lodicul, apjec tuberenlis 2 -nis, lemmate more I'onici arete implexa. basi liberi, tenuiter capillarcs, ad $5 \mathrm{~mm}$. longi; stigmata ex apiee 
anthoecii exserta, laxe plumosa, $3-3 \cdot 5 \mathrm{~mm}$. longa. Caryopsis (immatura?) arcte in anthoecio inclusa, plano-convexa, ambitu oblonga, hilo basilari punctiformi, embryonis macula obscura.

Madagascar. Andringitra Massif, 1200-2400 m., Perrier de la Bathie, 74 (H. Kew) ; 10816, 13589 (Hb. Paris).

Mlle. Aimée Camus, who justly calls this grass "extrêmement curieux," places it in Paniceae with affinities with Olyra and Ichnanthus. There seems to be no doubt as to its position in Paniceae, the structure of the spikelets being decidedly panicoid. It differs, however, fundamentally from Ichnanthus in the sexual differentiation of the spikelets into such as are purely male and others which possess a male lower floret and a female upper floret. No approach to it is known in any of the species of Ichnanthus, whose spikelets are uniformly bisexual, the upper floret being always hermaphrodite. The affinity was probably suggested by the presence of auricles at the base of the fertile spikelet; but these auricles are in Lecomtiella borne on the rhachilli and remain attached to it if the spikelet becomes detached, whereis in Ichnanthus the auricles are part of the lower glume. As to Olyra, I would remark that this genus can hardly be included in the Panicene. although the fertile floret is very similar to the fertile florets of a typicil Panicum. The spikelets are definitely one-flowered, having no trace of a second lower floret of either sex. They agree with those of Pharli. and Olyra has, for this and also for other obvious reasons, been placed in a special tribe, Phareae. I have failed to recognise an immediate affinity with any of the paniceous genera and would suggest that Lecomtiella shonld for the present be included in Paniceae as a "genlls" incertae sedis," as is the case with Spinifex. It may be the end-linl of a phylum whose earlier stages have been lost, but as to that we call offer at present nothing more definite than speculation.-O. STAPl.

FIa. 1, a flowering branch, natural size: 2 , a portion of a leaf, $\times 2 ; 3$, a portion of an inflorescence showing two male and one bisexual spikelet, $\times 3 ; 4, a \mathrm{~m}^{\mathrm{al}}$ spikelet, $\times 6 ; 5$, a bisexual spikelet, $\times 6 ; 6$, a palea of a male floret with stamen" still enclosed, $\times 6 ; 7$ and 8 female floret, front and side view, $\times 7 ; 9$, "stipe" of a female flower with continuation of rhachis and auricles, $\times 7 ; 10$, tip of pal and of a female floret, $\times 14: 11$, pistil and lodicules, $\times 7 ; 12$, lodicules, $\times 20 ; 13$ al 14, immature caryopsis in side and back view, $\times 7$. 



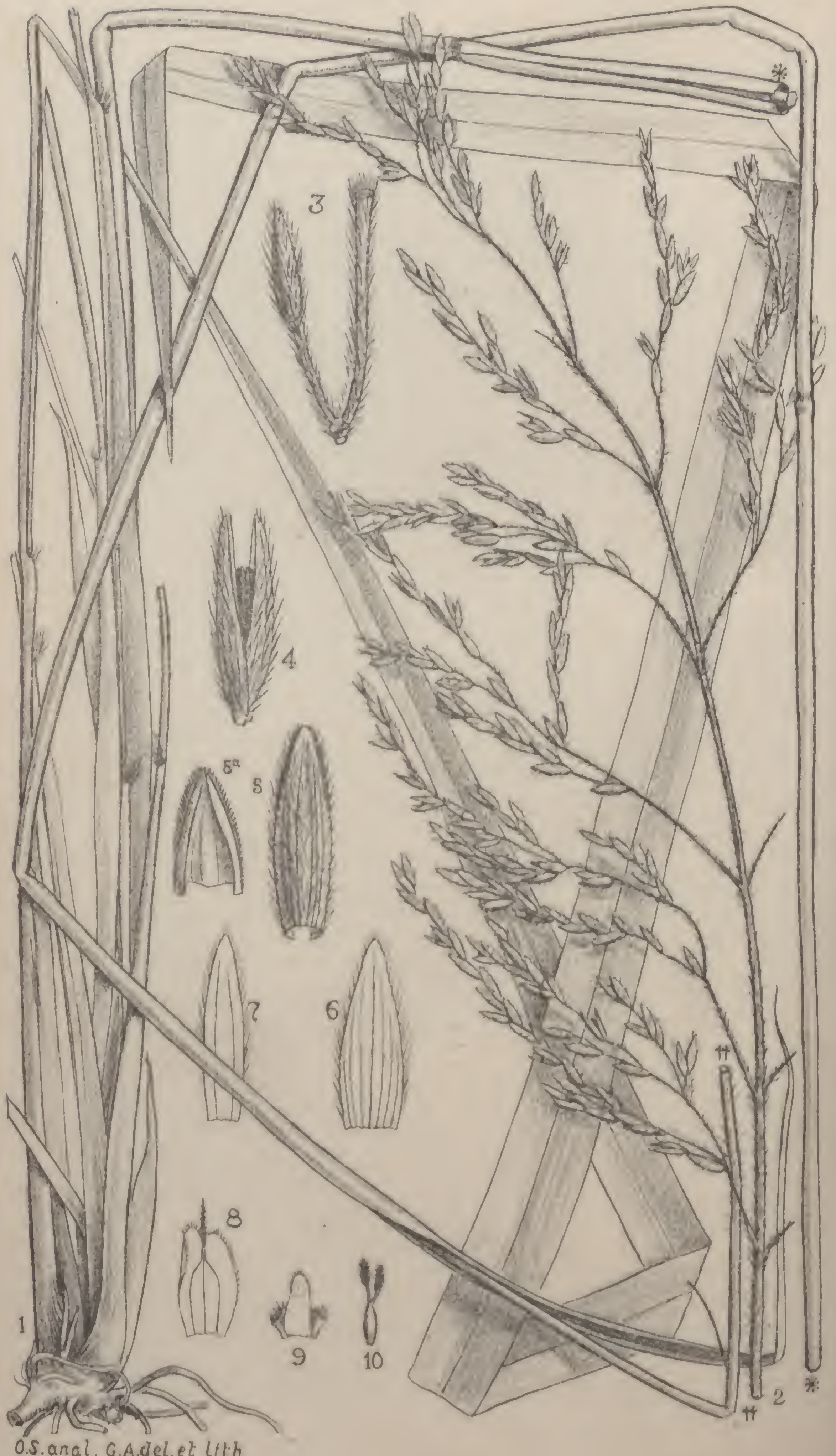




\section{Tabula 3124.}

\section{LASIORRHACHIS HILDEBRANDTII, Slapf.}

\section{Gramingar. Tribus andmopogoneae.}

Lasiorrhachis, Stapf; genus novum eum Sorgho, Pers, et Miscanthidio, Stapf, comparandum; al, illo differt spiculis saepissime homozygis o, glnmis totis tenuiter clartaceis, lemmate fertili lato; ab loc spiculis secundariis plane sessilibns, primariis saepe rorluetis et tune o vel neutris, glumarum nervatione, lemunate fortili lato brevissime aristulato: potins iuter Sorghastre poncndun ob spicularmu indolem, quamvis 'quad rhizoma, caules, folia cum Miscamthidis quibusslam bene yundrat.-Andropoyon, sect. Lasiorhachis, Hack. in Flora, vol. xxviii. P. 142 (1885) (subgen. Lasiorrhachis, Haek. in A.DU., Mon. Phan. vol. vi. p. $472 ; 1889)$.

Species 1, madagascaricnsis.

L. Hildebrandtii, Stapf (nov. comb.) ; species unica.

Gramen percnne, ad (vel ultra ?) $1 \mathrm{~m}$, altum, compacte caespitosum, rhizomate brevi, interuodiis brevissinis, innovationibus extravaginantibus. Culmi erceti, simpliees, 2-3-nodi, inferue compressi, glabri vel arl nolos et paniculam versus molliter pilosi. Nodi magis minusve temiter sericei. Foliorum vaginac basalium valde compressae, obtuse carinatac, circiter ad $15 \mathrm{~cm}$. longae, durae, inferne appresse pilosae vel glabcrrimat lavesque, magis inimsve glanecsecntes, cauliuorum minus compressae vel subterctes, vix earinatac, summa ultra $30 \mathrm{~cm}$. longa; ligulac rotundato-truncatae, ad 3 mu. longae, senriosae, in dorso pilosae, pilis in barlonm ad 5 mm. longum collectis: laminae lineares longe acutae, ncutissimae, foliorum basalium in petiolum canaliculatum angustum ad $10 \mathrm{~cm}$. longum sensim attematice, eo bisipto saepe ultra $40 \mathrm{~cm}$. longae, $815 \mathrm{~mm}$. latae, foliorum superiorum rigic vix angustiores, multo breviores, ommes planae, pallide virides, cestue, glabrac vel lasiu versus molliter pilosie, ald unargincs scaberulae, lasta albida in facie latinscula nervis primariis ntrinque a 6 tenuibus. surcula denum longissine exserta, pedunculo vel canlis internodio flaccidusape ultra 50 em. longo, ambitu oblouga vel ovato-oblonga, pilosila; rhachis uti ounes axes inflorescentiuc molliter serieeo10 anc rani al nodos 2 -ni vel inferiores solitarii, flexuosi, infini ad cm. longi et ad $2 \mathrm{~cm}$. indivisi, raecmos $1-1$ gerentes. Racemi 
longiores breviter pedunculati, 3-4 cm. longi, 5-6-articulati, infra spiculas fertiles ut videtur tarde disiuncti, articulis filiformibus $4-5 \mathrm{~mm}$. longis apice paulo incrassatis et recte truncatis. Spiculae sessiles semper cum flore unico of, oblongae, $5.5 \mathrm{~mm}$. longae, pallidae, callo brevi sericeo. Glumae aequales, chartaceae, sericeo-pilosae; inferior dorso plana, apicem subtruncatum versus anguste implicata atque 2 -carinata, carinis ciliolato-scabris, tenuiter 7-nervis; superior similis, sed magis acuta et supra medium subcarinata, nervis tenuissimis 7 . Anthoecium inferius ad lemma glumas aequans lanceolato-oblongum subhyalinum tenuiter 2 -nerve ciliatum reductum. Anthoecium superius के : lemma explicatum ellipticum, latum, subbilobum, $2 \mathrm{~mm}$. longum, tenuissimum, ciliolatum, 3-nerve, brevissime aristulatum, aristula setiformi quam lemma plerumque breviore; palea ovata, ciliolata, vix $1 \mathrm{~mm}$. longa, enervis. Lorliculae 2-cornutae, ad cornu maius barbatulae. Antherae $2 \mathrm{~mm}$. longae. Ocarium anguste oblongum, glaberrimum; stigmata stylum aequantia, $1 \mathrm{~mm}$. longa, e spicula late hiante lateraliter exserta. Spiculae pedicellatae sessilibus consimiles et tunc ơ vel magis minusve reductae et ô vel neutrae, interdum subnullae; pedicelli articulis simillimi, sed longiores.-Andropogon Hildebrandtii, Hack. ll.ce.

Centrat Madagascar. Near Andrangoloaka, smmy hills on the edge of virgin-forest, Hildebrandl, 3755 (Nov. 1880); Baron, 1991, 2017, 3871. Without exact locality.

When describing this grass in Flora as Audropogon Hildebrandtii, Hackel said of it, "Nulli alii affinis, potius typus sectionis propriae (Lasiorrhachis) habendus." A few years later, in his monograph of the Andropogoneae he recognised its peculiar position in Andropogon by founding on it a new subgenus "inter Arthrolophin et Amphilcphin medium, pistilli indole ab utroque diversum," the character of the pistil alluded to consisting in the presence of hairs at the top of the ovarium ("ovarium pilis coronatum"). In this he was mistaken, the ovary being in fact perfectly glabrous. It happens, however, occasionally that some of the stiff hairs of the lodicules become attached to the ovary at an early state and are subsequently carried up with it as it lengthens out. This was no doubt the case with the young flowers he examined. It may also explain his description of the lodicules as glabrous. They had apparently given up their hairs to the ovary when this was still young and had still "styli obsoleti. Why he placed Lasiomhachis between his sections Artholophis and Amphilophis is more difficult to understand, as the application of his key-characters of the subgenera of Andropogon leads direct to Sorghmm. It might indeed be included in this group but for the imperfect sex $\mathrm{u}^{\mathrm{a}}$ differentiation of the spikelets, which points to the more primitive, that is less specialised, Saccharastrae. In some panicles, as the one used for the preparation of the present plate, the homogamy of the spikelets - they have all a bisexual flower-is complete; in others, as in Hildebrandt's specimens, the pedicelled (primary) spikelets are either 
male or nenter, showing all stages of reduction down to a subulate rudiment barely $1 \mathrm{~mm}$. long and consisting usnally only of a much reduced lower glume and a minute scale representing the upper glume, whilst Baron 1991 and 3871 have nearly all the pedicelled sjikelets male. 'The reduction of the pedicelled spikelets from the perfect male state to rudiments of glumes or even to complete suppression is common enoughl in the Soryhastrae, but no case of variation equal to that observed in Lasiorrhachis is known so far in this group. It seems nevertheless appropriate to place Lasiorhachis here rather than in Saccharastrae, as the strncture of the panicle and of the spikelets has more in conmon With certain types of Sorghum than with any other genus; but the disposition of the branches of the panicle, the thin texture of the glumes, the broal fertile lemma with its minute bristle-like awn to which the broad lobes are alnost completely adnate, are distinctive characters Whieh, in aldition to the sexual condition referred to above, appear to justify the procednre followed here, according to which Lasiorrhachis is treated as a distinct genus, closely allieel to Soryhum. The mode of growth and the foliage are on the whole as in the South Africin species of Miscanthidium. 'Ihis grenus, however, differs widely from Iffiorhachis in having botlı spikelets of a jair pedicelled, in its differently nerved glumes and its narrow distinetly awned fertile lemma. Its spikelets are moreover always perfectly homoganous-O. STAPF.

\footnotetext{
Fies. 1 and "2, purt of a tuft with a flowering culm, nalural size; 3, a joint and 5. pricel with spikelet, $\times 6 ; 4, a$ spikclet in side view not quite npened, $\times 6$; 6) lower glume, back view, $\times 6$; $5 \mathrm{n}$, the tip of the same, seen from within, $\times 12$;

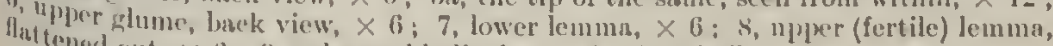
at tened out, $\times 6 ; 9$, palca and lodicules, $\times 6 ; 10$, pistil, $\times 6$.
} 




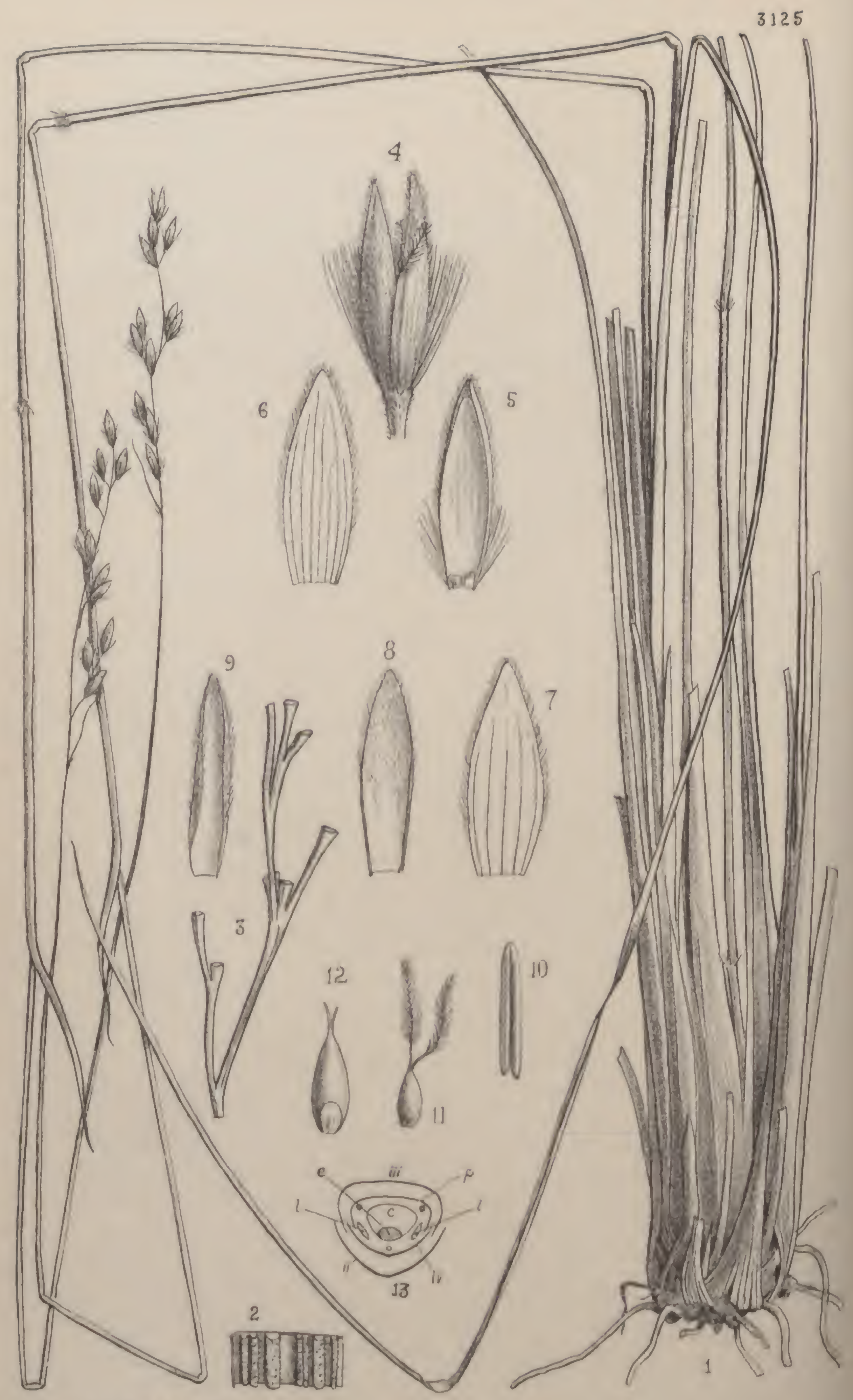

O.S.anal G.A del.el lith 


\section{Tabula 3125.}

\section{IEPTOSACCHARUM FILIFORME, A. Camus.}

Gramanate. Tribus Paniceate.

Leptosaccharum, A. Camus in Bull. Soc. Bot. France, vol. Ixx. p. 737 (1923) (deser. emend.) ; Ifplocoryphio, Nees, proximum, sed panicula macra spieiformi rigida, lemmate fertili et eins palea etiam maturitate tenuissime hyalinis, glumae unicac et lemmati sterili alpressis et cum is caryopsin laxe includentibus.

Spiculac e callo barbato obscuro oblongo-lanceolatae, leviter a dorso compressae, in paniculam nngnstan spiciformem nucram dispositae, naturac totac decidune. Anihoccia duo, inferius ad lemma redictmo, superius s. Gluma ob inferioris abortum unica, tenuiter membralinea, inter nervos fere hyalina, sericeo-pilosn. Lemma anthoecii inferioris glnme simile, 5-nerve, brevius pilosmm. Lemma anthoecii superioris oblongum, tenuissime membraunceum, liyalinum maturitate nullo modo induratum, enerve, sursum pilosinsculum cum palea Simillina aequilonga. Lodiculac 2, late cuneatae, glibrae. Stamina 3. Ourinm late oblongum; styli quam stigmata breviores. Caryopsis subollipsoidea, lilo punctiformi, embryonis macula maiuscula, in fpicula laxe inclusa.-Gramina perennia, compacte caespitosa foliorum laminis angustissimis duris; panicula aureo-vel fulvo-sericen, rhachi tenace gracili eompressa, ranis brevibus 3-1-spiculatis.

L. filiforme, A. Camus l.c. (descr, cmend.); speeies unica.

Gramen sub anthesi $40-70 \mathrm{~cm}$. altum, e rhizomate brevi compacte cacspitosum. Culmi filiformes, glabri, 2-3-nodi, internodiis elongatis, basalim al $30 \mathrm{~cm}$. longo. Nodi sericeo-barbati. Foliorum vaginac longate, angustae, laevissimae, arete nervoso-striatae, ad $30 \mathrm{~cm}$. ad 1.5 durae, summin vix laxior, $8-10 \mathrm{~cm}$. longa; ligulac ovatae, a vagina vix. longie, e dorso pilis stipatae; laminae e basi aequilata al 30 ein distineta angustissine lineares, acutae, culmeae inferiores imo apiee longae, 1-2 mm. latae, planae, exsiccando facile involutae, $2 \cdot 5-1 \cdot 5$ colosulie, caeterum in dorso glabrae laevesque, summa $20-30 \mathrm{~cm}$. lom. Ionga, innovationum filiformes vel setaceo-convolutae, in facio prugac, omnes circiter 6 -nerves, nervis primariis crassiusculis aureo- vel prumoso-puberulis albidis. Inforescentia 4-7 cm. longa, lufo-sericen; rhachis ad nodos sericeo-pilosa, 6-7-nodis, 
e nodis inferne et medio $1 \mathrm{~cm}$. distantibus ramulos ad $1 \mathrm{~cm}$. longos subadpressos spiculas 3-2 (vel imprimis superne 1) gerentes edens; pedicelli laterales brevissimi, terminales $3-4 \mathrm{~mm}$. longi, omnes sericeopilosi, apice incrassati et barbati. Spiculae oblongo-lanceolatac, subacutac, 5-6 mm. longae, $2 \mathrm{~mm}$. latae, aureo-vel rufo-sericeae, calli pilis ad $3 \mathrm{~mm}$. longis. Gluma in dorso undique pilosa, explicata ovatolanceolata, 7-8-nervis. Lemma inferius glumae simile, sursum leviter involutum, spiculac longitudine. Lemma superius explicatum oblongum, $4 \mathrm{~mm}$. longum, supra medium pilosulum cum palea simili lineari-oblonga ad latera inflexa. Antherae lineares, $3 \mathrm{~mm}$. longae. Ovarium ovato-vel oblongo-ellipsoideum; stigmata ad $2 \mathrm{~mm}$. longa. Caryopsis $2 \mathrm{~mm}$. longa, subplano-convexa.-Saccharum filiforme, Hack. in A.DC. Mon. Phan. vol. vi. p. 127 (1889).

South America. Brazil : Goyaz, between the rivers Rio Torto and Paranã, Glaziou, 32. Paraguay: Caaguazu, in marshy prairies, Balansa, 231.

Hackel, in his monograph of the Andropogoneae, p. 127 (1889), described from specimens, collected by Balansa (no. 231) in Paraguay, an atypical Saccharum, S. filiforme, for which he said he would have proposed a new genus had he not suspected that the specimens at his disposal were depauperate and that their lack of one of the universal characters of Saccharum was due to their impoverished condition and therefore taxonomically of doubtful account. In the circumstances he confined himself to the creation of a subgenus (Lepe(t)saccharum) for the reception of the species in question. T'he character he had in mind was that in typical Saccharum the spikelets occurred in pairs at each node, whilst in the subgenus Leptosaccharum the spikelets were solitary. More recently Mlle. Aimée Camus made the grass the subject of a short article in the Bulletin of the Société Botanique de France (vol. lxii. p. 737 ; 1923). Having ample material at her disposal she was able to establish the fact that Hackel's suspicion was unfounded. She drew therefore the only conclusion that appeared reasonable - namely, that of according the subgenus Leptosaccharem generic rank, adding as further but minor characters certain features which determine the habit of the panicles. Having had lately occasion to examine part of Balansa's collecting referred to above, I have contvinced myself that the grass in question does not belong to the Andropergoneae, but to the Paniceae, and that it approaches indeed so closely to Leplocoryphium that if we accepted the wider generic concepts of the Genera Plantarum we should have to merge it in Leptocoryph hivm and finally with this in Anthenantia. ${ }^{1}$ The mistake arose from an erroneous conception of the homology of the foliar parts of the spikelet. according to which the upper glume of the grass became gluma 1, to use Hackel's terminology, the lemma of the lower barren floret, gluma II.

1 Beauvais, the nuthor of Anthenantia, gives the derivation of the name fro ${ }^{\prime \prime}$ àvoćw and Évávriov. It is true he spells it Anthaenanthia in the text, but in the index he corrects it to Anthenantia, and this is no doubt the proper spelling. is no justification for the introduction of an " a " into the second syllable. 
the lemma of the upper fertile floret ghma III and its palca glnma IV. 'There was then still, if Hackel's interpretation werc right, the palea to glume IV to be looked for. He actually records its existence and describes it as "minutnla." I lave not been able to find an organ to eorrespond to it and must assume that he wats misled by a small picce of the lemma or the palea of the fertilc floret having become detached, mimieking a very mueh redueed palea. I myself in dissceting the first spikelet had the same experience. Now the palen of the npper floret of an andropogoneons grass is sometimes entirely suppressed. Its abscnec is thercfore not decisive. In all sureh cases it is the oricntation of the lodicules and that of the ovary which, as fixed features, help ns in the construetion of the dingram of the spikelet and the interpretation of its parts. The lodicules, where there are two, are always plieed to the right and the left of the ovary, so that they converge dorsilly to the ovary (that is towards the midhle of its baek), whilst the ovary fices the palea ventrally, that is with its earpellary suture. Here is where the lilum is formed, the embryo and conseqnently

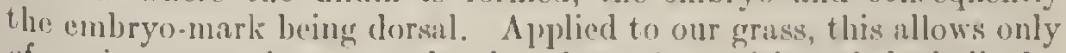
of one interpretation-manely, that. from the position of the lorlieules as well as thint of the hilum and of the cmbryo-mark being what they are, Hackel's gluma IV is in faet the palea of the fertile upper floret, whence gluma 111 bceomes its lemma, gluma 11 the lemma of the lower floret, and grluma l the upper member of the ghmal involuere, the lower member being absent. This, however, is the structure of the Anthenamtia group. Benthan in Genera Plantarum, and Ihekel, following him in the Natïrliche Pflanzcnfanilien, cxtended the original concept of Anthenautiu (Beauvais, Agnost. 48, t. x. f. 7; 1912) so as to takc ill also Nees's Leptocoryphium (1 grost. Bras. $83 ; 1829)$. Mrs. C'lase has since rescparated the two genera, and, as it seems to me, for good reasons. Accorling to her conecpt of them Autheramtio has tightly elosed inclurated "fruits" much after the fashion of l'anicum, whist in Lepocoryphium the fertile floret rcmains thinly umbranous in its upper part and gilpes at maturity. This necounts for the relative plumponess and heaviness of the mature spikelets of Anthenantia and the lightness of those of Leptocormphium, charaeters which impart quite ristinctive features to the ripe panicles. In Leptosaccharum the durinar and the palea of the fertile floret undergo no ehange whatever applying thration, rcmaining very delicate nerveless hyaline struetures elose ung themselves to the lower lemma and the upyer glume, which fuse up loosely and hy becoming more rigid take over the protective palen. To this in l'uniceap fall generally to the fertile lemma and its character thes may be added as a minor but convenient diagnostic false spike and the raction of the panicle into a narrow rather scunty Geographically soft silky liairiness of the spikclets.

(2 spceies) is ally these genera are so distributed that Anthenamia Lepecoryphim (s confincl to the southern states of North Amerien. whilst ancl subtropien (I species) ranges widely over the whole of tropieal subtropieal Ameriea from Mexieo and the West Inlies to Urmgnay 
and Northern Argentina. Leplosaccharum, on the other hand, is recorded so far only from one locality in Paraguay, Caaguazu, about halfway between Assuncion and the river Parana, and another in Brazil in the Serra do Paranã, about $47^{\circ} \mathrm{W} .15^{\circ} 30^{\prime} \mathrm{S}$. Both lie within the wide area of Leptocoryphium.-O. STAPF.

Fig. 1, part of a plant, natural size; 2, part of leaf, unrolled, in face view $\times 10$; 3 , part of panicle with indumentum omitted and spikelets removed, $\times 3$; 4, spikelet in side view ; 5 , upper glume and fertile lemma inside it with lodicules in front; 6, upper glume, flattened out, seen from within; 7, sterile lemma, flattened out, seen from within; 8 , fertile lemma, seen from back; 9, palea; 10. anther ; 11, pistil ; 12, caryopsis ; 13, diagram of spikelet (II = upper glume, III = lower $\quad$ (sterile) lemma, IV $=$ fertile lemma, $\mathrm{p}=$ palea, $\mathrm{l}=$ lodicules, $\mathrm{c}=$ earyopsis, $\mathrm{e}=$ embryo). Figs. $4-12 \times 6$. 



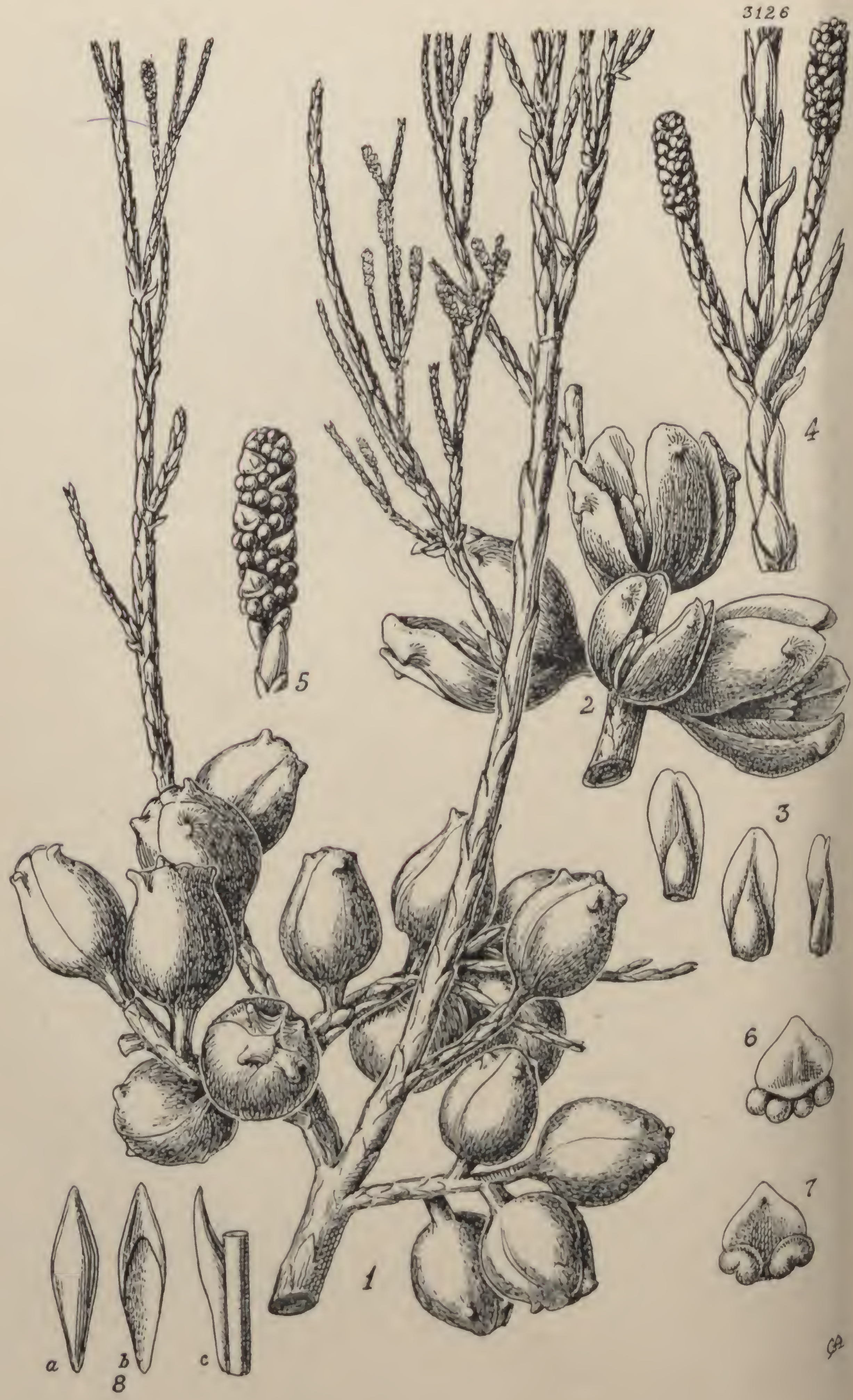




\title{
Tabula 3126.
}

\section{WIDDRINGTONIA STIPITATA, Stapf.}

\author{
Pinaceate. Tribus Cupresseal.
}

W. stipitata, Stapf; speeies nova, affinis W. Whytei, Rendle, sed monoiea (semper?), ramulis graeilioribus inter foliorum paria eonstrietis, foliis pro rata longioribus, eonis maturis laxe et saepissime raeemose aggregatis lene stipitatis ovoideis, sursum attenuatis, seminibus numerosis distineta.

Arbor. Folia juvenilia ignota; adulta squamiformia, macrocladiorum fere sua longitudine dissita, subadpressa, laneeolata, aeuta vel aeuminata, parte libera eireiter $2 \mathrm{~mm}$. longa, brachycladiorum arete adpressa, quadrifaria, dorso bene rotundata 11 ramulos teretes $(0 \cdot 6-$ $1 \mathrm{~mm}$. diametro) reddant, e basi euneata ad medium adnata, oblonga, aeuta vel obtusiuseula, tota $2 \mathrm{~mm}$. longa, subglauea, apiee subflaveseentia, duetibus resiniferis. Strobili $\hat{o}$ eum fruetibus maturis eoëtanei, breviter eylindraeei, ad $4 \mathrm{~mm}$. longi, sessiles; squamae eireiter 12, deeussatae, late rlomboideae, acutae, inferiores $1 \mathrm{~mm}$. longae lataeque, infra medium in dorso transverse depressae; antherae inter squamas protrusae, loeulis 4. Strobili o florentes ignoti. Coni maturi 3-5 laxe raeemose aggregati, rlachi spuria $2-3 \mathrm{~cm}$. longa, vel laxe glomerati, stipitati, stipite robusto ad $6 \mathrm{~mm}$. longo, eastanei, basin versus ut stipes glaueo-pruinosi, ovoidei, apiee obtusi et breviter 4 -cornuti, $2 \mathrm{~cm}$. longi, infra mediun $1.5 \mathrm{~cm}$. lati; valvae plane apertae, apieibus $2 \mathrm{em}$. distantibus, duae ovato-oblongae ad $11 \mathrm{~mm}$. latae, duae lineari-oblongae ad $8 \mathrm{~mm}$. latae, omnes obtusae, rarius subaeutae, $4.5 \mathrm{~mm}$. infra apieem breviter mueronato-eornutae. Semina $7-10$ eun quaque valva, ovato-oblonga vel oblonga, tenuiter rostrata, rostro excluso ad $5.5 \mathrm{~mm}$. longa, $3 \mathrm{~mm}$. lata, nigro-brunneo, ala e hasi angustissima seeundum rostrum ad $3 \mathrm{~mm}$. produeta et ibi ad $4 \mathrm{~mm}$. lata, biloba, lobis ineurvis oltusis, flavo-brunnea.

Tiransvanl. Zoutpansberg, Nortl Transvaal, Forest Dept. Herb.,
Union S. Afr., 7048, 7313 .

The present plate was prepared from speeimens taken from a tree growing in Mr. H. Harsen's garden at Piet Retief and originally obtained from the Zoutpansberg. W. stipitata resembles the more northern W. Whytei ratler than the southern speeies of South Afriea. It 
can be easily distinguished by its distinctly stipitate, more loosely clustered cones, and it is remarkable on account of its being apparently monoecious, its congeners having been found so far to be dioecious.

Since the present plate was prepared, further specimens of the Piet Retief plant have been communicated by Mr. J. J. Kotzé. These bear perfectly mature female cones and minute rudimentary male cones, but otherwise they agree perfectly with the original specimens. As stated above, the Piet Retief tree was originally "obtained from the Zoutpansberg," no exact locality being stated. According to a letter from Mr. Kotzé (F.2149, R.2453), it was taken from the farm "Hillside" near Louis Tricharat, but specimens collected there (F.D. Herbarium No. 7297) represent typical W. Whytei, as also do specimens taken farther west, in the Forest Reserve Hanglip, in the same range of mountains (Zoutpansberg; F.D. Herbarium No. 7298). Referring to these, Mr. Kotzé says they appear to him alike and that he is informed that "in general appearance the trees in the ficld also seem to be the same." He further adds that "they do not possess the markedly stipitate cones of the Pict Retief tree," which he "cannot connect with either the Hillside or Hanglip specimens." The appearance of $W$. Whyle in the Zoutpansberg is not surprising considering that its nearest station is in the Melsetter district in South-eastern Rhodesia. It appears, therefore, that there are two species of Widdringlonia in the Zoutpansberg, one new to science, W. stipilata, and the other $W$. Whytei, so far only known from the Mlangi Mountains, the Melsetter district and Gorongosa Mountains, Portuguese East Africa.-O. StapF.

FIc. 1, a branch with unopened fruits of last year's growth and with male catkins of this year's growth, natural size; 2, a cluster of dehisced fruits, natural size ; 3 , seeds in front, back and side view, $\times 2 ; 4$, portion of a branchlet with male strobili, $\times 3 ; 5$, male strobilus, $\times 6 ; 6$, a scale of a male strobilus with pollen sacs in back view, $\times 12 ; 7$, the same in front view, $\times 12 ; 8$, back, front and side view of a leaf, the middle figure (b) showing the extent to which the leaf is adnate to the axis, $\times 6$. 



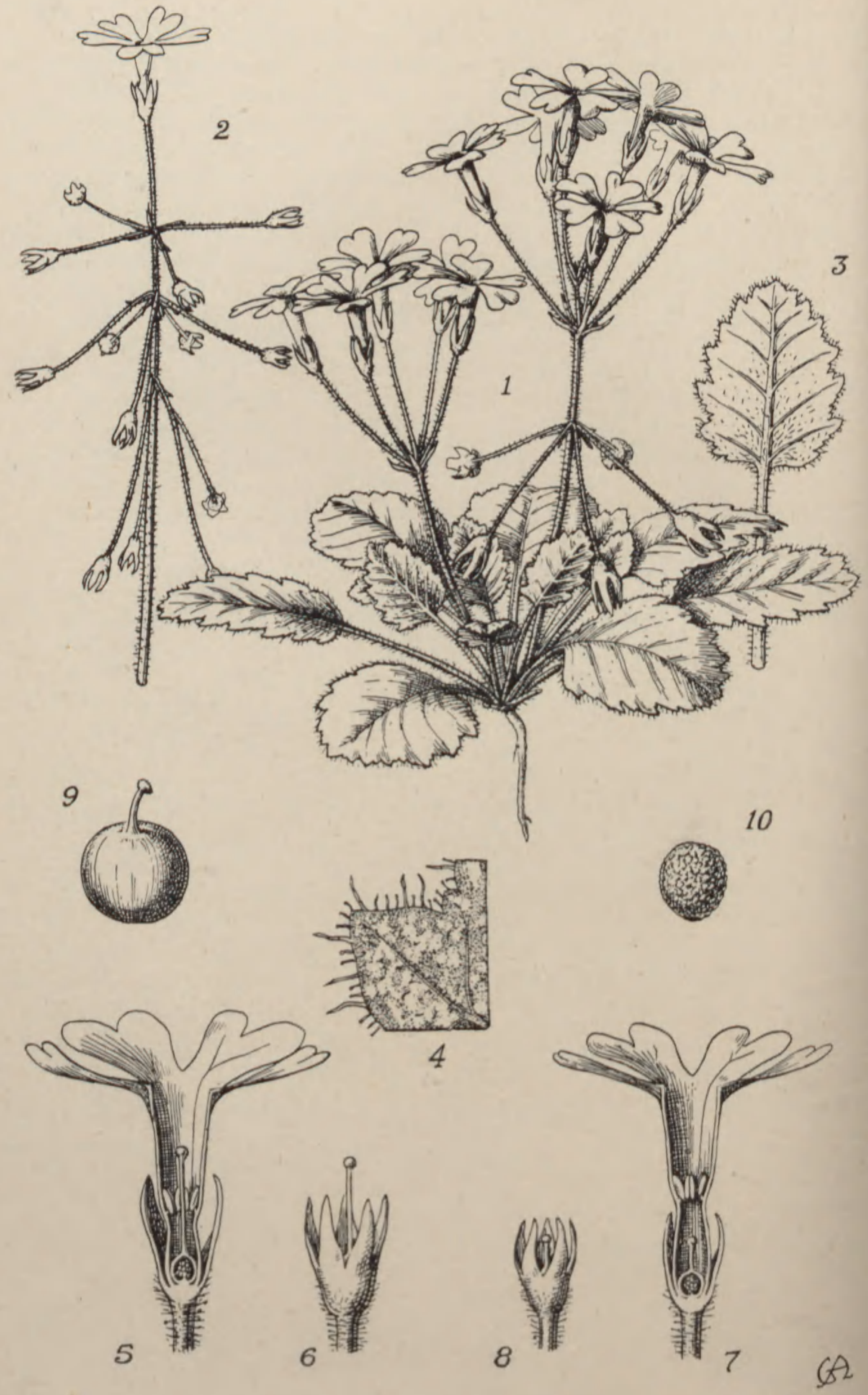

2

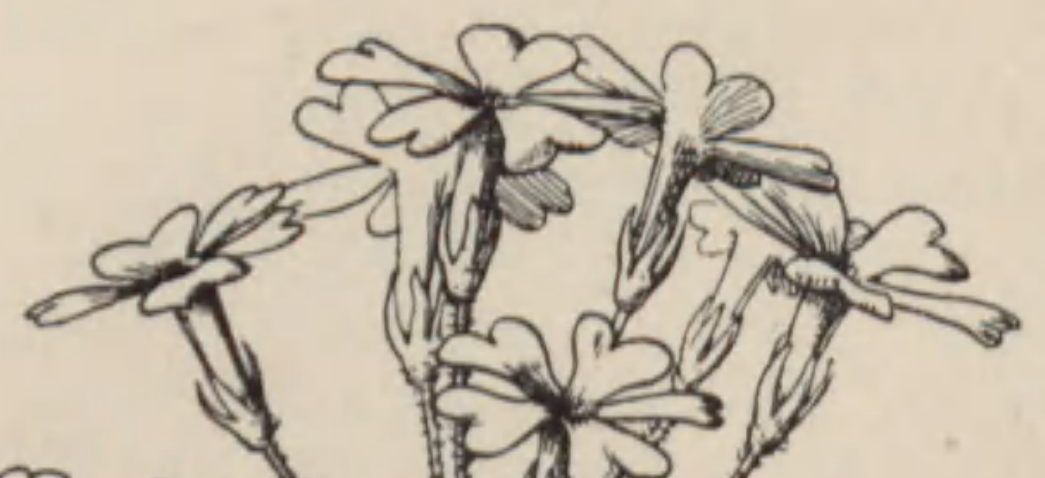




\section{TABUla 3127.}

\section{PRIMULA DUCLOUXII, Petitmengin.}

\section{Prinulaceae. Tribus Prinuleae.}

P. Duclouxii, Petimengin in Monde d. Pl. 1908, p. 7 ; IIandel-Mazzelli, Naturbild. a. Südwest-China, p. 11 (1927); inter species gregis Malacoidearum pedicellis dcmum $1-3 \mathrm{~cm}$. longis refractis insignis, calycc sub fructu 6-7 $\mathrm{mm}$. longo, dentibus lineari-lanccolatis, corollae tubo 6-8 mm. lougo, foliorum laminis lobulatis acutc dentatis $1 \cdot 5-4 \cdot 5 \mathrm{~cm}$. longis, $1-2 \cdot 5 \mathrm{~cm}$. latis, petiolo $1-4 \mathrm{~cm}$. longo.

IIerba peremnans, radice tenui, stolonifcra, rosulans, c rosula scapos plures umbelliferos vel saepius verticilliferos emittans, omnibus partis magis minusve farinosa. Folia saepissime longiusculc petiolata; lamina ovata vel obovato-oblonga, basi rotundata, rarius subcordata, apicc obtusa, sublolulata, lobulis inacqualiter acute dentatis, $1 \cdot 5-$ $4.5 \mathrm{~cm}$. longa, $1-2 \cdot 5 \mathrm{~cm}$. lata, utrinque parce tcnuissime glandulosopilosa, in dorso sacpe dense albo-farinosa; petiolus $1-4 \mathrm{~cm}$. longus, filosus. Scapi $1-5 \mathrm{~cm}$. longi. Umbellae vel rerticilli pedicellis $3-6$ filiformibus minute pilosulis, sul, anthesi suberectis, deinde patulis vel denum refractis et ad $3 \mathrm{~cm}$. longis, bracteis subulatis vel basi lanceolato-dilatatis, al $6 \mathrm{~mm}$. longis. Calyx 4-6 mm. longus, ferc ad medium fissus, dentibus linenri-lanceolatis, demum modice elongatis. Corollae tubus 6-8 mm. longus; limbus rosens, 12-17 mm. diametro, Ocar profunde obcordatis. Stamina ad vel paulo infra medium inserta. in emareilu longistylo antheras valde superante. Capsula e calycis crustace tubo brevissime exserta, 2-2.25 mm. cliametro, tenuitcr I a azacea. Semina globosa, olscure verruculosa.-P. refracla, Handel1924 tt in $A$ kal. Anzeig. Akad. Wiss. Wien, 1920, No. 15, p. 1; 4, Хo. 17, p. 3. "HINA. Yunnan, in fissuris hmmidis rupium calcearum unbrosarum
montis Hsi-slan ad litus occidentale lacus Kun-yang-hay prope Shi-lan-fu, 2250 m., Ducloux, C. K. Schneider, IIandel-Nazzelli, 351;

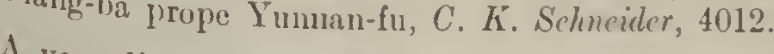

A very distinct member of the "Malacoides Scries" of Primula, most of le on account of its peculiar liabit in the fruiting stage when of its pedicels become refracted and often closely appressed to 
the stem, the capsules opening earthwards. This naturally restricts the area for dispersal, but at the same time enhances the chances of the seeds falling into the moist rock-fissures, where the mother plant had already found a suitable home.-O. S'APF.

Fia. 1, a whole plant in flower ; 2 , an inflorescence in a very advanced state; 3 , a leaf in back view ; 4 , a portion of the margin of the same in back view showing marginal hairs and farina; 5 , a pin-eyed flower in longitudinal section; 6 , the same without the corolla; 7 , a thrum-eyed flower in longitudinal section; 8 , the same without the corolla; 9, capsule of a thrum-eyed flower; 10, seed. Figs. 1, 2,3 , natural size ; figs. 4, 10, considerably enlarged; figs. 5, 6, 7, 8, $\times 2 \frac{1}{2} ;$ fig. $9, \times 9$. 



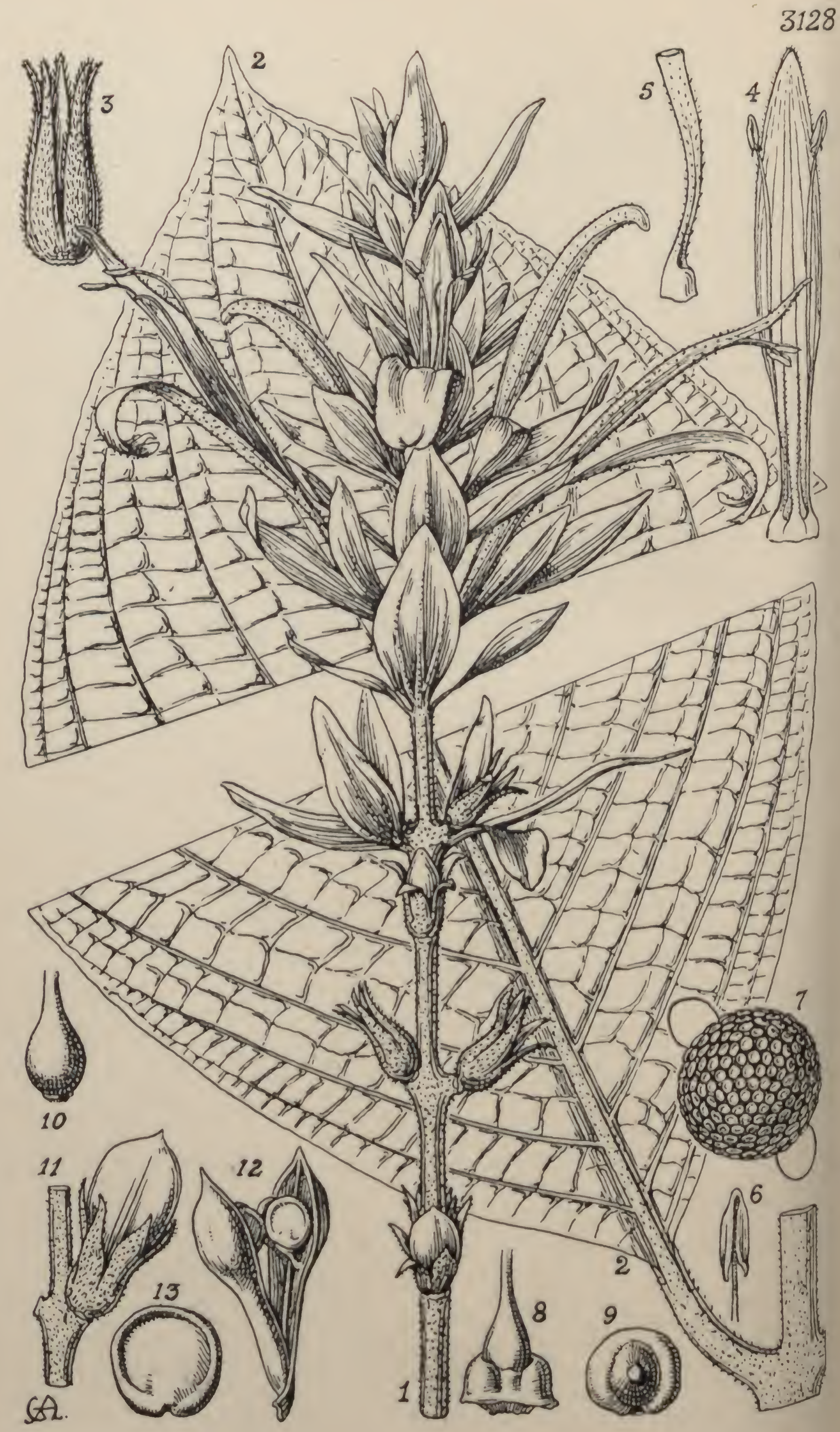




\section{TABULA 3128.}

\section{MEGASKEPASMA ERYTHROCHLAMYS, Lindau.}

acanthaceae, Tribus Isoglosseae.

M. erythrochlamys, Lindau in Bull. Herb. Boiss. vol. v. p. 666 (1897) ; spccies unica.

Fruex ultra $3 \mathrm{~m}$. altus, plurimis partibus pube tenui adpressa fulvida demum magis minusve cvanescente indutis; rami teretes vel olscurc tetragoni, crassiusculi, ad angulos lineis decurrentibus glanduligcris notati, ad nodos admodum constricti. Folia pctiolata; lamina oblongo-elliptica, apicc basique acuta vel brcvitcr acuminata, $15-30 \mathrm{~cm}$. longa, 6-16 cm. lata, utrinque circitcr 11-ncrvia, venis transversis tcnuilus laxe rcticulata, pube in gemma dcnsissima, in dorso ad ncrvos persistcntc, caeterum mox cvanida; pctiolus $2-4 \mathrm{~cm}$. longus. Spieae in paniculam terminalem $20-30 \mathrm{~cm}$. longam collectac, lateralium spicarum paribus plerumque binis rarius tcrnis quam spica tcrminalis multo breviorilus, omnes pedunculo $3-4 \mathrm{~cm}$. longo suffultac, eximic bracteatac; bractcae ovatac vel ovato-lanceolatae, utrinque acutae $\mathrm{vcl}$ subacutae, trinerves, maiores $2 \cdot 5-4 \mathrm{~cm}$. longac, lactc roseac; bractcolac lanccolatac, basi longe attenuatac, quam bractcac lircviorcs. Calyx alta fissus, segmentis 5 acqualibus lineari- vel subulato-lanccolatis, $12-14 \mathrm{~mm}$. longus, persistenter dense pubescens. Corolla bilabiata, 6-8 cm. longa, alba vel lcvissimc rosco-suffusa, cxtra puberula; tul us tenuis, $2 \cdot 5-3.5 \mathrm{~cm}$. longus; labium superum lanceola to-lincarc, integrum, subacutam vel obtusiusculum vel minute 2-dentatum, ad $4.5 \mathrm{~cm}$. longum, subrectum; labium inferum vix brevius, in tertia parte supera revolutum, apicc 3-dentatun. Stamina 2, ad tubi os inserta, filanicntis lasin vcrsus decurrentibus, parte libera sub labio lobulis adscendente ad $3 \mathrm{~cm}$. longa ; antherac ad $4.5 \mathrm{~mm}$. longac, poris 2 subarequalibus basi minutc apiculatis. Pollinis grama globosa, $1_{\text {sasi }}$ disco nbique verrueulis orbicularibus eentro depresso teeta. Oearium 5 cisco annulari cinctum, ovoidcum ; stylus filiformis, circitcr dorso vigus; stigma punctiformc. Capsula ad $3 \cdot 2 \mathrm{~cm}$. longa, a a dorso valubspatulata, acutc apiculata, stipitc $1 \cdot 5-1 \cdot 7 \mathrm{~mm}$. longo ad 4 valde compresso, valvis demum cymbiformibus; retinacula glabra, 5 m. longa. Scmina disciformia, marginc paulo incrassato, V nm. diamctro.

Vexezuela. Province of Merida, 1600 m., Funck de Schlim, 1171 ; ct (culta in insula Trinidad), Broaduay, 4403. 
The plant from which the present plate was prepared has been grown for a number of years in the Royal Botanic Gardens at Kew. The label containing the entry number was lost, so that the origin of the plant could not be traced with certainty, but there is very little doubt that it was raised from seed communicated by Mr. W. E. Broadway, who in 1913 sent dried specimens in flower and in fruit to Kew with the statement that they were obtained from "Lafond's garden, Valley Road, Belmont," Trinidad. These specimens and the Kew plant agree so completely with Lindau's description of Megaskepasma erythrochlamys that I do not hesitate to identify them. It is true that Lindau says the pollen grains of Megaslepasma are devoid of pores; but this statement is a priori open to doubt and may be due to the circumstance that he worked with dried specimens. In the fresh Kew material the pores are easily demonstrated. The sculpturing of the exine of the pollen is singular in that it is characterised by the presence of numerous almost contiguous circular slightly concave discs. The affinity is otherwise with Rhacodiscus, another member of the Porphyrocoma group, easily distinguished by its inconspicuous subulate bracts and echinate pollen grains.-O. STAPF.

Fia. 1, terminal spike of an inflorescence; 2, a leaf with middle cut out, tho upper portion showing the upper surface, and the other the lowor; 3 , calyx; 4, upper lip of corolla, with stamens; 5, corolla tube in sicle view; 6 , anther; 7, pollen grain; 8, base of a pistil with the surrounding dise; 9 , the same seen from above; 10, the ovary without the disc; 11 , a capsule not yet dehisced; 12, the same after dehiscence; 13, a seed. Figs. 1, 2, 4, 5, 11, 12, natural size; figs. 3, 6, 8, 9, 10, 13, all $\times 2$; fig. $7, \times 270$. 



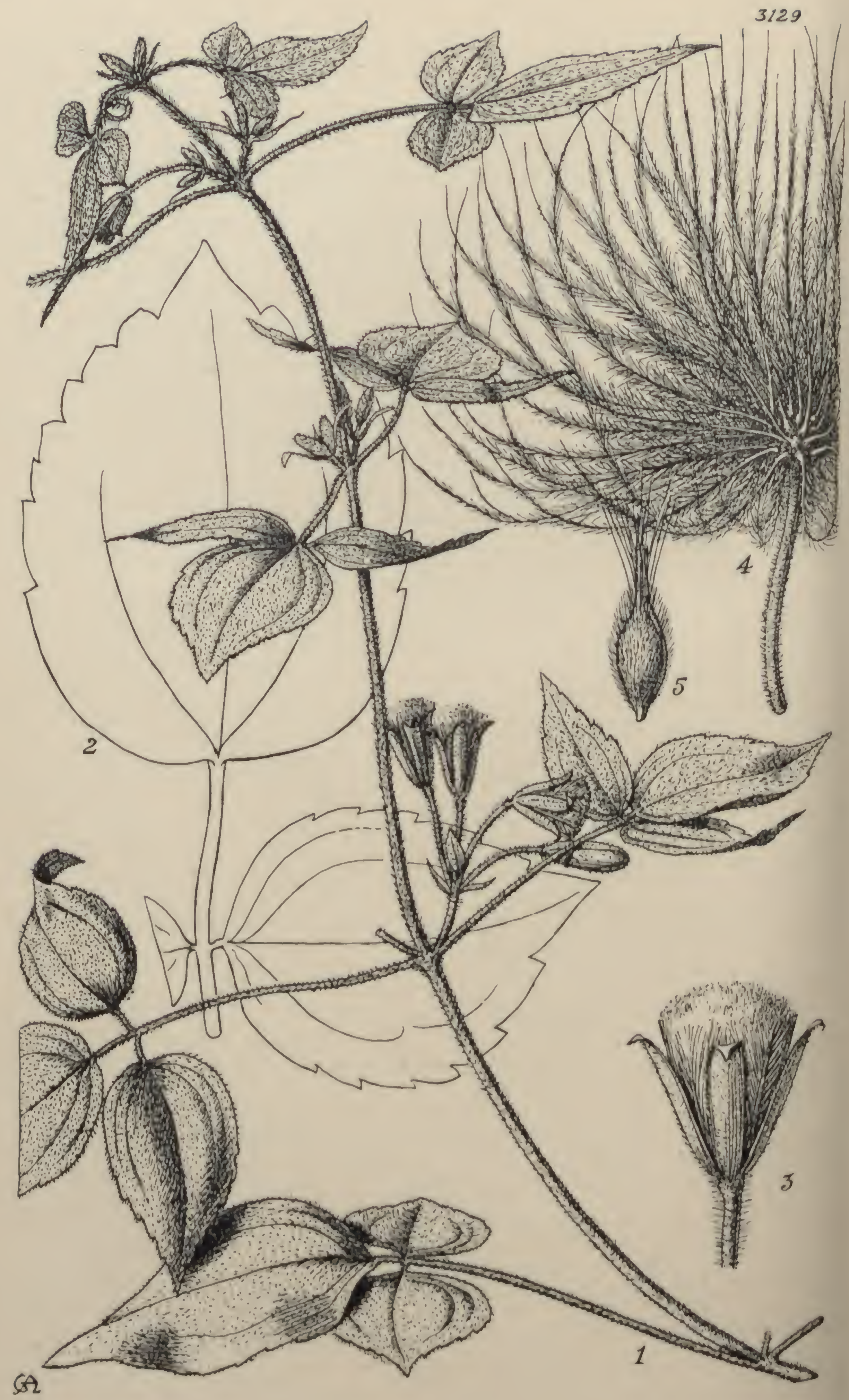




\section{TABUla 3129 .}

\section{CLEMATIS RUBIFOLIA, C. H. Wright.}

\section{Ranunculaceae. Tribus Clematideae.}

C. rubifolia, C. H. Wright in Kew Bull. 1896, p. 21 ; C. gratae, Wall., affinis, foliolis non lobatis infloreseentiaque subsessili distinguitur.

Frutex sarmentosus. Caulis tenuis, tomentosus. Folia trifoliolata, pilis appressis vestita; foliola ovata, acuminata, dentata, trinervia. Cymae axillares, 5-8-florae; peduneuli brevissimi. Sepala oblonga, aeuta, dorso narginibusque dense tomentosa. Filamenta sepalis aequilonga, pilis antheras attingentibus vestita. Stylus eolunnaris, pilis altis rigidis hirsutus, in fruetu $5 \mathrm{~cm}$. longus.

Cuina. Yunnan: Mengtze, $1800 \mathrm{~m}$., roeky plaees, seemingly rare, Dee. 1893, W. Ilancock, 18; Kochin Mountains, 600 m., 24 Dee. 1895, W. II ancock, 577.

This speeies is allied to the Northern Indian C. grata, Wall., from which it is readily distinguished by its unlobed, but dentate, leaflets and its alnost sessile infloreseenee. C. Wightiana, Wall., another Indian speeies, differs in its leaves being much more densely tomentose beneath.-C. H. WRIGHT.

Fra. 1, portion of a branch; 2 , two leaflets; 3 , old flower ; 4 , head of achenes; 5 , lower portion of a singlo aclene. Figs. $1,2,4$, natural size; fig. $3, \times 2$;
fig. $5, \times 4$. 



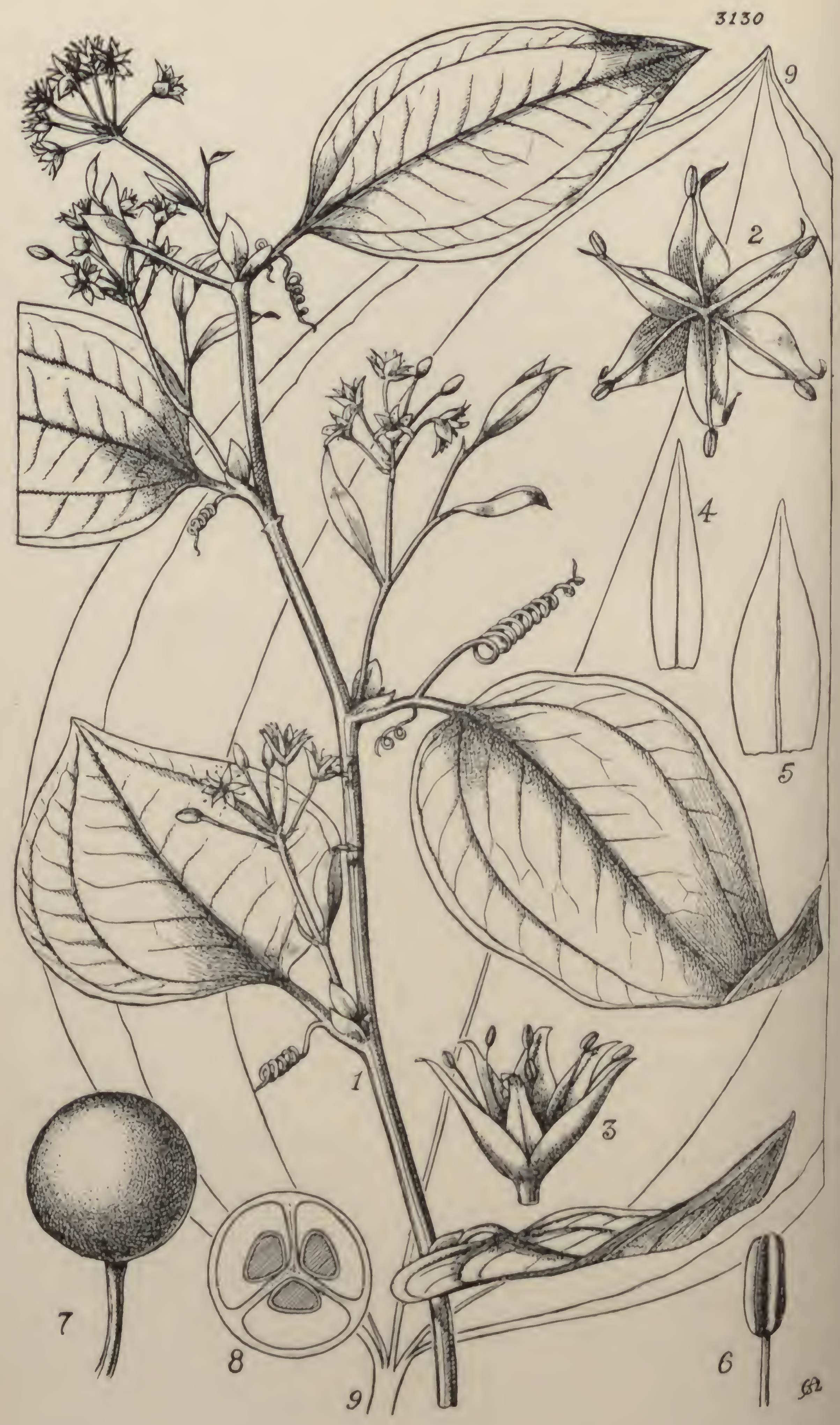




\section{Tabula 3130.}

\section{SMILAX MEGALANTHA, C. II. Wright.}

\section{Liliaceat. 'Tribus Smilaceae.}

S. (Eusmilax) megalantha, C. H. Wright in Kew Bull. 1895, p. 118, ct in Journ. Linn. Soc., Bot., vol. xxxvi. p. 99 ; W. J. B. in Kew Bull. 1920 , p. 124 ; S. stcnopctalae, A. Gray, affinis, racemo ex axilla folii juvcnilis oricnte distinguitur.

Frulex scandens, ad $5 \mathrm{~m}$. altus, sempervircns. Caulis flexuosus, leviter sulcatus, spinis paucis brevibus compressis instructus. Folia valde variabilia, ovata vel oblonga, acuta, 11 rvis jrimariis $3-5$ praedita, subtus glaucescentia, $9-18 \mathrm{~cm}$. longa, $5 \cdot 5-12 \mathrm{~cm}$. lata; petiolus 2-4 cm. longus, vagina 1-2 cm. longa cirrhis usque ad $16 \mathrm{~cm}$. longis terminata. Infloresecntia subumbcliata, ex axilla folii juvenilis in ramo laterali $2 \mathrm{~cm}$. longo oriens, squama magna persistente folii vaginac opposita; pedunculus $2.5 \mathrm{~cm}$. longus; bracteolac subulatae. Flores $\delta$ : perianthium 6-partitum, $1 \mathrm{~cm}$. longun ; segmenta lanceolata, acuminata, extcriora latiora; filamenta filiformia, perianthio paullo breviora. Flores $\$$ non visa. Fructus globosus, 1 cm. diametro, corallinus.

CinNa. Western Szechuen: near ''achicnlu, between 2700 and $4000 \mathrm{~m} .$, A. E. Prall, 811 ; Nount Omei, Rev. E. Faber; Hount Wa, in thickets at $1500 \mathrm{~m} .$, E. II. Wilson, 3253 (young flowers, May) and 3254 (fruit, November).

This species is allied to $S$. stenopetala, A. Gray, a native of Formosa, tle Luclu Archipelago, and Japan, from which it differs in its inflorescence, which, instead of arising directly from the axil of a mature leaf, consists of a much contracted raceme borne in the axil of a very young leaf (rarely an inch long) situated on an axillary branch about $4 \mathrm{in}$. long, at the basc of which a large lud-scale persists opposite to tle leaf-slicatl. The size and outline of the leaves vary considerably on the sane plant, and the flowers are anongst the largest in the genus. 'l'his species has proved lardy in linglish gardens, where it is a valuable evergreen climber.-C'. 11 . WI IIG

flowe. 1, branch, natural size; 2 , flower seen from above, $\times 3 ; 3$, sido viow of 6 , ant, $\times 3 ; 4$, inner perianth-segment, $\times 5$; 5 , outer perianth-segment, $\times 5$; size. 


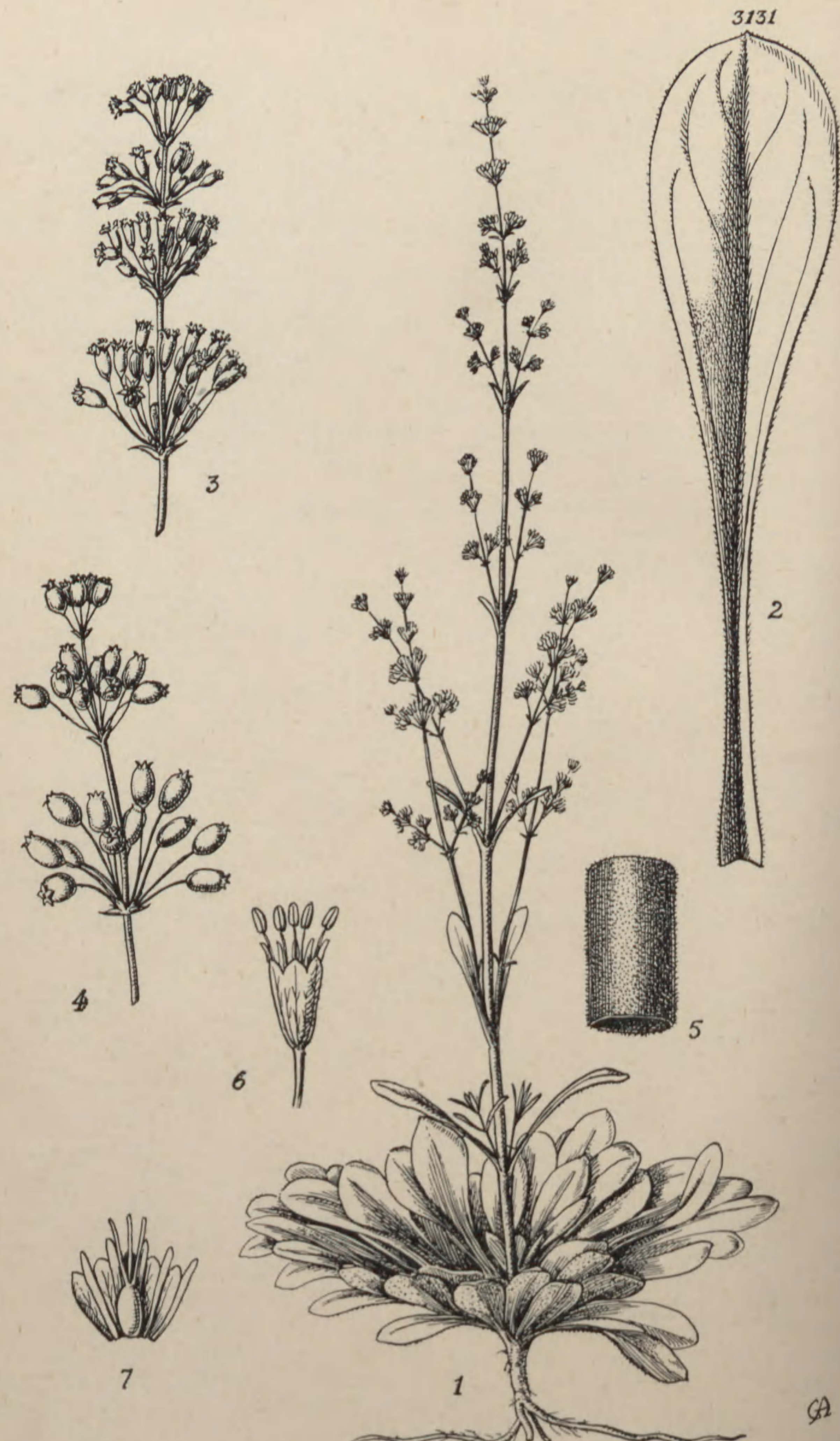


\section{TaBula 3131.}

\section{SILENE OTITES, Sim., var. PSEUDOTITES, Yis.}

\section{Caryormylaceae. Tribus Silexeae.}

S. Otites, Sm., var. pseudotites, Vis. Flor. Dalm. vol. iii. p. 170 (1850); a planta boreali infloreseentiae ramis elongatis patentibus differt.

IIerba ereeta, dioica, usque ad $9 \mathrm{dm}$. al ta, caulibus inferne minutissime puberulis superne glabris plus minusve viscosis. Folia radiealia ollanecolato-spathulata, apiee rotundata saepe apieulata, basi in petiolum gradatim angustata, usque ad $14 \mathrm{~cm}$. longa et $3 \mathrm{~cm}$. lata, saepissime eireiter $8 \mathrm{~cm}$. longa et $1.8 \mathrm{~cm}$. lata, in pagina superiore glabra vel leviter puberula, in inferiore plus minusve puberula; folia eaulina gradatim minora, angustiora, aeuta vel subaeuta. Inflorescentia ramosa maseula praceipue, braeteis lanecolatis albomembranaceo-marginatis ciliatis basi connatis. Flores maseuli : calyx oblongo-obeonieus, $4 \mathrm{~nm}$. longus, lobis ovato-orbicularilus rotunda tis 1 em. longis margine late searioso-membranaceis minute eiliolatofimbriatis; petala linearia, $4.5 \mathrm{~mm}$. longa, viridi-lutea; stamina $6 \mathrm{~mm}$. longa, antheris oblongis $1.5 \mathrm{~mm}$. longis; gynaeceum inehontum, $4.5 \mathrm{~mm}$. longum, stylis tribus instruetum. Flores feminci: ealyx oblongus vel oblongo-ellipticus, $4 \mathrm{~mm}$. longus; petala linearia, 4-4.5 mu. longa, viridi-lutea ; gynaeceum perfeetum, ovario oblongoellipsoideo $2 \cdot 5 \mathrm{~mm}$. alto, stylis tribus $3 \mathrm{~mm}$. longis. Capsula anguste ovoideo-ellipsoider, 6-7 mm. alta, $3 \mathrm{~mm}$. diametro, dentibus patentibus. "Semina subreniformia, vix $1 \mathrm{~mm}$. longa, non acute tubereulata sed "armadillo."-S. pscudotites, Besser in Reielıb. Flor. Germ. Hxeurs. p. 819 (1832) ; $\Lambda$ selsers. u. Graebn. Syn. Mitteleur. Flor. vol. v. seet. 2 , p. 196 (1921). Lyehnis Otites Seop. Flor. Carn. ed. 2, vol. i. p. 305 (1772), e deser. et loe., exel. syn.

Karst. Trieste, IIerb. Bentham; Karstwiesen bei Triest, 26.5.65, 1I. Bihoda; Monte Spaceato, 22.6.37, Bentham, 756 ; bei Bazovizza, 6.81, I'ospichal; ill dry stony pasture, near Briščiki, seeds colleeted seeds colltivated at liew as Turrill, K. 163 ; from the same loeality, eollected 15.8.25, and cultivated at Kew as Turrill, K. 320. The variety here figured was originally deseribed from specinens
eolleeted in stouy pasture on Mt. Spaceato near Bassowitza, east of
'Irieste. 'Irieste. From the writer's observations and re-interpreting the remarks 
of Pospichal (Flora des Oesterr.-Küstenl. vol. i. p. 463: 1897), it appears that this is the common variety on the dry stony limestone karstlands of the northern Adriatic districts. That the variety extends south to Dalmatia is indicated by Visiani's conclusions and there are specimens from Italy, France, and other European countries in the Kew Herbarium which must either be placed in the same variety or considered as links between it and the northern type variety. The leaves are not glabrous as stated in a differential diagnosis attached to the original description of Besser.

In the figure published by Reichenbach (Ic. Flor. German. vol. vi. t. cclxxxix.: 1841) the flowers are shown as hermaphrodite-very clearly so in the cnlarged uncoloured drawing of a flower. Neither in wild nor in cultivated material have other than dioecious plants been found by the writer. The peculiarities of sex-behaviour in crosses between the different varieties of $S$. Otites are being worked out at the John Innes Horticultural Institution, Merton. Sibs of the material here figured (Turrill, K. 163, 320) have been used in these experiments.-W. B. T'URRILL.

FIG. 1, plant, $\times \frac{1}{3} ; 2$, leaf, natural size; 3 , portion of male inflorescence, natural size; 4 , portion of young infructescence, natural size; 5 , portion of stem, $\times 3 ; 6$, male flower, $\times 3 ; 7$, female flower with corolla opened, $\times 3$. 

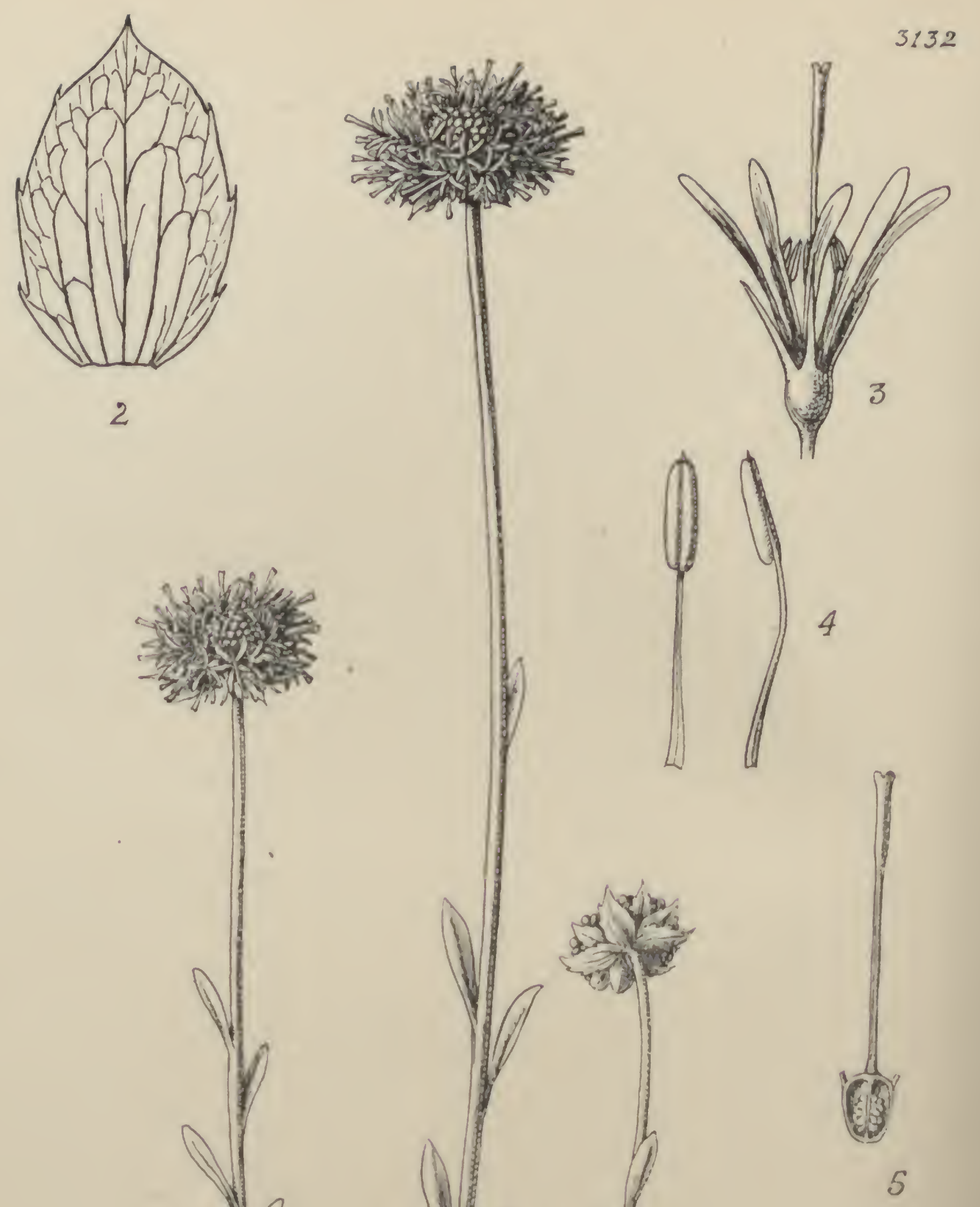


\section{Tabula 3132.}

\section{JASTONE BULGARICA, Sloy. el Slef.}

\section{Campanulacae. Tribus Campanuleae.}

J. bulgarica, Stoy. et Stef. in Oesterr. Bot. Zeitschr. vol. Ixx. p. 105 (1921), et Flor. de Bulg. p. 1095 (1925); Stoy. in Nolizbl. Bol. Gard. Mus. Berlin-Dahlem, vol. ix. p. 555 (1926) ; a J. orbiculala rhizomate repente saepe ramoso, foliis bracteis calycibusque omuino glabris, staminis liberis distinguitur.

Herla perennis, glabra. Rhizoma tenue, repens, saepe ramosum. Caulis erectus, teretiusculus, sulcato-striatus, ad medium vel supra foliatus, 5-22 cm. altus. Folia radicalia rosulata, ollanceolata, apice obtusa vel subacuta, basi gradatim attenuata, $1 \cdot 5-2 \cdot 5 \mathrm{~cm}$. Ionga, 5-6 mm. Inta, integra vel obsolete et remote denticulata; folia caulina lanceolata vel oblongo-ollanceolata, integra vel leviter denticulata. Flores in eapitulum terminale $1 \cdot 5-2 \cdot 2 \mathrm{~cm}$. diametro aggregati; involucri phylla elliptico-ovata vel elliptico-lanceolata, apice acuminata, circiter $7 \mathrm{~mm}$. longa et $4 \mathrm{~mm}$. lata, margine remote setaceo-denticulata; pedicelli 2-2.5 $\mathrm{mm}$. longi. Calyx laciniis lanceolato-subulatis acutis fere $3 \mathrm{~mm}$. longis. Corolla $6 \mathrm{~mm}$. longa, laciniis oblongo-linearibus vel apice obtusis linearibus primo erectis deinde divaricatis. Slamina antheris liberis nec connatis, $3 \mathrm{~mm}$. longr. Receplaculum oblongoulsconicum, 1.3 mm. altum, $1 \mathrm{~mm}$. diametro; stylus $7 \mathrm{~mm}$. longus.Jasione orbiculata Griseb. var. orbelica Vel. Flor. Bulg. Suppl. vol. i. p. 188 (I898), pro parte.

Bulgaria. Rila Planina, in snxosis montis Mus Allal, $2000 \mathrm{~m}$, 21.8.07, C. K. Schneider; Musalla, in stony and rocky places in open Vegetation, 2200 n., 29.7.26, Turill, 1263; Mt. l'iriu, Spano Pole, in alpine meadow, $2000 \mathrm{~m} ., 4.8 .21$, Sloyanoff d Sicfinoff, 873.

Il aldition to the specimens represented at Kew and quoted above, Stoyanoft and Stefanoff record the species from: in pascuis regionis ulperioris $(2000-2500$ 11.) montis Rila ad rivum Urdinam et suh cacumine Cader-Tepe, 7-9.19 (type); 1Rila in cacumiue Ibar, 5.8.99, Siribrny; in lapidosis in Musalla, 1906, Urumoff; in monte Kostenski Balkan, Belmeken, 1910, Urumoff; Kostenski Balkan, Kotlimite 12.7, S. Georgicff; Rila, subalpine Matten unter dem Gipfel Sari-Gjol, 19 ; Pirin, in rupestribus alpinis montis Jel-Tepe, alt. $2100 \mathrm{~m} ., 7.0 \%$, Dimonie; in graminosis alpinis montis Pirin, 27.7.18, Urumoff. 
The species has often been confused with $J$. orbiculata, Griseb., from which it is quite distinct morphologically, and no intermediate forms or possible hybrids have been recorded between the two species. $J$. orbiculata has a wider distribution than $J$. bulgarica and is known from mountains in Albania, N. Macedonia (S. Serbia), Bulgaria, Serbia, Montenegro, Bosnia and Hercegovina, as the var. supinoides, Stoy., from Epirus, and as the var. italica, Stoy., from Mt. Serino in S. Italy.

Phytogeographically the group of species centering round J. supina, (Sieb.) Griseb., is of great interest. Stretching from Asia Minor to S. Italy, the allied species and varieties exemplify the essential unity of the flora of the Balkan Peninsula and Asia Minor, and indicate the route along which so many species spread when the Balkan Peninsula was joined by land to Asia. Stoyanoff (l.c. 1926) gives evidence that $J$. bulgarica is one of the younger of this group of species, though it must be noted that in the character of having free stamens it is related to some Spanish species.-W. B. TurrIL.

Fig. 1, plant, natural size; 2 , involucral leaf, $\times 5 ; 3$, flower, $\times 5 ; 4$, stamens, $\times 10 ; 5$, gynacceum, ovary in section, $\times 5$. 


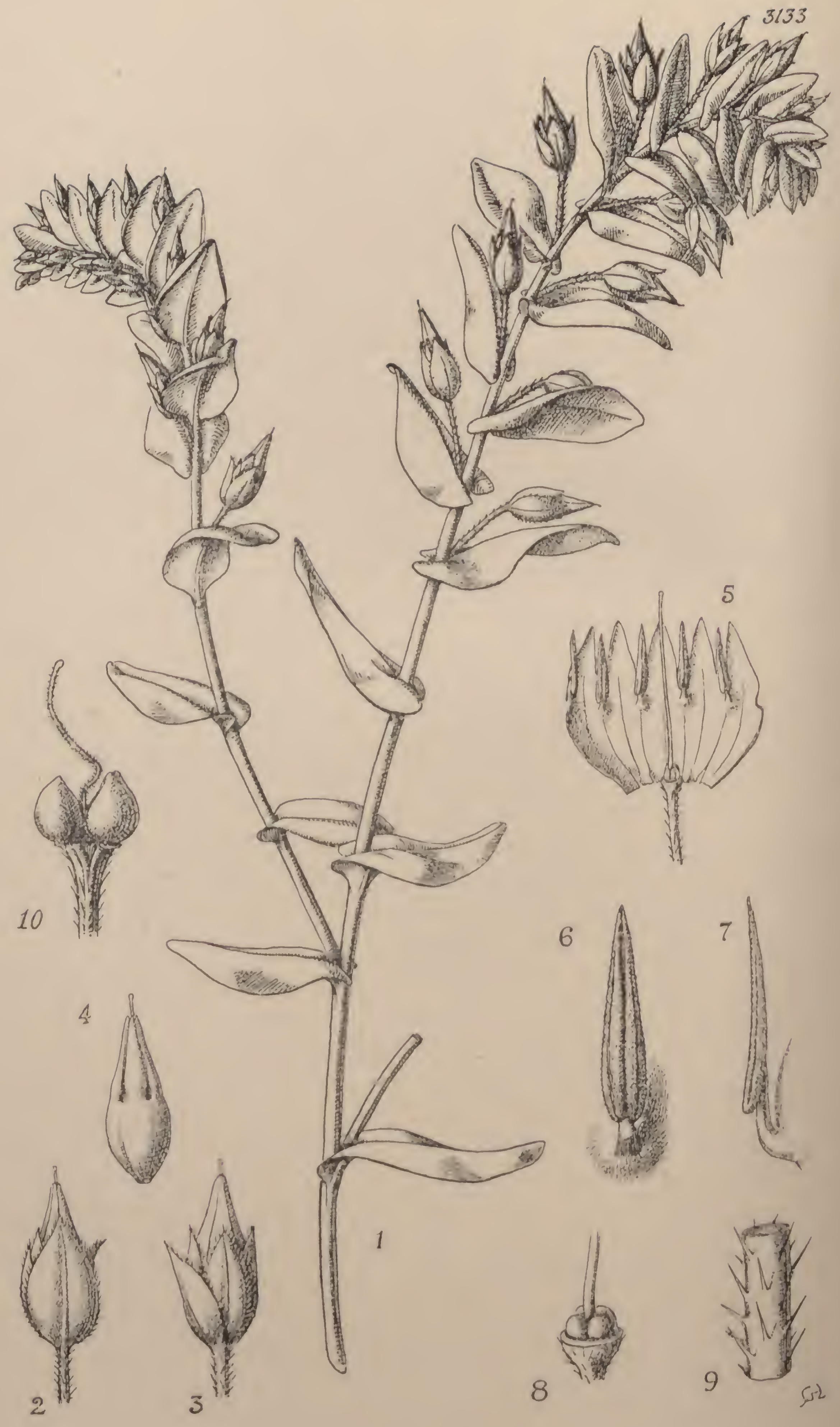




\section{Tabula 3133.}

\section{CERINTHE MINOR, $L$., var. HISPIDA, Turrill.}

\section{Boraginachae. Tribus Borageae.}

C. minor, L. Sp. Pl. p. 137 (1753), var. hispida, Turrill in L'ew Bull. 1924, p. 355 ; Hayek, Prodr. Flor. Penins. Balean. vol. ii. p. 9 (1928); pediccllis hispidis distinguitur.

IIerba perennis, caulibus asecndentibus vel prostrato-aseendentibus usque ad $5 \mathrm{dm}$. longis foliosis glabris. Folia oblongo-ovata, acuta vel subaeuta vel interdum obtusa, basi valde amplexieaulia, media eirciter $34 \mathrm{~cm}$. longa et $1.5 \mathrm{em}$. lata, glabra, saepe glauea, haud vel vix aspera. Inflorescentia primum compacta deinde valde elongata; bracteac foliis siniles sed gradatin minores; pedicelli 3-12 $\mathrm{mm}$. Iongi, hispidi. Scpala inaequalia, margine hispido-eiliata, externum ovatooblongum, acutum, $1 \mathrm{~cm}$. longum, $5 \cdot 5 \mathrm{~mm}$. latum, media lanceolata, $8 \mathrm{~mm}$. longa, 2-3 cm. lata, interua lanceolato-linearia, 7-8 mm. longa, $1-1 \cdot 5$ mn. lata. Corolla $1 \cdot 1 \mathrm{~cm}$. longa, lobis lineari-triangularibus $5.5 \mathrm{~mm}$. longis conniventibus. Antherae $6 \mathrm{~mm}$. longae. Gynaeceum glalırum; stylus $1 \cdot 1 \mathrm{~cm}$. longus. Nuculae iraequaliter ovoideac, $2 \cdot 75$ mm. longac, atro-brunneae.

BaLKan Peninsula. Greee: in rupestriluus herbidis regionis 8uperioris 'Taygeti loeo Koupartos dieto, July 1844, de IIeldreich. Macedonia : in dumetis ad Veles, June 1905, Adamović. 'Thrace: Gallipoli P'eninsula, Angadere, 22-24 July 1923, C. M. Ingoldhy, 450 (tylue of variety). N. Bulgaria, Varna, vineyards to the north of the town, 20 May 1923, B. Gilliat-Smith, 108; lills to the north of Varna, 25 July 1924 , B. Gilliat-Smith, 852 ; Varna distriet, cult. Herbarium Experimental Ground, Kew, 1925 1930, from seeds collected in 1924, K. 119. S. Bulgaria : prope Sliven in graminosis ad collum Sckerdze, 16 July 1907, C. Kí. Sehncider, 456. liodopes: hills above Bačkova, 600 m., 24 July 1926, W. B. Turrill, 1453. Dobruja: Tultscha, Stepje bei Malkorz, 8 May 1872, Sintenis, 285.

Soutri Russia. Crimea: Sebastopol, 1855, Saint-Supéry; prope Demerdski, litus meridion., 25 May 1905, N. A. Busch. P'rov. Kursk, $\mathrm{i}_{11}$ aggerilus prope Kursk, $7 \mathrm{Jun}$. 1897, D. Kladbisezew, 127. In Podolia australi, W. Besser.

Asm Minon. Boli, Wicdemann; Sabounjou-Kiaivé, entre Smyrne 
et Magnésie, dans les terrains calcaires, 8 Jun. 1854, Balansa, 366 ; ad Angora Galatiae, 1892, Bornmüller, 3076 ; Cilicia, 1896, Siehe, 422 ; in monte 'Tauro, 1838, T. Kotschy, 366, 367 ; bords des champs humides près Ermenek, Jul. 1872, A. Péronin, 190; in monte Solyma, Lyciae, Mai 1845, de Heldreich; Ali Dagh, à 7 kilom. au SE de Césarée (Cappadoce), vers 1400 mètr. d’alt., Jul. 1856, Balansa, 967 (pro parte); Arzani, Mitchell.

Armenia. Inter Baibont et Erzeroum, in valle Kassuklu, Mai 1853, Huel du Pavillon; prope Zara (Wilajet Siwas), 1300-1400 m., May 1893, Bornmüller, 3440; Egin, Kemengvep, 28 May 1890, Sintenis, 2423.

Caucasus. Paetigorsk, Becker ; sine loc., 1831, Prescol; sine loc., Radde; ex Iberia, 1824, Wilholms.

Kurdistan. Sine loc., 1840, J. Brant, W. H. F. Strangways.

Syria. Inter Bludan et Palmyra in jugis fissuras rupium incolit 5500 ped. 12 Jun. 1855, Kolschy, 115 ; sine loc., 1846, Pinard.

Persia. Yam, north of Tabriz, 22.5.27, B. Gillial-Smith, 1860; 21.8.27, B. Gilliat-Smith, 2125.

Cerinthe minor, L., is known to be a moderately polymorphic species. 'The chief interest of the character of hispid pedicels lies in its geographical distribution. The greater number of specimens from the eastern part of the Mediterranean Region, from Asia Minor, Caucasus, Armenia, Kurdistan, and Syria, as well as from S. Russia, and many from the southern and eastern parts of the Balkan Peninsula have hispid pedicels. On the other hand, all the numerous specimens examined from the central and western parts of the Mediterranean Region and from Central Europe have glabrous pedicels. The only exception to this last statement is a plant from Steier, Upper Austria, ex Herbario Brittingeriano, in which some of the pedicels have one or two short hispid hairs. The geographical scparation of the two variants is not complete. Both occur in the Caucasus and in Greece (Peloponnesus), and a few specimens from northern Asia Minor and Armenia have glabrous pedicels, though the majority have hispid pedicels. It is not without interest that the sheet of Balansa, 967, at Kew, quoted above (pro parte), has one specimen with glabrous and one with hispid pedicels. The pedicels of specimens from "Kurdistan" range from hispid to slightly hispid or even doubtfully glabrous. It is quite evident that the two variants meet and overlap, or alternately diverge from the Balkan Peninsula, northern Asia Minor and southern Russia.

The variety has been cultivated since 1925 in the Herbarium Experimental Ground at Kew from seed collected in 1924 near Varna by Mr. B. Gilliat-Smith. Only one plant now survives and makes luxuriant annual growth. It flowers from spring to late autumn and is visited by enormous numbers of hive and other bees. In spite of this it has never set seed till 1929 when, in the latter part of the season, a fair number of nutlets ripened. Why the self-sterility should thus 
suddenly break down is unknown. The plant behaves as a hemieryptophyte at Kew, but the new annual shoots appear very early in the year. The figure has been made from living material (K. 119). The flowers are pale yellow exeept for a reddish purple band around the top of the tube and involving the bases of the eorolla lobes.-W. B. 'Turrill.

Fig. 1, upper portion of branch, natural size; 2 and 3 , flowers, $\times 2 ; 4$, flower, with calyx removed, $\times 2 ; 5$, flower with corolla opened up, $\times 2 ; 6$ and 7 , stamens, $\times 7 ; 8$, ovary, $\times 7 ; 9$, portion of pedieel, $\times 9 ; 10$, fruit, $\times 3$. 



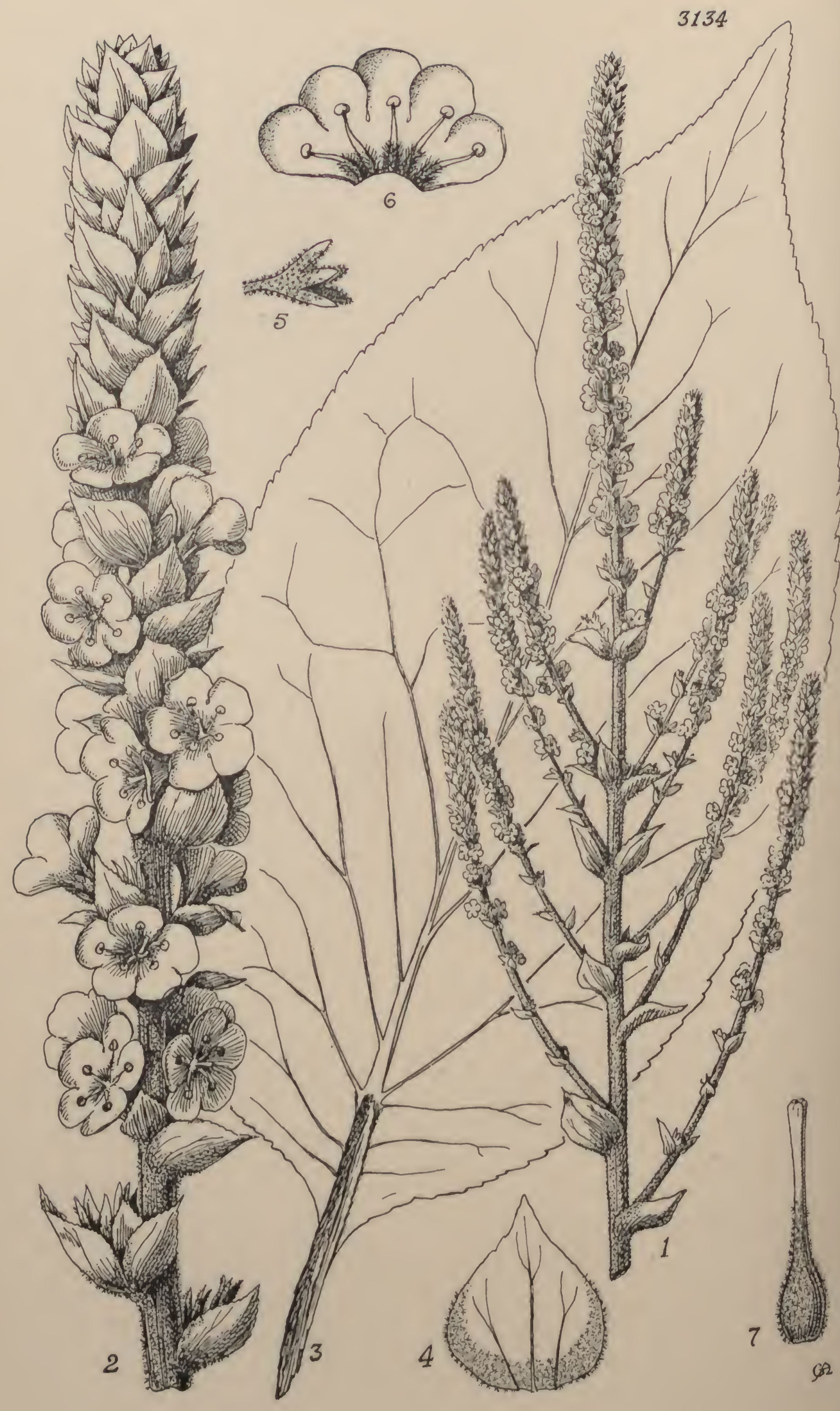




\title{
Tabula 3134.
}

\section{VERBASCUM LUTEO-VIRIDE, Turrill.}

\author{
Scrophulariaceak. Tribus Verbasckae.
}

V. luteo-viride, Turrill in Kew Bull. 1924, p. 263; Stoyanoff et Stefanoff, Flor. de Bulg. p. 988 (1925); Hlayek, Prodr. Flor. Penins. Balcan. vol. ii. p. 119 (1929); species Seet. Lychnitidis, Benth. in bC. Prodr. x. 230 (1846), Subseet. Thapsoideae, Benth. l.e., sensu Inutato Boiss. Flor. Or. iv. 299 (1879), a $V^{\prime}$. pinnatifido, Vahl, foliorum ambitu, inflorescentin densiore valde differt.

Planta tota plus minusve albo-tomentosa, pilis umbellato-ramosis sessilibus vel sacpissime stipitatis instructa. Caulis ereetus, inferne teres, glabreseens, superne leviter angulatus, dense albo-tomentosus. Folia ralliealia oblonga vel elliptico-oblonga, usque ad $4 \mathrm{dm}$. longa et $9.5 \mathrm{~cm}$. lata, crenata, eaulina aeute aeuminata, irregulariter erenata, in pagina inferiore dense albo-tomentosa, in pagina superiore minus albr-tomentosa fere viridia vel luteo-viridia, inferiora ovata, hasi cordata, $6.5 \mathrm{~cm}$. longa et $3 \mathrm{~cm}$. lata, vel in culto multo majora, usque ad $3.5 \mathrm{dm}$. longa, et $1.4 \mathrm{dm}$. lata, superiora fere orhicularia, amplexieaulia, $2 \cdot 3 \mathrm{~cm}$. cliametro. Flores glomerati, sessiles, glomerulis in racemun $4 \mathrm{dm}$. longum vel in paniculam ramis $3 \mathrm{dm}$. Iongis dispositis; bracteac inferiores foliis superioribus similes, superiores sessiles, late Ovatae, plus minusve aeumina tae, eireiter $1 \mathrm{~cm}$. longae et $7 \mathrm{~mm}$. latae, crenato-dentatae vel erenato-serratae, luteo-virides, venosae. Calyx fere ad basin in sepala 5 subaequalia divisus, sepalis anguste oblongis vel lanecolato-oblongis obtusis vel subaeutis minute apiculatis $4-6 \mathrm{~mm}$. longis 2-3 mum. latis, usque ad 2-3 min. infra apieem dense albotomentosis, apieem versus viridilus glal,risque. Corolla luten, cireiter $2 \mathrm{em}$. diametro, extra allo-tomentusa, intus glabra. Stamina filamentis inforne pilis albo-flavidis obteetis, antheris onnilus reniformilsus. Ovariun ovoidcum, $2.5 \mathrm{~mm}$. altum, $2 \mathrm{~mm}$. dianetro, dense alho-tomentosum ; stylus $7.5 \mathrm{~mm}$. longrus, glaber, superne leviter elavatus.

S. Burgaria. Distriet Rouseuck, near Shtrklevo (Strakliovo), 14.8.92, S. Gicorgiev (typus); betweell Shtrklevo and Ivanovo, on linestone Hecks, 18.9.24, D. Uopdanob \& D. Jordanoff; cultivated in the lectorium Experimental Ground at Kew, 1926-27, from seeds colK. 71, by Uupdanols and Jordanofi, 1.e., in flower 21.7.27 and 1.11.27, 
This very distinct species of Verbascum is of special interest as an endemic of the Danubian plain of North Bulgaria. This district is one of the poorest in plant endemics of the whole Balkan Peninsula, partly because the habitat conditions on the opposite side of the Danube are very similar, partly because of its flat uniformity, and partly because of its high degree of cultivation. It is, of course, possible that $V$. luteo-viride may be found in southern Roumania, but at present it is accepted as one of the most striking endemics in Bulgaria north of and excluding the Stara Planina.

Since the original description was published we have been fortunate in procuring viable seeds, by the kindness of Mr. B. Stefanoff of Sofia, and these have enabled us to study the living plant at Kew. Under cultivation quite handsome plants can be obtained, much larger than the wild material at first described. A study of the living plants has resulted in some modifications of the original description-especially with regard to the size of the leaves and the branching of the inflorescence. The figure has been made from specimens cultivated at Kew as K. 71 (see above).-W. B. Turrilu.

FIG. 1, portion of inflorescence, $\times \frac{1}{3} ; 2$, inflorescence-branch, nutural size; 3 , foliage leaf, natural size; 4, bract, $\times 2 ; 5$, calyx, slightly enlarged; 6 , corolla spread open, slightly enlarged; 7, gynaeceum, $\times 3$. 



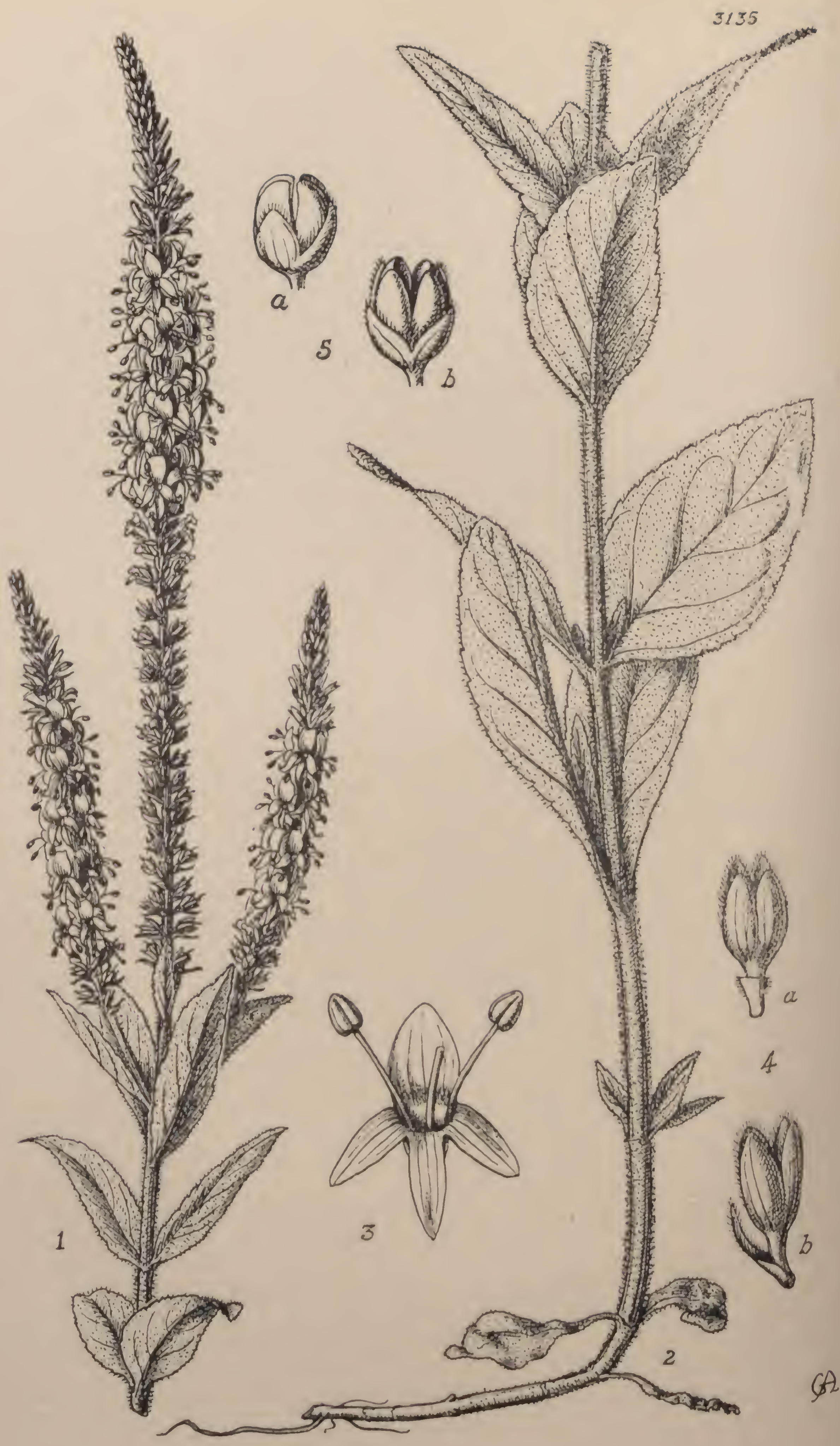




\section{TABUla 3135.}

\section{VERONICA EUXINA, Turrill.}

\section{Scrophulariaceat. Tribus Digitaleak.}

V. euxina, Turrill in Journ. Bot. vol. Ixiii. p. 161 (1925), el in Bull. Soc. Bot. Bulg. vol.ii. p). 22, 24 (1928); Hayck, Prodr. Flor. Penins. Balcan. vol. ii. p. 158 (1929); a V. spicata, L., sensu stricto, eaulibus foliisque densc glanduloso-pubescentibus, foliis inferioribus latioribus, omnibus sessilibus vel fere sessilibus, capsulis glabris differt.

Caules erecti vel aseendentes, usque ad $5 \mathrm{dm}$. alti, ima basi $3 \mathrm{~mm}$. diametro, subteretes, omnino dense glanduloso-pubeseentes. Folia late clliptiea vel ovato-elliptica, apice obtusa, rotundata, vel subacuta, basi angustata sacpe scmiamplexicaulia, media $4-6 \mathrm{~cm}$. longa, $2-3 \mathrm{~cm}$. lata, marginc crenata, pagina utraque dense glanduloso-pubeseentia, costa nervisque in siccitate supra subimpressis subtus prominentibus, nervis la teralibus utrinque cireiter 6 , in folia superiora minora angustiora acuta gradation transientia. Inflorescentia usque ad $1.2 \mathrm{dm}$. longa; spicae densac, multiflorac, solitariac, vel usque ad 5 aggrega tae; braeteae angustissime elliptieae, apice acutae, $1.5 \mathrm{~mm}$. longae, $0.5 \mathrm{~mm}$. latac, margine longe ciliatae, haud glandulosie; pedieclli $0.5 \mathrm{~mm}$. longi. Sepela 4, glabra, margine conspicue albo-ciliata exeepta, haud glandulosa, 2 adaxialia uvata, $1.5 \mathrm{~mm}$. longa, 2 abaxialia linearielliptica, $2 \mathrm{~mm}$. longa. Peiala $4,3.5 \mathrm{~mm}$. Ionga, abaxiale linearc, adaxiale ovatum, lateralia lineari-ollonga. Filamenta $2.5 \mathrm{~mm}$. longa; untherae vix $1 \mathrm{~mm}$. longae. Ovarium comprcsso-subsphaerieum, glnbrum; stylus $4 \mathrm{~mm}$. longus, glaler. Capsula compresso-subsphacrica, apicc leviter truncata, haud emarginata, $3 \mathrm{~mm}$. longa, $3 \mathrm{~mm}$. diametro, glabra, stylo saepe persistente. Semina plana vel subplana, ambitu oblonga vel subrotundata, circiter $0.75 \mathrm{~mm}$. longa, luteo-lirunea.

Bulgaria. Hills south of Varna, in flower June 1924, GilliatSmith, 671, 730, 752, 753, 879 (fruit); hills south of Varna, in flower and fruit, 8.8.26, Turrill, 1590 .

DomuJa. Tultseha, Steppe bei Malkodz, 20.6.72, Sintenis, 227 (form with narrower lcaves).

This species is one of several allied to the Linnean $V$. spicata. In castern Bulgaria it grows in grassy places letween sliblyak bruslrwood (see 'Turrill, Plant-Life of the Balkan Peninsula, 1). 152 seq.. 
Oxford, 1929) associated with $V$. orchidea, Crantz. From the latter species it remains quite distinct, and in the wild habitat is easily distinguished by the less erect habit, darker duller green and marked glandulosity. Both species have been cultivated, from Varna material, for four years in the Herbarium Experimental Ground at Kew and have retained their distinctive characters. The figure has been prepared from cultivated material obtained from the only known Bulgarian locality near Varna.-W. B. Turrill.

Fras. 1 and 2 , plant, natural size; 3 , flower, $\times 5 ; 4$, calyx, and calyx and bract, $\times 5 ; 5$, fruits, $\times 5$. 


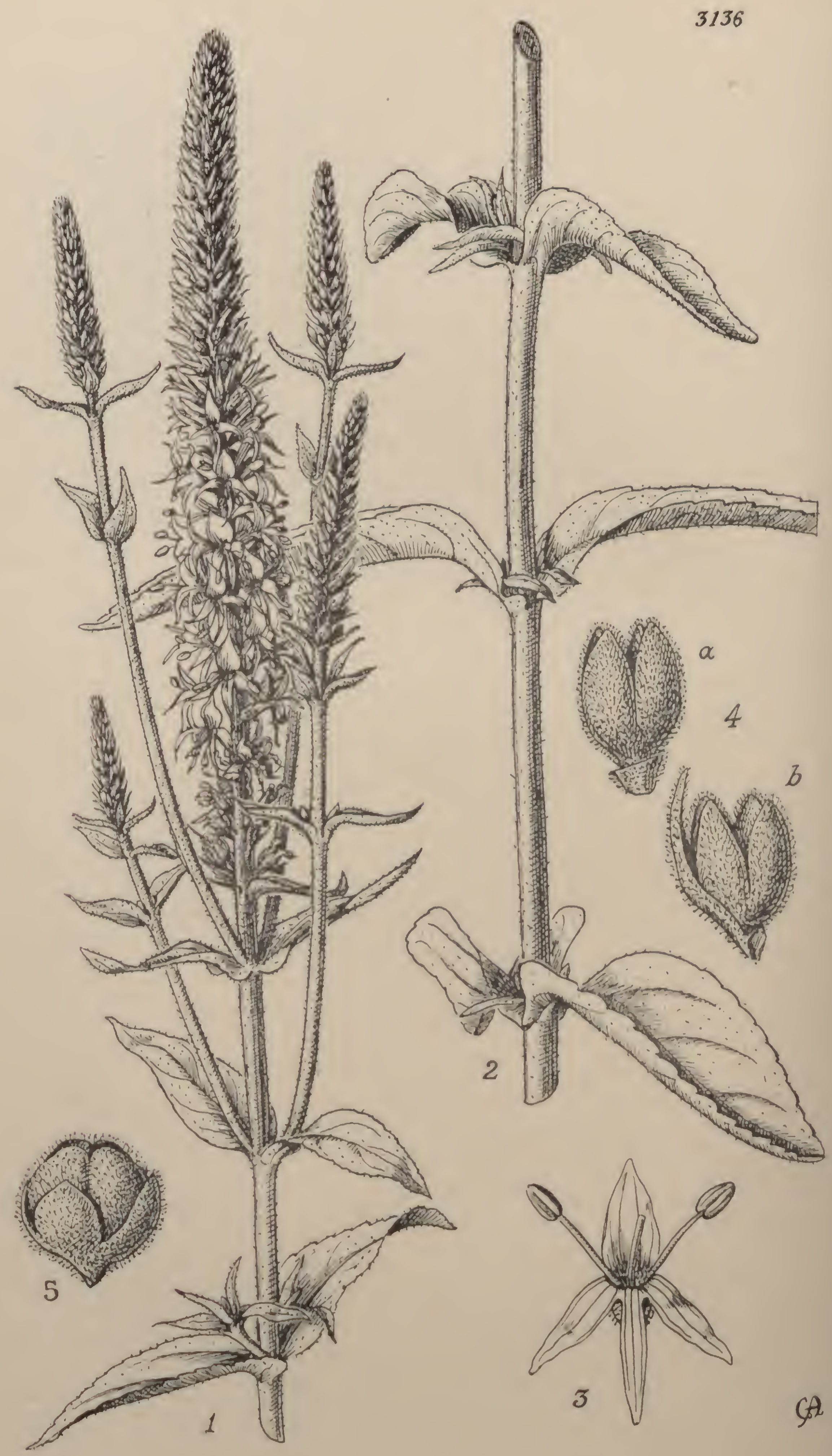




\section{TABUla 3136.}

\section{VERONICA ORCHIDEA, Crantz.}

\section{Scrophulariaceae. Tribus Digitaleae.}

V. orchidea, Crantz Stirp. Austr. Fase. iv. p. 333 (1769); Turrill in Journ. Bot. vol. 1xiii. p. 160 (1925), ct in Bull. Soc. Bot. Bulg. vol. ii. p. 22 (1928); a V. spicala, L., caulibus ealyeibusque glanduloso pubeseentibus reedit.

Ilerba peremis. Rhizoma breve, plus minusve horizontale, leviter inerassatum. Caules ereeti, simplices, teretes, usque ad 9 dm. alti sed saepissime breviores, puberuli. Folia in planta juveni oblongoovata, apiee rotundata, basi in petiolum abrupte eontracta, usqque ald in. longa, petiolo $2 \mathrm{em}$. longo exeluso, et $4.5 \mathrm{~cm}$. lata; folia eaulina in planta florifera lanceolata, elliptieo- vel oblongo-laneeolata, aeutir vel subaeuta, usque ad $7 \mathrm{enn}$. longa et $3 \mathrm{~cm}$. lata; inferiora abrupte vel subyradatim in petiolum eontracta ; superiora minores; omnia margine erenata vel rarissime integra, plus minusve pulserula vel in pagina superiore lueida glabra vel fere glabra, haud glandulosa, costil nervisque lateralibus in pagina superiore vix prominentibus in inferiore prominentibus. Iuflorescentia multum ramosa, ramis deusius puberulis et sujerne glandulosis, spieis elongatis, multifloris; breteae laneevlatie vel superiores lineares. Calycis segmontu elliptieo-oblonga, obtusa vel subacuta, $2 \mathrm{~mm}$. longa, $1.25 \mathrm{~mm}$. lata, dense glandulosia. Corolla atroviolaces, $7 \mathrm{~mm}$. longa, lobis $4-5 \mathrm{~mm}$. longis, $2.5 \mathrm{~mm}$. (Adaxiale) $-0.5 \mathrm{~mm}$. (abaxiale) latis, contortis. Stamina $6 \mathrm{~mm}$. longa, antheris $2 \mathrm{~mm}$. longis inelusis. Gynaeceum $6.25 \mathrm{~mm}$. altum; stylu. glaher; ovarium 1 mm. altum, pulbeseens. Capsulae glandulosir0.5 seentes, $2.25 \mathrm{~mm}$. longae. Semina complanuto-ellipsoider, Fl. 1 lit. longa. - V. spicata, L., subsp. orchidea, Hayek in Hegi 111 . Baleat. Eur. vol. vi. jars i. p. 46 (1915), et in Prodr. Flor. Penins. alean, vol. ii. p. 157 (1929).

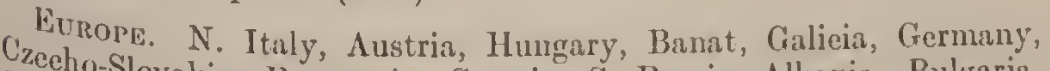
Dobo-Slovakia, Roumania, Croatia, S. Russia, Albania, Bulgaria, obruja, Serbia, Istria.

This mierospeeies of the $V$. spicata group of speedwells has been eultivated at Kew for some years from seeds colleeted on the lills sontl of Varna, eastern Bulgaria, where it grows in grassy plaees 
between shiblyak, associated with $V$. euxina. Under cultivation it retains its characteristic features and makes a plant of considerable horticultural value. In its general distribution it is essentially Pannonian-Caucasian so far as the available material allows us to judge. Morphologically the relatively long and narrow often twisted corolla-lobes of a dark violet-blue colour are very distinctive, and the shortness of the hairs makes the living plant appear glabrous till a lens is applied. Both $V$. orchidea and $V$. euxina normally over-winter as hemicryptophytes.-W. B. Turrill.

Frg. 1, upper portion of flowering plant, natural size; 2, lower portion of plant, natural size; 3 , flower, $\times 3 ; 4$, calyx, and calyx with bract, $\times 5 ; 5$, fruit, $\times 5$. 



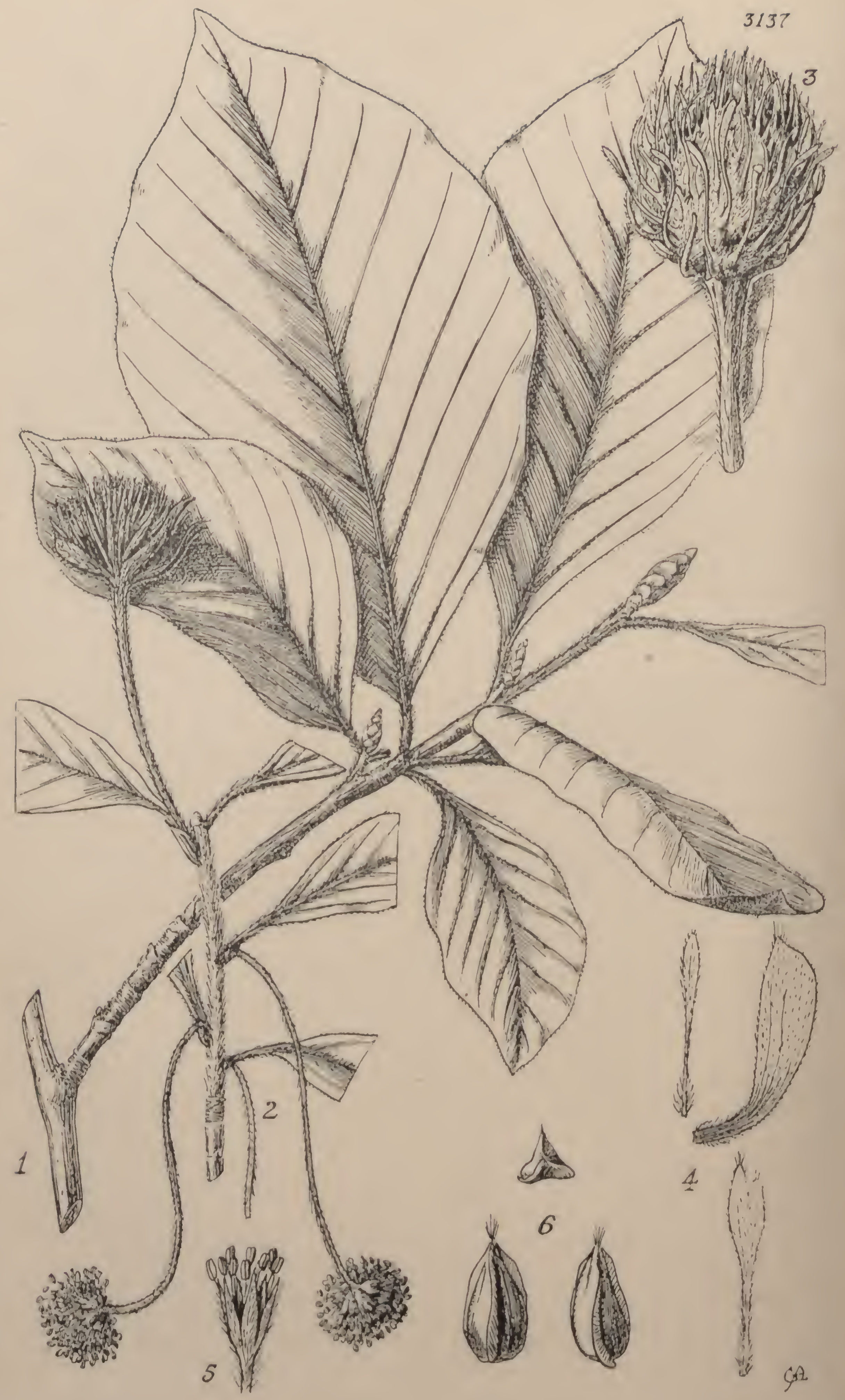




\section{TaBULA 3137.}

\section{FAGUS ORIENTALIS, Lipsky.}

\section{Fagachat. Tribus Fageaf.}

F. orientalis, Lipsky in Acla Hort. Petrop. vol. xiv. p. 300 (1897) ; Stefanoff in Oesterr. Bol. Zeilschr. vol. Ixx. p. 111 (1921); Stoyanoff el Stefanoff, op. eit. vol. Ixxii. p. 86 (1923); Turrill in Keno Bull. 1926, p. 102, et Plant-Life of the Balkwn P'eninsula, p. 139 (1929); Stoyanoff in Jahrb. d. Univer. Sofia. Landwirtsch. Fakultäl. vol. v. p1). 345-394 (1927), et in May. Bot. Lap. vol. xxv. p. 131 (1927); a F. silvatica, L., foliorum nervis utrinque sacpissime 9-11, floribus masculis perigoniis late ct breviter campanulatis lobis brevioribus late ovatis, fructus involucri laciniis majoribus inferioribus foliaceis differt.

Arbor alta, cortice cinereo. Folia elliptica, oblongo-, ovato-, vel olovato-elliptica, apice acuta subacuta vel leviter attenuata, basi rotundata vel plus minusve cuneata, lanina usque ad $12 \cdot 5 \mathrm{~cm}$. longa et $7 \cdot 5 \mathrm{~cm}$. lata, saepissime minore, venis lateralilus u trincpne saepissine 9-11 in pagina inferiora prominentibns adpresse sericeis; petiolns circiter $1 \mathrm{~cm}$. longus. Flores maseuli: perigonia late et breviter campanulata, 3 mm. longa, lobis late ovatis $1.5 \mathrm{~cm}$. longis $1.25 \mathrm{~cm}$. latis; stamina 9-12, 6 mm. longa ; antherne $1.25 \mathrm{~mm}$. longae. Fructus involneri lncinios majorilus dissimilibus, inferiorilus foliaceis viridilus unltinerviis $1 \mathrm{~cm}$. longis et usque ad $3 \mathrm{~mm}$. latis interlum in fructus pediecllo sitis ; intermediis snbsinilibus sed temnioribns et acntioribus, supremis subulatis; pedicellus $2-7 \mathrm{~cm}$. longns, adpresse seriens.

Burgaria. In silvis monte Strandje, Jnl. 1920, Stoyanoff el Senfanoff (forma macrophylla); in silvis ad rivnm Kantschia, 9.7.22, Sloyanoff el Sicfanoff; soutl of the Aladza Momastery, north of Varna, 8.6.25, B. Gillial-Smith, 1189; Central Rodope, in valley between Boju and Dariclere, c. $400 \mathrm{~m} ., 17-18.6 .26$, Turrill, 1450, 1482, 1483, 1646.

Climea. Woods of the Tcliatir-1)agh, 30.9.46, no collector; in descensu a montc Karabi-Jaila usque ad p. Kincznk-Usen, 22.5.05, N. A. Busch; forest on the mountain Ai Petri, 13.7.25, Zizime.

Asia Minot. Near tlıc roadside from Brusa on Mt. Olympus, about $3000-1000 \mathrm{ft} ., 30.8 .24$, C. W. James and Sir IIenry Miers, F.R.S.; It. Ida, Troas, T'schai-1)ere prope Kareikos, 24.7.83, Sintcnis, 581 (?) ; 
Paphlagonia, Wilajet Kastambuli, Kure-Nahas, in silvis ad TopschiChan, 9.9.92, Sintenis, 5113; Paphlagonia, Küre, between Kastamuni and Ineboli, $1400 \mathrm{~m}$., on the northern slope of Kush-Dagh, in mixed forest with Taxus, Abies Bormuelleriana, Carpinus, Fraxinus, etc., 5.8.25, H. Czeczott, Phrygia, Tchabanne-Dagh, à l'Est de Guédis, vers 1300 mètres, 19.7.57, Balansa, 1141.

Caucasus. Kusary, distr. Ruba, prov. Baku, 31.7.26, Kariagin; Ossetia, in silvis prope Alagir, 4 u. 7.98, B. Marcowicz; Terek, circa Shclesnowodsk, 28.8.98, F. Akinfiew, 438; Balkaria Dukh-Sou, in mixed beech and birch copse, on the mountain above Dykhskaya block-house, 1900 m., 18.7.27, E. and N. Busch; Karska region, district of Ardagan, 20.8.14, E.T. Kikodse; 6 versts from the village of Djoubia in the Black Sea Government, 1913, Mdme. M. Lavrouve; in mountain gorges near Batum, Massalsky.

Syria. Monts Amanus: Kusliji Dagh, 5000-6500 ft., 8.08, M. Haradjian, 2568.

Persia. Sylv. Ghilan, Aucher-Eloy, 5325.

The oriental beech has its main distribution in the Caucasus and northern Asia Minor where it forms considerable forests. It was first recorded in Europe from the Strandja mountains in eastern Bulgaria, later near Dolen-Ciflik in the eastern Stara Planina, still later north of Varna, and then in the Central Rodopes, north of Daridere. In 1927 Stoyanoff recorded it for many localities in the eastern parts of the Stara Planina, near Cape Emine and the village of Gjozeken. In the Balkan Peninsula the common beech ( $F$. silvalica, L.) grows generally at higher altitudes (commonly above $1000 \mathrm{~m}$.), and the oriental beech only in the eastern parts and at lower altitudes. Geographically their areas overlap in the Central Rodopes, and intermediates undoubtedly occur there (Turvill, 1431, 1472, 1713, in Herb. Kew). The writer suggested in 1926 that the beech recorded for the northern Dobruja might be $F$. orientalis, and this suggestion has since been eonfirmed by G. H. Grinţeseu (Bul. Grăd. Bol. Cluj. vol. vii. p. 58: 1928). In the Dobruja the oriental beech is said to occur: especially at Luncaviţa (distr. of. Tulcea), where it forms a small forest of 200-250 individuals. Accounts of the oriental beech forest in the Central Rodopes have already been published (Stoyanoff 1927, T'urrill 1929).

The beech or beeches of the Crimea are still in dispute. E. Wulft and T. Zyrina (Oesterr. Bol. Zeitschr. vol. Ixxiii. p. 276 : 1924) conclude that both $F$. silvatica and $F$. orientalis occur in the Crimea. Wulft, however, in Karsten u. Schenck, Vegelationsbilder, vol. xvii. t. 3B, says "Die Buchenwälder in der Krim werden von einer Form, die der Fagus orienlatis Lipsky sehr ähnlich ist, gebildet." It is understood that further recent investigations on the Crimean beeches have been made, but no publication dealing with the results has been traced. The few Crimean specimens at Kew are insufficient to decide the range of characters found in the genus in the Crimea, but they appear 
indistinguishable from the more abundant Caucasian material, and are here quoted as $F$. orientalis.

The distribution of $F$. silvatica is given, fairly accurately, by Lämmermayr in Die Pflanzenarenle, I. ii. Karte 17 (1926), and for $F$. orientalis, ineompletely, in Karte 18.-W. B. TURrILL.

Fia. 1, foliago branch, natural size; 2, flowering braneh, natural size; 3 , young infructescence, natural size; 4 , braets from eupule, $\times 2 ; 5$, malo flower, $\times 3$; 6 , fruits, natural size. 



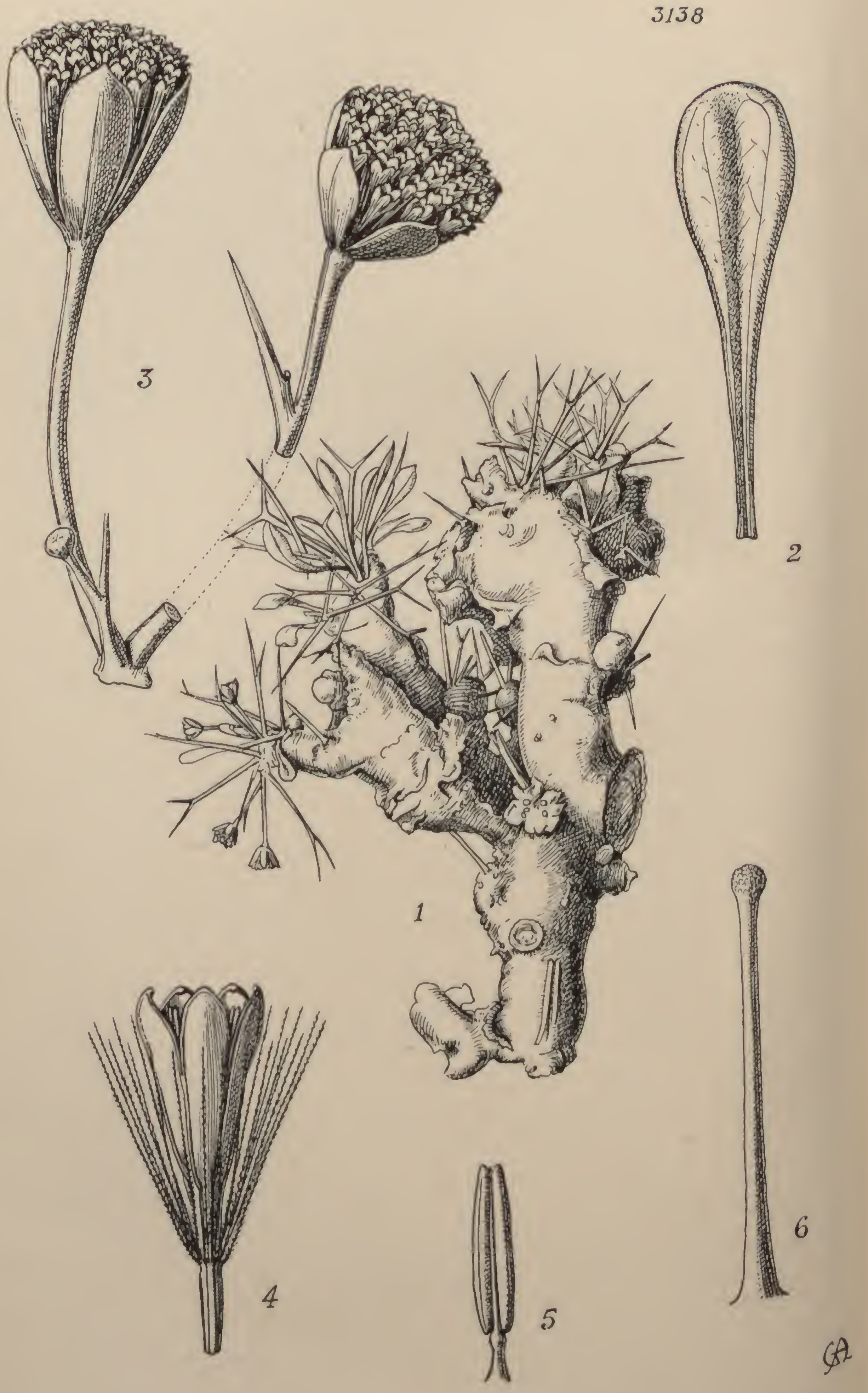




\section{Tabula 3138.}

\section{OTHONNA EUPHORBIOIDES, Hutchinson.}

\section{Compositak. Tribus Senecioneae.}

0. euphorbioides, Muthinson in Ann. S. Afr. Mus. vol. ix. p. 412, fig. 15 (1917) ; speeies insignis lrabitu Euphorbiae, foliis multo reduetis, peduneulis bifureatis demum spineseentibus distinetissima.

Caules robusti, erassi, breves, duri, peduneulis bifureatis persistentibus spinosi, eortiee laevi glabro obteeti. Folia redueta, pauen, eircum hases peduneulorum sulvertieillata, anguste oblaneeolata, vel spatulato-oblaneeolata, $1-1.3 \mathrm{~cm}$. longa, 2-3 mm. lata, erassa et probabiliter earnosa, glabra, e pulvino eano-tomentosoorta. Pedunculi rigidi, superne plerumque bifureati, ad $2 \cdot 5 \mathrm{em}$. longi, glabri. Capitula minima, turbinato-eampanulata, diseoidea, eireiter $5 \mathrm{~mm}$. diametro. Involucrum $3 \mathrm{~mm}$. longum, 5-lobatum, lobis ovato-triangularibus subaeutis $1 \mathrm{~mm}$. longis glabris. Florcs radii breviter ligulati ; eorolla papjo brevior, apiee bifida. Aehacnia lorevia, $1 \mathrm{~mm}$. longa, erassa, glalia. Pappus eopiosissimus, albus, plerumque $2.5 \mathrm{~mm}$. longus, minute barbellatus. Flores disci steriles; corollae tubus '2 $\mathrm{mm}$. longus, glaber, lobi oblongi, obtusi, $1 \mathrm{~mm}$. longi. Achacnia ungusta, elongata, glabra, $1.25 \mathrm{~mm}$. longa. Pappus ninus eopiosus, eeterum ut in florilus radii.

Soutu Africa. Little Namaqualand: Khamiesberg; in elefts of roeks on upper north-west slopes of Sneeuwkop, Pearson \& Pillans, 5795 ; sontlr-east slopes above Modderfontein, Pcarson \& Pillans, 5858 ; Bereon IIill, north-west of Leliefontein, $1680 \mathrm{~m}$., Pearson, 6326.

Among the many weird forms of Afriean plants this is perhaps one of the most remarkable. In habit it resembles vary elosely some speeies of Euphorbia and of Crissulacene. The peduneles are bifureate and beeome hard and spineseent, a very remarkable feature in the Compositae. Aceording to Pearson it forms a euslion-plant in the Khlamiesberg.-J. IUUTCHINSON.

F1(r. 1, portion of plant, naturul size; 2 , leaf, $\times 5 ; 3$, flower-heads, $\times 5$; 4, flower, $\times 12 ; 5$, stamen, $\times 30 ; 6$, style, $\times 30$. 



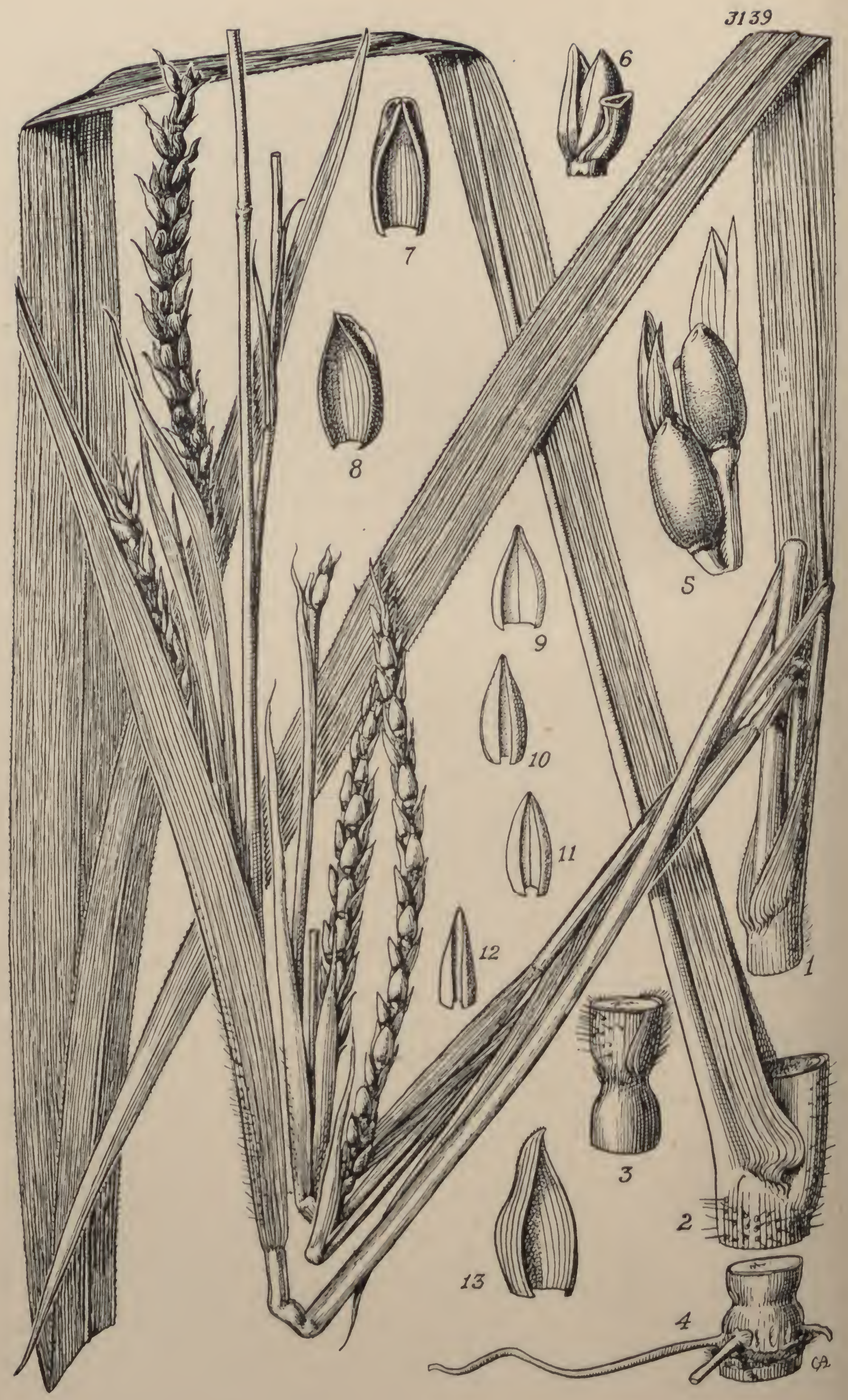




\section{TABULA 3139.}

\section{ROTTBOELLIA PURPURASCENS, Robyns.}

\section{Gramineae. Tribus Andiopononeat.}

R. purpurascens, Robyns, Flor. Agrost. Congo Belge, pars i. p. 66 (1929), et Bull. Jarl. Bot. Brux. vol. viii. p. 214 (1930); a R. exultala, Linn.f., culmis crassioribus, vaginis foliorum valde tubcrculatosetulosis, racemis leviter compressis, et spiculae sessilis glnma inferiore apice truncata satis distinguenda.

Gramen anumun. Culmi crecti, ad $1.5 \mathrm{~m}$. alti, robusti, teretes, sed internodiis facic folia spectante late canaliculatis vel applanatis, superne ramosi, glabri, purpurascentes, nodis plus minusve appresse pubescentibus. Foliorum vaginae terctes, striatae, setis deciduis basi valde tuberculatis dense indutae; ligulac brevissimac, truncatac, glabrae; laminae lineares, multi-plicatae vel planae, ad 55 (raro 70$) \mathrm{cm}$. longre, 4-19 mm. latae, ad apicom acutissimam seusim attematac, glabrae, plus ninusve purpurascentes, marginibus sealiris, costa subtus prominente. Racemi solitarii, spiciformes, cylindrici, rigidiuseuli, leviter curvati et compressi, spiculis sessililus stranineis exceptis pallicle virides, al $13 \mathrm{~cm}$. longi, $5 \mathrm{~mm}$. diametro, glabri; artieuli 4-4.5 mm. longi, facie interiore concavi, inferne complanati, apice excavati, sectione triangulares, pedicello spiculae pedicellatae e basi plus minusve alte lateruliter adnati ; pedicelli articulis paulo breviores ct latiores, complanati, facie interiore lcviter concavi. Spiculae sessiles $5.5 \mathrm{~mm}$. longar, callo brevi lato lacvi incluso, elliptico-ol) longac, ghalirace Glumac $4.5 \mathrm{~nm}$. longac, 2 num. latae; inferior coriacea, crassa, elliptico-oblonga, trucata, leviter cunarginata ad minute mucronata, ninute sealirilula, usque 16-nervis; superior cymbifornis, inferiori similis, carinn superue anguste alata. Anhoccium inferius of; lemma ovatum, neutum, glabrum, hyalinum, 3-nerve, circiter $3 \cdot 5 \mathrm{~mm}$. longum, 2 nur. latum: palea coblongo-lanceolata, acuta, glabra, hyalina, 2-nervis, lemmati acquilonga, 1.5 mu. lata. Anlloccium superius of: lomma cymliforme, lyyalinum, uniuerve, $3.5 \mathrm{~mm}$. longum, 1.5 min. latum; jalea lancelata, subacuta, hyalina, olscuro 2-nervis, lemmati actuilonga, 1.3 mm. lata. Caryopsis ruliro-brunnea, oblonga, 3 inm. Inugi, $1 \mathrm{~mm}$. Inta. Spicular pedierllalae sessilibus majores et inagis comprussas, verkus apjeem racemi sellsin magis imperfectae, gluma inferiore excopta spiculis sessilibus siniles. Gluma inferior 
ovato-lanceolata, acuta, membranacea, uno margine dimidium versus medium reduplicato, 6-7 $\mathrm{mm}$. longa, $2 \cdot 8 \mathrm{~mm}$. lata. Anthoecia ô, neutra vel partibus interioribus non evolutis valde imperfectaRottboellia compressa, Vanderyst in Bull. Agric. Congo Belge, vol. ix. p. 236 (1918), non Linn. $\not$

Tropical Africa. Belgian Congo: Kinshasa, Vanderyst, 6095 bis, 6407.

This grass was first described by Vanderyst as Rottboellia compressa, a name which had already been used by the younger linnaeus for another plant, Hemarthria compressa, (Linn.f.) R.Br. Although its congener, $R$. exallata, Linn.f., is a useful fodder grass, its own value in this connection is not known. It is a much coarser grass than $R$. exaltata, with an abundance of hispid hairs which Vanderyst suggests may make it definitely dangerous for cattle.

Up to the present, it has been recorded only from the lower Kasaï region of the Belgian Congo and around Leopoldville. According to Robyns, vernacular names for this grass in the neighbourhood of Leopoldville are Toanga-Malag and Sembi-Boiki.-F. Ballard.

FIG. 1, upper part of a plant with flowering culms; 2, one of the larger lowor leaves ; 3 , a node; 4 , one of lowest nodes with stilt roots; 5 , part of a raceme ; 6 , sessile spikelet in $\frac{3}{4}$ back view, showing joint of rhachis; 7 , lower glume from within ; 8, upper glume from within; 9, lemma of lower floret from within; 10, palea of lower floret from within; 11, lemma of upper floret from within ; 12, paler of upper floret from within; 13, lower glume of podicelled spikolut. ligs. 1-4, natural size; figs. 5-13, × 6 . 


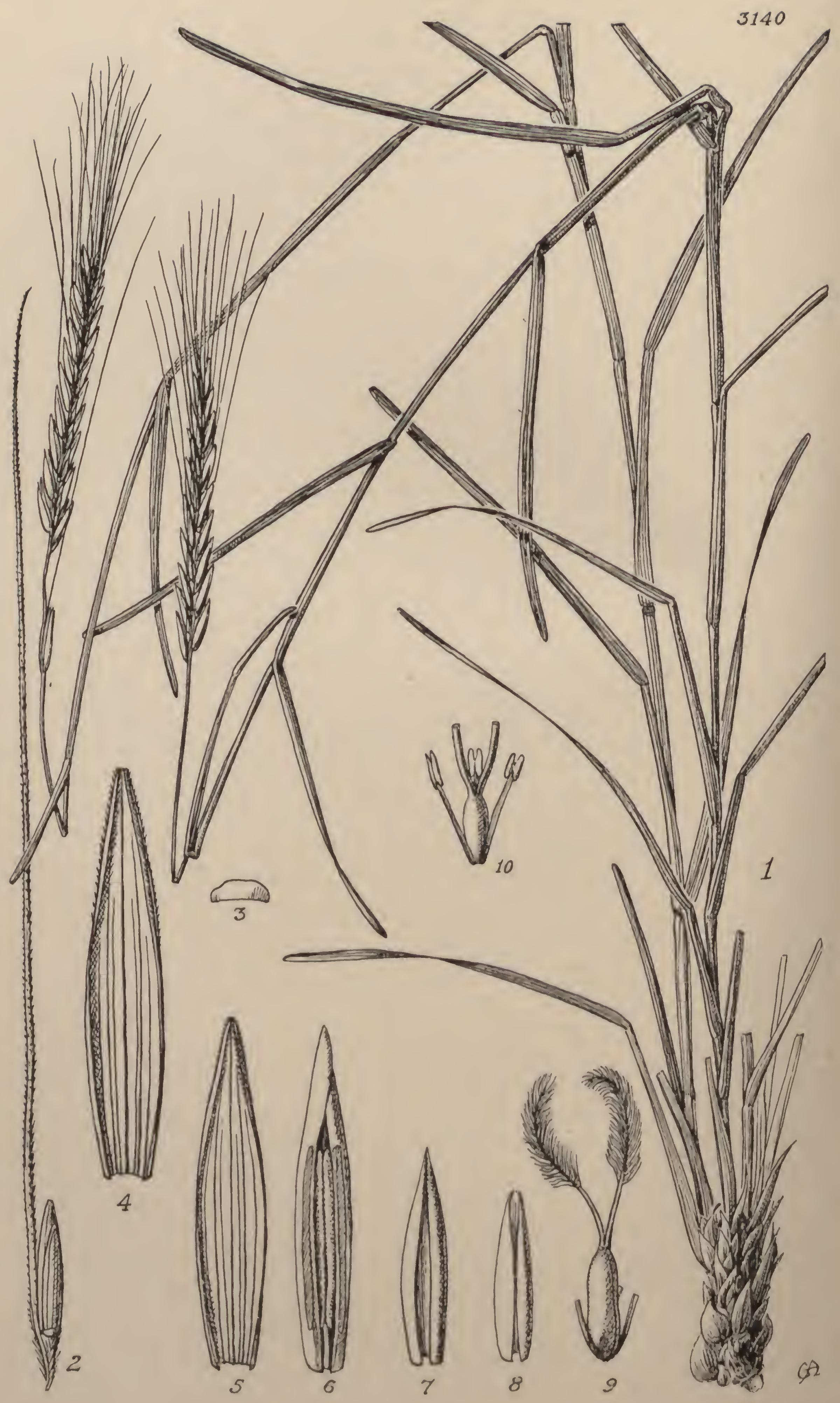




\title{
Tabula 3140.
}

\section{CHAMAERAPHIS HORDEACEA, $R . B r$.}

\author{
Graminear. Tribus Paniceae.
}

C. hordeacea, R.Br. Prodr. Flor. Nov. IIoll. p. 193 (1810); affinis Pseudoraphi paradoxae, (R.13r.) Pilger, a qua pedieello spieulae ramulo aristiformi adnato et ramulo cum spicula maturitate disarticulato differt.

Gramen perenne e rlizomate horizontali glabro. Culmi erceti, ad $60 \mathrm{~cm}$. alti, graciles, nodis ipsis atque infra plus minusve pubeseeutes, ceterum glabri, multinodes. Foliorum vaginac compressae, infimae pubeseentes, superiores glabreseentes; ligulac rotuudato-truncatae, seariosae; laminac lineares, apice late rotundatac ad $10 \mathrm{~cm}$. longae, 2.4 mm. latae, basi setis tubereulatis sparsis exceptis glabrac. Panicula deusa, spiciformis, ad $10 \mathrm{~cm}$. longa (aristis inelusis), $6 \mathrm{mun}$. lata ; axis valde complanatus, marginibus seabris; ranuli distichi, sursum sensim. attenuati et aristam seabridulam formantes, ad $7 \cdot 5 \mathrm{~cm}$. longi, basi spiculan singulam gerentes; pedicelli $3-4 \mathrm{~mm}$. longi, deorsum attenuati hasi aeutissimi, ramulo lateraliter adnati, plus minusve pubeseentes. Spiculae ambitu lineari-oblungae, 8-10 $\mathrm{mm}$. longae, $1-1.5 \mathrm{~mm}$. latae. Glumae valde inaequales; inferior minuta, decidua, $0.5 \mathrm{mu}$. longa, 1.8 mu. lata, lyyalina; superior lanecolato-oblonga, apiec auguste truncata, earinis seaberulis, membranaeea, 11-nervis, 8-10 mm. longa, 1.5-1.8 mm. lata. Aulhocium inferius ơ; lemma glumae superiori sinuile, ad $8 \mathrm{~nm}$. longum, $1.5 \mathrm{~mm}$. latum, 11 -nerve, apice obtusum vel subaeutum; palea lnneeulata, 2-nervis, tenuiter liyalina, ad $8 \mathrm{~mm}$. longa, 1.3 mm. lata. Antherae $5.5 \mathrm{~mm}$. longat. Anthoecium superius pseudo-liermaplıroditum, staminibus abortivis, anbitu lanceolatooblongum, neutum; lemma et palea hyalina; anlherae vestigiales, filanentis longis, filiformibus, anthoceium superantibus.-Selosa ereela, liwart et Cookson in Ewart et Davies, Flor. North. Terr. p. 33, tt. 2, 3 (1917) ; s. hordeneea, Ewart in Proe. Ruy. Soe. Vict. N.s. vol. xxxii. p. $204(1920)$.

Australia. Nortleen Territories: Islands in the Gulf of C'arpentaria ("h" and "I"), R. Brou'n, 6128; MacArthur River, G. $F$. II ill, 705 .

The present plant was the basis of Robert Brown's genus Chamaeraphis. later on, Poiret extended the eoneeption of the genus by 
adding three more Australian plants which Brown had included in Panicum. The spikelets in Chamaeraphis hordeacea occur singly on the axis of a spikelike raceme, whereas in the added species the spikelets are arranged in open panicles. Griffith, forty years later, proposed a new genus, Pseudoraphis, for those species of Chamaeraphis which had been added since Robert Brown's day.

In 1917, Ewart and Cookson, who were evidently unacquainted with the work of Robert Brown, redescribed Chamaercuphis hordeacea as a new genus and species, Selosa erecta. Subsequently, Ewart made the combination Setosa hordeacea (R.Br.), retaining the new generic name because of the differences existing between the original plant and the other species of Chamaeraphis (i.e. Pseudoraphis, Griff.). Bentham, in his Flora Australiensis, did not accept Griffith's genus, which thus had become somewhat overlooked. It is clear that Ewart's amended name is invalid, since the plant concerned is the original species of the genus Chamaeraphis, and Robert Brown's original generic name must therefore be retained for it.

One of the Australian species of Pseudoraphis, $P$. paradoxa, (R.Br.) Pilger, bears a great resemblance to Chamaeraphis hordeacea, since the panicle is a reduced one in which the individual branches bear only one or two spikelets. In a number of cases the solitary spikelet is borne low down on the branch near to its insertion, though there is never any partial fusion between the pedicel and the branch as in Chamaeraphis. The details of the spikelets are very similar in both plants and it is apparent that the two are closely allied. Thus, the Asiatic paniculate species of Pseudoraphis lead on quite naturally by a process of reduction through the Australian $P$. paradoxa to Chamaeraphis hordeacea.

The fusion of the pedicel with the base of the branch, though incomplete, cannot logically be regarded as a further stage in this reduction, whilst the disarticulation of the branch with the spikelet attached, so that the former functions as an awn, can also scarcely be connected with this retrogressive tendency. These two characters are connected with a progressive specialization and result in the production of an "awned" spikelet of a peculiar kind. Such are the grounds for treating Chamaeraphis as a monotypic genus. While it is, in many ways, convenient thus to separate $C$. hordeacea from $P$ seudoraphis, Poiret's extended conception of Chamaeraphis might possibly result in a more natural grouping.-F. BALLARD.

Fia. 1, part of a tuft with flowering culms, nalural size; 2, disarticulated spikelot with attached "awn," $\times 2 ; 3$, lower glume; 4, upper glume from within; 5, lemma of male floret from within; 6 , palea of male floret with stamens enclosed; 7 , lemma of fertile floret from within; 8 , palea of fertile floret from within; 9 , fertilo floret with barren stamens cut off below; 10, young fertile floret. Figs. 3-9, $\times 6$; fig. $10, \times 20$. 


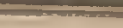




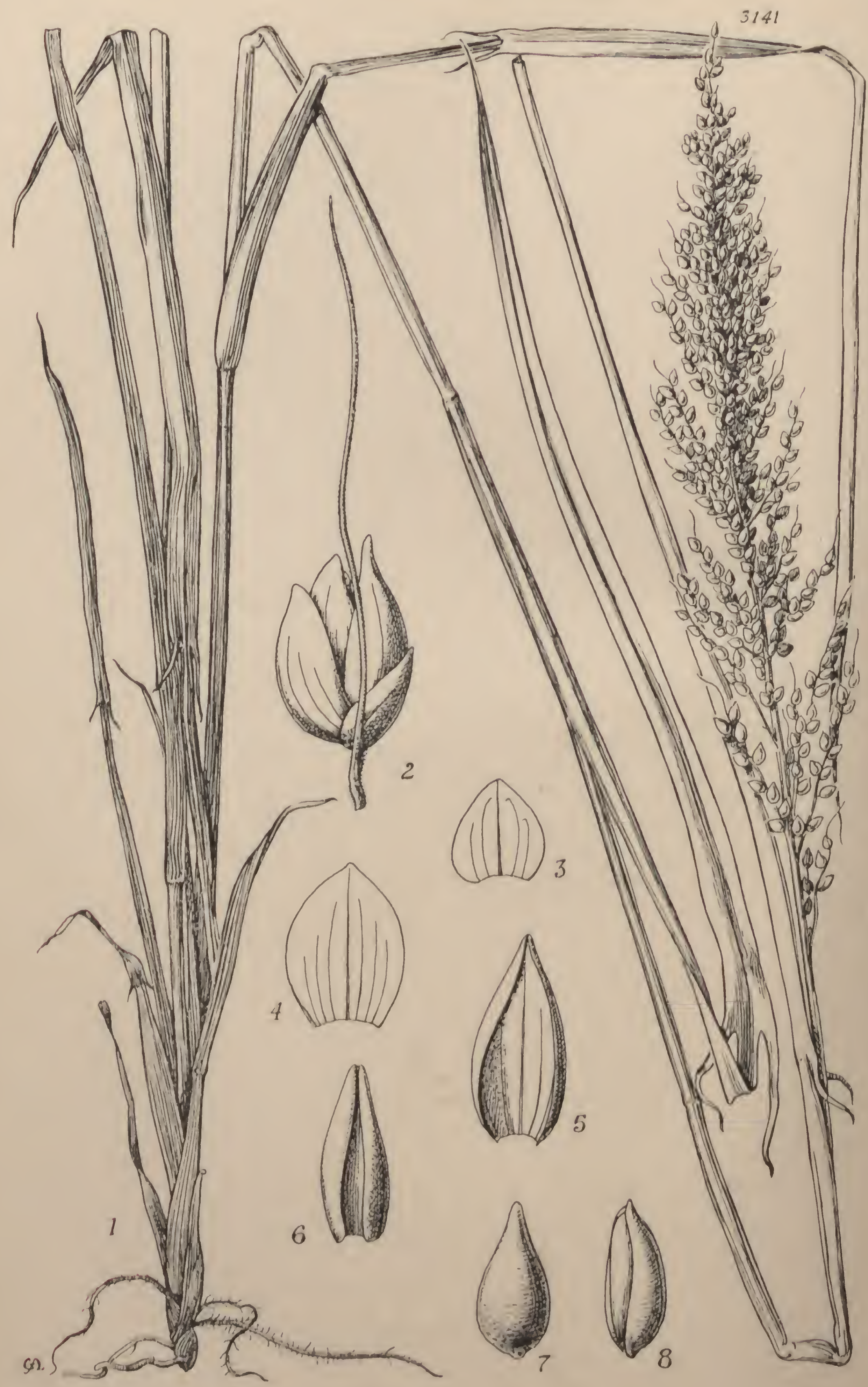




\section{Tabula 3141.}

\section{SETARIA HAARERI, Stapf cl Hubbard.}

Gramineae. Tribus Paniceat.

S. Haareri, Slapf cl IIubbard in Prain, Flor. Trop. Afr. vol. ix. p. 834, ined. ; a $S$. longiseta, P. Beauv., lrabitu minore, laminis basi sagittatis, spiculis majoribus differt.

Gramen perenne. Culmi erecti vel asendentes, ad $1 \mathrm{~m}$. alti, graeiles, seabridi et interdum infra infloreseentiam puluescentes, infra nodos plus minusve pubescentes, cetermm glabri, 4-5-nodes, pedmeulo ad 15 em. longo. Foliorum vaginae compressac, glabrac vel leviter puleseentes; ligulue ad funbriam eiliorum reduetae; laminac e basi profunde sagittata lineares, lobis subulato-acmminatis ad $1 \cdot 8 \mathrm{~cm} .10 n g i s$, sensim attenuatre, apiee longe et tenuiter setrecae, ad $30 \mathrm{~cm}$. longae, 6-12 inm. latac, pulescentes, pilis basi paulo tuberenlatis, margiuibus seabris. Panicula linearis al laneeolato-oblonga, $15-25$ em. longa, 1.3-5 em. lata; axis striatus, suleatus, scaberulus; ranuli solitarii ad quaterni, subereeti, scaberuli, inferiores ot intermedii 1.8-5 ens. longi; spiculae omues solitariae vel basi ramulorum in fascieulos breviter pedunculatos trifloros dispositac; rami et ramuli seta terminati, practerea seta noununquam spiculan subtendente; setae graciles, seaberulac, plerumque $0 \cdot 6-1 \cdot 2$ em. longac; pedieelli brevissimi, apice dilatati. Spiculac ovato-ad elliptico-ololongac, sulaeutae vel hiantes, a latere visae leviter obliquae, a dorso visac acutac vel apieulatae, fere $3 \mathrm{~mm}$. longae, $1.5 \mathrm{~mm}$. latae, viridescentes vel purpuraseentes. Glunac membranaecue, marginilus hyalinis; inferior late clliptieooblonga, obtusa et plerumque apiculata, ferc $1.5 \mathrm{~mm}$. longa, 5-6-nervis; superior inferiori similis sed anthoecio superiori aequilonga, 7-8-nervis. Anhoecium inferius ${ }^{\star}$; lemma ambitu spieulae dorso visae simule, 5-7-nerve. Puleu ovato-oblonga, lemmati aequilonga, earinis angustc marginatis. Antherae $2 \mathrm{~mm}$. longae. Anthoccium superius o, ambitu ovato-oblongum, acutum, nueronatum. Lemma ct palca coriacea, tenuiter transverse rligosa.

Tanganyka Tenritory. Pare Distriet: Kiruru, $750 \mathrm{~m}$., IIaarer, 1279. Moshi Distriet: Arusha Chini, in shade, 750 m., Haarer, 1188. 
This species is a very distinct member of the section Panicalrix, being at once separable from its congeners by its pronouncedly sagittate leaves. The spikelets also are larger and plumper than those of the other members of the section.-F. BALLARD.

Fig. 1, part of a plant with a flowering culm, natural size; 2, a spikelet with subtending bristle; 3 , lower glume ; 4 , upper glume; 5 , lemma of lower floret seen from within; 6 , palea of lower floret seen from within; 7 and 8 , upper floret seen from the back and in three-quarter profile. Figs. $2-8, \times 10$. 



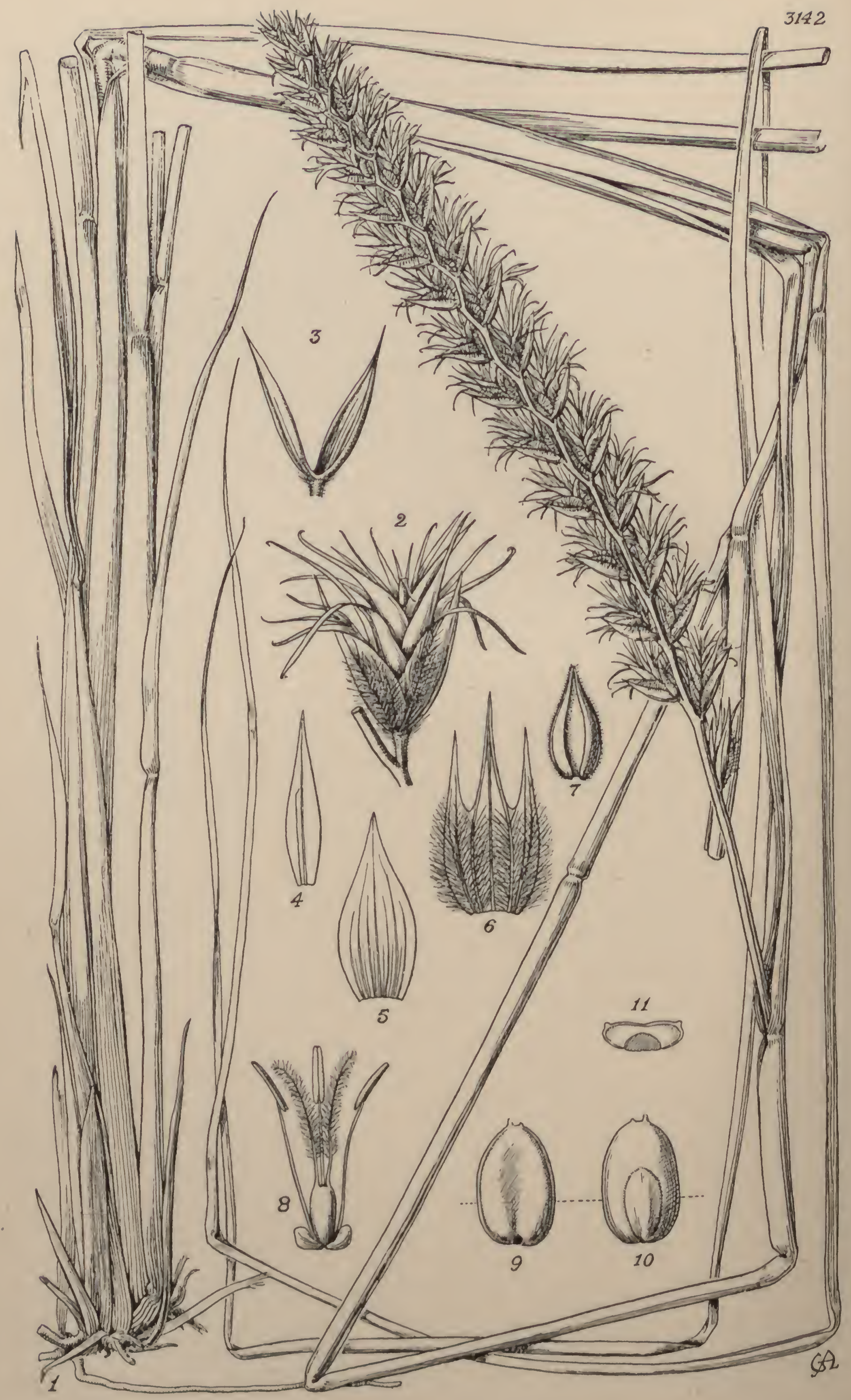




\section{TABULA 3142.}

\section{ASTREBLA SQUARROSA, C. E. IJbbard.}

\section{Gramineak. 'Tribns Chlorideat.}

A. squarrosa, C. E. II bbard in Kew Bull. 1928, p. 257; affinis A. lappacene, (Lindl.) Domin, sed foliis etuberculatis, racemis latioribus, spiculis majoribns, lobis lemmatum inter se similibus tenniter acuminatis differt.

Gramen perenue, cacspitosnm, foliorum vaginis numerosis persistentibus. Culmi e rlizomate brevi, primo erecti, deinde ascendentes, glabri, plus minusve graciles, ad $1.5 \mathrm{~m}$. alti, ad 7 -noles. Folia glabra ; vaginae solidac, laeves; ligulae valde truncatae, ad $0.5 \mathrm{~mm}$. longac, ciliatac; laminae lincarcs e basi angusta sensim attenuntae, acutissimae, ad $40 \mathrm{~cm}$. lougae vcl ultra, 3-6 mm. latae, laeves vel pagina superiore st marginibus aspernlac. Racemi solitarii, spicifornes, eomplanati, 7-18 em. longi, cun setis $1 \cdot 5-3 \mathrm{~cm}$. lati. Rhachis $1-1 \cdot 25 \mathrm{~mm}$. lata, dorso tenuiter striata, dense scaberula; pedicelli $1 \cdot 5-2 \cdot 5 \mathrm{~mm}$. longi, appressi, dense scabcruli. Spiculae arcte imbricatac, ovato-oblongae ad late elliptico-oblongac, 8-11 $\mathrm{mm}$. longac, $4-8 \mathrm{~mm}$. latae (setis exclusis), vel spienla infima ad $2 \cdot 5 \mathrm{~cm}$. longa. Gluma inferior lincarilanecolata vel lanccolata, acuta vel acuninata, 5-10 $\mathrm{mm}$. longa (illa spiculac infimac exeepta) glabra, 2-3-nervis. Gluma superior ellipticoovata vel elliptica, neuta vel acuminata, $6 \cdot 5-11 \mathrm{~mm}$. longa (illa spieulae infimao cxcepta), marginibus seariosis, 7-12-nervis. Anhoccia 6-9, arctc imbricata, sursum decrescentia, 3-4 infima perfecta, cetera sterilia, suprcmum ad valvam integram reductum. Lemma antloccii infuni 12-15 mm. longum, lobis exelusis late oblongo-ellipticnm vel fere quadratum, $4 \cdot 5-6 \cdot 5 \mathrm{~mm}$. longum, $4 \cdot 5-5 \cdot 5 \mathrm{~mm}$. latum, 5-7-nerve, dense et longe serieco-villosum; lobi inter se similes, rigidi, tenaces, acquilongi vel internedius lateralilus longior, primo ereeti, demnm reflexi vel interdum uncinati; lobi laterales subulati, $5-8 \mathrm{~mm}$. longi, lobus intermedius e hasi lata sensim angustatus apicc setiformis, 6-10 mm. longus. Palea elliptica, aenminata, 6-7 mm. longa, earinis dense ciliatis. Antherse 1-2.5 mm. longac. Caryopsis clliptica, dorsaliter compressa, 2.5-3 $\mathrm{mm}$. longa, 1.6-2 $\mathrm{mm}$. lata, brnnncn.A. trilieoides var. lappaceu, Benth. Fl. Austral. vol. vii. p. 603 (1878), fuoad specim. et descr.; et A. lappacen, Dumin in Biblioth. Bot. vol.lxxxv. p. 372 (1915), quond ic. et specim. ; non Danthonia lappacen, 
Lindl. A. triticoides, F. M. Bailey, Syn. Queensl. Fl. p. 660 (1883) ? ; Cat. Queensl. Pl. p. 57 (1890)? A. pectinata var. triticoides, F. M. Bailey in Queensl. Dept. Agric. Bot. Bull. no. xiii. p. 15 (1896).

Northern Australia. Sturt's Creek and Hooker's Creek, Mueller. Quemnsland. Between Cloncurry and Camooweal, McKinlay Ranges and Buckley River, June-Dec. 1889, Burton; Muttaburra, north of Longreach, April 1919, White; Iffley Station, Gulliver ; Darr River, near Longreach, Burgh-Birch; Longreach, April 1913, Bick (type); Flinders River, Aug. 1926, White; Georgetown, Green; Prairie, Raglan County, Chrisholm; Suttor River, Mueller; without precise locality, Bowman.

New South Wales. Between Darling River and Cooper's Creek, Neilson.

The present grass is one of four species of an endemic Australian genus, all of which, known as "Mitchell Grasses," form a dominant feature of the drier parts of the continent. As a source of fodder they are unrivalled, since their deep-rooting systems render them very resistant to drought, while their growth after rain is particularly rapid. Though not ranking as the best of these four grasses, our species is yet highly prized in eastern Australia, particularly in Queensland, where it is known as "Bull or Wheat-eared Mitchell Grass."

Its distribution, judging from the dried material in the Herbarium at Kew, is restricted to areas in which the annual rainfall ranges from 10 to 20 inches, or rarely up to 30 inches.

The genus has been revised by C. E. Hubbard in Kew Bull. 1928, p. 257, where more detailed information as to the somewhat complicated synonymy of the species may be obtained.-F. BALLARD.

Fia. 1, part of a tuft with a flowering culm, natural size; 2 , a spikelet, $\times 3$; 3 , an empty spikelet, $\times 3 ; 4$, lower glume, $\times 3 ; 5$, upper glume, $\times 3 ; 6$, lowest lemma seen from the back, $\times 3 ; 7$, palea seen from within, $\times 3 ; 8$, perfect flower, $\times 6 ; 9$ and 10 , caryopsis in back and front view, $\times 6 ; 11$, caryopsis in cross section, $\times 6$. 


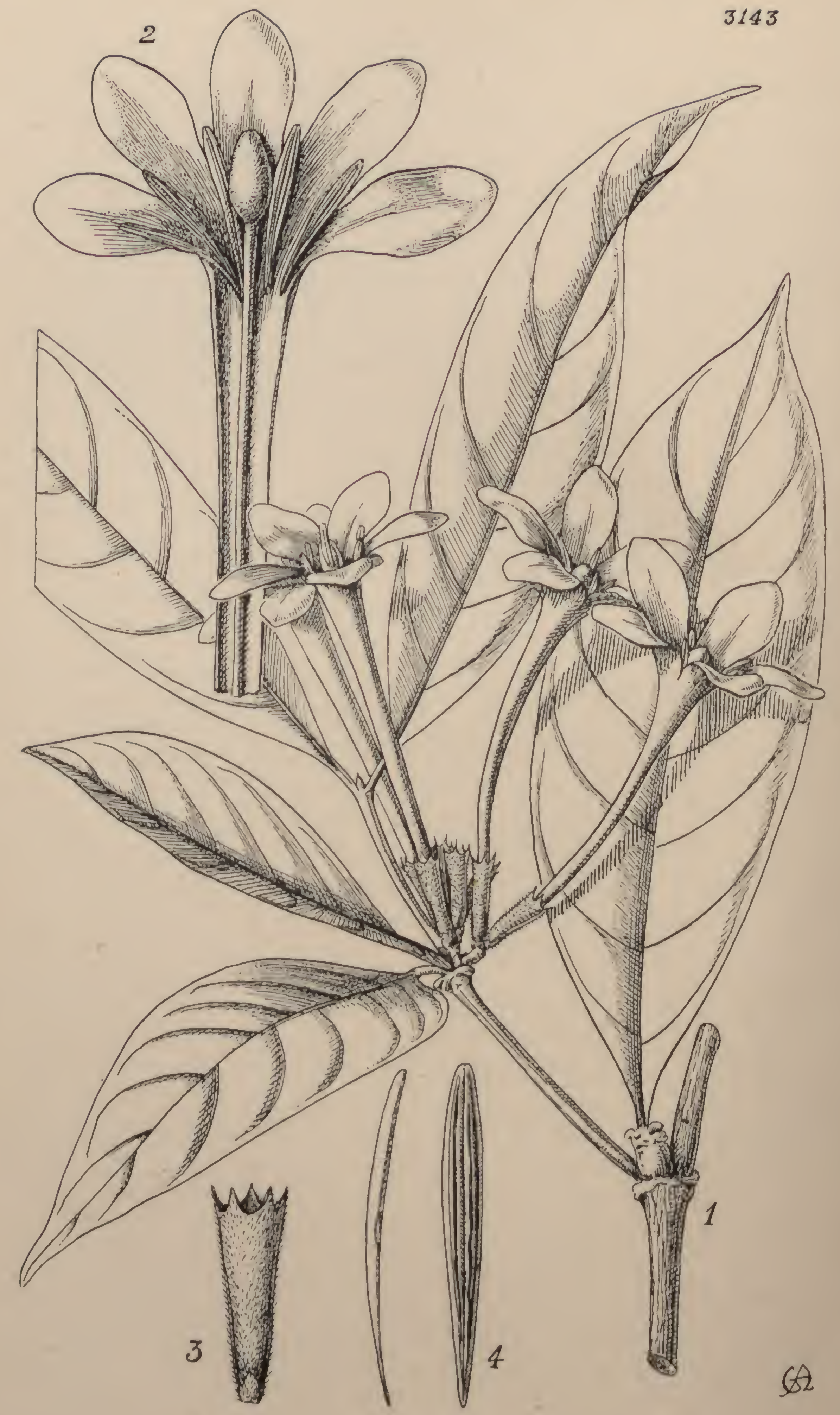




\section{Tabula 3143.}

\section{RANDIA URANTHERA, C. E. C. Fischer.}

Rubiaceae. Tribus Gardenieae.

R. uranthera, C. E. C. Fischer in Kew Bull. 1929, p. 314; species R. sootepensi, Craib, affinis, foliis floribusque majoribus, antheris longioribus enudatis differt.

Arbor eireiter $6 \mathrm{~m}$. alta. Folia coriaeea, lineari- vel ellipticolanecolata, longe aeuminata, basi aeuta, usque ad $18 \mathrm{~cm}$. longa et $5.75 \mathrm{~cm}$. lata, glabra; petioli robusti, usque ad $1 \mathrm{~cm}$. longi ; stipulae triangulares, aeutae, $3 \mathrm{~mm}$. longae. Peduneuli in axillis superioribus fascieulati, brevissimi; flores apiee peduneulorum sessiles, bini ; braeteolae 2, late ovatae, acutac. Receptaculum teres, usque ad $1 \mathrm{em}$. longum, $3 \mathrm{~mm}$. diametro. Calyx extra breviter appressolirsutus, intus pilis appressis rigidis rufis dense indutus; tubus $4-5 \mathrm{~mm}$. longus; lobi triangulares, euspidati, $2.5 \mathrm{~mm}$. longi. Corolla glabra ; tubus 6-7 em. longus, hasi $2 \mathrm{lnm}$. diametro, superne sensim dilatatus, apicem versus abrupte infundibularis, fauee ultra $1 \mathrm{em}$. diametro; lobi 5 , ohlongi, usque ad $2.5 \mathrm{~cm}$. longi, $1.5 \mathrm{~cm}$. lati. Antherae subsessiles, $2 \cdot 3 \mathrm{em}$. longae, apice exsertae, basin versus in eaudam aeutam sensim atteuluatae. Ovarium apice applanatum; stylus filiformis; stigma fusiforme, $1 \cdot 2 \mathrm{em}$. longum, semi-exsertum.

Burma. Tavoy: Ba Wa liorest Reserve, C. E. Parkinson, 8108 (Coll. Forester $B a P e$ ).

A handsome species. The stem is dark grey and the flowers, whiel were found in February, are white and fragrant. It differs from $R$. sootepensis, Craib, mainly by the longer corollas and the long-tailed large anthers.-C. E. C. Iiscier.

Fia. 1, twig in leaf and flower, $x \frac{2}{3} ; 2$, corolla opened out to show anthers and style, natural size; 3 , receptacle and calyx, $\times 13 ; 4$, anther, lateral and ventral asprects, $\times 2$. 



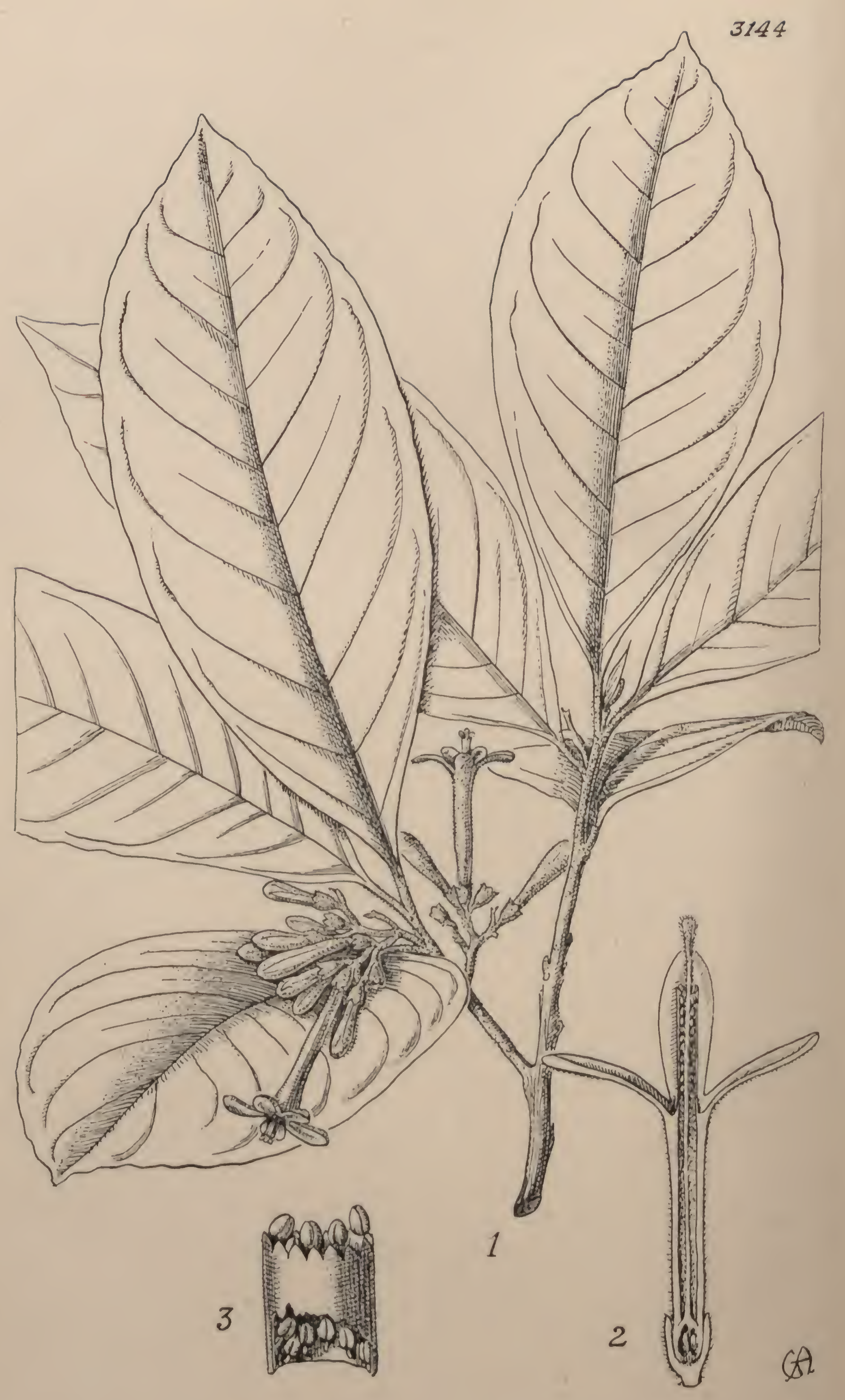




\section{Tabula 3144.}

SYMPLOCOS SUKOEI, C. E.C. Fischer.

SymplocachaE.

S. Sukoei, C. E. C. Fischer in Kew Bull. 1929, p. 315 ; species S. Maingayi, Bentlı., affinis, ramulis et infloreseentia cinereo-puberulis, foliis majoribus, corollis maturis extra fere glabris, tuho staminali longriore differt.

Arbor nsque ad $22 \mathrm{nr}$. alta. Folia elliptico-oblonga vel ellipticoobovata, basi attenuata, usque ad $19 \mathrm{~cm}$. longa, $8 \mathrm{~cm}$. lata, chartacea, subtus costa nervisque minuta puberula, eneternm glabrn. Cymae axillares, pauciflorae; rhachis usque ad $2 \mathrm{~cm}$. longa, fuseo vel cinereotomentosa; pedicelli brevissimi; bracteolae minutae, cnsiformes, cincreo-tomentosac. Receptaculum 3.4 num. longum, cincreotomentosum. Calyx carnosus, extra cinerco-tomentosus; tubus $2 \mathrm{~mm}$. longus; lobi 5; hemisphacriei, $1 \mathrm{~mm}$. longi, einereo-ciliati. Corolla carnosa ; tubus eylindrieus, usque ad $2 \cdot 2 \mathrm{~cm}$. longus ; lobi 5 , ligulati, usque ad $1.75 \mathrm{cn}$. longi. Tubus staminalis fauce corollae insertus, cylindrieus, $1 \mathrm{~cm}$. longus; antherae numerosac. Otarium recetaculo inmersum, apice conieum breviter extrusun, dense cincreo-pilosum, 3 loculare; stylns filiformis, tulum staminalem 2.5 mm. superans.

Burma. Mergui: Maliwun, Nalechaung, C. E. Parkinson, 7776 (Coll. Forester Sulioe).

The trunk is grey with white patelies. The corolla is white and the staninal tube yellow, the flowers are sweetly scented. The speeies falls in the section Cordyloblaste.C. E. C. Fiscuer.

Fra. l, twig in leaf and flower, $x \xi 3 ; 2$, flower, sectional view, $x 11 ; 3$, stamina tubo, lower part cut away, $\times 6$. 




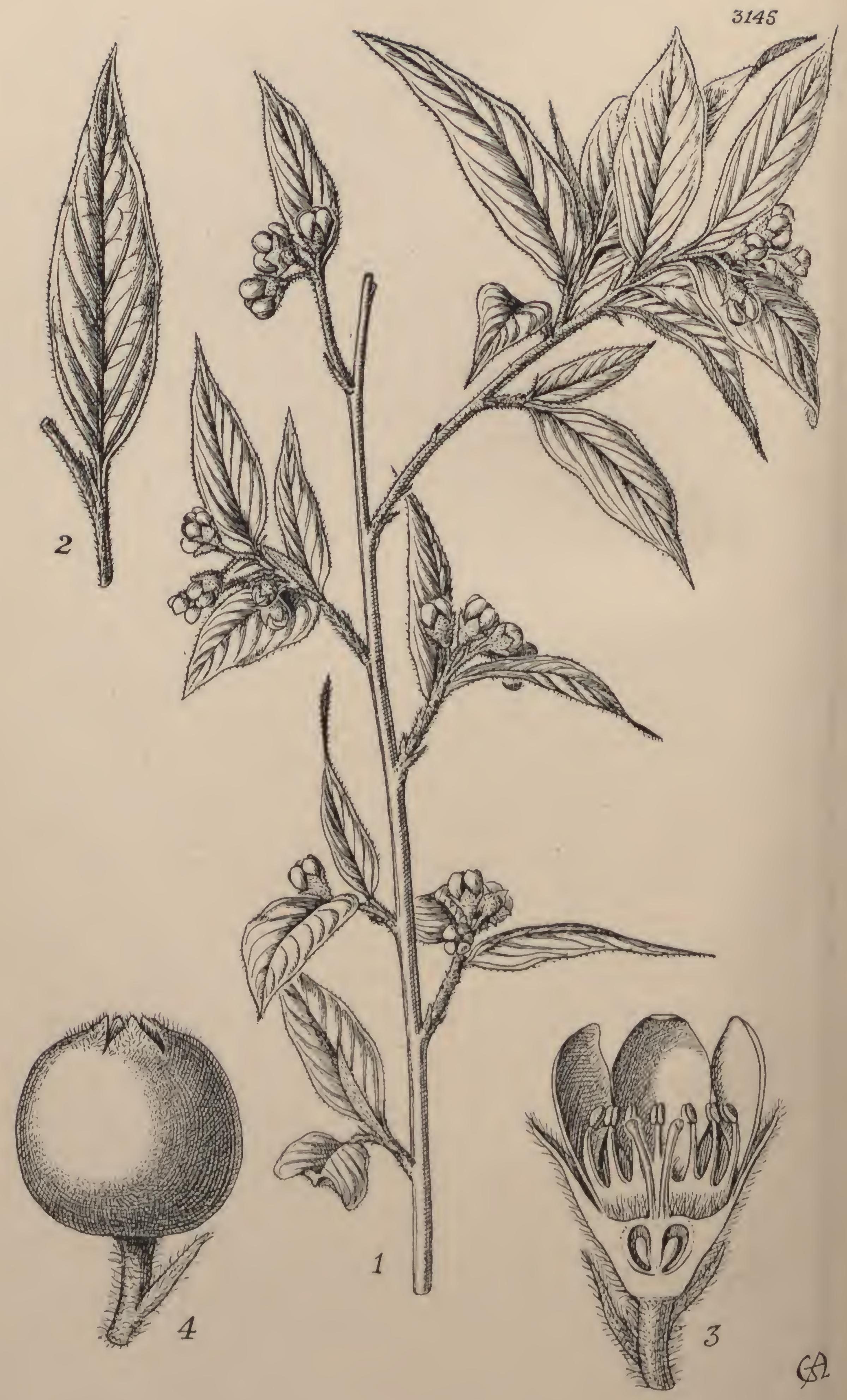




\section{Tabula 3145.}

COTONEASTER NITIDIFOLIA, Marquand.

Rosacfae. Subfamilia Pomordeae.

C. (Orthopetalum) nitidifolia, Marquand; species nova ex affinitate C. foveolatae, Rehl. et Wils., sed foliis supra glabris, in statu vivo nitentibus, fructibus parvis globosis saturate rubris differt.

Frulcx erectus. Rami annolini elongati, recti, patentes. Cortex laevis, glabrescens, rubro-brunneus. Rami hornotini steriles terminales, primum dense albo-tomentosi, mox glabri. Ramuli floriferi plures, laterales, breves, patentes vel penduli. Folia lanceolato-ovata, acuminata, basi cuneata, $4 \cdot 5-6 \mathrm{em}$. longa, $1 \cdot 5-2 \cdot 5 \mathrm{~cm}$. lata, tenues, supra glabra, in statu vivo pernitentia, pallide virides, subtus parec pubcsecntes: nervi laterales obliqui, utrinque circiter 6-8, supra, ut costa, valde impressi; petioli $2-3 \mathrm{~mm}$. longi, tomentosi. Stipulae sululatac, ad $7 \mathrm{~mm}$. longae, tomentosae, rubrae. Cymae parvae, 3-9-florae, primum albo-tomentosac; pedumeuli pedicellique breves; bracteac subulatae, 3-4 $\mathrm{mm}$. longae, pubeseentes, rubrac. Flores penduli. Calyx $4 \mathrm{~mm}$. diametro, tomentosits; lobi erecti, deltoidei, acuti, 2 mm. longi, 1·5-2 mm. lati. Petala crecta, subelliptica, 3-4 $\mathrm{mm}$. longa, 1.5 $2 \mathrm{~mm}$. lata, basi cuneata, integra vel apicc sulb-crosa, apice albescentia, basi rosea, utrinque glabra. Receplaculum vix $2 \mathrm{~mm}$. dianetro. Stamina eireiter $16,2 \mathrm{~mm}$. louga ; filamenta sulvulata, inter se arquilonga, apiee incurvata; antherac rosene. Carpitia 2, apice villosa; styli $2 \mathrm{~mm}$. longi. Fruetus parvus, oblatus, cireiter $5 \mathrm{~mm}$. diametro, fuseo-ruber. Pyrenac duae, lobis ineurvatis calycis obtectar.

YUNNAN. Flowering and fruiting speeimens from the same shrub, eultivated in the Royal Botanic Gardens, Kew, October 1929 and June 1930, Kew No. 526/1924, forrest 24072 (seed no.).

Colonerster nitidifolia is one of the most striking speeies of Sect. Orhopelalum. It is in cultivation at the Royal Botanic Gardens, Kew, Where it was reeeived in 1924 from Mr. J. C. Williams, of Caerhays Castlc, Cornwall, under Forrest's No. 24072, but that number is represented in the Hcrbarium of the Royal Botanic Garden, Edinburgh, by an immature specimen of a spreeies of Prunus, described in Ir. Eorrest's Field Notes as a "slirub of 12-20 ft. Flowers? immaturc. 
In open thickets by streams, Shweli-Salwin divide, lat. $25^{\circ} \mathrm{N}$., long. $98^{\circ} 50^{\prime}$ E., alt. 9-10,000 ft. April 1924." A specimen of Forrest's No. 24632, received from the Royal Botanic Garden, Edinburgh, belongs to this species. It seems therefore not unlikely that the numbers have been changed in horticulture. The collector's note on No. 24632 runs "Shrub of 5-10 ft. Fruits crimson. In thickets by streams on the Shweli-Salwin divide, 8-9000 ft. June 1924."

C. nitidifolia fruited for the first time at Kew in 1929. The small dark red fruits are rather sparingly produced and quite distinct from those of $C$. foveolata, Rehd. \& Wils., from which species it is also readily separable by the very shining, pale, almost yellowish green upper surface of the leaves.-C. V. B. Marquand.

Fia. 1, portion of a branch of last year's growth, with lateral flowering branchlets, natural size; 2 , a leaf, showing upper surface, natural size; 3 , longitudinal section of the flower, $\times 6 ; 4$, fruit, $\times 6$. 



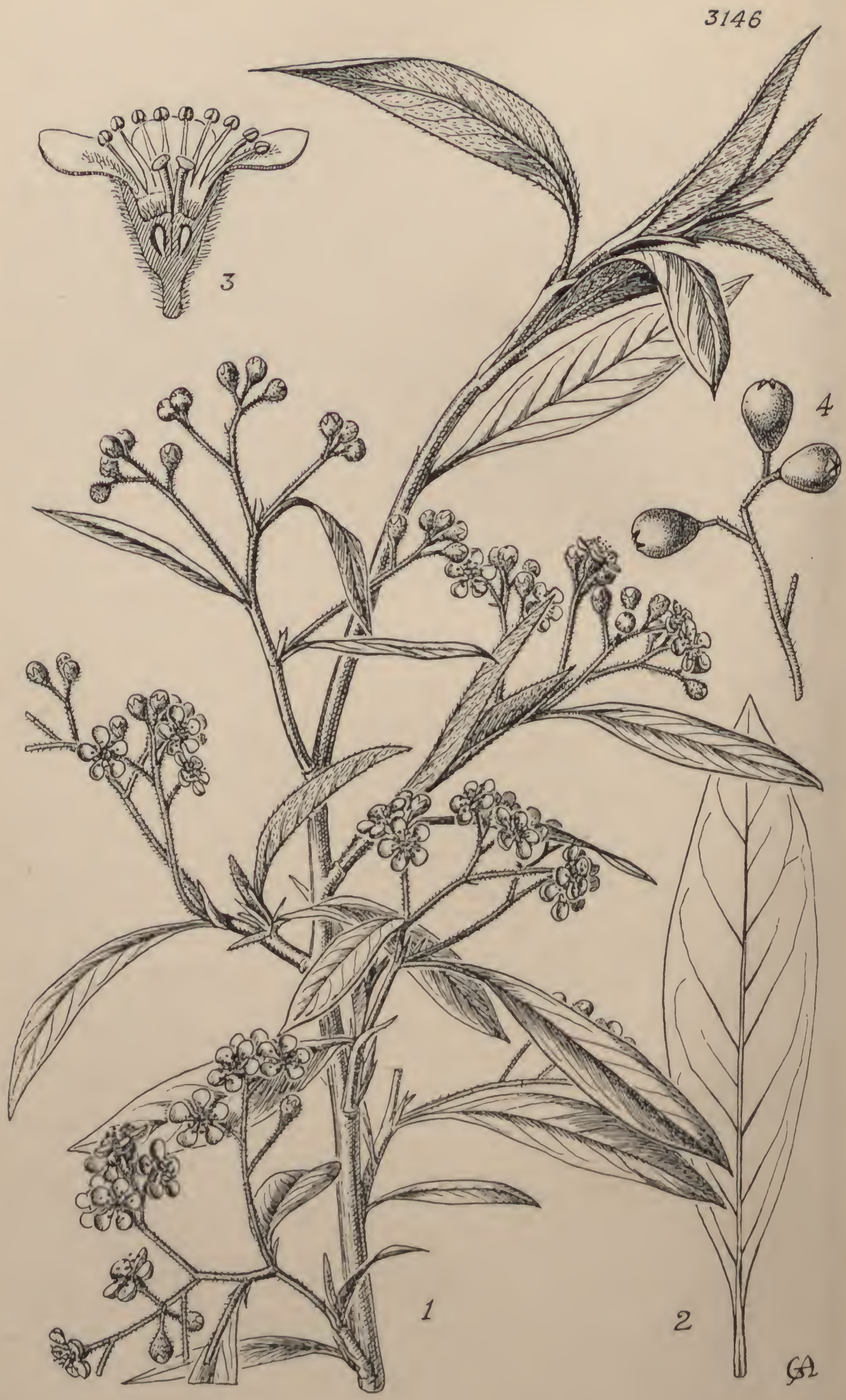




\section{Tabula 3146.}

\section{COTONEASTER COOPERI, Marquand.}

Rosaceae. Subfamilia Pomoideae.

C. (Chaenopetalum) Cooperi, Marquand; species nova ex affinitate C. affinis, Lindl., a qua foliis angustioribus lanceolatis acmminatis, inflorescentiis glabrescentibus, floribus minoribus, fructibns majoribus turbinatis differt.

Frutex altus. Rami annotini elongati, arcuati, internodiis longis. Corlex fusco-brunncus. Rami hornotini steriles terminales et laterales, primum albo-tomentosi, mox glabri. Ramuli hornolini floriferi plures, laterales, ereeti vel patentes. Folia elliptico-lanceolata, breviter acuminata, basi cuneata, $5-7 \mathrm{~cm}$. longa, $1 \cdot 5-2 \mathrm{~cm}$. lata, supra glabra, sulutus prinum albo-tomentosa, mox glabrescentia, glauca, leviter papillosa; petioli 5-7 mu. longi, primum pubescentes. Stipulae subulatae, 3-4 mm. longae, glabrae, rufescentes. Cymac multiflorae, 3-4 cm. dianetro, prinum parce pulescentes, mox glabrescentes; pedunculus elongatus; pedicelli breves; bracteac minutac, deciduae. Flores parvi. Calyx $2-2.5 \mathrm{~mm}$. dianctro, glabrescens; lobi late triangulares, acuti, vix $1 \mathrm{~mm}$. longi. Pelala patentia, late ovata vel suborbicularia, $2 \cdot 5-3 \mathrm{~mm}$. lata, integra, alba, intus pubescentia. Receptaculum $1.5 \mathrm{~mm}$. diametro. Stamina $16-20$, vix $2 \mathrm{~mm}$. longa; filamenta inter se requilonga; antherue pallide purpureac. Carpidia 2 , apice villosa; styli ].5 mm. longi. Fruclus turbinatus, $1 \mathrm{~cm}$. longus, $8 \mathrm{~mm}$. diametro, atro-purpureus. Pyrenae dnae, 4-5 $\mathrm{mm}$. longae, in apice fructus inter lobos incurvatos calycis conspicuac.

BuUtav. Flowering specimens, cultivated in Royal Botanic Gardens, Kew, IIay 1924, Cooper, 3311 (type); fruiting specimen, Botanic Garden, Glasnevin, Oct. 1929, Cooper, 3311.

Cotoneaster Cooperi is a rather handsome shrub, very distinct from its nearest ally both in the influrescence and the leaves. The barren stems much resemble a species of Salix. No wild specimens are known of Cooper's No. 3311, but a fruiting specimen of C'ooper's No. 3315 in Herb. Fdin., collected at Timpu, $8000 \mathrm{ft}$. alt., on Aug. 5, 1914, certainly belourgs to this species.

'The specics has been in cultivation in this country for at least cight 
years, the Kew plant having been received in 1922 from the Hon. Vicary Gibbs, Aldenham House, Herts. It was soon recognised as a new species, but publication was withheld until the fruit was known. This was first produced at Glasnevin, whence specimens were received in 1929 from Mr. Besant.-C. V. B. Marquand.

FrG. 1, end of a branch of last year's growth, showing about one-half of tho flowering branchlets with the young terminal growth of the present year ; 2 , maturo leaf from a plant in the fruiting stage; 3 , longitudinal section of the flower; 4 , fruit, showing the incurved calyx-lobes not completely covering the apices of the pyrenes. Figs. 1, 2, 4, natural size; fig. $3, \times 5$. 



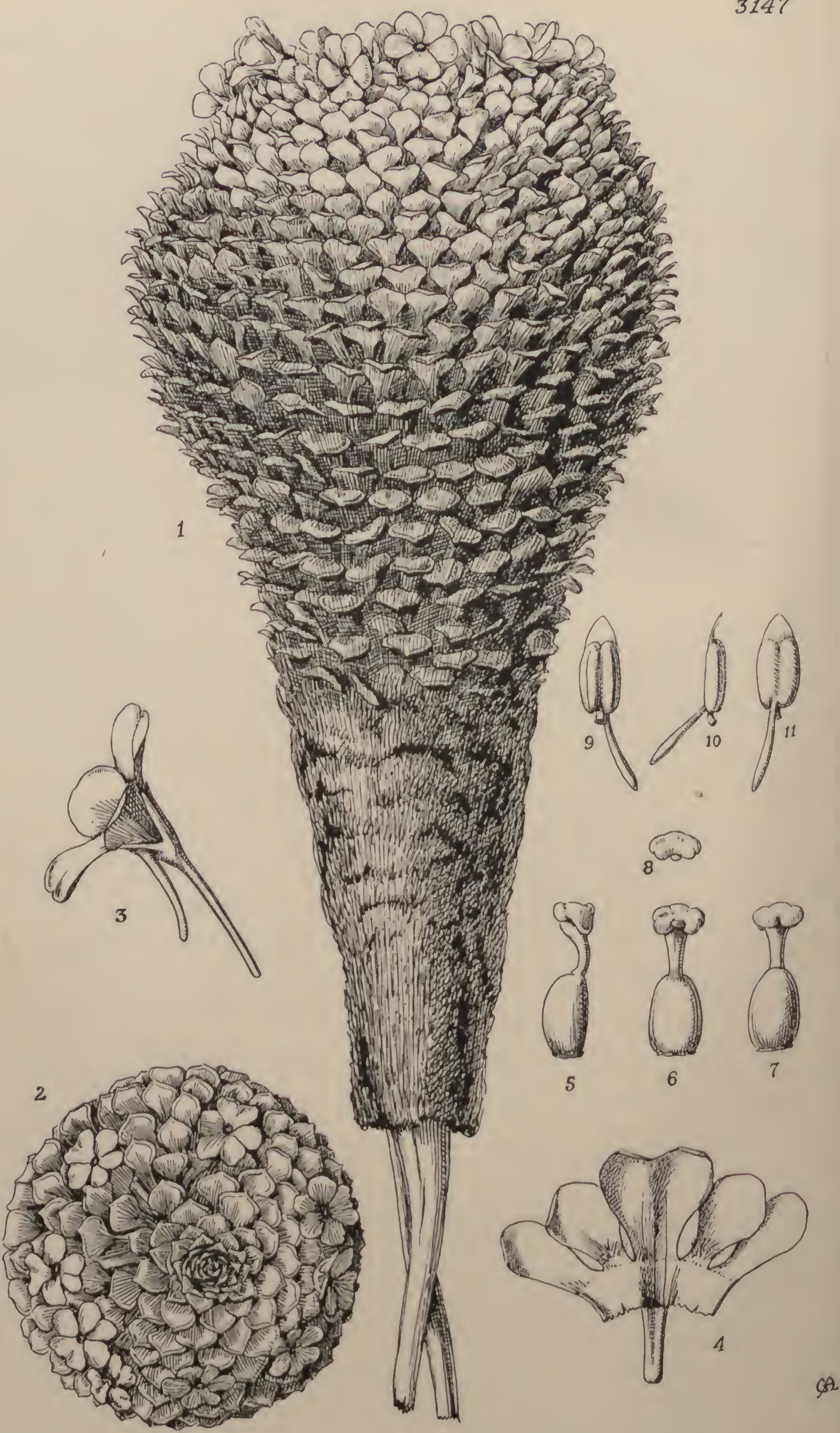




\section{TABULA 3147.}

\section{VIOLA CORONIFERA, W. Becker.}

\section{Vtolaceat. Tribus Violmae.}

V. coronifera, W. Becker in Kew Bull. 1928, p. 137 ; species inter ecteras sect. Andinium, W. Becker, ol, calcar longum valde distineta.

Herba perentis, rlizomatc verticali crasso lignoso; caulis 7-9 cm. altus, densissime praesertim inferne foliis vetustis siccat is nigrescentibus foliatus, in medio 5-6 cm. latus, forman clavatan vel ovoideam apice rosularem pracbens. Folia longe petiolata, eirciter $2 \mathrm{~cm}$. longa petiolis inclusis, juniora dilute viridia; lamina orbiculari-spathulati, circiter 5-6 mm. longa atque lata, margine albo-cartilagineo, apice subacuminata et in mucronulum albo-cartilagineum transiens, in petiolum circiter $1.5 \mathrm{~cm}$. longum subahrupte angustata; margo cartilagineus, vix $0.5 \mathrm{~mm}$. Iatus, nec deuticulatus nee ciliatus, neque versus folii apiccin angustatus. Flores suliconspicui, numcrosi, $1.2 \mathrm{~cm}$. lati, laete flavi vel aurantiaci, apice plantac coronam formantes, folia rosulata vix superantes. Sepala lanceolata, circiter $8 \mathrm{~mm}$. longa, trinervia, pallidissine viridia, margine liyalina. Pelala 7-9 mm. longa; superiora oblique oblongo-obovata, unguiculata; lateralia obovata, apice subtruncata, basi distincte barbata; petalum infimun late obcorlatum, apiec cmarginatum, basi horreolum pollinis non pilosum. gorens, longe calcaratum; ealcar circiter 1 cm. longum, deorsum recurvatum, apice sulcatum. Slamina eciliata. Ouarium subovoideum; stylus basi vix geniculatus, clavatus, apicc brevitcr creeto-rostellatus ct crista iufundibuliformi tamen in fronte aperta circumdatus.

Argentina. Jat. $38^{\circ}-41^{\circ}$ S., Cerro Cololuineul, between San Martin de los Audes and Jago Hluechulafquen, $2250 \mathrm{~m}$., Decenber 1926, H. F. Comber, 881 ; Vega Lolog, 840 in., December 1926, II. F. Comber, 854 .

Mr. Comler writes that this species grows in stones, gravel and sand; the specimens figured were found on a bare, windy, mountain top.-N. Y. SANDWITH.

Fia. 1, whole plant ; 2, apieal leaf-rosette and flowers ; 3, flower, Iateral viow ; 4, flower opened at back, showing shape and insertion of petals; $5-7$, ovary and style, side, front and back views; 8 , style-crest ; $y-11$, an unterior stamen, inner, lateral and outer viows. Figs. 1 and 2 , nolural size; 3 and $4, \times 2 ; 5-11, \times 5$. 



\section{8}

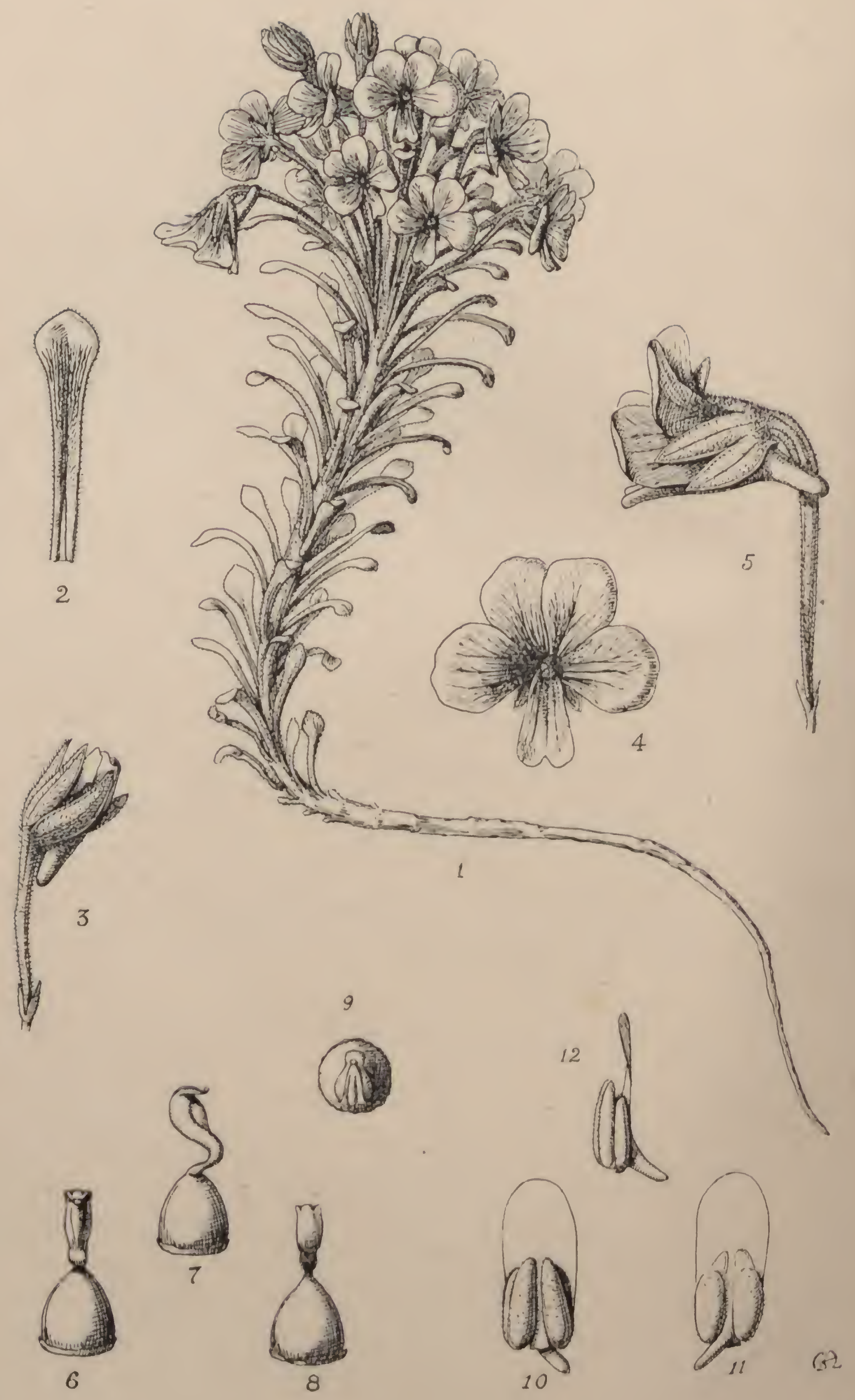




\section{TABULA 3148.}

\section{VIOLA ESCONDIDAËNSIS, W. Becker.}

\section{Violaceal. Tribus Violbah.}

V. escondidaënsis, W. Becker in Kew Bull. 1928, p. 138; speeies $V$. sacculus, Skottsb., affinis, indnmento albido-hispiclo, foliis peduneulisque longiorilus distinguitur.

IIerba perennis, pallide viridis, ylus mimsve dense albido-hispida ; rhizoma subterraneum, ramosum, in eaules eireiter $8-10 \mathrm{~cm}$. altos subereetos subdense foliatos transiens. Folia superiora cireiter $2 \mathrm{~cm}$. longa, inferiora sensim breviora, petiolo 1.5-2 $\mathrm{mm}$. lato, tum lamina a petiolo vix distinguenda clongato-spathulata atque apieulata $3-4 \mathrm{~mm}$. lata, integerrima, erassiuseula, supra sublaevin atque glabresecntia, subtus distinete saepe dense albido-hispida; stipulae non visae. Flores versus apicen eaulium axillares, longe peduneulati, teste leetore pallide virides, violneeo-lineati; peduneuli ad $2 \mathrm{em}$. longi, plus minusve dense hispidi, basi infuma brevissine bracteolati. Sepala oblongolanecolata, 4-6 mm. longa, dense albido-hispida vel glabra, margine luyalina. Petala omula deuse lougitudinaliter nervata, nervis versus apieen saepius ramosis ; superiora spathulata, $7 \mathrm{~mm}$. longa, $6 \mathrm{~mm}$. lata, versus basin usque ad $3 \mathrm{~mm}$. latitudinem angnstata, basi violaceomaeulata: lateralia late spathulata, $8 \mathrm{~mm}$. longn, $7 \mathrm{~mm}$. lata, versus basin usque ad $2.5 \mathrm{~mm}$. latitudinem angnstata, basi pilis paueis oruata; petalun infinum ealeari reeurvo $3 \mathrm{~mm}$. longo, elongatoobeordatum, apiee profunde emarginatum, violaceo-lineatum, versus basim aurantiaeo-a tque flavo-maculatum et horreolum pollinis bifariam. longe et dense pilosum gerens. Stamina breviter pilosa; connectivi proeessus aurantiacus, lasi dilatatus et lyaliuus. Ocarium globulosoconoideum; stylus basi genieulatrs, valde clavatus, apiee deruptedeplanatus et breviter acuteque rostellatus, lobulis binis angustis retroversis suldivarieatis adlaerentibus mumitus.

Araentina. Territory of Neuquen, lat. $38^{\circ}-41^{\circ} \mathrm{S}$, Valle Eseondida, 1925-6, II. F. Comber, 241.-N. Y. Sandwith.

Fia. I, whole plunt except for base of rhizome, nntural size: 2, leaf ; 3, unopened fowor with peduncle and bracteoles, lateral view; 4 , front view of flower : 5 , Hower in profile; 6-8, ovary and stylo; 9 , top of style; 10-12, stamens. Figs. 2-5, $\times 2 ; 6-12$, much enlarged. 

3149

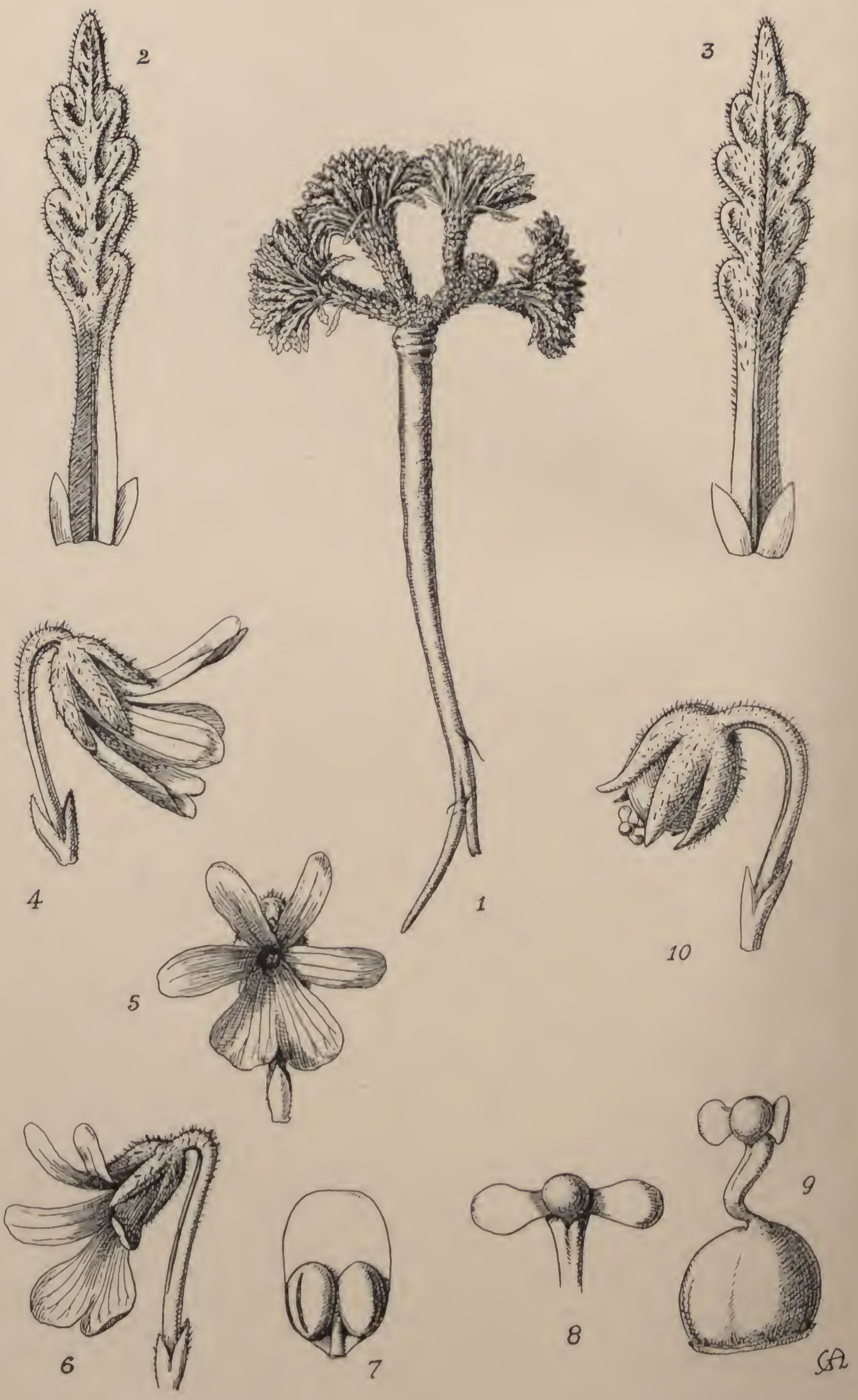




\section{Tabula 3149.}

\section{VIOLA HILLII, W. Becker.}

\section{Violaceae. Tribus Violeat.}

V. Hillii, W. Becker in Kew Bull. 1928, p. 134 ; species ab omnibus spcciebus scet. Andinium, W. Becker, remota.

Herba pcrennis; rhizoma crassum, verticale, lignosum, circiter $10 \mathrm{~cm}$. longum, cireiter $5 \mathrm{~mm}$. crassum, parte summa brevitcr 2-4partitum et reliquiis foliorun demortuorum obtectum; rosulac parvac, circiter $1.5 \mathrm{~cm}$. latae, foliis crectis angustis formatac. Folia lincarioblonga, circiter $8 \mathrm{~mm}$. longa, utrinque pilosula, crassiuscula, supra subfoveolata; lamina 4-5 $\mathrm{mm}$. longa, circiter $1 \mathrm{~mm}$. lata, insigne 4-5-repando-crenata; stipulac rudimentariac. Flores flavi, vix $5 \mathrm{inm}$. longi, breviter pedunculnti, basi bracteolati; bracteolae ollongae, subciliatae; pedunculi retrorsum hispidi, circiter $6 \mathrm{~mm}$. longi. Sepala oblonga, acutiuscula, pilosula. Petale superiora atque lateralia anguste oblonga, longe trinervia; petalum infimum obcordatotriangulare, valde dilatatun, plane cmarginatum, brevissine calcaratum. Ovarium globosum, distinctc longinerviun; stylus basi distincte geniculatus, sublorizontaliter rostellatus, apice utrinque lobulo rotundiusculo brcviter stipitato ornatus.

Boundary of PEru and Bolivia. On red sandstone lills between Moho and Vilque Chico, north-east of Lake Titieaca, 4050-4200 n., February 1903, A. W. Hill, 28.-N. Y. Sandwitir.

Fia. I, whole plant; 2 and 3 . leaf ; 4, flower, in siclo view, with peduncle and bracteoles; 5 , flower, front view; 6 , flower, sfont view; 7 , nuther, from within ; 8 , top of style; 9 , ovary and style; 10 , peduncle with fruit. All enlarged, except 1 , which is of natural size. 




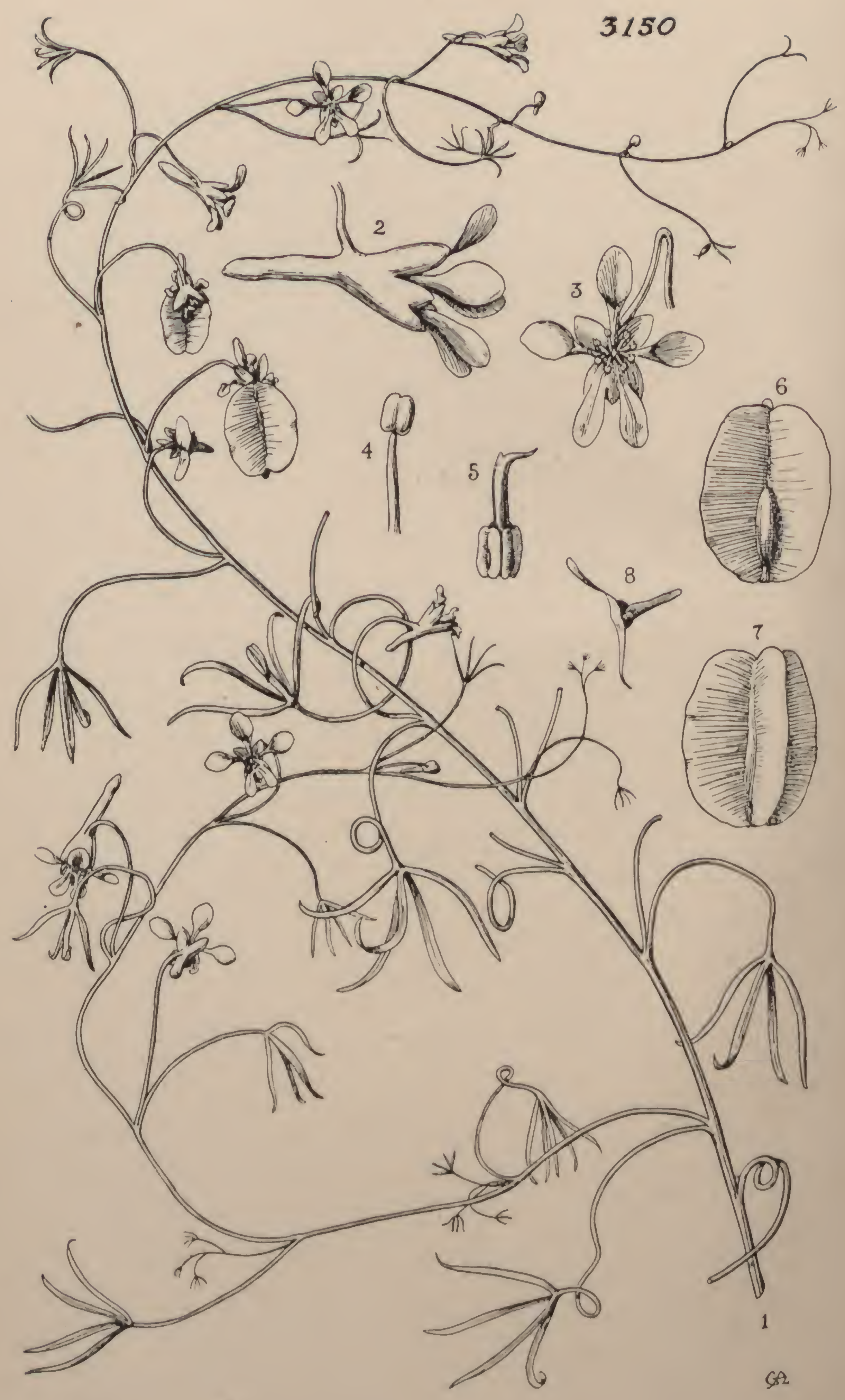




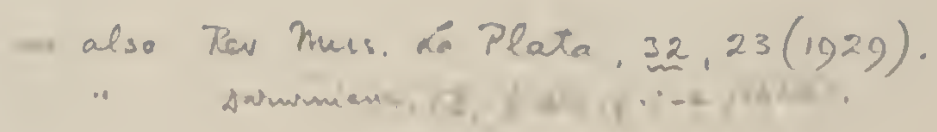

Tabula 3150.

MAGALLANA PORIFOLIA, Cav.

TropaEOLACEAE.

M. porifolia, Cav. Ic. et Descr. Pl. vol. iv. p. 51, t. 374 (1797); species inica.

IIerba perennis, glabra, radice earnosa, caulibus repentilus vel scandentibus 1-3-pedalibus filiformibus graeillimis flexuosis atque eontortis. Folia alterna, peltato-digitata, 2-5-partita, laciniis lincaribus integerrimis gracillinis, apice acutis saepius faleatis, lasi brevissime connatis, vulgo $0 \cdot 8-2 \mathrm{em}$. longis, $0 \cdot 5-1 \cdot 2 \mathrm{~mm}$. latis, 1-3-nervis, sub lente plus minusve dense poriferis; petiolus vulgo $2-4 \mathrm{~cm}$. longus. Flores axillares, solitarii, teste lectore luteo-virides; pedunculi $1 \cdot 5$ $2.5 \mathrm{~cm}$. longi. Calyx bilabiatus, 5-lobus, lobis 2 anticis superioribus fere liberis, divarieatis, ellipticis, $5-6 \mathrm{~mm}$. longis, $2 \cdot 5 \mathrm{nmm}$. latis, lobis 3 posticis in labium apice tridentatum coalitis, partibus liberis triangularibus acutis cireiter $2 \mathrm{mn}$. longis ad $2.5 \mathrm{~mm}$. latis inforne in ealcar siccitatc violaseens ad $1 \mathrm{~cm}$. longum sensim attenuatis. I'clele 5, lnciniis ealyeinis alternantia; 3 antica, pedunculi tortione superiora, lunguiculata, eirciter $8 \mathrm{~mm}$. longa, lamina obovato-elliptica ad $3 \mathrm{~mm}$. lata; 2 postica anguste obovato-spathulata, paullo breviora. Stamina 8 , hypogyna, ad $4 \mathrm{~mm}$. longa, postiea paullo lireviora. Ovarium glabrum, $1.5 \mathrm{~mm}$. longum, latitudine vix $1 \mathrm{~mm}$. superans, 3-loculare, tribloulatum (unum nonnunquam abortivum) loeulis dorso 3 -alatis; ovula in loculis solitaria, al angulo interno apice pendula; stylus ad 2 mm. longus, apice trilobato-stigmatosus, lobis 2 anticis brevissimis in mucronem crassiusculum reetum connatis, lobo postico patentidivaricato dinidium styli fere aequans. Fructus carpello unieo evoluto, insigne late trialatus, alis venosis atque maculis siecitate violaceis notatis, cum alis ad $1.5 \mathrm{~cm}$. longus, ad $1.2 \mathrm{~cm}$. latus.

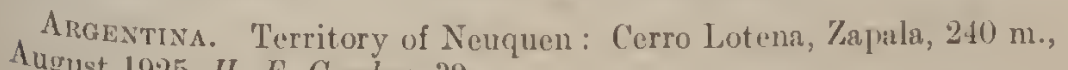
August 1925, II. F. Comber, 39.

This interesting plant is widely spread over Patagonia, growing in sandy places, where it climbs over small bushes. Although the genus Was well deseribed and figured by Cavanilles, Bentham and Hooker (Gen. Plant. i. 274) were incredulous of the existence of any ally of the isolated genu; Tropaeolum with so curious a fruit, and sceing in the 
figure a superficial resemblance to Tropaeolum pentaphyllum, Lam., they decided that Cavanilles had added a fruit from some totally different plant to his drawing of a depauperate specimen of $T$. pentaphyllum. 'This erroneous and, in view of Cavanilles' reputation, unjustifiable conclusion was accepted by Buchenau in his monograph of the Tropaeolaceae in Engler, Pflanzenreich, Abt. iv. 131: p. 30 (1902); but in the meantime the genus Magallana had been fully reinstated as a very well-marked genus by Spegazzini in Plant. Nov. Nonn. Amer. Austr. pp. 6-8 (1883). The specific epithet porifolia, referring to the pores in the leaf-segments, has been repeatedly misspelt porrifolia, "leek-leaf." -N. Y. Sandwith.

Fia. 1, plant, natural size; 2, ovary and style; 3 , front view of flower; 4, stamen ; 5 , flower in profile; 6-8, fruit. Figs. 2-8 enlarged. 


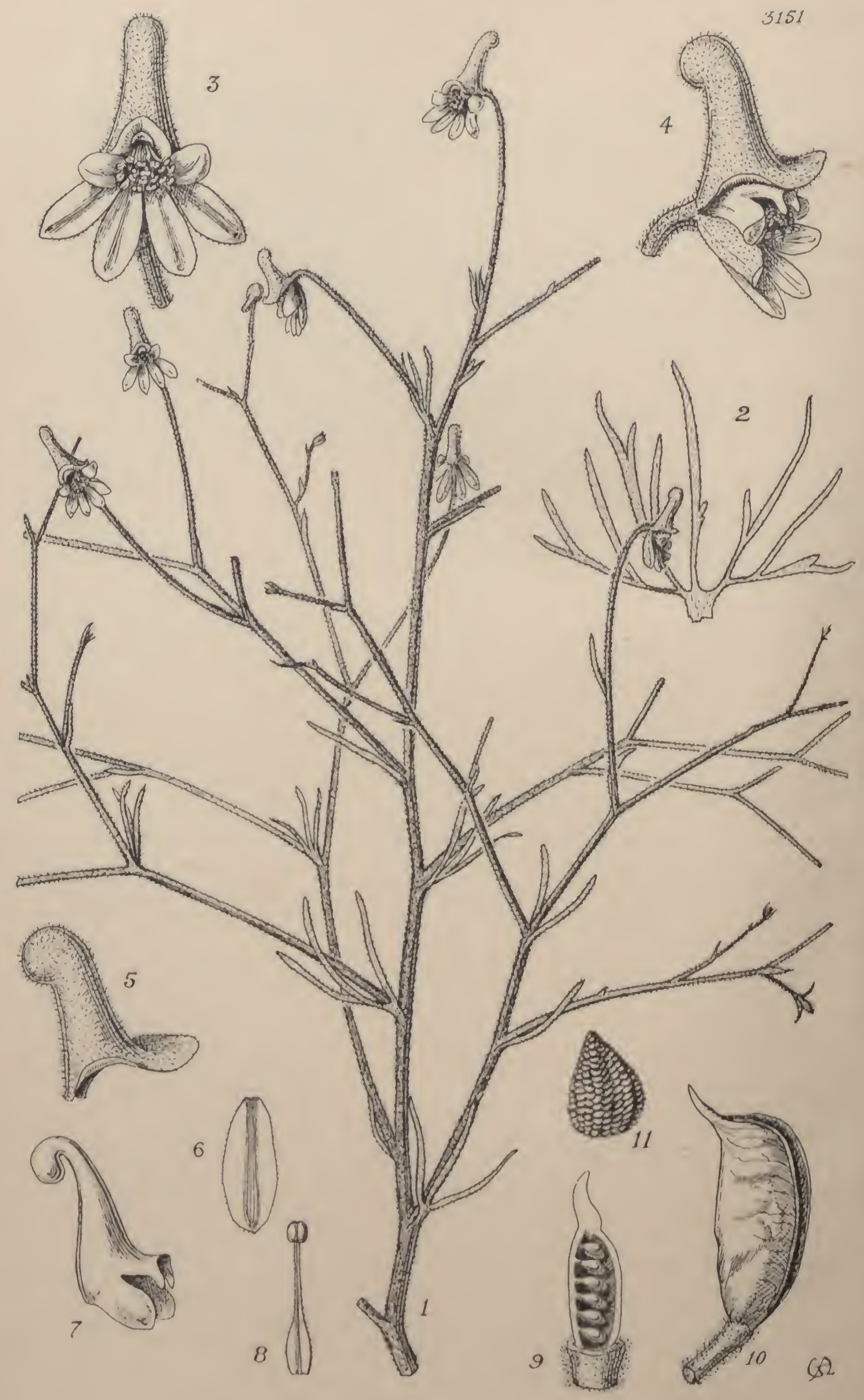


TABULA 3151.

DELPHINIUM ACUTILOBUM, Turrill.

\section{Ranunculaceae. Tribus Helleboreate.}

D. acutilobum, Turrill in Kew Bull. 1929, p. 223; a D. Thirkeano, Boiss., petali lobis mediis divarientim produetis elongato-triangularibus subaeutis differt.

Herba crecta, eanlibus rigidis divarieatim ramosissimis infcrne adpresse ct breviter hirtis superne patule denscque velutinis glandulosis, ramulis ultimis unifloris plns minusve $2 \mathrm{em}$. longis. Folia palmatim tri- vcl multipartita, adpressc pubcrula, laeimiis lincaribus vcl oblanceolato-lincaribus. Bracteac saepissime integrae, laneeolatae, aeutae, 2-3 mm. longac, hispidulae; bracteolae bracteis similes scd minorcs, a flore renotae. Sepala abarialia lateraliaque oblonga, apice rotundata, $7 \mathrm{~mm}$. longa, 2-3 $\mathrm{mm}$. lata, ncrvis 5-6 gracilibus viridibus hispidulis instructa. Sepalum adaxiale saceatum, extra hirsutulum. "Petalum" ealcaratum $1.5 \mathrm{~cm}$. longum, glabrum, quinquelolatum, calearis apiee clavato circinato-revoluto; lobus superior lcvitcr retısus; lobi medii divaricatim producti, elongato-triangulares, subacuti ; lobi inferiores mcmbranaeci, clongato-rotundati. Stamina inaequalia, filamentis obspathulatis leviter pubeseentibus. Carpellum unicum, glabrum, vix $3 \mathrm{~mm}$. longum, vix compressum. Folliculus subeompressus, oblongoobovoideus, basi attemiatus, apice abrupte rostratus, $1 \cdot 1 \mathrm{~cm}$. longus, glaber, nitens. Semina squamis longiuseulis distinctis densissinc obtecta.

N. Persia. Near Yam, Tabriz Distriet, 21.8.1927, Gilliat-Sinith, 2086; Yam, nid-Jnly 1928, Gilliat-Sinith, 2365 ;. Yam, end of July 1928, Gilliat-Sinith, 2388.

The Subgenus Consolida, "Tribus" Involuta, to which, following the elassifieation of Huth in Engl. Bot. Jahrb. vol. xx. p. 337 (1895), this species belongs, contains a small number of known speeies, all of them with an oricrtal distribution. The shape of the "petal" and the nature of the ind umentum of the stem are the best dingnostic charaeters ; the features distinguishing this plant from other speeies of the sane "tribc" have becn deseribed previously (Kew Bull. 1929, p. 223). 
Since the publication of the original description, additional material has been received from Mr. Gilliat-Smith, and the technical characters, confessedly rather "critical," suggested as sufficient to distinguish the species from others of the "tribe," are well developed in the better material collected in 1928. In addition the plant has been cultivated from seed in the Herbarium Ground at Kew, and the characters have been shown to be reproduced under conditions very different from those of the Yam district. The plant does not flourish in the English climate, and like many other N. Persian species is difficult to bring to the flowering condition before the damp, cold, and fogs of autumn damage or kill the specimens.-W. B. Turrill.

Fra. 1, upper portion of plant; 2, cauline leaf ; 3, 4, flower, front and side views; 5 , adaxial sepal ; 6 , lateral sepal from within; 7 , "petal" ; 8 , stamen ; 9, carpel, longitudinal section ; 10, follicle ; 11, seed. Fig. 1, $\times \frac{2}{3}$; fig. 2 , natural size; figs. $3-7, \times 2$; figs. 8 and $10, \times 3 ;$ figs. 9 and $11, \times 6$. 



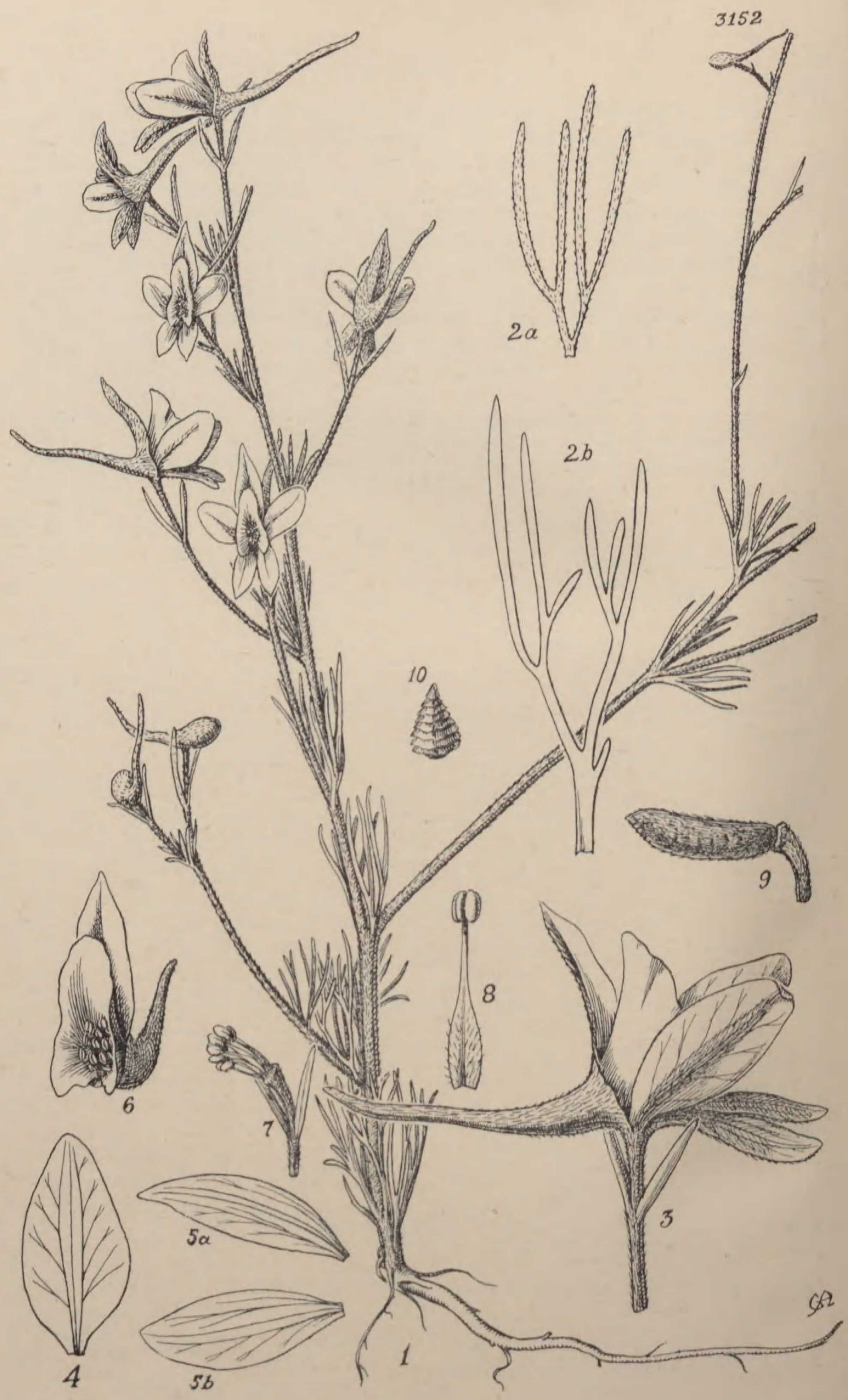




\section{TABUla 3152.}

\section{DELPHINIUM MACEDONICUM, Haláesy et Charrel.}

\section{Ranunculaceae. Tribus Helleborfae.}

D. macedonicum, Halciesy el Charrel in Oesterr. Bot. Zeitsehr. vol. xli. p. 374 (1891); et in Abd-ur-Rahman Nadji Effendi, Empire Ottoman Géogr. Bot., Faits nouv. relatifs à la prov. Salonique, 1). 8 (1892); a L. olopetalo, B3oiss., "petalo" elongato obscure trilobato difiert.

llerba annua, usque ad $3 \mathrm{dm}$. alta, plus minusve ramosa, caulibus ramisque adpresse pubescentibus. Folia multipartita, pubescentia vel glabrescentia, $1 \cdot 5-2 \cdot 7 \mathrm{~cm}$. longa, laciniis linearibus aeutis. Inforescentia 4-10 cm. longra, 3-9-flora; bracteae inferiores tripartitae, superiores integrac, lineares ; pedicclli $1 \cdot 3-3 \mathrm{~cm}$. longi ; bracteolae lineares, acutae, $0 \cdot 5-0.9 \mathrm{~mm}$. longre, a flore $1-5 \mathrm{~mm}$. remotae. Sepala eaerulea, extus adpresse pubescentia; sepala abaxialia lanccolata, acuta, $1 \cdot 4 \mathrm{~cm}$. longa, $5 \mathrm{~mm}$. lata, interdum leviter inaequalia ; lateralia ovata, apice sulbotundata, $1.4 \mathrm{~cm}$. longa, $8 \mathrm{~mm}$. lata; adaxiale $1.3 \mathrm{~cm}$. longuin, $4 \cdot 5 \mathrm{inm}$. latum, ealcari 1.6-2 cm. longo. "Petalum" obscure trilobatum, lobis lateralibus deorsum curvatis, $1 \cdot 2 \mathrm{~cm}$. longum, $1 \cdot 3 \mathrm{~cm}$. Intum, caeruleo-violaceum. Stanina circiter 17 ; filnmenta 4-6 mm. longa, in parte inferiore $2 \cdot 5-4.5 \mathrm{~nm}$. longa $1.5 \mathrm{~mm}$. lata leviter pubeseento plana; antherae $1.25 \mathrm{~mm}$. longae, luteac. Carpellum eylindricum, 4.75 $\mathrm{mm}$. longum, dense adpresse pubesccntc-strigosum; stylus in floribus vetustis elongatus. Fruclus cylindricus, $1.3 \mathrm{em}$. longus, adpressc strigosus. Semina oblique obeonica, 1.3 mm. longa, exaete Inmellata.-D. holopetalum, Griseb. Spie. Flor. rumel. ct bithyn. vol. i. p. 319 (1843). D. holopetalum, Huth in Engl. Bot. Jahrb. vol. xx. p. 381 (1895), partim. I). paphlagonieum, Huth in Bull. Herb. Boiss. vol. i. p. 328 (1843). D. armeniacum, Stapf ex Huth in Engl. Bot. Jahr. vol. xx. p. 380 (1895). Consolida olopetala, var. paphlagonica, Hayck, Prodr. Flor. jenins. Balean. vol. i. p. 313 (1924). Consolida macelonica, Soo in Oesterr. Bot. Zeitsclir. vol. lxxi. p. 245 (1922).

Truack. Xanthie (Souné Ialualla), rocky hill slopes, 90 m., 11.7.1930, II. G. Tedel, 476.

Avatolia. Soulouserai, in aprieis, $1000 \mathrm{~m} ., 4.8 .1889, J$. Bormmüller, 570 . Paphlagonia: Wilajet Kastambuli, Tassia, in montosis, 7.1892, 1. Sintenis, 4547. 
Armenta. Gumusehkane: Koesoedagh, 18.7.1889, P. Sintenis, 1320 ; Sipikordagh, in declivibus, 30.7.1890, P. Sintenis, 3177.

This very beautiful species of larkspur has a complicated synonymy the elucidation of which has been made more difficult by the absence from Kew of the type of Delphinium macedonicum and of Frivaldsky's specimen referred to $D$. holopetalum by Grisebach and to D. olopetalum and (later) to $D$. tomentosum by Boissier. Fortunately specimens which must be accepted as types of $D$. olopetalum, Boiss., and $D$. armeniacum, Stapf ex Huth, are preserved at Kew.

The botanical history of $D$. macedonicum is as follows. In 1841 Boissier's description of $D$. olopetalum appeared. 'This was based on a specimen of Aucher-Eloy's "absque numero in Coll. Musaei Parisiensis, cum D. tomentoso mixtum, è Persiâ probabiliter." A specimen in the Kew Herbarium under Aucher-Eloy, No.77, agrees well with Boissier's description. The only locality given on the label is "Persia." It should also be mentioned that Aucher-Eloy, No. 77-referred by Boissier (Flor. Or. vol. i. p. 80 : 1867) to D. oliganthum-is, indeed, one of the types of this species. Since the Kew specimen of No. 77 is not $D$. oliganthum, as is evident from a comparison of it with the original description and with Haussknecht's Syrian material, which is also quoted by Boissier, it would appear that at least two species were distributed under this number. The supposed connection of the plant here figured with $D$. olopelalum dates from a remark of Boissier attached to the description of Aucher-Eloy's Persian material: "eandem speciem in Macedonia a cl. Frivaldsky lectam sub nomine D. pubescentis habeo."

In the first part of the Spic. Flor. rumel. et bithyn. p. 319 (1843), Grisebach published a description of Frivaldsky's plant under the name D. holopetalum, Boiss. He notes, however, that the petal shape does not agree with that given in Boissier's description (of Aucher-Eloy's plant). Later, in Flor. Or. vol.i.p. 80 (1867), Boissier refers Frivaldsky's specimen to D. tomentosum, Auch. in Boiss. ex parte (i.e. so far as the Syrian plant is concerned). In 1891 (Bot. Zeitschr. vol. xli. p. 374) Charrel (Abd-ur-Rahman Nadji Effendi) published, as a nomen nudum, Delphinium macedonicum, Halácsy et Charrel, with the remark "ab Aucher et Boissier cum planta asiatica confusum." There can be little doubt that the confusion referred to is that involving Frivaldsky's specimen mentioned above, and any possible doubt is removed in a later publication, Empire Ottoman Géogr. Bot., Faits nouv. relatifs à la prov. Salonique, p. 8 (1892), in which the following appears: "Delphinium macedonicum Halácsy et Nadji, nec tomentosum Boissier. Plante magnifique, bicolore, à fleurs unilatérales de la plus haute élégance, confondue à tort par Boissier avec la plante asiatique et, fide von Halácsy!, différente. Kiel-tépé. 700 m." 'The late Prof. Wettstein of Vienna kindly sent on loan to Kew Nadji's specimen of $D$. macedonicum from Kiel-tépé. This agrees with Tedd's material as figured here, except that the petals are, in the dried condition, 
straw-coloured, tinged near the apex and sometimes also near the base with blue violet, and the leaves morc strongly pubesecnt.

Wc are thus able to traec back the eonneetion between the name D. macedonicum and Griscbaeh's description of Frivaldsky's matcrial, and it is proposcd that the name be applicd in this scnse. The remaining synonyms given above require no further eomment.

The general shape of the "petal" appcars to be a well-fixed and useful taxonomic eharacter and is particularly valuable in scparating $D$. macedonicum from $D$. olopetalum. The only morphologieal fcatures whieh eall for commcnt as showing a eertain degrce of fluctuation in D. macedonicum, as the spceies is here aeeepted, are flower size and the position of the bracteoles. The Asia Minor specimens have slightly smaller flowers, including slightly shorter spurs, than those from Thrace and Armenia. In Sinteris, No. 4547 (the type of D. paphlagonicum, Huth), the braetcoles are, as Huth deseribes them, "a flore paulum remotis." In the other specimens quoted thcy are situated on the pedieel up to about $5 \mathrm{~mm}$. below the ealyx. However, in the Armenian specimens there is suffieient fluetuation to include all the other variants of this character.- W. B. TurRILL.

Fia, 1, a small plant; $2 a, 2 b$, leares; 3 , flower, lateral view; 4, lateral sepal, inner surface; $5 a, 5 b$, abaxial sopals, inner surface; 6 , flower with abaxial and lateral sepals removed; 7 , flower with perianth removed; 8, stamen; 9 , young fruit ; 10 , seod. Fig. 1 , nalural size; figs. ㄴ-7 and $9, \times 2 ;$ figs. 3 and $10, \times 6$. 




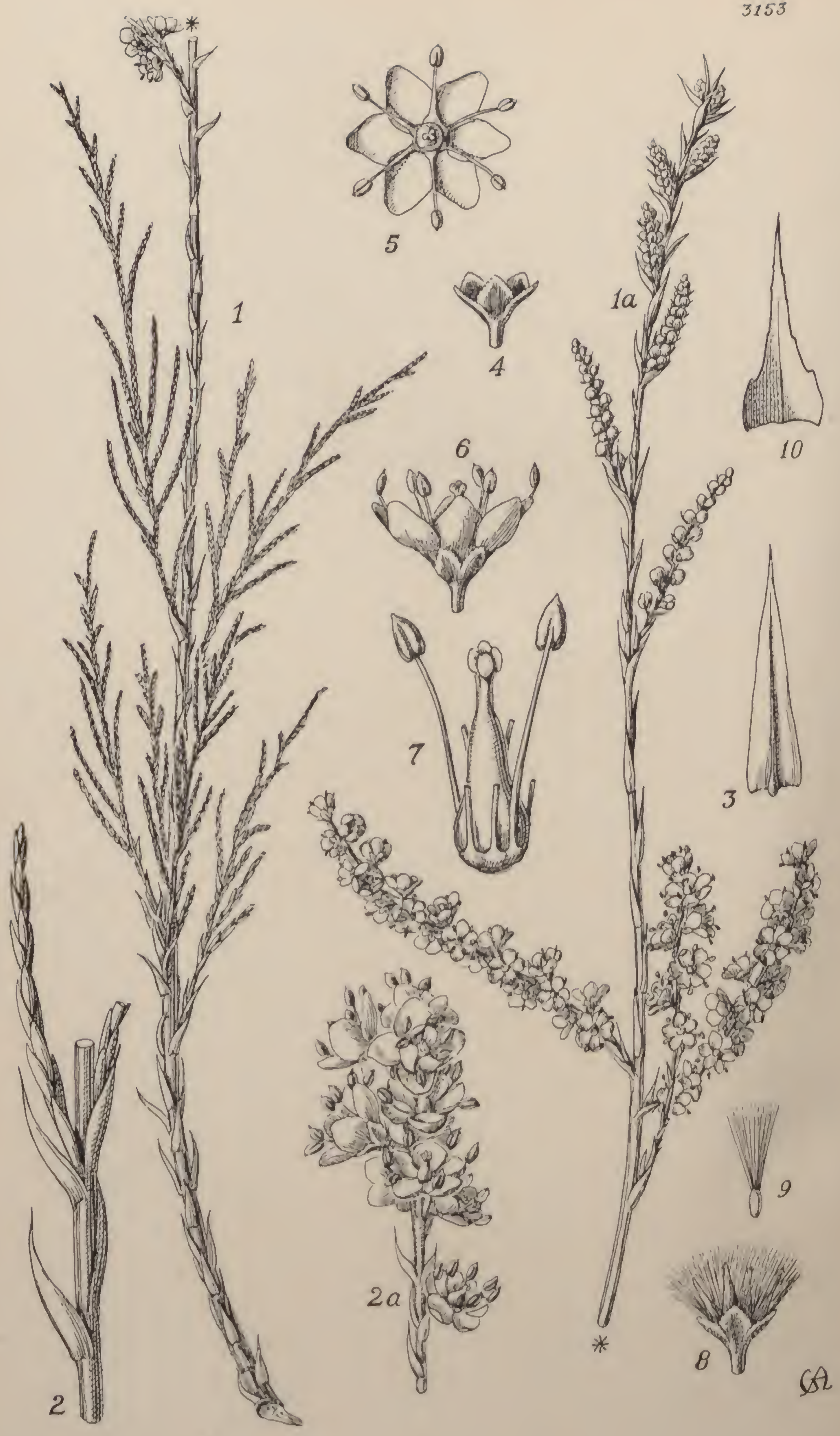




\section{'TABULA 3153.}

TAMARIX HAMPEANA, Boiss. ct Heldr., var. AEGAEA, Turrill.

\section{TAMARICACEAE.}

T. Hampeana, Boiss. et Heldr. in Boiss. Diagn. Ser. I, No. x. p. 8 (1819), var. aegaea, Turrill; var. nov. floribus saepissime pentameris vel licxameris, stylis plerumque $3-4$ cxeeptis, bracteis c lasi triangulari-vel oblongo-lanecolata longc acuminatis distincta.

Frutex 2-2.5 m. altus, glaber. Caules terctes, eortice brunneo. Folia vetusta sessilia, triangularia, aeute et saepissime longc acuminata, $6 \mathrm{~mm}$. longa, hasi $4 \mathrm{~mm}$. lata ; juniora alpresse imbricata vel leviter patcntia, lineari-laneeolat a, acut vel acuminata, basi saepc subeordata, 3-5 mm. longa, 0-5-1 $\mathrm{mm}$. late, glauco-viridia. Lacemi scens ramos hornotinos vel annotinos panieulam subspiciformem longam formantcs, multiflori, $2-5 \mathrm{~cm}$. longi, pelnneulis $0 \cdot 3-0 \cdot 7 \mathrm{~cm}$. longis instrueti; bracteae e basi triangulari- vel oblongo-lanecolata longe aeuminatae, 2.5-3 mm. longae, scssilcs; pcelicclli $1-1 \cdot 5 \mathrm{~mm}$. longi. Sepala 5 (vel 6), ovata, subobtusa, 1.5 mm. longa, $1 \mathrm{~mm}$. lata, dorso viridia, marginc albo-memloranacea crenulata. Petala 5-6 (vel rarissime 7), alba, patula vel erecto-patula, elliptica vel oljonga, apice rotundata vel leviter emarginata, hasi saepe leviter cuneata, $2 \cdot 5$ mm. longa, 1.5-1.75 mu. lata. Stamina 5-9; filamenta gracilia, basi vix dilatatir, $4 \mathrm{~mm}$. louga, in disco inserta id cst mesodiscica; antherae ambitu ovatae, apieulatac, purpureo-rubrae. Owarium elongatoconicunı; styli 34 (rarissime 5), obovato-spathulati, $1 \mathrm{~mm}$. longi, omnes basi colnerentes, interdum 2 plus minusve enaliti. Capsula saepissime 4-valvis, $5 \mathrm{~mm}$. longt. Semma oblongo-eylindrica, $0.7 \mathrm{~mm}$. longr, eoma 3 min. longa.

W. Turace. Bouloustra (Bulustra), 1.6.30 (flowers and huds), II. G. Tedd, $230 \mathrm{~A}$ (type of variety). Also No. 230C, from eastern shore of Lake Boru, sands at water's edge, 6.6.1931 (fruits); No. 250, from Buyuk Osmanli, 1.6.1930 (flowers and fruits).

The difficulties of a taxonomic study of the genus $T$ (amarix arc greater than appear from published accounts, lecause of the lack of stability of the cliaracters considered as dingnostie by most authors. Thus we find that in some species the number of sepals, petals, stamens, and 
styles frequently varies in the same raceme. The shape of the leaves is easily modified by position and age. Even the disk characters have been over-emphasized and in epilophicous species the degree of bi-lobing fluctuates. 'The occurrence of the racemes on the present or past year's wood is not always easy to determine, and does not appear always to be constant, as in the species a variety of which is here described. Indeed, in the material of our new variety it is difficult to say what is old and what is new wood.

T. Hampeana was described by Boissier who quotes specimens from Phalerum, collected by Spruner and Heldreich, and from "Argolis ad Astros" collected by himself. In his Diagnoses it is placed in the section Oligadenia, but in the Flora Orientalis (1867) this section is not accepted and the species is placed in Sect. Vernales $\S 1$. Anisandrae (vol. i. p. 767), thus following the classification of Bunge (Tent. Gen. Tamar., Dorpat, 1852). Bunge divides the species into three varieties which he names $\alpha$ Phalerea, from Greece, $\beta$ Marmorissac, from W. Asia Minor, and $\gamma$ Syriaca from Syria. Boissier, in the Flora Orientalis, makes T. syriaca a distinct species, and has two varieties (smyrnaca and composita, both from Asia Minor, and the former doubtfully the equivalent of Bunge's var. marmorissae) in addition to the Greek type. The next published account relevant to our subject is that of Niedenzu (Ind. Sect. Lyc. Reg. Hos. Brunsberg. 1895), who keeps T. syriaca distinct and separates as two distinct species plants collected by Pichler and Haussknecht in Greece and distributed as I'. Hampeana. One of the proposed species, T. phalerea, is reduced to T. Hampeana both by Halácsy (Consp. Flor. Graec. vol.i. p. 563 : 1900) and by Hayek (Prodr. Flor. penins. Balcan.vol.i.p.520: 1925). The other, T. Haussknechtiana, is the subject of a note by Halácsy (1.c. 564), who says the plant is unknown to him, but is accepted as a species by Hayek (1.c. p. 521), under the name T. Houssknechtii. After making a close study of the excellent material available at Kew, I believe that $T$. Hampeana must be accepted as a species in a sufficiently wide sense to include both T. phalerea and T. Hampeana as these plants are represented by specimens at Kew collected by Pichler and Haussknecht, and acceptable, from localities and dates, as equivalent to the types of Niedenzu in the strict sense. How far varietal names should be used is a matter of immediate convenience or need. In addition to fluctuating characters, it is obvious, from numerous dissections, that different combinations of characters with a probably genetic basis occur in plants both from Greece proper and from other Aegean countries.

The var. aegaea is especially remarkable for the shape of the bracts, whose broader base passes more or less abruptly or, sometimes, gradually into a long tapering acumen, the whole bract exceeding in length the axillary pedicel. The sepals, petals, and stamens, especially the last, vary in number, though most often they are pentamerous or hexamerous. Boissier, in his original description of the species, gives the sepal number as 4 , the petal number as 4 , and the stamen number as 6 to 8 . This is most often correct for specimens from Attica, but even in these the parts 
are not absolutely eonstant in number. Bunge (1.e.) allows the same range of variation in numbers of the floral parts within the species as is reeognized here.

In addition to the type material quoted above, a speeimen colleeted, aecording to the label, "in rivularibus ad Thessalonieam" by Adamović, vi. 1903, and preserved at Kew, has to be ineluded in the var. aegaea.

A faetor in preventing the var. aegaea from being considered as a species distinct from T. Hampeana is the presence in 'Tedd's 1930 colleetion of speeimens Nos. 230 and 230B, from Porto-Lagos, 21.4.30, " common on the edge of lagoon (braekish) and in marsh land of coastal distriets," which are decidedly nearer to the original T. II ampeana than the speeimens aeepted as syntypes of the new variety. Thus the Porto-Lagos speeimen has the racemes definitely arising on the old wood, and the braets are subobtuse and not long aeuminate.-W. B. TURIRILL.

Fus. $1,1 n$, flowering branch, natural size; 2 , vegetative portion of braneh, $\times 3 ; 2 a$, an unusually short infloreseenee, $\times 3 ; 3$, intermediate leaf, $\times 3$; 4 , calyx, $\times 4 ; 5$, flower from above, $\times 4 ; 6$, flower from the side, $\times 4 ; 7$, androccium (with parts of some stamens removed) and gynoceium, $\times 10$; 8 , fruit, $\times 4 ; 9$, seed, $\times 4 ; 10$, bract, $\times 10$. 



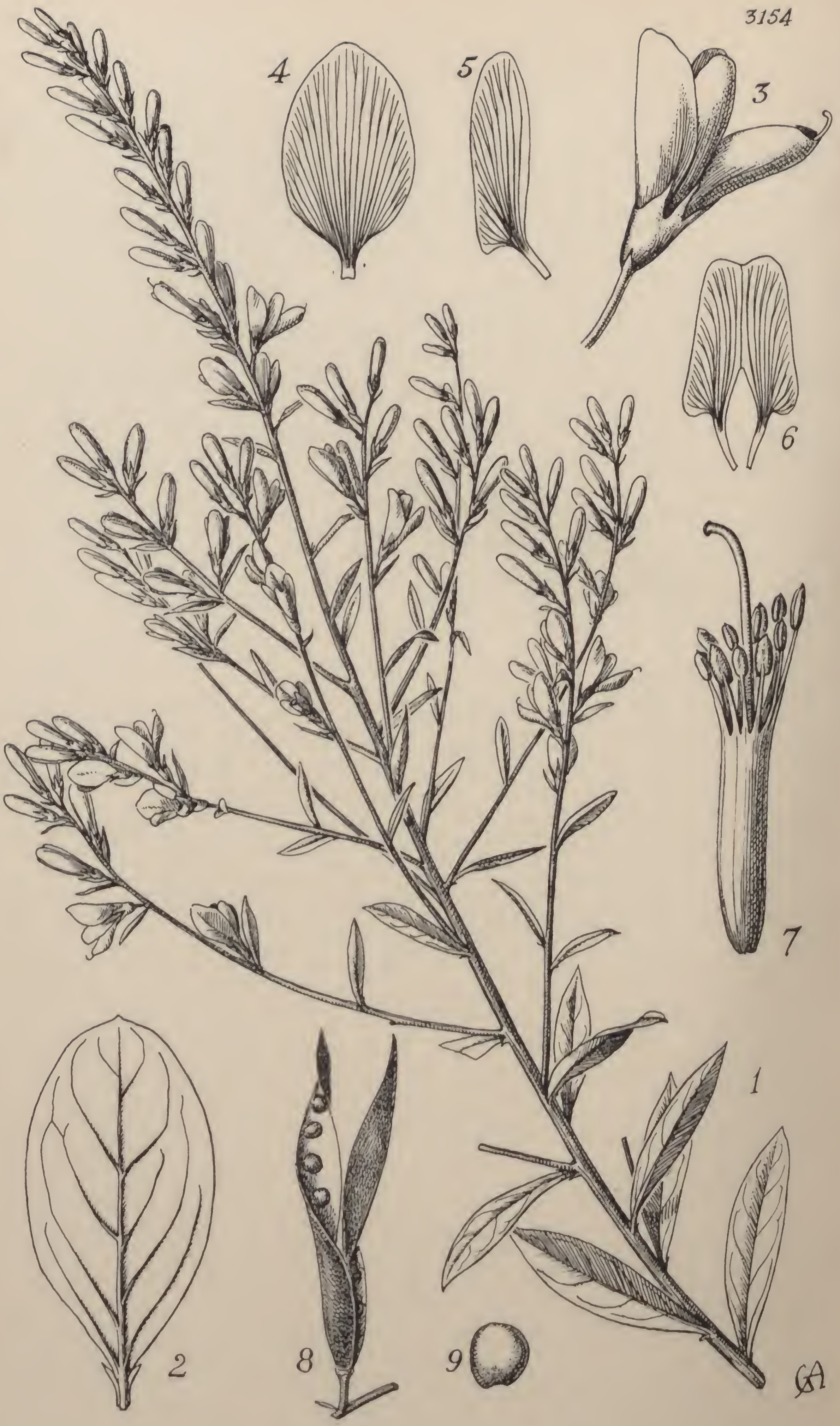




\section{TABUla 3154.}

GENISTA TINCTORIA, $L$, var. VIRGATA, Koch.

\section{Leguminosaz. Tribus Genisteat.}

G. tinctoria, L. Sp. Pl. p. 710 (1753), var. virgata, Loch in Röhlings Deutschl. Flor. vol. v. p. 90 (1839); Hayek, Prodr. Flor. penins. Bulcun. vol. i. p. 914 (1926); a planta Iimaeanea statura majore, panicula valde ramosa, foliis saepe majoribus latioribusquc, stipulis persistentibus dificrt.

Frutex inermis, ercetus, usque ad $2 \mathrm{~m}$. altns, valde ramosus, ranis virgatis supernc plus minusve adpresse vel subadpresse pilosis deinde glabresecntibus longitudinaliter striatis. Folia omnia spiralia; laminae semper simplices, lanecolatac, lanecolato-ellipticae, vcl elliptieac, apicc acutac, subacutae, vel (in foliis latioribus) obtusac, basin versus angustatae, $1 \cdot 5-5 \mathrm{~cm}$. longae, $0 \cdot 4-2 \cdot 5 \mathrm{~cm}$. Latac, pagina utraque leviter pilosac vel fere glabrae, ncrvis subprominentibus; petiolus nullus ; basis persistens valde trinervis, 1-3 mm. longa, 1-2 mun. lata, sucpissine leviter pilosa; stipulae persistentes, aeuminato-subulatae, fere spineseentes, $2-3 \mathrm{~mm}$. longac. Inflorescentia paniculam magnam pyramidalem formans; raceni laterales usque ad 26 versus ramorum apiecs colloenti, 7-13 em. longi, 6-20-flori ; raeemns terminalis $0 \cdot 6-2 \mathrm{dm}$. longus, 13-35-florus; flores in braetcarum axillis solitarii, pedieello $1-2 \cdot 5 \mathrm{~mm}$. longo suffulti; folia superiora in bracteas lineari-lanceolatas aeutas vel aeuniuatas pedetentim minores gradatim transientia; braeteolae angustissime lincari-lnnceolatae, $2 \mathrm{mn}$. longac, pedieclli apicc positas. Calyx $6 \mathrm{~mm}$. longus, margine et hinc indc etian in superficic subpilosus, dentibus adaxialibus Ianccolato-triangnlaribus valde divergentibus $3 \mathrm{um}$. longis, tribus abaxialibus $2.75 \mathrm{mu}$. longis angustioribus. Corolla fliva; vexillum lato ovatum, $1.5 \mathrm{~cm}$. longum, $9 \mathrm{~mm}$. latum, apice rotundatum coneavum, basi subito contrictum, glaberrimum; alae $1.5 \mathrm{~cm}$. longae, glabrae; carina $1.5 \mathrm{~cm}$. longa, ad summum subserieca. Stamina 10, monadelphia; antherae 5 majores 2 vel fere $2 \mathrm{~mm}$. longae, 5 alteruae minores vix $1 \mathrm{~mm}$. longac, omnes ninutissime apieulatae. Oearium anguste cylindricum, $5 \mathrm{mn}$. longun, glabrum; stylus cum stignate eapitato 7 mm. lougus. Lefiumen 1.5-4 cm. longum, 4-6 mm. latum, glabrum, lrunieum vel atro-brnnneum. Semina compressa, ambitn ellipties, $3.5 \mathrm{~mm}$. longa, $2.5 \mathrm{~mm}$. lata, atro-brunnea.-Genistoides elata, Joench, Meth. p. 133 
(1794). Genista virgata, Willd. Berl. Baumz. ed. 2, p. 159 (1811), non Lam.; Bornmüller in Engl. Bot. Jahrb. vol. lix. p. 462 (1925). G. gracilis, Poir. Encycl. Suppl. vol. ii.p. 715 (1811). G. sibirica, Reichb. Flor. Germ. Excurs. p. 519 (1832), non L. G. elata, Wender. in Linnaea, vol. xv. Litt.-Ber. p. 100 (1841). G. elatior, Koch, Syn. ed. 2, p. 441 (1843) ; Boiss. Flor. Or. vol. ii. p. 44 (1872); Vel. Flor. Bulg. p. 122 (1891). G. anxantica, Griseb. Spic. Flor. rumel. et bithyn. vol. i. p. 3 (1843), non Ten. G. frutescens, Schloss. et Vuk. Syll. p. 124 (1857). G. tinctoria, L., var. clatior, Reichb. Icon. vol. xxii. p. 22, t. 2088, fig. III (1903) ; Stoy. et Stef. in Ann. archiv. Minist. de l'Agric. Bulg. vol. iii. p. 13 (1922), et Flor. Bulg. vol. ii. p. 618 (1925). G. tinctoria, L., var. clata, Aschers. et Graebn. Syn. Mitteleur. Flor. vol. vi. pars 2, p. 261 (1907).

Bulgaria. Hills north of Varna, cultivated in the Herbarium Ground, Kew, seeds collected by B. Gilliat-Smith in 1924, specimens preserved as K. 82.

Genista tinctoria, in the broad sense in which it is accepted by most modern authors, is both highly polymorphic and decidedly plastic. With our present imperfect knowledge of this species, opinions as to the classification of its variations are bound to differ. The plant here figured and described is accepted as a varicty and not as a species because the series of herbarium specimens available indicate that the differential characters are not associated in constant combinations, and that the geographical distribution does not isolate groups of individuals, with the character combinations given, from other varieties. Moreover, it is doubtful if plants to which the trivials virgata, elata, or elatior are respectively applied by modern authors are always equivalent. The variety virgata appears to be spread in Central and South-Eastern Europe, and to be particularly characteristic of the northern and central parts of the Ballkan Peninsula. Its most noteworthy features are the tall, erect habit and numerous slender twigs-characters not well shown in many herbarium specimens. Experience of plants grown from seed collected in Eastern Bulgaria, and cultivated for five years in the Herbarium Ground at Kew, has also shown that habit and inflorescence branching are modifiable to a certain extent under altered environmental conditions. It is only specimens grown in good soil and well spaced out which reach their maximum development both of stems and of panicles.

Attention should be called to two interesting morphological features. At Kew, within the series of about a dozen plants which have been grown to maturity, a considerable range of leaf-shape and size occurs. In two or three of the plants such leaf differences occur, on different shoots of the same individual, as to warrant the use of the term "heterophylly" when comparing the lanceolate leaves of some shoots with the elliptic ones of others. The androecium shows another morphological feature, which has been ignored by many authors, though figured for 
G. tinctoria by H. Müller (see Knuth, Handbook of Flower Pollination, Engl. edit., vol.ii. p. 265 : 1908). The free parts of all the 10 filaments are approximately equal in length, but the anthers are of two distinct sizes. Five are smaller, ovate in outline, and alternating in position with five whieh are twiee their length and oblong-linear in outline. Both kinds of anthers earry pollen-grains which appear to be viable. The different sizes of the anthers are easily seen both before and after the shedding of the pollen. Bentham and Hooker, Gen. Pl. vol. i. p. 439 (1865), refer to the eharacter of the alternate stamens having larger anthers in their deseription of the tribe.-W. B. TURriLL.

Fro. 1, upper part of flowering branch, $\times \frac{2}{3} ; 2$, one of the lower leaves, natural size; 3 , flower, lateral view, $\times 2 ; 4$, vexillum, $\times 2 ; 5$, one of the alae, $\times 2$; 6 , earina, opened out, $\times 2 ; 7$, androccium with pistil inside, $\times 4 ; 8$, legume, natural size; 9 , sced, $\times 2$. 




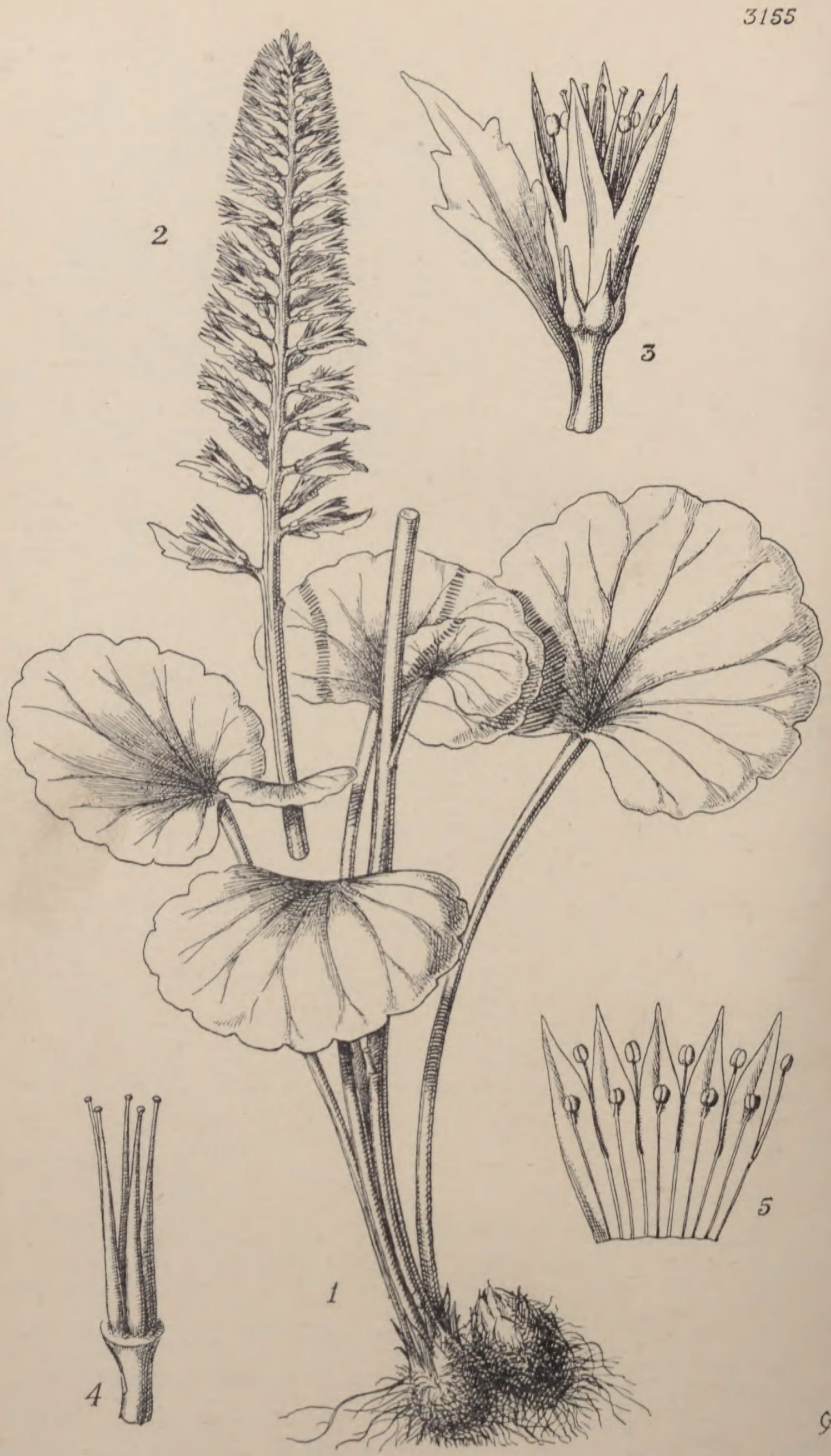




\section{TABULA 3155.}

\section{COTYLEDON LASSITHIENSIS, Hayek.}

\section{Crassulaceae.}

C. lassithiensis, IIayek, Prodr. Flor. penins. Balcan. vol. i. p. 632 (1925); a C. pendulino, Batt., bracteis argute serratis differt.

IIerba ereeta, $3 \cdot 5 \mathrm{dm}$. alta, glabra. Caulis floriferus teres, $3 \mathrm{~mm}$. diametro basi (vel radice ?) earnosa valde tuberosa. Folia basalia 4 ; lamina orbienlata, eordata, $6 \cdot 5-8 \mathrm{~cm}$. diametro, breviter grosse erenata ; petiolus $1-1 \cdot 1 \mathrm{dm}$. longus ; folia eaulina 3 , remota, truncata, petiolo 1-2 cm. longo instructa. Racemus $1 \mathrm{dm}$. longus, floribus 50-60 praeditus; braeteae inferiores ovato-lanceolatae, mediae et superiores laneeolatae eireiter $1 \cdot 1 \mathrm{~cm}$. longae, omnes pedicellis alte adnatae argute serratae; pedieelli $2-3 \mathrm{~mm}$. longi. Sepala lanceolata, acuminata, $4 \mathrm{~mm}$. longa, $1.5 \mathrm{~mm}$. lata. Corolla eylindrico-tubulosa, $1-1 \cdot 1 \mathrm{em}$. longa, luteseens, ad medium fissa, lobis laneeolatis acuminatis $6 \mathrm{~mm}$. longis $2 \mathrm{~mm}$. latis. Stamina longiora $4.5 \mathrm{~mm}$., breviora $2 \mathrm{~mm}$. longa. Carpella anguste eylindrica, ovario $7 \mathrm{~mm}$. longo, stylo $2 \mathrm{~mm}$. longo, stigmate eapitato.-Umbilicus lassithiensis, Gandoger, Flor. Cret. p. 40 (1916).

CRFTE. Lassithi : ad rupes et muros eoenobii Kronstallenia, Gandoger, 2093 ; in praeruptis ad Hagios Constantinos, Gandoger, 2309 ; montium Aloida, Gandoger, 2386 ; Lazaro, Gandoger, 2683.

Trrack. Atmadjali, among moss on rock face, $150 \mathrm{~m} ., 21.5 .30$, II. G. Teld, 320 .

The speeimen figured is the last of those quoted above, and has been identifiel from description only. Since Gaudoger's original description is somewhat meagre and Hayek (l.e.) does not say that he has seen the typo inaterial, it is advisable to state that the deseription of our plant agrees with those published by Gandoger and Hayek in such important eharaeters as the leaf shape, long dense raeeme, lobing of the eorolla, and above all in the shape and acute serration of the braets. The phrase "flores subsessiles" can, however, only be applied to the Thraeian specimen in a relative sense.

The interesting geographical distribution whieh follows for the species as tentatively accepted is similar to that known for other plants. 
Gandoger's material, as the trivial given by him indicates, came from the Lassithi Mountains in eastern Crete.

The present writer (Plant-Life of the Balkan Peninsula, pp. 330-337 : 1929) has given many examples of plants whose distribution "jumps the Acgean" from Crete to Thrace. It is stated that the list given "is sufficient to prove the existence of a route or routes of dispersal resulting in a north and south distribution, which, it must be noted, is not continued south to or from the African continent." The now discontinuous distribution of Cotyledon lassithiensis, and of many other species, across the Aegean-north and south, or east and west-is well explained as a relict " of a more continuous distribution when the Aegean was a land area."

Taxonomically C. lassithiensis seems quite distinct from its allies. The acutely serrated bracts distinguish it from $C$. Umbilicus-veneris, L., and C. horizontalis, Guss., C. intermedius, (Boiss.) Stefanoff, and C. pendulinus, (DC.) Batt. Hayek's key-character "corolla calyce 4-5-plo longior" is an exaggeration so far as our material is concerned. The vexed question whether or not the genus Colyledon, I., should be split into Cotyledon sensu stricto, Umbilicus, Rosularia, etc., cannot be discussed here, and it must suffice to say that, for those who accept Umbilicus as a valid genus, the correct name of $C$. lassithiensis is Umbilicus lassithiensis, Gandoger.-W. B. T'UrRILL.

Fia. 1, lower part of plant, $\times \frac{2}{3} ; 2$, inflorescence, $\times \frac{2}{3} ; 3$, flower and subtending bract, $\times 3 ; 4$, gynoecium, $\times 3 ; 5$, corolla, laid open, showing stamens, $\times 3$. 



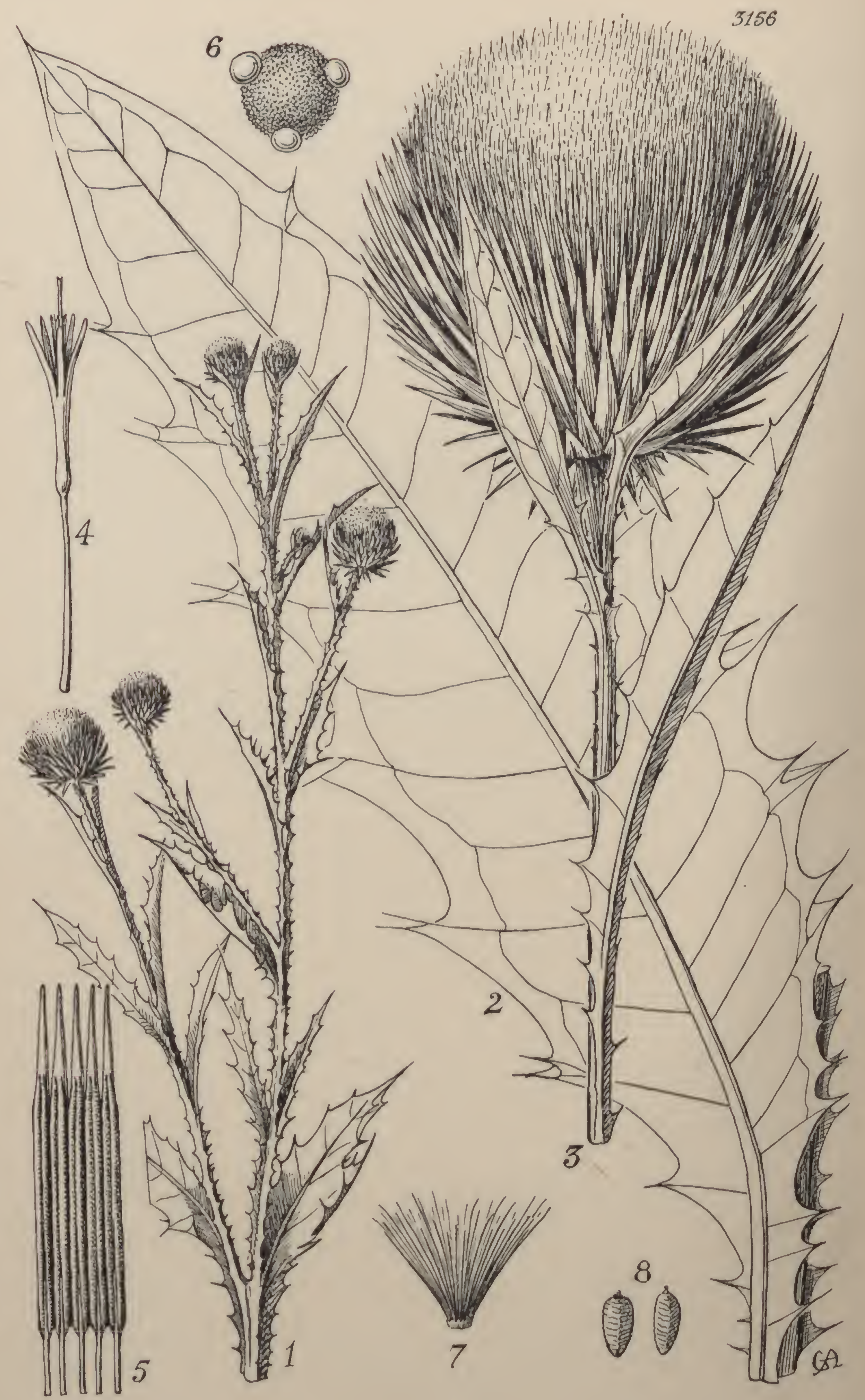




\section{TABUla 3156.}

\section{ONOPORDON TAURICUM, Willd.}

\section{Compositae. Tribus Cynarfaf.}

O. tauricum, Willd. Sp. Pl. vol. iii. p. 1687 (1801); Boiss. Flor. Or. vol. iii. p. 559 (1875); Rony, Rerision du Genre Onopordon, p. 14, t. xiii. (1896); ab 0 . erioeephalo, Rouy, capitulis majoribus glabrescentibus glandulosis, involueri phyllis inaequalibus spinoso-aeuminatis distinguitur.

Ilerba biennis, viridis, usque ad $2.5 \mathrm{~m}$. alta. Caules ereeti, valde ramosi, glanduloso-viscidi, $2-3$ alis $0 \cdot 5-1 \cdot 5 \mathrm{~cm}$. longis lobatis spinosis maruinati. Folia oblongo-lanceolata, grosse et irregulariter lobata, margine spinosa, apiec gradatim acuminato-spinosa, costa valele promi: nente, nervis lateralibus marginem versus anastomosantibus in pagina superiore vix consjicuis in inferiore prominentibus. Capilula globosa, 5-7 cm. diametro; involueri phylla inaequalia, virentia vel purpurascentia dense glanduloso-viseida, foliis superioribus in phylla externa lanceolata spinoso-acuminata plus minusve gradatin transientibus; phylla media $2.5 \mathrm{em}$. longa, $4 \mathrm{~mm}$. lata, externa ultimo reflexa vel patenti-reflexn. Flosculi numerosissimi, involueri phyllis longiores. Corolla $2.7 \mathrm{em}$. longa, glal,ra, purpurea, tubi parte angustata inferiore $1.5 \mathrm{~cm}$. louga, lobis linearibus $5 \mathrm{~mm}$. longis. Antherae circiter $1 \mathrm{~cm}$. longae, mppendice terminali subulata $1.5 \mathrm{~mm}$. longa. Cypselae compresso-tetragouac, ambitu oblaneeolatae, $5 \mathrm{~mm}$. longae, $2.75 \mathrm{~mm}$. latae, utro-brunneac, transverse rugosne; pappus caducus, albo-fulvus, nitens, $1 \mathrm{~cm}$. longus, setis scabris in annulum concretis.- 0 . clatum, Sibtl. et Sm. Prodr. vol. ii. p. 156 (1813), et Flor. Grnec. vol. ix. t. 833 (1837). O. virens, DC. Flor. Fr. vol. v. p. 456 (1815).

Rulgaria. Grown in the Herbarium Groutd, Kew, from seeds collected on the hills north of Varna, 9.8.26, by B. Gilliat-Smith and W. B. Turrill. Flowered at Kew, 31.7.28 and 3.10.28.

The specimen figured in our plate is from one of a considerable number of plants grown in the Herbarium Ground at Kew from seed collected on the hills immediately north of Varua in eastern Bulgaria. Under cultivation this thistle grows muel taller and more luxuriantly than in its natural habitats in Bulgaria, but always, in our experience, retains its biennial habit and produces abundance of good secd. 
As its trivial suggests, the species was first described from Crimean specimens. It is now known to have a wide distribution through Italy, South and Central Russia, Slavonia, Crete, Greece, the Cyclades, Macedonia, Thrace, Serbia, Bulgaria, Dobruja, Roumania, Bosnia, N. Asia Minor, and Chios. Its occurrence in the western Mediterranean as a native plant is doubtful. It is naturalized in southern France and is recorded by some authors for Aragon, though the records from Spain are probably due entirely to the acceptance of $O$. corymbosum, Willk., and $O$. humile, Loscos, as synonyms, varieties, or subspecies of O. tauricum (see, for example, Rouy, 1.c.). Boissier, and following him Rouy, makes two varieties in addition to the type. It is doubtful if these are more than habitat forms.-W. B. TuRRILL.

Fra. 1, upper part of plant, $\times \frac{1}{5} ; 2$, leaf, natural size ; 3 , inflorescence, natural size; 4 , flower (except ovary), $\times 2 ; 5$, androccium, spread open, $\times 4 ; 6$, pollon grain, much enlarged; 7 , pappus, $\times 2 ; 8$, cypselas, $\times 2$. 



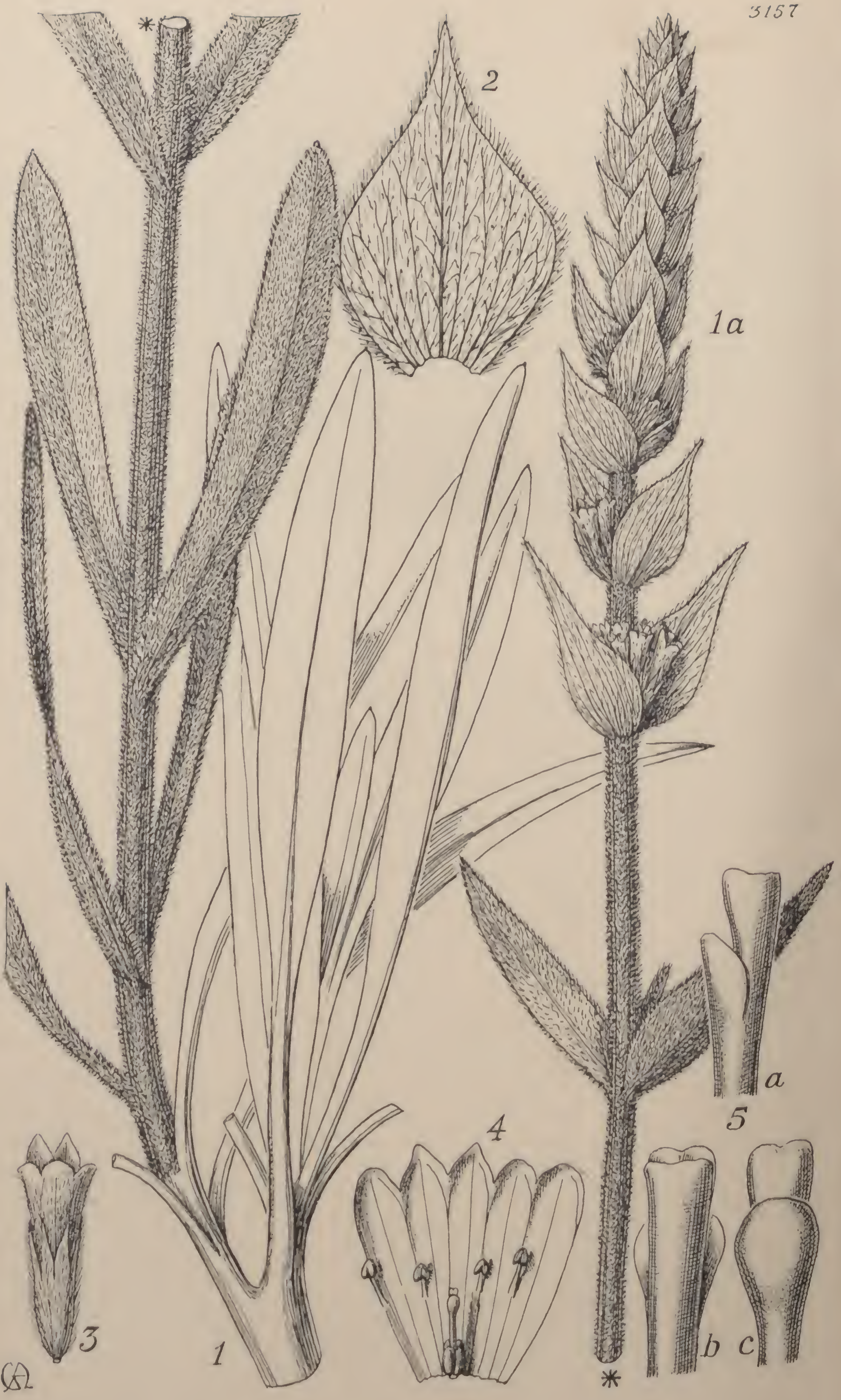




\section{TABULA 3157.}

\section{SIDERITIS SCARDICA, Griseb.}

\section{Labiatae. Tribus Stachydeae.}

S. scardica, Griscb. Spic. Flor. rumel. et bithyn. vol. ii. p. 144 (1844) ; Boiss. Flor. Or. vol. iv. p. 710 (1879); Wettstcin in Bibl. Bot. Heft 26, p. 85 (1892) ; IIalácsy, Consp. Flor. Graec. vol. ii. p. 498 (1902); Stoyanoff i Stefanoff, Flor. na Balg. vol. ii. p. 933 (1925) ; IIayck, Prodr. Flor. penins. Balcan. vol. ii. p. 257 (1929); species a S. cuboca, Heldr., foliis bracteisque longioribus, spiea latiore facile distinguenda.

IIerba perennis, basi suffruticosa, dense albo-lanata. Caulis usque ad $4 \mathrm{dm}$. altus, inferne sublignosus dense foliosus, simplex vel leviter ramosus. Folia caulina oblongo-linearia, apice obtusa, brevissime mueronulata, 7-12 $\mathrm{mm}$. lata, inferiora, $7 \cdot 5-8 \cdot 5 \mathrm{em}$. longa basi in petiolum $3-4 \mathrm{~cm}$. longum angustata, superiora sessilia $3 \cdot 5-4 \cdot 5 \mathrm{~cm}$. longa, margine integerrima vel leviter crenata. Verticillastri 4-10-flori in spicam breviter eylindricam densam usque ad $1.4 \mathrm{dm}$. longam $2-3 \mathrm{~cm}$. diametro congesti, interdum $1-2$ infimi $1-3 \mathrm{~cm}$. remoti; bracteac late cordato-ovatae, gradatim attenuatae, patentes vel leviter recurvae, pallide virides, reticulato-venosae, pubeseentes ct glandulosae, margine longe sericeo-ciliatac. Calyx tubulosus, $9 \mathrm{~mm}$. longus, longe sericeo-pubescens, dentibus 5 fere aequalibus lanceolatis acutis 3-3.5 num. longis. Corolla flava, extus sericeo-pubescens, $1.3-1.5 \mathrm{~cm}$. longa, tubo sursum gradatin ampliato ima basi $1.75 \mathrm{~mm}$. fauce $5 \mathrm{~mm}$. diametro, labio superiore vix $2 \mathrm{~mm}$. bifido, inferiore leviter trilobo, lobis subaequalibus. Stamina inelusa, longiora $3 \mathrm{~mm}$. breviora $2 \mathrm{~mm}$. longa: Stylus $4 \mathrm{~mm}$. longus, ramis stigmaticis inaequalibus truneatis 1.5 et $0.75 \mathrm{~mm}$. longis inclusis, ramo inferiore dilatato superiorem amplectente. -S. florida, Boiss. et Heldr, in Boiss. Diagn. Ser. I1. vol. iv. p. 31 (1859); Heldr. Nutzpf. p. 34 (1862).

THessaly. M. Olympi Thessal. reg. sylvat. pr. coenobium Hag: Dionysii, 20-23.7.1851, II ldreich, 2517 ; in reg. infer. 1n. Olympi Dessaliac, $1230 \mathrm{~m} ., 7-8.1857$, Orphanides, 539 ; It. Olympus, Hag. Olonysius, 30.7.1891, Sintenis et Bornmucller, 1429; in subalpinis mt. Olympus, 7.1905, Adamovid; in monte Olympo Thessaliae, in valle 1.7.lakki ultra Naum spilia usque, substrato calceo, 1100-1500 m., 29.7928 , Dibowski. In regione inedia mt. Pelion supra urbem Volo, 7.1893, Leonis (var. pclia Hal.). 
Macedonia. In Scardo: pratis montanis m. Ljubatrin sparsim in angusta regione alt. $920 \mathrm{~m}$. Grisebach.

Thrace. Near Xanthic, Tedd, 64; Tchal Dagh, 25.6.31, 700 m., rocky treeless slopes, north-east side of the mountain, Tedd, 691.

Bulgaria. Mt. Pirin (sensu lato), sold in packets for tea in Sofia.

In addition to the specimens (all in the Herbarium at Kew) quoted above, the species has been recorded from Mt. Ossa and Godaman in Thessaly, from Mirčevica Planina, Čeganska Planina, Batecina, Huma, Dobro Pole, Čaušovo, prope Ueskub and Jakupica in Macedonia, from Korab in Albania, and from Ali-Botus., the Central Rhodopes, and the Belasitsa (as var. pelia) in Bulgaria.

In the countries around the Aegean Sea there is a group of species of Sideritis all of which are closely related one to another. These include the plant here figured, S. euboea, Heldr. [known only from the upper region of Mt. Dirphys (Delphi) and Mt. Xerovuni in the island of Euboea], S. syriaca, L. (from Crete), S. Roeseri, Boiss. et Heldr. (from Greece, Thessaly, Epirus and Albania), S. theezans, Boiss. et Heldr. (from Greece), S. taurica, M. Bieb. (from Asia Minor eastwards to the Caucasus and Crimea), and S. sipylea, Boiss. (from Asia Minor). These together with $S$. sicula, Ucria (from Italy and Sicily), may well furnish another example of hamagenesis (vide Turrill, Plant-Life of the Balkan Peninsula, p. 361 : 1929).

Sideritis scardica is collected in considerable quantity in Bulgarian Macedonia and used for making an infusion which is drunk as "tea." The dried inflorescences are sold in packets in Sofia under the name "Pirinski tchaj," i.e. "Pirin tea." Markgraf (In Albaniens Bergen, p. $40: 1930$ ) records a similar use for this species, and for S. Roeser,", Boiss. et Heldr., under the Albanian names çaj malet ("mountain tea") or çaj shqyptare ("Albanian tea"). Heldreich (l.c.) refers to our species (under the name S.florida) and to other species of the group as yielding material for tea-making. The best results are obtained from Pirin tea when the dried inflorescences are boiled in four or five times their bulk of water for about fifteen minutes. The yellow-brown liquid is then decanted and drunk hot, preferably without the addition of milk.

The variety pelia, from Mt. Pelion and (according to Urumofi) from the Belasitsa, is rather a distinct-looking plant and may prove worthy of specific rank when more material is available for examination. T'edd's plant, No. 64, has bracts not or scarcely longer than the flowers. This is probably an abnormal state due to late-flowering or some other cause.-W. B. TurriLl.

Figs. 1, I 1 , lower and upper parts of flowering shoot, natural size; 2 , bract, $\times 2$; views respectively of stigma, $\times 18$. 



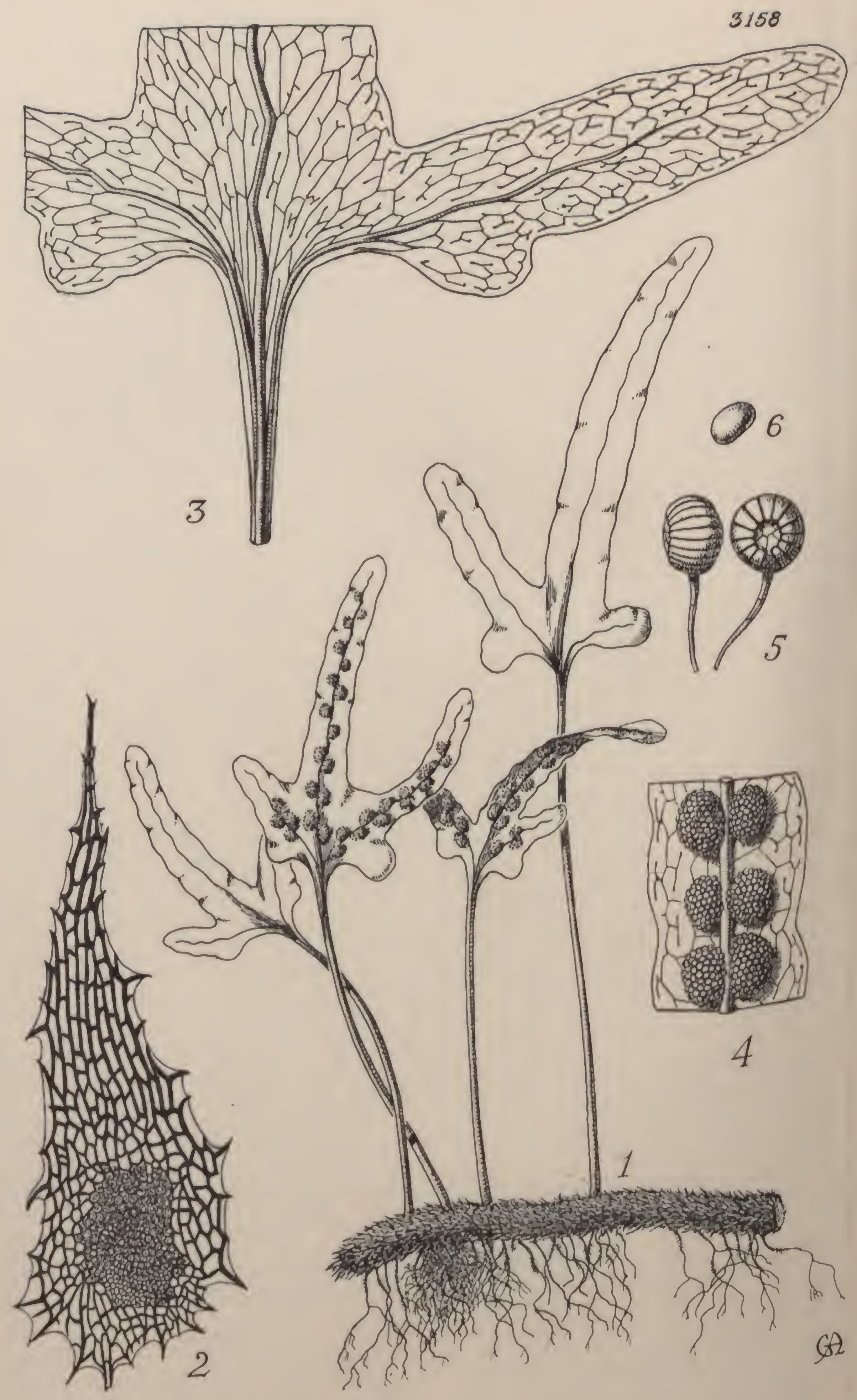




\section{Tabula 3158.}

\section{NEOCHEIROPTERIS WALTONI, Ching.}

\section{Polypodiaceae.}

N. Waltoni, Ching; speeies nova, affinis $N$. palmalopedatae, (Baker) Christ, a qua statura ninore frondibusque hastato-trilobis differt.

Rlizoma late repens validum pennac anserinae erassitie, nigrum, squamis clathratis nigris versus apicem patulis ecterum subimbricatis denticulatis e basi latissima lanecolatis longe acuminatis densissime vestitum. Folia seriata, sparsa vel subfaseieulata, stipite nudo tenui flexuoso pallide stramineo anguloso $4-6 \mathrm{~cm}$. longo basi vix $1 \mathrm{~mm}$. diametro ; lamina 4-7 cm. longa, basi $2-3 \mathrm{~cm}$. lata, ambitu hastata, 3- vel rarissime 5-lobata, lobo eentrali $3-6 \mathrm{~cm}$. longo $5-8 \mathrm{~mm}$. lato lanecolato apice rotundato vel obtuso, duobus lateralibus multo brevioribus fere erectis basi dilatato-cordatis, margine plus minusve leviter repando-undulato, costa prineipalisubtus prominente supra inconspicua, nonnunquam leviter impressa, nervis oceultis sed luce transeunte distinetis abunde anastomosantibus, arcolis inter costam et marginem $2-3$-seriatis plus minusve pentagonis nervulos elavatos liberos indivisos vel raro fureatos plerumque costam spectantes includentibus, textura herbacea, utraque pagina pallide viridi, pagina superiore glaberrima inferiore in planta juvenili paleis is rhizomatis sed minoribus cuspidatisque laxe obtecta. Sori magni, superfieiales, eostales, basales majores suboblongi, supremi rotundati, plerumque sese tangentes, brunnei, juveniles paleis peltatis nigris teeti. Sporangia longe pedunculata, globosa, annulo brunneo latissimo eompleto.-Polypodium hastatum, Hemsl. in Journ. Jinn. Soc., Bot. vol. Xxxv. p. 206 (1902), non Thunb. Polypodium clathratum, var. lobatum, Takeda in Notes Roy. Bot. Gard. Edinb. vol. viii. p. 282 (1915).

Tiвет. Kyichu Valley, 15 miles cast of Lhasa, August 1904, Capt. II. J. Walton (type). Lhasa, 3450 m., 18 Sept. 1901, L. O. Waddell.

A critical examination of the material now at hand shows at once the proper systematic position of the present speeies. The genus Neocheiropteris, Christ, has hitherto been regarded as a monotypic one, 
represented by $N$. palmatopedata from Yunnan, lately known also from West Szechwan and Kweichow. The new species differs from its relative chiefly by its decidedly smaller dimensions and hastately trilobed frond.-R. C. Ching.

FIG. 1, plant, natural size; 2 , ramentum from rhizome, $\times 27 ; 3$, part of a frond, showing venation, $\times 3 ; 4$, part of lower surface of a frond, with sori, $\times 3$; 5 , sporangia, much enlarged; 6 , spore, much enlarged. 



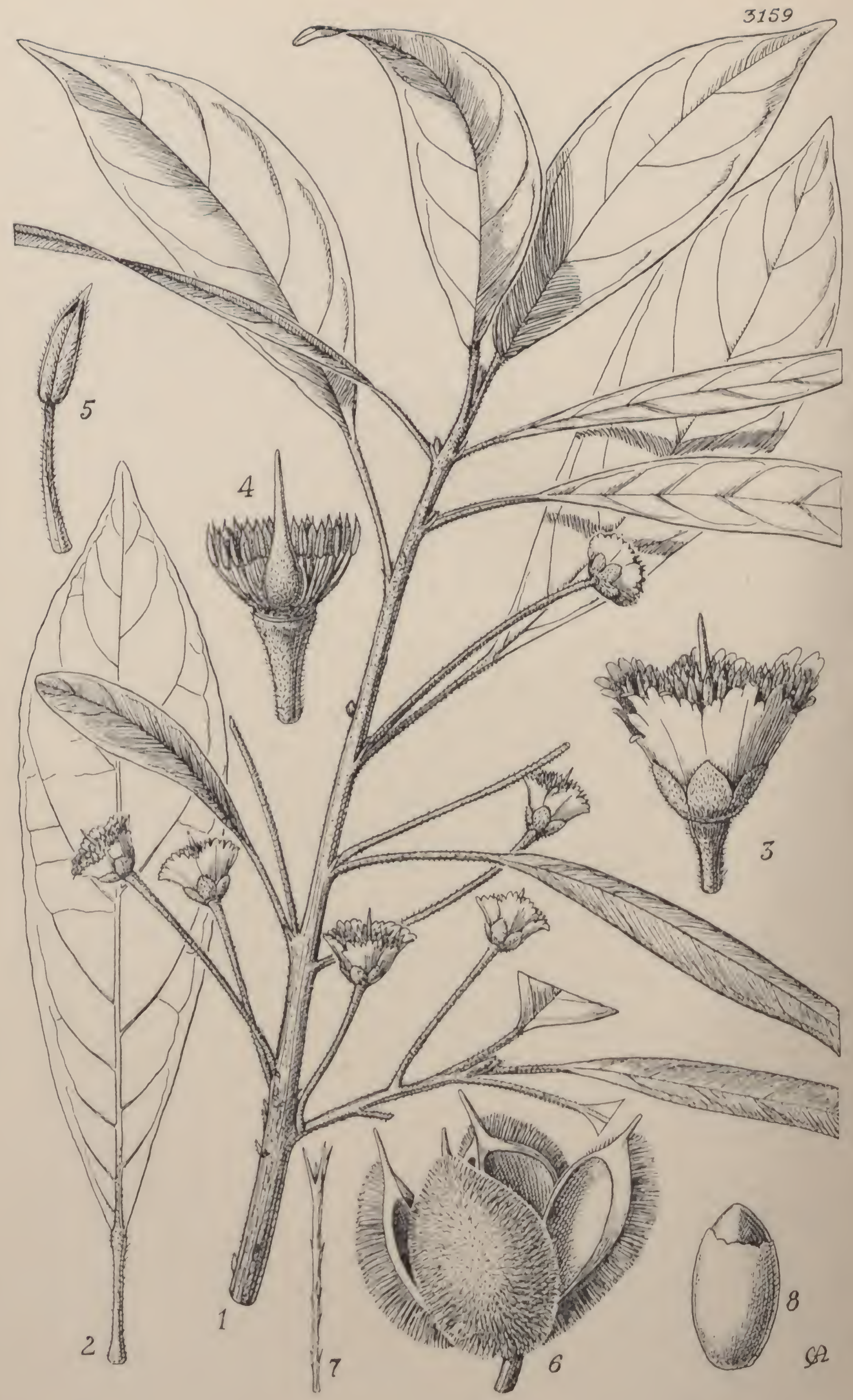




\section{'T'abula 3159.}

\section{SLOANEA ELEGANS, Chun.}

\section{Elacocarpaceae. Tribus Elafecarpeat.}

S. elegans, Chun; speeies nova affinis S. dasycarpae, (Benth.) Hemsl., quae foliis inulto majoribus oblongis eoriaceis serratis valde venosis, floribus majoribus sepalis orbieularibus, capsulis majoribus valvis erassioribus distinguitur; affinis etiam S. Chingii, Hu, eujus tamen eapsulae in peduneulo eommuni umbellatim sunt dispositae.

Arbor 7-8 m. alta. Innovationes dense pubeseentes, eito glabrae. Gemmac dense serieco-pilosae, pallide fulvae. Ramuli graeiles, leviter angulati, einereo-brunnei, pilis brevibus pallidis patulis plus minusve pubeseentes. Folia decidua, petiolata, laneeolata, oblaneeolata vel elliptieo-lanceolata, in basin aeutam vel subobtusam longe attenuata in apiec graeiliter longe vel breviter aeuminata, raro aeuta, 6-11 em. longa, 1.5-3 cm. lata, margine integro subirregulariter undulato, ehartacea, utraque pagina statu juniore minute puberula, eito glabra pilis eaespitosis in venarum axillis subtus nonnunquan persistentibus exeeptis, pagina superiore surde viridi costa immersa venis lateralibus indistinetis, pagina inferiore pallide viridi, eosta venisque lateralibus gracilibus sed conspicuis, venis lateralibus 7-8 irregularibus adseendentibus anastemosantibus sparse retieulatis; petiolus graeilis, subteres, apiee leviter dilatatus, 1-2 ein. longus, plus minusve sordide puberulus. Pedunculi in ramis hornotinis orti, in axillis foliorum inferiorum solitarii, $2 \cdot 5-4 \mathrm{em}$. longi, graeiles, teretes, adseendenti-patentes, reeti, sordide puberuli. Flores $1.8-2 \mathrm{em}$. diametro. Sepala 5, ovata usque deltoideo-ovata, aeuta, 4-5 $\mathrm{mm}$. longa, 3-4 mm. lata, utraque pagina tenuiter serieco-pubesecntia. Petala 5, leviter imbricata, 10-12 $\mathrm{mm}$. longa, latitudine valde inaequalia, oblique euneata, apiee truneata erosa vel in lobos lineari-oblowgos irregulariter laecrata, utraque pagina puberula, longitudinaliter 8-14-nervia. Stamina pernumerosa (eireiter 80 ), conferta, 6-7 mm. longa, interiora subbreviora, pilis brevibus patentibus sparse strigosa; antherae $2.5 \mathrm{~mm}$. longae, introrsae, rimis terminalibus dehiseentes, apiee prominenter apieulatae, theeis subina qualibus; filamenta $3 \cdot 5-4 \cdot 5 \mathrm{~mm}$. longa, fliformia. Discus eireiter $5 \mathrm{~mm}$. diametro, lentieulari-diseoideus, dense minute foveolatus, obseure puberulus. Ovarium eireiter $3 \mathrm{~mm}$. altum, eonieo-ovoideum, dense fulvo-sericeo-pilosum; stylus exsertus, subulatus, eireiter $6 \mathrm{~mm}$. 
longus, basin versus hispidulus, superne glaber; stigma minutum, punctiforme. Capsulae solitariae, pedunculis gracilibus plus minusve puberulis $2.5-4 \mathrm{~cm}$. longis ovoideo-globosae, circiter $1.8 \mathrm{~cm}$. longae ac paullo minus diametro, 4-5-valves, valvis styli fissi residuo, saepe coronatis, tenuiter lignosis, intus pallide fulgido-luteis, margine purpureo-rubris, extra spinis brevibus mollibus barbellatis circiter $2 \mathrm{~mm}$. longis facile deciduis dense vestitis. Semina in quaque capsula 1-3, ellipsoidea, circiter $12 \mathrm{~mm}$. longa et $6 \mathrm{~mm}$. lata, nitide purpureo-nigra, tribus partibus arillo tenui carnoso aurantiaco-miniato inclusis.W. Y. CHUN.

South Cirina. Kwangtung: Kook Kiang District, Lung-Tou Shan, roadside near temple, tree $8 \mathrm{~m}$. high, in flower, 3 April 1930, Ko, 50302 (type); same locality, at edge of wood, side of ravine, tree $7 \mathrm{~m}$. high, in fruit, 1 Sept. 1930, Ko, 50796.

FiG. 1, flowering branch, with young leaves, natural size; 2, leaf, lower surface, natural size; 3 , flower, $\times 2 ; 4$, flower, with perianth and half of the stamens removed, showing pistil, $\times 2$; 5 , stamen, $\times 6 ; 6$, capsule, after dehiscence, $\times 2$; 7 , bristle from capsule, $\times 15 ; 8$, seed, with aril, $\times 2$. 



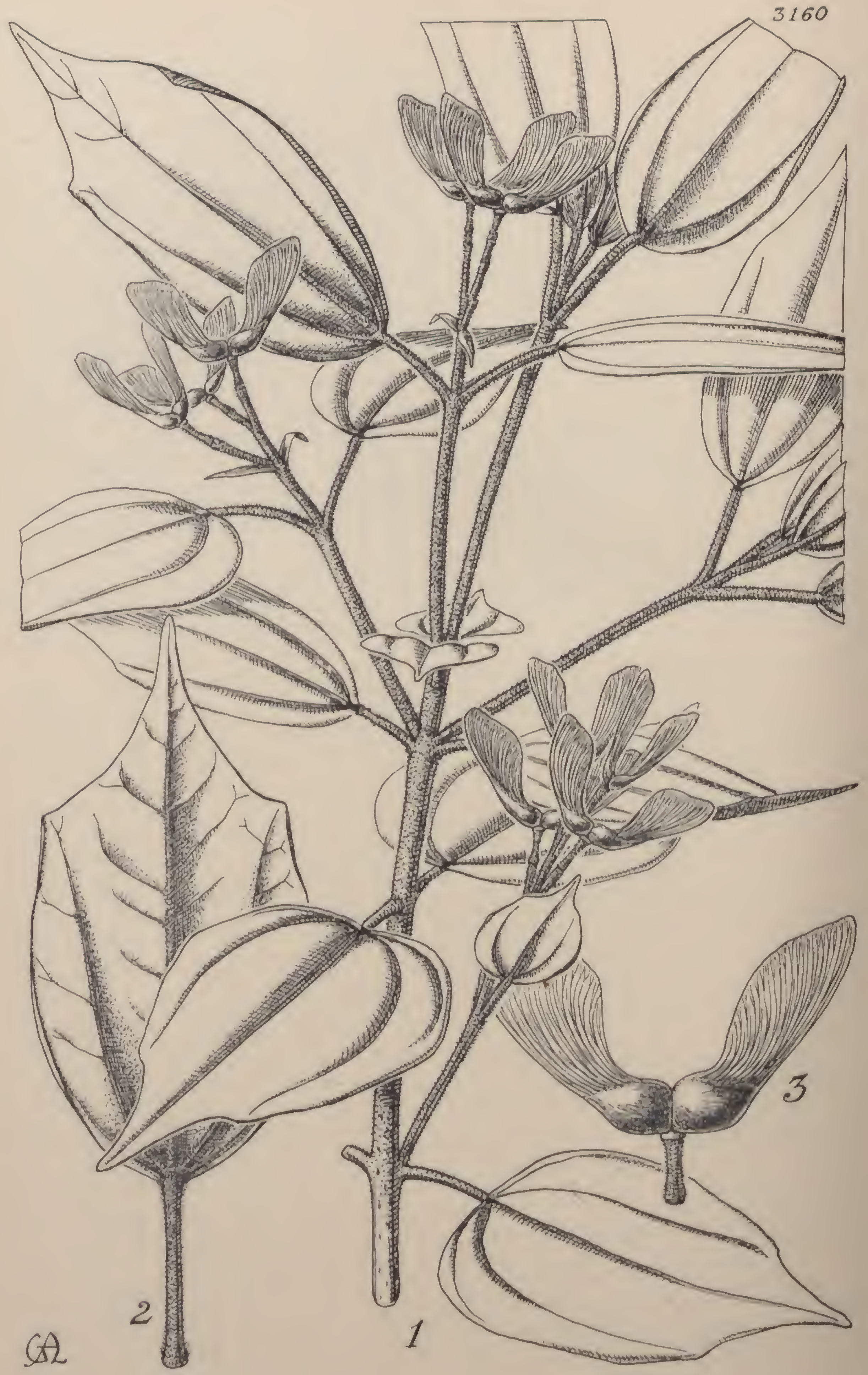




\section{Tabula 3160.}

\section{ACER SYCOPSEOIDES, Chun.}

\section{ACERACEAE.}

A. sycopseoides, Chun; speeies nova ab omnibus speciebus adhue deseriptis remota.

Arbor $6 \mathrm{~m}$. alta. Cortex cinereo-albus. Ramuli teretes, dense fulvotomentosi, annotini glabri vel glabreseentes purpureo-brunnei ; ranuli vetustiores sparse minute lentieellati. Folia persistentia, etiam novella jam eoriacea, longi-vel brevi-petiolata, 3 -nervia, 5-8 cm. longa, $2 \cdot 5-4 \mathrm{em}$. lata, ovata, oblongo-ovata vel obovata, basi rotundata, apice obtuse acuminata, margine valde revoluta integra vel supra laminae medium utrinque lobulo unico angulari obtuso praedita in quen solet exeurrero vena lateralis basalis, pagina superiore statu juniore plus minusve tomentosa demum glabra, surde viridia, statu vivo subbullata, siecitate minute dense retieulata, pagina inferiore glauea, minute foveolata, dense sericeo-puberula, seeundum venas louge serieeo-pilosa; costa venaeque laterales graeiles, supra impressae, subtus prominentes, a petiolo robusto paullo supra basin laminae abrupte discedentes, venis secundariis gracilibus brevibus indistinetis, paribus 2 vel 3 superioribus prope costae apicem ramifieantibus exeeptis, omnibus irıegulariter anastomosantilus ; petioli robusti, teretes, leviter suleati, longitudine variabiles, primum dense fulvo-tomentosi, dein glabreseentes; petioli foliorum superiorum eireiter $1 \mathrm{~cm}$. longi, inferiorum usque $2.5 \mathrm{~cm}$. lougi. Infructescentia corymbiformis, terminalis, folis brevior, oligoearpa, rhachi peduneulis pedicellisque dense fulvo-tomentosis; pedicelli 4-5 inın. longi. Samara demum glabra, eireiter $1.8 \mathrm{em}$. longa ; nueulus elliptico-oblongus, turgidus, haud angularis, tenuiter reticulatus, $5 \mathrm{~mm}$. longus, 3 un. latus; ala adseendenti-patens, 7-8 mu. lata.

\footnotetext{
Soutır China. Kwangsi; Tia Lian Shau, X. Luehen, elevation about $540 \mathrm{~m}$., medium-sized tree, in woods, rare, 25 May 1928, Ching,
5336.
}

A remarkably distinet species having leaves remiuiscent of those of some species of Sycopsis. The eomparatively sinall, thickly eoriaceous, 
more or less angular leaves glaucous beneath, the densely tomentose branchlets, and the small samara with ascending spreading wings, constitute a unique combination of distinctive characters which readily separates this from all described species.-W. Y. CHUN.

Fig. 1, upper part of a branch, in the fruiting condition, natural size; 2 , lower surface of leaf, natural size; 3 , fruit, $\times 2$. 



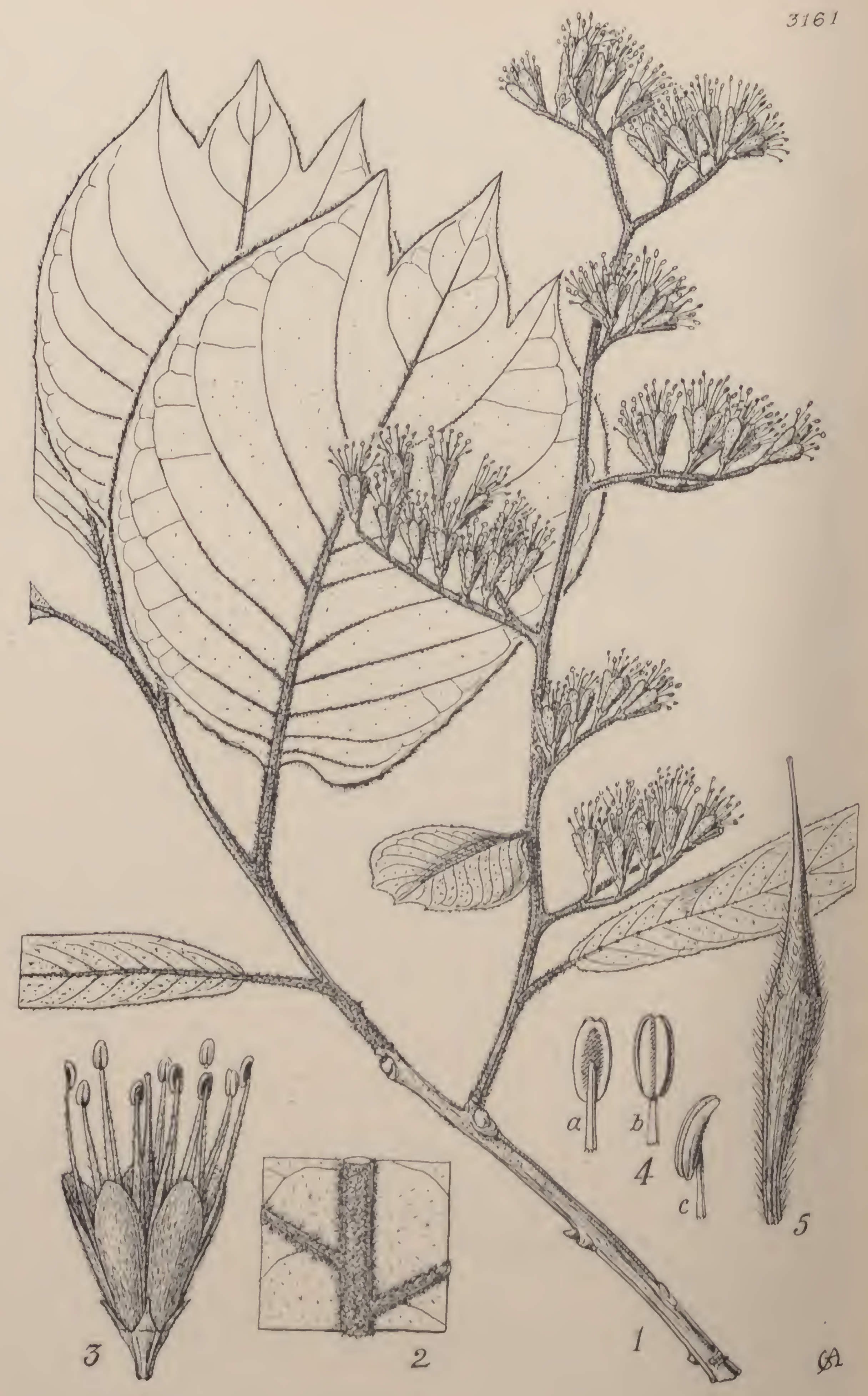




\section{TABULA 3161.}

PTEROSTYRAX LEVEILLEI, (Fedde) Chun.

\section{Styracaceae.}

P. Leveillei, (Fedde) Chum, eoml). nov.; species $P$. hispido, Sieb. et Zuce., affinis, foliis tricuspidatis, floribus sublongioribus, sepalis anguste lanceolatis nee deltoideo-ovatis, petalis late ellipticis, fructibus aliter formatis distincta.

Arbor $9 \mathrm{nı}$. alta, trunco cortice cinerco aspero pracdito. Ramuli subteretes, statu juniore pilis stellatis parvis fulvo-tomentelli ct paucioribus majoribus breviter hirsuti, aunotini glabreseentes, brunnescentes. Folia clartacen, 6-11 cm. longa, 3-6 cm. lata, forma variabilia, plerumque elliptico-oblonga usque ovato-vel obovato-oblonga, basi cuncata usque subrotundata atque in petiolum anguste decurrentia, apice tricuspidata lobis triangularibus acutis vel b reviter acuminatis calloso-nucronatis, margine minute calloso-denticulata, pagina superiore pallide viridi primum dense stellato-pilosa demum glabrata, pagina inferiore multo pallidiore plus minusve glauca secundum costan venasque pilis stcllatis flavescentibus tomentella ac sublirsuta ceterum pilis stellatis minute cinerco-tomentella indumento hoc arete adjuresso pilis stellatis majoribus hine inde inspersis ; venne latemles $6-11$, adscendentes, subparallelac, superiores singulac ad apices loborum lateralium exeurrentes, inferiores prope marginein anastomosantes, omnes cum costa subtus prominentes, venulis sparsis subparallelis; petiolus semiteres, supra canaliculatus, 1-2 cm. longus, juventute dense stellato-tomentellus, tandem pubescens. Paniculae multiflorae, anguste pyramidales, circiter $12 \mathrm{~cm}$. longae, ex axillis foliorum delapsorum superiorum ramuli annotini ortac, rhachi ramulis pedicellis calyco pilis stellatis flavescentibus subhirsutotolnentellis, ramulis sparsis brevilus vix $3 \mathrm{~cm}$. longis secundifloris; predicelli 1-2 mun. longi, infra calycem articulati; bracteac bracteolacque caducae. Flores $12-14 \mathrm{~mm}$. longi, albidi. Calycis tubus $2 \mathrm{~mm}$. altus, infundibuliformi-companulatus, ovario adnatus, margine truncatus 5 -eostatus, costis cum lobis alternantibus; lobi 5, distincti, anguste triangulares, acuminati, vix $1 \mathrm{~mm}$. longi, textura petalis homogenei, leviter pilosi. Petala 5, basi subcohaerentia vel libera, utraque pagina dense albido-pilosa, ellintico-spathulata, apice obtusa vel acutiuscula, $6 \mathrm{~mm}$. longa, $2 \mathrm{~mm}$. lata. Slamina 10 , cxserta, inaequilonga, 5 longiora 8-9 mm. longa; filamenta tenuia applanata, utrinque sparse pilosa, 
superne libera, sursum sensim angustata, inferne in tubum brevem connata ; antherae parvae, anguste oblongae, tandem arcuato-reflexae. Ovarium pro majore parte inferum, parte libera conica dense cinereopilosa in stylum sensim dilatata; stylus longus, cylindrico-subulatus, staminibus brevior, parte inferiore dense pilosa, apicem versus glaber ; stigma truncatum vel obsolete trilobum. Fructus (immaturus) cylindrico-fusiformis, supra medium leviter constrictus, stylo incluso 3-3.5 cm. longus, parte inferiore (id est infera) obscure 5-costata, dimidium fructus aequante, pilis patule adscendentibus flavis dense sericeo-villosa.-Styrax Leveillei, Fedde ex Léveillé, Flore du KouyTcheou, p. 407 (1915). Styrax Cavaleriei, Léveillé in Fedde, Repert. Sp. Nov. vol. ix.p. 447 (1911), non S. Cavaleriei, Léveillé, op. cit. vol. iv. p. 331 (1907). Pterostyrax hispidus, W. W. Sm. in Notes Roy. Bot. Gard. Edinb. vol. xii. p. 238 (1920), non Sieb. et Zucc. Pterostyrax Cavaleriei, Guillaumin in Bull. Soc. Bot. France, 1923, vol. 1xx. p. 886 (1924).

Soutri China. Kweichow: Pin-Fa road to Tou-Yun, rare, May 1905, J. Cavalerie, 2992 (type). Kwangsi: Bin Long, Miao Shan, north of Luchen, border of Kweichow, $1200 \mathrm{~m}$., in open wood along stream, very rare, 14 June 1928, Ching, 5962.

In inflorescence and fruit this species is clearly allied to Pterostyrax hispidus, Sieb. et Zucc., rather than to $P$. corymbosus as stated by Guillaumin. Besides the characters mentioned in the diagnosis, $P$. hispidus may be further distinguished by the calyx-lobes being continuous with the calyx-tube; in the present species as well as in $P$. corymbosus, the calyx-lobes are abruptly differentiated from the truncate calyx-tube, the sepals having the consistency and texture of the corolla, a character of diagnostic value hitherto unnoticed.W. Y. Chun.

Fig. 1, flowering branch, natural size; 2 , lower surface of leaf, $\times 4 ; 3$, flower, $\times 4 ; 4$, anthers, $\times 10$ ( $a$, seen from outside, $b$, from inside, c, lateral view); 5 , young fruit, $\times 2$. 



\section{(1) Nov}

W
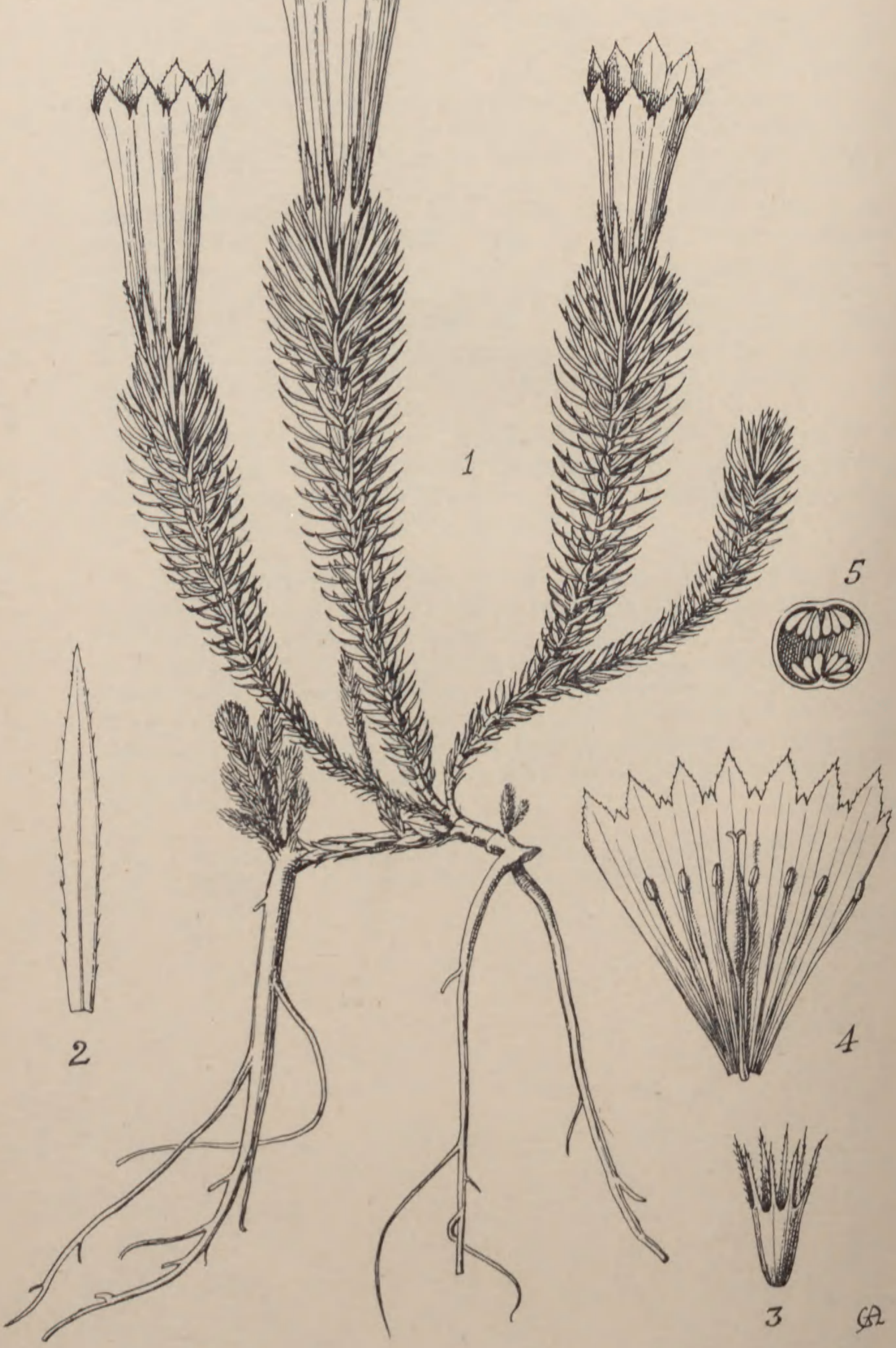


\section{TABUla 3162.}

\section{GENTIANA SETULIFOLIA, Marquand.}

\section{Gextiaxaceae. Tribus Swerteae.}

G. setulifolia, Marquand in Kew Bull. 1928, p. 56 ; affinis G. heptaphyllae, Balf.f. et Forrest, sed foliis angnstioribns, ealyeisque lobis margine setis nulto longioribus einetis differt.

Ilerba perennis, nonnibil serpens. Stolones eataphylla hyalina ovata aenta 3-4 mm. longa gerentes. Rami steriles plurini, breves. Rami floriferi ereeti, seabri, $10-15 \mathrm{~cm}$. longi, internodiis $2-4 \mathrm{~mm}$. longis. Folia rosularum desunt. Folia eaulina vertieillata, 7 pro verticillo, sessilia, patentia, linearia, aenminata, e basi ad apiecm ramorum gradatim majora, usque ad $9 \mathrm{~mm}$. longa, $0.5-1 \mathrm{~mm}$. lata, margine subulatosetosa; folia verticillornm superiorum ealyeem oceultantes. Flores magni, solitarii, terminales, sessiles. Calyx purpurasecns; tubus 7-9 $\mathrm{nm}$. longus, 5-6 mm. dianetro; lobi $7-8$, lineari-aeuninati, 6-8 mm. longi, 0.5-0.7 mm. lati, margine setosi, sinu lato olinso. Corolla eampanulato-infundibuliformis, eacrnlea; tubus albidus, creruleo-vittatus, $4-4.5 \mathrm{~cm}$. longus, $1.5 \mathrm{em}$. diametro; lobi 7-8 (rarius 6), ovati, acuninati vel brevissime euspidati, 5 mm. longi, $1 \mathrm{~mm}$. lati, margine minute erosi ; plieae breves, laciniatre. Stamina $7-8$, eirea $2 \cdot 5 \mathrm{em}$. longa; antherae oblongae, $3-3.5 \mathrm{im}$. longae. Ovarium stipitatum. Semina matura non visa.

S.E. Tizet. Valley of the Seinghku, near the frontier of Burma, lat. $28^{\circ} 10^{\circ} \mathrm{N}$., long. $97^{\circ} 20^{\prime} \mathrm{E}$., $3600-3900 \mathrm{~m}$., 13 Oet. $1926, F$. Kringdon Ward (with No. 7385) (type); valley of the Seinghku, on granite slabs in shelter under eliffs, but in the open, $3000 \mathrm{~m}$., $F$. Kingilon Ward, 7485.

This species, which belongs to the verticillate-leaved series of Seet. Frigida, is unique in the genus in having cilia on the margins of the leaves and ealyx-lobes. The number of leaves in a whorl and the number of parts in the corolla are never absolutely constant in the speeies of Series Vertieillatae, but vary within narrow limits.

The previously known speeies of this Series are natives of Western and North-Western China and the adjoining portions of Eastern Tibet, so that the diseovery of $G$. setulifolia has extended the known range of 
the Series considerably further southwards. The district where this plant grows has been very little explored botanically, and is of special phytogeographical interest in connecting the floras of the Eastern Himalaya and South-West China.

Captain Kingdon Ward unfortunately was unable to obtain ripe seed in 1926, but he informs me that he collected living roots on a subsequent expedition from which he has just returned. This fine species was not previously known in cultivation.

Duplicate specimens comprising part of the original gathering have been sent to the Herbarium of the Royal Botanic Garden, Edinburgh.-C. V. B. Marquand.

FIG. 1, portion of plant, natural size; 2 , leaf, $\times 5 ; 3$, calyx, natural size ; 4 , corolla opened out and seen from the interior, natural size; 5 , transverse section of ovary, $\times 5$. 


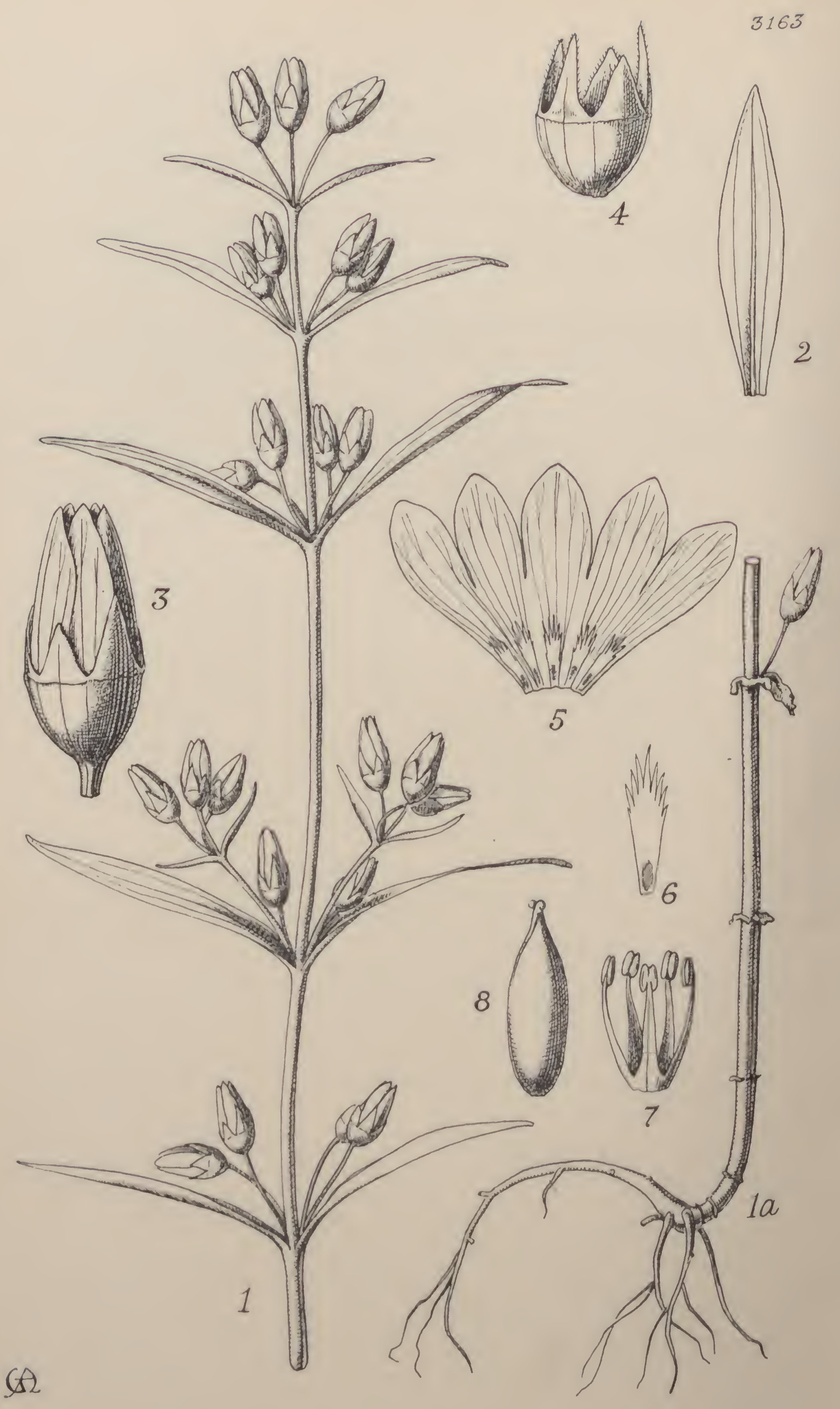




\section{TABULA 3163.}

\section{RINGDON-WARDIA CODONOPSIDOIDES, Marquand.}

\section{Gentianaceaf. Tribus Swertieae.}

K. codonopsidoides, Marquand in Journ. Linn. Soe., Bol. vol. xlviii. p. 207 (1929) ; species unica.

Herba annua. Caulis ercetus, infernc tortilis, 25-35 em. altus. Folia basalia nulla, eaulina opposita, sessilia, lanceolato-oblonga, 3-4 cm. longa, 0-7-1 cm. lata, subaeuta. Pedunculi axillarcs, $2-3 \mathrm{em}$. longi, flores 2-3 breviter pedicellatos gercntes. Calyx tubulosocampanulatus, usque medium quinquefidus, lobis inaequalibus, subglaber ; tubus 3-4 mm. longus ; lobi 5, inacquales, subulato-dcltoidei, $2 \cdot 5-4 \cdot 5 \mathrm{~mm}$. longi, 4-6 $\mathrm{mm}$. lati, saepius duo majores ct tres minorcs. Corolla tubuloso-campanulata, 8-10 mm. longa, 4-5 mm. diametro, cireiter ad quartain partcm lobata, pallide purpurea; tubus basin versus fovcolis 5 glandulosis supcrnc ciliato-fimbriatis infra lobos sitis pracditus ; lobi 5, aequales, ovati, 3-4 $\mathrm{mm}$. longi, $2 \cdot 5-3 \mathrm{~mm}$. lati, subacuti, integri. Stamina 5, corollae basi affixa, 6-7 mu. longa; filamenta subulata, inferne in annulum $1 \mathrm{~mm}$. longum connata, eetcrum libera; anthcrac oblongae, $1 \mathrm{~mm}$. longac. Ovvrium stamina superans; stigma subscssilc. Capsula ignota.

S.F. Tibet. Pa La (Tra La), in colonics under juniper or Picea trees, on the edge of the meadow in damp shady situations, $3600 \mathrm{~m}$., 26 Sept. 1924, F. Kingdon Ward, 6205 (typc). Previously found in 1882 by "Dr. King's collector" in Tibet, without precise loeality.

The genus oceupics a somewhat intermediatc position betwcen Gentiana and Suertia, differing from the former in the presenee of a fimbriate fovcola towards the basc of the eorolla below each eorollalobe, and from the latter in the conspicuous calyx-tube surmounted by triangular lobes as well as in the wcll-marked corolla-tube. From Jeschken it is readily distinguished by the position of the stameus, which arise from the basc of the eorolla instead of from the sinus between the lobes.

It is possible that this species may be less rare than might be inferred 
from the fact that the only two specimens known to exist are in the Kew Herbarium, since large areas of this part of Tibet are still unexplored botanically.-C. V. B. Marquand.

Fias. 1, 1a, upper and lower portions of plant, natural size; 2, leaf, natural size ; 3 , young flower ; 4 , calyx ; 5 , corolla, opened out to show fimbriate foveolao and drops of nectar ; 6 , foveola, $\times 6 ; 7$, androecium ; 8 , gynoecium. Figs. 3 , $4,5,7,8, \times 3$. 


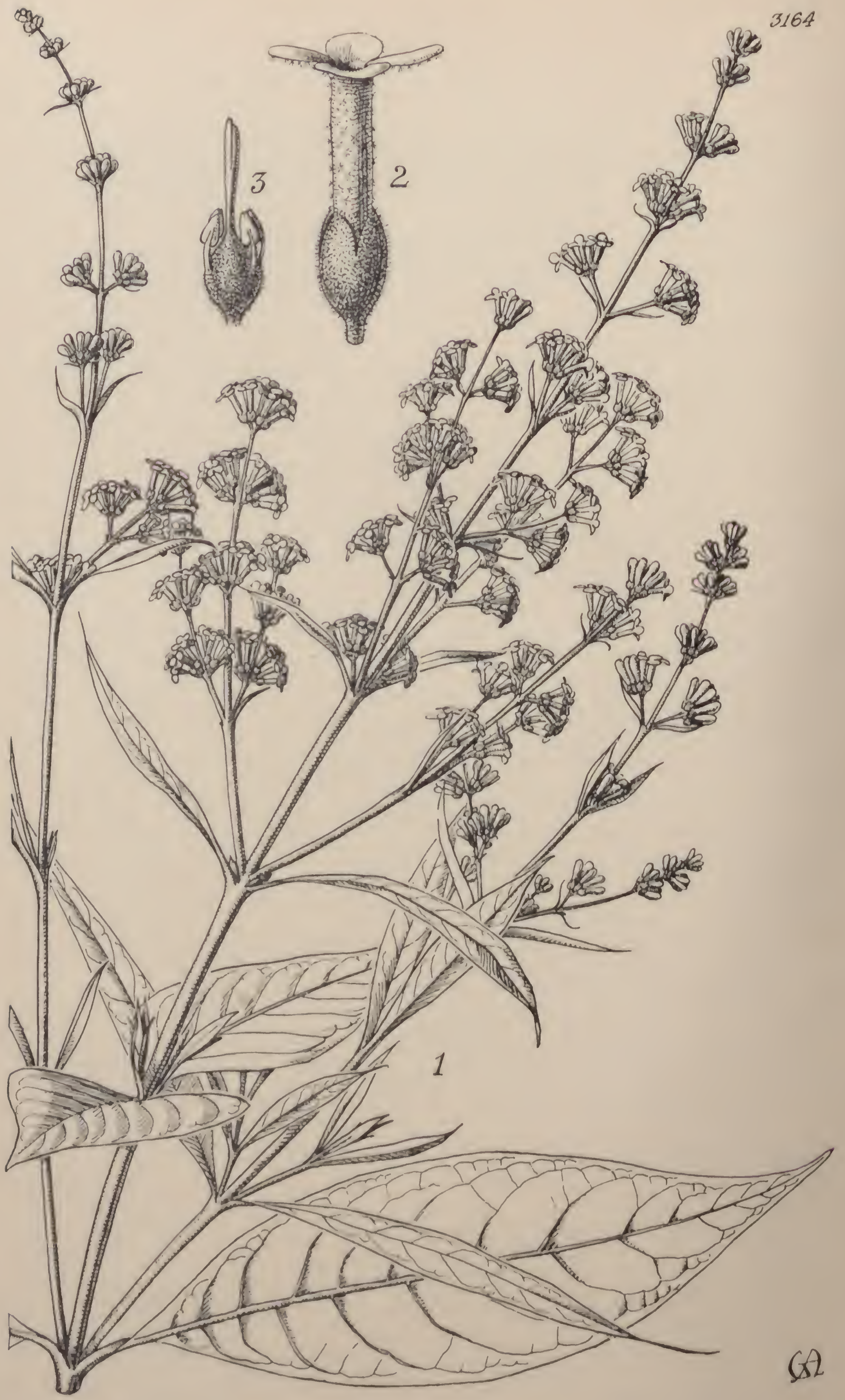




\section{TaBUla 3164.}

\section{BUDDLEJA GYNANDRA, Marquand.}

\section{Loganiaceae. Tribus Euloganieat.}

B. gynandra, Marquand in Kew Bull. 1930, p. 184 ; speeies distinctissima staminibus ovario nee corollae affixis.

Frutex. Rami subteretes, graciles, primum tomentosi. Folia opposita, lanceolata vel ovato-lanecolata, acuminata, basi attenuata, ad $13 \mathrm{~cm}$. longa, $3 \cdot 5 \mathrm{~cm}$. lata, integra vel interdum paullnm sinnata, novella ntrinque stellato-tomentosa, adulta supra glabreseentia, subtus paree tomentella; petioli $5-8 \mathrm{~mm}$. longi. Slipulae in annulnm redaetae. Thyrsi eaulem et ramulos laterales terminantes, eompositi ramis lateralibus cireiter 4 aseendentibus pro rata longinseulis, laxi; eymae 5-7-florae; bracteae lineares, superiores 6-8 mm. longae, inferiores majores foliaceae. Flores oehrolenci, fragrantes, pedieellis tomentosis. Calyx ad tertiam partem lobatns; lobi 4 , subobtusi, deltoidei. Corolla extra parce stellato-tomentosa ; tubus 4-5 mm. longus, eirciter $1 \mathrm{~mm}$. diametro, intns paree pubeseens; lobi 4, obovato-spathulati, integri, circiter $2 \mathrm{~mm}$. longi, $1.5 \mathrm{~mm}$. lati. Stamina 4 , in latere ovarii inserta, cireiter $1.5 \mathrm{~mm}$. longa; filamenta inferne adnata, parte superiore libern graeili antheris subdeltoideis subbreviore. Ovarium tomentosum, stylo staminibus duplo longiore, stigmate clavato. Fructus non visus.

Tonkix. Langson, in roeky places, 27 Jan. 1886, B. Balansa, 930.

This interesting speeies, on which a monotypie Series of the genus (\$ Gynandrue) has been established, is very distinct from all the other members of the genus in the position of the androeeium. When the corolla-tube is separated by disseetion of the flower, the stamens are found to adhere to the gynoeeium, not being attached to the corollatube as they are in all Asiatic speeies of Buldleja. Only a single colleeting of this remarkable plant is known to exist, but it is not a little strange that it should have eseaped the notiee of all systematists for nearly fifty years. 'The type sheet, whieh is in the Kew Herbarinm, bears a label, "Buddleja asiatica Lonr. determinavit Kränzlin," in that botanist's handwriting, and this may aceount for the faet that the 
plant was overlooked until 1930, when a critical study of the Asiatic species of the genus was published by the author.

Some systematists might possibly consider this plant to belong to a new genus, but as it is only an extreme condition of a series ranging from those species in which the stamens are inserted near the mouth of the corolla-tube to those where the point of insertion is near the base of the latter, it seems preferable to retain it in the genus Buddleja.-C. V. B. MARQUAND.

FIG. 1, upper part of flowering branch, natural size ; 2 , flower, $\times 6 ; 3$, androecium and gynoecium, $\times 6$. 



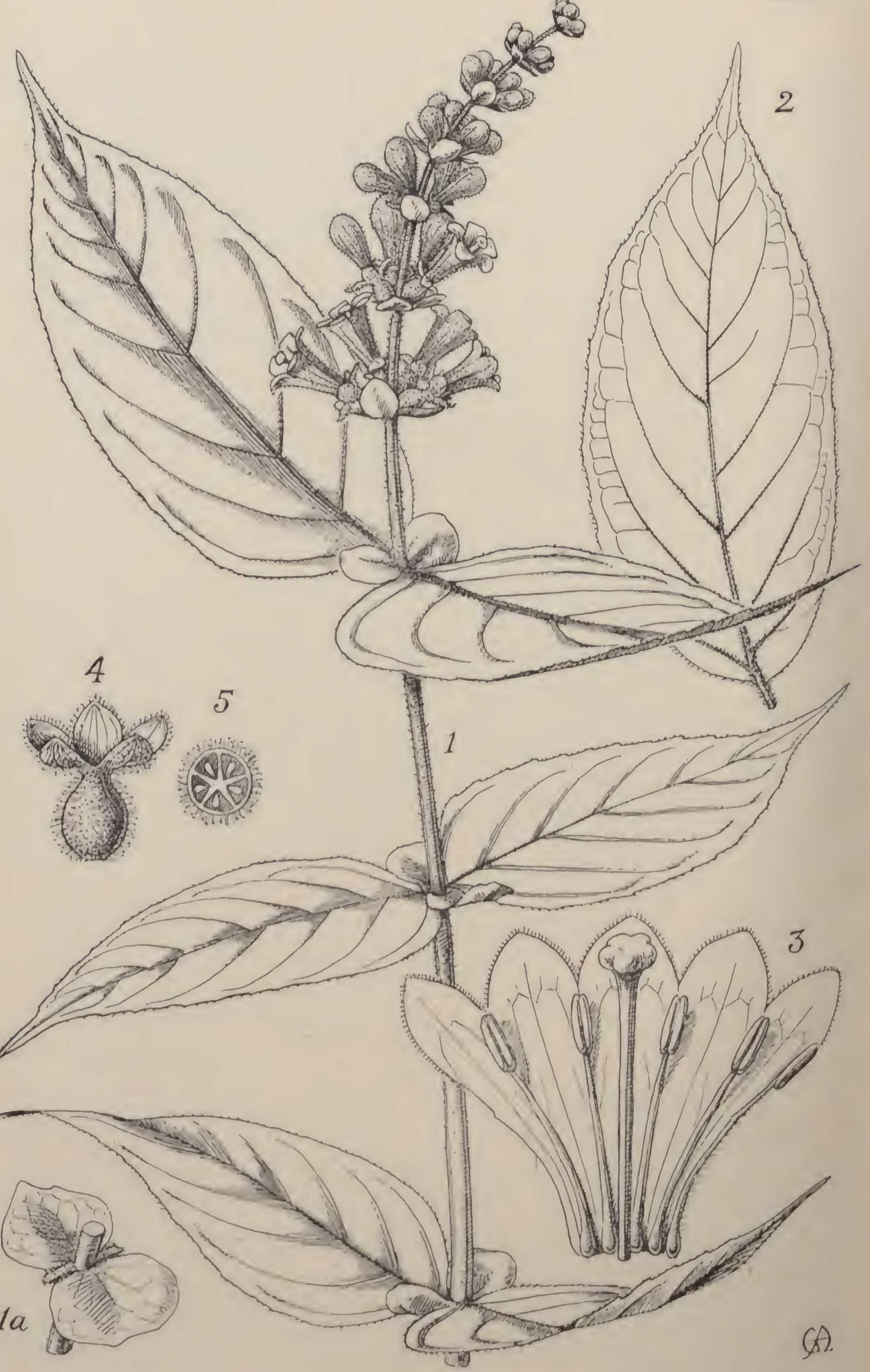




\section{Tabula 3165.}

\section{LEYCESTERIA CROCOTHYRSOS, Airy-Shaw.}

\section{Cairifoliaceat.}

L. (Euleycesteria) crocothyrsos, Airy-Shaw; specics nova, ab omnibus congeneribus corolla aurantiaca basi valde 5 -saccata distinctissima; a L. formosa, Wall, cui quam cetcris forsan propior, stipnlis magnis, stylo pubescente statim distinguenda ; inter species stipulatas, a L. glaucophylla, (Hook. f. et Thoms.) Hook. f., pseudo-verticillis 6-floris, et a $L$. stipulata, (Hook. f. et Thoms.) Fritsch, foliis subtus baud lanuginosis, stylo pubescente diversa.

Frutcx parvus, laxus, statura ignota. Rami annotini ignoti. Rami homotini fistulosi, teretes, usque $4 \mathrm{dm}$. longi (inflorescentia terminali inclusa), circiter $4 \mathrm{~nm}$. diametro, sparsc breviter glanduloso-pilosi vel glabrescentes, basi perulis scariosis latc triangularibus usquc lanceolatis 3-10 $\mathrm{nm}$. longis raro apice foliaccis circiter $2 \mathrm{~cm}$. longis cincti ; internodia circiter $8 \mathrm{~cm}$. longa. Folia is $L$. formosae similia, ovata usque oblonga raro fere ovato-lanceolata, basi rotundata vel vix angustata, apice acuninata conspicuc caudata, usque $12 \cdot 5 \mathrm{~cm}$. longa (cauda circiter $2 \mathrm{~cm}$. longa inclusa), $5 \mathrm{~cm}$. lata, margine (lasi caulaque exceptis) leviter ct subremotc dentata dentilus glanduloso-apiculatis, sparse ciliata, pagina supcriorc olivacen pilis persparsis circiter $1 \mathrm{~nm}$. longis praclita, costa densiusculc loreviter pubescente, nervis glabris, pagina inferiore glaucescente tota minutissime pubcscente (costa manifcstius), hervis utrinque circiter sex; petioli brevissimi, 3-5 mm. longi, plesunque anguste alati, pubcscentes praecipuc supra pilis plus minus "ureis. Stipulae interpctiolares maxinac, latissime reniformes vel suborbiculares, usque $2 \mathrm{~cm}$. latae et $1 \mathrm{~cm}$. longae, basi utrinque petiolis foliorum breviter adnatae, margine integrae vel indistincte crenuatie, supra olivaccac, subtus glaucescentes. Inflorescentia terminalis, longata, plus ininus pendula, usque $12.5 \mathrm{~cm}$. longa, rhachide dense flantluloso-villoso-pubescentc. Flores sessiles in pseudo-verticillis fi-floris (cymulis binis trifloris) dispositi; pseudo-verticilli circiter 7 , omnes loracteis hinis late ovatis acuminatis vel acutis integris basi inemerdatis vel angustatis usque $2 \mathrm{~cm}$. lungis et $1 \mathrm{~cm}$. latis tenuiter Inemloranaceis glabrescentibus dilute purpurascentibus margine dense glanduloso-ciliatis suffulti, bracteolis in quoque verticillo 4 bracteis
similibus sed subduplo minoribus. Receptaculum ovoideum, apice 
subattenuatum, densissime glanduloso-villoso-hispidum, circiter $5 \mathrm{~mm}$. longum, $3 \mathrm{~mm}$. diametro. Calycis segmenta breviter connata, maiuscula, aequalia, ovato-oblonga, subacuta, circiter $5 \mathrm{~mm}$. longa et $3 \mathrm{~mm}$. lata, herbacea, margine glanduloso-ciliata, extra sparse breviter pilosa, intus glabra. Corolla actinomorpha, laete aurantiaca (teste lectore), alabastro late clavata circiter $1.5 \mathrm{~cm}$. longa; tubus sub anthesi late infundibuliformis, circiter $1.5 \mathrm{~cm}$. longus, fauce $1.5 \mathrm{~cm}$. diametro, basi truncato-intrusa in sacculos nectariferos 5 sepalis alternantes conspicue gibboso-ampliatus, 4-5 mm. latus, extra dense glandulosopilosus, intus ad staminum filamenta et ad nervos 5 praecipuos glanduloso-pilosus ceterum glaber; lobi imbricati, patentes, ovato-triangulares, obtusi vel rotundati, circiter $5 \mathrm{~mm}$. longi et lati, extra plus minus glanduloso-pilosi, intus glabri. Staminum filamenta corollae tubo usque ad basin adnata, circiter $1 \cdot 3-1 \cdot 4 \mathrm{~cm}$. longa, dense barbata, parte sexta suprema libera, ipso apice ovoideo-tumidula, dein acuta; antherae oblongae, utrinque obtusae, 3-4 mm. longae, 1-1.5 mm. latae. Stylus in alabastro circiter $1 \mathrm{~cm}$., sub anthesi usque $1.7 \mathrm{~cm}$. longus, satis validus, parte tertia suprema glabra, ceterum dense pubescens; stigma magnum, capitatum, lobatum, circiter $3 \mathrm{~mm}$. diametro. Ovarium quinqueloculare, multiovulatum. Fructus non visi.

Assam. Delei Valley, $28^{\circ} 20^{\prime}$ N., $96^{\circ} 37^{\prime}$ E., $1800 \mathrm{~m}$., growing on the steep sheltered gneiss face, in dense thickets, 8 May 1928, F. Kingdon Ward, 8180. "A small lax shrub. Flowers bright orange."

The genus Leycesteria, Wall., was subdivided by Fritsch (in Engl. \& Prantl, Pflanzenfam. vol. iv. pt. 4, p. 169: 1891) into two sections, Euleycesteria, Fritsch, and Pentapyxis, (Hook. f.) Fritsch, based upon the absence or presence respectively of pith in the stems, the usual absence or presence of stipules, and the zygomorphy or comparative actinomorphy of the corolla. Though Fritsch was undoubtedly right in reducing Pentapyxis to Leycesteria, his two subdivisions are scarcely satisfactory in the light of further investigation. The following arrangement is therefore proposed. (See Kew Bull. 1932, p. 161.)

Subgenus I. EULEYCESTERIA (Fritsch pro sect., emend.), subgen. nov. Ovary 5-locular, glandular-pubescent. Flowers in sixes, rarely in pairs. Bracts more or less broadly ovate, longer than the ovary.Type-species : I. formosa, Wall.

* Section i. Fistularia, sect. nov. Pubescence of lower surface of leaves consisting of sparse, straight, more or less adpressed hairs. Branches subherbaceous, markedly fistular.-T'ype-species : L. formosa, Wall.

Series 1. Formosae, ser. nov. Stipules absent. Corolla white or pinkish, slightly enlarged above the conical base into white or pinkish, slightly enlarged above the conical base infor-
inconspicuous nectaries; style glabrous.-Iype-species: L. for-
mosa, Wall. 
Scries 2. Crocothyrsae, ser. nov. Stipules present. Corolla bright orange-yellow, much dilated at the truncate base into 5 very prominent ncetariferous saes; style pubeseent.-Typespecies: L. crocothyrsos, Airy-Shaw.

** Scetion ii. Pentapyxis, (Hook.f.) Fritsch, emend. Pubeseence of lower surface of leaves consisting of sparse or lanuginose, more or less erisped or ercet hairs, with apparently bulbous bases. Branches not herbaccous. Corolla as in Series 1.-Type-species : L. stipulata, (Hook. f. et Thoms.) Fritsch.

Series 3. Stipulatae, scr. nov. Plant densely lanuginose. Branches solid. Infloreseence of several 6 -flowered falsc whorls. Style glabrous.-Type-species: L. stipulata,(Hook. f. et Thoms.) Fritsch.

Series 4. Glaucophyllae, ser. nov. Plant pubesecnt. Branches fistular. Inflorescence of at most two 2-flowered false whorls. Stylc pubescent.-Type-species: L. glaucophylla, (Hook. f. et Thoms.) Hook. f.

Subgenus II. PARALESTERA, subgen. nov. Ovary 8-locular, glabrous. Flowers in pairs. Bracts very small, subulate, shorter than the ovary. Corolla as in Series 1,3 and 4. Style glabrous. Pubescence as in Section i.-Type-specics : L. gracilis, (Kurz) Airy-Shaw.

The orange colour of the corollas of $L$. crocothyrsos is unique in the genus; they appear also to be larger than those of any other species, and the basal nectariferous saes are very marked. The stipules, which are not developed in the other species of Sect. Fistularia, approach in sizc those of L. stipulata, (Hook. f. et 'Thoms.) Fritsch (Sect. P'cntapyxis). The character of a hairy style is sliared only with L. glaucophylla, (Hook. f, et Thoms.) Hook. f. (Sect. Pcntapyxis).

1. crocothyrsos appers to be extremely restricted in its distribution, and it is difficult to suggest whether it is more probably \& "young" or a " rcliet" species. In its vegetative characters and infloresence it approaches $L$. formosa, Wall., but this affinity can searcely be regarded as a close one.-H. K. AIrI-S11AW:

F'I. 1, upper part of flowcring branch; In, nodc, showing stipules and bases of petioles; ; leaf, lower surface; 3 , corolln. opened out to show stamens and style; 4, ovary and calyx; 5 , ovary, transverse section. Figs. $1,2, \times 3 ;$ fig. la, nalural size; fiys. $3,4, \overline{5}, \times 2$. 




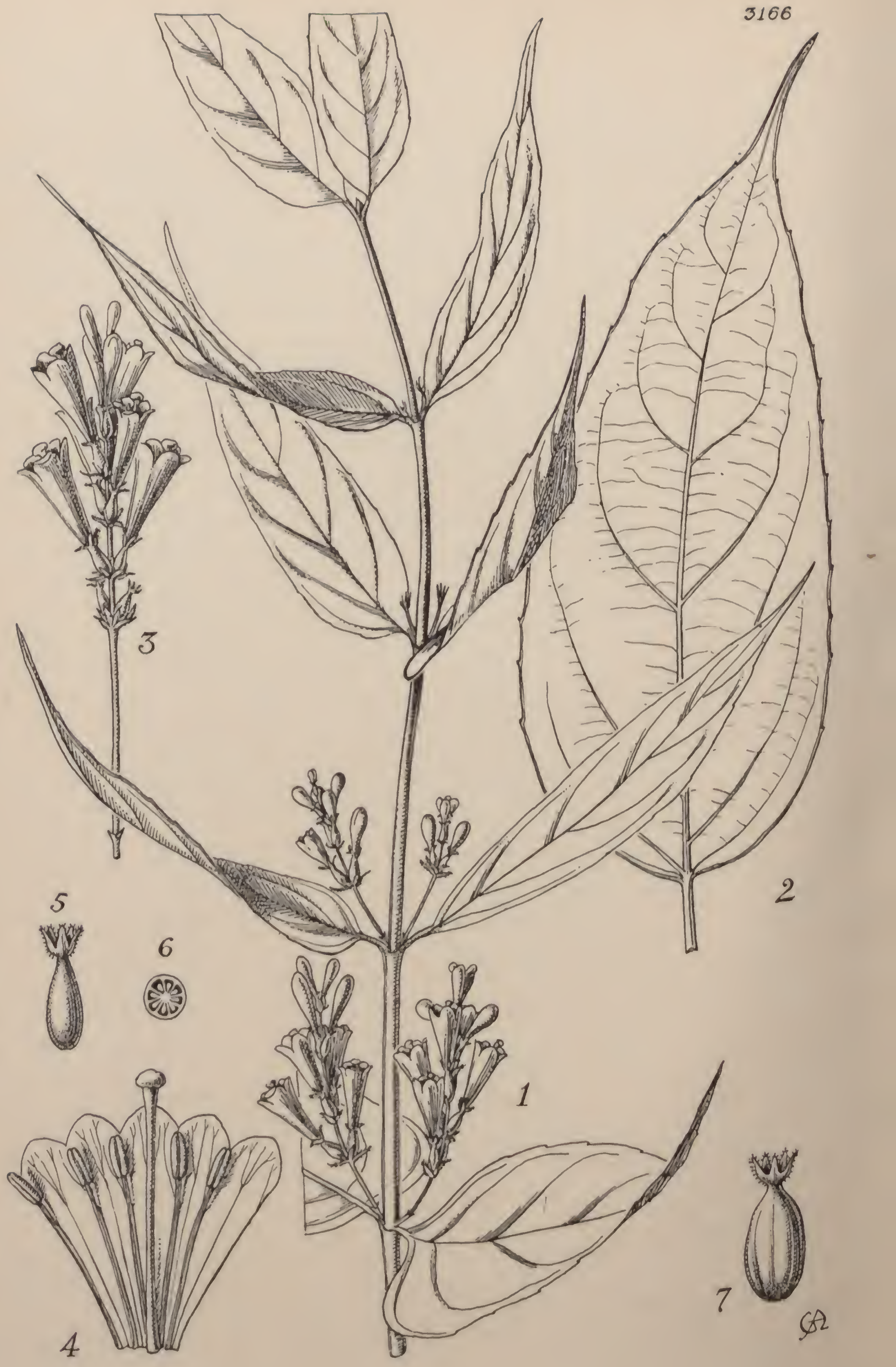




\section{TabUla 3166.}

\section{LEYCESTERIA GRACILIS, (Kurz) Airy-Shaw.}

\section{Caprtfoltaceate.}

L. (Paralestera) gracilis, (Kurz) Airy-Shaw, comb. nov.; ovario 7-8-loeulari, braeteis braeteolisque ovario brevioribus, floribus praeter ealyeis lobos glanduloso-eiliatos glaberrimis in genere unien; floribus pricterea in infloreseentias graeiles foliis multo breviores deeussatim dispositis porro distiuguenda.

Frutex glaber, graeilis, subscandens, 1-3-metralis. Rami subsimplices, inde a basi fere areuati, teretes, graeiles, subherbaeei, fistulosi, in speeininibus exstantibus raro usque $5 \mathrm{~mm}$. dianetro, nodis haud eonstrictis ; internodia 7-11 en. longa. Folia ovato-laneeolata usque oblongo-laneeolata, basi (raro levissime angustata) rotundata usque subtruneata (raro subeordata), apiee aeuminato-eaudata, acuta, usque $17 \cdot 5 \mathrm{em}$. longa, $8 \mathrm{em}$. lata, margine levissime et remote glandulosodentata, rarissime (in speeiminibus sinensibus) fere integra, pagina superiore surde viridia, glaberrima, pagima inferiore conspieue glauea, glaberrima vel eosta basin versus pilis sparsis praedita, nervis utrinque eireiter quinque; petioli usque $1.8 \mathrm{~cm}$. longi, supra suleati, basi in anıulun connati. Inflorescentiae axillares, oppositae, vel raro terninales, graciles, ereeto-patentes, usque $7 \mathrm{em}$. longae (pedunculo $1-3 \mathrm{em}$. longo ineluso), foliis multo breviores, simpliees, braeteis binis ad ipsam basin vel paullo supra basin transversim positis (raro etiam pari altero paullo superiore deeussato) sieeis deltoideis earinatis aeuto-aeuminatis basi eonnatis circiter 1-2 $\mathrm{mm}$. (rarissime usque $5 \mathrm{~mm}$.) longis semper praeditac. Flores sessiles, per paria usque sex decussata dispositi, internodiis 5-9 min. longis sejuneti. Bractea sub quoque flore unien, herbaeea, subulata usque ovato-laneeolata, 3-4 $\mathrm{mm}$. (raro usque $6 \mathrm{~mm}$.) longa, brevissime sparsiuseule eiliata, apiee acuta saepe acuminata, basi 1 inn. lata cum bratea floris alterius brevissime eonnata, angulo reeto a rhachide patens. Bracseolae sub quoque flore binac, oppositae, braeteis simillimae sed tantum 2-3 mm. longae, subglanduloso-eiliatae. Receplaculum sessile, anguste ovoidenm usque ellipsoideum, sub anthesi 4-5 min. longum, 1-2 mm. diametro, glaberrimum, npiee attenuato-constrictum. Calyx ex apice receptaculi abrupte ortus, $2-3 \mathrm{~mm}$. longus ; segmenta inferne in cupulam apertann breviter eonnata, superne libera, patula, sulsulata, subaeuta, sparso glanduloso-eiliata, simubus rotuudatis. Corolla albida, infundibuliformis, eireiter $1.5 \mathrm{em}$. longa, glabra, basi fere $2 \mathrm{~mm}$. diametro gibbis 5 oblongis eireiter $1 \mathrm{~mm}$. longis vix proninulis praedita, fanee $5-8 \mathrm{~mm}$. 
diametro, limbi lobis ovatis erectis vel vix patulis $3-4 \mathrm{~mm}$. longis et latis rotundatis. Staminum filamenta glaberrima, paullo sub sinubus corollae limbi inserta, sed manifeste corollae usque ad basin adnata, parte libera circiter $2 \mathrm{~mm}$. longa ; antherae oblongae, utrinque obtusae, circiter $2 \mathrm{~mm}$. longac. Stylus exsertus, circiter $12 \mathrm{~mm}$. longus, glaberrimus; stigma magnum, capitatum, lobatum, 1-2 $\mathrm{mm}$. diametro. Bacca ovoideo-ellipsoidea, usque $8 \mathrm{~mm}$. longa et $4 \mathrm{~mm}$. diametro, glaberrima, calyce persistente coronata.-Lonicera gracilis, Kurz in Journ. As. Soc. Beng. vol. xxxix. part 2, p. 77 (1870). Lonicera glaucophylla, [? Lindley] in Gard. Chron. \& Agric. Gaz. [vol. xviii.] p. 700 partim, fig. 2 sinistr., non dextr. (1858), non Hook. f. et Thoms. in Journ. Linn. Soc. vol. ii. p. 165 (1858). Leycesteria glaucophylla, Hook. f. ex C. B. Clarke in Hook. f., Fl. Brit. Ind. vol. iii. p. 16 (1880), pro parte.

Sikkrm. Yoksun [near base of Kinchinjunga, alt. 1500 m.], 1857, T. Thomson. Simonbong, [Anderson in] Herb. S. Kurz (type). Labah, Dumsong, $1800 \mathrm{~m}$., March 1875, Gamble, 3073A : "Very pretty small shrub ; fruits blue." Chota Rimitti, Darjceling, 2100 m., Nov. 1879, Gamble, 7451. Labah Ridge, 2100 m., Dec. 1904, H. H. Haines, BB 2002.

Bhutan. Without definite locality, Booth in Herb. Nuttall.

Yunnan, W. On hills to west of Tengyueh, amongst scrub, lat. $25^{\circ}$ N., 1800 m., June 1912, Forrest, 8261 : "Shrub of 3-6 ft., in fruit." Open situations in thickets on western flank of Shweli-Salwin Divide, lat. $25^{\circ} 20^{\prime}$ N., 2100-2400 m., Nov. 1912, Forrest, 9377 : "Shrub of 3-9 ft. Flowers white." Amongst scrub by streams on the ShweliSalwin Divide, lat. $25^{\circ} 10^{\prime}$ N., 2400 m., July 1918, Forrest, 17527 : "Shrub of 4-7 ft. Flowers white, flushed rose exterior." Open situations by streams on the Shweli-Salwin Divide, lat. $25^{\circ} 45^{\prime} \mathrm{N}$., long. $98^{\circ} 50^{\prime}$ E., $2400 \mathrm{~m}$., Nov. 1924, Forrest, 26032: "Shrub of 6-9 ft. Branches arched almost from base. Flowers white."

Yunnan, S.E. South of Red River from Manmei, 1800 m., Henry, 9767 : "Shrub, $10 \mathrm{ft}$. ; white flowers."

This species (long known erroneously under the name of L. glaucophylla, Hook. f.) occupies a rather isolated position in the genus. It is chiefly remarkable for the tendency to pleiomery of the gynoecium. The inflorescence presents a strikingly different appearance from those of the other species, being virtually glabrous, with extremely short bracts and bracteoles and the flowers arranged in pairs. L. glancophylla, (Hook. f. et Thoms.) Hook. f., is also notable for this last character, but has otherwise no close affinity with the present species.H. K. Airy-Shaw.

Fic. 1, upper part of flowering branch, $\times \frac{2}{3} ; 2$, leaf, lower surface, $\times \frac{8}{3}$; 3 , inflorescence, natural size; 4, corolla, opened out to show stamens and stylo; 5 , ovary and calyx; 6 , ovary, transverso section; 7 , fruit, with persistent calys. Figs. 4, 5, 6, 7, × 2 . 



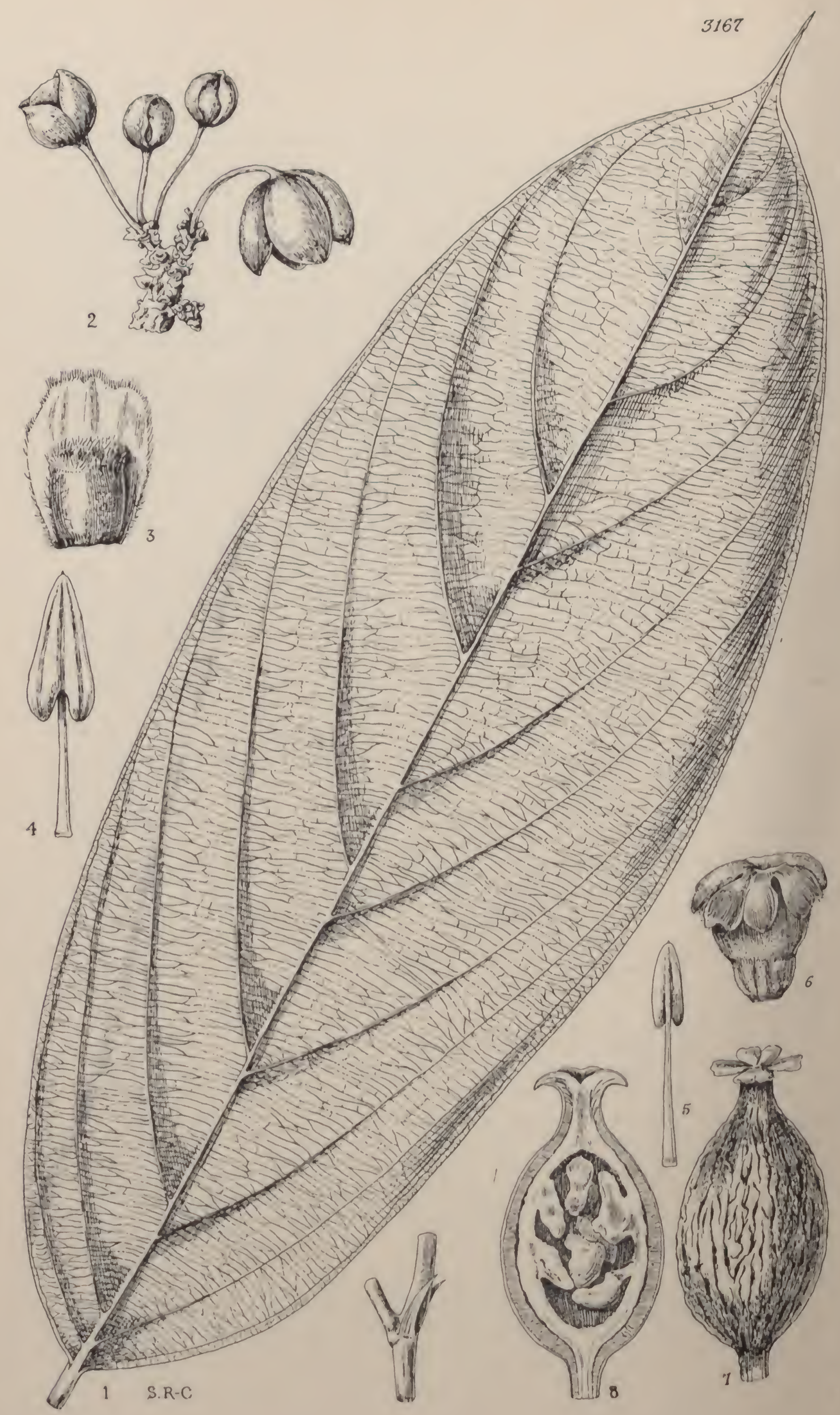




\section{Tabula 3167.}

\section{TARAKTOGENOS CALOPHYLLA, Ridley.}

\section{Flacourtiaceae. Tribus Pangieae.}

T. calophylla, Ridley; spccics nova, T. Kurzii, King, affinis, a qua foliis maximis, floribus e trunco exortis differt.

Frutex $3 \mathrm{~m}$. altus, caulc simplici. Ramuli angulati, profunde sulcati, pulscruli, apices versus circiter $2.5 \mathrm{~mm}$. diametro, corticc pallido. Folia oblonga vel elliptico-oblonga, abrupte cuspidata, cuspide acute acuminato $2 \cdot 5 \mathrm{~cm}$. longo basi $5-6 \mathrm{~mm}$. Iato medio $2-2 \cdot 5 \mathrm{~mm}$. lato, basi inaequilateralia, laterc altcro obtuso altero rotundato, vel subcuncata, 30-35 cm. longa, 9-13 cm. lata, coriacen, costa in apicem cuspidis producta, utrinque praccipuc subtus clevata, ncrvis lateralibus utroque latcre costae 8 supra prominulis subtus prominentibus, nervis tertiariis transversis copiosis parallelis conspicuis, rete venularum utrinque clevato manifesto; petioli $1-2 \mathrm{cn}$. longi. Raeemi crassi, pauciflori, bracteis persistentibus ovatis coriaccis tecti ; pedicelli

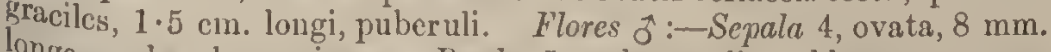
longa, pubcrula, coriacca. Petala 5, subaequalia, oblonga, squama singula basali crassa rotuudata hirsuta. Stamina 21 ; filamenta $5 \mathrm{~mm}$. longa, glabra; anthcrac lincares, basi retusac. Flores o:- Sepala longiora patentia vel deflexa, oblonga, $1 \mathrm{~cm}$. longa. Petala minora, rotundata. Orarium basi angustatum, superne incrassatum, costatum, vclutinum; stigmata 4, late oblonga, 3-4-lolsa. Staminodia pauca, reviora, filamentis gracilibus, antheris abortivis. Bacca fusiformis, versus apiccm et basin angustata, $4 \mathrm{~cm}$. longa, $2 \mathrm{~cm}$. lata (in siccitate). Semina circiter 13.

SAlawak, Kuching, unbranched shrub 20 fcet high, polygamodioecious, Haviland, 1795 (typc), Haviland and Hose, 3241.

I know no other specics at all like this. It is a shrub with the largest leaves in the genus, and the flowers in short racemes on the stem.-
II. N. Rinlry.

floresce 1, leaf, showing upper surface, and node with stipules, $x \frac{2}{3} ; 2$, 8 inoutsille, natural size; 3 , petal, seell from within, $x 4 ; 4$, stamen from longitudinal $\times 4$, staminode, $\times 8 ; 6$, pistil, $\times 2 \frac{1}{2} ; 7$, fruit, nutural size; 8 , fruit, gitudinal section, natural size. 




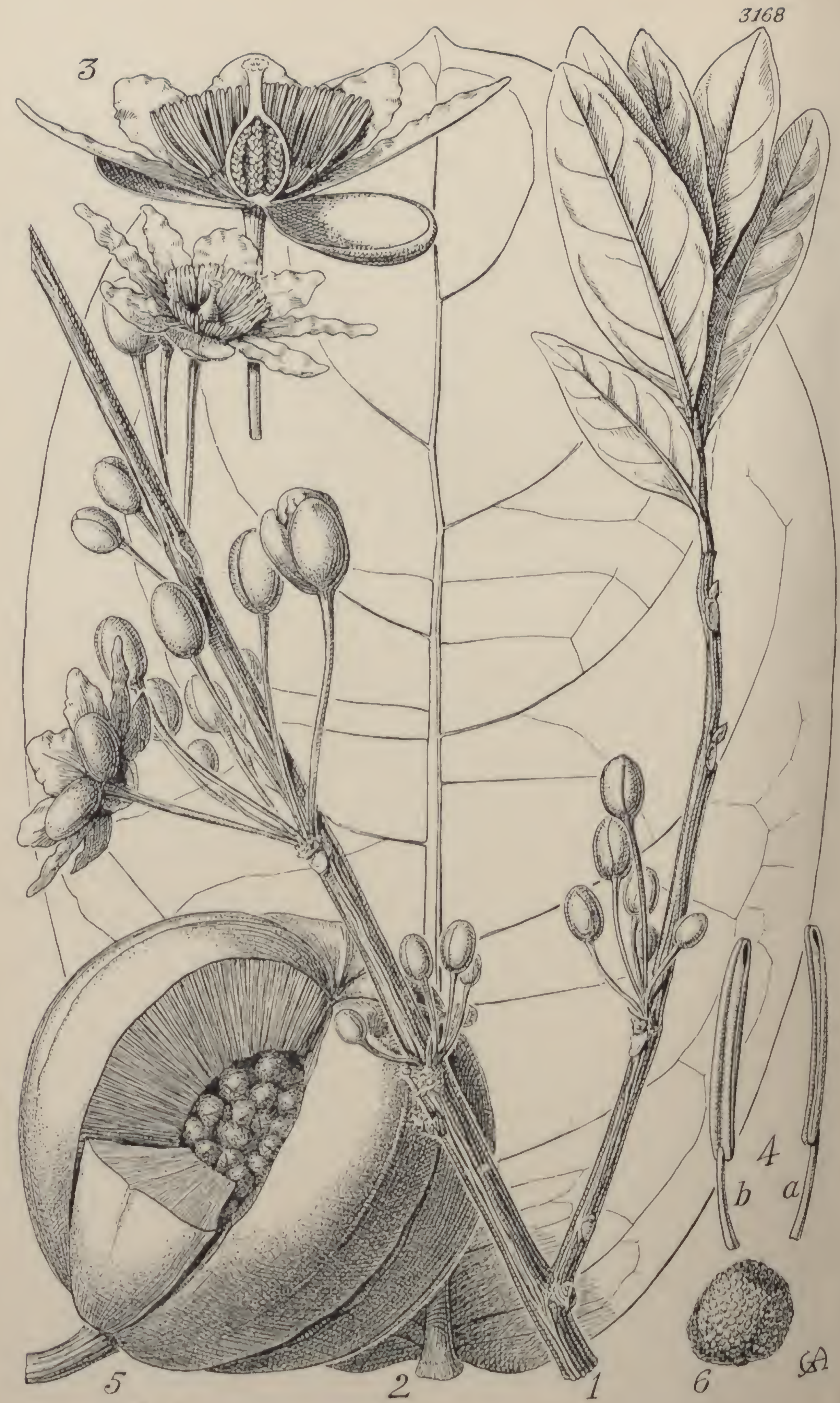




\section{TABULA 3168.}

\section{PARAPHYADANTHE SUFFRUTICOSA, Milne-Redhead.}

\section{Filacourtaceae. 'Tribus Oncobeae.}

P. suffruticosa, Milne-Relheal; speeies nova a P. Ragellifora, Mildbr., et $P$. coriacen, Mildbr., faseienlis florum in nxillis foliorum nee in eaulibus propriis ortis distineta; a $P$. lophocarpa, (Oliv.) Gilg, foliis subsessilibus basi eordatis reeedit.

Suffrutex decidnus, rhizomate crasso lignoso, eaulibus multis ereetis simplieibus vel paueiramosis usque $90 \mathrm{em}$. longis, cortiec longitudinaliter costato brunneo. Folia subsessilia, stipulata, elliptiea usque DVato-oblonga, nonnunquan subobliqua, apiee brevissime obtuse euspidata, basi eordata sinu 2-8 mm. alto, $13-26 \mathrm{~cm}$. Ionga, $7 \cdot 5-16 \mathrm{~cm}$. lata, integra sed verosiniliter subundulata; costa et nervi laterales utrinque prominentes; nervi laterales utringue $6-10$, e basi patente vel patula versus marginem aremantes, medii $1 \cdot 3-2 \cdot 8 \mathrm{~cm}$. intra marginem anastomosantes; nervi tertiarii e lateralibus patule orti, quaternarii et ultimi rete eonspieum formantes; folia juvenilia utrinque valde glutinoso-nitenia, perjuvenilia dense tubereulata; stipulae subulatae, circiter 2 mu. longae, eaduene. Flores ali maseuli alii hermaphroditi, hi saepe inajores, in axillis foliorum delapsorum 3-6-faseieulati; pedicelli $1.5-6 \mathrm{~cm}$. Iongi, bracteis singulis minutis triangularibus Sufulti, praesertim juventute dense purpureo-glandulosi. Flores $\hat{\sigma}$ :Sepala 3 , imbrieata, valde coneava, late elliptiea, $12 \mathrm{~mm}$. longa, $9 \mathrm{~mm}$. lata (statu explanato), parte in alabastro externa glandulosa. P'ctala 8 , oblongo-elliptica, margine irregulariter undulato, eireiter 2 em. longa, 2-11. lata, alba, basin versus aureo-venosa. Stamina eireiter 50, dith mm. longa; filamenta subfiliformia, 2-4 mm. longa; antherae ditheeac, basifixae, $6-8 \mathrm{~mm}$. longne, vix I mm. latae, seeus totam fongitudinem fissae sed apiee tantum porum dehiscentiae formantes. filores of:-Sepala et stamina iis floris of similia. Pctala etiam similia, cireiter 7 aucta usque $3 \mathrm{em}$. longa et $1.3 \mathrm{~cm}$. lata. Ocarium ovoideum, paullulo $7 \mathrm{~mm}$. longum et $5 \mathrm{~mm}$. diametro, longitudinaliter eostatum, uniloeu tuberculatum, apieem versus paree ae ineonspieue puberulum, vixiloeulare; plaeentre 5-7, ovulis numerosis; stylus $4 \mathrm{~mm}$. Iongus, quingueplicato unde stigms prino visu peltatum videtur. Capsulac 
circa basin caulium ortae, magnae, subcarnosae, immaturac laeves, virides, obovoideae vel subglobosae, obscure longitudinaliter costatae, maturae usque $12 \mathrm{~cm}$. diametro, pericarpii muro lacunis vacuis $5-7$ placentis alternantibus instructo, tandem per medias lacunas vacuas loculicide dehiscentes; valvae post dehiscentiam basi connatae, apice plus minusve connatae; pedicelli capsularum usque $5 \mathrm{~cm}$. longi, $7 \mathrm{~mm}$. diametro. Semina subglobosa, angulata, dense tuberculata, $7.5 \mathrm{~mm}$. diametro; testa crustacea, circiter $1 \mathrm{~mm}$. crassa; tegmen brunneum, membranaceum ; endospermium copiosum, $6 \mathrm{~mm}$. longum, $5.3 \mathrm{~mm}$. diametro ; embryo $5.3 \mathrm{~mm}$. longum, cotyledonibus ellipticis $2.6 \mathrm{~mm}$. longis apice strato endospermii $1 \mathrm{~mm}$. crasso a tegmine disjunctis ; radicula cylindrica, $2 \cdot 7 \mathrm{~mm}$. longa, $1 \mathrm{~mm}$. diametro, apice valde depresso-conica tegmen attingens.

Northern Rhodesia. Solwezi District; in dry dambo (grassland) at Solwezi Boma, before burning, mature leaves and unripe fruit, 10 June 1930, Milne-Redhead, 470; in open Brachyslegia woodland between R. Mumbezhi and R. Lumwana, to the west of Solwezi Boma, flowers and young leaves, 16 Sept. 1930, Milne-Redhead, 1133 (typus); in dambo at Solwezi Boma after burning, young shoots and mature fruit, 24 Sept. 1930, Milne-Redhead, 1133A. Also seen near R. Mutanda, west of Solwezi Boma, in open Brachystegia woodland. Vernaculiar name "Munkolokolo" (Chikaonde).

The genus Paraphyadanthe, described by Mildbraed in Noti\%bl. Bot. Gart. Berl. vol. vii. p. 402 (1920), was based on specimens collected by him in the Cameroons, representing two new species, namely $P$. flagelliflora, Mildbr., and P. coriacea, Mildbr. A third species, P. lop $\}^{10^{-}}$ carpa, (Oliv.) Gilg, also a native of the Cameroons, was doubtfully transferred to the genus from Oncoba by Gilg in 1925. The genus difiers from Oncoba and its segregated genera in the flowers arising on short shoots, and in the apical dehiscence of the anthers.

$P$. coriacea, Mildbr., is described as being an arborescent shrub, and $P$. lophocarpa, (Oliv.) Gilg, is a tree up to $12 \mathrm{~m}$. in height, while $P$ '. flagelliflora, Mildbr., is a small tree bearing its flowers on procumbent terrestrial shoots, $10 \mathrm{~m}$. long or more, arising from the base of the trunk. The subject of this plate, however, is a subshrub less than $1 \mathrm{~m}$. high, apparently adapted to withstand savannah conditions. The numerous erect shoots, arising from a woody rootstock, seldom escape destruction when the annual grass fires sweep the country at the end of the dry season. Before the start of the rains, however, buds at the base of the burnt-off shoots have come into growth, and not only is the plant in full flower but the new leafy shoots are rapidly developing. The fruit, when first seen early in June, was fully grown but had not dehisced. It was deep green, smooth, and almost spherical, and was resting among the fallen leaves which surrounded the leafless shoots. When seen in September, after the grass fires, the fruit was dry and had dehisced, but apart from slight external scorching, it was entirely 
undamaged, and the seeds, having fallen out, were scattered on the bare soil around the plant. When the one-year-old shoots escape destruction, the flowers occur on short shoots in the axils of the fallen leaves all up the stem.-E. MILne-REdHeAd.

Fia. 1, portion of flowering stem showing young leaves, natural size; 2, leaf, natural size; 3 , hermaphrodito flower, cut longitudinally, $\times 1 \frac{1}{2} ; 4 \mathrm{a}$, b, anthers, $\times 4 ; 5$, fruit, with portion of periearp removed to show seeds, $\times \frac{2}{3} ; 6$, seed, $\times 2$. 



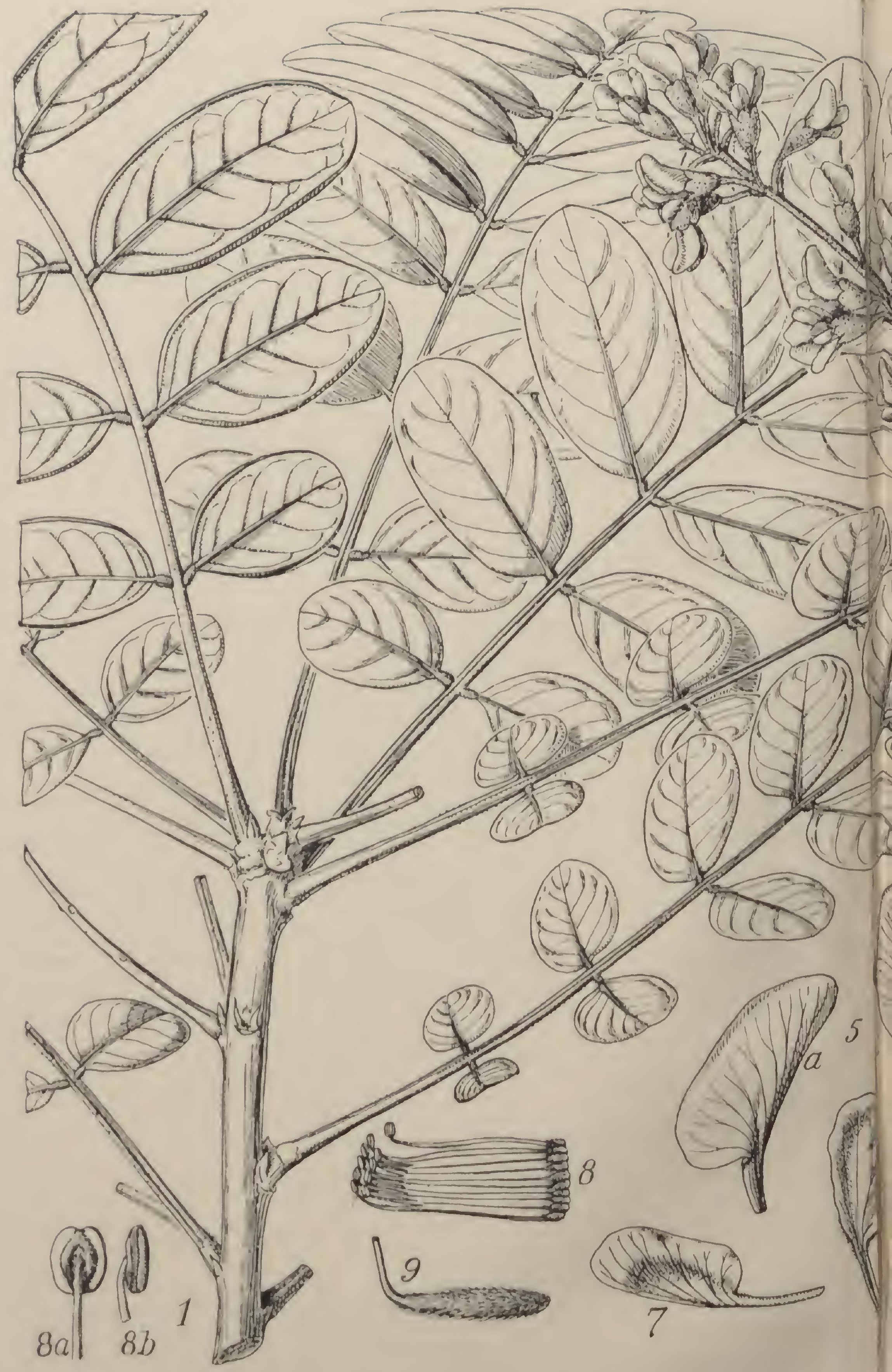





\section{Tabula 3169.}

\section{DALBERGIELLA NYASAE, L.G. Baker.}

\section{Leguminosae. Tribus Dalbergieate.}

D. nyasae, E. G. Baker, Leg. Trop. Afr. p. 535 (1929); a D. Welwitschi, (Baker) E. G. Baker, foliolis paucioribus, magis coriaceis, leguminum pilis plumosis differt.

Arbor parva, circiter $5 \mathrm{~m}$. alta, decidua, ramis diffusis. Ramuli cortice plumbco vel cincrco tecti. Folia imparipinnata, 14-24 cm. longa; petioli usquc $3 \mathrm{~cm}$. longi, primum brunneo-tomentosi, demum demeruli; rhachides 10-17 cm. longi, primum brunnco-tomentosi, demum puberuli ; foliola subopposita, 6-10-juga, petiolulata, oblonga vel clliptica, parum inacquilateralia costa subcentrali, apice obtusa vel brundata, basi late cuncata vel rotundata, petiolulis $1-2 \mathrm{~mm}$. longis latanco-tomentosis, margine revoluta, $1 \cdot 5-3 \cdot 5 \mathrm{~cm}$. longa, $1-1 \cdot 8 \mathrm{~cm}$. Juberuriaen, supra glabra, nitidula, subtus margine et nervis leviter subtulis cxceptis glabra; costa ct nervi laterales supra prominuli, stipulae lie conspicui ; foliola immatura discoloria, utrinquc puberula ; persistenteares, circiter $2 \mathrm{~mm}$. lougac, deuse brunnco-tomcntosac, racentes. Inflorescentiac densiflorac, angustc pauiculatae vel sublisque bae, 12-28 cm. longac, rhachidibus bractcis pedunculis pediceltomentrunneo-tomentosis. Calyx usque $6 \mathrm{~mm}$. longus, brumeolobuntosus, dentc inferiore paulo longiore, duolus supcriorilus in diametatum connatis. Verillum late suborbiculare, circiter $8 \mathrm{~mm}$. $5 \mathrm{mn}$. longue $3 \mathrm{~mm}$. longo; alac obovatac, longe unguiculatac, similis longae, $2 \cdot 5 \mathrm{~mm}$. latae, ungnc $5 \mathrm{~mm}$. longo; carina alis sub$0.5 \mathrm{~lm}$. Slamina diadelpha, vexillari libro, $7-8 \mathrm{~mm}$. longa; antherae stylus simp diametru. Oiarium liucare, tomentosun, 4-ovulatum; Ifgumen simplex, glaber, circiter $4 \mathrm{~mm}$. lougus, stigmate terminali. recta vel limmaturum) latc oblongum, sutura dorsali plus minusve ginata sinu leviter curvata, sutura ventrali magis curvata quasi emardita, ovul unico circa medium latissimo (sed haud rotundato) pracBensim paulo unico fertili sinus angulo affixo, sinu scminc inaturescentc omnino paullo profundiore facto, apicc latc acutum, basi cuncatum, diaphanum, plani, 7-9 cm. longum, 2-3 cm. latum, firme papyraceum, densissimis, viride vel rubescenti-viride, sutura ventrali pilis insignibus ssinis pallide fulvis valde plumosis irregulariter undulatis $3 \mathrm{~mm}$. 
longis vestitum, sutura dorsali pilis similibus multo brevioribus vestitum, pagina utraque pilis simplicibus pubescente pilis majoribus bifurcatis stellatisque inspersis.

Nyasaland. Lukoma, Lake Nyasa [Likoma Island, E. of Lake Nyasa], Aug. 1887, Wm. Bellingham, sine numero. (Typus in Herb. Mus. Brit.)

Northern Rhodesia. Chilanga District: several trees near King Edward's Copper Mine, Native Reserve Country, 11 Sept. 1929, Mrs. Sandwith, 4. Trees with few leaves and loaded with rather sweetscented flowers. Mazabuka District: in Acacia grassland at Mazabuka, 6 Oct. 1930, Milne-Redhead, 1209. Small tree up to $5 \mathrm{~m}$. high, with young leaves and unripe soft greenish fruits; a few mature leaves also obtained. Vernacular names "Kafundula " (Chila), "Mwambanongo" (Chitonga).

The genus Dalbergiella, E. G. Baker, was founded on Ostryocarpus? Welwitschii, Baker in Oliv. Fl. Trop. Afr. vol. ii. p. 240 (1871). This and D. nyasae, which have obtuse or rounded leaflets, appear to be closely related. The third species, D. Gossweileri, E. G. Baker, differs in having acuminate leaflets. Both D. Gossweileri and D. Welwitschii are described as scandent shrubs, whereas $D$. nyasae is a small tree attaining a height of about 5 metres.

It is surprising that this interesting tree, which is very conspicuous when in flower and fruit, and is by no means uncommon, should not have been collected in Northern Rhodesia before the year 1929, when Mrs. Sandwith obtained good flowering material from the Chilanga District. The writer collected it in fruit in Oct. 1930, during a short stay at Mazabuka, where it was common, growing with Lonchocarpus Menyharthii, Schinz, and L. Capassa, Rolfe. The fruits of Dalbergielle nyasae were hitherto unknown, and are here described and figured for the first time. In gencral shape and texture they are similar to those of $D$. Welwitschii, but are remarkable in being fringed with plumose hairs. In the figure of D. Welwitschii given in Journ. Bot. June 1928, Suppl. I. p. 129, the seed is inadvertently shown as though it were attached to the dorsal suture.

There is some doubt as to the exact position of the type-locality, given by Bellingham as "Lukoma, Lake Nyasa." It is probably what is now known as Likoma Island, situated towards the eastern shore of Lake Nyasa, but belonging to Nyasaland, although there is a possibility that Lukoma Bay, situated in Tanganyika Territory to the north of the island, was the locality concerned.-E. Mrune-Rediead.

Fia. 1, leafy branch ; 2, part of flowering branch ; 3, a, b, flower, anterior and 4 calys, cut open. $5, \mathrm{~b}$, vexillum, lateral and posterior views; lateral views ; 4 , calyx, cut open ; 5 , a, b, vexillum, lateral and poster $; 8 a, 8 b$,
6 , ala, from inside; 7 , petal of carina, from inside; 8 , androecium $; 8$ osterior anthers, exterior and lateral views ; 9 , pistil ; 10 , legumes; 11 , portion of post siae ; margin of legume; 12, marginal hair of the same. Figs. 1, 2, 10, natural figs. $3-8,9,11, \times 3$; figs. $8 \mathrm{a}, 8 \mathrm{~b}, \times 12 ;$ fig. $12, \times 20$. 



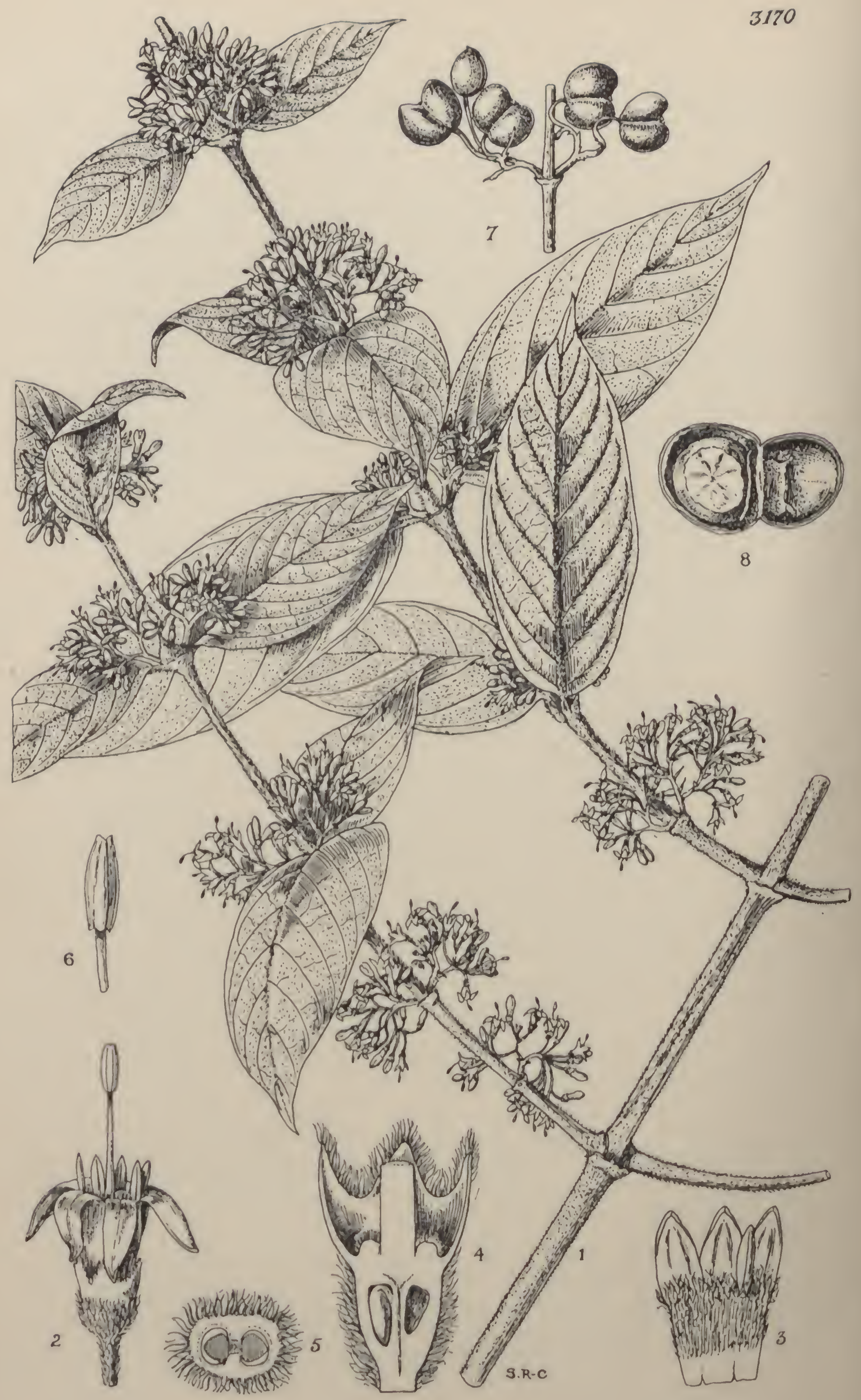




\section{TABULA 3170.}

\section{CANTHIUM GUEINZII, Sond.}

\section{Rubiaceae. Tribns Vasguerieae.}

C. Gueinzii, Sond. in Linnaea, vol. xxiii. p. 54 (1850); et in Harv. et Sond., Fl. Cap. vol.iii. p. $16(1861-65)$; $\mathrm{C}$. hispido, Bcuth., ramorum indumento multo densiore breviore nec laxe strigoso-villoso nec persistente facilc distingucuda.

Frutex scandens, ramis angulo recto iuscrtis, ramulis junioribus sul,teretibus, ferruginco-tomentosis usque hispido-tomentosis, demum glabresecntiluus vel leviter pubescentibus. Folia oblouga usque oblongo-clliptica vel obovata vel ovata, apice acute longe acuminata, basi subcordata usque satis profunde cordata, $4 \cdot 5-9 \mathrm{~cm}$. longa, $2-4 \cdot 5 \mathrm{~cm}$. lata, supra glabrescentia, sul,tus costa ct nervis lateralibus (utrinsceus 7-9) praesertim pubescentia; petioli circiter $5 \mathrm{~mm}$. longi. Stipulae mox caducac, triangulari-ovatae, apice longe acuminatac, 7-9 $\mathrm{mm}$. longae, intus glabrac, cxtra pubescentes. Cymae axillares, dichotomac, multiflorae, congestac, pedunculis tomentellis circiter $1-1 \cdot 5 \mathrm{~cm}$. longis, pediecllis tomentello-pubescentibus gracilibus 5-7 mm. longis. Calyx late campauulatus, 5 - -lenticulatus, $1.5 \mathrm{~mm}$. longus, denticulis margine setosis. Corolla alba vel lutco-alba, 5-lobn, alibastro circiter $6 \mathrm{~mm}$. longa, apice rotundata; tubus cylindrico-turbinatus, circitcr $3.5 \mathrm{~mm}$. li) ngus, fauce villosus; lobi oblongi, circiter $2.5 \mathrm{~mm}$. lougi, apico subacuti, sub anthesi reflexi. Otarium 2-loculare; stylus longc cxscrtus, 6 mun. longus, stigmate capitato-mitriformi $1.5 \mathrm{~mm}$. longo. Fructus drupraceus, didymus vel subglobosus, 2-locularis vel abortu 1-locularis, loculis 5-8 min. dianetro.-Plectronia Gueinaii, (Sond.) Sim, For. Fl. Cape Col. p. 241 (1907); Sim, Nistive Timbers S. Afr. p. 223 (1921); Marlotl, Dict. Fl. S. Afr. p. 129 (1917); Wood, Fl. Natal, p. 62 (1907), et in Trans. S. Afr. Phil. Soc. vol. xviii. p. 164 (1903). Kectia transvalensis, Phillips, Gen. S. Afr. Fl. Pl. p. 587 (1926), et in Bothalia, vol. ii. p. 368 (1927).

'T'ropical Africa. Uganda : Mit. Elgon, Bumoni, 1800 m., 23 March 1524, Snowden, 861; Ruwenzori, Wimi Forest, $2400 \mathrm{~m}$., June, Scoll liliot, 7913. Kcnya Colony: Eubu, 1650-1950 m., Battiseombe, 20; Feb ru, 2100 1n., 21 Junc 1918, Snowden, 634; Kisumu, 2100 m., . 1915, Jümmer, 1685 ; Aberdare Mts., 1500-1800 m., Moon, 752. 
Tanganyika Territory: N. of Lake Nyasa, higher plateau, Thomson, s.n.; near Ufiume Mt., 1650 m., 21 Jan. 1928, Burtt, 1229; forest, Kinyassi Scarp, Kondoa District, 1800 m., 7 Jan. 1928, Burtt, 960. Nyasaland: Plains of Zomba, 750-900 m., Whyte, 90, et s.n.; Shiré Highlands, Buchanan, s.n. Portuguese East Africa : Mt. Pene, 2100 m., Oct., Swynnerton, 6101.

South AFrica. Transvaal: Houtbosch, Rehmann, 6471, Nelson, 432 ; Barberton, 1050-1500 m., Sept. 1889, Galpin, 519. Natal: Durban, Gueinzius, s.n. (type), Gerrard, 535; Inanda, Wood, 305; Dumisa, 540 m., 28 Oct. 1908, Rudatis, 435a; Zululand, Wylie in Herb. Wood, 8550 .

The masses of creamy or yellowish-white flowers produced by this liane, and its wide distribution as a member of a genus the species of which are relatively local in occurrence, constitute its main claims to distinction. It is, however, of no less interest from the purely taxonomic point of view, on account of its close alliance with other species, notably C. hispidum, Benth., and C. sylvaticum, Hiern, and one or two others at present undescribed. This group of species is widely distributed over the whole of Tropical Africa, and the individual species overlap to a considerable extent. In the regions of overlap, it is often extremely difficult to assign a herbarium specimen to one or other of these species, though perfectly distinct examples of each occur in the same locality. Typical $C$. Gueinzii is readily distinguished from all other species by the reddish tomentum of the young branchlets and by the tertiary nerves being impressed in the glabrous upper surface of the mature leaves.

The locus classicus is Durban, where the plant was collected by Dr. Gueinzius. Since then it has been collected many times, and its range throughout the eastern half of tropical and subtropical Africa must now be almost completely known.

In South Africa C. Gueinzii is known popularly as "Monkey Rope," a name aptly indicating its widely scrambling habit. The Zulus know it as "um-Nyizi," and in Tropical Africa numerous native names have been recorded for it which, however, do not appear to be specific.A. A. Bulloock.

FIG. 1, portion of branch, showing two flowering branchlets, $x \frac{2}{3} ; 2$, flower, 4; 3 , part of corolla, thrown open and showing insertion of a stamen, $x$; 4 , longitudinal section of ovary showing the calyx and disk, $\times 12 ; 5$, transverso section of the same, $\times 12 ; 6$, stigma, $\times 8 ; 7$, infructescence, $\times \frac{2}{3} ; 8$, transverso section of fruit, $\times 2$. 

3171
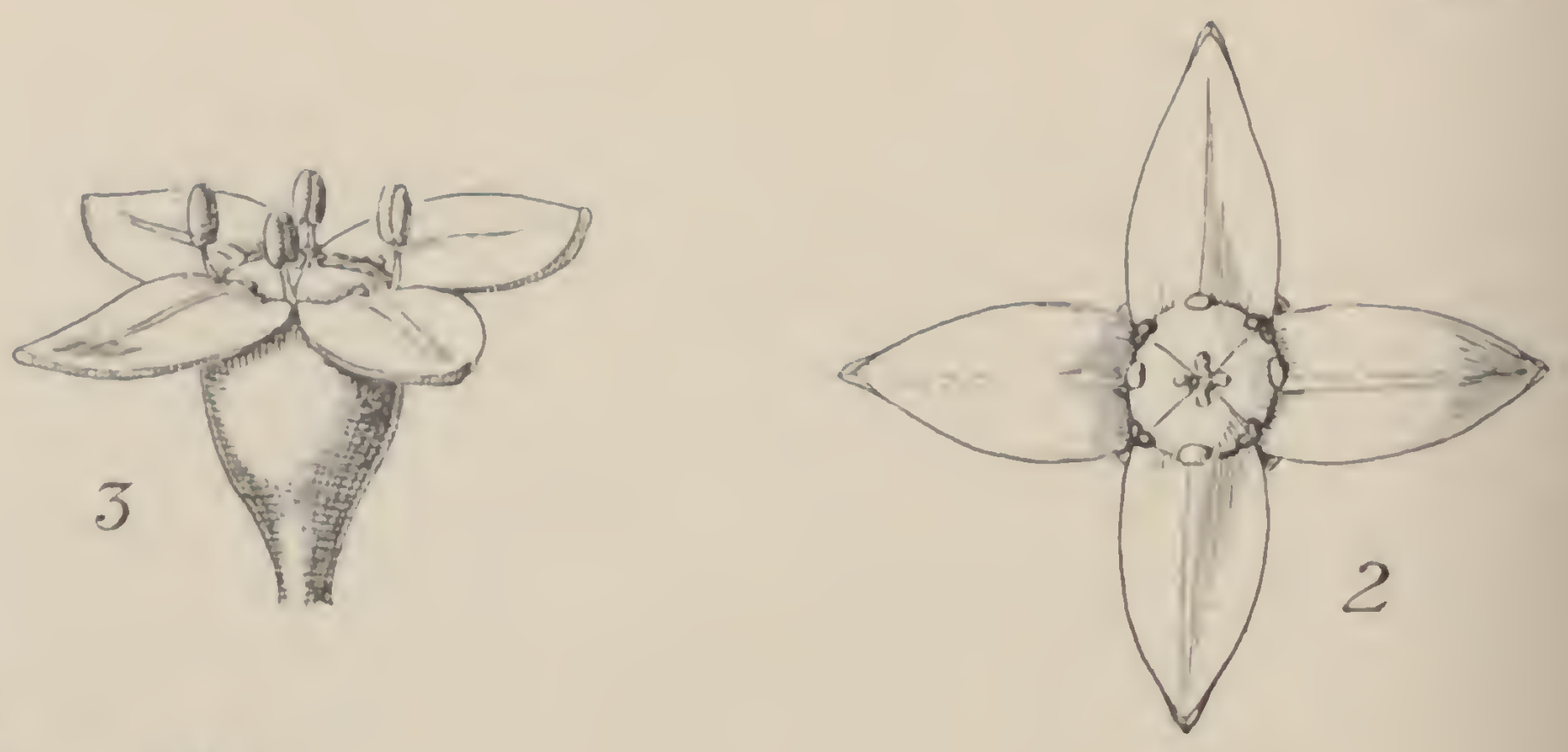

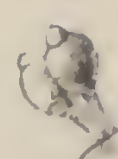

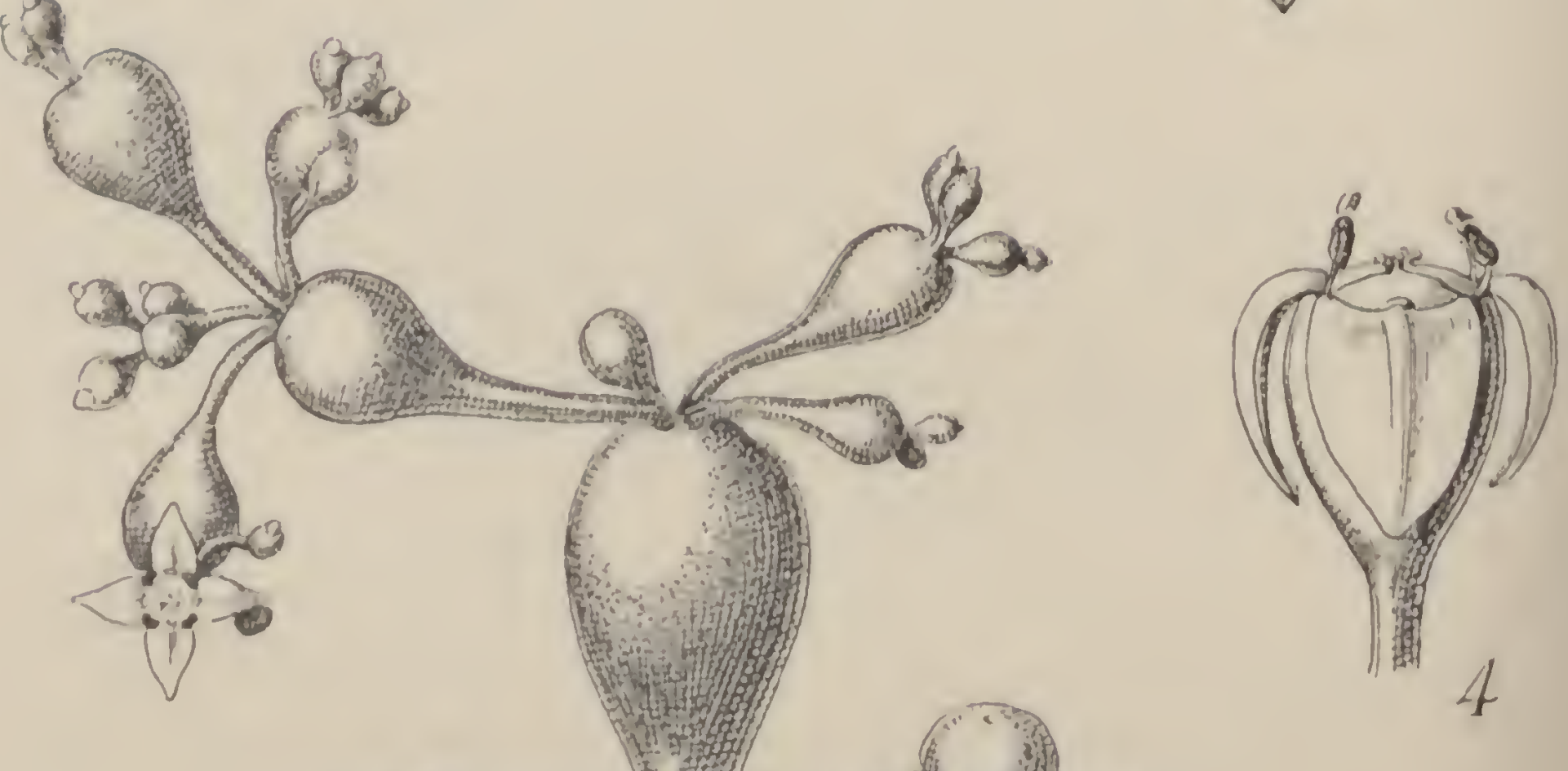

(1)

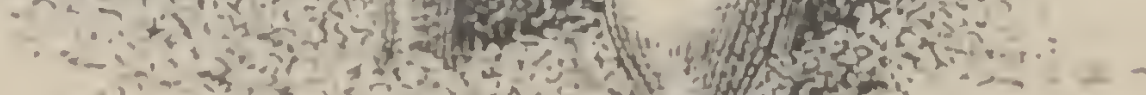

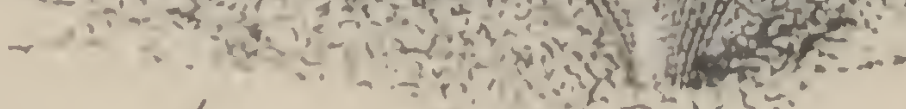

1

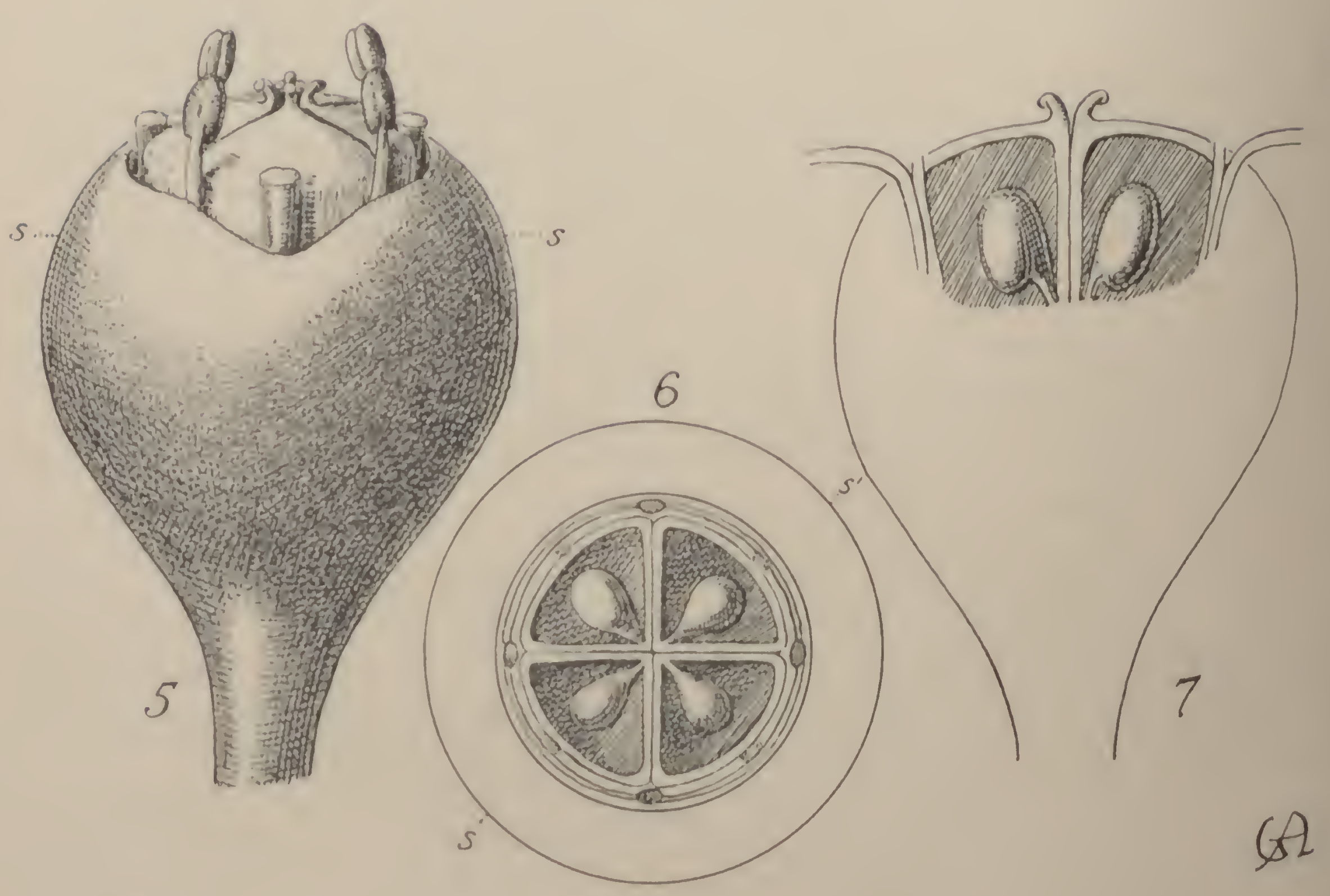




\section{TABULa 3171.}

\section{RHOPALOTA APHYLLA, N.E. Brown.}

\section{Crassulaceae. Subfamilia Crassuloideae.}

Rhopalota, N. E. Brown in Cactus \& Suee. Journ. vol. iii. p. 7 (1931) ; a Crassula, I., caulibus aphyllis, glandulis earpella superantibus, earpellis apiee truneato-eonvexis uniovulatis reeedit.

Ilerba percnnis, sueculenta, aphylla, aquatica, eaule ramulisque clavatis. Flores in quoque ramulo singuli, terminales, tetrameri, raro trimeri, omnino isomeri. Calyeis lobi brevissini, multo latiores quam longiores, erenas 4 efformantes. Petala cum calyeis lobis alternantia, primum patentia, tandem ad superfieiem ealyeis reflexa. Stamina eum petalis alternantia, creeta, apices carpellorum superantia. Glandulae conspicune, petalis oppositae, apices carpellorum superantes. Carpella in tubo calycis sive in apice ramuli elavati immersa, sed superiora et libera, a latere visa subeuneatim subquadrata, apice truneato-eonvexa, transverse seeta trigona angulo interiore stylo atissimo terminata. Ovula in earpella singula.

R. aphylla, N.E. Brown, l.e., speeies uniea adhue nota.

Stirps glabra, viridis, omnino aphylla, haud $2 \cdot 5 \mathrm{~cm}$. alta. Caulis $3 \mathrm{~mm}$. crectus, clavatus, $6-10 \mathrm{~mm}$. longus, superne subpyriformis patentisassus, apiee ostiolo ininuto eentrali praeditus, unde exorti rami liter flores $1-5$, eauli similes sed saepius ninores, quoque ramo similongi res $1-5$ circiter $3 \mathrm{~mm}$. diametro pariente. Calyeis lobi $0.5 \mathrm{~mm}$. alha vel breviores. Petala $1.5 \mathrm{~mm}$. longa, $1 \mathrm{~mm}$. lata, ovata, acuta, 0.5 vel rosea, crassiuscula, minute coruseantia. Stamina eireiter flavum. longa; antherae rubrae, marcescendo nigreseentes; pollen subdeltoideandulae in alabastro clavatae, superne applanatae inverse Carpella ine, tandem subcylindricae truncatae, brunneo-aurantiacae. Schonl. in medio flore plana, viridia ; styli minuti.-Crassula aphylla, Bolus Het E. G. Baker in Journ. Bot. 1898, p. 371 ; Sehonl. in Ann. vol. ii. p. 54 , t. 3, f. 7 (1916).

8665TI Arrica. Clanwilliam Division: Boontjes River, Sehlechter, belongot 8664 as is wrongly quoted by Sehonland, as that number in the Ce Pharnaceum pusillum, Schlechter); top of the Tafelberg, Cederberg lRange, Mrs. Levyns. 
This very remarkable and very small Crassulaceous plant was originally discovered by R. Schlechter in 1896, and was described as Crassula aphylla from dried material by Schonland and E. G. Baker in 1898. Recently the species has been found again by Mrs. M. R. Levyns, who brought living plants of it to Kew, where they flowered in May 1931. The description given above was drawn up from this living material. The figure published by Schonland in 1916 was prepared from dried material and represents a piece of a totally different and leafy plant mixed with the Rhopalota. This mixture was doubtless responsible for Schonland's statement that Crassula aphylla sometimes has leaves, and it is quite probable that it was from this leafy plant that he may have obtained carpels bearing 2-4 ovules. All the carpels of two living flowers that I dissected had but one ovule in each.

Apart from its odd appearance, $R$. aphylla is remarkable as being a succulent plant that is aquatic. Mrs. Levyns' account of it is as follows: "The Kew specimens came from the summit of the Tafelberg, the second peak in height (6500 ft.) in the Cederberg Range, Clanwilliam District. The top of the Tafelberg is composed of horizontally placed sandstone, which is much fissured. At the bottom of these fissures rock-pools occur and the Crassula grows in these pools. When we visited the mountain in September the pools were fringed with ice, and snow lay in sheltered places. The Crassulas were about 9 inches under water; some were just beginning. to produce flower-buds. The Tafelberg, of course, is frequently covered with S.E. clouds during the summer months, but I must confess that I was surprised to hear that the water was still to be found in these pools at the end of summer. I assume that the flowers are produced when the pools are relatively dry, but I have no information on this point. It flowered with me when growing on damp sand." At Kew the sand in which the plant is growing stands in a shallow pan full of water, so that the soil is kept saturated.

This quaint little plant differs from Crassula by being leafless, by the glands rising above the top of the carpels instead of being seated at their base, by the carpels being truncate at the apex instead of tapering into a short style, and by having only one ovule in each carpel. In the undissected flower only the transversely oblong apex of the glands is visible.

The generic name is derived from the Greek, por $\alpha \lambda \omega \tau \delta s$, clublike, in allusion to the shape of the stem and branches.-N. E. Brown.

Fia. 1, an entire flowering plant and threo young plants, $\times 3 ; 2$, flower from above, $\times 9$; 3 , flower (immersed in swollen upper part of a stem segment), sido view, $\times 9 ; 4$, old flower, showing the reflexed potals, $x 9 ; 5$, flower, with petals removed, $\times 27 ; 6$, the same, transverso section, $\times 27 ; 7$, flowor, longitudina soction, $\times 27$. 


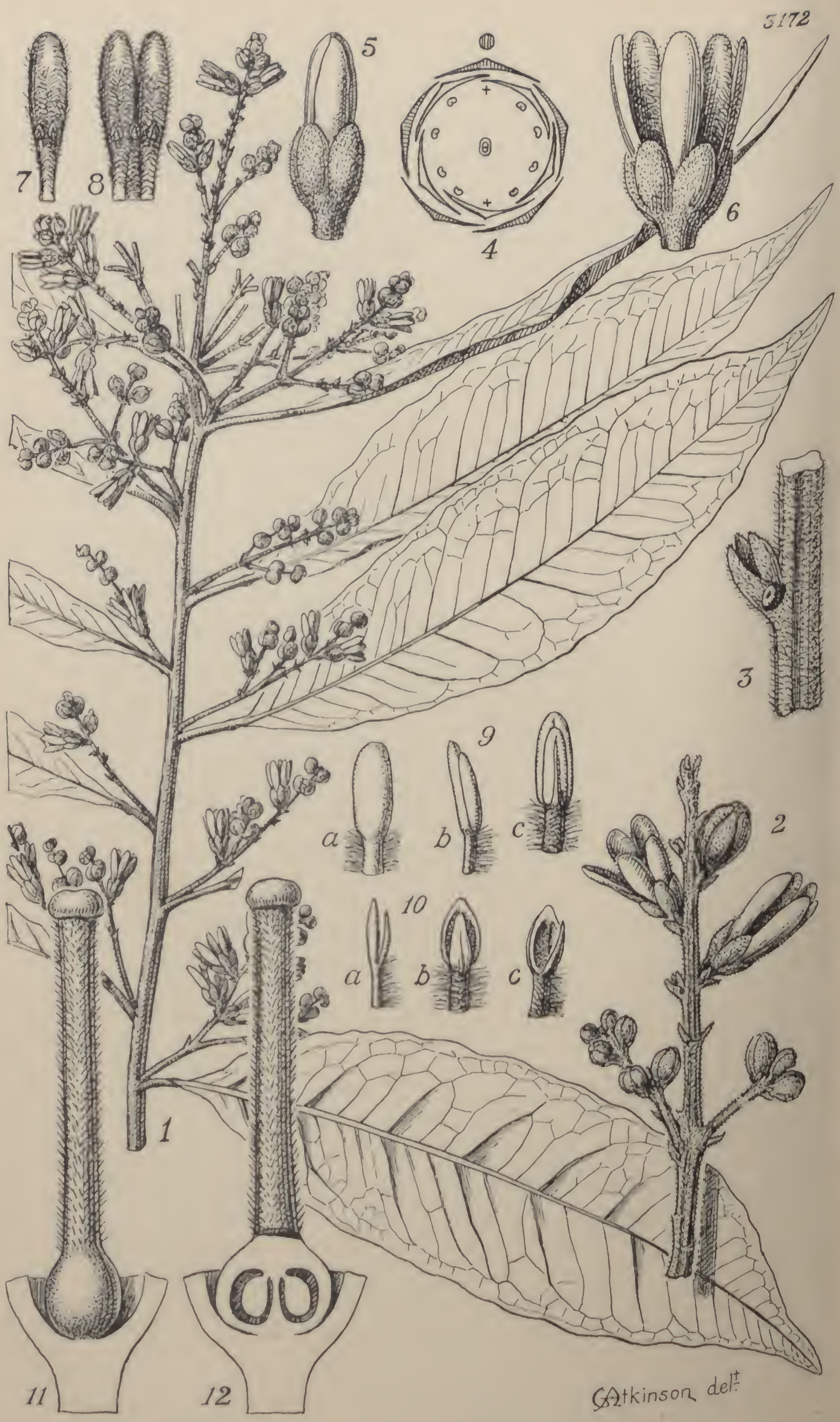




\section{TABULa 3172.}

BARNHARTIA FLORIBUNDA, Gleason.

\section{Poligalaceae.}

Barnhartia, Glcason in Bull. Torr. Bot. Club, vol. liii. p. 297 (1926); affinis Diclidantherae, Mart., a qua floribus subzygomorphis, petalo quinto libero ecteris 4 inferne per paria connatis, staminibus 8 , ovario biloculari reedit.

\section{B. floribunda, Gleason, l.e., speeies unica.}

Frutex alte scandens, nonnunquam per summas arbores pervagans; ramuli lornotini dense minute pubescentes, annotini glabreseentes, internodiis $1-3 \mathrm{~cm}$. longis. Folin alterna, anguste elliptico-oblonga vel lanccolata, in apicem rotundatum breviter apieulatum sensim tenuinata, basi cuneata, 9-14 $\mathrm{cm}$. longa, 2-2-5 cm. lata, integra, supra coriaeea, glabra vel juventute utrinque seeus eostam puberula, circiter nitida, subtus nitidula, nervis primnriis utroque costae latere ceteris 10-12 a margine satis longe amastomosantibus, his eum nervis petiolus venulisque utrinque elevatis atque conspieue retieulatis; utroque pubescens, demum glabrescens, 5-10 mm. longus, apice positi, simargine nectario circulari parvo instruetus. Racemi eompyramidale terminales et axillares, paniculam multifloram terminalem lors terminalinferue foliatam efformantes, ubique dense pubeseentes ; inforesecnalis aphylla 4-7 cm. longa, rhachi obtuse angulata sulcata; vel binistiac axillares 1-3 (revera singulae, ramis basalibus singulis chm bracteolis infriores trian valde concavae, superiores minores deltoideo-ovatae, dula sin triangulari-subulatae, $1 \cdot 5-2 \mathrm{~mm}$. longae, basi utrinque glandeltoideola tumida nigrescente orificio cireulari instrueta; bracteolac flores 0.75 perigyui, toro extra dense pubescente intus carnoso glabro apice $\mathrm{mm}$. alto. Sepula quincuncialia, aseendentia, elliptico-oblonga, put escentindata, 3-3.5 mm. longa, 1.6-2 mm. lata, extra dense vivo ereme, intus tomentella. Petala imbrieata, aseendentia, statu 8patlulata, apiecitate brunneo-rubris usque purpuraseentia, lineariata, apice rotundata, $6-6.5 \mathrm{~nm}$. longa ungue $2 \mathrm{~mm}$. longo 
incluso, 1.3-1.5 mm. lata, grosse albo-ciliata, extra lamina glabra ungue albo-piloso basi excepta, intus albo-pilosa basi ac apice exceptis; petalum anticum superne patulum, supra unguem stamina 2 gerens; utriusque lateris petala lateralia et postica filamento staminis cum iis alternantis conjuncta, praeterea stamina singula medio gerentia. Stamina 8 (posticum et anticum deficientia) $2 \mathrm{~mm}$. supra basin inserta; filamenta circiter $0.5 \mathrm{~mm}$. longa, intra valde pilosa, extra glabra; antherae oblongae, adhuc clausae circiter $1 \mathrm{~mm}$. longae, post dehiscentiam $0.6 \mathrm{~mm}$. longae; lobuli interiores thecarum exterioribus breviores; antherae ab. apice inter lobulos exteriores et interiores deorsum dehiscentes, muro lobulorum interiorum secedente. Pistillum e fundo tori ortum; ovarium compresso-subglobosum, inconspicue subdidymum, 0.8-0.9 mm. longum, $1.2 \mathrm{~mm}$. latum, $0.7 \mathrm{~mm}$. crassum, carnosum, glabrum, nitidum ; stylus tandem 3.5-4 mm. longus, rectus, breviter hispidus; stigma discoideo-capitatum, $0.7 \mathrm{~mm}$. diametro, rima mediana indistincte bilobulatum. Fructus ignotus.

British Guiana. Demerara River: Malali, about $5^{\circ} 35^{\prime} \mathrm{N}$., De La Cruz, 2727. Essequibo River: Moraballi Creek, above Bartica, in mixed forest, fl. Oct., Sandwith, 507. A giant bush-rope. Calys greenish-white; corolla cream-coloured, whitish woolly within. Upper Mazaruni River: Kamakusa, about $59^{\circ} 50^{\prime}$ W., De La Cruz, 2852.

Brazil. Amazonas: Fonteboa, in humid virgin forest, fl. Nov., Ducke, 22332. A tall stout climbing shrub. Flowers white, foetid.

The genus Barnhartia was placed by Gleason (1926) beside Diclidanthera, to which undoubtedly it is closely related. Diclidanthera had had a chequered history: originally referred by Martius to the family Ebenaceae, it was afterwards transferred by Reichenbach to the Styracaceae, and unaccountably removed by Miers to the Hamamelidaceae. It was generally treated as an anomalous genus of Styricaceae until 1907, when Perkins excluded it from that family, but without suggesting a better position for it. Finally in 1924 Gilg (Engl. \& Gilg, Syll. ed. 9-10, 323) proposed a new family, Diclidantheraceac, for its reception, placing this immediately after Ebenaceae.

Comparison of Barnhartia with Chodat's summary of the characters of Polygalaceac (Nat. Pflanzenfam. vol. iii. 4, p. 323), however, shows no single point of disagreement. We may add that nectaries similar to those occurring on the bracts in Diclidanthera and Bamhartia are found in the same position in at least six genera of Polygalaceae ; that the facies of Diclidanthera and Bamhartia is very much the same as that of various woody climbers belonging to that family; and that the floral diagram of Barnhartia closely resembles that of Polygala (see fig. 4). There can be little doubt, accordingly, that the Diclidantheraceae should be included in the Polygalaceae. It is significant that Diclidanthera was associated by Martius (Fl. Bras. vol. vii. p. 16: 1856) with Moutabea, a genus long since assigned to the Polygalaceae, and that he then suggested that the true affinity of both genera was 
with that family. The diseovery of Barnhartia affords a striking confirmation of the eorreetness of his view.

A detailcd aceount of Diclidanthera and Barnhartia will appear elsewhere. In the meantime the preeise position of these genera within the Polygalaceae is left open.-T. A. Sprague, N. Y. Sandwith.

Fia. 1, upper part of flowering branch, natural size; 2, an axillary inflorescence, 4. 2 ; 3 , rhachis of inflorescence with bract, two bracteoles, and nectary, $\times 7$; 4, flower dingram, the position of the suppressed anterior and postcrior stamens indicated by crosses; 5 , flower-bud, $\times 3 ; 6$, flower, $\times 3 ; 7$, anterior petal, $\times 3$; , paired petals, united by intervening stamen, $\times 3 ; 9$, stamens before dehiscence : a, b, c, exterior, lateral and interior views, $x 14 ; 10, \mathbf{a}, \mathrm{b}$, c, stamens after dehisconce, $\times 14$. 




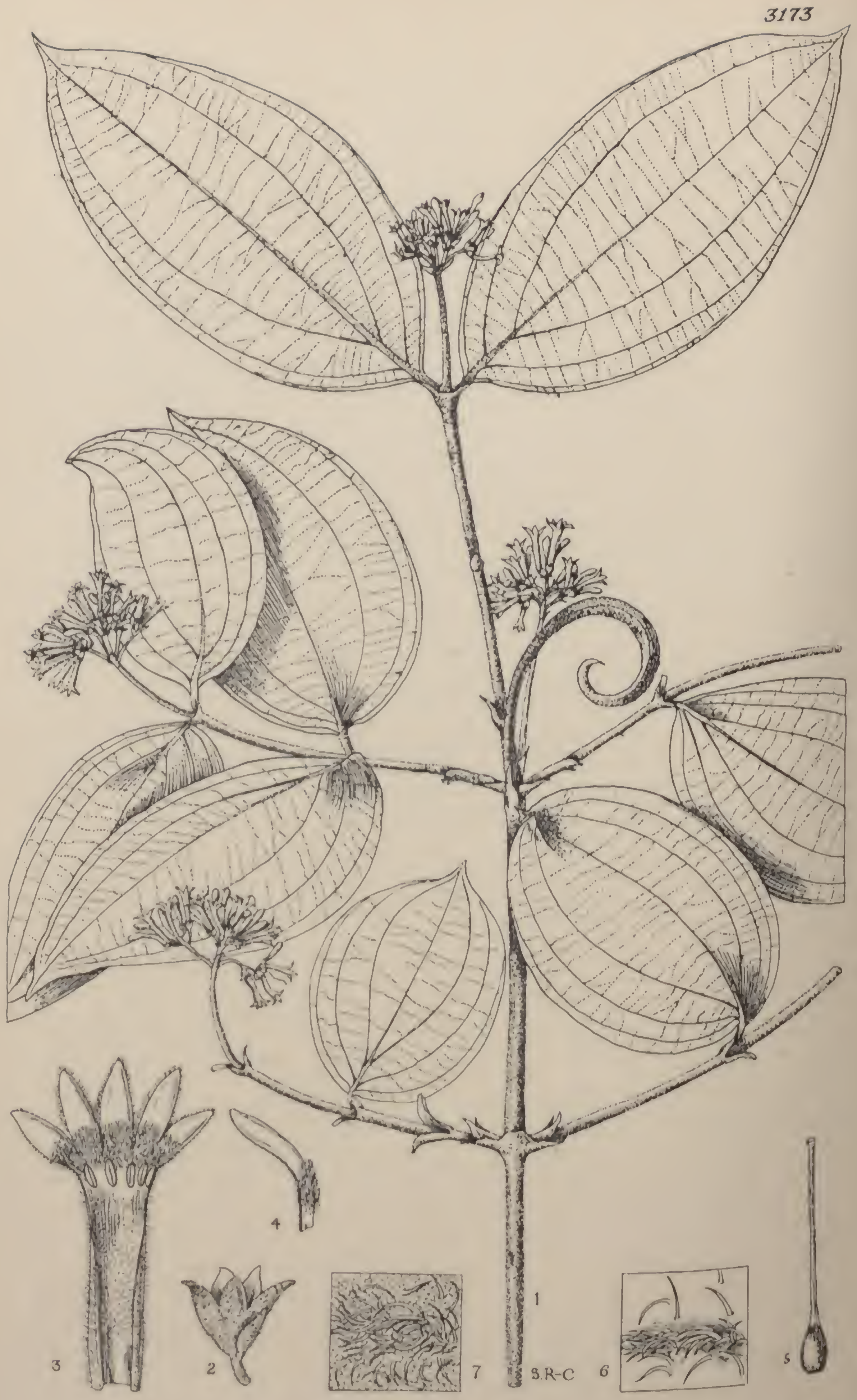




\section{TABULA 3173.}

\section{STRYCHNOS DIABOLI, Sandwith.}

\section{Loganiacear. Tribus STrichneaE.}

S. (\$ Longiflorae) diaboli, Sandwith in Kew Bull. 1931, p. 486; species nova, inter S. tomentosam, Benth., atquc S. triplineriam, Mart., ponenda; ab illa foliis latioribus subtus haud dense lanatis, inflorescentiis densis, laciniis calycinis angustis, floribus multo brevioribus, staminibus inclusis, ab hac folis haud coriaceis, indumento utriusque foliorum paginae, venatione, floribus brevioribus, staminibus inclnsis differt.

Frutex altissine scandens, ramulis teretibus dense tomentosis, summis novellis fulvis ad $12 \mathrm{~cm}$. longis ad $2 \mathrm{~mm}$. diametro; cirrhi grisci vel grisco-fulvi, dense tomentosi, cireiter $9 \mathrm{~cm}$. lungi. Folia in ramulis novellis per paria 1-3 disposita; cataphylla bnsi ramulormm conspicua, acuminata, concava, 4-5 mm. longa; intcrnodia $2-5 \mathrm{~cm}$. longa ; lamiua late ovata vel ovato-elliptica, nonmunquam ferc suborbicularis, apiec vulgo obtusa vel rotundata atque breviter (2-8 mmm.) aeute euspidata, in exemplis subellipticis attcnuata aemminata, in exemplis sulorbicularibus rotundata vix cuspidata, basi obtusa, nonnurquam obliqua uno latere rotundato, vel cuueatn, $4 \cdot 5-12 \mathrm{~cm}$. ollga, 3-7.5 cm. lata, tenuiter chartacea, supra siccitate obscure olivacen vel purpurascentia, densc regulariter molliter pilosula, subtns pilis brevibus fulvis dense molliter velutino-pubescentin laud lanatia, pilis quan iu pagina superiorc laad multo densioribus, venatione ut in S. lomentosa saepius septupliuervia, nervis binis iutimis a costa in medio folio cireiter 0.7 ad forc 2 em. distantibus, intermediis his paullo magis approxinatis, cxtimis prope marginem vel eum margine conjunetis, nervis secundariis subhorizontalibus subparallelis sinuatis subtus cun rete veuularum prominentibus; petiolus fulvo-tomentosus, $2-6 \mathrm{~mm}$. thyus, Inflorescentiae ramulos terminantes, congeste corymbosofyl voideae, densifiorac, $2-4 \mathrm{~cm}$. dianetro, ubique indumento ramulorum ralni stipatis lat atis; bracteac imae lanceolatac, $4-6 \mathrm{~mm}$. Longac, cireitcr $1.5 \mathrm{~mm}$. $l_{1} t_{1}$, supcriores bracteolaeque ovato-lanceolatae vel ovatae, $1 \cdot 5-2 \mathrm{~mm}$. lati, ,ireiter $1 \mathrm{~mm}$. latac. Flores pentameri, vix ad 1 mus. pedieel$\mathrm{t}$, albi, sed siccitate faucc cxeepta omniuo fulvi. Calyx liciniis 
lanceolatis $2 \mathrm{~mm}$. longis vix ad $1 \mathrm{~mm}$. latis extra fulvo-tomentosis intus glabris. Corolla extra indumento simili fulvo-tomentoso praedita, pilis ut in S. triplinervia brevibus homogeneis patulis, nec ut in $S$. tomentosa pilorum serie altera conspicua longiore patente; tubus $8 \mathrm{~mm}$. longus, $1.5 \mathrm{~mm}$. diametro, intus apice basique glaber, ceterum adpresse pilosus; lobi lanceolati, acuti, $3-3.5 \mathrm{~mm}$. longi, $1-1 \cdot 25 \mathrm{~mm}$. lati, flore aperto patentes, extra indumento tubi, intus basi lana densa conspicua nivea induti, ceterum pulverulento-tomentelli. Antherae subsessiles, fauce sub lana insertae, inclusae nec cernendae, oblongae, $1 \mathrm{~mm}$. paullo excedentes. Ovarium glabrum, ovoideum, circiter $1 \mathrm{~mm}$. altum, ad $0.75 \mathrm{~mm}$. diametro; stylus glaber, cum stigmate capitato circiter $8 \mathrm{~mm}$. longus. Fructus non visus.

British Guiana. In dense forest, Moraballi Creek, Essequibo River, 24 Aug. 1929, Sandwith, 109.-Bush-rope with tendrils. Branchlets dark-rusty. Flowers white, whitish woolly at the throat. Vernacular name "Black Devil-Doer."

The name "Devil-Doer" is given by the Arawak Indians of British Guiana to numerous species of Strychnos found in the Colony, on account of their poisonous properties. Three species were collected in perfect flowering condition by members of the Oxford University Expedition to British Guiana in 1929: one of these, S. tomentosa (t. 3175), is a rediscovery; a second, S. Melinoniana (t. 3174), is a first record for the Colony; while the present species is described here for the first time. Duplicates of $S$. diaboli are distributed to the Herbaria of New York, Rio de Janeiro, Utrecht, Berlin, Paris, Washington, Stockholm, Leningrad, and Geneva. The "Devil-Doers" are giant bush-ropes climbing to the forest canopy, where the flowering branches sprawl over a wide area, beneath which the forest-floor is littered with their fallen corollas.-N. Y. SANDwiTH.

FIG. 1, flowering branch, $\times \frac{2}{3} ; 2$, calyx, showing one of the bracteoles, $\times 4$; 3 , corolla laid open, showing insertion of stamens, $\times 4 ; 4$, part of corolla from within, showing lanate base of Jobe, $\times 4 ; 5$, pistil, $\times 4 ; 6$, upper surface of leaf, $\times 22.5 ; 7$, lower surface of leaf, $\times 22.5$. 



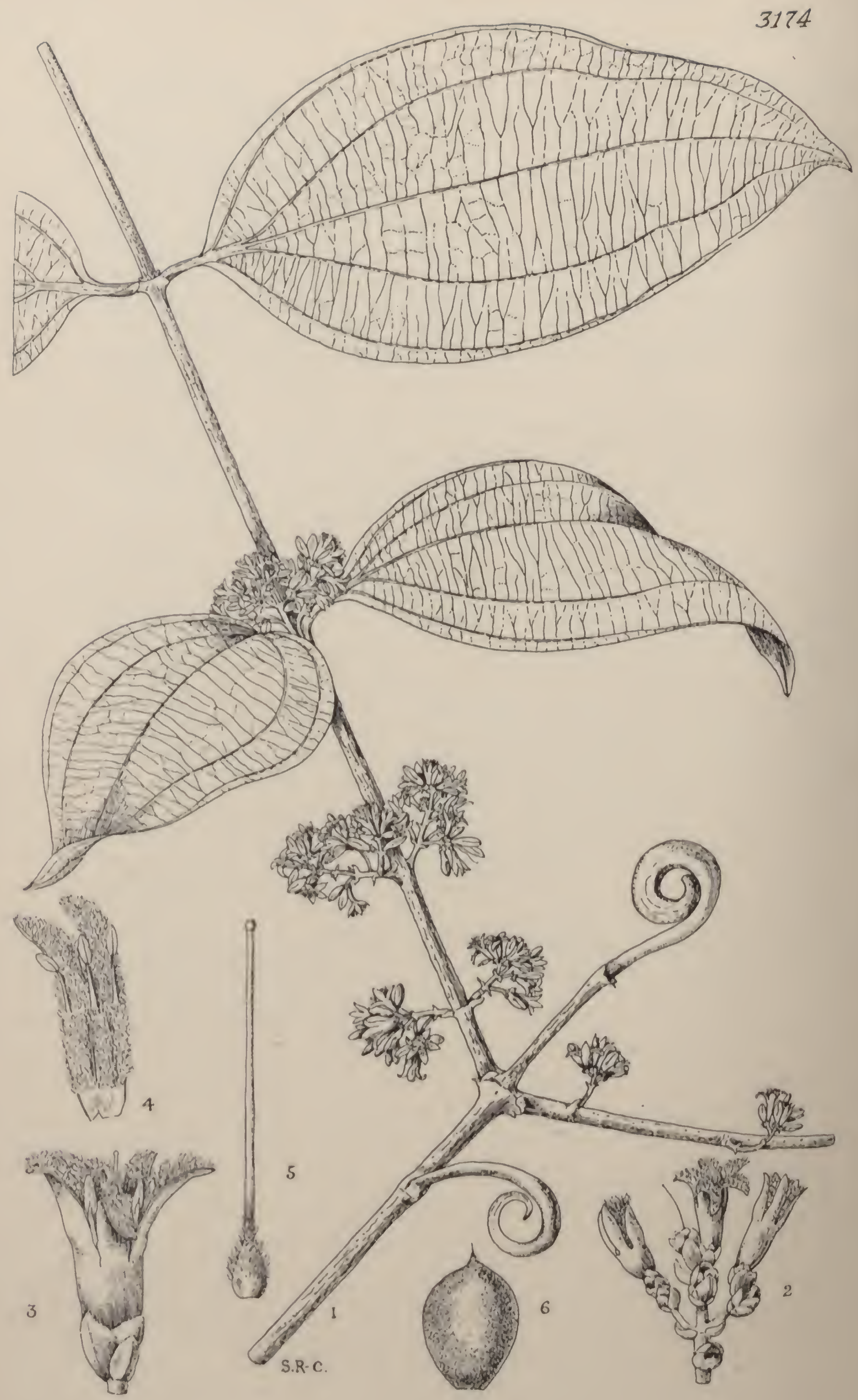




\section{TABULA 3174.}

\section{STRYCHNOS MELINONIANA, Baill.}

\section{Loganiaceak. Tribus Struchneaf.}

\$. (\$ Intermediae) Melinoniana, Baill. in Bull. Soc. Limn. Par. Vol. i. p. 256 (1880); Sandwith in Kew Bull. 1931, p. 487 ; inter species hujus sectionis hucusque cognitas foliis magnis, laciniis calycinis rotundatis vel obtusis, lolis corollac ubique densissinc albo-lanatis, ovario dimidio supcriore piloso distinguenda.

Frutex altissime scandens, ramulis summis tcretibus glaberrimis cinercis vel purpurasecntibus ad $2.5 \mathrm{~mm}$. dismetro; internodia $2-10 \mathrm{~cm}$. longa; cirrhi glabri, 4-7 cm. longi. Folia in eodem frutice baceolata ad ovata, apice attenuata acuta vel nonnunquam acuminata, nitid cuneata, $7 \cdot 5-20 \mathrm{~cm}$. louga, $3 \cdot 5-10 \mathrm{~cm}$. lata, coriaccu, utrinquc nitida, glaberrina, supra siccitatc pallide olivacca vel brunnescentia, subtus sibepius glaucescentia, quinqueuervia usque conspicuc quintuplinervia, jugo intimo a costa prope medium folium $1 \cdot 5-3 \mathrm{~cm}$. distante, cum secundariis regulariter subhorizontalibus parallclisquc, his glaber, venulis utrinque pracsertim subtus valde reticulatis; petiolus moso-, digresccns, 5-11 mm. longus. Inflorescentiae axillarcs, raccbreviuyroidcac, sacpe a basi ranosac, cymis apice ramulorum minutc congcstis, $1-1 \mathrm{~cm}$. longae, $1-2 \cdot 5 \mathrm{~cm}$. latae, ubique densc primariatellac, vel inferne glal rescentes nigrescentes; bracteac rarius ovato- ovatac, obtusac, concavo-cymbiformes, ad $2 \mathrm{~mm}$. longae, imbricatac - lanceolatae, ad $3 \mathrm{~mm}$. longac ; hracteae cymarum propriac longacatac: bractcolsc rotundato-ovatac, obtusac, vix ad $1.5 \mathrm{~mm}$. Flores circiter $1.2 \mathrm{~mm}$. latae, cxtra lirtcllac, conspicue ciliatac. valde pentameri, alti, suaveolentissimi. Calyx extra hirtellus, laciniis obtusis imbricatis ciliatis scmiorbicularibus rutundatis vel latc ovatis excepta 1 inm. longis ferc ad $1 \cdot 5$ inm. latis. Corolla cxtra basi glabra canpanulatverulento-tomentella; tubus cylindricus vel fere subLasi glatatus, $3-3.75 \mathrm{~mm}$. longus, rpplanatus, ad $3 \mathrm{~mm}$. latus, intus reflexi, tub excepta albo-pilosus; lobi flore aperto patentes, dcinum lati, intubo longtores, lanccolati, acuti, 4-5 mm. longi, basi ad $1.2 \mathrm{~mm}$. densissus ubique per totam longitudinem sed pracsertim in medio loborume albo-lanati. Stamina flore aperto cxscrta, faucc inter bases antherae oblong, filimentis conspicuis glabris $2-2.5 \mathrm{~mm}$. longis; $1 \mathrm{~mm}$. altum oblonga, $1.2 \mathrm{~mm}$. longae. Qvarium ovoidco-subglobosmin, 
stylus inferne pilosus, ceterum glaber, cum stigmate capitato $3.5-6 \mathrm{~mm}$. longus. Fructus immaturus viridis, obovoideus, apiculatus, ad $11 \mathrm{~mm}$. longus, ad $8 \mathrm{~mm}$. diametro.

British Guiana. Moraballi Creek, Essequibo River, 26 Sept. 1929, Sandwith, 342. Bush-rope with hard hook-like tendrils in moramorabukea forest. Flowers white, white-woolly within, strongly and sweetly scented of Philadelphus. Moraballi Creek, in mixed forest, 5 Oct. 1929, Sandwith, 377. Young fruit green. Vernacular name "White Devil-Doer."

French Guiana. Without locality, Mélinon (Herb. Paris.).

The original description of S. Melinoniana, Baill., was based on material without flowers, and is somewhat misleading, the leaves being described as three-nerved at the base, and the sepals as acute. When the fine flowering material collected by the Oxford Expedition in British Guiana, upon which the above description is based, was compared with the type of $S$. Melinoniana in the Paris Herbarium, they were found to agree remarkably well. The sepals of the type were, in fact, rounded or obtuse, and could not reasonably be described as acute. An important feature of this species is the great variability in the venation of the leaves which, on the same plant, may be quinquenerved or very conspicuously quintuplinerved, the inner pair of nerves arising a long distance above the base. This breaks down one character that has been used for separating the closely allied S. Solerederi, Gilg, of French Guiana, which was also described without flowers. The type collection (Mélinon, 430) of S. Solerederi has been examined in the Paris Herbarium, and it is certainly remarkably close to S. Melinoniana; but it may be retained for the present as a distinct species on the ground of the narrower, more acute sepals and the glabrous apex of the very young fruit.

The leaves of $S$. Melinoniana resemble also those of $S$. Mitscherlichii, Rich. Schomb., and S. smilacina, Benth., in the section Longiflorae. $S$. cogens, Benth., which was described without flowers, differs in the indumentum of the branchlets and the veins of the lower surface of the leaves, which bave a much finer and more intricate reticulation. Of other possibly allied species described without flowers, S. panurensis, Sprague et Sandwith, differs in the narrow, somewhat acute calyx-lobes and the glabrous ovary; while S. gigantea, Barb. Rodr., has more acuminate leaves, more rounded at the base, their secondary nerves ascending, instead of subhorizontal, and far less regular and parallel.

It is satisfactory to be able to emend and complete the description of S. Melinoniana, after an examination of the type, and to distribute flowering material to many Herbaria (New York, Rio de Janeiro, Utrecht, Berlin, Paris, Washington, Stockholm, Leningrad, Geneva, Vienna, Chicago).-N. Y. SANDWTTH.

FIG. 1, flowering branch, with tendrils, $\times \frac{8}{3} ; 2$, inflorescence, $\times 2 ; 3$, flower, $\times 4 ; 4$, interior of corolla, with stamens, $\times 4 ; 5$, pistil, $\times 6 ; 6$, fruit, $\times 2$. 


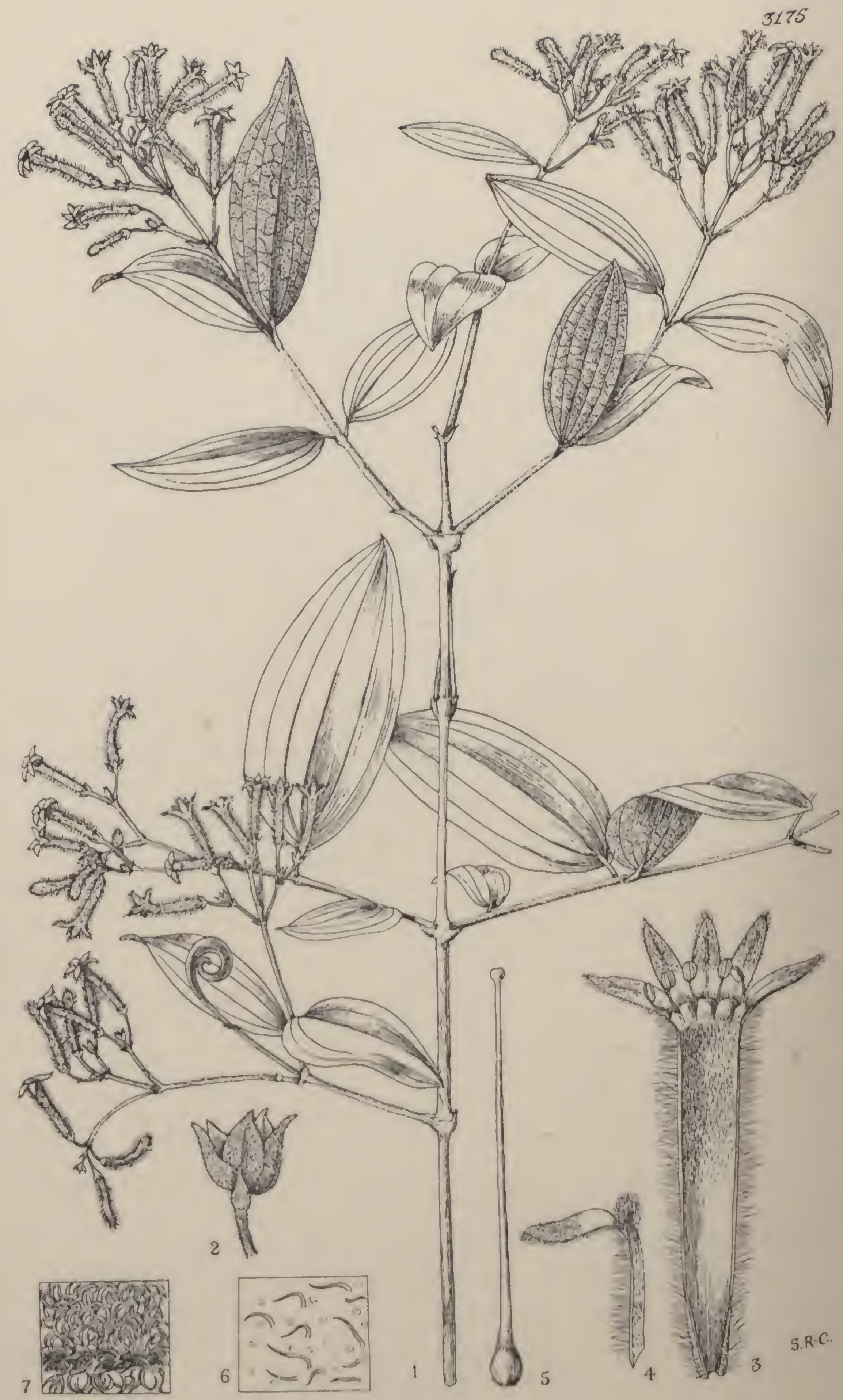




\section{TabUla 3175.}

\section{STRYCHNOS TOMENTOSA, Benth.}

\section{I oganiaceae. Tribus Strychanak.}

S. (\$ Longiflorae) tomentosa, Benth. in Journ. Limm. Soc., Bot. vol. i. P. I0t (1857); Progel in Mart. Fl. Bras. vol. vi. pars i. 1. 271 (1868); S. toxiferae, Rol. Schoml). ex Bentll. affinis, ramulis pubesecntibus nec patenti-hirsutis, foliis supra pubeseentibus subtus dense lanatotomentosis, laciniis ealycinis ovatis brevibus differt.

Frulex altissime seandens, ranulis summis novellis pilis fulvis arlpressis jubeseentibus; cirrhi juniores dense pubeseentes. Folia Vata usque elliptica vel oblonga, apice aeuta, obtusa atque mucrouata, vel rotundato-truncata atque breviter cuspidata, basi obtusa vel rotundata, 2-8 cm. longa, 1-3.6 cm. lata, membranaeca, opaea, supra siecitate olivaceo-nigrescentia pilis brevibus haud densis pubescentia, subtus fulvo-viridia dense molliter lanato-tomentosa, quintuplinervia vel saepins septuplinervia, nervis in medio folio fere aequidistantibus supra impressis subtus prominentibus veuulis satis conspicue reticulatis ; Detiolus fulvo-pubeseens, ad $5 \mathrm{~mm}$. longus. Inflorescentiae ramulos 4.5 mantes, satis laxe corymboso-thyrsoideac atque paneiflorae, ad prima. diametro, ubique adpresse fulvo-pubesentes; peduneulus clitisque vulgo $2-3$ em. longus. Flores pentameri; laterales eymae excento eonspiene ad $5 \mathrm{~mm}$. pedicellati, siecitate limbo intus albo ad 1.5 ferruginei. Calyr laciniis ovatis acuminatis ad $2.5 \mathrm{~mm}$. longis tubus $1.5 \mathrm{~m}$. latis, extra fulvo-pubescentibus intus glalıris. Corollae subadpress $1 \cdot 4 \mathrm{~cm}$. longus, 1.5-2 nm. latus, extra dense patule vel conspicuse fulvo-pilosulus, practerea serie pilorum lougorum patente supra praeditus, intus superne dense lanatus inferne glaber, apice productus in eoronam $1 \mathrm{~mm}$. altam apice densissime albo-lanatan. praditi, ; lobi lanceolati, patentes vel reflexi, extra indumento tubi sarpe purtus breviter albo-lanati, pulverulenti, basin versus siceitate spicue purpuraseentes. Stamina sub lana coronac aflixa, e fauee conovato-obserta, flamentis glabris $0.75 \mathrm{~mm}$. longis; antherae late subg-oblongac, $0.6 \mathrm{~mm}$. longae, $0.5 \mathrm{~mm}$. latac. Otarium glabrum, longus osun, ad $1 \mathrm{~mm}$. altum ; stylus glaber, longe exsertus, ad $1.6 \mathrm{~cm}$. Reisen. Fructus ignotus. - S. rhexioides, Klotzseh in Rich. Seliomb. sen, vol. iii. p. I14t (184S), nomen. 
British Guiana. Moraballi Creek, Essequibo River, 25 Oct. 1929, Sandwith, 524: a bush-rope with tendrils, in mixed forest on hill; leaves soft and tomentose (pale greenish in the fresh state) beneath; corolla-tube green with spreading rusty hairs; limb a beautiful pure white within, brownish-sericeous on the back. Roraima, 1843, Schomburgk, 723 (1095B), in Herb Kew., Cantab., Paris. Rich. Schomburgk (l.c.) gives the locality as "stony wooded slopes near Pirara."

This rare and beautiful species had apparently not been collected, since Schomburgk met with it, until its rediscovery in 1929. As Schomburgk's specimen in the Kew Herbarium is very poor, the fine material gathered by the Oxford University Expedition to British Guiana is particularly welcome. Specimens have been distributed to the Herbaria at New York, Rio de Janeiro, Utrecht, Berlin, Paris, Washington, Stockholm, Geneva, and Leningrad.-N. Y. SANDwiTH.

FIG. 1, flowering branch, $\times \frac{2}{3} ; 2$, calyx, showing one of the bracteoles, $\times 4$; 3 , corolla laid open, showing corona and stamens, $\times 4 ; 4$, part of corolla from within, showing insertion of corona-lobe, $\times 4 ; 5$, pistil, $\times 4 ; 6$, upper surface of leaf, $\times 30 ; 7$, lower surface of leaf, $\times 30$. 
3176

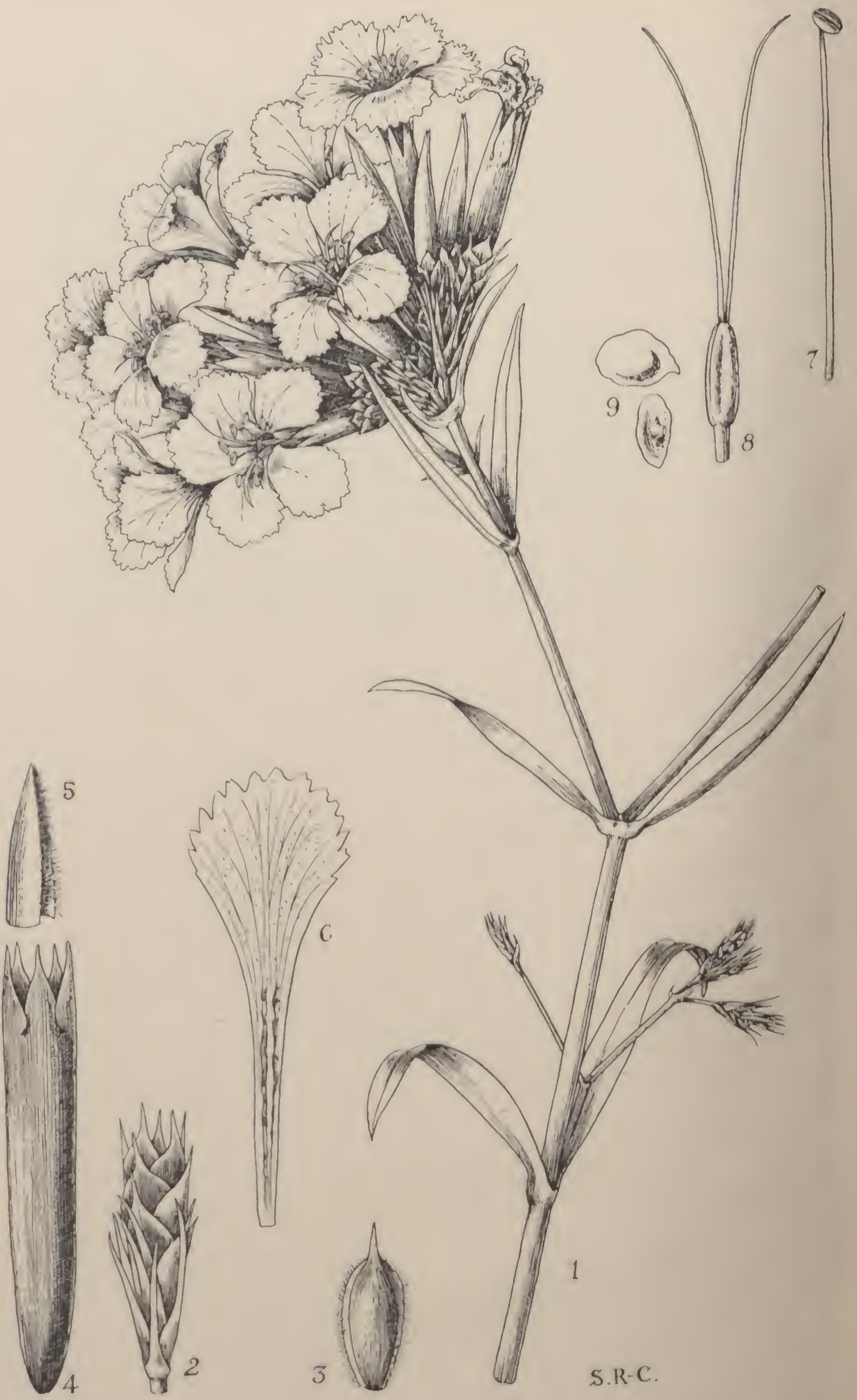




\section{TABULa 3176.}

\section{DIANTHUS RUPICOLA, Biv.}

\section{Caryothyllaceae. Tribus Sileneae.}

D. rupicola, Biv. Sic. Pl. cent. prima, p. 31, t. 1 (1806); Presl, Flor. Sicula, vol. i. p. 145 (1826) ; Pojero, Flor. Sicula, vol. i. pars 1, p. 163 (1888) ; Fiori el Paolelti, Flor. Anal. Ital. vol. i. p. 377 (1898) (rupicolus), fig. 1226 (1899); a $D$. arborco, L., foliis lanecolato-linearibus vel angustissime oblanecolatis valde aeutis fere planis facile distinguitur.

Suffrulcx glaberrimus, viridi-glaueus, inferne lignosus, superne tosiceus, usque ad $5.5 \mathrm{dm}$. altus, valde ramosus, ramis dense caespisubs firmis erectis vel e rupibus dependentibus inferne teretibus superne subtetragonis. Folia numerosa, laneeolato-linearia vel angustissime 7 necolata, valde acuta, inferne angustata, usque ad $6 \mathrm{~cm}$. longa ct mm. lata, eoriaeea, vix carnosa, supra enervia, infra leviter sublata. ex earinata, caulina remotiuseula; vagina $2-3 \mathrm{~mm}$. longa et bra. Flores 4-23, dense fasciculati, saepissime in ramulis binis superne cuspicatis congesti ; braetene 6-10-jugae, imbricatae, infimae lineares, cuspidatae, sequentes gradatim inajores, oblongo-ovatae, abrupte cylindatae, nultinerviae, margine membranaceae et eiliolatae. Calyx nervatieus, tubo $2-2 \cdot 5 \mathrm{~cm}$. longo longitudinaliter tenuiter sulcatoacuminato plus ininusve purpureo, dentibus lanccolatis aeute aliquatis $4 \mathrm{~mm}$. longis $1.5 \mathrm{~mm}$. latis 10 -11-nerviis saepissime vel obtulum eiliolatis. Petala $3.5 \mathrm{~cm}$. longa, lamina late obovata inciso-dato-triangulari $1 \cdot 1 \mathrm{~cm}$. longa $1 \mathrm{~cm}$. lata leviter et irregulariter superionticulata pallide purpurco-rosea vel albida inferne in pagina drieum leviter pubescente. Antherae $2 \mathrm{~mm}$. longae. Ovarium cylinlongi. leviter sulcatum, $9 \mathrm{~mm}$. longum, $2 \mathrm{~mm}$. diametro; styli $2 \mathrm{~cm}$. pla na, Capsula cylindrica, $2 \mathrm{~cm}$. longa, valvis patentibus. Semina fere $\mathrm{T}$ en. ambitu elliptica utrinque rotundata vel aeuta.-D. Bisignani, Flor. Cat. Orto bot. Princ. di Bisign. p. 13 (1805), nomen nudun, et vol. Nap. vol. i. p. 228, t. 39 (1811-15), deser.; Reiehb. Pl. Crit. t. 29 (1838) p. 810 (1828) ; Bot. Reg. vol. xxiv. (new series, vol. xi.) Villiam (1838); Gussone, Flor. Sie. Syn. vol. i. p. 478 (1842); F. N. suffruticosus Journ. Linu. Soe, Bot. vol. xxix. p. 362 (1893). $D$. Sruticosus, Willd. Enum. Hort. Berol. p. 466 (1809)? D. involucratus 
Poir. in Lam. Encycl. suppl. vol. iv. p. 132 (1816) ? D. arborescens, Hoffmgg. Verz. Pflanzenkult. p. 56 (1824)?

Italy. "Calabria," Tenore; Calabria, ad rupes maritimas prope Scillam, 2.6.1877, Biondi.

Sicily. Sine loc., 1828, Jan.; sine loc., 1830, Gussone; rochers calcaires à S. María del Gesù près Palerme, 29.8.1834, A. Richard; in rupium fissuris ad littora maris, Termini, 7.7.1840, Herb. Heldreich; Palermo, 9.4.1845, Herb. R. C. Alexander Prior; rochers à Taormine, 26.7.1846, Cosson; sine loc. et coll., 1847; Palermo, 1847, Todaro; ex rupibus pracruptis Siciliae, juxta Panormum (monte Pelegrino), 11.1853, J. Ball; in rupibus calcareis, Palermo, Herb. Churchill; Palermo, Parlatore; ad rupes calcareis Misilmeri, 25.7.1855, E. et A. Huet du Pavillon; in rupibus calcareis, Palermo a S. Ciro, Todaro, 1333: in rupibus calcareis erectis sub Trormina, $100-200 \mathrm{~m}$., 30.6.1877, Huter, Porta et Rigo, ex itinere italico III., 459; in rupibus calcar. marit. M. Pellegrino, 10.1879, Lo Jacono in F'. Schullz, herb. norm. 749 ; in rupibus calcareis reg. inferioris, Palermo, 8.1898, H. Ross, 113; Taormina, in rupibus montium solo calc., 14.7.1898, G. Rigo, 479; Panormum (Palermo), in rupibus montis Pellegrino, alt. 50-300 m., solo calcareo, 14.9.1912, A. Vaccari in Flor. Ital. Exsicc. ser. II. 1831.

Crete. Cape Maleka, P. L. Giuseppi (cult. in hort. "Trevose, Felixstowe," 26.9.1930).

The species here figured is of very considerable phytogeographical interest. It was placed, with ten other species, in the Sect. Suffruticosi, Subsect. Tubulosi by F. N. Williams (l.c.). The species of the subsection are, with one exception (D. rigidus, Bieb. from S.E. Russia). inhabitants of the Mediterranean basin, chiefly of its eastern parts. Williams's classification has been somewhat modified by more recent research, but the relationship of $D$. rupicola with $D$. fruticosus, L. and $D$. arboreus, L. can scarcely be doubted. D. fruticosus is known with certainty only from rocks in the island of Seriphos, in the western Cyclades, above the town of the same name. Sibthorp (Flor. Graec. Prodr. vol. i. p. 289: 1806; et Flor. Graec. t. 407: 1825) records it "in insulae Seriphi rupibus, at rarissime. In insula Creta." Sibthorp's plant is correctly named (see Shaw and Turrill in Kew Bull. 1926, p.126), but no confirmation of its occurrence in Crete has been obtained. Heldreich (Flor. Cephal. p. 24: 1882) records it from near Asso in Cephalonia, but again confirmation is lacking as no specimen has been seen. Halácsy (Consp. Flor. Graec. Suppl. p. 19: 1908) adds the island Pholegandros, in the south-western Cyclades. D. arboreus has a wider distribution, being known from several islands of the Cyclades (Naxos, Paros, Cythnos, and Amorgos), from several localities in Crete, from Cerigo, from Messenia, from Karpathos, and from Kalymnos.

Turning now to the distribution of $D$. rupicola, it should be noted that the species has been known for a long time in cultivation. Tenore when he first recorded it, as D. Bisignani, did so as a garden plant of 
unknown origin. Bivona, in lis account of the speeies, quotes "Caryophyllus sylvestris vulgaris latifolius floribus conglobatis sive eopulatis. Cup. IIort. Cath. p. 40" (1696) as \& synonym, probably eorreetly. Bivona himself docs not quote an exact Sicilian loenlity for $D$. rupicola. The diffieulty of being eertain that the names $D$. suffruticosus, $D$. involucralus, and $D$. arborescens are eorrectly referred to the synonymy of $D$. rupicola is partly due to their being based on garden material of unknown origin. Thanks, however, to the energy espeeially of Italian eollcetors the distribution of $D$. rupicola, Biv. (D. Bisignani, Ten.) ean now be mapped with a fair degree of aceuraey. It oeeurs sporadically on maritime roeks, igneous and ealeareous, on the northern and eastern coasts of Sicily, in the Lipari and Egadian islands and in Lampedusa. On the Italian mainland it is found in several loealities in Otranto, Basilieata, and Calabria. Munby (Cat. Plaut. Algeria, ed. 2, p. 6: 1866) reeords it from Algeria, "prov. Alger r. r. (loe. Babor)," and Battandier and Trabut, Flor. de l'Algér. p. 144 (1883), give a short deseription and quote Muuby's record without comment. In their Flor. Anal, et Synopt. p. 61 (1902), they record D. Bisignani, Ten., var. hermaeënsis for Tunis and do not refer to Munby. It is possible that all the North Afriean material is D. hermaeënsis, Cosson, 11l. Flor. Atlant. vol. i. p. 121, t. 76 (1890), which from the deseription, figure, and solitary sheet at Kew appears to be a distinet, though allied species. Cosson reeords it from Cape Bon, near El Hrouiria "juxta loeum a civitate eversa (Hermwum) olim occupatum," and from the island of Kew a tet-Djamour (Zembra). Finally Dr. P. I. Giuseppi scnt to at a speeimen of $D$. rupicola, which he had growing in his garden seed revose, Felixstowe, with the information that he grew it from inter colleeted by himself at Crpe Maleka in western Crete. The special Penint is that Cape Maleka (and perhaps otlier parts of the Akrotiri been It eolleeted there by Sieber, Heldrcieh, Baldaeei, and Gandoger. It thus appears that we have a small gromp of morphologieally
vieariollied speeies, showing in the main a distiuct but essentially Distribution :

D. frutieosus: W. Cyelades.

coust of arbore : Crete, S. Greece, Cyelades enstwnrds to islands off the D. of Asia Minor.

D. rupicola: Sieily and Sieilian islands, S. Italy, W. Crete.

It

eommons a reasonable conelusion that these have evolved from a intran ancestor, morphological differenees not being amalganated into stocks. Peveral minor varintions within D. rupicola have been reeorded. Sieily. Gus a varicty albiflorus, with white flowers, from ncar Termini, "foliis Gussone, l.e., names a variety virescens, with the deseription acutioribus virentibus angustioribus," and quotes for it nany 
Sicilian islands. Williams (l.c.) ranges, without descriptions, the following under $D$. Bisignani: (a) glaucus (presumably what he regards as the typical plant); (b) viridescens, Guss. (presumably = var. virescens, Guss.); (c) albiflorus, Presl ; and (d) hermaeënsis, Coss. (sp.).

W. B. TURrill.

Fig. 1, flowering branch, natural size; 2 , bracts, $\times 2 ; 3$, a single bract, $\times 2$; 4 , calyx, $\times 2 ; 5$, apex of calyx-lobe, $\times 20 ; 6$, petal, $\times 2 ; 7$, stamen, $\times 2$; 8 , pistil, $\times 2 ; 9$, young seeds, $\times 10$. 



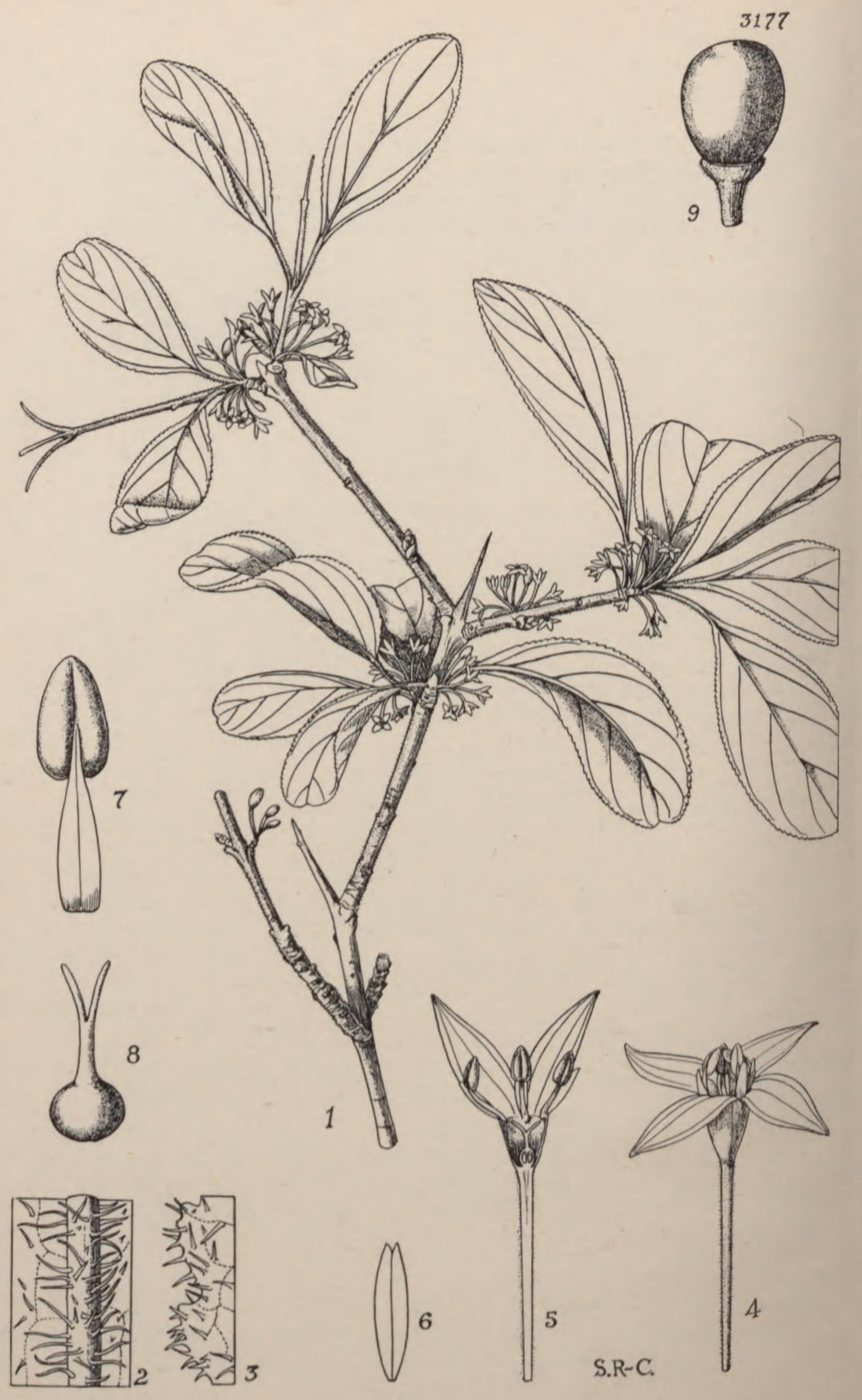




\section{TABULA 3177.}

\section{RHAMNUS RHODOPEUS, Vel.}

\section{Rhamnaceae. Tribus Rhaminaae.}

R. rhodopeus, Vel. Flor. Bulg. p. 119 (1891), et Suppl. p. 63 (1898); Stoyanoff in God. Sof. Univ. vol. xv.-xvi. p. 107 (1921); Bornmüller in Engl. Bot. Jahrb. vol. lix. p. 459 (1925); Hayek, Prodr. Flor. penins. Balcan. vol. i. p. 612 (1925); Bornmüller in Fedde, Repert. vol. xxix. p. $37 / 341$ (1931); a R. tinctorio, W. et $K$., foliis utrinque velutinopubeseentibus differt.

Frutex vel arbor parva, usque ad $4.6 \mathrm{~m}$. alta, valde ramosa, ramulis primo dense pubeseentibus deinde laevibus griseo-rubro-nigris apice sacpissime spineseentibus. Folia late elliptiea vel elliptieo-obovata, apice rotundata vel obtusa, basi rotundata vel (subvar. subcuneatus, Bornm. l.e. p. $459: 1925)$ euneata, petiolo exeluso saepissime $1 \cdot 5-3 \cdot 3$ $\mathrm{cm}$. sed usque ad $3.8 \mathrm{~cm}$. longa (Tedd, 585 ), $0 \cdot 9-2.5 \mathrm{em}$. lata, in pagina utraque plus minusve dense velutino-pubesecntia, margine serrulatocrenulata, costa nervisque supra leviter impressis infra prominentibus, nervis lateralibus graeilibus utrinque $3-5$ areuatis mox vel tarde in rete venosum dissolutis; petioli $0 \cdot 3-1 \cdot 4 \mathrm{~cm}$. longi, breviter pubesentes. Flores axillares, faseiculati, ramulorum a piees versus aggregati, Recepri ; pedieelli eireiter $5 \mathrm{~mm}$. longi, leviter papilloso-puberuli. Sepalaeulum (ealyeis tubus) obconieum, $1.25 \mathrm{~mm}$. longum, glabrum. Iata anguste elliptico-lanceolata, subaeuta, $3 \mathrm{~mm}$. longa, $1.25 \mathrm{~mm}$. Pelala trinervia, nervis lateralibus ad marginem areuatis obseuris. Filala spathulato-linearia, emarginata, $1.5 \mathrm{~mm}$. longa, $0.3 \mathrm{~mm}$. lata. Gynocium subulata, $1.25 \mathrm{~mm}$. longa; antherae $0.75 \mathrm{~mm}$. longae. bifidus. parvum, $1.25 \mathrm{~mm}$. longum; stylus eireiter ad medium torius, Fruetus obovoideus, $3-4 \mathrm{~mm}$. longus, niger.-Rhamnus infecp. 150 (1843). pubeseens, Griseb. Spie. Flor. rumel. et bithyn. vol. i. in Denksch). R. tinetorius, W. et K., var. pubescens, Degen et Dörfler R. saxatitis. Math.-Naturw. Cl. K. Akad. Wiss. vol. Ixiv. p. 717 (1897). p. 740 (1925) Jaeq., var. rhodopeus, Stoy. et Stef. Flor. Bulg. vol. ii. (1925).

BUlgariA. In collinis ad Tekir, 9.6.1895 et 26.7.1897, StYibrný;

in dumetis submontanis mt. Rodope, 5.1906, Adamovic.

Timeace. Mesta Valley, roeky side-valley off main river valley, on mestone, 17.5.1931, a tree, height about $15 \mathrm{ft}$., Tedd, 585 . 
In addition to the above specimens, preserved in the Herbarium at Kew, the following records must be noted: Grisebach, l.c., gives " in fruticetis pr. Rusköi Chersonesi thracici sparsim alt. 6-800' (substr. sax. aren.), rarius in sylva mixta m. Athûs alt. 1200'-2600' (substr. marm.); in Macedonia (Friv.) Fl. Maj. Jun. M." Velenovský, in addition to Tekir, records the species from "in rupestribus calidis calcareis supra Stanimaka (Vel.)." This would be from the northern foot-hills of the Rodope and is Velenovský's type. Degen and Dörfler (l.c.) record it from "Macedonia centralis. In declivibus rupium inter Rošzdan et Allchar; 21 Jun." Stoyanoff, l.c. 1921, collected $R$. rhodopeus from near Gabrovo, on the northern foot-hills of the Belasica (Belasitsa) Planina.

Bornmüller, l.c. 1925, collected it in 1891 on Athos and in 1918-19 in various localities in North Macedonia (Southern Serbia or Vardar), in the districts of Veles, Drenovo, Demirkapu, and Lake Doiran. Lastly he records it, l.c. 1931, from the arid region of the high plain of Central Anatolia, in the district around Angora (Ankara).

It is of interest that $R$. rhodopeus has been reduced by different authors to varietal rank under at least three distinct species, $R$. infectorius (presumably of Visiani, non L., i.e. R. intermedius, Steud. et Hochst.), $R$. tinctorius, and $R$. saxatilis. The indumentum of the mature leaves is an important taxonomic character and, though somewhat variable according to age and habitat, distinguishes the species from all its Near Eastern relatives. Velenovský described the leaves as broadly elliptic and obovate-elliptic, obtuse, and shortly attenuated at the base. The size and especially the breadth of the leaves and the shape of the leaf-base vary very considerably. Bornmüller (1925) published the name subvar. subcuneatus for specimens collected near Drenovo and on the Marianska Planina, with narrower leaves (2-3 times as long as broad), whose cuneate base passes into a short petiole. However, there is such variation amongst leaves on the same specimen that extensive field-studies are essential before the taxonomic value of leafcharacters can be determined. 'The leaves in Tedd's 'Thracian material are larger than those in any other flowering specimens at Kew.

\section{W. B. Turrill.}

Fia. 1, flowering branch, nalural size; 2 , lower surface of leaf, $\times 10 ; 3$, margin of upper surface, $\times 10 ; 4$, flower, $\times 6 ; 5$, longitudinal section of flower, $\times 6$; 6 , petal, adaxial view, $\times 12 ; 7$, stamen, abaxial view, $\times 20 ; 8$, pistil, $\times 20$, 9 , fruit, $\times 4$. 



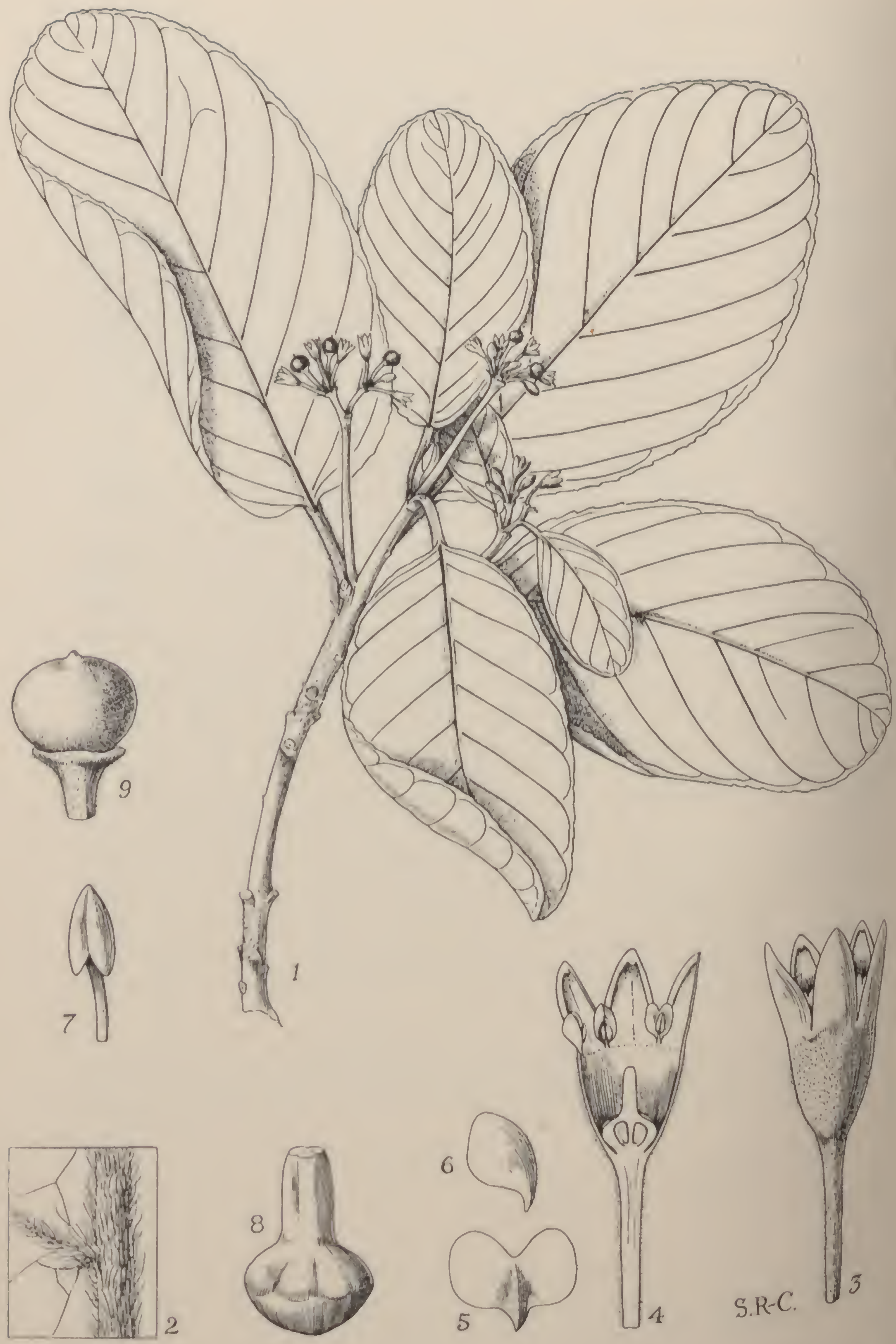




\section{Tabula 3178 .}

RHAMNUS RUPESTRIS, Scop., var. RUMELIACUS, IIayek.

Rhamiaceae. Tribus Rhamnean.

R. rupestris, Scop. Fl. Carniol. ed. 2, vol. i. p. 164, t. 5 (1772), var. rumeliacus, Hayck, Prodr. Flor. penins. Balcan. vol. i. p. 1087 (1927); a jlanta Seopoliana partibus omnibus majoribus, foliis saepius subcordatis differt.

Frutex usque ad $3 \mathrm{~m}$. altus, ramis vetustis einereis glahris, junioribus atrorubro-brunneis leviter pilosis glabresentibus. Folia elliptiea, ovato- vel obovato-elliptica, apice rotundata vel suboltusa rarissime exeluso) ct 5 asi subeordata vel truneata, usque $7 \mathrm{~cm}$. longa (petiolo supra sulentis. lnta, nervis lateralibus utrinque 8-11, eosta nervisque pagina inferis subtus prominentibus, in pagina superiore glabra, in glabresentio costa nervisque inferne praecipue pubeseentia vel petiolus tia, margine ineonspieue et irregula riter crenato-dentieulata ; Inforescentiae $0.2 \mathrm{~cm}$. longus, dense pubeseens vel fere glaber. pedunculus in foliorum superiorum axillis positae, 3-10 florae; lineares, circiter $0.5 \mathrm{~cm}$. longus; bractene rarissime folineea, saepissime eampanulatus, $1 \mathrm{~mm}$. longae; pedieelli $3-4 \mathrm{~mm}$. longi. Calyx sub$2 \mathrm{~mm}$. longis, $3.5 \mathrm{~mm}$. longus, lobis 5 aeutis ovato-triangularibus Antherae ().75. Pelala late obcordata, $1 \mathrm{~mm}$. longa, $1.75 \mathrm{~mm}$. lata. $1 \mathrm{~mm}$. longys. liriv. in Fingus, Fruclus immaturus subglobosus. $R$. rumcliaceus,

'THRace. Xanthic-Shaliin Road, 93 m., rock erevices, 10.6.1931, ush 4-6ft. high, II. G. Tcdd, 614 .

Rhamnus rupestris was originally deseribed from material colleeted ctescription refers to of Gorizia by P. Wulfen. It is obvious that the leaves, which is cho the dwarf unarmed shrub, witl relatively small of the Adriatic. $\mathrm{K}$ ew and eonsideration of thon of the rich material of the species at a very polymorphic of the senttered literature force one to recognise leaf size and sphie species. Variation is especially apparent in habit, at the other extreme, and indumentum. The specimen here figured is 
type. Frivaldszky (l.c.) described a Rhamnus from the Rodopes as $R$. rumeliaceus. His description is not a very full one, but the characters given agree with those shown by Tedd's material except for the words "foliis . . acutis." Hayck (l.c.) quotes Simonkai, Növém. Közl. vol.vi.p. 57 (1907), as the author of the variety rumeliacus, but Simonkai does not appear actually to have made the combination. It must remain for future detailed field-work to describe how far varietal names are desirable within this species, the more so that most collectors have given no details of the habit of the plants from which their specimens were taken. While Tedd's specimens have the leaf apices rounded, subobtuse, or, rarely, emarginate, it is probable that this is a fluctuating character, since other sheets of the species at Kew show a range from acute to rounded and emarginate. This is particularly well seen in matcrial collected by Jávorka in northern Albania (M. Hekurave, in saxosis calc. ad faucem vallis Valbora ad pag. Margegaj, $450 \mathrm{~m} ., 1.9 .1918)$, and which is referred by the collector to "var. rumeliacus, (Friv.)."

The species, $R$. rupestris, as a whole, is distributed from northern Italy and Carniola through Istria, Croatia, Dalmatia, Bosnia, Hercegovina, Montenegro, Serbia, the Rodopes, N. Macedonia, Albania and Epirus, to Greece. An interesting account of the typical (northern) plant is given by Hegi, Illustr. Flor. Mittel-Eur. vol. v. part 1, p. 349 (1925). Hegi keeps the genera Frangula and Rhamnus distinct, and evidently intended to use the name Frangula rupestris (Scop.) Brongniart for the species under consideration. Actually the name Rhamnus rupestris, Scop. heads the description within the gentls Frangula.-W. B. Turrill.

Fig. 1, flowering branch, natural size; 2, portion of lower surface of leaf, $\times 20$ 3 , flower, $\times 6 ; 4$, longitudinal section of flower, $\times 6 ; 5,6$, petal, abaxial and lateral views, $\times 12 ; 7$, stamen, adaxial view, $\times 20 ; 8$, pistil, $\times 12 ; 9$, fruit, $\times 4$. 



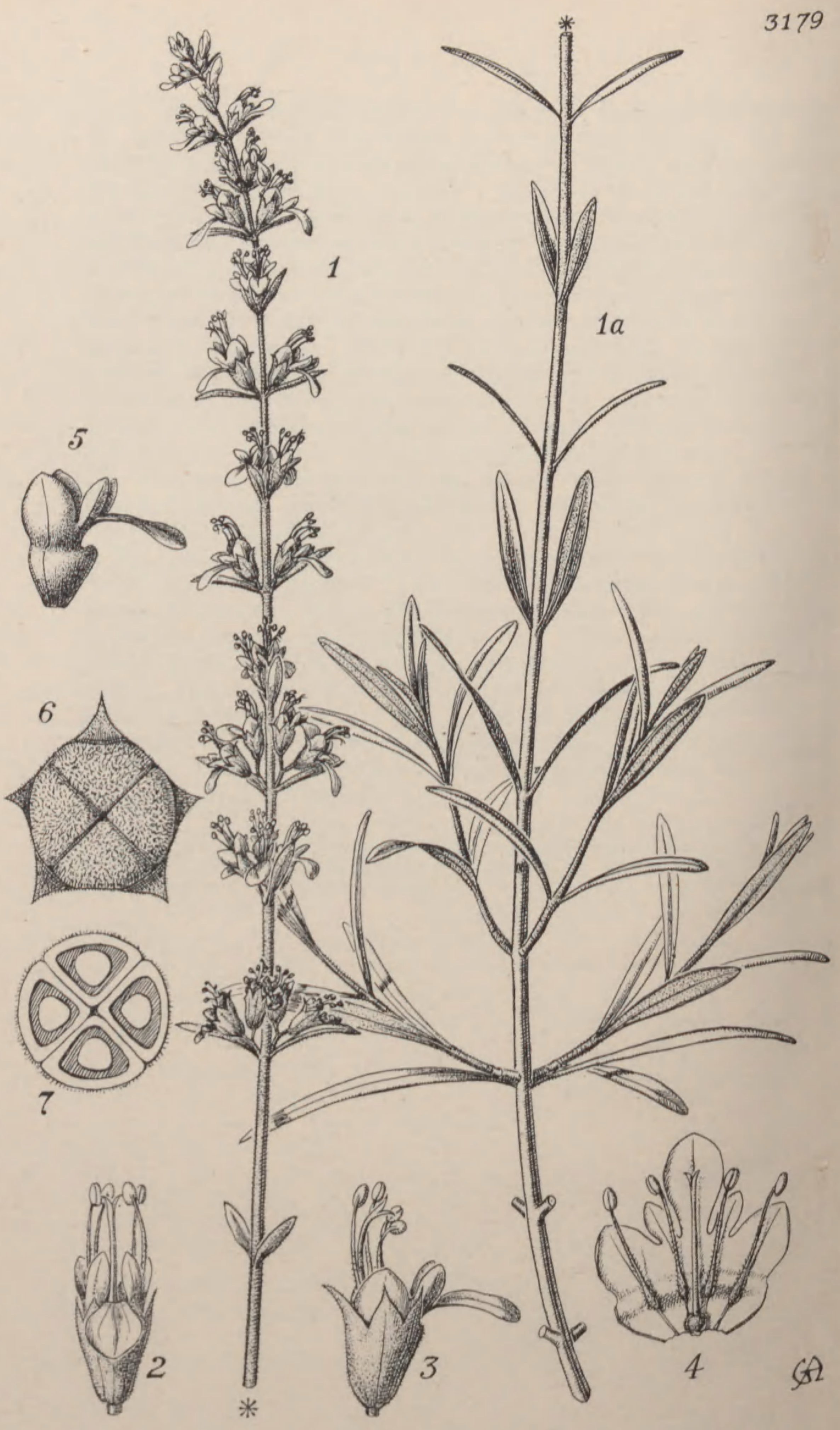




\section{TabUta 3179.}

\section{TEUCRIUM CRETICUM, $L$.}

Labiatae. Tribus ajugeae.

T. creticum, L. Sp. Il. p. 563 (1753); Sibch. et Smith, Flor. Graec. Prodr. vol. i. p. 391 (1806); et Flor. Graec. t. 529 (1826); DC. Prodr. vol. xii. p. 576 (1848); Unger el Kolsehy, Die Insel Cypern, p. 275 (1865); IIolmboc, Stud. Veg. Cypr. p. 151 (1914); a T. brevifolio, Sehrel,, foliis linearibus vel elliptico-linearibus supra glabris vel glahrescentibus subtus dense albo-tomentosis, infloreseentiis saepc clongatis freile distinguitur.

Frulex crectus, ramosus, ramis elongatis, internodiis $1-7 \cdot 5 \mathrm{~cm}$. longis, juvenilibus dense albo-tomentosis, vetustis glabris. Folia sessilia, linenria vel elliptico-linearia, acuta, inferne angustata, usque ad $4.5 \mathrm{~cm}$. (saepissime eireiter $3 \mathrm{~cm}$.) longa, usque ad $5 \mathrm{~mm}$. (saepissime eireiter $3.5 \mathrm{~mm}$.) lata, marginibus revolutis, supra glabra vel glabrescentia, subtus dense allo-tomentosa, costa supra plus minusrc impressa, sulbtus prominente. Infloreseentici 4-30 em. longa, internodiis in anthesi l-4 em. longis, multiflora, in quaque supcriorc axilla floribus 1-3 rarissime pluribus; folia superiora in loractens gradatim transientia; uractene floribus aequales vel paullo longiores; peduneulus (1-3-florus) 7 sque ad $5 \mathrm{~mm}$. longus; pedieelli $1-3 \mathrm{~mm}$. longi. Calyx eampanulatus, trian. longus, cxtra albo-tomentosus, dentibus subacqualibus ovatotriangularibus aeuto-spinosis $2.5 \mathrm{~mm}$. longis $2 \mathrm{~mm}$. latis utrinque longo osis. Corolla $1.4 \mathrm{em}$. longa, pallide purpuren, tubo $4 \mathrm{~mm}$. $9 \mathrm{~mm}$ superne abraialiter saceato, labello 5-lobato. Filamenta 8 et 8tylus longa, glanduloso-lispidula. Otarium dense albo-tomentosum; tolus $1 \mathrm{~cm}$. longus. Nuculae $4 \mathrm{~mm}$. longae, superne dense alboverticill. Ertieill. unilab. gen. et sp. p. 28 (1774). T. rosmarinifolium, Laun. T. chel. vol. ii. p. 693 (1786); Boiss. Flor. Or. vol. iv. p. 806 (1879). - charamanicnse, Cav. Descr. p. 82 (1827).

Asia Minor. Village de Bouloukli, pris de Mersina (Cilieie). Coteaux Cyires de la région chaude, 8.6.1855, Balansa, 526 .

Kotschy, 934. Frequens inter Panteleimon et Paleo Milo, 24.5.1862, Houston's $K_{\text {; }}$ ad rupes pr. Bellapais, 27.5.1880, Sintenis el Kigo, 565; SYron's Kyrenia, 3.1902, Lascelles; Kytenia, 6.1926, IIouston. entre Sinc loc., 1845, P'inard; eollines ealcnires, Kherbet-Besré sine Sachla et Maktara, 14.6.1853, Blanche, 1598 (Rcliquiae Mailleanae); Nusac., 9.10.1860, Ilooker and IIanbury; Liban, Gaillardol. Monts 
Palestine. "In deserto S. Joannis" et "Arimath.", Sieber ; désert de St. Jean, Aucher-Eloy, 1587; Carmel, 4.1846, Boissier; Judaea, in montibus calc. ad Bab-el-Wad ditionis Latrun, 16.5.1897, Bornmüller, 1323. Mt. Carmel, rocky hill-sides, 9.5.1913, Meyers, B. 2818; "from the country round Jerusalem," 1919, Campbell.

It is unfortunate that Linnaeus, apparently through accepting Bauhin's Polium angustifolium creticum as a synonym, adopted the trivial creticum for this species. Halácsy, Consp. Flor. Graec. vol. ii. p. 470 (1902), says "indicatur a Linnaeo in Creta, ubi tamen sec. Boiss fl. or. iv. p. 806 non crescit." Hayek, Prodr. Flor. penins. Balcan. vol. ii. p. 242 (1929), describes the species, and gives Crete with a question mark. I have seen no Cretan material and no reliable record of the plant from Crete. The nomenclature has been further confused by Lamarck describing as $T$. creticum, Lam. non L., the congeneric but quite distinct species $T$. brevifolium, Schreb., which is not uncommon in Crete, though not endemic there. Lamarck's name for the plant here figured, $T$. rosmarinifolium, is adopted by Boissier, Nyman, and other authors as descriptively accurate and therefore preferable to Linnaeus's "nomen incongruum." Some of the figures quoted in the Index Londinensis under Teucrium creticum represent $T$. creticum, L. and others $T$. creticum, Lam. (T. brevifolium, Schreb.).

$T$. creticum, $L$. is essentially a plant of the countries bordering the eastern Mediterranean. It is not uncommon in parts of Cyprus, Syria, and Palestine, and extends north to Cilicia. According to Nyman, and also to Fiori and Paoletti (Flor. Anal. Ital. vol. iii. p. 11: 1903), it occurs also in the island of Lampedusa to the south of Sicily. Sommier in his work, "Le isole pelagie Lampedusa, Linosa, Lampione e la loro flor" " (Boll. Ort. Bot. Palermo, vol. v. Append. 1906, p. 132), states that it has been collected on Lampedusa by Gussone. Striking and undoubted instances of discontinuous distribution occur in the eastern Mediterranean area, but further confirmation of the accuracy of Gussone's record is much to be desired.

The plant flourishes especially in dry, rocky and stony places, particularly on calcareous hill-slopes. Holmboe (l.c. 280) records it, in Cyprus, as a constituent of the Shinia-Maquis, i.e. maquis or macchia, with Pistacia Lentiscus as a dominant shrub.

The leaves, with their glabrous or glabrescent, apparently rather dark green upper surfaces and tomentose under surfaces, bear a striking superficial resemblance to those of Rosmarinus officinalis. Structurally, the peculiar abaxial, erect, sac-like enlargement of the upper part of the rather short corolla-tube is the most interesting feature. Its function, if any, must be studied in living material.-W. B. Turrilu.

Fic. 1, 1a, flowering branch, natural size; 2, 3, flower, abaxial and lateral views. $\times 2 ; 4$, corolla, laid open, showing stamens and pistil, $\times 2 ; 5$, corolla, lateral view, $\times 2 ; 6$, calyx and nutlets, from above, $\times 6 ; 7$, transverso section of nutlets, $\times 6$. 



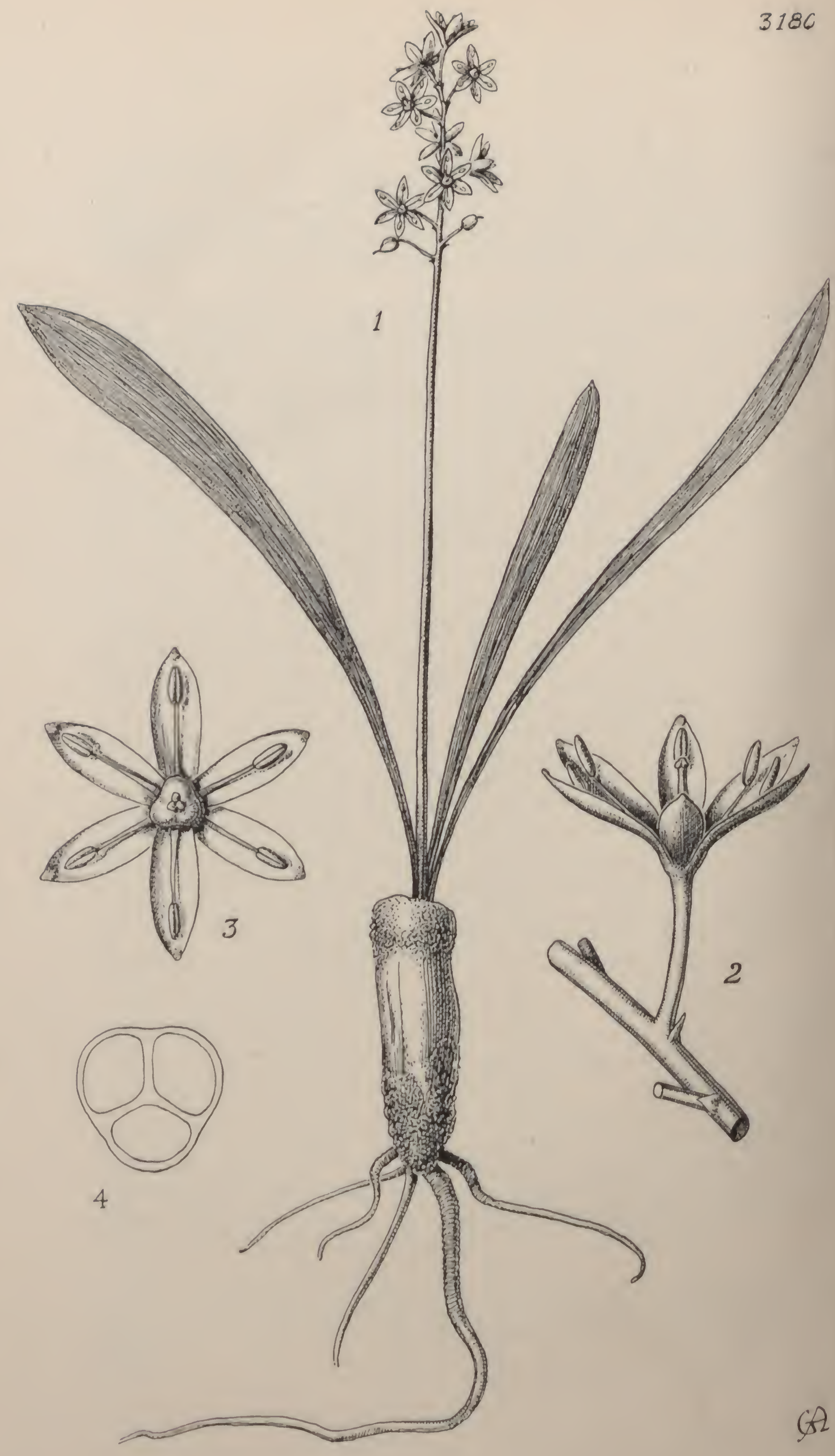




\section{Tabula 3180.}

\section{SCILLA ALBANICA, Turrill.}

\section{Liliaceae. Tribus Scilleae.}

S. albanica, Turrill in Kew Bull. 1932, p. 197 ; a S. messeniaca, Boiss., bulbo elongato, floribus minoribus, ovario latc olpyramidato differt.

Bulbus elongatus, $3.5 \mathrm{em}$. longus, $1.1 \mathrm{em}$. diametro, tunieis pallide brunneis instructus. Folia 3 , synanthia, linearia, plana, a piee breviter subabrupte acutata, basi longe attenuata, $10 \mathrm{em}$. longa, 4-8 $\mathrm{mm}$. lata, glabra, nervis 13-19. Scapus gracilis, glaber, $10 \cdot 5 \mathrm{em}$. longus, raeemo ovato 12-floro, pedicellis erccto-patulis $3.5 \mathrm{~mm}$. longis, braeteis ininutissime deltoideis $0.5 \mathrm{~mm}$. longis. Perigonii phylla subpatentia, oblongoelliptiea, apiee subobtusa et papillosa, $5 \mathrm{~mm}$. longa, $1 \cdot 5-2 \mathrm{~mm}$. lata, ut videtur eaeruleo-violacea. Filamenla $3 \mathrm{~mm}$. longa, apicem versus attenuata, basi vix dilatata, eaeruleo-violacea; antherae atroviolaceae, $1.5 \mathrm{~mm}$. longae. Ovarium late trigono-obpyramidatum, $1.75 \mathrm{~mm}$. longum, $1.75 \mathrm{~mm}$. diametro; stylus $2.5 \mathrm{~mm}$. longus.

Albania. Oloman, roeks, 1900 m., 23.6.1930, Giuseppi 39.

The species, S. messeniaca, Boiss., with which $S$. albanica lias been contrasted above, is known only from the Peloponnese (Messenia, its onia, and Areadia). The more widely spread S. bifolia, L.-with other vaties nivalis (Boiss.) Baker and polyphylla, Boiss.-is the only S. bifolizecies ealling for eomment here. S. albanica differs from the sifolia in the shape of the bulb, the larger number of smaller flowers, It shorter pedieels, and the redueed number of ovules.

It should be remarked that three ovaries were disseeted in drawing up the deseription. In one a single ovule was found, in the others traec of ovules eould be diseovered.-W. B. Turrill.

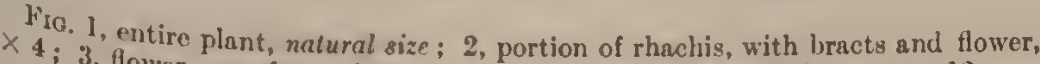
3 , flower, seen from above, $\times 4 ; 4$, transverse section of ovary, $\times 12$. 


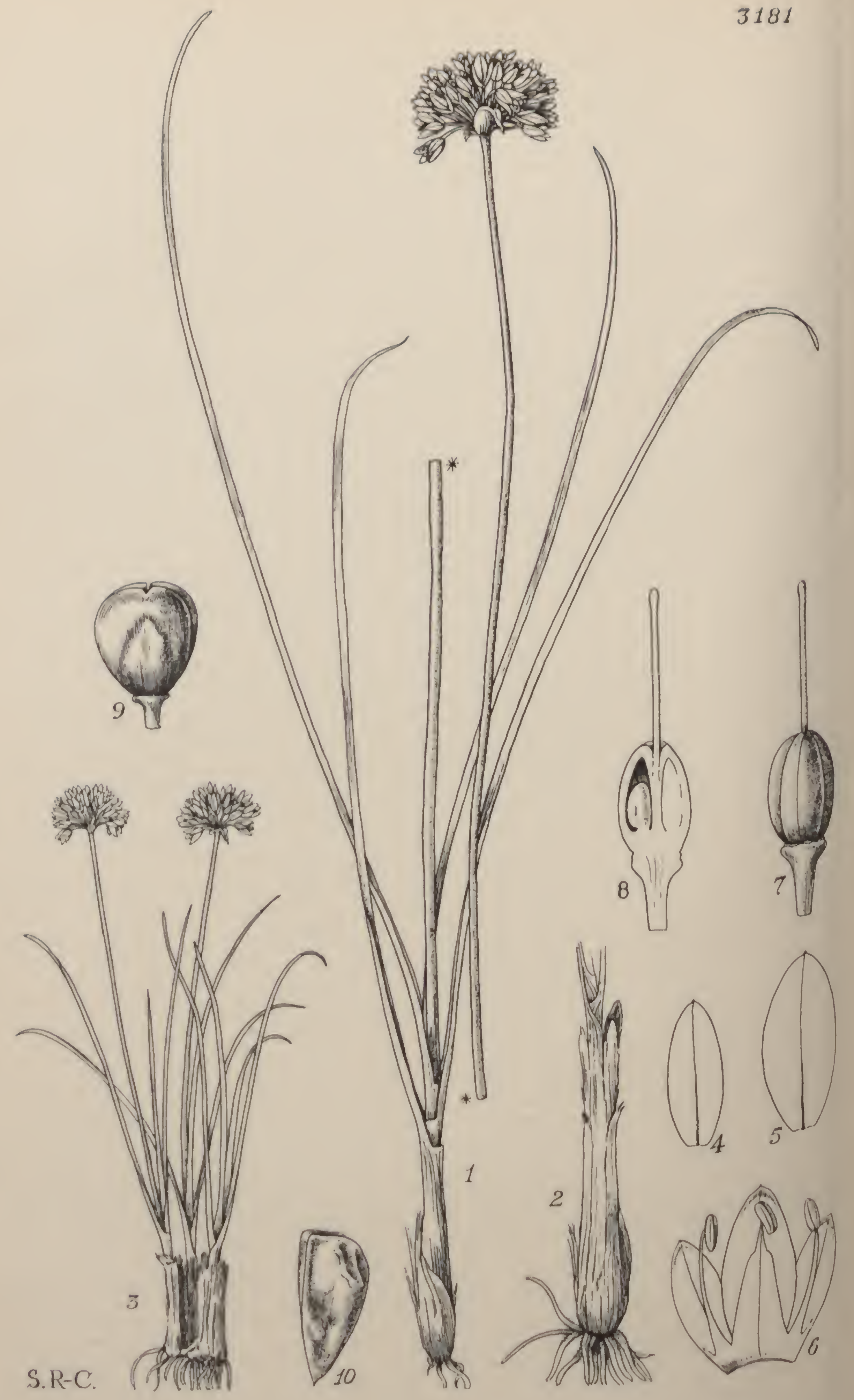




\section{Tabula 3181.}

\section{ALLIUM BIDENTATUM, Fisch.}

\section{Liliaceae. Subfamilia Allioïdeae.}

A. (Rhiziridium) bidentatum, Fisch. apud Prohhanov in Prokhanov et Ikonnikiov-Galitzky, Compte rendu prélim. expéd. Mongol. 1926, in Matér. Commiss. Etude Rép. Mongol. etc., vol. ii. p. 83 (1929), in adnot.; et in Bull. Jard. Bot. Princ. URSS, vol. xxix. p. 564, fig. v. (1930); A. subangulato, Regel, proximum, sed perianthii segmentis inaequilongis aplec obtusiuseulis, bulborum tunicis nunquam in fibras reticulatas solutis distinetum.

$1 \mathrm{~mm}$ crba perennis. Rhizoma non visum. Radices faseiculatac, circiter crassi, erassae. Bulbi aggregati, angustissimi, subeylindrici, 2-3 mm. e quoquorun yaginis fibroso- (haud reticulato-) solutis vestiti. Folia breviora bulbo plerunque $3-4$, angustissime plano-filiformia, seapo involut vel raro ei subaequilonga, striatula, marginibus inferme sacpe Scapus usproximatis sub lente minutissime papilloso-seaberulis. angulis usque $3 \cdot 7 \mathrm{dm}$. altus, ereetus, strietus, tenuiter angulatus, acquals. perimuthiumbella capsulifera, hemisphacriea, pedieellis subaequilongis vivi (test subaequantibus gracilibus laevibus. Flores siceitate rosei, inacquilong Prokhanov) saturate purpurei. Perianthii segmenta subacutang: exteriora adseendentia, elliptiea, subobtusa usque elliptiea, minute apiculata, $4-5 \mathrm{~mm}$. longa; interiora ereeta, late leviter vel ovato-elliptiea, apice rotundato-obtusa, nonnunquam annulum breve minute apieulata, 6-7 mm. longa. Filamenta basi in exteriora simem connata, periant hii segmentis interioribus subbreviora: obcunenta simplicia, subulato-filiformia, interiora anguste usque late quasi lu, superne sub euspide antherifera truneata et denticulo vel ovoideum, eiulo utrinque praedita: antherae oblongae. Ovarium simplici. Cireiter $2 \mathrm{~mm}$. longum, stylo filiformi $3 \mathrm{~mm}$. longo, stignate sub lente Capsula olovoideo-globosa, circiter $3.5 \mathrm{~mm}$. diametro, trigono- vel totissime punetulata. Semina in quoque loculo gemina, diametro, nigetragono-cuneiformia, circiter $2.5 \mathrm{~mm}$. longa, I $\mathrm{mm}$. [pars 2] p. 157 - A. tenuissimum, Regel in Aet. Hort. Petrop. vol. iii. Polanini, Reg (1875), pro parte, non Linn. A. polyrrhizum, Turez, $\gamma$ Airy-Shaw inel in Aet. Hort. Petrop. vol. x. p. 340 (1887). A.omiostema, 
Siberia. Transbaikalia: "Dahuria," Fischer (syntype?); in campis apricis transbaicalensibus, 1833 [Turczaninov]; lacus Baical, pars borealis, Radde; Nertschinsk, in Steppen, 1889, F. Karo, 120.

Chrna. Chihli : Mt. Gulick, Kalgan, 11 Aug. 1921, N. H. Covdry, 1889 ; high exposed rocks, Kalgan, Aug. 1921, N. H. Cowdry, 1982.

Przhevalsky's specimen from Kansu, cited by me (l.c. 145) under Allium omiostema, Airy-Shaw, is probably $A$. dentigerum, Prokhanor (Bull. Jard. Bot. Princ. URSS, vol. xxix. p. 563, fig. iv.: 1930). and may be syntype material: if so, I am unable to find sufficient distinctions to separate it specifically from $A$. bidentatum, Fischer. In the absence of definitely authenticated material, however, I am unwilling to make the reduction.-H. K. AIry-SHaw.

FIG. 1, flowering stem, natural size; 2, base of flowering stem, natural size; 3 , habit, $\times \frac{1}{2} ; 4$, outer perianth-segment, $\times 4 ; 5$, inner perianth-segment, $\times 4$; 6 , perianth and stamens, from within, $\times 4 ; 7$, pistil, $\times 6 ; 8$, longitudinal section of pistil, $\times 6 ; 9$, capsule, $\times 4 ; 10$, seed, $\times 8$. 


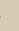




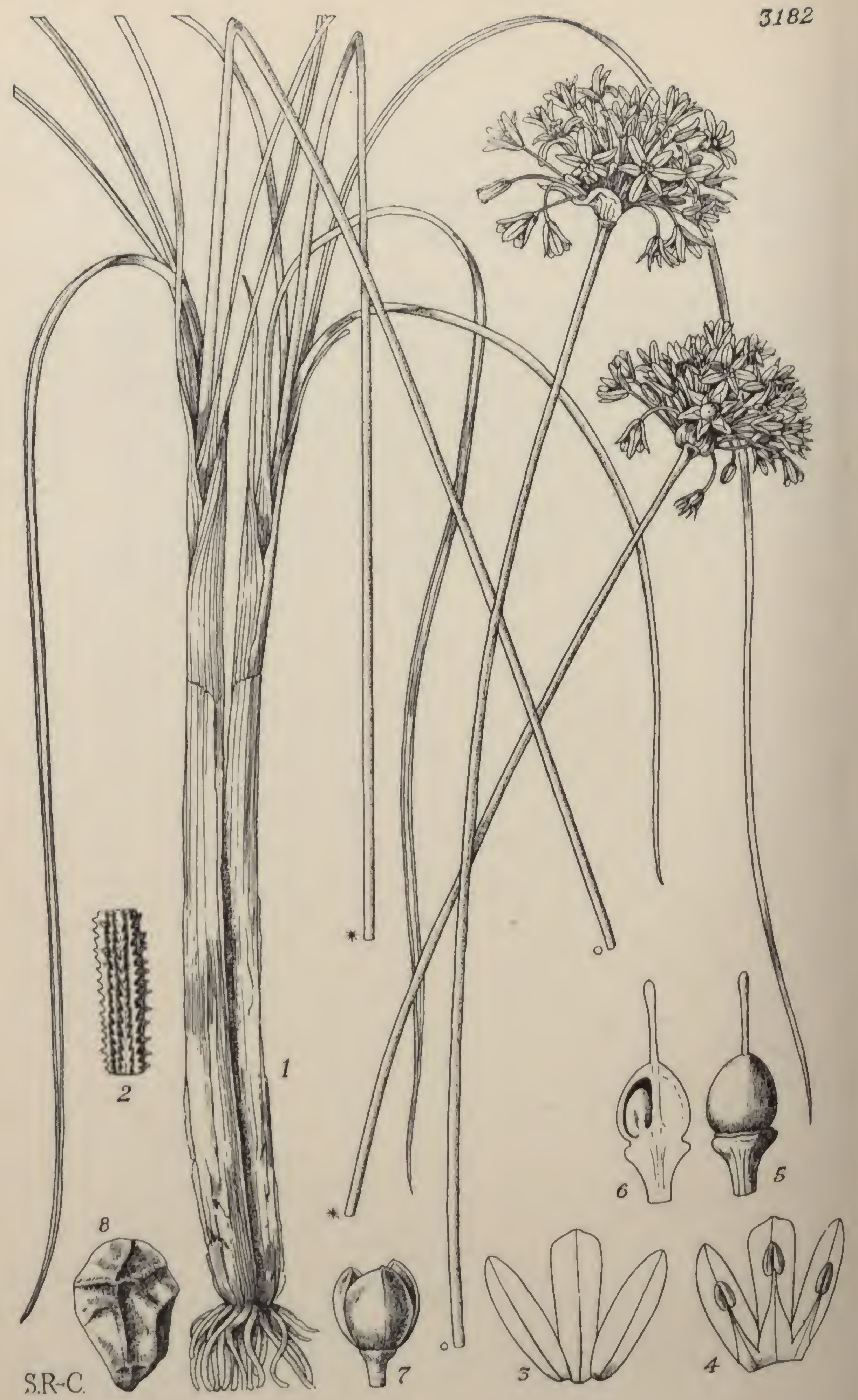




\section{TABULA 3182.}

\section{ALLIUM ZIMMERMANNIANUM, Gilg.}

\section{Liliaceae. Subfamilin AlLtö̈Deae.}

A. (Rhiziridium) Zimmermannianum, Gilg in Engl. Bot. Jahrb. vol. xxxiv. suppl. 75, p. 23 (1904); Loesener in Beih. Bot. Centralbl. vol. xxxvii. sect. 2, p. 99, tab. 2, fig. B-D (1919) : Airy-Shaw in Notes Roy. Bot. Gard. Edinb. vol. xvi. p. 145 (1931); ab A. anisopodio, Ledeb., caulibus pedicellisque sub lente valdc papilloso-scabris, floribus pulehre roseo-sanguincis distinguitur.

Iferba perennis. Rhizoma circiter $4 \mathrm{~mm}$. crassum. Radices fasciculati, vix $1 \mathrm{~mm}$. crassi. Bulbi solitarii vel bini, angustissini, eaulis basi vix crassiores, foliorum vaginis hyalino-membranaceis parallelinerviis haud reticulatis inelusi. Folia linearia, angustissima, plana, circiter $1.5 \mathrm{~mm}$. lata, scapo plerumque breviora, nervis marginibusque fere tota longitudine papilloso-scabra, infernc in vaginas circiter $12-14 \mathrm{~cm}$. longas plus minus subito dilatata. Scapus erectus, usquc $5 \mathrm{dn}$. altus, scabris, clevato-pluristriatus, angulis (maxime supernc) valde papilloso1-valva, apicem versus fuscescens, ipso a pice subito ampliatus. Spatha membran ovata, plus ininus acuminata, circiter $1.2 \mathrm{~cm}$. longa, sulgyloboseca, albida. Umbella capsulifera, hemisphacrica usque ad instar liinultiflora, pediccllis plus minus aequilongis nigresecntibus rosei. Prinne per angulos papilloso-scabris. Flores saturate sanguincoinfernc Prianthii segmenta subaequilonga, suberecta, ncrvo medio acuta urominentc percursa, cxteriora anguste elliptico-oblonga, sub-
subeun sulte subobtusa, cireiter $4 \mathrm{~mm}$. longa, interiora vix longiora, longa, Stamionga, npice obtusissima subito subtruncata, $4.5 \mathrm{~mm}$. incentis Stamina subaequilonga, ima basi connata et perianthii segcirciter aduata, exteriora late subulata, hasi abruptiuseule expansa, ovato-acun partes pcrianthii longitudinis aequantia, interiora late acquantia cireiter 1.5 antherac ovato-oblongac. Ovarium globoso-ovoidenm,

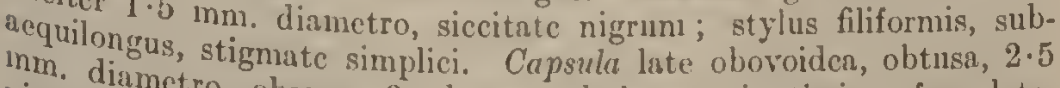
nigra. - A metro, obscure 3-sulcata, sul, lente minutissine fovcolata,

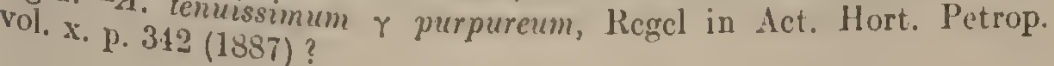


China. Chihli : Kalgan, mountain side, 7 July 1921, N. H. Cowdry, 1625 ; Kalgan, high rock ledges, 29 July 1921, N. H. Cowdry, 1830 : "Flowers crimson." Shensi : Wu-tai-shan, 1876, W. Hancock (Kew Distrib. no. 78).

This very beautiful and apparently rare species is a close ally of Allium anisopodium, Ledeb. and A. tenuissimum, L. Other species show the same type of scabridity on either the pedicels or the leaves (e.g. A. Farreri, Stearn, A. anisopodium, Ledeb.), but not to the same remarkable extent. Under a lens the pedicels look like a coarse file. A. Zimmermannianum was originally described from specimens collected by Nebel and by Zimmermann in the vicinity of Kiau-tschau, Shantung. Being now known from three provinces of northern China, it may be expected to occur in the intervening and adjacent provinces.

Loesener's figure, drawn apparently from a poor specimen in bud, is hardly recognizable.-H. K. AIry-Shaw.

FIG. 1, plant, natural size; 2, portion of pedicel, $\times 20 ; 3$, perianth-leaves (two outer and one inner) from without, $\times 4 ; 4$, the same, from within, showing stamens, $\times 4 ; 5$, pistil, $\times 6 ; 6$, longitudinal section of pistil, $\times 6 ; 7$, capsule, $\times 4 ; 8$, seed, $\times 8$. 



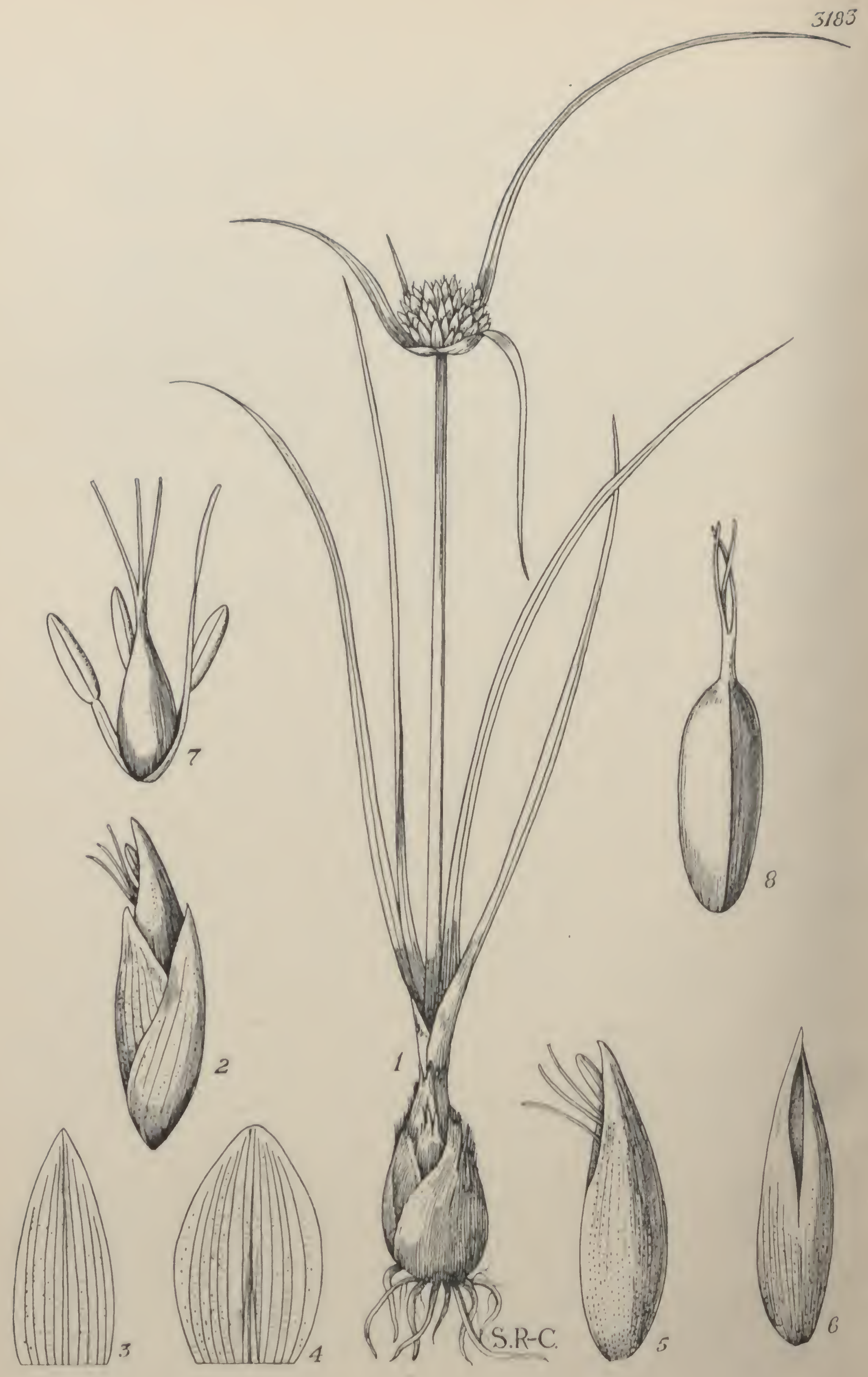




\section{TABULa 3183.}

\section{ASCOPHOLIS GAMBLEI, C.E.C. Fischer.}

\section{Cyperaceae. Subfamilia ScirpoÏdeae.}

Ascopholis, C. E. C. Fischer in Kcw Bull. 1931, p. 104; genus inter Mariscum et Ascolepidcm medium; ab illo squamella utriculari evoluta, ab hoc eaulis basi tumida, spiculis 1 -floris, ab utroque gluma secunda spathiformi differt.

Spiculac anguste lanceolatae, uniflore, floribus omnibus hermaphroditis. Cilumae 2, oppositae, sublyyalinae, inferiori vacua, altera florifera spathacea. Rhachilla supra glumas 2 vacuas disarticulans, tulerculo gibboso relicto. Squamella hypogyna utriculiformis, glumam excedans, subtus integra, supra longitudinaliter aperta florem includens. Seta 0 vel unica, brevis. Stamina 3 ; antherae lineares, paullo exscrtae. Stylus cum ovario continuus, basi haud incrassatus, ramis stigmatosis 2 vel 3 filiformibus. Nux squamella inclusa, sessilis, anguste oblonga, plano-convexa vel obtuse subtrigonn.-Herbac; caules solitarii, basi tumidi, squanis carnosis involuti. Folia angusta ad basi caulis conferta. Spiculae in spicas breves oblongas densissime confertae, terminales, intra bracteas lineares foliaceas valde inacquales sessiles.

\section{A. Gamblei, C. E. C. Fischer, l.c. 105, specics unica.}

Hcrba erecta, glabra, radicibus fibrosis. Caulis solitarius, striatus, basi tumidus, vaginis inferne carnosis albis superne scariosis ferrugineo-punctatis $4-10 \mathrm{~cm}$. longis involutus. Folia compluria, supra eaulis basin turgidam conferta, fliformia vel anguste lincaria, caulem aequantia vel superantia; viginae membranacene, ore truncatae. Spicae oblongae, circiter 1 cm. longare, 3 usque complures in capitulo denso subgloboso sessiles. Bracleac 4, lineares e basi lata, acuminatac, naequales, minimae circiter $1 \mathrm{~cm}$. longae, maximae circitcr $7 \mathrm{~cm}$. spirac. Spiculac lineares, uniflorae, in rhachillam satis robustam relieto insertae, jam delapsae tuberculo parvo interdum marginato macul Glumae 2, oppositae, hyalinae, punctis ferrugineis plus ininus ieuta eon, venosae; gluma inferior abaxialis, ollonga vel lanceolata, formi, concava, carinata, $2 \cdot 7-3 \mathrm{~mm}$. longa, vacua; adaxialis spathilonga, $2 \cdot 5-2 \cdot 7 \mathrm{~mm}$. longa, rotundata, parte inferiore $0 \cdot 5-0.8 \mathrm{~mm}$. ga tubulari. Squamclla solitaria, utricularis, $3 \cdot 5-3 \cdot 8 \mathrm{~mm}$. longa, 
facie adaxiali circiter ad medium supra aperta, apice obtusa, venosa, pallide brunnea, punctis ferrugineis saepe maculata, florem includens. Seta 0 vel unica, abaxialis, capillaris, alba, levis, ovario multo brevior. Stamina 3, adaxialia; antherae lineares, $1 \cdot 2-1 \cdot 5 \mathrm{~mm}$. longae, paullo exsertae. Stylus cum ovario continuus, $0 \cdot 75-1 \mathrm{~mm}$. longus; stigmata 2 vel $3,1 \cdot 1-5 \mathrm{~mm}$. longa, glabra. Nux anguste oblonga, planoconvexa vel obtuse subtrigona, circiter $2.5 \mathrm{~mm}$. longa, fusco-brunnea; cellulae extimae minutae, obtuse hexagonae.

India. Madras Presidency at Ootacamund in the Nilgiri Hills, 2100 m., June 1884, J. S. Gamble, 14279.

The generic name Ascopholis is derived from àoxós, sack, and podis, scale, in allusion to the sack-like squamella.-C. E. C. Fischer.

Fig. 1, an entire plant, natural size; 2, spikelet; 3 , lower glume ; 4, upper glume; 5 , flower enclosed in squamella; 6 , squamella, with flower removed, adaxial view; 7 , young flower, with seta; 8 , nut. Figs. $2-8, \times 12$. 



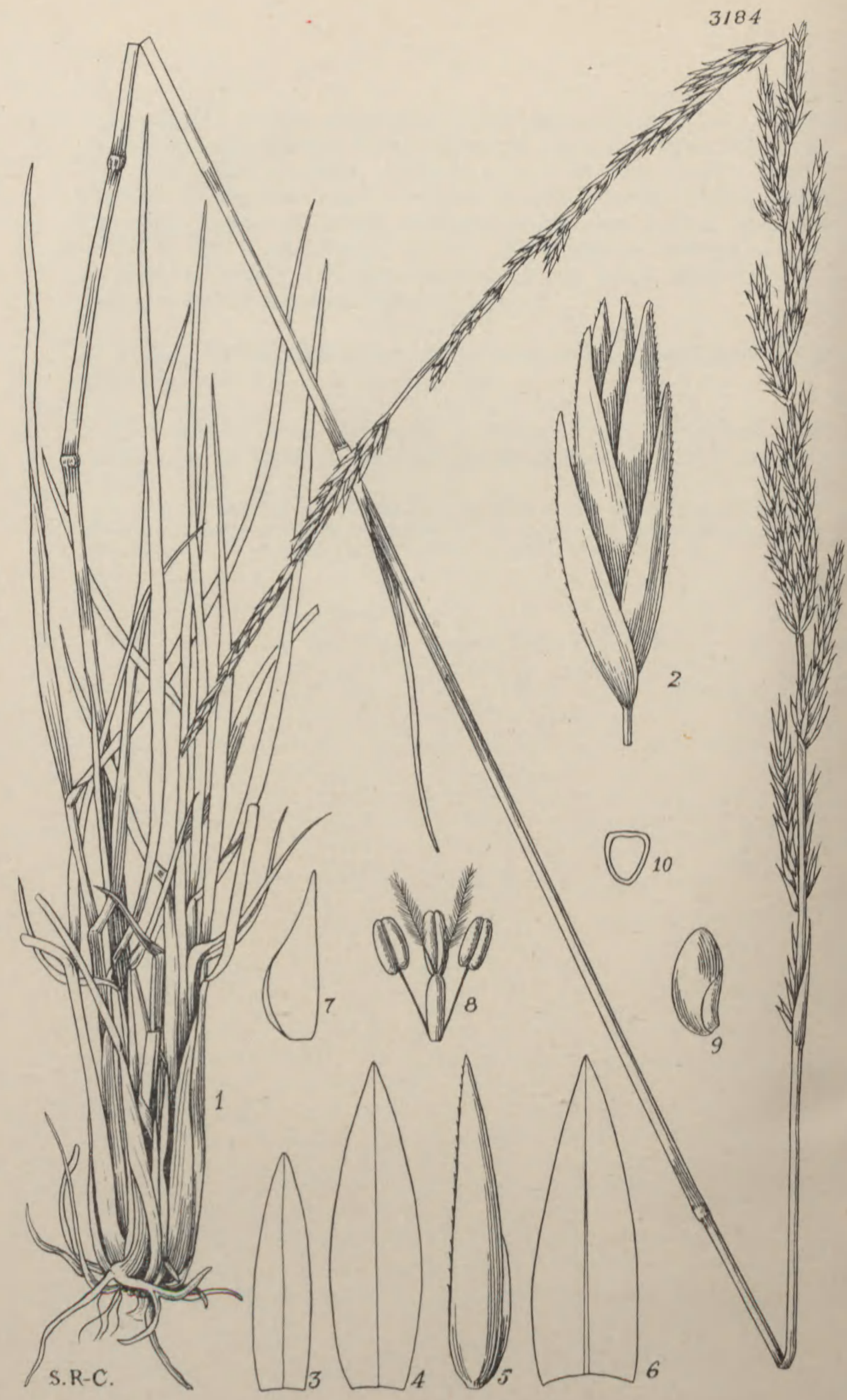




\section{Tabula 3184.}

\section{THELLUNGIA ADVENA, Stapf.}

\section{Gramineae. Tribus Eragrosteae.}

T. advena, Stapf ex Thell. in Viertelj. Nat. Ges. Zürich, vol. lxiv. p. 814 (1919), nomen; et ex Probst in Mitteil. Naturf. Ges. Solothurn, 1914-19, Hrft vi. Brr. xviii. p. 17, cum tab. (1920), nomen; et in Kew Bull. 1920, p. 98 , fig. p. 99, deser.; species generis unica.

Gramen perenne, dense cacspitosum, inflorescentia inclusa ad $1.2 \mathrm{~m}$. altum; innovationes intravaginales, basi leviter bulboso-incrassatac. Culmi c rhizomate brevi erecti vel leviter geniculati, graciles, teretes, rigiduli, simplices, raro ramosi, 2-4-nodes, glabri lacvesque. Folia pallide viridia vel glauea, glabra vel pilis paucis ore vaginarum induta; vaginae basales persistentes, inferne dilatatae, leviter compressac, pallidar vel flavac, coriacene, lacvissimae, nitentes, superiors internodiis breviores, teretes, arcte appressac, tenuissime striatae, lacves vel superne paulo seaberulac; ligula ad serien ciliorum minutorum densorum redacta ; laminac anguste lineares, in acumen longe attenuatae, 4-25 cm. longac, 2-4.5 mm. latae, planac vel convolutae, firmac. rigidae, supra et marginiluss superne minute scaberulac, subtus laeves. Panicula demum c vagina superiore exserta, angustissima, densa vel inferne interrupta, spiciformis, $15-65 \mathrm{~cm}$. longa, $0.4-0.8 \mathrm{~cm}$. Iata, erecta vel plerumque curvata et nutans, glabra, allido-viridis, raro purpureo-suffusa ; rhachis gracilis, laevis ; rami solitarii, usque basin lense spiculati, erecti, inferiorss ad $4.5 \mathrm{~cm}$. longi, internodiis usque $3 \mathrm{~cm}$. longis sejuneti, superiores sensin breviores et approximati; pedicelli filiformes, ad $1.5 \mathrm{~nm}$. longi. Spiculae solitariae vel binac, subsessiles vel brevissime pedicellatae, lateraliter compressar, dense inbricatae, muticae, anguste oblongac vel oblongac, $3-5 \mathrm{~mm}$. longac, ad $1 \mathrm{~mm}$. Iatac, 3-4-florac, nitentes, plerumque albido-virides; rlachilla flexuosa, supra glumas et iuter anthoecia continua vel tarde disarticulata. Glumae lineari-lanecolatae vel lanceolato-oblongae, acutae vel obtusac, delicate membranaceac, uninerves vel inferior enervis, carinatac, carina seaberula; inferior $1.8-2.5 \mathrm{~nm}$. longa; superior 2.8-3.5 $\mathrm{mm}$. longa. Lemmata glımis subsimilia, cxplanata lanceolata, lanceolato-oblonga vel ovata, acuta vel obtusa, 4-2 mm. longa, membranacea, uninervia, supra dimidiam vel tertiam partem carinac scaberula. Paleae dorso curvatac, 2-1 mm. longac, bieariuatac, inter 
carinas plicatae. Antherae oblongae, $0 \cdot 3-0 \cdot 5 \mathrm{~mm}$. longae. Caryopsis oblique ovato-oblonga vel elliptico-oblonga, lateraliter compressa, 0.8-1 $\mathrm{mm}$. longa, pallide brunnea; pericarpium tenue, siccum semini appressum.-Ectrosia? mutica, Hack. ex Probst in Mitteil. Naturf. Ges. Solothurn, 1911-14, Heft v. Ber. xvii. p. 169 (1914), nomen.

Queensland. Burke District: Mt. Emu Plains, 54 miles N. of Hughenden, 2.1931, Hubbard and Winders, 7487; Mt. Emu Plains Station, 64 miles N. of Hughenden, 2.1931, Hubbard and Winders, 7502. Kennedy District: without precise locality, Daintree. Leichhardt District: Clermont, 3.1927, White, 3446 ; between Emerald and Capella, 3.1931, Hubbard, 7942; Emerald, 3.1931, Hubbard, 7921: Malvern Downs, Emerald, 8.1929, Finlay and Farquhar, 20; Wandoan, 1930, Belson; 2.1930, Hubbard, 4922. Warrego District: Victoria Downs, near Morven, 1930, Lord. Maranoa District: Mungallala, 420 m., 12.1930, Hubbard and Winders, 6031 ; between Amby and Eurella, 375 m., 1.1931, Hubbard and Winders, 6353 ; Mitchell, 330 m., 1.1931, Hubbard and Winders, 6302. Darling Downs District: Pickanjinnie, near Wallumbilla, 1930, Belson; Macalister, 320 m., 1.1931, Hubbard and Winders, 6452; Dalby, 4.1916, White, K. 31.

New South Wales. Courallie County: Moree, 5.1914, Carne; Gilgil Creek, near Moree, 3.1898, Campbell.

Switzerland. Derendingen Mill, near Solothurn, on wool refuse, 1918, Probst (type).

In 1907 Dr. Probst, whilst investigating the adventive and ruderal flora of Solothurn in Switzerland, collected undeveloped specimens of this grass, which he listed as Ectrosia? mutica, Hack., without description. Eleven years later good flowering material was found growing on wool refuse from the worsted mill at Derendingen, near Solothurn. It was from this material that Thellungia advena was described. The rich alien flora around the mill included many plants of Australian origin, and this led to the suggestion that Australia was the source of the new grass; a supposition which has since been proved correct.

Whilst studying Queensland grasses in the Brisbane, Sydney and Melbourne Herbaria, specimens of Thellungia advena were observed in the covers of the genus Sporobolus. They were usually confused with Sporobolus elongatus, R. Br., to which they bear a superficial resemblance on account of their densely tufted habit and narrow spiciform panicle.

Thellungia advena is more or less confined to the belt of soils known as the Black Earths which extend from Northern N.S. Wales through the greater part of the Maranoa, Darling Downs, and Leichhardt Districts of Queensland to south of Charters Towers in North Kennedy District. These soils are mainly of basaltic origin. They vary somewhat in colour and texture, but are usually dark brown or black, and of a heavy nature. Pockets of similar soils occur north of Hughenden where Thellungia advena has also been collected. The vegetation 
associatcd with the Black Earths is mainly Brigalow (Acacia harpophylla) serub, alternating with savannah and Eucalyptus woodland. Thellungia advena is usually found as scattered tufts in open Brigalow serub or on the margin of Brigalow serub and Eucalyptus woodland where the vegetation is less densc. It is frcquently abundant on savannah which has becn heavily stoeked. In such eascs over-grazing has resulted in the lcss pala table Thellungia advena becoming the dominant grass. The average rainfall of the area in which it occurs, ranges from 22-28 inches, but the major portion of this falls during the summer months.

Both Sporobolus and Eragrostis are very closely allied to Thellungia. From the former it differs in having more than one floret in each spikelet, whilst the onc-nerved lemmas alone serve to distinguish it from the latter.-C. E. HuBBARI).

FIa. 1, complete plant, natural size : 2, spikelet, $\times 14 ; 3$, lower glume; 4, upper glume; 5 , floret, lateral view ; 6 . lemma; 7 , palen, lateral view ; 8 , stamens and pistil ; 9 , caryopsis ; 10 , transverse section of caryopsis. Figs. 3-10, $\times 15$. 




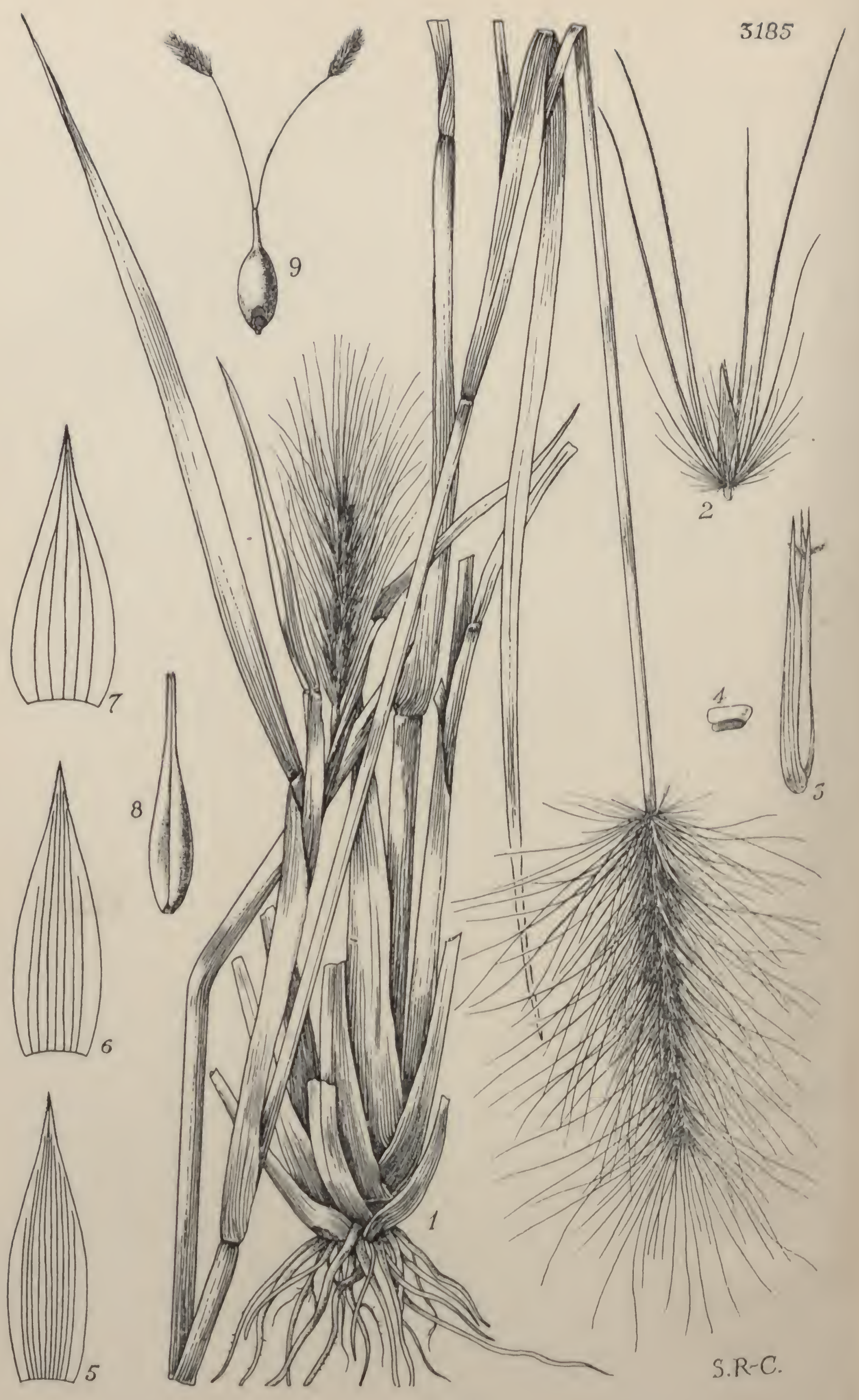




\section{TABUI.A 3185.}

\section{PENNISETUM BASEDOWII, Summerhayes et C. E. Hubbard.}

\section{Gramineae. Tribus Paniceae.}

P. Basedowii, Summerhayes et C. E. Hubbard in Kew Bull. 1926, p. 440 ; speoies affinis $P$. villoso, R. Br., sed annua, setis eciliatis, spieulis brevioribus, gluma superiore 9-11-nervi differt.

Gramen annuum. Culmi laxe enespitosi vel solitarii, ereeti vel genioulati, usque $70 \mathrm{~cm}$. alti, graeiles vel validiuseuli, subteretes vel plerumque uno latere suleati, e nodis plurimis ramosi, ramis solitariis vel faseieulatis, 3-5-nodes, panieulam versus tenuiter striati seaberuli et pubeseentes, ceterum glabri laevesque. Foliorum vaginae internodiis breviores, laxac, leviter compressae, carinatae, tenuiter striatac, glabrae laevesque vel superne seaberulae; ligulae truneatae, usque $0.5 \mathrm{~mm}$. longae, dense eiliatae; laminae lineares, aeutissimae, neutae Vel raro subobtusac, a pice leviter eallosae, 5-40 cm. longac, 5-7 $\mathrm{mm}$. latae, virides vel subglaueae, moderate firmac, glabrae, scaberulae vel marginibus et apieibus exeeptis plerumque lacves. Panicula spieilata (densa vel laxiuseula, eylindrien, ereota, 3-8 cm. longa, 3-6 em. rhachis (setis inelusis), pallide straminea vol leviter purpureo-tineta; lasibus rigida, angulata, seaberula, angulis eiliolatis, fasciculorum patentes minutis subpatelliformibus laxe adspersa; faseieuli demum simis ind peduneulis usque $1.5 \mathrm{~mm}$. longis pilis appressis densis brevispallidae indis; iuvolueri setae numerosae, densae, ad basin liberae, longae, vel apieibus purpureac, exteriores breviores, $0.5-18 \mathrm{~mm}$. longe, strietae, filiformes, scaberulae, interiores saepe $3-4,2-3 \cdot 8 \mathrm{~cm}$. eiliolatigidae, basin versus triquetrae leviter dilatatae ot scabridolanecolat superne filiformes et seaberulac. Spiculae solitariae, sessiles, 6-7.3 $\mathrm{mme}$ vel anguste lanceolatae, acutissimae vel acuminatac, prominm. longae, pallidae vel uno latere purpureo-sufiusae, glabrae, et enerviter nervosae. Gluma inferior nulla vel minutissima, hyalina aeuminas; superior explanata late lanecolata vel elliptico-lanecolata, 3-11-nervis, 5.5-6.8 $\mathrm{mm}$. longa, membramaeea, marginilus hyalinis, ad lemervis, nervis parallelis, apiee seaberula. Anthoecium inferum lanecolatum redaetum: lemma spieulae aequilongum, explanatum late apiee seuber vel ovatum, aeuminatum, membranaeeum, 7-9-nerve, scuberulum; palea nulla. Anthoccium superum \$े, laneeolatum, 
acuminatum, infero subaequilongum: lemma explanatum late lanceolatum vel ovatum, acuminatum, tenuiter crustaceum, marginibus membranaceis, minute obscureque rugulosum, 5-nerve, apice scaberulum; palea lemma paullo brevior, apice minute bifida, scaberula. Lodiculae nullae. Antherae lineares, usque $0.7 \mathrm{~mm}$. longae, apice glabrae. Styli basi breviter connati, superne liberi. Caryopsis oblonga, $2 \mathrm{~mm}$. longa.

Western Australia. Northern Kimberleys: King Sound; May River, 4.1916, Baserlow, 13 (type).

Queensland. Cook District: Gilbert River, Wildash. Burke District: Nonda, between Hughenden and Cloncurry, in grassland on heavy dark-brown soil, 515 ft., 2.1930, Hubbard and Winders, 7207, 7252. Flinders River, 8.1916, White. Mitchell District: Wantalanya, 50 miles south of Winton, 1930, Pollock, 12. Muttaburra, 4.1919, White.

The discovery of this grass by Dr. Basedow has increased the number of indigenous Australian species of Penniselum to three, the other two being $P$. alopecuroides (L.) Spreng. (P. compressum, R. Br.) and $P$. arnhemicum, F. Muell. The former differs in being a perennial grass with simple densely-tufted culms and long strongly-compressed basal leaf-sheaths, whilst the latter may be readily distinguished by its densely-plumose and shorter involucral bristles. P. villosum, R. Br., with which our plant is compared, is a species from the mountainous region of North-East Tropical Africa, which is now commonly naturalized in parts of the coastal districts of temperate and subtropical Australia.

The eastern stations for $P$. Basedowii are more than 1200 miles away from the type locality in Western Australia. On this account it is very probable that when the botanical composition of the grasslands of Northern Australia is investigated, additional stations for our species will be recorded linking up the two distant areas. In Queensland this species occurs mainly on Mitchell Grass downs, in association with Astrebla lappacea, A. elymoides, A. squarrosa, and species of Panicum, Eriochloa, Dichanthium, etc. It is one of a number of annual grasses which are prominent after the summer rains amongst the perennial Mitchell Grasses (Astrebla sp.).

As with many other species of Penniselum, P. Basedowii is apparently protogynous.-C. E. Hubbard.

FIG. 1, entire plant, natural size; 2, fascicle of bristles (reduced branches) surrounding a spikelet, $\times 2 ; 3$, spikelet, lateral view, $\times 6 ; 4$, lowor glume, $\times 20 ; 5$, upper glume, $\times 6 ; 6$, lemma of lower floret, $\times 6 ; 7$, lemma of upper floret, $\times 6 ; 8$, palea of upper floret, $\times 6 ; 9$, pistil, $\times 6$. 



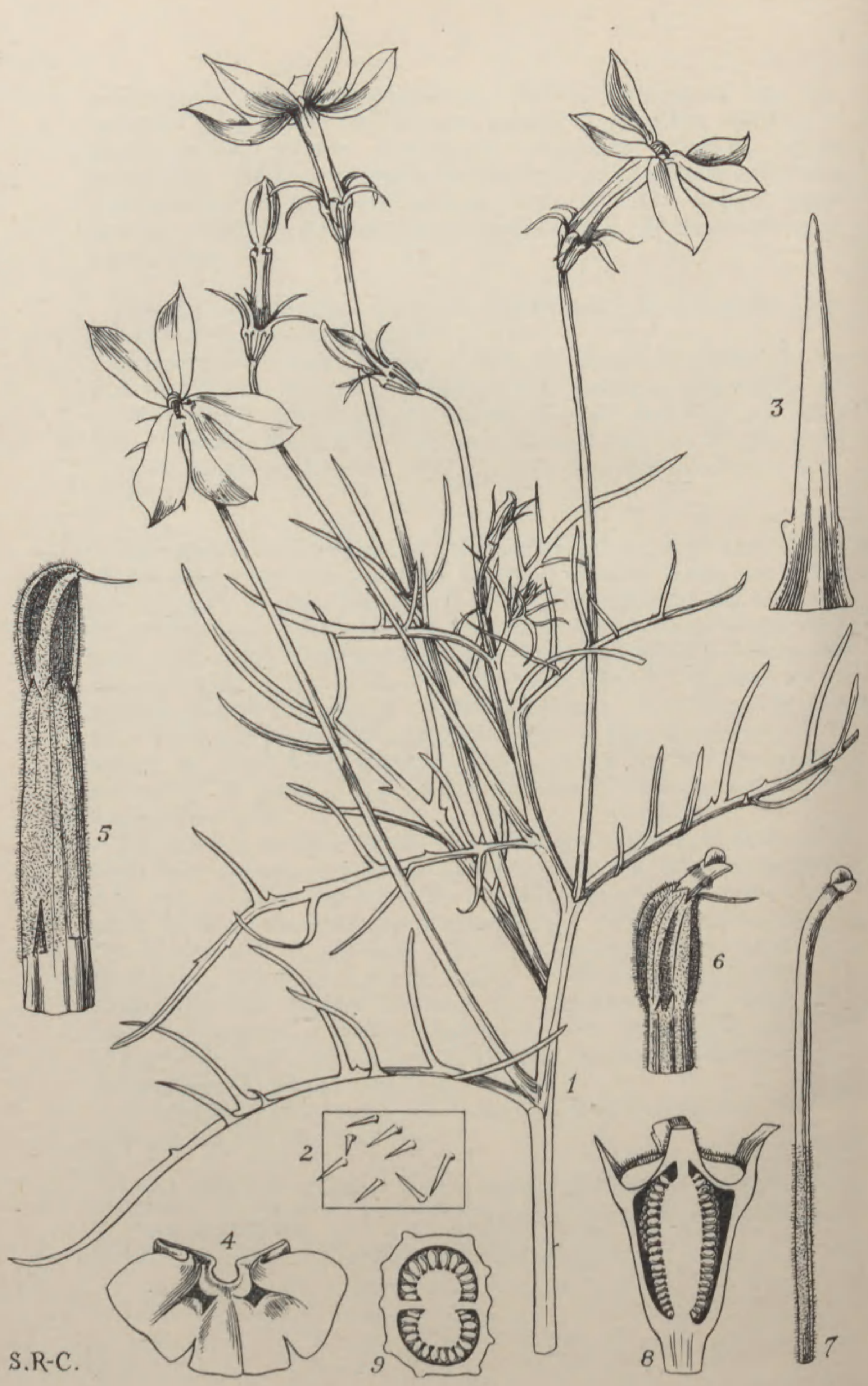




\section{TABULA 3186.}

ISOTOMA ANETHIFOLIA, Summerhayes.

\section{Campanulaceae. Subfamilia Lobeliö̈deae.}

I. anethifolia, Summerhayes in Kew Bull. 1932, p. 318; affinis 1. axillari, Lindl., a qua foliis angustioribus segmentis longioribus, floribus albis, corollae lobis anterioribus oblanceolatis latioribus, tubo circiter $1 \cdot 4 \mathrm{~cm}$. longo differt.

Herba perennis (?), erecta, usque $50 \mathrm{~cm}$. alta, fere glabra. Caules multi, satis ramosi, teretes. Folia alterna, pinnatipartita, ambitu ellipticolanceolata, usque $8 \mathrm{~cm}$. longa, partc media indivisa usquc $2 \mathrm{~mm}$. lata, segmentis valde inaequalibus, longioribus utrinsecus 3-4 distantibns linearibus usque $2 \mathrm{~cm}$. longis ct $1.5 \mathrm{~mm}$. latis basin versus intcrdun dente brevi instructis, brevioribus usque dentiformibus. Flores ex axillis foliorum supcriorum orti; pedicelli suberecti, nsque $15 \mathrm{~cm}$. longi. Sepala lineari-subulata, acuta, recurvata, 6-7 nm. longa, basi $] .5 \mathrm{~mm}$. lata, infernc anguste alata alis plus minusve in dentem desinentibus. Corolla alba ; tubus cylindricus, medio leviter constrictus, $1 \cdot 3-1 \cdot 5 \mathrm{~cm}$. longus, $3 \mathrm{~min}$. diametro; lobi 2 posteriores oblongo-clliptici, acute acuminati, $1 \cdot 2-1 \cdot 5 \mathrm{~cm}$. longi, 4-5 $\mathrm{mm}$. lati, 3 anteriores oblanceoluti, cuspidato-apiculati, $1 \cdot 3-1 \cdot 6 \mathrm{~cm}$. longi, $6-9 \mathrm{~mm}$. Inti, internedio basi callis duobus senicircularibus instructo. Antherae pubescentes, 2 inferiores apicc seta singula recta instructac. Stylus inferne pubescens, superne glaber; stigma apice dilatatum, bilabiatum, annulo pilorunı instructum; ovarium obconicum, circiter $5 \mathrm{~mm}$. longum. Capsula obconica vel cylindrico-obconica, circiter $1 \mathrm{~cm}$. longa; semina nigra, oblongo-cylindrica, $0.7 \mathrm{~mm}$. longa.

QueEnsland. Stanthorpe, in crevices of granite rocks in open forest on an exposed mountain top, $990 \mathrm{~m} ., 3.1930$, II ubbard, 5693 (type) ; flowered at Royal Botanic Gardens, Kew, 6.1932, from sced of same.

NEw Souti Wales. Ncar Tcnterfield, C. Stuart.

The flowers are white, with a faint mauve line down the centre of the anterior corolla-lobes. The calli at the base of the median anterior lobe are bright green.

This species was included by Bentham under I. axillaris, Lindl., in Flora Australiensis, but is easily distinguished by the cliaracters given 
in the diagnosis. It stands in the genus as the culmination of a morphological series showing increasing dissection of the leaves. At the opposite extreme is $I$. Brownii, G. Don, with entire linear leaves, next follow I. pusilla, Benth., and I. scapigera, G. Don, with slightly toothed leaves, and these are succeeded by I. longiflora, Presl, I. petraea, F. Muell., and finally I. axillaris, Lindl., in which the leaves are very similar to those in $I$. anethifolia. In the latter species, however, the lateral segments are longer and narrower, while the portion on each side of the midrib has been reduced in width until the central part is little wider than the lateral segments.

The species was collected by Mr. Hubbard on a rocky hill not far from Stanthorpe in Southern Queensland, where it was growing in the crevices of the large granite blocks scattered about the summit. The soil was very dry at the time of collecting, but the plants were covered with blossom and obviously flourishing. It was seen only at this locality but was exceedingly common there. The lower slopes of the hill bore the usual open type of Eucalyptus forest.

The species is known only from the neighbourhood of the QueenslandNew South Wales border, there being a specimen in the Kew Herbarium, under the name of $I$. axillaris, Lindl., collected by C. Stuart near Tenterfield in northern New South Wales. It is possible that it may also occur farther south along the New England plateau.

\section{S. Summerhayes.}

FIG. 1, upper part of flowering stem, natural size ; 2 , upper surface of leaf, $\times 27$; 3 , calyx-segment, from without, $\times 6 ; 4$, mouth of lower lip of corolla, showing calli, $\times 4 ; 5$, androccium, $\times 6 ; 6$, upper part of androccium, and stylo, $\times 6$; 7 , style, $\times 4 ; 8$, longitudinal section of ovary, $\times 4 ; 9$, transverso section of ovary, $\times 6$. 


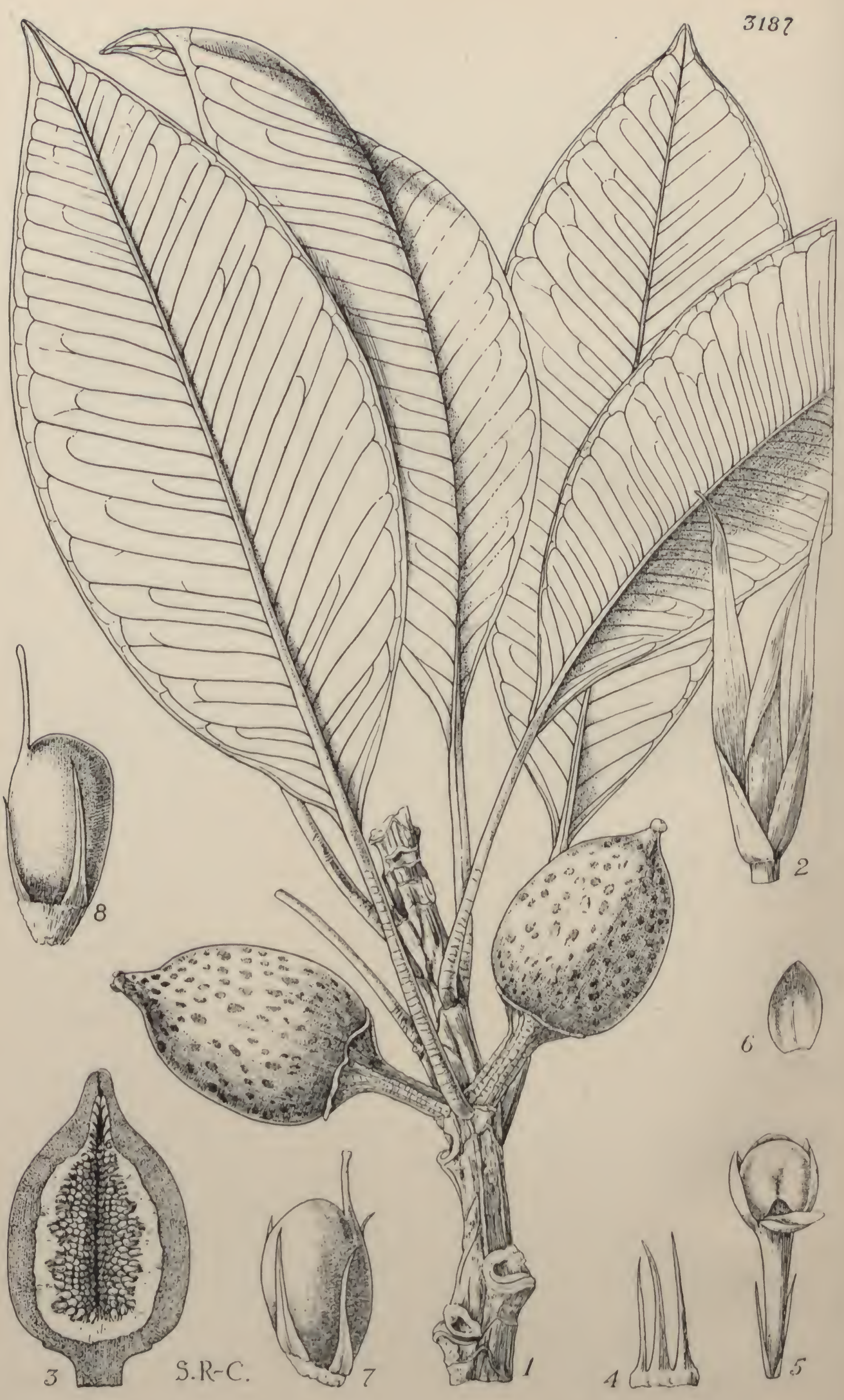




\section{TABULA 3187.}

\section{FICUS WATKINSIANA, $F$. MI. Bailey.}

\section{Moraceae. Tribus Ficeat.}

F. Watkinsiana, F. M. Bailey in Qucensl. Dept. Agric., Bot. Bull. no. ii. p. 18 (1891) ; F. M. Bailey, Queensl. Fl. p. 1472 (1902); ct Comprehens. Cat. Qucensl. Pl. p. 487, fig. 485 (1913); Francis, Austral. Rain Forest Trees, p. 69, fig. 32 (1929) ; F. macrophyllae, Desf. similis, sed foliis basi cuncatis oblongo-ovoidcis, receptaculis apice in mamillam productis facile distingucnda.

Arbor magna, usque $50 \mathrm{~m}$. alta, trunco usque $2 \mathrm{~m}$. diametro basi obtuse carinato, cortice griseo leviter ruguloso. Ramuli crassi, glabri, cicatrieibus foliorum et stipularum delapsorum valde notati. Folia alterna, longe petiolata, omnino glabra, clliptica, oblongo-elliptica vcl elliptieo-laneeolata, utrinque angustata, apicc breviter obtuseque acuminata, basi cuneata, 8-20 cm. longa, 2-7 cn. lata, costa supra impressa subtus prominente, nervis lateralibus utrinsecus 11-16 parallelis c costa angulo $45-60^{\circ}$ exeuntibus pro rata inconspicuis prominulis prope marginem in ncrvum submarginalcm conjunctis, retc venularum indistineto, utrinque viridia; stipulae lanceolatae, acuminatae, concavac, usque $9.5 \mathrm{~cm}$. longae, glabrae; petioli graciles, supra canalicula ti, 4-7 cm. longi, inferne transverse costulati. Receptacula axillaria, singula vel bina, stipitata, oblongo-ovoidea, apicc in mamillam producta, $2 \cdot 5-4 \mathrm{~cm}$. longa, $1 \cdot 5-3 \mathrm{~cm}$. diametro, lenticcllis orbieularibus ct ellipticis valde notata, bractcis basalibus in discum truucatum 1-1.7 $\mathrm{cm}$. diamctro basi receptaculi adnatum connatis. Flores ơ et + cecidiophori commixti ; receptaculum intus inter flores squamis linearibus acutis membranaceis $2 \cdot 5 \mathrm{~mm}$. longis praeditum. Flores $0^{t}$ $1 \cdot 5-3 \cdot 5 \mathrm{~mm}$. longe pedicellati, perianthii scgmentis 4 ovatis subacutis cireiter $1 \mathrm{~mm}$. longis; stamen singulum, anthera reniforni, filamento brevi. Flores of cecidiophori floribus of siniles sed pericarpio tenuiore, stylo breviorc, stigmate parvo capitato. Flores o sessiles, perianthii scgenentis 4 e basi latiorc linearibus acutis ovario brevioribus, ovario ellipsoideo $2.5 \mathrm{~mm}$. longo, stylo infra-apicali cum stigmate obtuso $2 \mathrm{~mm}$. longo. $-F$. Bellingeri, Moore et Betche, Handb. FI. N.S. Wales, p. 81 (1893). 
Queensland. Mooloolah, Aug. 1892, Bailey. Springbrook, slopes of Macpherson Range, near an old homestead, 900 m., 29 Sept. 1930, Hubbard, 5413.

According to Francis (l.c.) the species is distributed from Gympie in Queensland in the north, as far south as the Bellinger River in New South Wales. It is mostly found in rain forest near the coast, but also extends as far inland as the Bunya Mts., which are 100 miles from the sea. The specimen from which the drawing was prepared, was obtained from an isolated tree in the middle of a clearing in the rain forest on the north slopes of the Macpherson Range. For the general affinities of this species see under $F$. glandifera, Summerhayes (t. 3188). $F$. Watkinsiana may be distinguished among its allies by the elliptical, relatively narrow leaves, cuneate at the base, and by the rather longstipitate and hard receptacles which have the ostiole placed on a nipple-like projection at the apex.-V. S. Summerhayes.

Fig. 1, branch with leaves and receptacles, natural size ; 2 , stipules from terminal bud, $\times \frac{2}{3} ; 3$, longitudinal section of a receptacle, natural size; 4 , scales from the inside of the recoptacle, $\times 8 ; 5$, male flower, with one perianth-segment turned back to show the anther, $\times 8 ; 6$, a perianth-lobe from the same, $\times 8 ; 7$, galled fomale flower, $\times 8 ; 8$, female flower, $\times 8$. 



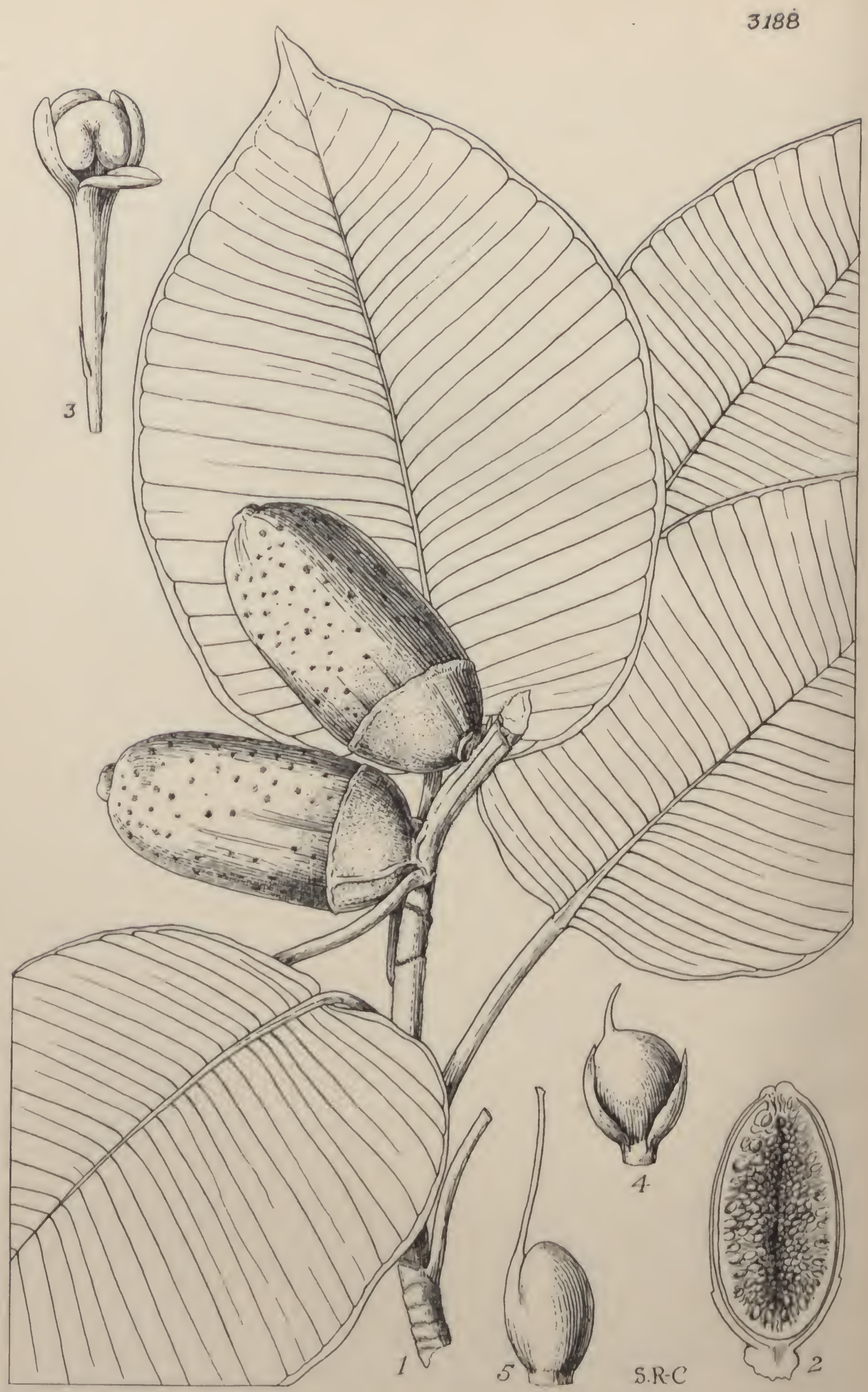




\title{
TABULA 3188.
}

\section{FICUS GLANDIFERA, Summerhayes.}

\author{
Moraceal. Tribus Ficeae.
}

F. (§ Urostigma) glandifera, Summerhayes in Journ. Arn. Arb. vol.xiii. p. 99 (1932); aftinis $F$. cylindricae, Warb., a qua foliis late ovatis petiolis brevioribus, receptaculis sessilibus, cupula magis evoluta differt.

Arbor magna, habitu F. indicae, I. similis. Ramuli crassi, juniores sparsiuscule pubeseentes, demum glabrescentes, cortice brunneo oltecti, cicatricibus foliorum et stipularum delapsorum valde notati. Folia petiolata, late ovata, apice hreviter acuminata, acuta, basi obtusissima vel saepius rotundata, $7-14 \mathrm{~cm}$. longa, $4-8 \mathrm{~cm}$. lata, costa supra impressa subtus prominente, nervis lateralibus utrinseeus $20-30$ parallelis e costa angulo $70-80^{\circ}$ exeuntilus utrinque distinctis supra prominulis nervo submarginali eurvato conjunctis, nervis secondariis numerosis sulparallelis crebris, rete venularum subtus distincto, coriaeen, supra subnitentia, utrinque glabra; petiolus pro rata gracilis, supra leviter canaliculatus, $3-4 \cdot 5 \mathrm{~cm}$. longus, glaber; stipulae non visae, ut videtur caducae. Receptacula axillaria, singula vel gemina, sessilia vel subsessilia, oblongo-ellipsoiden, circiter $4.5 \mathrm{~cm}$. longa, $2.5 \mathrm{~cm}$. diametro, apice in mamillam $5 \mathrm{~mm}$. diametro producta, ostiolo ipso leviter depresso bracteis haud manifestis, bracteis basalibus in cupulam cireiter $1 \mathrm{~cm}$. longan breviter pubescenten receptaculo adnatam connatis, receptacula ergo glandes Querei specierum simulantia; pedunculus usque $4 \mathrm{~mm}$. longus, srepius brevissimus, $4 \mathrm{~mm}$. diametro. Flores ô, $q$ et $q$ cecidiophori commixti. Flores ô longipedicellati, pedieello bracteis duabus lanceolatis instrueto; perianthii segmenta 4, libera, elliptica vel ovata, valde coneava, vix $1 \mathrm{~mm}$. longa, glabra, stamen singulum arcte incluclentia. Flores of cecidiophori pedicellati vel rarius sessiles, perianthii segment is eis florum ơ similibus, ovario sessili, stylo brevi, stigmate elavato. Flores $q$ sessilcs, ovario ovoideo $1.5 \mathrm{~mm}$. longo, stylo infra-rpicali $2.5 \mathrm{~mm}$. longo, stigmate minuto.

New Henrides. Tanna: Lenakel, $200 \mathrm{~m}$., rain forest, conmon, 3 Marel 1928, Kajeuski, 80. Aneityum: Anelgauhat Bay, sea level, rain forest, common, 21 Feb. 1929, Kajeusski, 802 (type). 
F. glandifera belongs to a group of species in Sect. Urostigma, possessing large leaves and fruits; the other members of the group are natives of Queensland. These species exhibit in various degrees two modifications: firstly, the prolongation of the ostiolar region into a proboscis-like structure and, secondly, the fusion of the basal bracts to form a kind of disk or collar. The former feature is best seen in F. Watkinsiana, F. M. Bailey (t. 3187) and F. crassipes, F. M. Bailey, but is less well developed, although clearly evident, in $F$. glandifera. The cupular development of the bracts, on the other hand, reaches its maximum for this group, perhaps indeed for the whole genus, in $F$. glandifera, in which species the receptacle bears a strong resemblance to an acorn. $F$. cylindrica and $F$. crassipes have a strongly-developed bracteal disk, and the same type of structure is also present in $F$. Baileyana, Domin and $F$. Watkinsiana, although to a less degree. This disk-like fusion of the bracts is found less strongly developed in many species of Urostigma.

In $F$. glandifera the receptacles are practically sessile, in which respect it approaches closely to $F$. crassipes, but the leaves and receptacles in that species otherwise show many points of difference. $F$.cylindrica has acorn-like fruits with short thick stalks, but the leaves are longer and relatively narrower than those of $F$. glandifera.

It will be seen that $F$. glandifera is known only from the southern islands of the New Hebrides archipelago. So far as can be ascertained the floras of the northern and southern islands differ considerably, so that it is possible that the species is restricted to the latter region.

\section{S. Summerhayes.}

FIG. 1, branch, with leaves and receptacles, natural size; 2, longitudinal section of receptacle, natural size; 3 , male flower, with ono perianth-segmont turned back to show the anther, $\times 15 ; 4$, galled fomale flower, $\times 10 ; 5$, female flower, $\times 15$. 


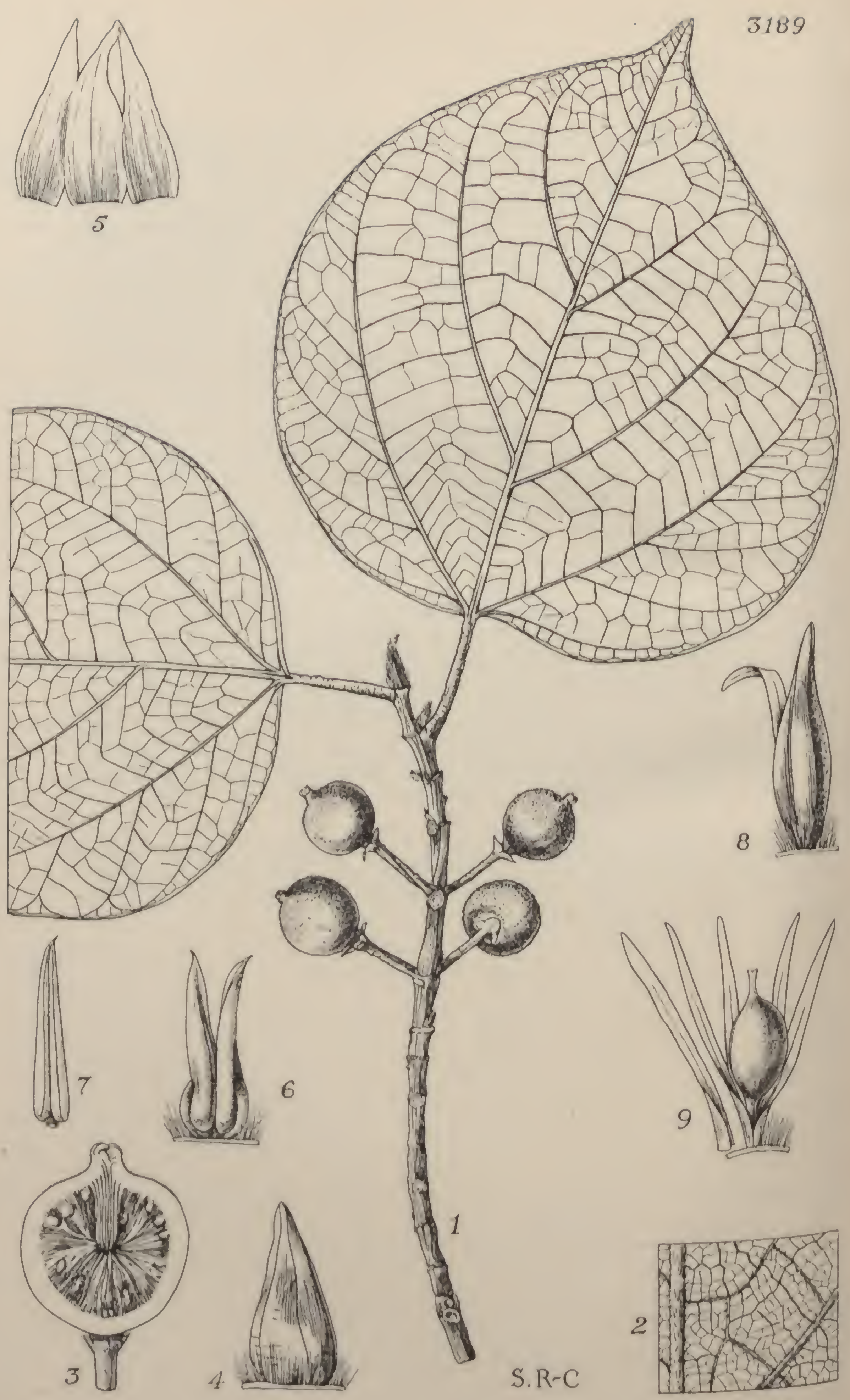


\section{Tabula 3189.}

\section{FICUS NASUTA, Summerhayes.}

\section{Moraceae. Tribus Ficeae.}

F. (§ Eusyce) nasuta, Summerhayes; species nova affinis $F$. laevi, Bl. et $F$. obtusae, Hassk., ab hac foliis orbiculari-ovatis breviter acuminatis basi leviter cordatis supra fere lacvibus, pedunculis gracilioribus, ab illa foliis pro rata brevioribus et latioribus, petiolis satis brevioribus, receptaculis distinete umbonatis difiert.

Frutex seandens, silvarum primacvarum incola. Caulis truncos arborum arcte amplectens, ramis patenti-dependentibus; ramuli subteretcs, lcviter longitudinaliter rugosuli, annotini cortice atrobrunnco obtecti, cicatricibus prominentibus foliorum delapsorum et stipularum notati. Folia alterna, pctiolata; laminae ovatae vel orbiculari-ovatac, apiculatac vcl breviter acuminatac, basi rotundatac usque levitcr cordatae, $8-10 \mathrm{~cm}$. longac, $6-9 \mathrm{~cm}$. latae, basi tri- vel subquinque-ncrviae, costa supra impressa subtus prominente, nervis lateralibus utrinsecus $4 \mathrm{e}$ costa angulo $40-50^{\circ}$ exeuntibus incurvatis prope marginem arcuatim eonjunctis, rete venularum crebro distinctissimo, tenuiter coriaceae, supra glabrae vel pilis sparsissimis praeditae, subtus pracsertim in venis pilis plus minusve adpressis sparsiuscule obtcctae; petioli graciles, supra anguste et leviter canalieulati, 1.3$1.6 \mathrm{~cm}$. longi, ferrugineo-puberuli; stipulae lanceolatae, acuminatac, 7-8 $\mathrm{mm}$. longae, dense adpresse ferrugineo-hirsutac. Receptacula solitaria vel sacpius bina, pedunculata, globosa, apice anguste et prominenter umbonata, $2 \mathrm{em}$. diametro, matura sordide purpurea, densiuscule puberula, basi bracteis tribus triangulari-ovatis subacutis instructa, bracteis osteolaribus manifestis; peduneuli graeiles, dense ferrugineo-puberuli, eireiter $1 \mathrm{~cm}$. longi. Flores ot et $q$ cecidiophori commixti ; recptacula inter flores pilis setuliformibus $0 \cdot 6-0.9 \mathrm{~mm}$. longis dense obtecta. Filores ơ sessiles, acuminato-ovoidei ; perianthii segmenta 3-4, plus minusve connata, $4.5 \mathrm{mn}$. longa; stamina 2 , filamentis brevibus leviter areuatis $1 \mathrm{~mm}$. longis, antheris subulatotriangularibus acuminatis $3.5 \mathrm{~mm}$. longis. Flores of cecidiophori sessiles; perianthii segmenta 4, linearia, subacuta, $4-4 \cdot 5 \mathrm{~mm}$. longa ; ovarium $0 \cdot 7-2 \mathrm{~mm}$. longe stipitatum, compresse ellipsoideunl, $1 \cdot 3-$ $1.7 \mathrm{~mm}$. longum ; stylus plus minusve apicalis, $0.5-0.7 \mathrm{~mm}$. longus, stignate minuto leviter excavato coronatus. 
Santa Cruz Islands. Vanikoro, $50 \mathrm{~m}$, common vine growing on rain-forest trees, main thick stem clinging close to trunk, branches hanging out up to $2 \mathrm{~m}$., fruit dirty-purple when ripe, 24 Oct. 1928, Kajewski, 525.

A species chiefly notable for the proboscis-like projection of the ostiolar region of the receptacle. Its affinity is with $F$. laevis, Bl. and $F$. obtusa, Hassk., both natives of the Malay Archipelago. The differences are set out in the diagnosis. There are several specimens from Borneo in the Kew Herbarium which are named $F$. piperifolia, Miq., but which do not seem to agree with the description of that species, which is reduced to $F$. obtusa, Hassk. by King in his monograph. These specimens agree closely with $F$. nasuta in external characters, differing mainly in the much longer setae on the inside of the receptacles. It is, however, clear that this group of species requires further investigation. I have not seen any close allies from New Guinea, so that as far as is known at present the Santa Cruz species is widely separated geographically from its nearest relatives.

V. S. Summerhayes.

Fic. 1, branch with leaves and receptacles, natural size; 2, portion of lower surface of leaf, $\times 4 ; 3$, longitudinal section of receptacle containing malo and galled female flowers, $\times 2 ; 4$, male flower, showing setae on receptacle, $\times 8$; 5 , perianth of male flower, spread out, $\times 8 ; 6$, male flower, with perianth removed, showing stamens, $\times 8 ; 7$, a stamen, seen from within, $\times 8 ; 8$, galled fomale flower, with bract, $\times 8 ; 9$, the same with perianth segments opened out, $\times 8$. 


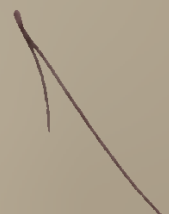




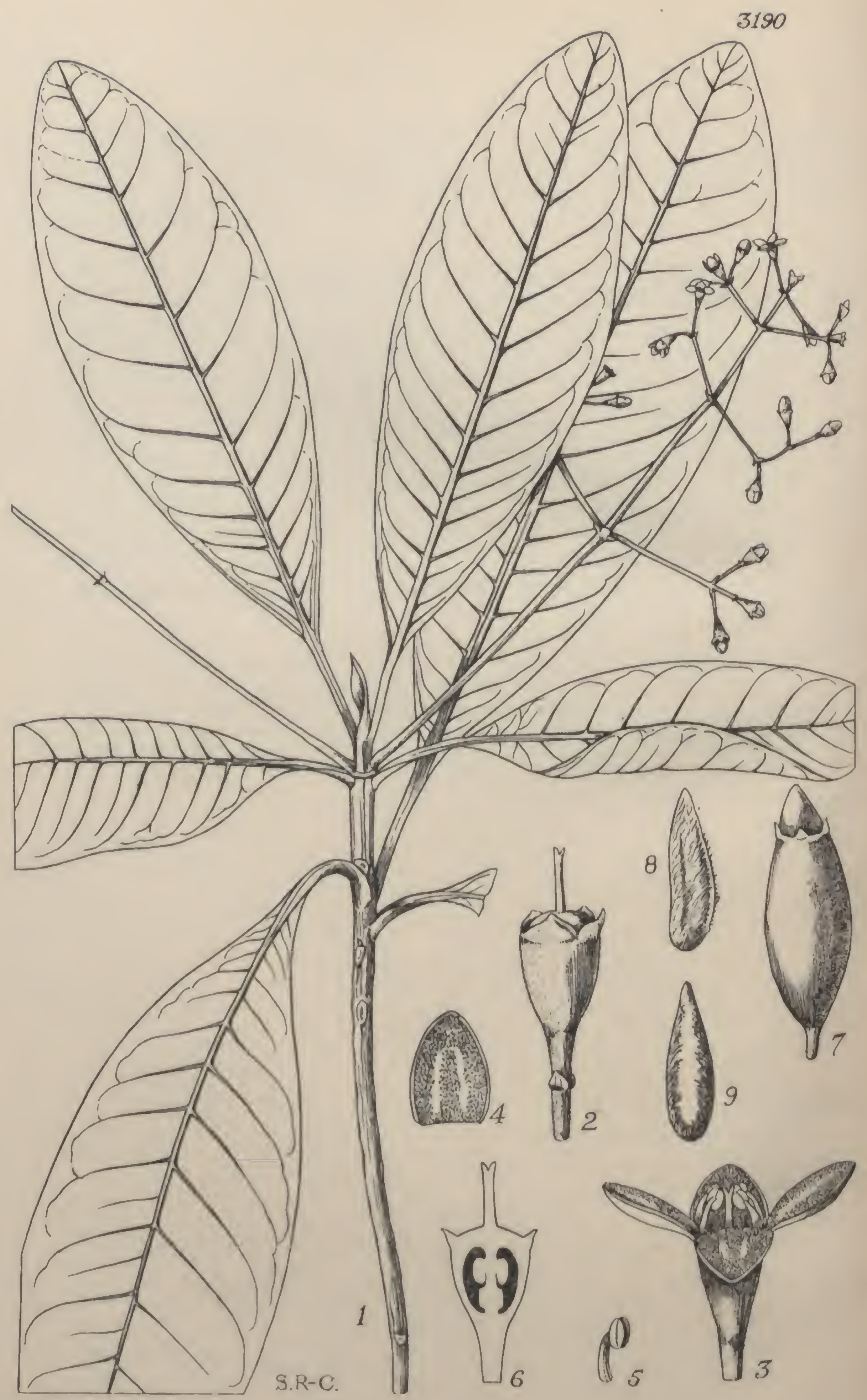


Tabula 3190.

\section{DORISIA RARISSIMA, Gillespie.}

\section{Cornaceae. Tribus Mastixiö̈deae.}

Dorisia,* Gillespie; gcnus novum, Mastixiae, Bl. et Mastixiodendro, Meleh., affinc, ab illa ovario biloeulari, ab hoe ovario omnino inferiore et calycis segmentis liberis differt.

Flores epigyni, hermaphroditi. Calyeis tubus nullus; scpala 4, parva, aperta. Petala 4, libera, valvata. Stamina 4, alternipctala, filamentis liberis, antheris dorsifixis longitudinaliter dehisecntibus. Ovarium inferum, biloculare, orulis in loeulo solitariis supra medium affixis. Drupa anguste ellipsoidca, earnosa, annulo prope apieem distincto, scpalis persistentibus.-Arbor parva. Folia opposita; stipulae in gemmis magnac, mox cadueac. Flores parvi, in thyrsis terminalibus et axillaribus dispositi.

D. rarissima, Gillespie, speeics unica.

Arbor parva, glabra ; ramuli recti, crassiusculi, ad extremitates valde compressi, in sieeitate rugosi, eicatricibus magnis. Folia elliptiea vel oblongo-clliptiea, apice obtusa vel subacuminata, basi acuta paululum dceurrentia, 13-20 em. longa, 4-7 cm. lata, subcoriacea, supra nitidula viridin, subtus pallidiora, nervis primariis utroquc costac latere eirciter 10 fere rectis ad margincm areuatis eun venulis supra prominulis conspieue reticulatis subtus minus distinetis; petiolus erassiuseulus compressus, $2-3 \mathrm{~cm}$. longus; stipulae oblongo-laneeolatae, $1-2 \mathrm{~cm}$. longae, mox cadueae. Thyrsi terminales vel in summis axillis folia subaequantes, multiflori, ramulis ultimis trifloris; peduneuli primarii (usque ad $8 \mathrm{em}$. longi) et partiales graciles, rigidiusculi; bracteae eireiter $1 \mathrm{~mm}$. longac; pedicelli graeillimi, $3-5 \mathrm{~mm}$. longi, apiec bibractcolati. Flores inconspicui. Sepala latc deltoidea, apieulata, vix $1 \mathrm{~min}$. longa. Pelala lutea, ovata, aeuta, eireiter 2 min. longa, coriacca, intus papillato-verrueosa, extus laevia. Diseus $1 \mathrm{~mm}$. latus, leviter elevatus. Stylus crassus, $1.5 \mathrm{~mm}$. longus, minute bilobatus. Silamina I. $5 \mathrm{~mm}$. longa; filamenta crassa ; antherae oblongae, longitudinaliter dehiseentes. Otarium elavato-turbinatum, $4 \mathrm{~mm}$. longum,

* Named in honour of my wife, Doris Kildalo Gillespie, Ph.D., a well-known Californian plant-collector. 
carnosum. Drupae (immaturae) ellipsoideo-cylindraceae, 12-16 $\mathrm{mm}$. longae, circiter $6 \mathrm{~mm}$. crassae, laeves, carneae, 1- vel 2-loculares, disco prominenti $2-3 \mathrm{~mm}$. longo et lato acuto, sepalis persistentibus coronatae.

Fisi. On the northern coast of Vanua Levu, at the edge of a clearing, vicinity of Lambasa, about 60 m., 17 Sept. 1922, Greenwood, 517. Only a single tree seen.

The species is also represented by Horne, 608, from Vanua Levu, at the top of mountains between Waiwai and Lomaloma, and Horne, 441, from the forests of Rambi. Horne, 1132, from Vanua Levu in the vicinity of Mbua, is certainly of the same genus and possibly the same species, but the leaves are pubescent beneath.

The essential differences between Dorisia and its allies Mastixia, Bl. and Mastixiodendron, Melch. are given below :

Mastixia. Flowers 4-5-merous; calyx-tube turbinate or subcampanulate; ovary inferior, 1-locular.

Mastixiodendron. Flowers 4-merous; calyx-tube patelliform; ovary semi-inferior, 2-locular.

Dorisia. Flowers 4-merous; calyx-tube none; ovary inferior, 2-locular.

The known geographical range of the three genera is interesting. Mastixia occurs in the Indo-Malayan region from Ceylon, the Philippine Islands, Java and Borneo; Mastixiodendron is found in New Guinea; Dorisia is known from Fiji, occurring there only on Vanua Levu and the adjacent island of Rambi.

Fruits in the glabrous-leaved specimens are immature, but those of Horne, 1132, are similar to Mastixiodendron pachyclados (K. Schum.) Melch.* in that frequently only one of the two ovules develops, so that a 1 -celled 1-seeded fruit arises; they also agree in having the seed attached to the axis for nearly its entire length. The little "flap " of tissue projecting from the axis of the ovary immediately below each ovule is not explained: apparently it is not an abortive ovule.-J. W. Gildespie. $\dagger$

Fia. 1, flowering branchlet, natural size; 2, pedicel with bracteoles and flower, corolla and androecium removed, $\times 6 ; 3$, expanded flowor, $\times 6 ; 4$, potal, from within, $\times 6 ; 5$, stamen, $\times 6 ; 6$, longitudinal section of pistil, $\times 6 ; 7$, fruit, $\times 2 ; 8,9$, seed, lateral and adaxial views, $\times 2$.

* Engl. Bol. Jahrb. vol. 1x. p. 168, t. 1 (1925).

$\dagger$ Dr. Gillespio died in September 1932. 



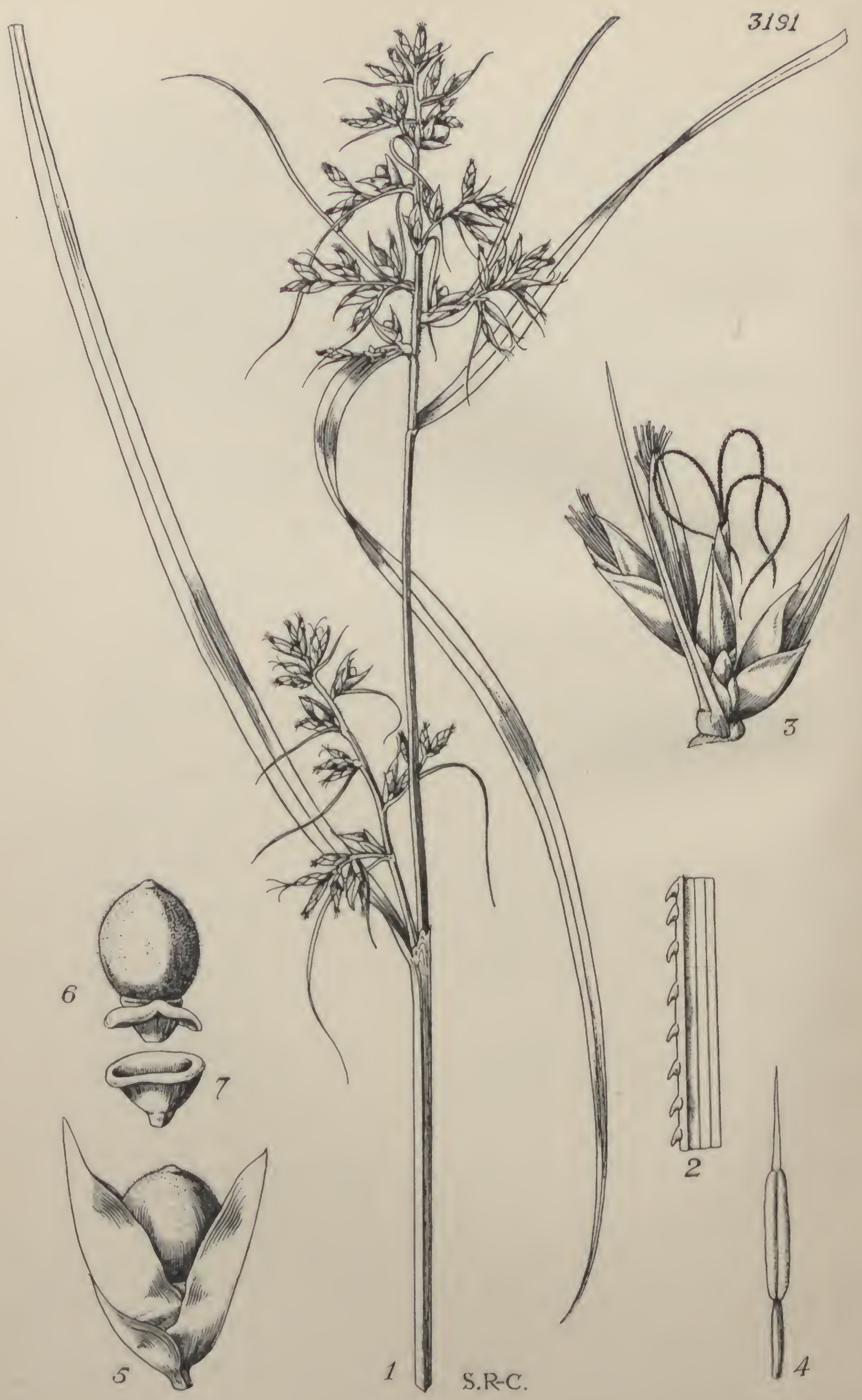




\section{TABULA 3191.}

\section{SCLERIA BARTERI, Bock.}

\section{Cyperaceat. Tribus Sclerieak.}

S. Barteri, Boech. in Linnaea, vol. xxxviii. p. 504 (1874); C. B. Cl. in Durand el Sehinz, Conspect. Fl. Afr. vol.v. p. 669 (1894); et in Dyer, Fl. Trop. Afr. vol, viii. p. 507 (1902); Th. et Hél. Durand, Syll. Fl. Congol. p. 595 (1909); species caule alte scandente angulis vaginorum ct foliorum marginibus minutc retrorse denticulatis, nucc purpurnscente minute pubescente distinetissima.

Caulis altc scandens, triangularis, angulis vaginorum anguste alatis retrorso-denticulatis, inter angulos glaber vel parec pilosus. Folia linearia, ad apiccm scnsim angustata, usquc ad $25 \mathrm{~cm}$. longa, $4-5 \mathrm{~mm}$. lata, utrinque circiter 12-ncrvia, marginibus ct interdum costa media infra erebrc retrorso-denticulatis; ligula magna, usque as $6 \mathrm{~mm}$. longa, sicco brunnea et scariosa, cxtra ncrvoso-reticulata. Paniculac axillarcs, pedunculatae, pyramidales, circiter $6 \mathrm{~cm}$. longac et $3-4 \mathrm{~cm}$. latac, pubescentes; pedunculi triquetri, angulis retrorso-denticulatis vel ferc lacvibus; rhachis molliter pubescens; bracteac primarine basin versus paniculac foliaccae, superiores abrupte minorcs et fcre lineari-filiformcs, ciliolatne, spiculis nulto longiores. Spiculae atropurpureac, ô circiter $5 \mathrm{~mm}$. longac, brevitcr pedunculatac, glumis subaequalibus ovatis earinatis atropurpurcis, antheris apicc longe aristatis, $q$ breviores, glumis inacquilongis extcrioribus minoribus oblongis intermediis latc ovatis intcrioribus longissimis ovato-lanceolntis; ovarium anguste oblongum, glabrum; stylus infra medium tripartitus, ramis hirtis. Nux alba vel purpurasccns, lato ovoidea, paree et minute pubesecns. Diseus hypogynus dupliciter patelliformis, partc superiore leviter triloba ct recurva. - S. reflexa, Benth. in Hook. Niger. Fl. p. 555, non H. B. ct K. S. ovuligera, Rendle in Cat. Talb. Nig. Pl. p. 150, non Nees.

Tropical Africa. Sierra Leonc: Kambia, Scareies, Jan., Scott Elliot, 4388 ; Ccntral Province, July-Aug., Dawe, 545 ; Rowalla, July, Thomas, 1195 ; Mabum, Aug., Thomas, 1589 ; without definite locality, Sept., Dcighton, 2112. Liberia : Grand Bassa, Aug., Dinklage, 2010 ; without definite locality, Reynolds. Ivory Coast: Guideko, May, Chevalier, 16454 ; Dabou, Feb., Chevalier, 17259 ; Tepos country, July, Chevalier, 19548. Gold Coast: Assin Yan Kumasi, Cummins, 238; 
Tarkwa, Dec., Johnson, 1000 ; Angje Oil Plantation, Oct., Howes, 988. Dahomey: Atacora Mts., June, Chevalier, 24184. S. Nigeria : Onitsha, Barter, 1786 (type) ; Onia Olona, Oct., Thomas, 1854; Oban, Talbot, 855. Fernando Po, Nov., Vogel, 87; Mann, 113. Cameroons: Bipinde, Zenker, 3651 ; Yaunde, 800 m., Zenker and Staudt, 376; 423 ; Batanga, common, Aug., Bates, 342. Uganda : Entebbe, lake shore near forest, Aug., Maitland, 78 ; Sesse Islands, Lake Victoria, Nov., Brown, 120 ; Dawe, 955; Maitland, 443; Sezibura Falls, Nov., Dümmer, 1079. Pemba Island, Vaughan, 622 ; Greenway, 1458. Belgian Congo: Jangambi, Michiels, 74.

Vernacular names.-Sierra Leone: Ingiwoya (Sc. Elliot); Njewe (Dawe; Thomas; Deighton).

Scleria Barteri is a very remarkable species on account of its peculiar habit. It is a climber, sometimes as much as $20 \mathrm{ft}$. long, and occurs mainly in dense, damp forests. According to Barter it even renders passage through the forest impossible, and is said to form the impenetrable thickets of the Timne country, in the Southern Province of Nigeria. It climbs by means of minute reflexed barbs on the angles of the leaf-sheaths, and on the margins and sometimes the midrib of the leaves, after the manner of the common "Goosegrass," Galium Aparine, Linn.

The numerous tributaries of the Ubangui and Congo rivers support a narrow belt of evergreen vegetation, even in the dry savannah regions, and these streams form the connecting link for the migration of species from the great forest area of the west to that around the East African lakes. Scleria Barteri follows closely the distribution of this evergreen forest, ranging from its extremity in Sierra Leone through Upper Guinea and the Cameroons to the shores of the Victoria Nyanza in Uganda, and in the island of Pemba off the east coast of Africa. According to Belgian authors it is found in most of the lower-lying districts of the Congo. Its occurrence in the isolated island of Pemba is interesting. According to Greenway it is fairly common in woodlands and damp shady places throughout the island.-J. Hutchinson.

Fig. 1, upper part of flowering branchlet, natural size; 2, margin of lamina, $\times 10 ; 3$, branch of inflorescence, with $\sigma^{*}$ and $q$ spikelets, $\times 4 ; 4$, stamen, $\times 14$; 5 , nut with its subtending glumes, $\times 6 ; 6$, nut with upper half of hypogynous disk, $\times 6 ; 7$, hardened base of disk, $\times 6$. 


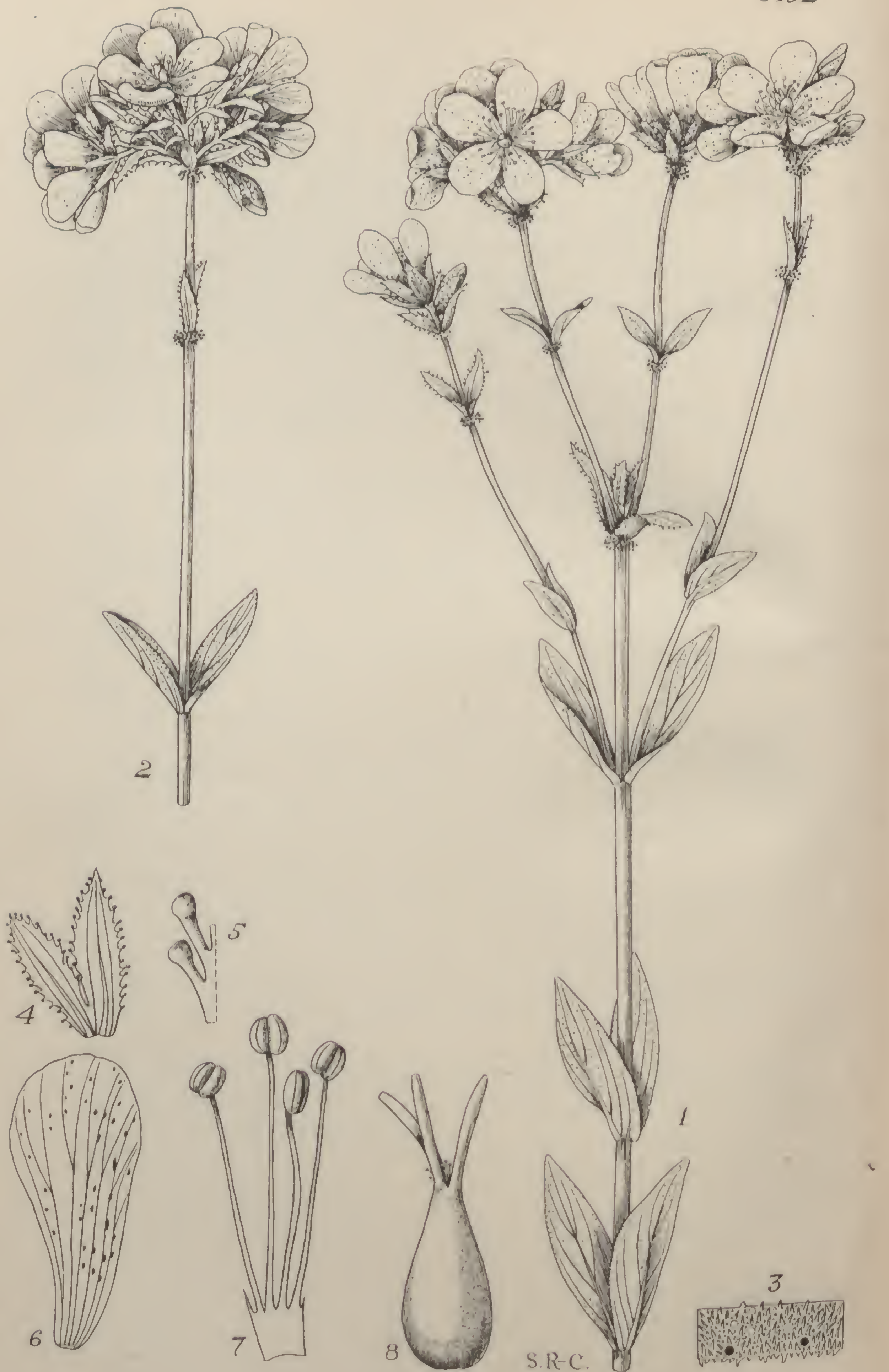


\section{Tabula 3192.}

\section{HYPERICUM AFROMONTANUM, Bullock.}

\section{Hypericacear. Tribus Hyphicear.}

H. afromontanum, Bullock in Kew Bull. 1932, p. 492; H. intermedio, Steud. affinis, floribus capitato-congestis, petalis multo majoribus, sepalis latioribus, glandulis stipitatis brevioribus et erassioribus, stylis brevioribus, eaulibus simplicibus, foliis valde aseendentibus multo minoribus ut rinque puberulis facile distingnitur.

Herba perennis usque 45 (raro 60-90) cm. alta. Caules annui, simpliees vel apiecn versus paree ramosi, ramis semper floriferis, glabri vel priesertim inferne minute puberuli, teretes, graciles, internodiis basin versus eireiter $1 \mathrm{em}$. longis scd superne saepe multo longioribus. Folia valde aseendentia, sessilia, oblonga vel oblongolanceolata, apiee rotundata (pracsertin inferiora) usque subacuta, basi truneata vel leviter auriculato-amplexicaulia, usquc $2 \cdot 3 \mathrm{~cm}$. longa, sed plerumque eirciter $1 \cdot 5-2 \mathrm{em}$. longa et $5-7 \mathrm{~mm}$. lata, utriuque puberula, glandulis oleiferis dense pellueide punetata, plerumque (marginibus praesertim) glandulis resiniferis nigro-punetata; folia summa interdun basi stipitato-glandulosa. Flores 5-mcri, in eymas. capituliformes terminales aggregati; peduneuli usque $10 \mathrm{~cm}$. longi sed saepe minores, cirea vel supra medium braetcis duabus oppositis pracditi; bractere foliis subsimiles sed multo minores, basi glandulis nigris stipitatis dense indutae, laminis glandulis sessilibus prueditis, marginibus lacvibus vel glandulis stipitatis eiliatis; bracteolae semper satis dense glanduloso-ciliatac. Sepala ovato-Ianceoluta, apicc acuta, $5 \mathrm{~mm}$. longa et fere $2 \mathrm{~mm}$. lata, glandulis stipitatis ciliata. Pelala lutea, rubro-vittata, inaequilateralia, oblanceolato-obovata, apice rotundata, eireiter $1.3 \mathrm{~cm}$. Ionga et usque $5 \mathrm{~mm}$. lata, glandulis nigris parce punetata. Stamina 35 ; filanenta fere libera. Otarium ovoidcum, $1.5 \mathrm{~mm}$. longum, glabrum, apiee glandulis stipitatis eireiter 6 ornatum ; styli 3 , eireiter $3 \mathrm{~mm}$. longi. Fructus nuturi nou visi.

Kenya Colony. Mt. Elgon : $3500 \mathrm{~m}$., Dec. 1930, Major E. J. and Mrs. Cyril Lugard, 338n (typus); moorland, $3300-3600$ n., Feb. 1930 , H. M. Gardner, 2259.

UGand)a l'ROtectokate. Mt. Elgon : short grass-land, 3000-3600 nı. 22 Oet. 1916, J. D. Snowlen, 479; grassy swanıp on the west side 
of the crater, 3600 m., Jan. 1918, R. A. Dümmer, 3301 ; grass country below Madangi Camp, 3500 m., March 1930, L. C. C. Liebenberg, 1622.

This interesting species has been collected only at high altitudes on Mt. Elgon, between 10,000 and 12,000 ft. The small erect leaves and the dense head of yellow flowers render it strikingly distinct in general appearance from any other African member of the genus, but detailed examination at once reveals its relationship with the widely distributed $H$. intermedium, Steud.

The simple stems, which are often purplish in colour, sometimes branch slightly in the upper part, such branches, like the main stem, terminating in a dense cymose head of flowers up to about two inches in diameter. Each yellow petal has a red streak running down the back. The two bracts about the middle of the peduncle form an interesting morphological feature. In shape they are similar to the ordinary leaves, but are provided, at any rate at the base, with a dense fringe of black-headed stipitate glands which are otherwise confined to the bracteoles and sepals. In some cases the uppermost pair of otherwise ordinary foliage leaves have also a few of these peculiar glands at their bases. Sessile black glands may accompany the stipitate ones, but these are scattered over the surface.

The specific epithet, afromontanum, refers to its resemblance, particularly in habit, to the British and European H. montanum, Linn.

A. A. BULlock.

Fia. 1, upper part of a flowering stem, natural size; 2, uppermost part of another stem with a single inflorescence, natural size; 3 , lower surface of leaf, $\times 26 ; 4$, part of calyx, from within, $\times 3 ; 5$, marginal glands of sepals, $\times 14 ; 6$, petal, $\times 3$; 7 , portion of androecium, from within, $\times 8 ; 8$, pistil, $\times 8$. 



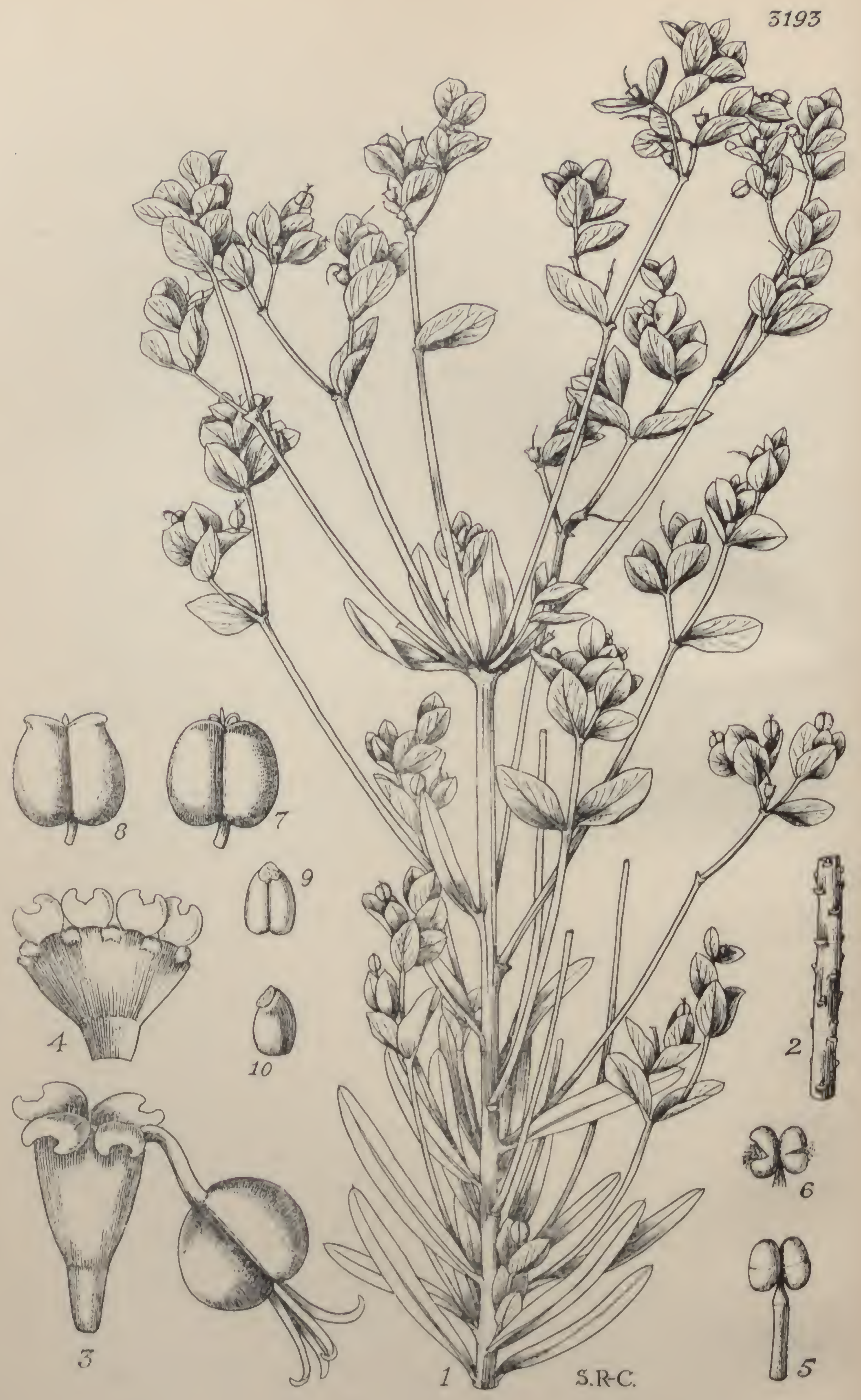




\section{Tabula 3193.}

\section{EUPHORBIA EURYOPS, Bullock.}

\section{Euphorbiackae. Tribls Euphorbieae.}

E. Euryops, Bullock in Kew Bull. 1932, p. 492; E. Sehimperianae, Schcele, affinis, caulibus simplieibus dense foliatis, foliis anguste oblongis usque oblanceolatis, petiolis promiuentibus tubereuliformibus foliorum delapsorum valde distineta ; habitu ramulorum floriferorum E. epicyparissias, E. Mey., sed foliis majoribus, inflorescentiis majoribus multo laxioribus faeile distinguitur; ab ambalous ovario 2-loeulari differt.

IIerba perennis, usque $6 \mathrm{dm}$. alta ; eaules pilis erispis leviter pubescentes, simplices, lignosi, dense foliati, petiolis tubereuliformibus foliorum dclapsorum eonspieue notati ; rami floriferi cymam termiualem 4-7-radiatam efformantes, bracteis foliaceis oblongo-lanecolatis $2 \cdot 5$ em. longis suffulti, ramis aliis similibus infra umbcllam ex axillis foliorum ortis. Folia brevissime petiolata, alterna, spiraliter disposita, utrinque minute densissime papilloso-pustulata, exstipulata, anguste oblonga usque oblanceolata, apice obtusiuscula, mueronulata, basin versus angustata, $3 \cdot 5-4 \cdot 5 \mathrm{~cm}$. longa, $4 \cdot 5 \mathrm{~mm}$. lata, inferne decidua. Rami infloreseeutiae $5-10 \mathrm{~cm}$. longi, ramulis brevibus secundariis 1-3 vel 4 praediti. Braeleae (saltcm maturac) saturate sanguineocoloratae, oppositac, altera saepe mox decidua persistente altera, sessiles, ovatae usque rhomboideo-ovatae, a pice subobtusae, mucronulatae, basi cuneatae 11 sque fere rotundatac, usque ad $1.5 \mathrm{~cm}$. longae et $8 \mathrm{~mm}$. latac. Involuera solitaria, subsessilia, campanulata, $1 \mathrm{~mm}$. longa et circiter $1 \mathrm{~mm}$. diametro, glandulis 4 et glandula abortiva minima eum lobis 5 inflexis oblongis vel ovatis ciliatis apice obtusis vel bifidis alternantibus; glandulae ambitu suborbiculares, $1.1 \mathrm{~mm}$. diamctro, superne crescentiformes. Pedicelli florum maseulorum filiformes, glabri. Filamenta brevia, basi leviter incrassata, glabra. Antherae in alabastro sulborhieulares, $0.4 \mathrm{~mm}$. diametro, loculis ellipsoideis transverse dehiscentibus. Ovarium 2-loculare; styli 2 , biramosi. Capsula exserta, graciliter pedicellata, glabra, bilocularis, leviter compressa, inter loeulos valde constricta, ambitu quadrato-suborbieularis, eireiter $2 \mathrm{~mm}$. longa et lata, emarginata, basi truncata latissima, sursum satis angustata, saepe inarginibus apice leviter reeurvata, obtuse subrostrata. Semina oblongo-ellipsoidea, $1.5 \mathrm{~mm}$. louga, apiee unilateralitcr carunculata, basi cordata, pallide cinerca, laevia. 
Kenya Colony. Mt. Elgon, 3000 m., Dec. 1930, Major E. J. and Mrs. Cyril Lugard, 280.

The simple erect stems, up to about two feet high, clothed except in the lower part with crowded, spirally arranged, narrow leaves, and branching above to form a considerable inflorescence with numerous deep crimson-coloured bracts, render this species strikingly distinct in general appearance from its close ally E. Schimperiana, Scheele. There is a superficial resemblance to the flowering branches of several South African species, notably E. epicyparissias, E. Mey., but it is doubtful whether this indicates affinity or merely parallel development.

The bilocular ovary appears to be a constant character, but as only two flowering stems, very probably taken from the same rhizome, are available for study, it may not be so. The fruit is more or less square in shape, but very frequently the shoulders become somewhat produced into short, recurving, blunt beaks.

The specific epithet, Euryops, is given to indicate the superficial resemblance of the leafy portions of the stem to some species of the genus Euryops, Cass. (Compositae).-A. A. Bullock.

FIG. 1, upper, leafy part of stem and inflorescence, natural size; 2 , lower part of stem, showing persistent petioles, natural size; 3 , a cyathium, $\times 12 ; 4$, the same, opened, with flowers removed showing the glands and the inflexed involucral lobes, $\times 6 ; 5$, young male flower, $\times 20 ; 6$, anther, after dehiscence, $\times 20$; 7,8 , capsules, $\times 6 ; 9$, seed, adaxial view, $\times 6 ; 10$, seed, lateral view, $\times 6$. 



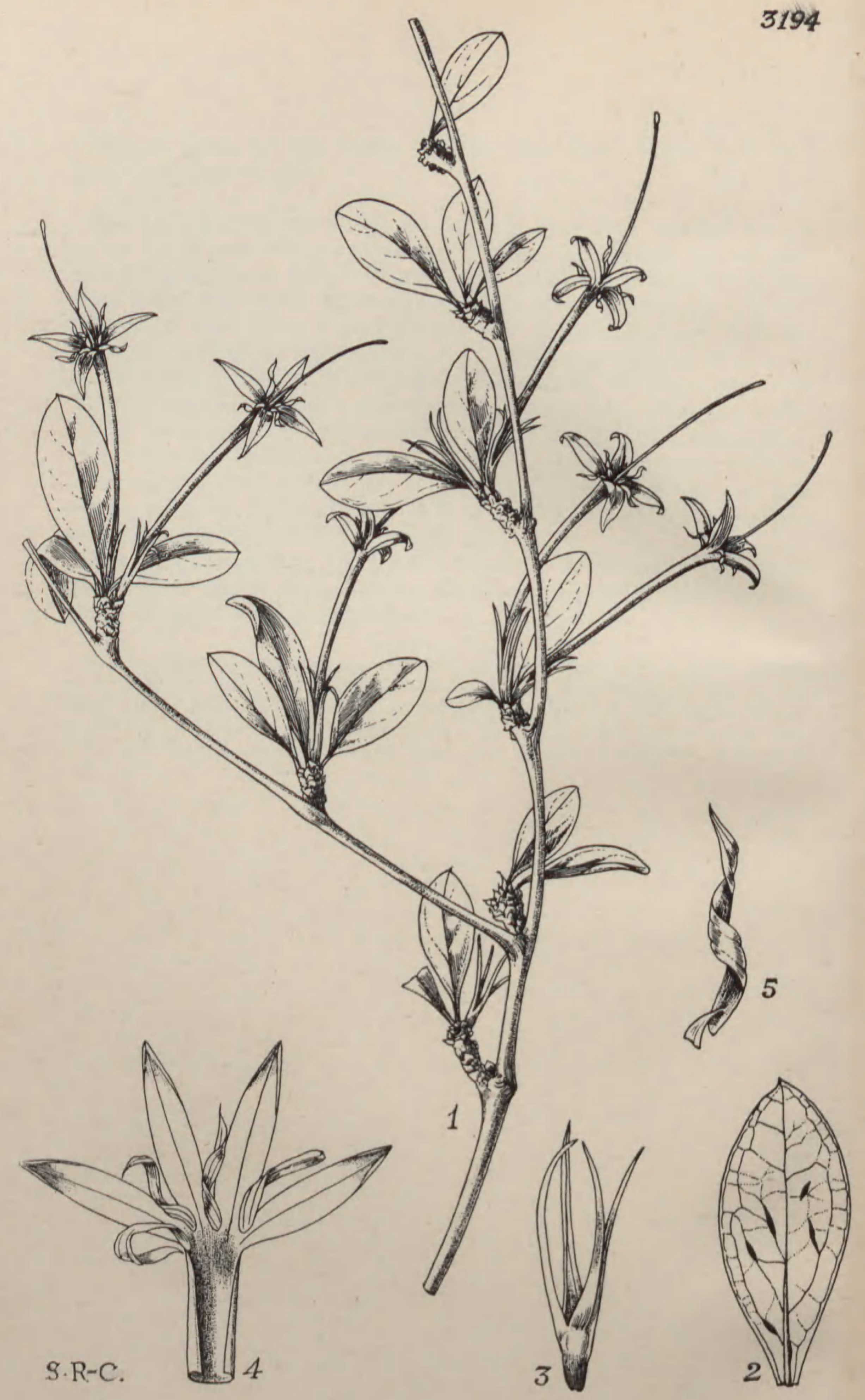




\section{Tabula 3194.}

\section{PAVETTA UNIFLORA, Bremekamp.}

\section{Rumiaceae. Tribus Ixoreae.}

P. uniflora, Bremekamp; species nova ab omnibus congeneribus hactenus eognitis floribus solitariis distinguenda.

Frutex seandens, eireiter $3 \mathrm{~m}$. altus, omnibus partibus facic interiore stipularum et bractearum excepta glaber. Ramuli longi sympodiales, ex internodiis concatenatis $3-5 \mathrm{~cm}$. longis constantes; internodia singula in ramulos abbreviatos usque ad $0.6 \mathrm{~cm}$. Iongos desinentia. Ramuli abbreviati apice plerumque foliis quattuor coronati. Folia brevissime petiolata; lamina obovata, $2-2 \cdot 5 \mathrm{~cm}$. longa, $0 \cdot 7-1 \cdot 2 \mathrm{em}$. lata, apice oltusa, calloso-mucronulata, basi cuneata, membranaeea, nervis utroque latere costac 2-3, domatiis nullis, nodulis bacteriorum paueis linearibus irregulariter dispersis; petiolus usque ad $0.3 \mathrm{~cm}$. longus; stipulae ovatac, cuspidatae, intus scrieco-villosae. Flores ramulos abhreviatos ordinis secundae perbreves in parte defoliata ramulorum abbreviatorum primariorum dispositos terminantes, solitarii, subsessiles, parte inferiore bracteis stipularibus connatis eircumdati, inodori. Calycis tubus $0.6 \mathrm{~mm}$. longus; lohi filiformes, $9 \mathrm{~mm}$. longi. Corollae tubus $3.5 \mathrm{~cm}$. longus, tenuissimus; lobi $0.5 \mathrm{~cm}$. Iongi, acuti. Stylus $5 \cdot 5$ cm. longus.

Tropical Africa. Kenya Colony: Arabuko, in undergrowth of Brachylaena forest, K. M. Graham, 1856.

The solitary flowers distinguisl $P$. uniflora from all previously described speeies of Pavelta. They are subtended at the base by a pair of connate braets sueh as subtend the infloresecnee in the other speeies. The flowers terminate minute "short shoots" which are borne on the older, leafless part of the primary "short shoots."

The "long shoots" of $P$. uniflora are sympodial, formed by a ehain of axes eaeh consisting of a single internode. The upper part of each axis develops into a pseudo-luteral "sloort shoot," from the base of which the next axis of the sympodium arises as a lateral branch.-C. E. B. BREMEKaMP.

Fic. 1, flowering branch, nalural size; 2, leaf, upper surface, showing bacterial " nodules," $\times 2 ; 3$, receptacle and calyx, $\times 2 ; 4$, upper part of corolla, with stamens, $\times 4 ; 5$, stamen, $\times 6$. 



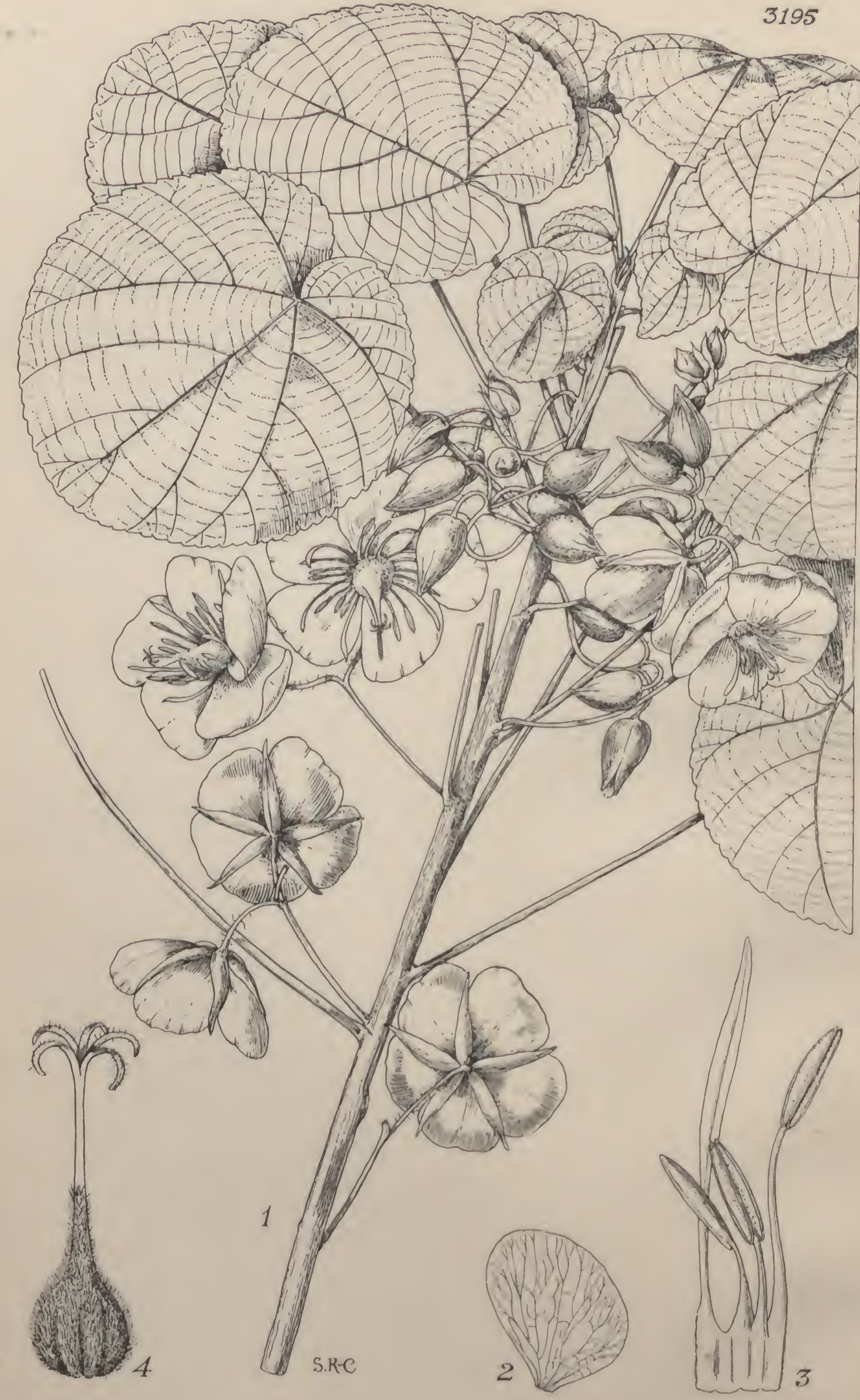




\title{
TABULA 3195.
}

\section{DOMBEYA BRACHYSTEMMA, Milne-Redhead.}

\author{
Sterculaceat. Tribus Dombeyeal.
}

D. (Eudombeya) brachystemma, Milne-Redhead; species nova affinis $D$. parvifoliac, K. Sclum. et $D$. roseae, E. G. Baker, ab illa foliis rotundatis vel obtusissimis, pedunculis petiolis multo brevioribus, ab hac ramis glabris, foliis indivisis differt.

Frutex subseandens, deciduus, usque $6 \mathrm{~m}$. altus. Rami tenucs, pauciramosi, glabri, cortice longitudinaliter costato brunneo; rami juniores minute puberuli. Folia longe petiolata, late ovata vel suborbiculata, indivisa, apice rotundata vel olutusissima, basi cordata sinu $2-2.5 \mathrm{~cm}$. alto, 8-11 cm. longa, 8-11 em. lata, crenulato-dentata, supra pilis stellatis velutino-pubesentia, subtus glauco-tomentella; costa et nervi laterales útrinque $6-7$ (tribus e basi costae inclusis), utraque pagina tomentelli, subtus promincntes; petioli teretes, vix $11 \mathrm{~cm}$. longi, glabri, prope apiecm minute puberuli ct sparse hirsuti; stipulae caducne, subulatac, circiter $1 \mathrm{~cm}$. longac, inferne ut innovationes dense glanduloso-papillatae et, praescrtim superne, sparsiuseule stcllatohirsutac. Infloreseentiae umbclliformes, 3-5-florac, cx axillis foliorun ortae, foliis breviores; peduneuli $2 \cdot 5-3 \mathrm{~cm}$. longi, stellato-pubescentes et glanduloso-papillati; pedicelli $1 \cdot 2-1 \cdot 5 \mathrm{~cm}$. longi, minute stellatotomentelli, pilis longis simplicibus hine inde inspersis; bracteolae 3 , deciduac, laneeolato-subulatae, usque $9 \mathrm{~mm}$. longae, utrinque dense tomentellac. Flores conspicui, $4.5 \mathrm{~cm}$. liametro; alabastra ovata, ucuta, oirciter $1.7 \mathrm{em}$. longa et $0.9 \mathrm{~cm}$. lata. Sepala 5 , lanecolata, acuta, $1 \cdot 9 \mathrm{~cm}$. longa, $3 \mathrm{~mm}$. lata, extra dense tomentella, intus glabra. Petala 5, pallide rosea, rotundato-triangulata, basi late cuneata, $2 \cdot 2 \mathrm{~cm}$. longa, $1.7 \mathrm{~cm}$. lata, glabra, nervis siceitate prominentibus. Stamina 15, per tria cum staminodiis 5 altcrnantia; triadis stamen medium breve, extra tubum paullum infra apicem inscrtum, staminum lateralium alterum breve, alterum longum; filanentorum tubus sinibus valde inaequalibus itaque $2-3.5 \mathrm{~mm}$. longus; staminodia spathulato-linearia, 1.5-1.7 cm. longa (tubo incluso); staminum filanenta subulata, longiora $9 \mathrm{~mm}$. longa, breviora 6-7 $\mathrm{mm}$. longa (tubo incluso); anthcrae lineares, $3 \cdot 5-4.5 \mathrm{~mm}$. longac. Ovarium late ovoideum vel subglobosum, usque $6 \mathrm{~mm}$. altum et $6 \mathrm{~mm}$. diametro, obscure 5 -lobatum, 
horride hirsuto-tomentosum, 5-loculare, ovulis 6 pro loculo; stylus circiter $1 \mathrm{~cm}$. longus, inferne densissime stellato-hirsutus, superne glaber, stigmatibus 5 recurvatis sparse longihirsutis. Capsula non visa.

Northern Rhodesia. Solwezi District: among shrubs in evergreen vegetation by Mbulungu Stream, west of Mutanda Bridge, 3 July 1930, Milne-Redhead, 657.

During the months of July and August, Dombeya brachystemma forms a conspicuous feature of the evergreen fringing forests in the Solwezi District of Northern Rhodesia. It is a weak shrub, sometimes only $2 \mathrm{~m}$. high, but frequently reaching as much as $6 \mathrm{~m}$., gaining support from the evergreen shrubs among which it grows. The large pale-pink flowers, which much resemble wild roses, are very fragrant.

E. Milne-Redhead.

FIa. 1, flowering branch, $\times \frac{2}{3} ; 2$, petal, natural size; 3 , part of androocium, seen from without, showing a staminode and a group of three stamens, $\times 4$; 4 , pistil, $\times 3$. 


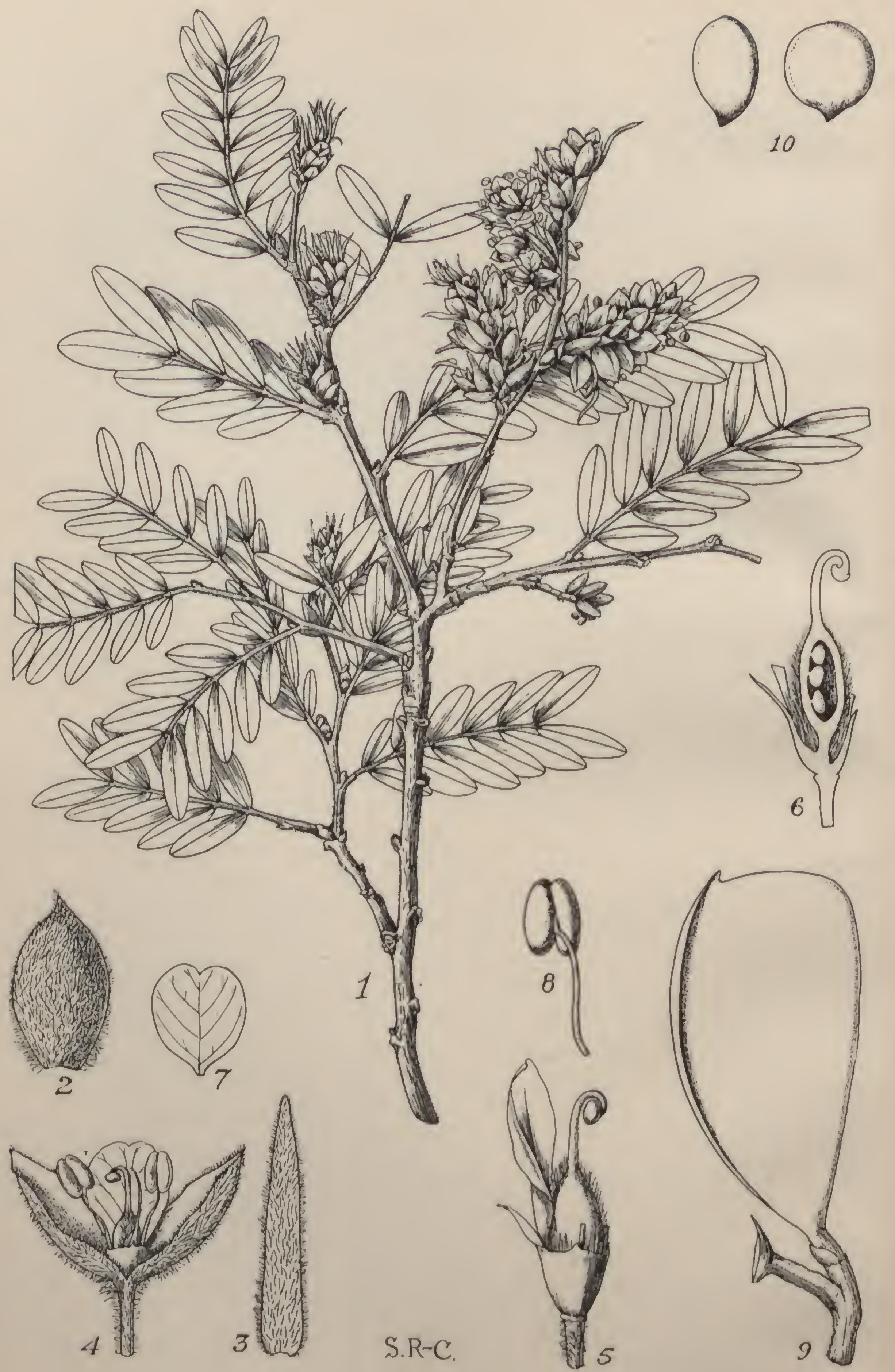


\section{TaBula 3196.}

\section{CRYPTOSEPALUM PSEUDOTAXUS, E. G. Baker.}

\section{Leguminosae. Tribus Anhfrstieae.}

C. pseudotaxus, E. G. Baker in Journ. Bot. vol. Ixvi. suppl. T, p. 148 (1928); a C. arboreo, E. G. Baker, habitu scmpcrvirente, foliis ct floribus minoribus, foliolis apice obtusis vel rotundatis, raccmis axillaribus vel pseudoterminalibus recedit.

Arbor parva vel interdum magna, usque $30 \mathrm{~m}$. alta, scmpervirens, trunco recto simplici interdum usque $20 \mathrm{in}$. alto, supra copiose ramosa, ramis horizontalibus densissime foliosis. Ramuli pilis cinereis rectis patentibus densiuscule hirsuti. Stipulae lineares vel subulatae, usque $1.5 \mathrm{~cm}$. longac, hirsutac, caducac. Folia abruptc pinnata, 4-7-jugata, circiter $3 \mathrm{~cm}$. longa, 1.5 cm. lata; petiolus 1-2 mm. longus; rhachis usque $2.5 \mathrm{~cm}$. longa, cum petiolis cinereo-hirsuta; foliola subacqualia, subsessilia, oblonga, parum inaequilatcralia costa subcentrali, apice rotundata, basi leviter inaequilateralia, usque $1.7 \mathrm{~cm}$. longa, $0.5 \mathrm{~cm}$. lata, coriaces, supra glabra, nitiduln, subtus margine et costa sparsc hirsutis exccptis glabra ; costa supra prominula, subtus valde conspicua; nervi laterales utraque pagina inconspicui ; petioluli minuti, hirsuti. Racemi perulati, multiflori, densissimi, axillares vel pseudotcrminales; perulac ovatac, coneavac, apice acutae, usque $7 \mathrm{~mm}$. longac, ferruginco-hirsutac; bractcac florum singulorum lineari-lanccolatac vel subulatac, vix $1 \mathrm{~cm}$. longac, hirsutac, caducae; pedicelli usque 5 min. longi, pubescentes; bracteolac 2, concavae, alabastrum includentes, ovatae, obtusae vel subacutae, circiter $6 \mathrm{~mm}$. longac, $3.5 \mathrm{~mm}$. latac, pubcscentes. Calyx brevis, cupuliformis, truncatus, lobo unico adaxiali deltoidco acuto $1.5 \mathrm{~mm}$. longo cxcepto, nonnunquam denticulis 3 (2 latcralibus et 1 antcriori) additis. Petalum unicum calycis lobo oppositum, prope apiccn tubi insertum, cllipticum vel ovatum, apice rotundatum, basi cuneatum, usquc $6 \mathrm{~mm}$. longum, $3.5 \mathrm{~mm}$. latum, glabrum, ochrolcucum. Stamina 3 , perfecta vel interdum 1-2 staminodiales; filamenta fliformia, usque $5 \mathrm{~mm}$. longa ; antherac vix $2 \mathrm{~mm}$. longae, rubro-brunneae. Ovarium inconspicue stipitatum, stipitc pilis occulto, oblongum, circiter $1 \mathrm{~mm}$. longum, suturis hirsutis, circiter 2-3-ovulatunı; stylus circiter $1 \mathrm{~mm}$. longus, glaber, superne recurvatus stigmate capitato instructus. Legumen late oblongum vel obovato-oblongum, usque $6 \mathrm{~cm}$. longum ct $2.5 \mathrm{~cm}$. latum, lignosum, glabrum, sicpissime 1-spcrmum. 
Angola. 'T'Chirondongombe, Rio Luassingua, 18 June 1906, Gossweiler, 2709 (type in Herb. Mus. Brit.). An evergreen tree of total height of $60 \mathrm{ft}$.; head small, densely branched; branches spreading, recalling the habit of a Cedar of Lebanon; flowers whitish; petal white, one only; calyx greenish-white, tomentose; anthers purplishviolet; filaments white; slightly fragrant. It is this species that gives the phytological and physiographical characters to the country known as Ganguellas and Umbuellas. Native name "Mucuwe." Cavange, 27 Aug. 1905, Gossweiler, 1900 (Herb. Mus. Brit.). The "Mucuwe" of the Ganguellas, a dwarf evergreen tree and as such resembling a Cedar or Taxus at a first glance; leaves remarkably dusky green; trunk erect, head broad, branches spreading dilately; flowers white, scented; an early-flowering specimen from Cavange. It is this tree that so distinctly characterizes the woods; it is common in the dense secondary woods and constitutes, with a few other Caesalpinieae, the primeval densely wooded grassless forests of this region; underneath its densely leaved crown only mosses occur. On an ant-hill east of Fte. P. Amelia, Sept. 1905, Gossweiler, 1900A (Herb. Mus. Brit.). A small and dwarf evergreen tree branched from the base; branches densely branched again, short, spreading; flowers whitish. Native. name "Mucuwe." In thickets together with Diplorhynchus sp. at Cuito by Capunda, 1 July 1906, Gossweiler, 3032 (Herb. Mus. Brit.). A dwarf evergreen tree resembling a conifer; flowers white, anthers blackish-purple. Cutchi, near Fte. Conselheiro Barja, in fruit, Nov. 1906, Gossweiler, 3486 (Herb. Mus. Brit., Herb. Kew.).

Northern Rhonesia. Mwinilunga District: dominant on areas of sand between R. Kabompo and R. Kasingiko, 1 Aug. 1930, MilneRedhead, 810. A flat-topped cedar-like evergreen tree, up to $9 \mathrm{~m}$. high, not yet in flower, and no fruits seen; young and previous season's foliage present together on the tree. The dominant tree of the "Mavunda" sand country about $60 \mathrm{Km}$. south of Mwinilunga, and $19 \mathrm{Km}$. west of R. Lunga, 15 Aug. 1930, Milne-Redhead, 916. An evergreen tree usually about $15 \mathrm{~m}$. high, but sometimes met with as much as $30 \mathrm{~m}$. high ; flowers cream-coloured, anthers red-brown. Vernacular name "Mukwechi" (Chikaonde).

Cryptosepalum pseudolaxus is the dominant tree of the woodlands, occurring on the so-called Kalahari sand in the Mwinilunga District of Northern Rhodesia and the adjacent portion of Eastern Angola. This tree at times grows to a great height, and beneath its shade a dense growth of evergreen shrubs, knit together by species of Landolphia, forms an almost impenetrable tangle. Below this evergreen shrub layer the shade is so dense that the loose sand is practically destitute of any herbaceous vegetation, two species of moss (Leucobryum madagassum, Besch. and Campylopus inandae, Rehm.) alone appearing able to enjoy the very unfavourable conditions. This Cryptosepalum woodland is known by the Kaonde natives as "Mavunda," and is almost entirely uninhabited. Associated with Cryptosepalum pseudo- 
taxus in these woodlands are Copaifera coleosperma, Benth., Marquesia acuminata (Gilg) R. E. Fr., Parinari mobola, Oliv., Pterocarpus angolensis, DC., Afrormosia angolensis (Bak.) Harms, and one or two speeies of Brachystegia, to mention only some of the more important timber trees. It is interesting to note that Cryptosepalum pseudotaxus has not been reeorded from the Kalahari sand area to the south of Northern Rhodesia, where the rainfall is eonsiderably less than it is in the Mwinilunga Distriet, and conversely that the two eommon trees of this southern area of similar sand, Baikiaea plurijuga, Harms, and Pteroearpus Stevensonii, Burtt Davy, were not notieed in the Cryplosepalum woodland, and that neither species appears to have been eolleeted by Gossweiler in Angola.-F. MiLne-Redient.

Fig. 1, flowering branchlet, natural size; 2, one of the perulae from the base of the inflorescence, $\times 4 ; 3$, subtending bract of flower, $\times 4 ; 4$, flower with pedicel and pair of loracteoles, anterior view, $x 4 ; 5$, flower, with braoteoles and upper part of stamens removed, lateral view, $\times 8 ; 6$, medinn longitudinal section of flower, showing attachment of petal and pistil, and placentation, $\times 8 ; 7$, petal, $\times 4 ; 8$, stamon, from the hnck, $\times 8 ; 9$, part of infructescence, showing maturo legume and persistent basal part of a second one after dehisecnec, natural size; 10, secds, natural size. 




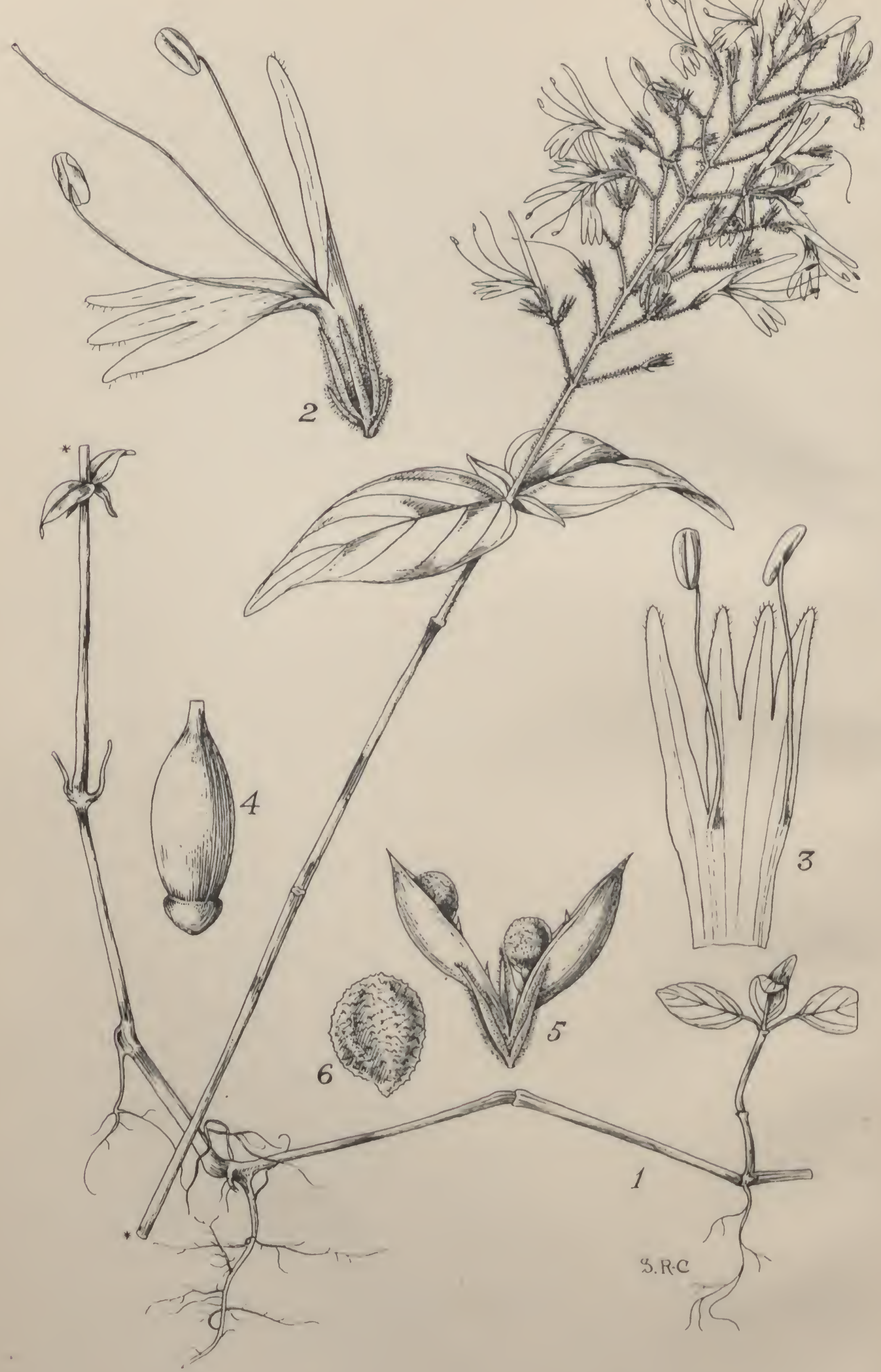




\section{TABULA 3197.}

\section{OREACANTHUS MONTIFUGA, Milne-Redhead.}

\section{Acanthaceae. Tribus Isoglosseae.}

O. montifuga, Milne-Redhead; speeies nova, affinis O. Mannii, Benth., sed habitu humili, foliis minoribus, infloreseentiis dense purpureo-glanduloso-pilosis, floribus magis eonfertis, tubo eorollae paullo longiore differt.

IIerba perennis, vix $3 \mathrm{dm}$. alta; caules deeumbentes, nodis inferioribus radicantibus, infra paniculam puberuli vel glabreseentes. Folia ovata vel ovato-laneeolata, aeuminata, in petiolun euneatim angustata, vix $5 \mathrm{em}$. longa, $2 \mathrm{em}$. lata, utrinque paree puberula; petioli usque $6 \mathrm{~mm}$. longi. Thyrsi oblongi, 5-6 em. longi, eireiter $3 \mathrm{em}$. lati, pilis purpureis erispatis glandulosis dense pubeseentes. Calyx fere usque ad basin 5-partitus, $4 \mathrm{~mm}$. longus, segmentis linearibus subaequalibus purpureo-glanduloso-pilosis. Corolla alba vel subeacruleo-alba, glabra, loborum apieibus pareissime hirsutis, $11 \mathrm{~mm}$. longa ; tubus eylindrieus, $4 \mathrm{~mm}$. longus; limbus $7 \mathrm{~mm}$. longus, labiis aequilongis; labium posticum anguste laneeolato-oblongum, integrum, subereetum; antieum patens, alte trifidum, lobis planis anguste laneeolato-oblongis $3.5 \mathrm{~mm}$. longis. Stamina 2, fauei inter labia affixa ; flamenta filiformia, $9 \mathrm{~mm}$. longa, limbo hiante conspieua; antherae monotheere, oblongae, dorsifixne, purpureo-caeruleae; staminodia nulla. Discus minutus, cupularis. Stylus filiformis, usque ad $18 \mathrm{~mm}$. longus, subinteger; ovarium eireiter $2 \mathrm{~mm}$. longum, 4-ovulatum. Capsula elliptiea, in basin attenuata, $8 \mathrm{~mm}$. longa; semina abortu 2, eompressa, rugosotubereulata, $2 \mathrm{~mm}$. dinmetro.

Northers Rhodesia. Solwezi District: in evergreen vegetation by strean just east of River Kabompo near Mebranki's village, 1400-1600 m., 31 July 1930, Milne-Redhead, 807. Perennial herb, growing in dense shade of cvergreen shrubs on damp ground rieh in humus; flowers white or bluislı-white.

The diseovery in Northern Rhodesia of a sceond speeies of Oreacanthus cxtends the known distribution of this hitherto monotypie genus by a distanee of no less than $2400 \mathrm{Km}$., for O. Mannii, Bentl. is known only from the Cameroons Mountain. 
In Bentham's description of Oreacanthus Mannii (Hook. Ic. Pl. t. 1211: 1877), the stamens are said to be attached near the bottom of the tube. An examination of the type material proves, however, that the point of attachment of the stamens is near its mouth. As the tube in that species is very short the point of attachment is consequently not far from the bottom of the corolla, which is in agreement with the generic description in Benth. et Hook. f. Gen. Pl. vol. ii. p. 1104.

In Dyer, Fl. Trop. Afr. vol. v. p. 176, the capsule of Oreacanthus is said to be 4-seeded. In Gen. Pl., l.c., Bentham describes the capsule as being 4-seeded, or by abortion, fewer-seeded, and an examination of the type material reveals that 2 -seeded capsules are most frequent. O. Mannii is described by Mann in his field notes as being an "herbaceous pl. $12 \mathrm{ft}$. high" (Mann, 1259), and an "herb. pl. 10-12 ft. high" (Mann, 1971), whereas C. B. Clarke in Fl. Trop. Afr., l.c., describes it as a shrub. According to Dunlap (No. 50 in Herb. Kew.), it is very common on the Cameroons Mountain, "forming thickets 12-15 ft. high, from $3000 \mathrm{ft}$. up to the timber line."-E. Milne-Redhead.

Fra. 1, plant, natural size; 2 , flower, lateral view, $\times 4 ; 3$, corolla, laid open, showing insertion of stamens, $\times 4 ; 4$, ovary and disk, $\times 10 ; 5$, capsule after dehiscence, showing the two seeds, $\times 4 ; 6$, a seed, $\times 6$. 



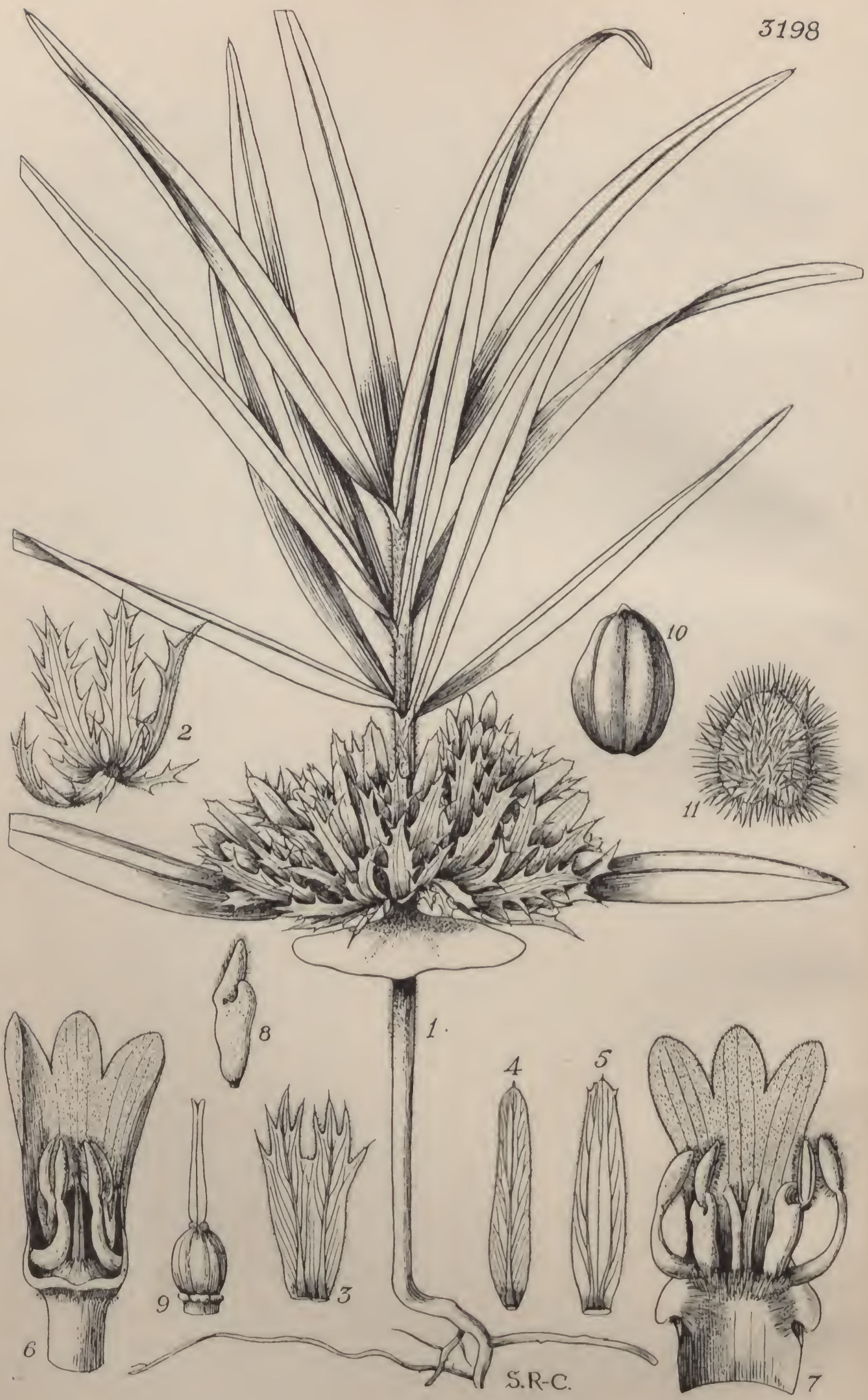




\section{Tabula 3198.}

\section{BLEPHARIS MENOCOTYLE, Milnc-Redhead.}

Acanthaceae. Tribus Acantheae.

B. (Acanthodium) menocotyle, Milne-Redhead; species nova a B. Buchneri, Lindau, foliis pseudo-verticillorum subaequalibus marginibus espinosis, foliis duobus infimis cum cotyledonibus persistentibus pseudo-verticillum formantibus, inflorescentiis saepc ex axillis cotyledonum exortis, floribus multo minoribus recedit.

Ilerba annua, erecta; caules simplices, usque $26 \mathrm{~cm}$. longi parte hypoeotylari $5-14 \mathrm{~cm}$. longa superne hirsuta inclusa, hirsuti. Cotyledones persistentes, cum foliis infimis pseudo-verticillatae, lunatoflabelliformes, $1 \cdot 1 \mathrm{~cm}$. longae, $3.5 \mathrm{~cm}$. latre, glabrae, inferne aspere ciliatac. Folia pseudo-verticillata, sessilia, subaequalia, oblonga vel linearia, usque $14 \mathrm{~cm}$. longa, $1 \cdot 3 \mathrm{~cm}$. lata, apice acuta vel apiculata, sparsiuscule albo-hirsuta vel glabrata, minute serrulato-ciliata, venis perinconspicuis. Infloreseentiae 1-2, ex axillis cotyledonum vel foliorum inferiorum exortae, valde confertae, usque $4.5 \mathrm{~cm}$. diamctro; bractene laneeolatae, 6-15 $\mathrm{mm}$. longre, apice et margine valde spinosae, glanduloso-hirsutae. Calyx usque ad basin 4-partitus, parce glanduloso-lirsutus ; segmentum posticum oblongo-lanceolatum, apice minute dentatum, apiculatum, 3 -nerve, $1.7 \mathrm{~cm}$. longum, $3.2 \mathrm{~mm}$. latum; anticum hincrve, apice bifidum, margine valde spinoso bracteis similc, $1.3 \mathrm{~cm}$. longum, $5 \mathrm{~mm}$. latum; segmenta lateralia uninervia, oblongo-lanceolata, apice obtusa, apiculata, $1.4 \mathrm{~cm}$. longa, $2 \cdot 2 \mathrm{~mm}$. lata. Corolla caerulea, $1.3 \mathrm{~cm}$. longa; tubus $3 \mathrm{~mm}$. longus, cxtra gla ber annulo pilorum a picali excepto, faucc pilis horizontalibus clausa; labium oblongum, apice 3-lobum, utrinque breviter pubescens, intus basin versus lamellis duabus parallelis longitudinalibus $3 \mathrm{~mm}$. longis instructum. Stamina quatuor, fauce affixa ; filamenta postica arcuata, sursum angustata, $3 \mathrm{~min}$. longa, basin versus $1 \mathrm{~mm}$. lata; filamenta antica subrecta, $3 \mathrm{~mm}$. longa, $1.2 \mathrm{~mm}$. lata, lobo antherifero $0.5 \mathrm{~mm}$. longo, lobo altero curvato obtuso $1 \mathrm{~mm}$. longo; antherae monothecae, puberulae, valde ciliatre, $2.5 \mathrm{~mm}$. longae. Otarium late ovoideum, $1.5 \mathrm{~mm}$. altum, $1.2 \mathrm{~mm}$. diametro, glalorum, apice postice glandulis duabus papillatis instructum; stylus ensiformis, breviter bifidus. Capsula ovoiden, leviter compressa, $1 \mathrm{~cm}$. longa, $6 \times 4 \mathrm{~mm}$. diametro, glabra, nitidula. Semina duo, alba, compressa, ovato-orbicularia, 
$7 \mathrm{~mm}$. longa, $5.5 \mathrm{~mm}$. lata, $2 \mathrm{~mm}$. crassa, pilis inconspicuis arcte adpressis dense induta, pilis post humectandum patentibus satis longis albis mucilaginosis subtiliter plumosis.

Northern Rhodesia. Solwezi District: among grass in Brachystegia woodland at Mutanda Bridge, 20 June 1930, Milne-Redhead, 537 (type). Erect annual, $2 \mathrm{dm}$. high, leaves smooth, linear ; persistent cotyledons just below the flower-heads; flowers blue. Mumbwa District: near Mumbwa, 1911, Mrs. Macaulay, 648, pro parte.

This species, which is known only from Northern Rhodesia, is remarkable in having part of its inflorescence borne in the axils of the persistent cotyledons. The hypocotyl is frequently $10 \mathrm{~cm}$. or more in length, and the persistent crescent-shaped cotyledons form a false whorl in conjunction with the lowest pair of foliage leaves; in the axils of this false whorl the inflorescence is frequently but not invariably borne, as it sometimes occurs in the axils of the next false whorl of foliage leaves. Blepharis glumacea, S. Moore, with which B. menocotyle was found growing, also has persistent cotyledons, but they do not form a false whorl nor bear the inflorescences in their axils.

Both species were found growing in very hard dry ground in partial shade of species of Brachystegia and other deciduous trees. B. menocotyle was both flowering and fruiting, and in every specimen the cotyledons were alive and functioning as assimilatory organs.

The seeds, while still dry, appear smooth and glabrous, but after soaking in water are seen to be densely hispid with mucilaginous hairs (fig. 11). The hairs are present in the dry condition, but escape notice owing to their being closely appressed to the testa. This peculiar phenomenon occurs also in various other genera of Acanthaceae such as Asteracantha, Chaetacanthus, Dyschoriste and Ruellia, according to Lindau (Engl. u. Prantl, Nat. Pflanzenfam. vol. iv. 3B, p. 284 : 1895).

The presence of two glands at the apex of the ovary on its posticous surface is a generic character of Blepharis, according to C. B. Clarke (Fl. Trop. Afr. vol. v. p. 94 : 1899).-E. Mrlne-Redhead.

FIG. 1, an entire plant, showing the persistent cotyledons forming a false whorl with the first pair of foliage leaves, natural size; 2 , bracts, $\times 2 ; 3$, bifid anticous calyx segment, $\times 2 ; 4$, a lateral sepal, $\times 2 ; 5$, posticous sepal, $\times 2 ; 6$, corolla seen from the back, $\times 4 ; 7$, the same laid open, $\times 4 ; 8$, an anticous stamen, $\times 4$; 9 , pistil, $\times 4$; 10 , capsule, lateral view, $\times 2 ; 11$, moistened seed, showing the mucilaginous hairs, $\times 2$. 



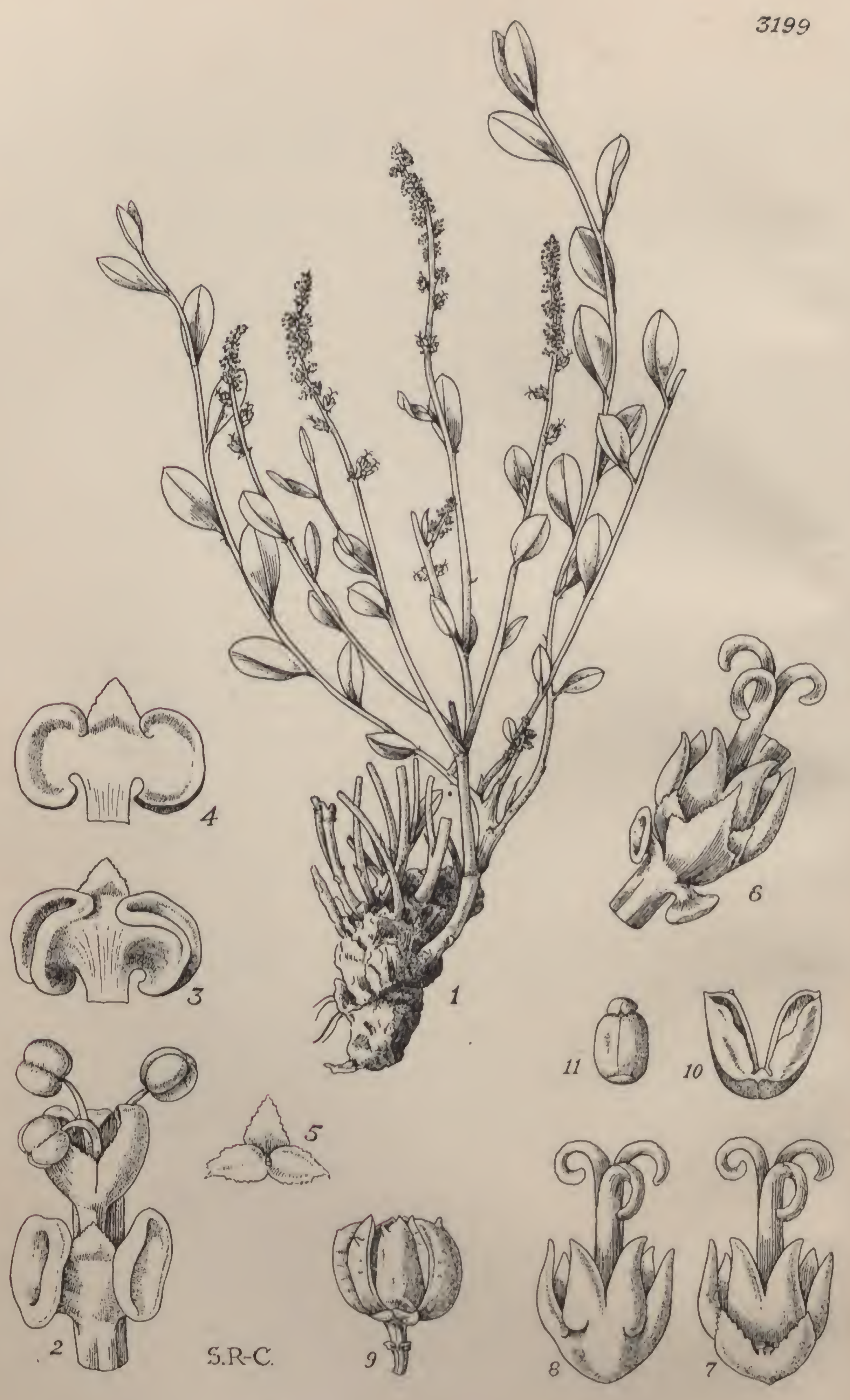




\section{Tabula 3199.}

\section{SAPIUM ACETOSELLA, Milne-Redhead.}

Euphorbiceae. Tribus Hippomaneae.

S. (Armata) Acetosella, Milne-Redhead; species nova a S. suffruticoso, $\mathrm{Pax}$ habitu humiliore, foliis minoribus subsessilibus eglandulosis, bracteis ot unifloris, floribus + sessilibus, seminibus carunculatis differt.

Herba perennis, valde caespitosa, tota glabra; caules multi, erceti, e caudice crasso lignoso valde ramoso orti, simplices vel parte inferiore ramis paucis axillaribus instructi, circiter $10-15 \mathrm{~cm}$. longi, usque ad basin foliferi. Folia clliptica vel elliptice ovata vel obovata vel lanccolata, usque $1.8 \mathrm{~cm}$. longa et $0.9 \mathrm{~cm}$. lata, vel usque $2.3 \mathrm{~cm}$. longa ct $6 \mathrm{~mm}$. lata, apicc acuta, hasin versus attenuata, vix petiolata, margine minutissime scrrulata, eglaudulosa, plus minusve glauco-viridia venis perinconspicuis; stipulac minutissimac, lineari-subulatae, mox deciduac. Inflorescentiae terminales, $2-3 \mathrm{~cm}$. longac, inferne flores of 1-4 gerentes, floribus ceteris ot. Flores to:- Bracteae uniflorac, supernc triangulares, acutae, irregulariter denticulatae, inferne biglandulosae; glandulac breviter compresse cornucopiiformes, $1 \mathrm{~mm}$. longac. Calyx trifidus lobis triangularibus irregulariter denticulatis. Stamina 3, filanentis liberis. Flores $9:-$ Bracteae superne subrhomboidcre, medio utrinque dentc grosso instructae, inferne biglandulosac; glandulac stipitatac, cornucopiiformes, leviter compressae. Calyx e scpalis 3 libcris latc triangularibus denticulatis compositus, glandulis 1-2 sepalis alternantibus instructus. Ovarium glabrum, grosse 6 -appendiculatum appendiculis aliformibus; styli basi in columnam brcvem connati. Capsula tricocca, circiter $8 \mathrm{~mm}$. alta, $8 \mathrm{~mm}$. diametro, crustacea (nec lignosn nce drupacca), lreviter 6-cornjculata. Semina subcylindrica, eirciter $5 \mathrm{~mm}$. longa, $4 \mathrm{~mm}$. diametro, valde et conspicue carunculata.

Northers Rhodesia. Mwinilunga District : in sandy plain after carly burning, east of Mwinilunga and alout $25 \mathrm{Km}$. west of R. Kinbompo, 11 Sept. 1930, Milne-Redhead, 1105. Tufted perennial forming patches $3 \mathrm{dm}$. in diameter; leaves glaucous; infloresccnce rcsembling that of Rumex Acetosella; fruits corniculate; sceds carunculatc. 
In the key to the genera of the tribe Hippomaneae of Euphorbiaceae in Engl. Pflanzenreich, vol.iv. 147 V. p. 13, Pax and Hoffmann separate the genus Sapium from Sillingia on account of the former having ecarunculate seeds. Yet they include under Sapium the Madagascan plant, Sapium melanosticlum (Baill.) Pax et K. Hoffm., which has carunculate sceds. S. Acetosella agrees with S. melanostictum in this character, and can be distinguished from Stillingia by the base of the pericarp not being persistent after the dehiscence of the fruit.

The affinity of Sapium Acetosella appears to be with S. suffruticosum, Pax, an Angolan species the fruit and seed of which are unknown. S. suffruticosum has been placed by Pax and Hoffmann in their section Armata, the numbers of which are characterized by having six spiny outgrowths on their capsules. The ovary of $S$. suffruticosum has six wing-like appendages, which it is presumed would develop into the spines as the capsule ripens. Similarly $S$. Acetosella has an appendiculate ovary, and its capsule is known to be spiny. However, the capsule of $S$. Acetosella differs from all those that are known in the section Armata in its texture, being neither woody nor drupaceous, but crustaccous.

Not only is $S$. Acelosella of interest in connection with its taxonomic position, but it is remarkable on account of its very reduced habit, it being by far the smallest member of the genus. It is an undershrub with a woody underground rootstock, and forms large patches on the sandy plains in the Mwinilunga District of Northern Rhodesia. After the annual fires, and before the beginning of the rains, the plant sends up large numbers of flowering shoots, and at the same time leafy shoots develop from their lower buds. The shoots at the time of collecting were about $10-15 \mathrm{~cm}$. high, and apparently were not yet mature, whilst the plant was in full flower, and a number of capsules were already ripe.-E. MILne-Redhead.

Fig. 1, plant, natural size; 2, portion of rhachis with bract and male flower, $\times 21 ; 3,4$, bract of male flower, flattened, abaxial and adaxial views, $\times 12$; 5 , calyx of same, from below, $\times 6 ; 6$, portion of rhachis with bract and female flower, $x 12 ; 7$, female flower, abaxial view, showing calyx with intersepaline glands, $\times 12 ; 8$, the same, with calyx removed, showing the wing-like appendages of the carpels, $\times 12 ; 9$, dehiscing capsule, $\times 2 ; 10$, a single coccus, $\times 2 ; 11$, seed, adaxial view, $\times 2$. 

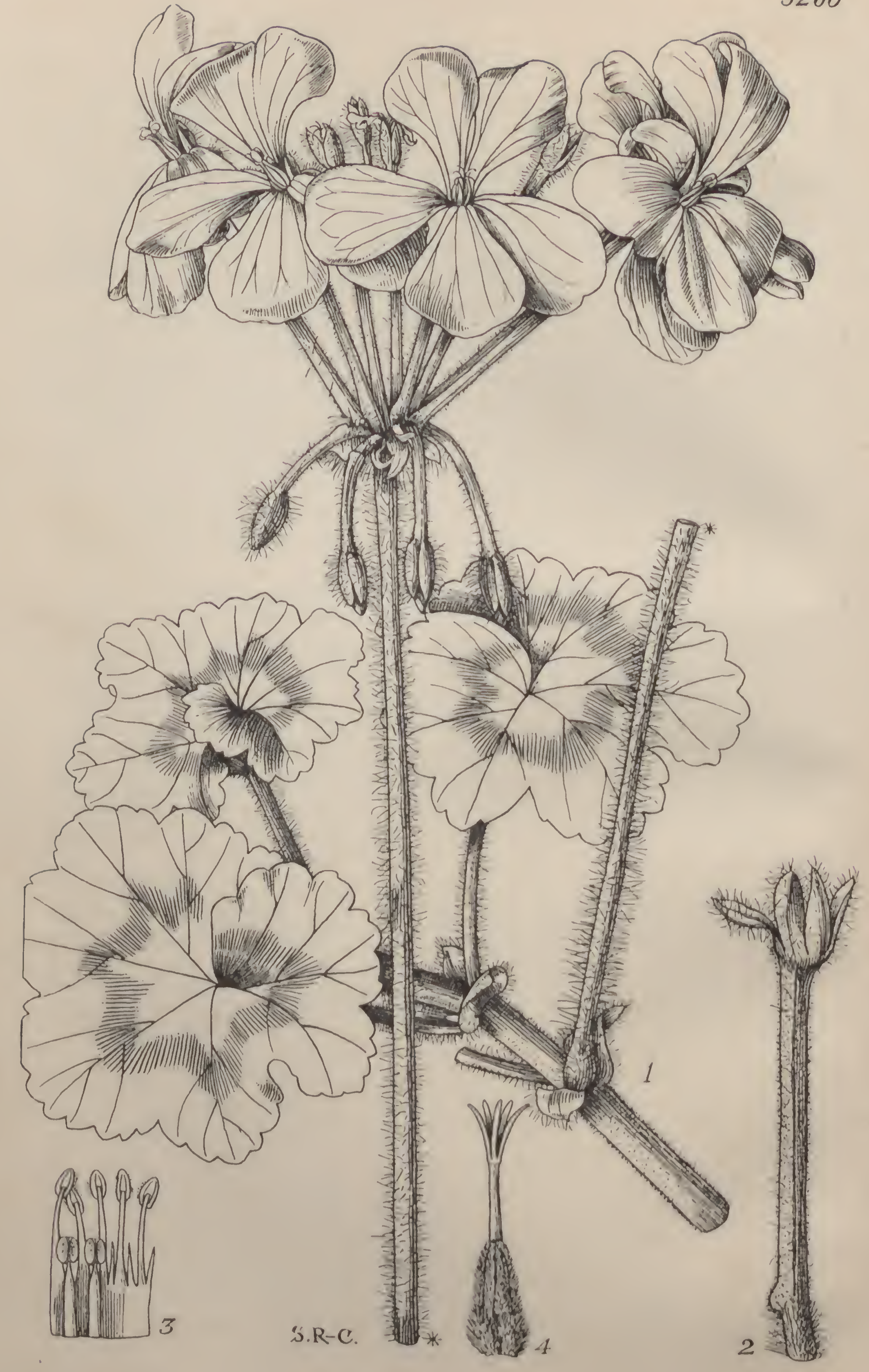


\section{TABULa 3200.}

\section{PELARGONIUM FRUTETORUM, $R$. A. Dyer.}

\section{Gerantaceae. Tribus Pelargonieae.}

P. frutetorum, R. A. Dyer in Kew Bull. 1932, P. 446; affine P. inquinanti, I. et $P$. zonali, L. ; ab illo foliis zonatis, petalis salmoneis nec ernento-ruluris, $a b$ hoe petalis latioribus, florum colore, sepalis oblongolinearibus apice rotundatis vel breviter apieulatis, foliis mollius pubescentibus lobis erenatis differt.

IIerba suffrutescens, sparse ramosa, ramis plus minusve seandentibus, usque $1.25 \mathrm{~m}$. alta. Caules pubescentes, pilis brevibus glandulosis et longioribus eglandulosis instructi, teretes, $5-7 \mathrm{~mm}$. erassi, carnosulosublignosi. Folia orbieulata vel reniformi-orbieulata, basi cordata, 5-lohata, lobis crenatis vel crcnato-dentatis, basalibus sesc imbricantibus, usquc $5 \mathrm{~cm}$. longa, $4-7 \cdot 5 \mathrm{~cm}$. lata, vix carnosula, zonata, utrinque induncnto molli satis induta; stipulae latc vel latissime ovatae, 1.1-1.8 em. longae, $0 \cdot 9-1 \cdot 3 \mathrm{em}$. latae, abruptc acuminatac, acutac, nox nembranaceae. Pedunculi 8-20 em. longi, pubescentes, pilis glandulosis brevihus et eglandulosis longis instrueti, usque 14-flori. Bracteae plerumque 6, stipulis similes sed multo minores. Flores pediccllati, pedieellis $3 \cdot 5-5 \cdot 5$ en. longis, infra calear pilosis, calycis calcare tenui, $3 \cdot 3-4 \cdot 7 \mathrm{~cm}$. longo eis adnato, pilis brevibus glandulosis et perpaucis longioribus cglandulosis ornato. Sepala oblongo-lincaria, 6-8 $\mathrm{mm}$. longa, circiter $1.5 \mathrm{~mm}$. lata, breviter apiculata extra pilosa. Pelale sulinequalia, obovata, vel ohovato-cuneata, apice plcrumquc rotundata, 3 inferiora usquc $2 \mathrm{~cm}$. longa, $1 \mathrm{~cm}$. lata, leviter emarginata, cxtra dilutissime rosea, intus rosev-salmonea, 2 superiora saturatius colorata. Stamina 10 , antheris fertilibus 7,5 antesepala calyci ferc aequilonga, 2 antepetala posteriora breviora. Ocarium densc villosum. Fructus ferc 3 cin. longus, rostro pilis patulis albidis hirsuto.

Soutu Africa. Cape Provinec: Bathurst Div.; near the Kowie River, 9 Oct., Burchell, 4029, 4090 (type) ; in Kowic bush near Salt Vlei, shady, Britten, 6891. Alexandria Div.; in bush at Bushmans River moutl, oceasional, 12 May, Galpin, 10664.

In the wild state this spccies is found as a member of the middlc tier of the coastal scrub vegetation. In conscquenec of its shady habitat 
it assumes a somewhat scandent habit and seldom flowers profusely, and is never very abundant in one place. It was from a living plant from the type locality, brought to Kew by Miss E. M. Hill during 1931, that the accompanying figure was drawn. A specimen has been preserved in the Kew Herbarium under the number P. 103. As compared with wild specimens, the cultivated plants show a more compact growth, and a more pronounced zonal leaf-marking, and the sepals are more uniformly narrowed towards the apex. The beautiful salmon-pink colour of the flowers, combined with the dark zonal leafmarking, make it a very desirable species for cultivation.

In the diagnosis, $P$. frutetorum has been compared with $P$. inquinans and $P$. zonale, both of which occur in the Eastern Cape Province, rather than with cultivated species with no "wild" history and which may well have originated by hybridization. Although $P$. inquinans and $P$. zonale occur in the same botanical region, neither species has been found in the coastal bush to which $P$. frutetorum is restricted.

The true relationship between the wild species of this group has certainly been obscured by the presence of artificial hybrids and possibly of natural hybrids also. The classifications of Harvey (Harv. and Sond. Fl. Cap. vol. i. p. 198: 1860) and Knuth (Engl. Pflanzenr. vol. iv. 129, p. 439 : 1912) include too many forms under $P$. inquinans and $P$. zonale, but owing to the delicate nature of the flowers and the absence of adequate herbarium material accompanied by good field notes, the solution of the various problems concerned lies more in the hands of residents than with overseas botanists.-R. A. DYER.

FIG. 1, a branch showing the spreading scandent tendency of the plant, natural size; 2 , pedicel and flower, with petals removed, the solid basal part of the pedicel long-pilose, the portion fused with the calyx-spur glandular-pubescent with only a few long hairs, and the pilose sepals with fewer glandular hairs, $\times 1 \cdot 5 ; 3$, staminal tube opened out, 3 staminodes and 2 posterior stamens viewed from the back; the two short filaments fused on the outside of the staminal tube, their antliers dehiscing extrorsely; the anthers of the longer stamens opening in a circle round the immature style, $\times 3 ; 4$, ovary with rostrum and 5 -branched style, $\times 4$. 







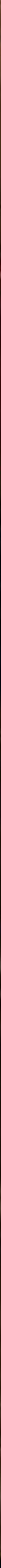

